\title{
O SOM E O SOBERANO: \\ uma história da depressão musical carioca \\ pós-Abdicação (1831-1843) \\ e de seus antecedentes
}

Lino de Almeida Cardoso

São Paulo

2006 
UNIVERSIDADE DE SÃO PAULO

FACULDADE DE FILOSOFIA, LETRAS E CIÊNCIAS HUMANAS

DEPARTAMENTO DE HISTÓRIA

PROGRAMA DE PÓS-GRADUAÇÃO EM HISTÓRIA SOCIAL

\author{
O SOM E O SOBERANO: \\ uma história da depressão musical carioca \\ pós-Abdicação (1831-1843) \\ e de seus antecedentes
}

\title{
Lino de Almeida Cardoso
}

Tese apresentada ao Programa de Pós-Graduação em História Social, do Departamento de História da Faculdade de Filosofia, Letras e Ciências Humanas da Universidade de São Paulo, para obtenção do título de Doutor em Ciências.

Orientador: Prof. Dr. István Jancsó

São Paulo

2006 
Para Luciana e Luana. 


\section{AGRADECIMENTOS}

A minha mãe, Zelia, pelos diários ensinamentos;

a meu pai, Odon, por me mostrar que a música é quase tudo;

ao professor István Jancsó, pelo acolhimento, pela orientação, pela confiança e pelo constante estímulo;

ao amigo e professor Maurício Monteiro, pela agradável convivência, pelo contínuo aprendizado e pela sempre generosa boa vontade em coorientar informalmente este trabalho;

aos professores João Paulo Garrido Pimenta e Iris Kantor, pela meticulosa leitura das versões preliminares deste trabalho e pelas inestimáveis sugestões, oferecidas durante os exames de qualificação;

aos professores Carlos Alberto Zeron, Elias Thomé Saliba, Ana Maria de Almeida Camargo e Nicolau Sevcenko, pelo interesse preliminar no projeto original, pelo incentivo e pelo encaminhamento, durante o processo seletivo da pós-graduação;

aos colegas Luciane Beduschi e Adriano de Castro Meyer pela troca de idéias e pela disponibilidade de oferecer-me, prontamente, informações e fontes solicitadas;

ao maestro Júlio Medaglia pela amizade, pelo respeito profissional e pelo auxílio nas traduções aqui apresentadas de um idioma sobre o qual aprendi muito, mas não tenho domínio: o alemão;

a todos os funcionários de arquivos e bibliotecas nacionais e estrangeiros que gentilmente me atenderam, em pessoa ou por correspondência, fornecendo informações e preparando cópias de documentos;

enfim, a todos os familiares, amigos e colegas com quem conversei sobre música e história, exercitando a reflexão de idéias. 


\section{RESUMO}

Entre os anos de 1808 e 1831, a cidade do Rio de Janeiro tornou-se um dos mais fecundos centros operísticos das Américas. Não o fora por acaso. Na primeira década do século XIX, o Teatro de São Carlos, de Lisboa, ainda era tido na Europa como a melhor ópera italiana além dos limites da Itália, e todo o fino cultivo do drama cantado italiano, desenvolvido desde o reinado de Dom João $V$, se transferiu, em parte, para a então capital do Estado do Brasil, quando a família real portuguesa e membros de sua corte ali se instalaram. Além de importantes autores e executantes europeus, o Rio passou a dispor, em poucos anos, de uma grande casa de ópera, comparada às melhores do Antigo Continente, e nesses pouco mais de vinte anos, cerca de quarenta títulos de óperas diferentes foram ali estreadas, fora as centenas de repetições.

Além de ópera, podia-se também ouvir, no Rio desse mesmo período, excelente música sacra na Capela Real, depois Imperial. Para Manuel de Araújo Porto Alegre, esse gênero, "que encantava os estrangeiros em Roma, era executado com a mesma perfeição, durante a Semana Santa, no Rio de Janeiro", elogio, diga-se de passagem, endossado pela maior parte dos europeus que tiveram a oportunidade de ouvir tal conjunto musical, como Debret, Freycinet, Graham, Caldcleugh. Tal cultivo excelente da música sacra devia-se, em parte, à existência, ali, de exímios músicos nativos, como José Maurício Nunes Garcia e Pedro Teixeira de Seixas, mas, também, graças ao esforço de Dom João em fazer vir de Portugal, desde a sua chegada, muitos dos músicos que formaram, durante o reinado de Dona Maria I, "a primeira Capela da Europa, superior inclusive à do Vaticano", como testemunhou o viajante inglês William Beckford, em 1787.

Por outro lado, entre setembro de 1831 e janeiro de 1844 , surpreende notar que nenhum espetáculo de ópera completa tenha sido estreado ou sequer encenado no Rio de Janeiro. Como se não bastasse, cerca de dois meses após a abdicação de Dom Pedro I, o governo regencial fez cumprir, com extremo rigor, o orçamento imperial de 1831-1832, praticamente extinguindo a orquestra da Capela Imperial e reduzindo o número de músicos, que chegou a cerca de setenta na época de Dom Pedro I, a menos de trinta integrantes. A reorganização dessa orquestra somente iria ocorrer em maio de 1843, já em pleno segundo reinado.

Nenhuma dúvida paira quanto ao fato de que essa depressão musical repentina e ao mesmo tempo duradoura dos anos 1831-1843 tenha uma íntima relação com o interregno de 1831-1840. Porém, nenhum estudo histórico ou musicológico foi realizado até hoje buscando, em meio a eventos de diversas naturezas - social, política e econômica -, estabelecer, com precisão, que fatores mais teriam contribuído para esse fulminante declínio da ópera e da música sacra na capital do Império, em 1831. Igualmente, jamais se explicou por que razão tantos anos, incluindo-se alguns já do segundo reinado, foram necessários para que o Rio de Janeiro voltasse a ter uma atividade musical similar à que tinha antes da partida de Dom Pedro I. 
Diante disso, procuraremos - acompanhando os moldes de alguns importantes estudos internacionais, os quais, paulatinamente, têm contribuído para a edificação de uma história mais geral da música - abrir não apenas um amplo leque de causas diretas dessa derrocada, como demonstrar que essa parte mais importante da atividade musical no Rio de Janeiro - a produção de te-déuns e óperas - esteve, até então - e desde muito antes do que se imaginava, ainda nos tempos dos Governadores e Vice-Reis assim como em Lisboa e em outras capitais européias, intimamente ligada ao simbolismo da figura do soberano, ao status do artifício maravilhoso e sagrado do poder real. E, daí, propor que a fundamental causa da decadência dos dois mais importantes organismos musicais do Rio de Janeiro durante os anos 1831-1843 tenha sido o concomitante enfraquecimento, após a partida de Dom Pedro I, dessa antiga expressão simbólica da monarquia, um ritual de manutenção de um poder real que se efetivava na atividade social de corte, prática recuperada, em parte, entre 1840 e 1841, com a Maioridade e a Coroação, e, cabalmente, em 1843, com o imperial consórcio.

Palavras-chave: Música, Rio de Janeiro, Monarquia, Sociedade de corte, Poder político.

\section{ABSTRACT}

In the years between 1808 and 1831, the city of Rio de Janeiro became one of the most active operatic centers in America. This had not been by chance. In the first decade of the $19^{\text {th }}$ century, the São Carlos Theatre, in Lisbon, was still considered the best Italian opera house in Europe, outside Italy, and all the intense cultivation of the Italian lyric drama, developed since the reign of Dom João V, was, in part, transferred to the capital of the State of Brazil at that time, when the Portuguese royal family, together with members of the court, settled down there. Within a few years, besides important European composers and performers, Rio already had a great opera house which could be compared to the best ones in Europe, and during little more than those twenty years, nearly forty different opera titles were first performed there, not to mention hundreds of repetitions.

In the same period, besides opera, it was also possible to listen to excellent sacred music in the Royal Chapel, called Imperial later on. According to Manuel de Araújo Porto Alegre, that kind of music "which enchanted foreigners in Rome was equally played with the same perfection during the Holy Week in Rio de Janeiro", a praise, in passing, supported by most of the Europeans who had the opportunity of listening to such a musical ensemble, as Debret, Freycinet, Graham, Caldcleugh and many others. Such an excellent cultivation of sacred music was due not only to the existence, there, of extraordinary native musicians, as José Maurício Nunes Garcia and Pedro Teixeira de Seixas, but also to the effort made by Dom João since his arrival, to fetch from Portugal several of the musicians who, during the reign 
of Dona Maria I, had formed "the fist Chapel of Europe, superior to that one in the State of Vatican", as the English traveller, William Beckford, had testified in 1787.

On the other hand, it is a surprise to notice that, between September 1831 and January 1844, no complete opera had been first performed or even staged in Rio de Janeiro. Moreover, about two months after the abdication of Dom Pedro I, the regent government carried out the imperial budget of 18311832 with extreme severity, practically extinguishing the Imperial Chapel Orchestra and reducing the number of musicians that had almost reached seventy, during the time of Dom Pedro I, to less than thirty. The reorganization of that orchestra would only occur on May 1843, in the second reign already.

There is no doubt about the fact of that sudden and, at the same time, lasting musical depression of the years 1831-1843 has had a close relationship with the interregnum of 1831-1840. But no historical or musicological research has been accomplished so far, trying, among events of different nature - social, politic, economic - to establish precisely which other causes had contributed to the extreme decline of opera and sacred music in the capital of the Empire in 1831. Likewise, it has never been explained why so many years, including some in the second reign, were necessary for Rio de Janeiro to have again a musical activity similar to that one before the departure of Dom Pedro I.

Thinking of that - following the patterns of some important international researches that have slowly contributed to the edification of a more general history of the music - , we'll try not only to open a huge set of direct causes of such a destruction, but also to demonstrate that those most important musical activities in Rio de Janeiro - to produce Te Deum and opera - were since then - and since long before it could be imagined, still in the time of the Governors and Viceroys -, so as in Lisbon and other European capitals, closely connected to the symbolism of the image of the sovereign, to the status of the marvelous and sacred artifice of the royal power. And, from that, to propose that the chief cause of the decline of the two principal musical organisms of Rio de Janeiro, during the years 18311843, had been the concomitant debility, after the departure of Dom Pedro I, of that old symbolic expression of monarchy, a ritual to maintain a royal power which became effective in the social activity of the court, custom recovered, in part, between 1840 and 1841, with the Majority and Coronation of Dom Pedro II, and finally completed with the imperial marriage, in 1843.

Key words: Music, Rio de Janeiro, Monarchy, Court society, Political power. 


\section{SUMÁRIO}

INTRODUÇÃO

PARTE I - REGNUM

CAPÍTULO I - Reminiscências musicais dos áureos tempos 26

CAPÍTULO II - A sedução da ópera e suas primeiras implicações 58

CAPÍTULO III - Uma capela real nos trópicos 92

CAPÍTULO IV - Uma corte, um teatro decente 117

CAPÍTULO V - Outros sons 161

\section{PARTE II - INTERREGNUM}

CAPÍTULO VI - O adeus do príncipe filarmônico 167

CAPÍTULO VII - A corte silente 194

CAPÍTULO VIII - Mais do que republicana, uma experiência "soberana"

CAPÍTULO IX - Muito barulho, pouca música 298

CAPÍTULO $X$ - Outros sons, agora amplificados 310 


\title{
INTRODUÇÃO
}

\begin{abstract}
Ainda há tempo, Senhor, de manter-se V. M. I. no trono como o deseja a maioria dos brasileiros, mas se V. M., indeciso, continuar com as palavras de Constituição e brasileirismo na boca, a ser português e absoluto de coração, neste caso a sua desgraça será inevitável, e a catástrofe que praza a Deus não seja geral, aparecerá em poucos meses; talvez não chegue a seis ${ }^{1}$.
\end{abstract}

Não foram necessários nem quatro meses para que o augúrio do então Senador e ex-Ministro da Fazenda, Felisberto Caldeira Brant - o qual tentou pela primeira vez durante o primeiro reinado, promover um governo com o voto de confiança da Câmara dos Deputados - , se tornasse fato, digno de figurar na história brasileira pelo resto dos tempos. A 7 de abril de 1831, exatos três meses e vinte e três dias após as supramencionadas linhas terem tentado alertar Dom Pedro I de que a sua permanência no poder estava bastante ameaçada, dava-se por realizado o que o aventureiro teutônico e oficial do exército brasileiro Carl Seidler escarneceu, alguns anos mais tarde, como "uma caçada à lebre (...) sem que os atiradores tivessem tido a necessidade de disparar os seus fuzis"2. Pois, evitando uma revolta popular de graves proporções e, quiçá, sua própria destruição, aquele que exercia a "chave de toda a organização política" ${ }^{3}$ brasileira abdicava "mui

${ }^{1}$ Carta do Marquês de Barbacena a Dom Pedro I, de 15 de dezembro de 1830. (Apud SOUZA, Octavio Tarquínio de. História dos fundadores do Império do Brasil. Rio de Janeiro: José Olympio, 1960, v. 4, t. 3, p. 867).

2 "Ich nenne die Revolution des 7ten Aprils selbst kein Trauerspiel; denn sie ist eigentlich nur als eine Hasenjagd zu betrachten, wo der furchtsame Dom Pedro, von gut abgerichteten Hunden gehetzt, davon lief, ohne dass die Schützen nötig gehabt hätten, ihre Gewehre abzufeuern;" (SEIDLER, Carl. Brasiliens kriegs-und revolutionsgeschichte seit dem jahre 1825 bis auf unsere zeit. Leipzig: Eduard Kummer, 1837, p. 169).

${ }^{3}$ Essa era a definição do Poder Moderador, dada pela Carta de Lei outorgada a 25 de março de 1824; enunciado, diga-se de passagem, traduzido rigorosamente dos Principes de politique, do publicista suíço Benjamin Constant, quando este apresenta, em seu trabalho, a natureza do Poder Real, distinta do Poder Executivo: "Cette distinction (...). C' est en effet, selon moi, la clef de toute organisation politique" (CONSTANT, Benjamin. 
voluntariamente".

Diversos fatores - complexos e relacionados entre si - contribuíram para que Dom Pedro I renunciasse a uma delegação vitalícia antes mesmo de completar 33 anos de idade. A historiografia costuma apontar-nos dois essenciais: portuguesismo e antiliberalismo, fatores, diga-se de passagem, já claramente esboçados pelo Marquês de Barbacena em sua vaticinadora carta de 15 de dezembro de 1830.

Por muito tempo, deu-se como certa a análise de que o primeiro fator, ou seja, a íntima ligação do monarca com os conterrâneos e com a terra de origem teria sido o principal motivo de sua queda. De John Armitage a Caio Prado Jr., não faltou quem tenha dado ao dissentimento entre "brasileiros" e "portugueses"4, do qual o Imperador teria participado em favor dos últimos, papel preponderante no processo histórico que resultou na Abdicação.

Fatos precisamente ligados a questões portuguesas - como 0 Tratado de Paz e Aliança que Dom Pedro I assinou com seu pai a 29 de agosto de 1825, reservando para este o título de Imperador do $\mathrm{Brasil}^{5}$, além

Principes de politique. Cours de politique constitutionnelle et collection des ouvrages publiés sur le gouvernement représentatif. Paris: INALF, 1961, p. 18-19).

${ }^{4}$ Note-se que essa melindrosa dicotomia tem por base as mentalidades da época e não o ordenamento jurídico em vigor àquele momento. Para tanto, cabe aqui a ressalva de que muitos "portugueses", assim denominados - ou, muitas vezes, apelidados de "adotivos" - , eram, em realidade, legítimos "brasileiros", pelo menos, a partir de 25 de março de 1824, uma vez que o artigo $6^{\circ}$ da Carta de Lei entendia como cidadãos brasileiros "todos os nascidos em Portugal, e suas possessões, que sendo já residentes no Brasil na época em que se proclamou a Independência nas Províncias, onde habitavam, aderiram a esta expressa, ou tacitamente pela continuação da sua residência" (COLEÇÃO das Leis do Império do Brasil de 1824. Constituição Política do Império do Brasil. Rio de Janeiro, Imprensa Nacional, 1886, parte 1, p. 8)

5 "EM NOME DA SANTÍSSIMA E INDIVISÍVEL TRINDADE. SUA MAJESTADE FIDELÍSSIMA (...) por seu diploma de 13 de maio do corrente ano, reconheceu o Brasil na categoria de império independente, e separado dos reinos de Portugal e Algarves, e a seu sobre todos muito amado e prezado filho DOM PEDRO por Imperador, cedendo e transferindo de sua livre vontade a soberania do dito império ao mesmo seu filho, e seus legítimos sucessores, e tomando somente, e reservando para a sua pessoa o mesmo título" (TRATADO feito entre Sua Majestade Fidelíssima sobre o reconhecimento do Império do Brasil, aos 29 de agosto de 1825. E ratificado por Sua Majestade o Imperador no dia imediato. Rio de Janeiro: Tipografia Nacional, 1825). O desabafo sarcástico que José Bonifácio fez, no exílio, em uma carta de 14 de novembro de 1825 a seu amigo Vasconcelos de Drummond nos dá uma idéia de como esse tratado teria soado mal para parte da opinião pública da época: "Enfim, pôs o ovo a Grã pata e veio a lume o decantado Tratado, que saiu melhor do que esperava; - ao menos temos Independência reconhecida, bem que a soberania nacional recebeu um coice na boca do estômago, de que não sei se 
de ceder à velha mãe-pátria e ao bolso do próprio Rei uma série de vantagens financeiras; e, mais adiante, a aspiração de Dom Pedro I, mesmo esconsa, de reunificar as duas coroas com a morte de Dom João VI também sempre foram lembrados como fortes causas do enfraquecimento político e da impopularidade que levou nosso primeiro Imperador à renúncia ${ }^{6}$.

Pedro Octávio Carneiro da Cunha, no entanto, em seu brilhante artigo "A fundação de um império liberal”, presente na História geral da civilização brasileira, ponderou com muita competência esses dois fatores essenciais, criticando veementemente a opinião de quem acreditou que "o germe da última crise" teria sido aquele "'pecado original': não ter o monarca nascido em Macacu". Para Cunha, esse "conflito das naturalidades", embora "culminante" nos julgamentos finais em relação a Dom Pedro I - sobretudo das camadas menos abastadas ou mais populares da sociedade - não passou de um "subproduto", de um "problema postiço", utilizado artificialmente pela elites contrárias ao Imperador para agravar a sua impopularidade $^{7}$. A aversão ao liberalismo é que, antes de tudo, teria pesado

morrerá, ou se se restabelecerá com o tempo; tudo depende da conduta futura dos Tatambas. Que galantaria jocosa de conservar João Burro o título nominal de Imperador, e ainda mais de convir nisso o P. Malasartes!" (CARTAS Andradinas. Anais da Biblioteca Nacional. Rio de Janeiro, v. 14, p. 11, 1890).

${ }^{6}$ Mesmo fontes estrangeiras da época, não tão contaminadas com o entusiasmo de quem vivia o ambiente foram taxativas em avaliar que a causa principal da queda de Dom Pedro I teria sido a íntima ligação do Imperador com os conterrâneos e com a terra de origem. O jornal Iondrino The times, por exemplo, publica, a 17 de junho de 1831, um editorial, apontando, como causas da ruína de Dom Pedro, os seus atos paternalistas em favor dos emigrados portugueses que haviam fugido do despotismo de Dom Miguel, em 1829, e as enormes despesas gastas para assegurar a Dona Maria da Glória o trono português, além de um empréstimo em seu favor: "Don Pedro had about his person many Portuguese refugees, partisans of the constitution, who had fled from the despotism of Don Miguel. These individuals he employed in preference to the Brazilians (...) the ruin of Don Pedro has been the continuation of his political relations with Europe - the enormous expense which he has been at to secure the throne of Portugal for his daughter, by supporting the Regency of Terceira, and paying ambassadors or agents in the courts of Europe for the interests of the House of Braganza and not of the Brazils. These expenses had fallen too often upon the Brasils, and finally a loan was contracted by the Emperor for the affairs of Donna Maria and the Regency of Terceira, which he wished the Congress to ratify, but which that assembly formally opposed" (THE TIMES, 17/06/1831).

7 Raymundo Faoro é de mesma opinião ao afirmar, que "a facção nativista", representada pelos fazendeiros, "utiliza demagogicamente os contrastes, agigantando uma corrente portuguesa, recolonizadora, reacionária, na verdade de pequena expressão", esta última, representada pelo comércio (FAORO, Raymundo. Os donos do poder: formação do patronato político brasileiro. São Paulo: Globo, 2000, v. 1, p. 331). 
como fator primaz no encaminhamento da crise política que resultou na Abdicação ${ }^{8}$.

Quanto a esse aspecto, são inúmeros os fatos relacionados, a começar pela arbitrária dissolução da Assembléia Constituinte e Legislativa, a 12 de novembro de 1823. Tal e qual profetizou José Bonifácio, Dom Pedro I já teria ali perdido a coroa ${ }^{9}$. No mais, além do processo espúrio em que a Constituição foi lavrada e a detença em convocar o parlamento, pesou na balança do fator "antiliberalismo", o invariável desprezo do Imperador por quaisquer outros agentes do poder: fossem parlamentares, juízes ou até mesmo, seus subordinados diretos, os Ministros de Estado ${ }^{10}$. Isso Ihe

${ }^{8}$ HOLANDA, Sérgio Buarque de (org.). História geral da civilização brasileira. São Paulo: Difel, 1985 , v. 3, p. 392-397. De fato, se havia na lusofobia popular desse período uma natureza espontânea, essa não era fundamentalmente política, mas econômica e social; de luta de classes; "de pobres contra ricos" - como asseverou Pedro Calmon (CALMON, Pedro. História do Brasil. Rio de Janeiro: José Olympio, 1959, v. 5, p. 15841585) - ou, como preferimos, de desempregados contra empregados. Pois, foi o monopólio que os estrangeiros exerciam no comércio e o privilégio que os negociantes "portugueses" concediam aos seus "conterrâneos", "filhos do reino", em todos os postos de trabalho desse setor, até mesmo nos inferiores, que colocaram muitos "brasileiros" à margem da sociedade e, conseqüentemente, à mercê de um discurso político antilusitano, demagógico ao ponto de condenar Dom Pedro I e tantos outros "pés-de-chumbo", sob o argumento de serem inimigos dos interesses do Brasil, e admitir exceções, como, por exemplo, o transmontano - porém, liberal - Senador Vergueiro, feito um dos membros da Regência do Império, a 7 de abril.

9 Foi o diplomata, jornalista e político Antônio de Meneses Vasconcelos de Drummond (1794-1864) que lembrou, em sua autobiografia, as palavras "proféticas" de José Bonifácio, ditas ao general Moraes, quando este o levou preso ao arsenal da Marinha, poucos dias após a dissolução: "Diga ao Imperador, repetiu José Bonifácio, que eu estou com o coração magoado de dor, não por mim, que estou velho, e morrer hoje fuzilado ou amanhã de qualquer moléstia, é causa para mim bem indiferente; que é por seus filhos inocentes que eu choro hoje; que trate de salvar a coroa para eles, porque para si está perdida desde hoje; a sentença o Imperador mesmo a lavrou e já não pode subtrair-se aos seus efeitos..." (DRUMMOND, Antônio de Meneses Vasconcelos de. Anotações de A. M. V. de Drummond à sua biografia publicada em 1836 na Biographie Universelle et Portative des Contemporains. Anais da Biblioteca Nacional. Rio de Janeiro, v. 13, parte 3, p. 84, 1890). A esse respeito, o Barão Homem de Melo também nos deixou, em seus escritos, uma frase lapidar: "7 de abril é o resultado de 12 de novembro" (MELO, Francisco Inácio Marcondes Homem de. A constituinte perante a história. Brasília: Senado Federal, 1996, p. 25. Edição fac-similar).

${ }^{10}$ A respeito desse fato, o publicista alemão Johann Jakob Sturz (1800-1870), que nos legou um dos melhores panoramas sobre a situação financeira do Brasil durante as três primeiras décadas do século XIX, comenta, com ironia, que "a freqüente demissão de ministros da fazenda durante o reinado de Dom Pedro I ocorria pela sua incapacidade de fazer dinheiro rápido o suficiente para a demanda imperial"; tradução nossa de: "The frequent dismissal of his ministers of finance was occasioned by their not being able to coin money fast enough for the imperial demand for it..." (STURZ, Johann Jakob. A review, financial, statistical, and commercial, of the Empire of Brazil and its resources: together with 
proporcionou um antagonismo político aguerrido, sobretudo na medida em que a Câmara dos Deputados e a imprensa ganhavam, a cada ano que passava, mais atrevimento. E a tudo isso, ainda se soma a verdadeira esparrela que Dom Pedro armou para si próprio ao desejar assumir poderes e responsabilidades quase absolutos e que superavam de longe as suas capacidades pessoais como governante ${ }^{11}$. Desastres políticos, como a Guerra da Cisplatina, se não foram fundamentais no seu processo de desgraça, também não ajudaram a dispersar o descontentamento geral ${ }^{12}$.

Enfim, como se não bastasse, o ocaso de Dom Pedro I não foi conseqüência apenas de seus atos políticos — ou ainda meramente sociais, como o afamado desregramento de sua vida privada ${ }^{13}$. A chegada ao Rio, em meados de setembro de 1830 , de notícias externas a respeito da revolução que destronara Carlos X, na França, e sua rápida propagação nos periódicos cada vez mais numerosos e agressivos, somadas a motivações

a suggestion of the expediency and mode of admitting brazilian and other foreign sugars into Great Britain for refining and exportation. London: Effingham Wilson, 1837, p. 19).

${ }^{11}$ Note-se que essas "responsabilidades", embora reconhecidas pela população, não eram admitidas constitucionalmente. O artigo 99 da Carta de Lei de 1824 dizia: "A pessoa do Imperador é inviolável, e sagrada: ele não está sujeito a responsabilidade alguma" (COLEÇÃO das Leis do Império do Brasil de 1824. Constituição Política do Império do Brasil. Rio de Janeiro, Imprensa Nacional, 1886, parte 1, p. 20).

${ }^{12}$ A esse respeito, citemos, por exemplo, a opinião de Eduard Theodor Bösche (1807-?), alemão que esteve radicado no Brasil de 1825 a 1834 e que fez parte do Exército Imperial. Para ele: "O infeliz desfecho da dispendiosa guerra com Buenos Aires, unicamente atribuída à teimosia de Dom Pedro, também não foi oportuno para dispersar o descontentamento geral"; tradução nossa de: "Der unglückliche Ausgang des kostspieligen Kriegs mit Buenos Ayres, den man bloß dem Eigensinn Dom Pedro's zuschrieb, war ebenfalls nicht geeignet, die allgemeine Unzufriedenheit abzuleiten" (BÖSCHE, Eduard Theodor. Wechselbilder von land-und Seereisen, Abenteuern, Begebenheiten, staatsereignissen, volks-und sittenschilderungen während einer fahrt nach Brasilien und eines zehnjährigen Aufenthalts daselbst, in den Jahren 1825 bis 1834. Hamburg: Hoffmann und Campe, 1836, p. 205).

${ }^{13}$ A ligação amorosa de Dom Pedro I com Domitila de Castro - Viscondessa e Marquesa de Santos - "indecente e indecorosa", nas palavras do mesmo Vasconcelos de Drummond (Op. cit., v. 13, p. 72), marcaria, do ponto de vista social, uma constante deterioração da honra do Imperador, agravada, em especial, com a morte da Imperatriz, Dona Leopoldina, a 11 de dezembro de 1826. Na opinião de Robert Walsh (1772-1852), reverendo irlandês que esteve no Brasil entre os anos de 1828 e 1829 , a diminuição da popularidade do Imperador - mais do que qualquer outra causa - estaria intimamente relacionada ao escancarado desprezo que Dom Pedro tinha pela opinião pública quanto a "certos deveres morais": "But the circumstance, perhaps, which has caused his popularity to decline more than any other, is his open contempt for public opinion on certain moral duties" (WALSH, Robert. Notices of Brazil in 1828 and 1829. London: F. Westley and A. H. Davis, 1830, v. 2, p. 467). 
socioeconômicas, acirraram os ânimos e catalisaram o desenvolvimento de um ambiente pré-revolucionário, que, já nos primeiros meses de 1831, gerou nas ruas da capital do Império diversos enfrentamentos entre os insatisfeitos com o Imperador e os seus minoritários defensores ${ }^{14}$. Os embates mais violentos foram certamente as "garrafadas" de 13 e 14 de março ${ }^{15}$, embora os dias que antecederam ao Sete de Abril tenham sido também "cheios de assassinatos", como testemunhou o viajante inglês Joseph William Moore ${ }^{16}$.

De nada adiantou, pois, fazer-se publicar, a 26 de março de 1831, no principal diário da capital, o Jornal do comércio, que o dia anterior, quando se comemorou o sétimo ${ }^{17}$ aniversário do juramento da Constituição, tinha sido um dos "mais belos, que hão brilhado no horizonte do Brasil", com direito a Te Deum "com grande pompa" na Capela Imperial, parada, fogos de artifício, ruas "juncadas de folhas e flores", casas "ricamente adornadas com colchas" e entusiásticos gritos de "viva" ao Imperador Constitucional e Defensor Perpétuo do Brasil. Segundo John Armitage, nessa mesma oportunidade,

14 As motivações socioeconômicas das agitações populares pré-abdicação travadas entre os insatisfeitos com Dom Pedro I - em sua maioria nativos desempregados; muitos deles mulatos e negros, esses últimos fugidos ou forros - e seus defensores - em grande parte empregados das firmas comerciais; brancos e reinóis - foram deslindadas por Lenira Menezes Martinho em seu trabalho "Caixeiros e pés descalços: conflitos e tensões em um meio urbano em desenvolvimento", publicado, em 1992, na coleção Biblioteca Carioca (Rio de Janeiro: Prefeitura da Cidade do Rio de Janeiro), sob o título Negociantes e caixeiros na sociedade da Independência. Sobre esse assunto, ver também o dossiê "Metáforas e ações na longa luta pela liberdade: conflitos entre 'portugueses' e 'homens de cor', Corte do Rio de Janeiro, 1827-1834" de Gladys Sabina Ribeiro, publicado no $10^{\circ}$ número (dez/2000) da revista Tempo, do Departamento de História da UFF; e, da mesma autora, A liberdade em construção: identidade nacional e conflitos antilusitanos no primeiro reinado (Rio de Janeiro: Relume Dumará, 2002).

${ }^{15}$ Esse acontecimento resultou da infrutífera viagem de Dom Pedro I a Minas, em busca de apoio político. No retorno do Imperador à capital, seus simpatizantes, em sua maioria "portugueses", saudaram Sua Majestade com fogos, iluminações e vivas, agravando o descontentamento da maioria insatisfeita com o monarca. Nas noites de 13 e 14 de março de 1831, ocorreram sangrentos enfrentamentos entre aqueles que defendiam o Imperador e os exaltados contra o Governo.

16 "April 5th. Tuesday. (...) The City was under great excitement today saw about forty Brazilians march up Rua do Ouvidor armed. The two leaders carrying Horse pistols. They went into the Campo de Saint Anna after being joined by many others and practiced marching and military movements in the presence of the police without being disturbed. Several assassinations took place in the evening..." (MOORE, Joseph William. The Revolution of 1831. Notas de J. M. Harvey. São Paulo: Sociedade Brasileira de Cultura Inglesa, 1962, p. s/n). Joseph William Moore era irmão do fundador da firma carioca John Moore \& Co.

17 Uma pequena curiosidade: nesse dia, o Jornal do comércio erra ao mencionar a 
pouco mais à tarde, vivas a outro $\operatorname{Pedro}^{18}$, uma criança de apenas cinco anos e alguns meses de idade, também teriam sido ouvidos na Igreja de São Francisco de Paula durante mais um tedéu comemorativo, ao qual Sua Majestade compareceu, mesmo não tendo sido convidado ${ }^{19}$. Um mês exato se passou do início das "garrafadas", e "Pedro Segundo" passava de brado de protesto a fato inexorável diante da retirada definitiva do ex-Imperador do Brasil, a 13 de abril de 1831. O ato da Abdicação dera-se seis dias antes, decorrente da incontrolável desordem da véspera ${ }^{20}$, instaurada no momento em que a populaça, já plenamente insatisfeita, tomou conhecimento da substituição do gabinete "incolor" ${ }^{21}$, de 19 de março, por outro ministério, composto de velhas figuras do poder, tão impopulares quanto o Imperador.

data de 25/3/1831 como sendo o "sexto" aniversário do juramento da Constituição.

18 "In this state of menacing indecision fluctuated the affairs of Brazil until the 25th March. On this day, the anniversary of that on which oath was made to the Constitution, the patriots caused a solemn Te Deum to be celebrated in the Church of San Francisco de Paulo [sic], where the Emperor suddenly made his appearance, though neither expected nor invited. On his arrival he was greeted with vivas, 'while constitutional,' and with some few cries of 'Viva Don Pedro II.'" (ARMITAGE, John. The history of Brazil: from the period of the arrival of the Braganza family in 1808, to the abdication of Don Pedro the First in 1831. London: Smith, Elder and co., 1836, v. 1, p. 125).

${ }_{19}$ O Jornal do comércio reitera a mesma informação de Armitage quanto ao fato de Dom Pedro I não ter sido convidado para esse Te Deum: "Consta, que aí S. M. se entretera [sic] com alguns patriotas, e que, entre outras coisas, Ihes disse: 'não me convidaram, porém eu assim mesmo vim"' (JORNAL DO COMÉRCIO, 28/3/1831).

${ }^{20}$ Resgatemos aqui um outro texto de época, pouco conhecido, do The times, que, de forma bastante sucinta, descreve com alguns detalhes a insustentável situação política do Imperador, instaurada após a troca do gabinete ministerial, em 5 de abril. Trata-se da primeira notícia publicada no jornal Iondrino, relativa à Abdicação: "Dom Pedro procedeu, no dia 5 de abril, à designação de um novo Ministério (...). Essas nomeações foram tão impopulares que, nem bem se tornaram conhecidas, os descontentes promoveram uma série de desordens públicas e atacaram o palácio. Dom Pedro recorreu ao exército para protegê-lo e ordenou aos soldados que atirassem nos revoltosos; mas quase todos eles, com exceção de um pequeno grupo, decidiram depor as armas. Vendo-se abandonado, nada restou ao Imperador senão fugir"; tradução nossa de: "Don Pedro proceeded, on the 5th of April, to appoint a new Ministry (...). These appointments were so unpopular, that as soon as they were known the disaffected broke out into open tumults, and attacked the palace. Don Pedro called on the military to protect him, and gave orders to fire on the people; but with the exception of a very small number, the whole of them laid down their arms. Thus deserted, nothing remained for the Emperor but Flight" (THE TIMES, 10/06/1831).

${ }^{21}$ O ministério "incolor" de 19 de março, assim apelidado por Caio Prado Jr., já teria sido, por si só, uma erro político de Dom Pedro, ao buscar na sua composição um governo conciliatório, logo após os tumultos de 13 e 14 de março. "Não o conseguindo, apela para elementos neutros, suspeitos a ambos os partidos. Este ministério incolor só contribuiu para agravar a situação, que aceleradamente marchava para um desfecho revolucionário" (PRADO JR., Caio. Evolução política do Brasil e outros estudos. São Paulo: 
Tal atitude suicida de Dom Pedro I teria sido motivada pela suposta conivência dos então Ministros, Manuel José de Sousa França, da Justiça, e José Manuel de Morais, da Guerra, com as arruaças que ocorreram no dia 4 de abril, enquanto o monarca, "na sua melomania" - como salientou Tarquínio de Souza ${ }^{22}$ - apreciava um concerto musical em São Cristóvão, em companhia de sua filha aniversariante, a Rainha de jure de Portugal, bem como dos principais membros da elite "portuguesa" ${ }^{23}$.

Mas se a partida do agora Duque de Bragança na corveta Volage animou ainda mais o debate e a luta política nos anos subseqüentes, fazendo consumar-se no Império aquilo que Justiniano José da Rocha chamaria, ironicamente, anos mais tarde, de "obra da democracia" ${ }^{24}$, levou, por outro lado, parte importante da atividade musical ${ }^{25}$ no Rio de Janeiro, que até então só experimentara progressos, a uma rápida e duradoura decadência,

Brasiliense, 1969, p. 58).

${ }^{22}$ SOUZA, Octavio Tarquinio. Op. cit., v. 4, t. 3, p. 914.

23 Formada principalmente por grandes negociantes, naturais de Portugal ou brasileiros de curta ascendência lusa, foi, essa elite, a mais fiel aliada política de Dom Pedro I desde a saída dos Andradas do governo, em julho de 1823. Alimentando, de forma bajulatória, as veleidades absolutistas do Imperador e as dignidades da Coroa, visou a obter, em troca disso, além de títulos de nobreza e cargos na administração, forças políticas para realargar seus espaços na economia do país, cada vez mais disputados pelos estrangeiros e natos. Seu desejo profundo de ver o Brasil voltar à sua antiga condição de colônia, garantindo-se, assim, a manutenção do tráfico negreiro - já tão combatido pelos interesses industriais ingleses - e a extinção da concorrência comercial estrangeira, se viu, no entanto, adiado com a Abdicação e totalmente extinto com a morte de Dom Pedro I, em 1834.

24 "Assim achou-se consumada a obra da democracia; ela por toda a parte, mais ou menos diretamente intervindo em tudo, tudo subordinando: o poder legislativo era todo seu; o judicial o não era menos; pois tinha o júri, e os juízes de paz, e os promotores, e os juízes de órfãos e os municipais. Não lhe escapava o poder executivo; pois tinha o regente, filho imediato da mesma eleição que os deputados, com a diferença única de computaremse-lhe todos os votos de todos os colégios de todas as províncias; pois tinha esse regente limitadíssimas atribuições; pois os seus delegados imediatos, os presidentes de província, estavam subordinados às assembléias provinciais, que enfim eram as que elegiam os seus substitutos. Não havia exército, e a força armada que existia era a cidade inteira, obedecendo temporariamente a chefes da sua escolha" (ROCHA, Justiniano José da. Ação; reação; transação. Rio de Janeiro: Tip. Imp. e Const. de J. Villeneuve, 1855, p. 26).

${ }^{25}$ É preciso deixar claro, embora o seccionamento proposto a seguir esteja longe de ser absoluto e crie controvérsias, que estamos aqui nos referindo a uma "atividade musical" relativa a uma música "erudita", que tenha sido registrada em partitura e feita para ser realizada por executantes treinados, sobretudo em ambientes fechados, como igrejas, teatros ou salões especialmente preparados para a sua audição ou dança. Não será objeto de nossa atenção a música rueira, improvisada, realizada com instrumentos rústicos, dita, muitas vezes, "popular", ou, ainda, "folclórica". 
tipificada pelo desfalecimento, ainda em 1831, das duas principais instituições musicais cariocas ${ }^{26}$ de então: a Capela Imperial e a Companhia Italiana do Teatro Constitucional Fluminense, nome pelo qual passaria a chamar-se, a partir de junho de 1831, o Imperial Teatro de São Pedro de Alcântara.

Em frontal contraposição às temporadas de ópera expressivamente movimentadas que o Rio de Janeiro desfrutou até os últimos bruxuleios do primeiro reinado, de setembro de 1831 a janeiro de 1844 , ou seja, por mais de doze anos, não se registrou nessa cidade a apresentação de nenhum espetáculo lírico completo. Outrossim, cerca de dois meses após a abdicação de Dom Pedro I, o Ministério dos Negócios da Justiça e Eclesiásticos cortou em mais da metade o efetivo de músicos da Capela Imperial, interrompendo uma fase brilhante desse conjunto de música sacra, até então comparado aos melhores do Antigo Continente. Tal situação permaneceria praticamente inalterada até meados de 1843, quando, ao tempo do consórcio de Dom Pedro II e Dona Teresa Cristina, reestruturou-se o efetivo musical em moldes próximos ao que era antes.

Nenhuma dúvida paira quanto ao fato de que essa depressão musical repentina e ao mesmo tempo duradoura dos anos 1831-1843 tenha uma íntima relação com o interregno de 1831-1840 e com a inauguração, no Império do Brasil, após a Abdicação, de uma nova conjuntura, a qual, especialmente no Rio de Janeiro, se manifestou de forma rápida e eficaz, estabelecendo paradigmas políticos, econômicos e sociais bastante singulares em relação aos dos tempos precedentes. Não se questiona também que, em meio a essas novas circunstâncias, dispositivos

${ }^{26}$ Segundo o depoimento do aventureiro alemão Carl Schlichthorst, que esteve no Brasil entre 1825 e 1826, o adjetivo "carioca" já era comumente usado àquela época com o sentido de designar coisas ou pessoas pertencentes ou relativas à cidade do Rio de Janeiro (SCHLICHTHORST, Carl. Rio de Janeiro wie es ist. Beiträge zur Tages und Sitten Geschichte der Hauptstadt von Brasilien mit vorzüglicher Rücksicht auf die Lage des dortigen deutschen Militairs. Hannover: Hahn, 1829, p. 54). Apesar de o termo "fluminense", em certas épocas, inclusive a estudada, também se prestasse ao mesmo serviço, optamos por utilizar, neste trabalho - com esse mesmo sentido de "designar coisas ou pessoas pertencentes ou relativas à cidade do Rio de Janeiro" - , apenas o adjetivo "carioca", por tratar-se do atualmente utilizado e, assim, dar menos margem a dúvidas, já que, hoje, 
anteriormente praticados com vista à produção de aparatosas obras musicais, como óperas e missas cantadas, deixaram de funcionar com o vigor de antes, seja pela arrefecimento dos fatores que até então os favoreciam, seja pelo progresso dos que, a partir daí, passaram a estorvá-los.

Porém, nenhum estudo histórico ou musicológico foi realizado até hoje buscando, nesse enleio de acontecimentos, estabelecer, com precisão, que fatores foram esses e quais deles mais teriam contribuído para o fulminante declínio da ópera e da música sacra na capital do Império, em 1831. Igualmente, jamais se explicou por que razão tantos anos - incluindo-se alguns já do segundo reinado - foram necessários para que o Rio de Janeiro voltasse a ter uma atividade musical similar à que tinha antes da partida de Dom Pedro I. Em vista disso, lançamos nosso principal desafio, qual seja, procurar todas as vinculações possíveis - políticas, sociais, econômicas entre essa longa crise musical e a conjuntura pós-Abdicação, e determinar ações e atores que não apenas justifiquem a rápida depressão das duas principais instituições musicais da corte como a persistente inércia desse estado decadencial até a sua resolução, entre os anos de 1843 e 1844.

Tal objetivo descortina, antes de mais nada, um mergulho em documentos da época, pois excetuando-se raros trabalhos, como o de Maurício Monteiro ${ }^{27}$, a literatura voltada ao estudo histórico da música no Brasil ainda se tem limitado à descrição e análise evolutiva de obras e estilos musicais ou à mera narrativa biográfica de músicos - ainda assim, somente aquilo que se julgou, historicamente, relevante, do ponto de vista estético ${ }^{28}$

\footnotetext{
"fluminense" se relaciona mais ao Estado do Rio de Janeiro como um todo.

${ }_{27}$ MONTEIRO, Maurício Mário. A construção do gosto. Música e sociedade no Brasil no tempo de D. João VI (1808-1821). São Paulo, 2001. Tese (Doutorado) FFLCH/USP.

${ }^{28}$ Tal adjetivo refere-se à "Estética", ramo da Filosofia tradicionalmente entendido como estudo racional do "belo" - Baumgarten, como afirmou Hegel em sua Ästhetik, teria sido o primeiro a utilizar tal palavra nessa acepção, por volta de 1750 - e que tenta estabelecer para tal atributo uma regra geral. Sabemos que, apesar dos esforços de um sem-número de filósofos, e embora o "belo" tenha sido sempre universalmente aceito e conceituado como "aquilo que apraz, agrada" - ou ainda "o que alcançou a perfeição, ou seja, que correspondeu precisamente a um fim determinado" - como pensou Hirt - tudo ainda dependerá do "gosto" sui generis, do sentido pelo qual cada indivíduo percebe as coisas à sua própria maneira como "belas", ou não (Cf. HEGEL, Georg Wilhelm Friedrich. Estética: a idéia e o ideal. Tradução de Orlando Vitorino. São Paulo: Nova Cultural, 1999).
} 
ou técnico ${ }^{29}$. É incipiente a nossa produção bibliográfica - e não somente em relação à música carioca - que acompanha os moldes de alguns importantes estudos internacionais, os quais, paulatinamente, têm contribuído para a edificação de uma história mais geral da música ${ }^{30}$.

Perplexo diante da extraordinária tarefa de se definir o belo, Diderot lançou tal questão em seu Traité du beau: "Comment se fait-il que tous les hommes soient d'accord qu'il y a un beau, qu'il y en ait tant entre eux qui le sentent vivement où il est, et que si peu sachent ce que c'est?" (DIDEROT, Denis. Euvres - Tome IV. Paris: Robert Laffont, 1996, p. 81). Ou seja, "como é possível todos concordarem que o belo existe, muitos o sentirem com grande intensidade e tão poucos saberem o que realmente ele é?".

${ }^{29}$ O primeiro caso - a prática de idéias de caráter estético - é mais comum quando o receptor é leigo e contemplará a realização artística apenas por intermédio de seu "gosto". Na hipótese de a arte ser destinada a connaisseurs, ela, decerto, não terá uma intenção meramente "estética". Ela terá também um propósito "técnico", no sentido de provocar no receptor - especializado - o reconhecimento de tal obra de arte como "habilidade superior" ou "inovadora" em relação a um conjunto de princípios fundamentais, teóricos, até então acumulados para a prática de tal atividade. Nada impede, no entanto, que uma obra musical contenha ambas as qualidades, tanto estéticas, quanto técnicas.

${ }^{30} \mathrm{Em} \mathrm{1938,} \mathrm{em} \mathrm{artigo} \mathrm{intitulado} \mathrm{Music} \mathrm{and} \mathrm{society,} \mathrm{o} \mathrm{compositor} \mathrm{norte-americano}$ Elie Siegmeister se dizia abismado ao constatar que o estudo do papel da música na sociedade e das influências das forças sociais no desenvolvimento musical estava ainda em um estágio tão insignificante: "It is astonishing that at this late date the place of music in society and the influence of social forces on its development have been so little studied. Social analysis has in recent years cast new light on the meaning and development of literature and painting, the sciences, technology, religion and almost every aspect of human culture, yet towards an interpretation of the functions of music in society and its relation to the life of its time, little more than a beginning has been made" (SIEGMEISTER, Elie. Music and society. New York: Critics Group Press, 1938, p. 1). Pouco mais de 10 anos depois, em 1951, ao prefaciar a Sociologie de la musique, de Marcel Belvianes, o professor do Conservatório de Paris, Marcel Samuel-Rousseau, também atentava para o fato de que as numerosas histórias da música - embora estudassem a influência do grupo sobre as estruturas musicais e vice-versa - não tinham por objeto essencial o valor social da música: "(...) les nombreuses histoires de la musique — bien qu'elles étudient nécessairement l'influence du groupe sur les structures musicales et l'influence de la musique sur les structures du groupe - n'ont pas pour objet essentiel de mettre en relief particulièrement la valeur sociale de la musique" (BELVIANES, Marcel. Sociologie de la musique. Paris: Payot, 1951, p. 4). Como considerou o sociólogo, musicólogo e professor de belas-artes da Universidade de Colônia, Alphons Silbermann, em sua Wovon lebt die Musik? Die Prinzipien der Musiksoziologie (1957), foi por essa época que surgiram, em conexão com outros métodos de abordagem musical, algumas "novas" visões históricas, como a importância da história social e a conexão entre sociologia e história: "In connection with methods of approach to music, we have considered some new views of history, the importance of social history and the relationship between sociology and history". (SILBERMANN, Alphons. The sociology of music. Tradução do alemão para o inglês de Corbet Stewart. London: Routledge \& Kegan Paul, 1963, p. 51). Dado o pequeno avanço nas décadas subseqüentes, o historiador Henry Raynor ainda ressaltava, em 1972, o aspecto inovador de seu trabalho afirmando ser ele "um esforço para preencher parte da lacuna entre a história normal e necessária da música, que trata do desenvolvimento dos estilos musicais, e a história geral do mundo no qual os compositores desempenharam a sua função" (RAYNOR, Henry. História social da música: da Idade Média a Beethoven. Tradução de Nathanael C. Caixeiro. Rio de Janeiro: Guanabara, 1986, p. 7). Depois de Raynor, destaca-se a volumosa Histoire de la musique occidentale, organizada, em 1983, 
No afã de investigar, quase que exclusivamente, autores e obras notáveis, e dada a aparente irrelevância desses fenômenos no corte temporal proposto (1831-1844), a historiografia musical brasileira pouquíssimo se ateve, até hoje, a esse período. Concorreu apenas em lembrar-se, particularmente, de uma única personalidade: Francisco Manuel da Silva. E não o fez senão por duas razões específicas. Primeiramente, pelo fato de tratar-se do autor do nosso Hino nacional; e em segundo lugar, por ter sido ele considerado o principal idealizador do Imperial Conservatório de Música, instituição fundada no Rio de Janeiro em 1848, que, por sua vez, atrairia Antônio Carlos Gomes, do interior paulista para a capital do Império, doze anos mais tarde, promovendo o seu extraordinário desenvolvimento artístico entre 1860 e 1863, complementado posteriormente na Itália. Daí Mário de Andrade destacar, de forma tão incisiva, em 1939, a importância de Francisco Manuel para este período da vida musical brasileira:

\begin{abstract}
É então que surge a maior figura musical que o Brasil produziu até agora, e que com o seu fecundo gênio vinha dar bases mais sólidas a todo esse castelo fundado na corrediça areia do litoral, Francisco Manuel da Silva. É este o grande nome que a música brasileira apresenta em suas vicissitudes sociais. Dotado de uma visão prática genial que o levava a agir contra quaisquer impedimentos, este é o criador que funda a nossa técnica musical definitivamente. Viola o domínio da epidêmica iniciativa particular em que todo o nosso ensino musical se dispersara até então, concentrando nas mãos permanentes do Governo a educação técnica do
\end{abstract}

por Jean e Brigitte Massin, em cujo prefácio encontramos clara a preocupação de tornar inseparáveis a história da música e a história geral: "Tal como a da arquitetura, das artes plásticas ou da literatura, a história da música é indissociável da história geral. Da história política e, mais ainda, da socioeconômica, cultural e religiosa (...). Assim, se ignorássemos tudo o que diz respeito ao luteranismo, um certo aspecto musical de Bach nos escaparia; desconhecendo tudo sobre a ascensão da burguesia no fim do século XVIII, a nova linguagem musical de Haydn, Mozart, Beethoven e Schubert se nos tornaria parcialmente inexplicável; (...). Demos, portanto, muita importância ao esclarecimento das sucessivas situações sócio-históricas da música através dos séculos..." (MASSIN, Jean (org.). História da música ocidental. Tradução de Ângela Ramalho Viana, Carlos Sussekind e Maria Teresa Resende Costa. Rio de Janeiro: Nova Fronteira, 1997, p. xxi-xxii). 
músico brasileiro. É o Conservatório (...). E o resultado de tudo isso foi Carlos Gomes ${ }^{31}$.

Em 1942, foi a vez de Renato Almeida, fazendo sair à luz a segunda edição "correta e aumentada" de sua História da música brasileira, dar ao compositor carioca o título de um capítulo - "O Período Francisco Manuel" -, destacando-o como o exclusivo mantenedor do "patrimônio musical brasileiro" entre a volta de Dom João VI a Portugal e o surgimento de Carlos Gomes:

Depois do tempo de D. João VI, projetou-se larga sombra sobre a música brasileira até o aparecimento de Carlos Gomes. Neste período, só uma figura velava pela conservação do nosso patrimônio musical. Era Francisco Manuel da Silva ${ }^{32}$.

Mais adiante, no final da década de 1960, Ayres de Andrade publicaria a mais minuciosa pesquisa histórica realizada até hoje sobre a vida musical carioca da primeira metade do século XIX. Fê-la, no entanto, sob a órbita desse mesmo músico, deixando de preocupar-se, efetivamente, com o quadro histórico geral. O título da obra: Francisco Manuel da Silva e seu tempo ${ }^{33}$.

Repitamos, pois, a mesma crítica à nossa historiografia musical: posta quase sempre em um patamar dissociado da história geral, estabelecendo apenas como fatos merecedores de valoração, a vida do músico autor ${ }^{34}$ e a

${ }^{31}$ ANDRADE, Mário de. Aspectos da música brasileira. São Paulo: Martins, 1975, p. 26.

${ }^{32}$ ALMEIDA, Renato. História da música brasileira. Rio de Janeiro: Briguiet, 1942, p. 337. Note-se que o musicólogo baiano também amplia aquilo que denominamos "depressão" (1831-1843) para um período muito maior, de praticamente quarenta anos, incluindo, naquilo que ele preferiu chamar de "larga sombra", épocas ricas em atividade musical, como o primeiro reinado $(1822-1831)$ e parte das duas primeiras décadas do segundo reinado (1844-1861).

${ }_{33}$ ANDRADE, Ayres de. Francisco Manuel da Silva e seu tempo. 1808-1865. Uma fase do passado musical do Rio de janeiro à luz de novos documentos. Rio de Janeiro: Tempo brasileiro, 1967.

${ }^{34}$ Note-se que o autor é, muitas vezes, visto pelos historiadores de forma romantizada, como um gênio intocável, como um habitante de uma "torre de marfim", ou 
obra de arte musical ${ }^{35}$, não se preocupou em entender que essa prática artística, como parte dos hábitos de uma época, jamais se constituiu apenas em atividade humana isolada, individual ou profissional, mas em um dispositivo cultural, processador de aspectos da vida social relacionados à transmissão de conhecimentos que constituem aperfeiçoamento material ou moral - conhecimentos esses, em um dado momento, patrimônio próprio de indivíduos ou grupos específicos - e que, uma vez propalados entre os demais indivíduos da sociedade - muitas vezes por empreendimento governamental ou por interesses particulares de indivíduos e grupos que, via de regra, lutam para se impor no corpo social, tentando estabelecer para si um grau de distinção ou de prestígio —, resultaram, de um modo geral, no aprimoramento de padrões de comportamento "civilizados" 36 . Destarte, tão necessário quanto conhecer o valor estético e técnico das obras e a biografia de seus autores e executantes, impõe-se-nos saber também como se processou todo o métier musical, desde a sua concepção até a sua plena

seja, alguém absorto, alheio ao seu meio social, enquanto, na verdade, dependendo do momento histórico, não passará de um empregado subalterno, pago para fazer música segundo o gosto de seus patrões.

${ }_{35} \mathrm{Da}$ mesma forma, a obra musical é, também, muitas vezes, entendida como criação meramente abstrata e formal, como que dotada de um sentido próprio e afastado das idéias intelectuais gerais. Sobre essas duas últimas questões, o filósofo austríaco Ernst Fischer (1899-1972) bem as colocou em termos em Von der Notwendigkeit der Kunst: “... a experiência de um compositor nunca é puramente musical, mas pessoal e social, (...) pretender ouvir na música "apenas a música", pretender ignorar aquilo que o compositor "elevou" à música ou subestimá-lo, é um procedimento de banalidade ainda mais crassa do que se dispor a analisar uma obra de arte em termos puramente sociológicos, sem atentar na sua qualidade e na sua forma" (FISCHER, Ernst. A necessidade da arte. Tradução de Leandro Konder. Rio de Janeiro: Zahar Editores, 1966, p. 207).

${ }^{36}$ Foi durante o Antigo Regime e no âmbito da sociedade de corte européia, sobretudo a francesa, que se firmaram os conceitos de "civilidade", ou os padrões de comportamento conhecidos como "civilizados". Tais normas de convivência humana surgiram com o intuito de criar uma distinção entre a nobreza e as demais classes sociais - sobretudo as burguesias - desqualificando essas últimas quanto ao acesso à corte e aos privilégios políticos. No entanto, a publicação de diversos "tratados de civilidade", a influência da religião, o poderio econômico burguês e ainda a própria ação esclarecida dos monarcas, não tardaram a permitir que tais códigos de conduta fossem imitados, embora a nobreza tenha sempre tentado resguardá-los criando diferenciações de costumes cada vez mais artificiais. Inevitável, no entanto, esse processo civilizador - ou cultural - de transmissão social dos padrões de civilidade, que teriam legitimado os privilégios das nobrezas durante os século XVI e XVII, acabou, nos séculos XVIII e XIX, tornando-se um verdadeiro passaporte para que as burguesias adentrassem em espaço sociais e políticos antes não permitidos. Sobre esse assunto, a obra referencial é Über den Prozeß der Zivilisation (1939) do sociólogo Norbert Elias (1897-1990), traduzido para o português como 
realização social.

Empregaremos, pois, nossas forças na tentativa de construirmos o "capítulo inicial" de uma "nova história da música brasileira" ou de uma "história geral da música brasileira", procurando promover uma investigação, a mais ampla possível, dos fatores políticos, econômicos e sociais que propiciaram - ou não —, num dado momento, a utilização dessa arte como atividade cultural, ou seja, como um conjunto de meios que permitiu - ou não - a uma coletividade, compartilhar, passiva ou criticamente ${ }^{37}$, de valores intelectuais intrínsecos - gostos, habilidades do ofício - e extrínsecos a essa arte - demais códigos de conduta, crenças, ideologias etc ${ }^{38}$.

O processo civilizador (Rio de Janeiro: Jorge Zahar, 1990).

37 Note-se que não estamos aqui defendendo a idéia de que a cultura seja um dispositivo elitista, no sentido de apenas propagar valores humanos de cima para baixo, ou seja, de indivíduos privilegiados intelectualmente ou espiritualmente a uma massa desconhecedora de tais valores intelectuais ou espirituais. Ao procurarmos estudar a realização social da música por meio de mecanismos culturais, imaginamos, ao contrário, um ciclo, no qual, primeiramente, os valores artísticos disseminam-se para a massa mediante ideais individuais já socializados, uma vez que o artista está plenamente inserido em um meio social; e em segundo lugar, imaginando que esses valores sempre retornam criticamente dessa mesma coletividade para quem os idealizou, podendo esse último, por conta de uma repercussão pública negativa, rever, mudar, enfim, aperfeiçoar ou simplificar as idéias contidas em sua obra de arte. Resumindo nosso ideal de cultura, citemos o sociólogo tcheco Inocenc Arnošt Bláha (1878-1960), para quem, ela é também um "esforço de criação, de crítica e de aperfeiçoamento como de difusão e de realização de ideais e valores espirituais" (Apud AZEVEDO, Fernando de. A cultura brasileira. Brasília: Editora Universidade de Brasília, 1963, p. 38).

${ }^{38}$ A princípio - ou intrinsecamente, como já dissemos -, a música exprime apenas valores de caráter estético ou técnico. Mas, apesar de ser muitas vezes considerada o mais hermético, menos direto e mais sofisticado meio de expressão criado pelo homem -, essa arte carregará, principalmente quando vinculada a outras formas de manifestação artística - literatura, cena, dança - além do gosto ou de uma habilidade ímpar, outras idéias não puramente artísticas, como valores significativos de relações que muitas vezes conferem unidade a, por exemplo, um partido político ou uma religião. Vejamos que um mero título ou dedicatória já bastariam para caracterizarmos, por exemplo, "propósitos ideológicos" em uma obra musical (Vide a Sinfonia Bonaparte, que se tornou ainda mais ideológica ao ser eternizada como Heróica, "per celebrare la morte d'un eroe", ou seja, para "enterrar" Napoleão como herói republicano de Beethoven). Já, dos gêneros musicais "híbridos" com outras artes, a ópera certamente carregou o maior número de intenções não artísticas, especialmente durante a chamada "Era das Revoluções", como denominou, Eric Hobsbawm, o período 1789-1848. Sobre tal tema, esse historiador fez o seguinte comentário: "Mesmo a arte aparentemente menos política, a música, teve as mais fortes vinculações políticas. Este talvez tenha sido o único período na história em que as óperas eram escritas ou consideradas como manifestos políticos e armas revolucionárias" (HOBSBAWM, Eric J. A Era das Revoluções (1789 - 1848). Tradução de Maria Tereza Lopes Teixeira e Marcos Penchel. Rio de Janeiro: Paz e Terra, 1977, p. 278). 
Antes, porém, de nos defrontarmos com a decadência musical imediatamente posterior à renúncia de Dom Pedro I e toda essa sua problemática, impõe-nos demonstrar, comparativamente, que a vida musical no Rio de Janeiro, em tempos precedentes, tenha atingido, graças a um contexto histórico geral diferenciado em relação ao do período em foco, um grau mais elevado, tanto qualitativamente, como, sobretudo, quantitativamente. Dada a incompletude - ou mesmo, por vezes, a inexatidão - das obras que até o momento compõem a bibliografia específica ${ }^{39}$, julgamos por bem realizar, como parte primeira - e fundamental - deste trabalho, vasta sondagem de fontes de época - muitas ignoradas, outras tantas revisitadas criticamente - sobre a música no Rio de Janeiro anterior à abdicação de Dom Pedro I, incluindo-se aí uma tentativa de preenchermos uma outra lacuna da história cultural brasileira, qual seja, o do conhecimento da atividade musical carioca setecentista.

A análise de toda essa rica documentação nos permitirá sugerir que a produção de te-déuns e óperas no Rio de Janeiro esteve, até então - e desde muito antes do que se imaginava, ainda nos tempos dos Governadores e Vice-Reis -, assim como em Lisboa e em outras capitais européias, intimamente ligada ao simbolismo da figura do soberano absoluto - ao status do artifício maravilhoso e sagrado do poder real ${ }^{40}$-, e que a causa

${ }^{39}$ Em relação à música realizada no Rio de Janeiro antes da transferência da família real portuguesa (1808), pode-se dizer que a bibliografia é anódina. A respeito do período de 1808 até 1831 - e muito em função do estudo biográfico do principal compositor brasileiro do período, José Maurício Nunes Garcia —, Moreira de Azevedo e Araújo Porto Alegre publicaram os primeiros estudos, ainda no século XIX, ambos para a Revista do IHGB. No século $X X$, os trabalhos gerais de história da música brasileira de Guilherme Teodoro Pereira de Melo, Renato Almeida, Vincenzo Cernicchiaro, Luiz Heitor, Bruno Kiefer e Vasco Mariz pouco contribuíram para o aprofundamento desses conhecimentos. Destacam-se, desta época, as pesquisas mais minuciosas de Cleofe Person de Matos e, principalmente, de Ayres de Andrade. Nos últimos anos, os trabalhos acadêmicos de Maurício Monteiro (FFLCH/USP), Luiz Antônio Giron (ECA/USP), André Cardoso (Instituto Villa-Lobos/Uni-Rio) e Carlos Eduardo de Azevedo e Souza (UFF) avançaram na qualidade e variedade de fontes pesquisadas, sem, contudo, ultrapassarem os limites, tanto da crítica bibliográfica, como, no caso específico dos três últimos trabalhos, de uma abordagem histórica mais ampla.

40 Sobre esse tema, Lilia Schwarcz nos apresenta os principais trabalhos teóricos ao resenhar um dos mais recentes destes, A fabricação do rei: A construção da imagem 
fundamental da decadência dos dois mais importantes organismos musicais do Rio de Janeiro, durante anos 1831-1843, foi o concomitante enfraquecimento, após a partida de Dom Pedro I, dessa antiga expressão simbólica da monarquia, um ritual de exaltação do poder real que se efetivava na atividade social de corte, prática recuperada, em parte, entre 1840 e 1841, com a Maioridade e a Coroação, e, cabalmente, apenas em 1843, com o imperial consórcio de Dom Pedro II e Dona Teresa Cristina, época em que, justamente, as grandes obras musicais voltam a ser produzidas na Capela e no Teatro cariocas.

pública de Luís XIV (Rio de Janeiro, Jorge Zahar, 1994), de Peter Burke: "Dizia Montesquieu que 'o esplendor que envolve o rei é parte capital de sua própria pujança'. Mais do que um elogio, a consideração sintetiza particularidades da monarquia, ou mesmo, a dimensão simbólica presente em qualquer tipo de poder público e político. Com efeito, se é só a realeza que introduz o ritual em meio à sua lógica formal e no corpo da lei, pode-se dizer, porém, que não há sistema político que abra mão do aparato cênico, que se conforma tal qual um teatro; uma grande representação. Seguindo essas pistas, Marc Bloch, em ensaio pioneiro sobre as mentalidades, datado de 1924, analisava o fenômeno do toque real - o caráter maravilhoso dos reis taumaturgos -, demonstrando como se devia atentar antes para a expectativa coletiva do milagre, do que para o milagre em si. Norbert Elias, por outro lado, acentuou a importância da etiqueta no interior do Antigo Regime, encontrando uma lógica que nada tinha a ver com o mero adereço, ou com a idéia da existência de vogas aristocráticas luxuosas e sem sentido. $\mathrm{Na}$ verdade, não foram poucos os autores que, partindo de eixos e perspectivas diversas, destacaram a relevância do ritual na efetivação do poder, no caso monárquico. Autores como Starobinski, com a análise dos símbolos da realeza, Kantorovicz, com a demonstração do corpo duplo do rei, e ainda C. Geertz, que em Negara demonstrou como em Bali não existiam cisões entre realidade e representação, revelaram as potencialidades do tema e os vínculos entre lógica racional e lógica simbólica. Na verdade, essas e outras obras têm destacado, a partir de ângulos diversos, como as vestes, os objetos, a ostentação e os rituais próprios da monarquia são parte essencial desse regime, constituem sua representação pública e, no limite, garantem sua eficácia. Como diz o dito popular 'rei que é rei não perde a realeza' e se a perde - digamos assim - é cada vez menos rei" (SCHWARCZ, Lilia K. Moritz. A fabricação do rei. A construção da imagem pública de Luis XIV. Revista de Antropologia, São Paulo, FFLCH/USP, v. 43, n. 1, p. 257-258, 2000). Na verdade, eis o dito popular na sua forma mais conhecida: "quem é rei não perde a majestade". 


\title{
PARTE I - REGNUM
}

\section{CAPÍTULO I - Reminiscências musicais dos áureos tempos}

\begin{abstract}
A música, pintura, e escultura também se conheciam com perfeição; principalmente a primeira, que era quase geral, se considerarmos a imitação unicamente por gênio, e só por uma curiosidade, e perfeita atenção ao que se ouvia, e via; e freqüentada por muitos, olhando os preceitos da arte. Portanto havia alguns compositores hábeis, chamados vulgarmente contrapontistas, e muitos entregues à invenção; e eram em grande número os executores de que alguns se distinguiam, e muito se agradavam ${ }^{41}$.
\end{abstract}

Muito em conseqüência da ordem de se proibir o funcionamento de tipografias - formalmente, de 1747 a 1808 —, poucos vestígios nos restaram sobre a música realizada no Brasil colonial. Para termos uma idéia da quantidade de documentos relativos à atividade musical de que poderíamos dispor hoje se a imprensa tivesse aqui funcionado nesses tempos, basta lembrar que um dos raríssimos textos impressos no Rio de Janeiro colonial, escrito pelo Juiz de Fora Luiz Antônio Rosado da Cunha, continha informações musicais, sendo hoje a mais antiga notícia que conhecemos a respeito de uma encenação operística nessa cidade:

E por ser tão estimável esta chegada, em o dia 2 do mesmo mês de dezembro [de 1746], se preparou e deu início a uma noite ática, na representação da Ópera intitulada Filinto

${ }^{41}$ Esta foi a definição dada pela História do Brasil desde 1807 até ao presente, atribuída a Pedro Ciríaco da Silva e Antônio Cândido Cordeiro Pinheiro Furtado, do estado da música realizada na capital do Brasil ao tempo da chegada da família real portuguesa (HISTÓRIA do Brasil desde 1807 até ao presente: originalmente composta em português para servir de continuação à que se publicou vertida do francês. Lisboa: Na Impressão de J. B. Morando, 1820, t. 8, p. 105-106). 
Exaltado, com excelente música, e os representantes especialmente vestidos, que no luzido das pedras, com que se guarneciam, mostravam o brilhante deste ato, ao qual assistiram Suas Excelências, Mestres de Campo, Ministros, Religiões, e Nobreza, convidados pelo Doutor Juiz de Fora, que pelo afeto e obrigação a sua Excelência Reverendíssima, lhe permitiu este obséquio claustral, sendo para os assistentes de contento este agradável passatempo ${ }^{42}$;

A quase total ausência de fontes impressas - salvo as adventícias e a escassez de fontes manuscritas que sirvam de base para a reconstituição da história musical brasileira desse período sempre dificultaram um estudo mais aprofundado do assunto. Silvio Romero, em sua História da literatura brasileira, já bem sintetizava, há um século, a principal problemática desse setor de nossa historiografia - a ausência de partituras impressas -, embora, mesmo que por suposição, admitisse a existência de tais fatos históricos:

Passemos à música. Fomos nela quase tão pródigos como na poesia. (...) Aparece hoje quase toda anônima. Não há uma província do Brasil que, desde os mais remotos tempos, não contasse um certo número de músicos notabilíssimos, cujas produções foram sempre apreciadíssimas. Não sendo publicadas, desapareceram sem deixar a lembrança dos nomes de seus autores. (...) Deles nada hoje se

\footnotetext{
${ }^{42}$ CUNHA, Luiz Antônio Rosado da. Relação da entrada que fez o excelentíssimo e reverendíssimo senhor D. Fr. Antônio do Desterro Malheiro, Bispo do Rio de Janeiro, em o primeiro dia deste presente ano de 1747 havendo sido seis anos Bispo do Reino de Angola, donde, por nomeação de Sua Majestade e Bula Pontifícia, foi promovido para esta Diocese, composta pelo Doutor Luiz Antônio Rosado da Cunha Juiz de Fora e Provedor dos defuntos e ausentes, Capelas e Resíduos do Rio de Janeiro. Rio de Janeiro: Na segunda Oficina de Antônio Isidoro da Fonseca, 1747, p. 7-8. A Divisão de Obras Raras da Biblioteca Nacional do Rio de Janeiro possui um exemplar dessa invulgar publicação sob o número $24,1,9 \mathrm{n}^{\circ}$ 21. Quanto à composição, trata-se de uma ópera portuguesa, em três atos, de autor por ora desconhecido: Filinto perseguido e exaltado. Seu libreto, consta do quarto tomo da coletânea Teatro Cômico Português, ou Coleção das operas portuguesas, que se representaram na Casa do Teatro Público do Bairro Alto e Mouraria (Lisboa: S. T. Ferreira, 1787-92, p. 3-99).
} 
sabe e nada se saberá, porque os pobres artistas nunca imprimiram suas obras, nem jamais isto Ihes passou pela cabeça ${ }^{43}$.

Quanto às partituras manuscritas, não restaram, igualmente, muitos exemplares, sobretudo no que diz respeito aos primeiros duzentos e cinqüenta anos de colonização. Essa estranha carência documental, que tanto intrigou estudiosos do passado, como Souza Viterbo (1845-1910) ${ }^{44}$, parece estar intimamente relacionada às profundas mudanças de estilo musical que se operaram em Portugal a partir do reinado de Dom João $\mathrm{V}$ (1706-1750), como sustenta o musicólogo português J. M. Bettencourt da Câmara:

\begin{abstract}
Com efeito, D. João $V$ parece operar, no curso da música portuguesa, uma viragem que, fazendo uso da linguagem da chamada Nova História, diríamos estrutural. Ao longo da segunda e terceira décadas do século XVIII morre uma grande época do nosso devir musical e outra se instaura, por ação de medidas devidas à decisão real, as quais prolongam as suas seqüelas pelo século XIX dentro. Instituições, concepções, formas musicais fenecem no espaço de alguns anos, substituídas por outras - uma revolução, efetivamente (...) Tudo parece confirmar que o protagonista desta revolução é o próprio rei que, alguns anos depois de investido como senhor absoluto, avança resolutamente para ela, impondo-a com um dirigismo cultural que a nossa música talvez não haja conhecido em nenhum outro momento da sua história ${ }^{45}$.
\end{abstract}

${ }^{43}$ ROMERO, Silvio. História da literatura brasileira. Rio de Janeiro: José Olympio, 1960 , t. 2, p. $529-530$.

44 "Que foi feito da música derramada nos Autos de Gil Vicente e dos seus sucessores, nas tragicomédias latinas dos jesuítas? Que é feito do acompanhamento de inúmeros vilancicos celebrados nas igrejas, sobretudo pelo Natal? Que mão misteriosa destruiu ou guarda a sete chaves tantas relíquias, que deviam ser hoje preciosas para o estudo da evolução musical entre nós?" (VITERBO, Francisco Marques de Souza. Subsídios para a história da música em Portugal: a música sagrada nas diversas terras do reino. Lisboa: Tipografia do Comércio, 1911, p. 3-4).

${ }^{45}$ CÂMARA, J. M. B. da. O lugar de D. João $V$ na História da música portuguesa. Revista ICALP, Lisboa: Instituto de Cultura e Língua Portuguesa, v. 16 e 17, p. 136-145, 
Uma vez superadas essas "formas musicais" - ou mesmo proibidas, como foi o caso dos vilancicos - , suas partituras acabaram desaparecendo pela falta de uso ${ }^{46}$.

Outra conjetura, bastante plausível, levada em consideração por Régis Duprat, vai ao encontro de um outro problema crucial, desta vez, teórico-musical:

\begin{abstract}
Aventou-se a hipótese de que o princípio do século [XVIII] teria conhecido mudanças profundas na notação musical, as quais teriam conduzido ao abandono da notação branca redonda e suas características inerentes (...). Adotou-se, então aquela escritura que se tomou a base do sistema notacional até nossos dias, vigente nas músicas convencionais. Abandonados os papéis da fase anterior, por desuso, teriam acabado por se perder ${ }^{47}$.
\end{abstract}

Exceção a essa regra são, justamente, as mais antigas partituras encontradas até hoje no Brasil. Descobertos no ano de 1984 em Moji das Cruzes pelo historiador Jaelson Trindade, os "manuscritos de Moji", como assim ficaram conhecidos - que, como papel obsoleto, servia de recheio para a capa e contracapa de couro de um livro de foral, aberto nessa vila em 1748 - , ainda preservam essa "notação branca redonda" e foram escritos, provavelmente, na década de 1720 ou 1730. Analisadas esteticamente por Régis Duprat, tais folhas levaram o musicólogo a concluir

\footnotetext{
jun./set. 1989.

${ }^{46}$ Segundo Ernesto Vieira, "Os vilancicos tiveram sua maior florescência no século $\mathrm{XVII}$, e todos os compositores da península que viveram nessa época escreveram música para eles; o catálogo da livraria de D. João IV menciona mais de dois mil vilancicos. Em 1723 foram absolutamente proibidos em Portugal, por ordem de D. João V..." (VIEIRA, Ernesto. Dicionário musical ornado com gravuras e exemplos de música. Lisboa: Tip. Lallemant, 1899, p. 523).

47 DUPRAT, Régis. A música sacra no Brasil colonial e imperial. Revista do Instituto do Patrimônio Histórico e Artístico Nacional. Rio de Janeiro: IPHAN, p. 247-248, 2001.
} 
... do perfeito uso dos recursos vocais em música de correta feitura polifônica extrapolando tais características para toda a música brasileira do período. Presente em Moji das Cruzes, pequena vila a poucos quilômetros da também pequena vila de São Paulo da época, tal música constitui amostra eloqüente do que se produziria nos grandes centros do Brasil colonial como Rio de Janeiro, Olinda e Recife e sobretudo, Salvador, onde recursos e demanda permitiam, sem dúvida, a manutenção de um culto religioso muito mais ostensivo e suntuário ${ }^{48}$.

Ou seja, aos poucos, os avanços dos trabalhos arquivísticos e historiográficos relativos à música aqui realizada durante o período colonial têm provado, como supunha Romero, que já havia, mesmo em centros urbanos pouco relevantes, como Moji das Cruzes, uma música, de certa forma "notável", sendo criada, executada e apreciada.

Apesar da alegada raridade das fontes, os últimos sessenta anos revelaram uma série de novas informações e fatos relativos à música aqui composta nessa época. Citemos, dentre os pesquisadores que voltaram seus olhos, nesse período, para a atividade e a criação musical durante os tempos coloniais, os mais relevantes: Régis Duprat, já referido, que, entre alguns trabalhos importantes, redescobriu André da Silva Gomes (1752-1844) ${ }^{49}$, português radicado em São Paulo durante mais de meio século; Jaime Diniz, que se ocupou sobremaneira com a música pernambucana, da qual se destaca a obra de Luiz Álvares Pinto (1719-1789) ${ }^{50}$; Cleofe Person de Matos, autora do mais completo estudo da vida e da obra do Padre José Maurício Nunes Garcia (1767-1830) ${ }^{51}$; e o norte-americano, Professor Emérito da

${ }^{48}$ Idem. Garimpo musical. São Paulo: Novas Metas, 1985, p. 16-17. Sobre essa descoberta, ver também TRINDADE, Jaelson; CASTAGNA, Paulo. Música pré-barroca lusoamericana: o grupo de Mogi das Cruzes. Revista Eletrônica de Musicologia. Curitiba: Departamento de Artes da UFPr, v. 1, n. 2, dezembro 1996. Disponível em:<www.rem.ufpr.br> Acesso em: 10 de dezembro de 2005.

49 DUPRAT, Régis. Música na Sé de São Paulo colonial. São Paulo: Paulus, 1995.

50 DINIZ, Jaime, Músicos pernambucanos do passado. Recife: Universidade Federal de Pernambuco, 1969.

${ }^{51}$ MATOS, Cleofe Person de. Catálogo temático das obras do padre José Maurício Nunes Garcia. Rio de Janeiro: Ministério da Educação e Cultura, 1970. 
Universidade da Califórnia, Robert Murrell Stevenson, que colecionou, nas suas diversas pesquisas sobre a música ibero-americana, tanto renascentista como barroca, algumas importantes fontes relativas ao Brasil ${ }^{52}$.

Ainda maior destaque devemos dar ao pioneiro dentre esses, o musicólogo teuto-uruguaio Francisco Curt Lange, que, em 1944, revolucionou a história da música no Brasil ao encontrar, em arquivos de Minas Gerais, documentos que possibilitaram, alguns anos depois, o resgate histórico de fatos musicais importantíssimos, entre os quais, obras de valor de autores completamente esquecidos como, por exemplo, José Joaquim Emerico Lobo de Mesquita (1746-1805).

Vale dizer que tal pioneirismo não resultou de um acaso feliz, de uma descoberta fortuita. Para supor a existência de uma vida musical florescente nas cidades mineiras setecentistas, Lange partiu de fatos históricos gerais que, a princípio, nada tinham a ver com música; porém, tangiam elementos socioeconômicos proporcionadores, por sua vez, dessas pretensas práticas musicais $^{53}$. O musicólogo teuto-uruguaio acreditava que em um novo ambiente de concentração populacional - antagonizando o movimento expansionista e ruralizante dos séculos XVI e XVII, das bandeiras e das grandes propriedades agrárias açucareiras - e bastante favorável, economicamente - onde tanto floresceram a arquitetura, a escultura, a pintura e a literatura - a música não poderia ter tido destino diferente, senão evoluir na mesma proporção dessas outras manifestações artísticas e culturais. E o resultado de sua posterior pesquisa de campo provou que ele estava realmente certo.

Essa exposição, em relevo, da bem-sucedida experiência de Curt Lange não é casual. Pelo contrário, servirá de pretexto para lançarmos aqui

52 STEVENSON, Robert Murrell. Renaissance and baroque musical sources in the Americas. Washington: General Secretariat, Organization of American States, 1970.

${ }^{53}$ Note-se aí, mais um pioneirismo de Curt Lange: o de pensar historicamente a música de uma forma mais ampla, como parte de um contexto histórico geral. Um de seus primeiros estudos em língua portuguesa, apresentando tais idéias e criticando veementemente a literatura musicológica contemporânea denomina-se Compositores na Capitania Geral das Minas Gerais, segunda metade do século XVIII (Marília: Estudos Históricos, 1965). 
conjectura análoga em relação à produção musical do Rio de Janeiro setecentista, diga-se de passagem, tão pouco estudada até o presente momento ${ }^{54}$. Para termos uma idéia da escassez bibliográfica relativa a esse tema, tomemos, por exemplo, a História da música no Brasil, de Vasco Mariz, em sua quinta edição, ampliada, atualizada e publicada no ano 2000. O musicólogo, membro da Academia Brasileira de Música, gasta apenas uma frase - note-se, ainda, bastante contraditória - para descrever a música carioca do século XVIII:

As atividades musicais no Rio de Janeiro eram modestas, antes de se tornar a capital do ViceReinado, embora já tivesse dois teatros e a atuação das irmandades ${ }^{55}$.

É provável que essa falta de interesse dos musicólogos em perscrutar o passado musical do Rio setecentista tenha origem no fato de a hipótese anteriormente aventada contrariar parte importante de nossa historiografia geral, que, de certa forma, firmou a vida social e cultural carioca anterior a vinda da família real portuguesa, em 1808, como acanhada, e, até, muitas vezes, secundária, em relação à de outras cidades brasileiras de então, como a primeira capital, Salvador, e as mais relevantes urbes mineiras, fundadas após a descoberta do ouro, na última década do século XVII.

${ }^{54} \mathrm{O}$ próprio Curt Lange já conjeturara a respeito, em seu artigo "A música erudita na Regência e no Império", que consta da História geral da civilização brasileira, organizada por Sérgio Buarque de Holanda: "A lacuna maior consiste no desconhecimento do período colonial. Para os historiadores, a acidental radicação temporária de D. João VI e da sua corte no Brasil (1808-1822) representou um primeiro e grande benefício para a deficiente vida musical não só carioca como brasileira em geral. Emerge deste páramo uma figura singular, de contornos notáveis: o Padre José Maurício Nunes Garcia, considerado a primeira coluna do edifício sonoro do Brasil. Não poderia nunca ter atingido tais alturas um gênio solitário, circundado por músicos medíocres e um meio musical pobre. $O$ raro talento deste homem, já madurecido quando se começou a organizar a Capela Real em 1808, e a incentivar-se ainda mais a atividade operística, não podia ser apenas resultado dum esforço autodidata, produto dum ambiente raquítico, quando ele teve oportunidade de levar à estréia virtualmente todas as obras da sua autoria até aquele ano, fosse por encomenda, fosse por iniciativa pessoal. No Rio de Janeiro anterior a 1800 deve ter existido uma vida musical superior àquela mísera porção de meia dúzia de nomes citados até hoje nas referências publicadas" (HOLANDA, Sérgio Buarque de (org.). Op. cit., v. 5, p. 369).

${ }_{55}$ MARIZ, Vasco. História da música no Brasil. Rio de Janeiro: Nova Fronteira, 2000 , p. 37. 
Oliveira Lima, por exemplo, sustentou, em D. João VI no Brasil, que, em 1808, ao tempo da chegada da família real portuguesa,

... era o Rio de Janeiro capital mais no nome do que de fato. A residência da corte foi que começou a bem acentuar-lhe a preeminência, foi que a consagrou como centro político, intelectual e mundano ${ }^{56}$.

A justificativa para tal atraso veio logo depois, com a assertiva de que, também, somente após a vinda da realeza lusitana se teria formado ali uma classe

... que é indispensável numa sociedade bem organizada sobre a base hodierna, de burgueses ricos, derivando seus proventos do comércio estrangeiro, o qual dantes também não existia, e familiarizando-se cada dia mais com as idéias e cousas da Europa ${ }^{57}$.

Arthur César Ferreira Reis, na História geral da civilização brasileira, também formou, patentemente, a opinião de que o Rio de Janeiro setecentista não passava de um passadouro de mercadorias:

O Rio de Janeiro era a porta de entrada para as Gerais. Toda uma imensa gama de artigos, de utilidades, dos mais bisonhos, da rotina diária, aos que registravam a existência de uma sociedade que dispunha do poder de compra e gastava com decisão. (...). É preciso recordar que todo esse imenso acervo de gêneros importados não tinha consumo imediato na própria capitania. O Rio de Janeiro servia de entreposto, insista-se. O consumo quase total realizavam-no as Gerais ${ }^{58}$.

\footnotetext{
${ }^{56}$ LIMA, Manuel de Oliveira. D. João VI no Brasil. Rio de Janeiro: Topbooks, 1996, p. 87.

${ }^{57}$ Ibidem, p. 87.

${ }^{58}$ HOLANDA, Sérgio Buarque de (org.). Op. cit., v. 4, p. 317. A já citada opinião de João Cruz Costa, também presente na História geral da civilização brasileira, é ainda mais
} 
Fernando de Azevedo, em A cultura brasileira, embora tenha concedido ao Rio de Janeiro setecentista qualidades, como "uma extensão considerável e as proporções de uma capital", foi outro que, da mesma forma, reduziu esta cidade a um plano secundário quando comparada às urbes mineiras, especialmente do ponto de vista do "aspecto urbano" e da "vida social":

Se o ouro que saiu das minas, permitiu a $D$. João $\mathrm{V}$ o luxo oriental de sua corte e deu a Portugal Queluz e Mafra, foi bastante o que ficou na colônia para o esplendor de Mariana, de São João Del-Rei e, sobretudo, da tortuosa Vila Rica, engrimpada no flanco das serras e em cujas igrejas, rutilantes de riquezas, pompeia o fausto da arte barroca, brilha o ouro batendo no ribete dos altares e se erguem as estátuas e os púlpitos de pedra-sabão lavrados pelo Aleijadinho. Mas, não são somente as cidades da região das "minas gerais" que se desenvolvem, produzindo-se, em conseqüência de mineração, o mais poderoso surto urbano do período colonial; deslocando-se o centro político do país, da Bahia para Rio de Janeiro em 1763, essa cidade, - escoadouro da opulenta produção das minas, e já agora a nova capital do Brasil, adquire um tal impulso que em 50 anos, de 1750 a 1800 , a sua população se multiplica, aumentando de 25 mil para $100 \mathrm{mil}$ habitantes; cresce notavelmente a sua importância econômica e, se não se aformoseia propriamente o seu aspecto urbano nem ganha brilho a sua vida social, já apresenta uma extensão considerável e as proporções de uma capital ${ }^{59} \ldots$

manifesta quanto ao fato do Rio de Janeiro não ter propiciado, até a chegada da corte e a abertura dos portos, qualquer entrada de objetos capazes de promover a cultura: “... nesse pobre cenário colonial teria lugar verdadeira febre de empreendimentos. (...) Criava-se tudo quanto até então nos havia sido recusado, tudo o que nos faltara, principalmente os utensílios, os instrumentos capazes de engendrar progressos no domínio da cultura intelectual" (Ibidem, v. 3, p. 181). 
Enfim, exempli gratia, outro que menosprezou peremptoriamente - e mais recentemente - a antiga capital do Estado do Brasil foi IImar Rohloff de Matos, em O tempo saquarema:

Do Rio de Janeiro (...) pode-se dizer que preservava as características de uma quase aldeia ao encerrar-se o período colonial. Ruas estreitas, escuras e sujas; não havia remoção de lixo, sistemas de esgotos, nenhuma noção de higiene pública. As casas eram térreas na maioria, ocupadas pelos próprios donos. Obras públicas, somente $o$ passeio público e $o$ aqueduto do [sic] Carioca. (...) Quase não havia festas, somente as religiosas ${ }^{60}$.

Foram, portanto, opiniões como estas - eloqüentes, consagradas, convergentes e, assim, tidas muitas vezes como ponto pacífico - que certamente desalentaram grande parte dos interessados na pesquisa histórica da atividade musical carioca a buscar, nas bibliotecas e nos arquivos, vestígios do contrário. Contudo, o pertinaz esforço da subseqüente pesquisa - visando colecionar o maior número possível de textos de época ${ }^{61}$, que tirem do desconhecimento informações mais detalhadas sobre a vida social, cultural e musical do Rio setecentista, bem como referências historiográficas produzidas pelos poucos pesquisadores que, de fato, se aprofundaram no estudo do local e do período em questão - revelará um Rio de Janeiro muito mais dinâmico ou muito menos modorrento do que até hoje se tem considerado.

Iniciamos, então, resgatando um trecho da História da América portuguesa, do fidalgo baiano Sebastião da Rocha Pita (1661-1738), oferecida a Dom João $\mathrm{V}$, e publicada, pela primeira vez, na capital do reino,

${ }^{59}$ AZEVEDO, Fernando de. Op. cit., p. 139-140.

${ }^{60}$ MATOS, IImar Rohloff de. O tempo saquarema. São Paulo: Hucitec, 2004, p. 42.

${ }^{61}$ Note-se, a tempo, que todos o textos de época aqui aduzidos, em grande parte transcritos diretamente de fontes manuscritas ou impressas originais, receberam cuidadosa atualização ortográfica, de modo a facilitar a sua leitura e compreensão. Tal observação vale também para os títulos dessas mesmas obras, quando apresentadas em referências bibliográficas. 
em 1730:

Em altura de vinte e três graus está a província do Rio de Janeiro, assim chamada, por ser no primeiro dia deste mês descoberta. É a sua cabeça a cidade de S. Sebastião, corte de todas as nossas praças do Sul: os prezados gêneros, que daquelas partes por mar e terra se lhe conduzem, a foram fazendo rica, e hoje se acha opulenta com os descobrimentos das copiosas minas de ouro, que daqueles dilatadíssimos sertões se leva àquela praça, como a feira deste precioso metal, e a buscá-lo se acham no seu porto inumeráveis embarcações de Portugal e do Brasil; (...) São soberbamente suntuosos os edifícios que a adornam, magníficos os templos, a Sé, os conventos da Companhia de Jesus, dos religiosos do Carmo, de $S$. Francisco e de $S$. Bento, este em magnificência e sítio superior aos outros. (...) É sumptuoso o [edifício] do Governador, e nobremente edificadas as casas dos moradores. Em todo o tempo teve graves famílias, que permanecem com a mesma nobreza. (...) Foi esta província do Rio de Janeiro cabeça de todas as da repartição do Sul, e de presente é um dos três governos em que está dividida aquela região; porque as enchentes de ouro (que, moderadas no princípio, a vieram depois com profusão imensa a inundar), atraindo inumerável cópia de gente de todo o Brasil e Portugal, com as suas fábricas e comércio a fizeram tão opulenta, que para poder reger-se, foi preciso partir-se; outro é o das Minas, de cujos descobrimentos e das fundações das suas vilas daremos em seu próprio lugar notícia; o último é o de S. Paulo.

O mais ilustre dos três é o do Rio de Janeiro, pela antigüidade, magnificência e trato político dos seus moradores, pela sua Casa da Moeda, que incessantemente labora, fazendo correr para todas as partes sólidas torrentes de oiro, reduzindo ao valor do cunho aquela áurea produção, que nas suas ricas fontes não tem mais cunho que o peso; e finalmente pela grandeza do seu porto, aonde vão numerosas frotas todos os anos a buscar os gêneros de 
todas aquelas praças, e levar as mercadorias que por eles trocam, as quais, despachadas no Rio de Janeiro, se encaminham às outras povoações do Sul ${ }^{62}$.

Embora esta obra já tenha sido pejorativamente definida como uma "novela histórica, recheada de descrições, fábulas e divagações" "63, outras referências contemporâneas a ela não a desmentem quanto à realidade de o Rio de Janeiro já ser, em princípios do século XVIII, graças ao pujante ciclo econômico do ouro, a principal praça de comércio brasileira, e, por conta disso, um centro urbano de grande opulência ${ }^{64}$. O autor anônimo do Journal d'un voyage sur les côtes d'Afrique et aux Indes d'Espagne, por exemplo, define o Rio de 1703 como "uma das mais consideráveis colônias, e talvez a melhor praça que os portugueses tenham no Brasil” 65 , retrato muito parecido com o pintado pelo corsário francês René Duguay-Trouin (1673-1736), que o revela, em suas Mémoires, como "uma das colônias mais ricas e mais poderosas do Brasil"66.

Correspondências dos Governadores da Capitania, tombadas no Arquivo Nacional (RJ), apresentam igualmente um Rio de Janeiro abastado,

${ }^{62}$ PITA, Sebastião da Rocha. História da América portuguesa desde o ano de mil e quinhentos do seu descobrimento, até o de mil e setecentos e vinte e quatro. Rio de Janeiro: W. M. Jackson, 1952, p. 93-99.

${ }^{63}$ ROMERO, Silvio. Op. cit., t. 2, p. 396-397.

${ }^{64}$ Dos poucos vestígios da opulência urbana do Rio de Janeiro do auge do ciclo do ouro mencionemos os atuais "Arcos da Lapa", antigo "Aqueduto da Carioca", talvez a mais vultosa obra de engenharia construída no Brasil durante o período colonial.

65 "Le Rio de Janeiro, dans l'état ou il est, est une des plus considérables Colonies, et peut-être la meilleure Place que les Portugais aient dans le Brésil. Mais il serait bien autre chose sans les Mines" (JOURNAL d'un voyage sur les côtes d'Afrique et aux Indes d'Espagne. Amsterdam: Paul Marret, 1723, p. 291).

66 "Ce fut dans ce voyage que je commençai à former une entreprise sur la colonie de Rio-Janeiro, l'une des plus riches et des plus puissantes du Brésil" (DUGUAY-TROUIN, René. Mémoires de monsieur Duguay-Trouin, lieutenant général des armées navales de France et commandeur de l'ordre royal \& militaire de Saint Louis. S.I., 1740, p. 157-158). Embora Duguay-Trouin não tenha sido tão enfático quanto o autor anônimo do Journal acima citado, parece bastante lógico acreditar que a escolha do Rio de Janeiro como alvo dos franceses tenha sido motivada pelo fato de esta cidade já ser, entre 1710 e 1711, a mais opulenta praça brasileira. Quanto às incursões em si (de Duclerc e Duguay-Trouin), segundo Fernando Novais, seriam elas resultado da política externa portuguesa em relação à sucessão espanhola, alinhada aos interesses ingleses e contrária aos franceses (NOVAIS, Fernando. Portugal e Brasil na crise do antigo sistema colonial. São Paulo: Hucitec, 2001, p. 39-40). 
já nas primeiras décadas do século XVIII. Antônio Brito de Menezes, Governador de 1717 a 1719, retrata esta cidade, em 1718, como "opulenta mais que todas as do Brasil, por razão do seu largo comércio, e serem os seus gêneros os mais preciosos" ${ }^{67}$. Já Luís Vahia Monteiro, que governou o Rio de 1725 a 1732, o compara a "um império, donde carrega todo o tráfico da América e descarrega todo o peso, e aviamento dos governos das Minas Gerais e São Paulo"68.

Estudos modernos sobre o abastecimento da Capitania das Minas Gerais nos Oitocentos também reforçam a veracidade dessas descrições de época. Apontam mais uma vez para o fato de que, já no primeiro lustro do século XVIII, essa vila, até então de importância apenas militar ${ }^{69}$, começou a transformar-se rapidamente, não apenas no principal porto pelo qual todos os preciosos minerais passariam a ser escoados para a Europa, mas também no mais importante centro de abastecimento das regiões mineiras.

Até o início desse século, além dos três caminhos pioneiros realizados pelos paulistas, o acesso às minas se deu através do chamado

${ }^{67}$ Apud SAMPAIO, Antônio Carlos Jucá de. Os homens de negócio do Rio de Janeiro e sua atuação nos quadros do império português. In: FRAGOSO, João, (org); BICALHO, Maria Fernanda, (org); GOUVÊA, Maria de Fátima, (org); O Antigo Regime nos trópicos: a dinâmica imperial portuguesa: (séculos XVI-XVIII). Rio de Janeiro: Civilização Brasileira, 2001, p. 75.

68 Ibidem, p. 75.

69 Segundo Corcino dos Santos, "O Rio de Janeiro, depois de sua fundação em 1565, não teve grande prosperidade. No século XVII, com a conquista da Baixada Fluminense e do Recôncavo da Guanabara pela lavoura e indústria açucareiras, cidade e porto experimentaram relativo progresso. Possuía o melhor ancoradouro de toda a costa brasileira, mas apesar disso não era grande o número de barcos que o procuravam (...) No final do século XVII, com a fundação da Colônia de Sacramento - cuja manutenção iria exigir de Portugal a concentração de recursos nessa direção - e a descoberta do ouro das Minas Gerais, houve uma completa transformação. Em primeiro lugar, sobressaiu a importância estratégica do porto do Rio de Janeiro, do ponto de vista militar. Aí eram preparadas e dai partiam as expedições contra os espanhóis. De outro lado, constituía um baluarte fortificado para a defesa contra possíveis invasões castelhanas" (SANTOS, Corcino Medeiros dos. Relações comerciais do Rio de Janeiro com Lisboa (1763-1808). Rio de Janeiro: Tempo Brasileiro, 1980, p. 15). José Honório Rodrigues também destaca a importância militar do Rio seiscentista: "Nesta fase, o Rio ajudou a luta pernambucana contra os holandeses; libertou sozinho Angola com seus recursos, sua gente, seus navios aqui construídos; (...) ajudou a conquista, a consolidação e formação do Rio Grande do Sul, no esforço de guerra, no abastecimento e, mais tarde, com os casais e as gentes, homens e mulheres, que o povoaram; nas lutas na Colônia do Sacramento, o esforço do Rio de Janeiro não é menor" (RODRIGUES, José Honório. Vida e história. São Paulo: Perspectiva, 1986 , p. 139). 
"caminho velho" (1697-1699), que ia, pela alta Serra do Mar, de Parati a Guaratinguetá, transpondo, posteriormente, a Mantiqueira. Existiu, também, um outro caminho, mais longo, que partia da Bahia e margeava o Rio São Francisco. Esse último era, apesar de muito mais longo, menos acidentado e mais fácil de transpor, permitindo-se a utilização de transporte animal durante um maior percurso. No entanto, por estratégia que visava a proteção e o controle das minas, a Coroa decretou, em 1701, o fechamento do caminho do São Francisco e o Rio de Janeiro beneficiou-se muito com isso, principalmente quando surgiu o "caminho novo" (1704-1705), saindo diretamente desse porto e encurtando sensivelmente 0 trajeto e o tempo gasto no percurso. Segundo Mafalda Zemella,

A abertura desse caminho representou uma verdadeira revolução no sistema de comunicações com as Gerais. Representava uma diminuição de distância e uma economia de tempo assombrosas. Enquanto o caminho paulista exigia dois meses para ser transposto, e no "caminho velho do Rio de Janeiro" gastavam-se quarenta e três dias, o "caminho novo" era vencido, antes de ser aberta a variante chamada de "terra firme", em apenas 17 dias. (...) Em pouco tempo ele se integrava na função econômica a que fora destinado; tornou-se a principal via do povoamento e do abastecimento das Gerais. Mercê da abertura do "caminho novo", o Rio de Janeiro converteuse na porta de entrada da corrente imigratória que se despejava nas minas, Para essa cidade, canalizou-se a maior parte do comércio que dantes se fazia entre as minas e São Paulo e entre as minas e a Bahia. Também o ouro colhido nas Gerais e o diamante do Distrito Diamantino escolheram o Rio de Janeiro para seu principal escoadouro. O "caminho novo" realizou um verdadeiro fenômeno de captura econômica, roubando aos caminhos paulistas e aos baianos os lucros auferidos pelo comércio com o pujantíssimo "hinterland" mineiro ${ }^{70}$.

\footnotetext{
${ }^{70}$ ZEMELLA, Mafalda P. O abastecimento da Capitania das Minas Gerais no século
} 
Nas minas, era, pois, possível auferir lucros de até $900 \%$ na venda de mercadorias $^{71}$, impressão que teve, em 1711, Plessir-Parseau, tripulante da esquadra de Duguay-Trouin:

Na verdade, é extraordinário o que se gasta nas minas. Tudo o que vale uma moeda de ouro no Rio de Janeiro, nas minas vale pelo menos dez vezes mais $^{72}$.

Corcino Medeiros dos Santos, com base em farta documentação de época, também confirma o fato de que, nos primeiros anos de exploração do ouro,

... havia carência de tudo e o pouco que existia era vendido por preços exorbitantes. Os mercadores, atraídos pelos grandes lucros, passaram a conduzir para a área todos os produtos que seus habitantes reclamavam, desde os artigos de primeira necessidade até os mais sofisticados artigos de luxo vindos da Europa ou do Oriente. Com o ouro se pagava tudo $^{73}$.

Assim, é de se asseverar que esse vantajosíssimo e açambarcado negócio teria enriquecido surpreendentemente a classe comerciante estabelecida no Rio de Janeiro ${ }^{74}$ e que esta cidade, tenha, por sua vez, se

XVIII. São Paulo, 1951. Tese (Doutorado) - FFLCH/USP, p. 127-129.

${ }^{71}$ Inclui-se aí, é claro, também como mercadoria, o escravo, diga-se de passagem, como bem comentou Raymundo Faoro, um "comércio sem paralelo pela sua lucratividade" (FAORO, Raymundo. Op cit., v. 1, p. 247).

${ }_{72}$ PLESSIR-PARSEAU, Du. Campanha do Rio de Janeiro em 1711 por Du PlessirParseau. Tradução de Adalberto Rechsteiner. Revista do Instituto Histórico e Geográfico Brasileiro, v. 176, p. 172, 1941.

${ }^{73}$ SANTOS, Corcino Medeiros dos. Op. cit., p. 57-58. Esse autor ainda apresenta em suas Relações comerciais do Rio de Janeiro com Lisboa (1763-1808), uma lista de preços exorbitantes que alguns gêneros poderiam alcançar nas minas na primeira década do século XVIII. Por exemplo, uma camisa de linho poderia valer 3 oitavas de ouro $(10,758$ g). Um chapéu ordinário, $6(21,516 \mathrm{~g})$.

${ }_{74}$ Por muito tempo, esses comerciantes foram admitidos por nossa historiografia como uma arraia-miúda, subalterna de firmas sediadas em Portugal. No entanto, estudos 
tornado, a par das minas, um grande centro consumidor. Para termos uma idéia da quantidade e da qualidade dos artigos que poderíamos encontrar nas residências dos cariocas apenas alguns anos após a descoberta das lavras auríferas - e posteriormente diamantíferas -, recorramos a uma interessante descrição realizada pelo capitão-general francês Chancel de Lagrange, que, assim como o já mencionado Plessir-Parseau, participou da invasão francesa ao Rio, em 1711, chefiada por René Duguay-Trouin:

\begin{abstract}
Jamais se viu, de uma vez só, tantos bens oriundos de Portugal, França, Inglaterra, Itália e Índias, chegados pelas frotas. Cada residência parecia uma verdadeira loja, repleta de tudo o que de mais curioso havia na Europa, China, Índias Orientais, Pérsia e Japão; estando tais riquezas avaliadas em quatro milhões. Mas nossos soldados destruíram tal quantidade de porcelanas, escrivaninhas e lavatórios em laca, espelhos, cristais, quadros, cadeiras de marfim e madeiras odoríferas, e outras mobílias preciosas, que se perdeu, no saque desta triste cidade, três milhões ${ }^{75}$.
\end{abstract}

mais recentes que revisaram documentação da época têm cada vez mais dado devida importância econômica e social a essa classe estabelecida na colônia. Citemos, por exemplo, o trabalho de Luís Lisanti Filho, que resgatou vultosa e interessante correspondência trocada, na primeira metade do século XVIII, entre o negociante português Francisco Pinheiro e diversos de seus comissários radicados no Brasil, muitos deles no Rio de Janeiro. Do estudo dessa vasta documentação, Lisanti Filho concluiu que: "A grande 'escola' era, ao que se observa, a carreira começada como simples auxiliar - caixeiro de alguma casa comercial importante como a de Beroardi e Medici, em Lisboa. A prática comercial quotidiana e o contato com outros mercadores permitiam aos mais atilados adquirir os conhecimentos necessários para depois tentar estabelecer-se independentemente". Ainda para esse autor, sobretudo, nas relações comerciais com a Costa da Mina (oeste africano), ou seja, o tráfico negreiro, esse lucrativíssimo negócio esteve "de maneira predominante em mãos de gente solidamente estabelecida no Rio de Janeiro" (LISANTI FILHO, Luís. Negócios coloniais: uma correspondência comercial do século XVIII. Brasília: Ministério da Fazenda, 1973, v. 1, p. CXLVIII-CLVIII).

75 Tradução nossa de: "Jamais on n'a tant vu à la fois de marchandises du Portugal, de France, d'Angleterre, d'Italie et des Indes, que la flotte avait apportée. Chaque maison était un magasin rempli de tout ce qu'il y a de plus curieux en Europe, en Chine, aux Indes Orientales, en Perse et au Japon; le prix s'en montait à plus de quatre millions; mais nos soldats brisèrent une si grande quantité de porcelaines, de bureaux et cabinets de vernis de Chine, de miroirs, de cristaux, de tableaux, chaises d'ivoire et bois odoriférants et autres meubles précieux, qu'il s'en consomma de la sorte la valeur, de trois millions dans le sac de cette misérable ville" (LAGRANGE, Louis Chancel de. Campagne du Brésil faite contre les portugais, 1711. Revista do Instituto Histórico e Geográfico Brasileiro, v. 270, p. $24,1967)$. 
Tendo em vista tamanho fausto encontrado pelos piratas franceses nas casas dos cariocas, não é nada utópico crer que essa localidade próspera e urbana $^{76}$, na qual, ao contrário do que afirmou Oliveira Lima, formou-se, sim, uma classe de "burgueses ricos"77, tenha tido, ainda na primeira metade do século XVIII, oportunidade de realizar manifestações culturais similares aos dos centros europeus, entre as quais, uma atividade musical rica e ampla, e não, como até hoje se costumou afirmar, acanhada e restrita meramente aos ritos religiosos.

${ }^{76}$ Ao contrário do que se firmou em nossa historiografia - sem a devida ida às fontes - os relatos de viajantes comumente enaltecem a arquitetura do Rio de Janeiro setecentista, sobretudo a fina construção das ruas, das casas e das igrejas, essas, riquíssimas em seu interior. Citemos, por exemplo, um fragmento da descrição realizada pelo Abade francês La Caille (1713-1762), que visitou o Rio em 1751: "Rio-Janeiro est une Ville à présent fort considérable. Le nombre de ses habitants, y compris les Nègres, est d'environ cinquante mille. Les rues y sont assez belles, presque toutes tirées au cordeau, la plupart des maisons assez bien bâties, avec de la pierre de taille \& de la brique (...) La Ville est ornée d'une fort belle place en face du Port, au milieu de laquelle on construisait une belle Fontaine, dont l'eau devait être fournie par un bel Aqueduc, soutenu sur des arcades que l'on découvre avant d'arriver à la Ville" (LA CAILLE, Nicolas Louis de. Journal historique du voyage fait au cap de Bonne-Espérance, par Feu M. I'Abbé de La Caille, de L'Académie des Sciences; précédé d'un discours sur la vie de l'auteur, suivi de remarques \& de réflexions sur les coutumes des Hottentots et des habitants du Cap. Paris: Chez Guillyn, 1763, p. 122-124). Assim, como dissemos, não é nada utópico crer que essa localidade urbanisticamente desenvolvida tenha tido, ainda na primeira metade do século XVIII, oportunidade de realizar e desenvolver as mais variadas manifestações culturais. Sobre a íntima relação entre urbanismo e cultura, lembremos Fernando de Azevedo. Para ele, "entre os fatores que mais contribuem para a produção dos fenômenos de cultura, o desenvolvimento das cidades é um dos mais importantes, na sua função de intensificar as energias coletivas e de levar ao mais alto grau de desenvolvimento possível as capacidades latentes e dispersas na população" (AZEVEDO, Fernando de. Op. cit., p. 4041).

${ }^{77}$ Note-se que, utilizando o termo de Oliveira Lima, "burgueses ricos", estamos nos referindo, na verdade, a uma elite mercantil, comercial ou financeira, que, pela peculiaridade de uma sociedade colonial e escravista como a do Brasil, não deve ser chamada, propriamente, de "burguesia", não obstante diversos autores já a terem assim denominado com certa precisão. Caso, por exemplo, de Caio Prado Jr. em seu ensaio Evolução política do Brasil: "A relativa simplicidade da estrutura social brasileira no primeiro século e meio do descobrimento se complica na segunda metade do séc. XVII, com o aumento da riqueza e desenvolvimento econômico do país, pela intromissão de novas formas econômicas e sociais. Ao lado da economia agrícola que até então dominara, se desenvolve a mobiliária: o comércio e o crédito. E com ela surge uma rica burguesia de negociantes, que, por seus haveres rapidamente acumulados, começa a pôr em xeque a nobreza dos proprietários rurais, até então a única classe abastada e, portanto, de prestígio da colônia. É por obra dela que as cidades do litoral, onde se fixa, se transformam em centros populosos e ricos. (...) Compunha-se esta burguesia quase toda de naturais do Reino. São de fato os imigrantes recém-vindos de Portugal que empalmam o comércio da colônia" (PRADO JR., Caio. Op. cit., p. 36-37). 
Essa, pela sua função intrínseca ao culto divino, presume-se que deva ter existido no Brasil desde a chegada das primeiras ordens. Segundo Serafim Leite, a Sé de Salvador, por exemplo,

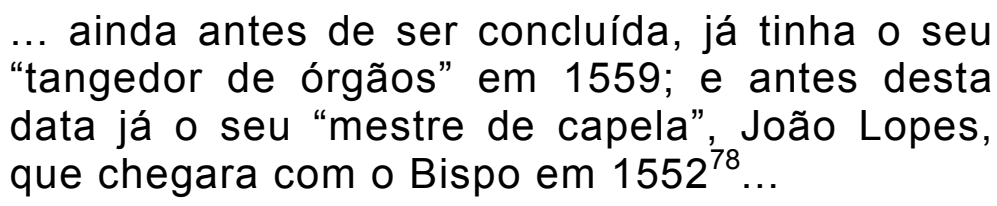

Concernente à música sacra no Rio de Janeiro, a mais antiga referência que encontramos é a de uma carta jesuítica, escrita pelo padre português Miguel de Araújo, em 1621, e publicada na Itália, em 1627. Em tal missiva, o jesuíta afirma ter presenciado, após uma grande festa religiosa, vésperas "cantadas solenemente" pelo próprio prelado, além de uma "decoração preciosa, música em demasia e vários instrumentos, terminandose tudo com uma belíssima procissão"79.

Com a elevação dessa cidade a diocese, por Inocêncio XI, em 1676, o Santo Ofício ganhou, sem dúvida, solenidade ainda maior, agora, sob a proteção de um bispo. A partir daí, e sobretudo com o esplendor do comércio carioca e a centralização de poderes nas mãos dos Governadores locais depois Vice-Reis -, muitas composições sacras devem ter sido grandiosamente executadas nessa cidade, onde a ostentação religiosa foi tida, mais de uma vez, durante o século XVIII, por viajantes, como "maior do que a de qualquer país católico europeu" ${ }^{80}$. Infelizmente, relativos à Igreja

${ }^{78}$ LEITE, S. I. Serafim. Artes e ofícios dos jesuítas no Brasil. Rio de Janeiro: Livros de Portugal, 1953, p. 62.

${ }_{99}$ "Nel giorno poi della festa, egli stesso cantò il vespro solennemente, vi fu musica triplicata, strumenti varii, addobbi preziosi, e con una bellissima processione si terminò il tutto" (DARAŸO, Michele. Estratto di alcune cose scritte dal Brasile nell'anno MDCXXI Collegio e Residenza del Fiume Gennaio. In: VITELLESCHI, Mutio. Lettere annue d'Etiopia, Malabar, Brasil, e Goa. Roma: Francesco Corbelletti, 1627, p. 131).

${ }^{80} \mathrm{O}$ primeiro testemunho nesse sentido é do navegante inglês James Cook, que esteve no Rio em 1768: “... there is more religious parade in this place than in any of the Popish countries in Europe..." (HAWKESWORTH, John. An Account of the voyages undertaken by the order of His Present Majesty for making discoveries in the Southern Hemisphere, and successively performed by Commodore Byron, Captain Wallis, Captain Carteret and Captain Cook, in the Dolphin, the Swallow, and the Endeavour. London: Strahan and T. Cadell, 1773, v. 2, p. 28). Quase vinte anos depois, em 1796, os oficiais e 
Episcopal carioca e aos músicos que para ela trabalharam nessa época, restaram-nos pouquíssimos documentos: nenhum depoimento e algumas raras partituras, todas obras já das duas últimas décadas do século XVIII e de autoria do Padre José Maurício Nunes Garcia ${ }^{81}$. Nada remanesceu, por exemplo, do notável intelectual e membro da Academia dos Seletos, Antônio Nunes de Siqueira (1701-1782), que exerceu o cargo de mestre-de-capela da Sé do Rio de Janeiro, de 1733 a $1752^{82}$, à época em que o cabido se transferiu da Igreja de São Sebastião, no Morro do Castelo, para a Igreja de Santa Cruz dos Militares, antes de fixar-se, em 1737, na Igreja do Rosário, onde permaneceu até $1808^{83}$.

$\mathrm{Na}$ falta de solfas que testemunhem a capacidade criativa, tanto quantitativa quanto qualitativa, dos compositores cariocas de música sacra durante quase todo o século XVIII, exemplifiquemo-la mediante uma rara notícia, publicada na Gazeta de Lisboa de 6 de janeiro de 1729, relativa a uma solenidade religiosa e cívica realizada no Rio, no ano anterior, em comemoração aos casamentos dos, então, Príncipes, Dom José, futuro Rei de Portugal, e sua irmã, Dona Maria Bárbara, futura Rainha da Espanha:

Pelos últimos avisos do Rio de Janeiro se teve a notícia, de que havendo o Governador Luís

missionários do navio inglês Duff, comandado por James Wilson, deixaram-nos uma mesma opinião, publicada pela London Missionary Society, em 1799: "This capital appears to exceed all popish places in the parade of religion" (A MISSIONARY voyage to the Southern Pacific Ocean, performed in the years 1796, 1797, 1798, in the ship Duff, commanded by Captain James Wilson: compiled from journals of the officers and the missionaries: and illustrated with maps, charts, and views. London: T. Gillet, 1799, p. 33).

${ }^{81}$ Segundo Cleofe Person de Matos, a mais antiga delas é a antífona Tota pulchra es Maria, de 1783 (MATOS, Cleofe Person de. Op. cit., p. 61).

${ }^{82}$ O mais completo estudo sobre esse eminente músico - segundo Sacramento Blake, "contrapontista e compositor inspirado" tendo escrito "varias composições de musica" - foi realizado, recentemente, por Carlos Eduardo de Azevedo e Souza em sua tese de doutorado Dimensões da vida musical no Rio de Janeiro: de José Maurício a Gottschalk e além, 1808-1889. (Niterói, 2003. Universidade Federal Fluminense, p. 38-44).

${ }^{83} \mathrm{Na}$ opinião do musicólogo norte-americano Robert Stevenson, a atual escassez de partituras setecentistas nos arquivos do Cabido Metropolitano do Rio de Janeiro se deveu, em parte, a essas várias mudanças de endereço da catedral ao longo de sua história (STEVENSON, Robert. Op. cit., p. 310). De fato, tal detalhe, adicionado à destruição de várias igrejas setecentistas cariocas e ao extremo desleixo com a manutenção dos arquivos eclesiásticos da cidade, certamente contribuiu para a perda definitiva de inúmeras partituras, sobretudo do século XVIII. 
Vahia Monteiro, recebido pela fragata nossa Senhora da Nazareth, que ali chegou em 22 de Abril, a plausível nova dos felicíssimos matrimônios; dispôs logo festejá-la, e com o seu incansável zelo, e atividade conseguiu fazê-lo nos dias 9,10 e 11 do mês de maio, dando princípio ao festejo com o hino do Te Deum Laudamus, cantado a quatro coros, pela melhor música, e instrumentos do País, na Igreja Paroquial de nossa Senhora da Candelária ${ }^{84} \ldots$

É de se notar que tal documento, embora pouco detalhado, mais corrobora a suposição que Silvio Romero tinha - de haver, no Brasil dessa época remota, compositores e instrumentistas "do país", fazendo "melhor música", "a quatro coros", ou seja, nos mesmos moldes da contemporânea polifonia barroca européia - do que a hipótese, proposta por Renato Almeida, de que essa música "não teve significado artístico nenhum" e foi composta na base da unissonância, do canto gregoriano ${ }^{85}$. E não é de se estranhar que essa solenidade não tenha ocorrido na Sé, por incumbência do cabido, mas sob o patrocínio, muito provavelmente, da mais rica irmandade do Rio de Janeiro, a do Santíssimo Sacramento da Freguesia de Nossa Senhora da Candelária. Essa paróquia, segundo Francisco Batista Marques Pinheiro, foi "muito importante pela sua extensão, população e riqueza" sendo, talvez, "a mais rica da República" porque ali residiam "todos os comerciantes de grosso trato, estabelecimentos bancários e onde as maiores e mais avultadas transações" se faziam "todos os dias" 86.

Em relação às irmandades, vale ressaltar que a ineficiente

${ }^{84}$ ALMEIDA, Manuel Lopes de. Notícias históricas de Portugal e Brasil. Coimbra, 1961, v. 1 , p. 141.

${ }_{85}$ "Essa [música] não teve significado artístico nenhum, nem passaria de adaptações do que os padres traziam de Portugal e aqui se repetia com uma ou outra modificação ou cópia sem merecimento próprio. A base era o gregoriano, ensinado para o serviço religioso ..." (ALMEIDA, Renato. Op. cit., p. 291).

${ }_{86}$ PINHEIRO, Francisco Batista Marques. Irmandade do Santíssimo Sacramento da Freguesia de Nossa Senhora da Candelária e suas repartições, coro, caridade e hospital dos lázaros. Rio de Janeiro: Moreira Maximino, 1894, v. 1, p. 21 . Note-se também que Francisco Curt Lange deu continuidade a alguns trabalhos de Francisco Marques Pinheiro em seu artigo "Pesquisas esporádicas de musicologia no Rio de Janeiro: a Irmandade do Santíssimo Sacramento da Igreja da Candelária do Rio de Janeiro" (Revista do Instituto de 
administração das jurisdições espirituais na América Portuguesa e a vigência de um código social que privilegiava aqueles que contribuíssem para o esplendor do culto divino levaram essas sociedades religiosas seculares a desempenhar um importante papel na organização da vida religiosa colonial e conseqüentemente no desenvolvimento das práticas musicais eclesiásticas ${ }^{87}$. A autonomia de que gozavam para gerir seus recursos, obtidos mediante doações e heranças de seus irmãos, levou as irmandades não apenas a erguer importantes templos nas principais cidades brasileiras, como também a promover pomposas festas religiosas e cívicas - com muita música, é claro - em homenagem aos seus santos padroeiros ou à realeza e seus principais representantes na colônia ${ }^{88}$.

Entretanto - fechado esse pequeno parêntese sobre a música de caráter sacro -, quando falávamos de uma arte sonora rica e ampla, nos referíamos principalmente a uma música profana, de interesse burguês, que, assim como já vinha ocorrendo à mesma época no Antigo Continente, imitava os modelos da música aristocrática, de corte, e encontrava, já sob a presença de um príncipe soberano no camarote central de um teatro público - no qual, para entrar, bastava pagar —, seu principal meio de desenvolvimento ${ }^{89}$.

Estudos Brasileiros. São Paulo: IEB/USP, v. 4, 1968).

87 A importante atuação dessas sociedades religiosas leigas no desenvolvimento da música sacra brasileira, não apenas no século XVIII, mas também no XIX, tem sido alvo, já há um bom tempo, de trabalhos acadêmicos e artigos, sobretudo relacionados a Minas Gerais. Sobre esse tema, ver, por exemplo, LANGE, Francisco Curt. História da música nas irmandades de Vila Rica. Belo Horizonte: Imprensa Oficial, 1981; e as dissertações de mestrado de Flávia Toni (Música nas irmandades da Vila de São José e o capitão Manoel Dias de Oliveira. São Paulo: ECA/USP, 1985) e Maurício Monteiro (João de Deus de Castro Lobo e as práticas musicais nas associações religiosas de Minas Gerais. São Paulo: FFLCH/USP, 1995).

${ }^{88}$ Cf. SCARANO, Julita. Devoção e escravidão: a Irmandade de Nossa Senhora do Rosário dos Pretos no Distrito Diamantino no século XVIII. São Paulo: Companhia Editora Nacional, 1978.

${ }^{89}$ Segundo Ivo Supicic, na Histoire de la musique occidentale, de Jean Massin: "No século XVIII, paralelamente à vida musical da corte e dos salões aristocráticos, desenvolveu-se aos poucos uma vida musical nova, a da burguesia. Gozando de considerável prosperidade econômica, a burguesia em parte retomou elementos da vida musical da corte e dos salões da aristocracia, e em parte criou, já em meados do século, os elementos de uma cultura musical autônoma, sobretudo nas grandes cidades européias, como Londres, Paris, Leipzig, Hamburgo, Viena, Veneza e Nápoles. Há nisso uma transformação profunda e importante para a vida musical do futuro, e, em particular, para a do concerto público. Passara-se da execução em círculos privados à execução em público..." (SUPICIC, Ivo. Situação sócio-histórica da música no século XVIII. In: MASSIN, 
Não foi à toa que José Vieira Fazenda, um incansável perscrutador das coisas da nossa velha capital, encontrou, ainda no início do século $X X$, indícios de que, em meados do século XVIII, mais precisamente em 1748, o Rio de Janeiro já dispunha de um teatro público: uma tal de "Ópera dos Vivos". Fatos registrados no livro II do Tombo do Convento de Santo Antônio presumiam a existência, nessa época, de uma "rua da Ópera dos Vivos", e, conseqüentemente, de uma "Ópera dos Vivos" 90.

O edifício suposto por Fazenda deve ser o mesmo descrito por um viajante francês que esteve no Rio, no mesmo ano de 1748, e decerto foi construído - embora o teatro, como veremos, fosse de propriedade particular - em um impulso governamental de urbanização que Gomes Freire de Andrada impôs a essa cidade em seu longo governo de trinta anos (17331763), marcado pelo ápice da produção aurífera e pela centralização governamental no Centro-Sul ${ }^{91}$. Nessa opulenta época, foram erguidos, por exemplo, o Aqueduto da Carioca, o Palácio do Governador (futuro Paço Real e Imperial), a Igreja do Rosário (Sé, a partir de 1737) e iniciou-se a

Jean (org.). Op. cit., p. 411-412). É bom complementar que, apesar de o século XVIII ter sido o período de maior "democratização" da música, o surgimento dos primeiros teatros públicos da era moderna ocorreu ainda na primeira metade do século anterior, na Itália. Citemos o San Cassiano, de Veneza, inaugurado em 1637 ou o San Giovanni e San Paolo, também de Veneza, em 1641. Foi para o primeiro desses que o compositor Claudio Monteverdi escreveu suas últimas óperas. Quanto ao Rio de Janeiro, apesar de ser muito improvável que esta cidade tenha tido um teatro público ainda no século XVII, o drama não foi, no entanto, estranho às festividades cariocas seiscentistas. Das pouquíssimas informações de festas que nos restaram, relativas a esta época e local, uma delas, pelo menos, refere-se à representação, em 1641, de uma comédia na casa do Governador Salvador Correia de Sá e Benevides (Cf. RELAÇÃO da Aclamação que se fez na Capitania do Rio de Janeiro do Estado do Brasil, \& nas mais do Sul, ao Senhor Rei Dom João o IV por verdadeiro Rei, \& Senhor do seu Reino de Portugal, com a felicíssima restituição que dele se fez a Sua Majestade que Deus guarde. Lisboa: Jorge Rodrigues, 1641).

90 FAZENDA, Vieira. Antiqualhas e memórias do Rio de Janeiro. Revista do Instituto Histórico e Geográfico Brasileiro, t. 86, v. 140, p. 61-63, 1919.

${ }^{91}$ Foi ainda sob o comando de Andrada - Conde de Bobadela a partir de 1758 que o poder defininitivamente centralizou-se no Rio de Janeiro, propiciando, quiçá, o desenvolvimento de uma verdadeira corte em torno dessa autoridade. Segundo José Honório Rodrigues, "O Rio de Janeiro crescera muito, comparado às cidades mais antigas, e não fora por obra do Vice-reinado. O longo período do Governo de Gomes Freire de Andrade (1733-1763) representa anos decisivos para o crescimento e consolidação do Rio de Janeiro, como centro de transmissão de comando da vida brasileira. (...) a cidade foi-se tornando ainda mais importante quando, com Bobadela, as capitanias de Minas Gerais, São Paulo, Goiás, Mato Grosso, Santa Catarina e o Rio Grande do Sul ficaram subordinadas ao seu governo" (RODRIGUES, José Honório. Op. cit., p. 138-139). 
construção da Igreja do Carmo (posterior Capela Real e Imperial).

Passemos, então, à descrição do tal viajante anônimo, documento que

Vieira Fazenda não conheceu e que, segundo quem o publicou pela primeira vez, em 1806, era obra d'un ancien officier de la marine française:

Alguns dias depois, nós fomos a um espetáculo que se dava de tempos em tempos para aperfeiçoamento moral do povo (Do povo que tinha dinheiro para aperfeiçoar-se, pois os lugares para esse espetáculo custava 40 soldos do país). (...) O lugar onde se representava essa peça tinha cerca de trinta metros por vinte. $O$ palco ocupava dez metros no fundo, deixando a platéia quadrada. Era um pouco menos elevado do que os nossos, cingido espaçadamente com arames e iluminado por grande quantidade de velas, permitindo-se avistar com muita clareza a movimentação das marionetes. A platéia estava repleta de cadeiras dotadas de espaldar e braço, semelhantes aos bancos da igreja. Ali, os homens tomavam seus lugares indistintamente porque as mulheres ficavam nos camarotes, situados em torno do edifício, a uns três metros de altura. De lá, elas viam comodamente o espetáculo e olhavam de esguelha os espectadores jogando displicentemente as cortinas destinadas a ocultá-las. A orquestra estava muito boa de violinos. Havia um inglês que tocava excelentemente a flauta transversal ${ }^{92}$.

${ }^{92}$ Tradução nossa de: "Quelques jours après, nous allâmes à un spectacle que l'on donnait de temps à autre pour l'édification du peuple (C'est du peuple en état de s'édifier argent comptant, car les places à ce spectacle coûtaient 40 sous du pays) (...) Le lieu de la représentation de cette pièce était d'environ quinze toises sur dix; et le théâtre, qui en prenait cinq sur la profondeur, laissait le reste carré. Ce théâtre était un peu moins élevé que les nôtres, et cerné de fil de fer à claire-voie, à travers laquelle on distinguait fort bien, par le moyen d'un grand nombre de bougies, l'action des marionnettes. Le carré servait de parterre, et était couvert de sièges à dossiers à bras, comme nos bancs d'église, où tous les hommes étaient placés indistinctement; car les femmes étaient dans des loges attenantes au pourtour de l'édifice, à neuf ou dix pieds d'élévation, d'ou elles voyaient commodément le spectacle, et lorgnaient les spectateurs en jouant nonchalamment avec les rideaux destinés à les cacher. L'orchestre était assez bon en violons, et il y avait un anglais qui jouait excellemment de la flûte traversière" (SONNERAT, Pierre. Voyage aux Indes Orientales et à la Chine. Paris: Dentu, imprimeur-libraire, 1806, v. 4, p. 26-27). Esse texto, de autor anônimo, foi publicado talvez pela primeira vez em 1806 pelo navegador francês Pierre Sonnerat, na segunda edição de sua Voyage. Trata-se de um adendo à 
Se podemos, por meio deste precioso relato, provar - e não mais conjecturar sobre - a existência, no Rio de Janeiro e ainda na primeira metade do século XVIII, de uma casa de espetáculos, onde música desvinculada do Ofício Divino se fazia ouvir com o intuito de "aperfeiçoar moralmente" pessoas "aptas a pagar ${ }^{93 "}$ - gente que, em fins de 1748 , segundo o abade Francês René Courte de la Blanchardière (1712?-1794), já se vestia "perfeitamente bem, à moda francesa" também por meio de relatos de estrangeiros, difundidos em livros, bem como notícias publicadas na Gazeta de Lisboa, reforçam ainda mais a idéia de que uma música profana, vinculada a hábitos cortesãos, existiu, mesmo antes do governo de Bobadela ${ }^{95}$, e garantiu o divertimento das elites locais, em festas, solenidades e espetáculos quase sempre protagonizados pelos Governadores.

Conheçamos, então - apesar de não haver menção explícita à

primeira edição de 1782, na qual são incluídos um histórico sobre a Índia, de 1778 a 1805, notas e várias memórias inéditas, entre as quais, essa, do "ancien officier de la marine française". A informação de que tal relato seria de um certo "Pierre", tripulante da nau L'arc-en-ciel, que arribou no Rio em 1748, foi publicada por Gilberto Ferrez na Revista do Instituto Histórico e Geográfico Brasileiro, v. 280 (1988).

${ }^{93}$ Apesar de sublinhar, em seu texto, que "somente o povo que tinha dinheiro entrava no teatro", é um pouco difícil estimar o que o viajante francês quis dizer com "40 sous du pays". Se esse autor anônimo fez a comparação com base no valor metálico da moeda francesa de então, é possível que tal valor equivalesse à pataca de 320 réis (2 oitavas e 50 grãos de prata), uma vez que 40 sous correspondiam, à época, a aproximadamente $2 \frac{1}{2}$ oitavas de prata (Cf. DROULERS, Frédéric. Répertoire général des monnaies de Louis XIII à Louis XVI. Paris: Copernic, 1987; CAVALCANTI, Amaro. O meio circulante nacional. Brasília: Editora da Universidade de Brasília, 1983). Já, se a comparação referia-se a valores nominais - e levando-se em consideração que 40 sous correspondiam a 2 livres -, isso pode significar que o ingresso custava cerca de seis vezes mais: uma moeda de ouro de 2 mil réis.

94 "Les gens de quelque chose sont parfaitement bien vêtus \& à notre façon Françoise" (BLANCHARDIĖRE, René Courte de La. Nouveau voyage fait au Pérou. Paris: De l'imprimérie de Delaguette, 1751, p. 187).

${ }_{95}$ Nireu Cavalcanti publicou, recentemente, a descoberta, no Arquivo Nacional do Rio de Janeiro ( $2^{\circ}$ Ofício de Notas, livro 28$)$, de uma escritura de fundação de uma sociedade particular, datada de 1719, cuja finalidade seria gerenciar um teatro de marionetes no Rio de Janeiro. Um dos sócios, Antônio Pereira, se incumbiria de realizar no tal teatro "música polifônica de pelo menos quatro vozes, além de cuidar dos instrumentos musicais necessários". (CAVALCANTI, Nireu. O Rio de Janeiro setecentista: a vida e a construção da cidade da invasão francesa até a chegada da corte. Rio de Janeiro: Jorge Zahar, 2004, p. 171). Mais um indício de prática musical não vinculada às funções eclesiásticas, ainda em plena segunda década do século XVIII. 
música -, uma ocasião social de vulto, pelo expressivo número de convidados, que não se imagina ter sido realizada sem a manifestação dessa arte. Por exemplo, a 10 de outubro de 1726, a Gazeta de Lisboa publicou notícias chegadas do Rio, entre as quais a

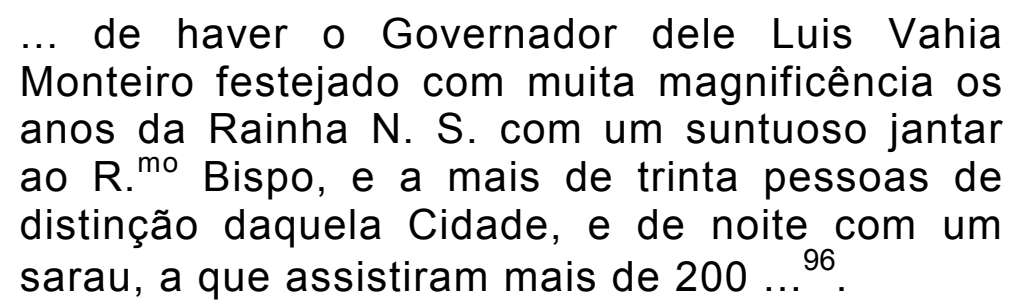

Passemos, agora, a testemunhos de audições musicais seculares explícitas, empreendidas, a princípio, pelos governantes locais, ou em seu obséquio. Em $1752^{97}$, por exemplo, criou-se, no Rio de Janeiro, a "Academia dos Seletos", sociedade que, como veremos, não apenas cultivava a poesia nessa cidade, sob a proteção do Governador Gomes Freire de Andrada, mas organizava, também, concertos de música; possivelmente coordenados pelo já citado "seleto", Antônio Nunes de Siqueira, então mestre-de-capela da Sé carioca. Uma das reuniões dos acadêmicos, ocorrida no teatro da cidade ${ }^{98}$, foi narrada na coleção de obras dos próprios "seletos", Júbilos da América, publicada em 1754 na capital portuguesa. Segundo a obra, promoveu-se naquele encontro, juntamente com leituras de poemas e elogios em homenagem ao Governador,

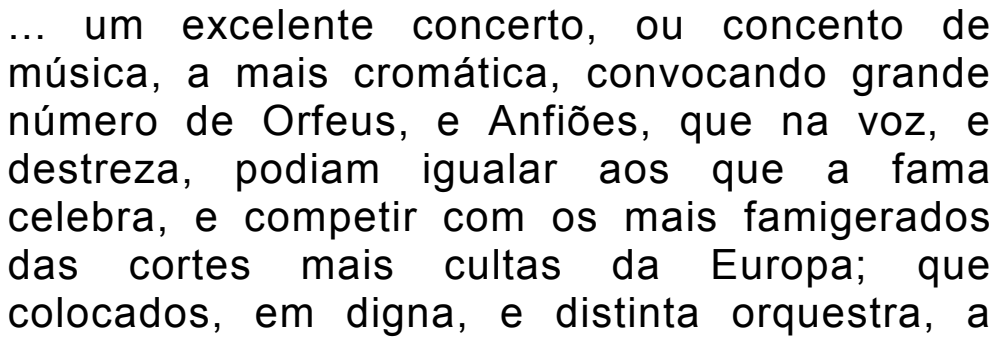

\footnotetext{
${ }^{96}$ ALMEIDA, Manuel Lopes de. Op. cit., v. 1, p. 124.

97 CANDIDO, Antônio. Formação da literatura brasileira. São Paulo: EDUSP, 1975, v. 1, p. 81 .

98 Isso prova mais uma vez que já havia, ainda nos tempos de Gomes Freire de Andrada, um teatro no Rio de Janeiro.
} 
intervalos, transformavam o teatro em paraíso, transportando todo o expectável auditório à contemplação do celestial ... 99

Outro relato sobre atividade musical do tempo de Gomes Freire de Andrada - uma chistosa anedota de um oficial do exército francês que, a caminho das Índias, esteve por dois meses e meio no Rio, em meados de 1757 - , caracteriza, desta vez, um diferente tipo de execução musical de ambiente profano - o do baile - mesmo que, neste caso, a ausência da figura feminina tenha ocasionado percalços para o bom andamento da diversão:

O Governador do Rio de Janeiro, homem educado nos padrões de polidez das cortes européias, e conhecedor dos hábitos que regem a gente honrada, quis retribuir ao general francês uma festa que este havia dado aos mais notáveis da cidade. Assim, ofereceu e fez preparar a todos os oficiais de nossa esquadra, um baile e uma esplêndida ceia. Qual não foi, porém, a nossa surpresa, quando, ao chegarmos a um salão magnificamente iluminado e onde se fazia ouvir a melhor música, vimos somente um monte de portugueses e nem uma única dama? ${ }^{100}$

${ }^{99}$ SÁ, Manoel Tavares de Siqueira e. Júbilos da América. Lisboa: Na oficina do Dr. Manuel Álvares Solano, 1754, p. 41.

100 Tradução nossa de: "Le Gouverneur de Rio-Janeiro, homme élevé dans la politesse des Cours de l'Europe et connaissant les usages qui lient les honnêtes gens, voulut rendre au Général François une fête que celui-ci avait donnée aux plus notables de la ville. Pour cet effet, il invita tous les Officiers de l'escadre à un bal et à un souper splendide qu'il avait fait préparer; mais quelle fut notre surprise, quand, arrivant dans une pièce magnifiquement illuminée et où se faisait entendre la meilleure musique, nous ne vîmes que beaucoup de Portugais et pas une seule femme?" (LA FLOTTE, M. de. Essais historiques sur l'Inde, précédés d'un journal de voyages et d'une description géographique de la côte de Coromandel. Paris: Chez Herissant le Fils, 1769, p. 17-18). Tal baile "sem mulheres" nos parece, no entanto, uma exceção: o próprio oficial La Flotte assevera, em outro momento de sua narrativa, ter o Governador "convidado as damas da cidade", tornando evidente que as mulheres não teriam comparecido à ocasião social por motivo fortuito. Para o autor dos Essais historiques, "era o temor que os portugueses colonos tinham dos galanteios dos franceses", mas, na verdade, poderia muito bem ser um ódio ou um medo, remanescentes dos enormes prejuízos causados, em 1711, por Duguay-Trouin. Uma correspondência de 17 de agosto de 1757 realizada entre duas autoridades portuguesas (Agostinho Felix Santos Campelo e Tomé Joaquim da Costa Corte Real) mostra bem a sensação de ameaça que a população carioca ainda tinha de novas invasões 
Não foi, sem dúvida, este encontro musical, um fato isolado. Como o próprio La Flotte faz questão de salientar, era o Governador pessoa educada nos modelos de "politesse" das cortes do Antigo Continente, códigos de controle de conduta que, como já afirmamos, vinham sendo fixados e refinados pelas nobrezas européias, desde a formação dos Estados Modernos, com a finalidade de essas elites manterem seu prestígio junto aos monarcas absolutos, e, ao mesmo tempo, afastarem do convívio cortesão, por desqualificação comportamental, os demais grupos sociais, especialmente a burguesia ascendente, impedindo-a, desta forma, de participar dos assuntos e interesses políticos, em suma, dos governos de tais Estados $^{101}$.

E como ouvir e dançar música compunham tais hábitos "que regem a gente honrada"102, ações como essas também foram praxes, mesmo aqui, do outro lado do Atlântico, em pleno regime colonial. Outro viajante a constatar uma rotineira prática musical cortesã no Rio de Janeiro setecentista - desta vez em 1787 - foi o Governador de New South Wales (futuramente, Austrália), Arthur Phillip (1738-1814). Em seus escritos de viagem, compilados por David Collins, em 1798, o inglês mencionou o fato de o ViceRei - então, Dom Luiz de Vasconcelos, futuro Conde de Figueiró - não ter

francesas: "Participo a Vossa Excelência que entrando nesse porto por causa de doenças uma esquadra de naus francesas (...) sentiram-se mal desta arribada não só o povo desta cidade, mas ainda o comandante da frota, e o tenente-coronel Patrício Manoel de Figueiredo, que por ausência de José Antônio Freire nas minas, se achava governando as armas ..." (REVISTA do Instituto Histórico e Geográfico Brasileiro. Rio de Janeiro, v. 105, p. 74, 1902). José Antônio Freire de Andrada era irmão de Gomes Freire de Andrada e o auxiliava, governando as Minas Gerais. Nessa ocasião, nenhum dos dois irmãos se encontrava no Rio e La Flotte deve, portanto, ter sido recebido pelo citado tenente-coronel Patrício Manoel de Figueiredo.

101 Sobre esse tema, os trabalhos de Norbert Elias $O$ processo civilizador e $A$ sociedade de corte são referências obrigatórias.

102 Lembremos novamente que nos estamos referindo a uma música aristocrática, de corte, em suma, "erudita", que já no século XVII diferenciava-se completamente das demais manifestações musicais, como nos mostra, mais uma vez, a História da música ocidental, de Jean Massin (SUPICIC, Ivo. Situação sócio-histórica da música no século XVII. In: MASSIN, Jean (org.). Op. cit., p. 316). Quanto ao fato dessa prática musical estar amplamente vinculada às etiquetas e aos hábitos de corte europeus, e mais especificamente portugueses, Maurício Monteiro realizou amplo estudo, nesse sentido, em sua já mencionada tese de doutorado, A construção do gosto (Cf. MONTEIRO, Maurício. 
deixado de realizar, mesmo durante o luto pelo falecimento do Rei de Portugal, Dom Pedro III, encontros musicais semanais em sua residência "para a sua diversão e a de alguns poucos e seletos amigos" ${ }^{103}$.

Comuns, esses hábitos musicais, praticados no Palácio dos Governadores e Vice-Reis por uma elite social - "Suas Excelências, Mestres de Campo, Ministros, Religiões, e Nobreza", como relacionou o já citado Rosado da Cunha, em 1747 —, criariam, sem dúvida, elementos para sua reprodução na vida privada, tanto dessa mesma elite social, como também das grandes fortunas do comércio carioca. Afinal, almejando obter títulos de nobreza e os privilégios políticos que os acompanhavam, essa elite econômica passava a imitar cada vez mais e a todo custo - tal como ocorria, à mesma época, com as burguesias européias ${ }^{104}$ - os mesmos rituais cortesãos absolutistas que foram praticados e aperfeiçoados pelas nobrezas do Antigo Continente ao longo dos dois séculos anteriores com o intuito de assegurar a sua submissão social ${ }^{105}$.

Uma reunião musical e dançante no Rio setecentista, realizada em

Op. cit.).

103 “... all private and public amusements being since that time discouraged as much as possible, the viceroy himself setting the example. Once a week, indeed, his excellency had a music-meeting at the palace for the entertainment of himself and a few select friends" (COLLINS, David. An account of the english colony in New South Wales: with remarks on the dispositions, customs, manners etc. Of the native inhabitants of that country. To which are added, some particulars of New Zealand. Compiled, by permission, from the Mss. of Lieutenant-Governor King. London: T. Cadell Jun. and W. Davies, 1798, v. 1, p. 23).

104 Sobre esse tema, Eric Hobsbawm lembra que "as classes em ascensão naturalmente tendem a ver os símbolos de sua riqueza e poder em termos daquilo que seus antigos superiores tinham estabelecido como o os padrões de conforto, luxo e pompa" (HOBSBAWM, Eric J. Op. cit., p. 203).

${ }^{105}$ Segundo Norbert Elias, "para a nobreza de corte, o autocontrole a ela imposto por sua função e situação serviu ao mesmo tempo como valor de prestígio, como meio de distinguir-se dos grupos inferiores que a fustigavam e ela tudo fez para impedir que essas diferenças fossem apagadas. Só o membro iniciado devia conhecer os segredos da boa conduta, só na boa sociedade podiam eles ser aprendidos". Porém, "a aristocracia de corte não podia impedir - através de seus contatos com o estrato burguês rico, do qual ela necessitava por uma razão ou outra - a difusão de suas maneiras, costumes, gostos e linguagem por outras classes. Inicialmente no século XVII, essas maneiras foram adotadas por pequenos grupos dirigentes da burguesia - a Digressão sobre a Modelação da Fala na Corte constitui um exemplo vívido - e, em seguida, no século XVIII por estratos burgueses mais amplos. A massa de livros sobre a civilité publicados nessa época mostra claramente esse fato" (ELIAS, Norbert. O processo civilizador. Tradução de Ruy Jungmann. Rio de Janeiro: Jorge Zahar, 1993, v. 2, p. 214-215). 
casa de particulares, foi observada, por exemplo, pelo poeta francês Évariste Désiré de Forges (1753-1814), futuro Visconde de Parny, de passagem pela capital do Estado do Brasil, em 1773, a caminho de l'Isle de France (posteriormente, Ilhas Maurício):

Nós tivemos, ontem, um agradável concerto, seguido de um baile. Aqui, somente se conhece o minueto. Tive o prazer de dançá-lo com uma charmosa portuguesa de dezesseis anos e meio $^{106}$.

Companheiro de viagem de Parny, o oficial Joseph Auguste Pinczon du Sel deixou-nos, por sua vez, não apenas um testemunho mais detalhado do mesmo "joli concert", mas de outro encontro musical dançante privado, mais informal do que o primeiro, já que este, conforme tudo indica, realizouse de improviso, demonstrando, de forma patente, como esses hábitos incluindo-se não apenas a audição e a dança, mas a própria execução musical - já estavam consolidados nos ambientes privados cariocas:

Nossos guias nos levaram ontem à tarde a uma casa, onde vimos, diferentemente do usual, três belas portuguesas; uma delas executou ao cravo várias peças musicais e nós dançamos, ao som desse instrumento, alguns minuetos com as outras duas irmãs ${ }^{107}$.

106 Tradução nossa de: "Nous eûmes hier un joli concert, suivi d'un bal. On ne connaît ici que le menuet. J'eus le plaisir d'en danser avec une Portugaise charmante, de seize ans \& demi ...". CHAPELLE, Claude Emmanuel Lhuillier et alii. Voyage de Chapelle et Bachaumont, suivi de quelques autres voyages dans le même genre. Londres [i. e. Paris], 1782 , p. 142.

107 Tradução nossa de: "Nos guides nous introduisirent hier soir dans une maison où nous vîmes, contre l'usage ordinaire, trois jolies Portugaises; l'une d'elle exécuta sur un clavecin plusieurs morceaux de musique et nous dansâmes au son de cet instrument quelques menuets avec les deux autres soeurs" (Apud BOISANGER, Béatrice de. Mémoires des Isles. Paris: O. Orban, 1986, p. 273). Sabemos que se trata de um outro "baile", porque o oficial Joseph Auguste também relata, mais adiante, em seu diário - e com palavras muito parecidas - a mesma ocasião à qual Parny se referiu: "Há dois dias, o médico, do qual lhes falei, nos levou à casa de um de seus confrades, que nos ofereceu um belíssimo concerto seguido de um baile. Dançamos bastante; havia muitas dançarinas bonitas. (...) Tivemos permissão de dançar, nesse baile, até as nove horas da noite; eu me diverti muito; só se dança aqui o minueto, o que torna os bailes um pouco sérios. Dançamos, entretanto, entre nós, uma contradança alemã e percebi que nossos passos agradavam infinitamente 
Aproveitando a menção, deixemos de lado, por um momento, os bailes, e digressionemos sobre a existência, no Rio de Janeiro setecentista, de instrumentos musicais que também apontam para o pleno conhecimento e prática dos usos da sociedade cortesã européia. Note-se aqui, em 1773, a presença do cravo, não apenas em ambientes privilegiados como o teatro ou os Palácios do Governador ou do Bispo, mas também em residências. Passados quase vinte anos, esse instrumento em questão - de nobreza já centenária ${ }^{108}$ - seria, segundo George Macartney (1737-1806), embaixador britânico em missão à China, de passagem pelo Rio em fins de 1792, o "favorito" das damas, ao lado da viola de mão ${ }^{109}$. Tal objeto deveria fazer parte da enorme variedade de produtos ingleses ${ }^{110}$ que o mesmo Lord

ao belo sexo que, neste país, mais do que em outros lugares, parece sensível às impressões do prazer e da volúpia"; tradução nossa de: "il y a deux jours que le médecin dont je vous ai parlé, nous conduisit chez un de ses confrères qui nous donna un fort joli concert suivi d'un bal. Nous y dansâmes beaucoup; il y avait plusieurs jolies danseuses. (...) Nous eûmes permission de danser à ce bal jusqu'à neuf heures du soir; je m'y amusai beaucoup; on ne danse ici que le menuet, ce qui rend les bals un peu graves. Nous avons cependant exécuté entre nous une contredanse allemande et j'ai vu que nos pas plaisaient infiniment au beau sexe qui, dans ce pays plus qu'ailleurs, paraît sensible aux impressions du plaisir et de la volupté" (Apud BOISANGER, Béatrice de. Op. cit., p. 275).

108 "No início do século [XVII], o cravo passou por uma importante mutação técnica, particularmente sob o impulso dos fabricantes Rückers, de Antuérpia. Por volta de 1630, o cravo já atingira todas as suas possibilidades, com os dois teclados e todos os registros. Foi nessa época que o primeiro dos grandes cravistas franceses [Jacques Champion] conferiu a esse instrumento os seus títulos de nobreza..." (BEAUSSANT, Philippe. A música barroca da França "clássica". In: MASSIN, Jean (org.). Op. cit., p. 316). Daí ser um dos objetos de consumo prediletos de uma "burguesia" ou elite comercial que buscava, na imitação dos hábitos nobres, um meio de ascender socialmente.

109 "The ladies (...) were fond of music, and their favorite instruments the harpsichord and guitar" (STAUNTON, Sir George. An abridged account of the embassy to the Emperor of China, undertaken by order of the King of Great Britain; including the manners and customs of the inhabitants; and preceded by an account of the causes of the Embassy and voyage to China. Taken principally from the papers of Earl Macartney. London: John Stockdale, 1797, p. 58). Note-se que decidimos traduzir o termo inglês "guitar" por "viola de mão", tratando-se esse último de um termo mais genérico, indicativo, não de um, mas de um conjunto de instrumentos - ancestrais dos atuais violão e viola caipira -, que sucederam em uso o alaúde, e existiram, por essa época, tanto no Brasil como em Portugal e outros países da Europa. Eram todos instrumentos de cordas dedilhadas - cinco, seis ou sete ordens, simples ou duplas -, com caixa de ressonância no formato do algarismo "8", fundo plano, e que aqui tiveram designações variadas, entre as quais: guitarra espanhola, viola francesa, viola braguesa, viola chula, viola de arame etc. (Cf. VIEIRA, Ernesto. Op. cit. p. 525-528).

110 Anúncios encontrados no Correio mercantil e econômico de Portugal, das duas últimas décadas do século XVIII e primeira do XIX, mostram que, em Lisboa, os cravos e 
Macartney assegurou ter visto no comércio carioca àquela época:

A opulência e importância comercial do lugar não pode ser melhor determinada do que por suas lojas, depósitos e mercados, todos ricos em qualquer espécie de manufaturas inglesas ${ }^{111}$;

Dados relativos às importações de Lisboa para o Rio de Janeiro no ano de 1798, confirmam tal hipótese. Entre linhos, pratarias e porcelanas da Índia, Corcino dos Santos encontrou três pianos ${ }^{112}$, um instrumento moderno, que vinha substituindo o cravo, e que cada vez mais ganhava adeptos na Europa. Flautas, fagotes, rabecas e um piano aparecem igualmente nas listagens das balanças de comércio entre Lisboa e o Rio de Janeiro da década anterior à chegada da família real portuguesa ${ }^{113}$.

Aproveitando, façamos, também, rápida referência a informações relativas à existência de construtores de instrumentos musicais no Rio setecentista. Informações da época do vice-reinado de Dom Luiz de Vasconcelos (1779-1790) asseveram, por exemplo, que, nesse período, havia, entre os profissionais mecânicos cariocas, cinco "violeiros",

pianofortes ingleses estavam entre os mais comercializados. E. g.: "Vende-se um cravo de cinco oitavas, tem caixa de pau de nogueira, foi feito em Londres por um dos primeiros autores, tem seu pedal de pianoforte, e conserva muito a afinação" (20/05/1788); "Pretende-se vender um pianoforte, feito na Inglaterra: quem quiser comprar fale com José da Silva Gomes" (23/09/1788); "Vende-se um pianoforte novo, com quatro registros, do melhor autor de Londres, muito harmonioso e o mais bem acabado que é possível" (21/01/1800); "Quem quiser comprar um pianoforte de cinco oitavas, inglês, feito por Volsman, na loja da Gazeta poderá haver as demais informações" (20/11/1804)

111 Tradução nossa de: "The opulence and commercial importance of the place could not be more fully ascertained than by its shops, magazines, and markets: all of which abounded with every species of British manufacture" (STAUNTON, Sir George. Op. cit., p. 57-58). Outro a ter a mesma impressão dez anos antes foi Don Juan Francisco Aguirre: "La libertad de comercio ha puesto la plaza del Rio Janeiro en un estado que no parece americana; el tráfago que se nota en la Aduana diariamente prueba que el giro en general es de consideración; á lo que corresponde la abundancia y baratura con que se despacha. Las mas de las calles están llenas de tiendas y entre ellas hay algunas magníficas en que se encuentran todos los géneros de las fábricas de Europa y Oriente" (AGUIRRE, Juan Francisco. Diario del Capitán de Fragata D. Juan Francisco Aguirre. Revista de la Biblioteca Nacional. Buenos Aires: Imprenta de Ministerio de Educación, t. 17, n. 43-44, p. 143, 1949).

112 SANTOS, Corcino Medeiros dos. Op. cit., p.186.

113 SOUZA, José Antônio Soares de. O Rio de Janeiro nas balanças de comércio de Portugal de 1796 a 1807. Revista do Instituto Histórico e Geográfico Brasileiro. Rio de 
designação genérica que tinham os fabricantes de instrumentos de cordas ${ }^{114}$. O inventário post-mortem de um boticário, falecido em 1801 - descoberto por Nireu Cavalcanti —, revela-nos, ainda, a inusitada existência, entre os bens declarados, de um instrumento de teclado "da terra" ${ }^{\text {"115. }}$.

De volta aos divertimentos privados, citemos ainda uma instigante informação, a qual nos permite presumir que tais atividades não eram esporádicas, mas corriqueiras e organizadas, pelo menos em fins de 1797. Passando nesse tempo pela Guanabara, o major inglês James George Semple Lisle declarou que, entre os principais divertimentos dos cariocas, "sociedades privadas despertavam muito interesse"116. Tal informação é confirmada, dez anos depois (1807), por outro inglês, James Vaux:

O português sobressai-se em música, particularmente no violino e no violoncelo; e havia freqüentemente em nossa casa grandes festas de amadores, as quais convertiam-se no mais agradável concerto noturno. Na realidade, este é o costume de todas as pessoas de bomtom ....117

Eis, aí, mais um indicativo de que as atividades musicais concertos, bailes - contavam como hábito de distinção e eram praticadas com assiduidade e competência no Rio de Janeiro, mesmo antes da chegada da corte portuguesa.

Janeiro, v. 342 , p. 56, 1984

114 MEMÓRIAS públicas e econômicas da cidade de São Sebastião do Rio de Janeiro para uso do Vice-Rei Luiz de Vasconcelos por observação curiosa dos anos de 1779 até o de 1789. Revista do Instituto Histórico e Geográfico Brasileiro. Rio de Janeiro, t. 47, parte 1, p. 44-45, 1884.

${ }^{115}$ CAVALCANTI, Nireu. Op. cit., p. 184.

116 "The amusements (...) private societies are very engaging" (LISLE, James George Semple. The life of Major J. G. Semple Lisle; containing a faithful narrative of his alternate vicissitudes of splendor and misfortune. London: W. Stuart, 1799, p. 278).

117 Tradução nossa de: "The Portuguese excel in music, particularly the violin and bass-viol; and there were frequently large parties of amateurs at our house who formed a most delightful evening concert. This is, in fact, the custom of all people of fashion..." (VAUX, James Hardy. Memoirs of James Hardy Vaux. Londres: W. Clowes, 1819, v. 1, p. 216). 


\title{
CAPÍTULO II - A sedução da ópera e suas primeiras implicações
}

\author{
Os divertimentos são essencialmente \\ limitados à ópera, para a qual eles \\ dispõem de um pequeno teatro ${ }^{118}$.
}

Uma vez mencionada - pelo mesmo Major Semple Lisle, há pouco referido - como espécie de "divertimento essencial", concentremos agora o nosso foco na ópera, espetáculo poético, cênico e musical ${ }^{119}$, tão consumido pela corte portuguesa, sobretudo a partir de meados do século $\mathrm{XVIII}^{120}$, e que, também, nessa mesma época, seguindo, pois, a moda da metrópole, já ganhava apreciadores e protetores suficientes no Rio de Janeiro - ao lado das apresentações cênicas comuns, ou entremeadas com canções - a ponto de essa cidade abrigar, antes mesmo de tornar-se capital do Estado do Brasil, pelo menos, duas casas do gênero.

118 Tradução nossa de: "The amusements are chiefly confined to the opera for which they have a small theatre" (LISLE, James George Semple. Op. cit., p. 278)

119 Rousseau (1712-1778), em seu célebre Dictionnaire de musique, de meados do século XVIII, já definia "ópera" como um misto de poesia, música e cenário: "Les parties constitutives d'un Opéra sont, le poème, la Musique, \& la Décoration. Par la Poésie on parle à l'esprit, par la Musique à l'oreille, par la Peinture aux yeux;" (ROUSSEAU, Jean-Jacques. Collection complète des oeuvres de J.-J. Rousseau. Genève: Du Peyrou, 1782-1789, t. 9, p. 478).

${ }^{120}$ Segundo Luiz de Freitas Branco, a ópera penetrou em Portugal no ano de 1682 (BRANCO, Luiz Maria da Costa de Freitas. Música em Portugal. Lisboa: Imprensa Nacional, 1929, p. 16). Teófilo Braga vai ainda mais além admitindo a existência do gênero já no reinado de Dom João IV (1640-1656): "Não se havia recolhido fatos por onde se conhecesse que a Ópera existira na corte musical de Dom João IV e assinava-se a sua introdução em Portugal com datas muito recentes. Nas obras de Francisco Manuel de Mello temos bastantes elementos para determinar a admissão da Ópera" (BRAGA, Teófilo. História do teatro português: a comédia clássica e as tragicomédias. Séculos XVI e XVII. Porto: Imprensa Portuguesa, 1870, p. 349). Sabe-se ao certo que, com a ascensão de Dom João $V(1706-1750)$ e seu casamento em 1708, deu-se a implantação definitiva desse gênero italiano na corte portuguesa. Nesse período e também nos subseqüentes, importantes compositores e intérpretes, sobretudo de Nápoles e Bolonha, estiveram em Lisboa. Domenico Scarlatti, por exemplo, morou na capital portuguesa de 1721 a 1729 . Foi, no entanto, já no reinado de Dom José I (1750-1777) que se concluiu a "Ópera do Tejo", suntuoso teatro - idealizado por Giovanni Bibiena, o mesmo arquiteto bolonhês que construiu o igualmente aparatoso Teatro Josefina, de Viena - , destruído, porém, no ano da sua inauguração em conseqüência do terremoto que assolou Lisboa, em novembro de 1755. 
A primeira delas, que teria sido conhecida como "Ópera dos Vivos" segundo concluiu Vieira Fazenda —, foi descrita, como já vimos, pelo anônimo oficial da marinha francesa de passagem pelo Rio, em 1748; e, segundo estudos recentes de Nireu Cavalcanti, situava-se nas imediações de onde está localizada hoje a estação de metrô Uruguaiana ${ }^{121}$. Já, a segunda, é esta, agora referida, pela primeira vez, em um opúsculo, intitulado Epanáfora festiva - uma relação das festas celebradas no Rio de Janeiro por ocasião do nascimento, em 1762, do Príncipe da Beira, Dom José, primogênito da Princesa Real, Dona Maria, futura Rainha -, como "um teatro que se construiu na praça contígua ao Palácio de residência dos Governadores" ${ }^{122}$; portanto, situada ao lado do Paço Imperial, na atual praça Quinze de Novembro. Ali, por ocasião dos mesmos festejos,

... se deram ao povo três Óperas à custa dos homens de negócio, que para este obséquio concorreram com mão larga. Com dizer que havia ali uma decoração soberba, que as vistas eram naturalíssimas, que a orquestra era numerosíssima, e as personagens excelentes na Música, e peritos na arte de representar, digo todo o mérito desta ação. Gostoso emprego do tempo, onde entrando de revolta o útil com o agradável igualmente se instruem os homens, e se divertem! $!^{123}$

${ }^{121}$ CAVALCANTI, Nireu. Op. cit., p. 173.

122 EPANÁFORA festiva, ou relação sumária das festas, com que na cidade do Rio de Janeiro capital do Brasil se celebrou o feliz nascimento do sereníssimo Príncipe da Beira Nosso Senhor. Lisboa: na Oficina de Miguel Rodrigues, 1763, p. 27-28.

123 Ibidem, p. 28. Note-se que uma outra publicação lisboeta contemporânea à Epanáfora narra os mesmos festejos com outros dados interessantes. O título da referida publicação é Relação dos obsequiosos festejos, que se fizeram na Cidade de S. Sebastião do Rio de Janeiro, pela plausível notícia do nascimento do sereníssimo senhor Príncipe da Beira o senhor d. José no ano de 1762, oferecida ao nobilíssimo Senado da mesma cidade, que tão generosamente concorreu para estes grandes festejos, em que se empenhou a sua fidelidade, e desempenhou o seu afeto, por um seu cidadão e anônimo (Lisboa: na oficina patriarcal de Francisco Luiz Ameno, 1763). Segundo um dos Anais da Biblioteca Nacional, que reproduz parte do conteúdo dessa rara publicação setecentista (a Biblioteca Nacional possui um exemplar em sua Seção de Obras Raras sob o código 23, 1, 5, n. 23), teriam os comerciantes cariocas desembolsado para esses três dias de ópera - realizadas precisamente a 2, 5 e 8 de junho de 1762 -, a vultosa quantia de 8.000 cruzados, ou 3 contos e 200 mil réis (ANAIS da Biblioteca Nacional. Rio de Janeiro, v. 2, p. 187-188, 1877). Essa soma, doada pelos negociantes, corresponderia à venda de exatos 10.000 
Em vista desse texto, atentemos, inicialmente, para uma importante informação; a de que os "homens de negócio" agiam não apenas como espectadores de uma música derivada de hábitos cortesãos, mas como mecenas de tais espetáculos. A explicação para esse fato se deve à própria trajetória histórica dessa elite mercantil na América Portuguesa, formada em sua maioria, por naturais do reino, sem qualquer estirpe, que, chegando ao Brasil e fixando-se nos principais portos, como o Rio de Janeiro, vinham, após a descoberta do ouro, em fins do século XVII, enriquecendo rapidamente com o comércio e suplantando, em cabedais, a chamada "nobreza da terra", esta descendente dos conquistadores, tradicionalmente vinculada ao senhorio da terra, e, por tais qualidades, hereditariamente possuidora do status social e dos principais postos locais de governança ${ }^{124}$. Isso consolidou, logo em inícios do século XVIII, uma situação social - em certos aspectos semelhante ao que ocorreu na Europa com a ascensão

ingressos para a platéia do teatro, caso o valor de cada entrada fosse o de uma pataca (320 réis), como já conjecturamos e como será confirmado mais adiante.

${ }_{124}$ Uma das melhores definições dessa chamada "nobreza da terra" é, sem dúvida, a que foi dada por João Fragoso: "Como se sabe, na antiga sociedade lusa cabia ao governo cuidar do bem comum da República: dirigir a organização social e política das regiões, sendo isto feito pelas pessoas de melhor qualidade da localidade - reunidas na Câmara - e pelos ministros do Rei, ambos subordinados à Coroa. (...) Seguindo um velho costume luso, os postos camaristas e os ofícios régios - se concedidos como propriedade - podiam ser hereditários. O acesso à Câmara pressupunha pertencer à governança da terra, ou seja, descender de antigos camaristas. O cargo de Juiz de Órfãos podia passar de pai para filho. A soma destes aspectos do "governo" contribuiu para a formação de uma nobreza da terra e, conseqüentemente, de uma hierarquia social estamental e excludente. Em outras palavras, algumas famílias detinham parte do mando local, por terem melhor qualidade que as demais mortais. Como tais, as primeiras famílias interferiam na vida da República e nos seus negócios, em particular no mercado. (...) O processo de montagem da sociedade colonial fluminense e de sua elite ilustra bem estes cenários. Coubera à Coroa a ocupação da região, porém com a decisiva participação de segmentos das elites vindas de outras áreas americanas. Estes últimos, no melhor estilo da época, colocaram suas fazendas, suas parentelas, seus escravos e flecheiros ao serviço do rei. Em troca, receberam mercês, como de sesmarias e ofícios régios. Da mesma forma, a tais conquistadores caberiam os postos da Câmara da "cidade", transformando suas famílias nos homens bons da região. Portanto, a organização da nova sociedade não fora dirigida apenas pelas autoridades vindas do Reino ou do Governo Geral do Brasil, mas também pelos conquistadores. Neste sentido, a constituição do Rio colonial seria, simultaneamente, de uma hierarquia social de matizes do Antigo Regime, sendo o seu topo dominado pelos conquistadores, agora transformados na nobreza da terra" (FRAGOSO, João. Afogando em nomes: temas e experiências em história econômica. TOPOI. Revista de história. Rio de Janeiro: PPGHIS/UFRJ, n.5, p. 44-45, 2002). 
econômica de "grupos burgueses"125 —, de plebeus riquíssimos e desejosos em adquirir esse mesmo status social e os privilégios, foros e isenções inerentes à condição de nobreza, o que, pela prática do Antigo Regime, ainda tinham certa dificuldade de alcançar. Afinal, para obter tais prerrogativas, não bastava aos ricos comerciantes apenas viver "com todo luzimento à lei da nobreza" - como alegaram, certa vez, em $1707^{126}$-, em suma, imitando os códigos de conduta dos nobres. Era também necessário ser apoio da soberania, "coluna do Estado"127, desempenhar o papel que, em séculos anteriores, fora representado pelos conquistadores do continente americano. Assim, inúmeras foram as situações que levaram essa elite mercantil a negociar mercês e títulos em troca quase sempre de grossos donativos que dessem sustentação financeira ao fausto real ou a obras de cunho

${ }^{125}$ A esse respeito, Norbert Elias novamente nos mostra que "A aceleração da monetarização e da comercialização no século XVI deu aos grupos burgueses um estimulo ainda maior e empurrou fortemente para trás o grosso da classe guerreira, a velha nobreza. Ao fim das lutas sociais nas quais essa violenta transformação da sociedade encontrou expressão, crescera consideravelmente a interdependência entre partes da nobreza e da burguesia. A nobreza, cuja função e forma social em si estavam passando por uma transformação decisiva, tinha nesse momento que enfrentar um terceiro estado, cujos membros haviam se tornado, em parte, mais fortes e mais socialmente ambiciosos do que até então. Numerosas famílias da velha nobreza guerreira se extinguiram, muitas famílias burguesas assumiram caráter aristocrático e, dentro de algumas gerações, seus próprios descendentes defendiam os interesses da nobreza transformada contra os da burguesia, interesses que, nessa ocasião, acompanhando a integração mais estreita, eram mais inescapavelmente opostos entre si. O objetivo dessa classe burguesa, ou pelo menos de seus principais grupos, não era - como o de partes substanciais da burguesia em $1789-$ eliminar a nobreza como instituição social. O mais alto objetivo do burguês enquanto indivíduo era, conforme já dissemos acima, obter para si e sua família um título aristocrático, com os privilégios que o acompanhavam. Os grupos representativos dirigentes da burguesia como um todo partiram para conquistar os privilégios e o prestígio da nobreza militar. Não queriam acabar com a nobreza como tal, mas, no máximo, assumirIhe o lugar como nova nobreza, suplantando ou meramente suplementando a antiga. Incessantemente, esse grupo dirigente do terceiro estado, a noblesse de robe, insistiu no século XVII, e mais ainda no século XVIII, que sua nobreza era exatamente tão boa, importante e autêntica como a conquistada pela espada. A rivalidade assim expressada certamente não se manifestava apenas em palavras e ideologias. Por trás dela, travava-se uma luta mais ou menos disfarçada e sem decisão por posições de poder e vantagens entre os representantes dos dois estados" (ELIAS, Norbert. Op. cit., v. 2, p. 152).

${ }_{126}$ Segundo Caio Prado Jr., em 1707, negociantes do Rio de Janeiro, em representação à Coroa, clamavam providências contra a nobreza da terra, que empregava "toda sorte de fraudes e violências para os excluírem do número dos eleitores e dos postos da administração. E para fundamentarem seus direitos, alegavam 'que com abundância de seus próprios cabedais viviam com todo luzimento à lei da nobreza'" (PRADO JR., Caio. Op. cit., p. 39).

${ }_{127}$ Cf. OLIVEIRA, Luiz da Silva Pereira. Privilégios da nobreza e fidalguia em 
urbanístico, militar, religioso ou assistencial ${ }^{128}$. Maria Fernanda Bicalho, em artigo da Revista brasileira de história, que, entre outros méritos, resgata interessantes documentos do Arquivo Histórico Ultramarino, atenta para o fato de que,

... desde o século XVII, os mercadores do Rio
de Janeiro - dada a constante falta de recursos
dos cofres régios - contribuíram com grossos
cabedais no serviço de Sua Majestade,
sobretudo no que se refere à defesa da
Capitania. Almejando participar dos cargos de
governança, desenvolviam estratégias de
enobrecimento, quer casando-se com as filhas
da "nobreza da terra", quer ingressando na
carreira militar e mesmo eclesiástica, e ainda
nas irmandades e confrarias religiosas. Outra
forma muito comum de ascensão por parte dos
mercadores baseava-se na expectativa de
recebimento de honras e mercês da Coroa, em
troca do investimento pecuniário no serviço real,
mormente nos negócios da defesa e
acrescentamento do Império, e ainda em obras
públicas de saneamento e embelezamento das
cidades. Em troca de tais serviços não raro
demandavam à Coroa recompensas em status
- como era prática institucionalizada no Antigo
Regime - pedindo mercês e mais
especificamente hábitos das Ordens militares ${ }^{129}$.

Portugal. Lisboa: na Nova Oficina de João Rodrigues Neves, 1806.

${ }^{128}$ Lembremos mais uma vez que a abundância de associações religiosas leigas as irmandades - na colônia, suprindo as falhas da organização eclesiástica formal, foi importante no sentido de dar aos membros das elites mercantis cariocas mais oportunidades de conquista de prestígio social. Participar da direção das irmandades, como provedor ou tesoureiro, ou mesmo ser apenas irmão de algumas delas, doando somas importantes para a realização de obras pias, foi, sem dúvida, outra forma, além do já tradicional socorro às finanças públicas, de obter pontos em um eventual processo de nobilitação. Em relação à já mencionada Irmandade do Santíssimo Sacramento, da Paróquia de Nossa Senhora da Candelária, figuraram como provedores, por exemplo, conhecidos negociantes de grosso trato da época, como Brás Carneiro Leão (1785-1786), Antônio Gomes Barroso (1794-1795), Manoel Velho da Silva (1797-1798) e Elias Antônio Lopes (1803-1804) (PINHEIRO, Francisco Batista Marques. Op. cit., v. 1, p. 42-43).

${ }_{129}$ BICALHO, Maria Fernanda. As Câmaras Municipais no império português: o exemplo do Rio de Janeiro. Revista Brasileira de História. São Paulo: ANPUH, v.18, n. 36, p. 251-280, 1998. 
Obsequiar, "com mão larga", o Rei, homenageando o nascimento de seu neto com música e teatro suntuosos, foi, então, para os ricos "homens de negócio" cariocas, outra ótima oportunidade de barganhar tais hábitos e mercês, e fortalecer cada vez mais seu status social na difícil competição com a "nobreza da terra" pelos postos políticos mais importantes da cidade, entre os quais, as cadeiras do Senado da Câmara ${ }^{130}$.

Por outro lado - mais estritamente musical —, eis, também, impresso nessa Epanáfora festiva, mais um indício de que a música secular, tomando parte efetiva dos hábitos cariocas setecentistas, era de boa qualidade, quanto à sua execução. Evidentemente, devemos ressalvar que tal conjunto de descrições - muitas vezes rasteiras, ou mesmo exageradamente apologéticas - não são uma prova definitiva de que a música ouvida no Rio de Janeiro setecentista era bem executada. Pela própria natureza da documentação, não se trata, em nenhum caso, de críticas musicais, escritas por connaisseurs. Pelo contrário. Podem ser, na maior parte, impressões de pessoas pouco dadas às artes, de sensibilidade duvidosa. Além disso, a execução musical, por sua natureza precária, dificilmente permite ao ouvinte

${ }^{130}$ Bicalho, no mesmo artigo já mencionado, também atenta para a dificuldade que os comerciantes cariocas tinham de galgar postos políticos durante todo o século XVIII: "a casta de comerciantes reinóis das principais cidades marítimas da colônia foi sistematicamente rechaçada pela 'nobreza da terra' dos serviços nos postos da governança, sob a alegação de não possuírem os requisitos necessários de status exigidos pelas leis metropolitanas. Assim, foi comum nas cidades marítimas brasileiras a existência de uma profunda tensão entre a defesa aguerrida das prerrogativas ligadas ao status dos proprietários de terra - mesmo que empobrecidos e crescentemente endividados - e a afirmação econômica do segmento de comerciantes portugueses que lutavam por um lugar nos códigos estamentais da época e nos cargos políticos da colônia" (Cf. BICALHO, Maria Fernanda. Op. cit., p. 251-280). Em relação a esse assunto, note-se ainda que, almejando privilégios, foros e isenções, os comerciantes não apenas abriam sua "mão larga" nos eventos em obséquio ao Rei, mas também em benefício do mais altos representantes do monarca na colônia. Para tanto, os Governadores e Vice-Reis certamente souberam negociar com essa gente seu apoio político em troca de opulência. Tal hipótese é denunciada por uma representação, de 1732, dos oficiais do Senado da Câmara do Rio de Janeiro. Em tal documento, os nobres acusam o Governador Luiz Vahia Monteiro de, em 1729, "sugerir" - e, subentende-se, ajudar a eleger "por conveniências e interesses particulares" - "um intruso vereador de barrete e outro de menor capacidade". Eram os dois, muito provavelmente, comerciantes - um deles, subentende-se, judeu -, pois, ao final da mesma representação, os Oficiais da Câmara rogam ao Rei que "caixeiros, tendeiros ou homens (...) de tratos mercantis, nem seus filhos e netos, sem embargo de serem formados ou oficiais de ordenança" jamais pudessem assumir "os lugares da câmara e cargos honrosos dela" (ANAIS da Biblioteca Nacional. Rio de Janeiro, v. 46, p. 129-131, 
- mesmo o entendido - uma análise apurada de seu próprio valor estético. Reflete-se sobre suas qualidades quase tão fugazmente quanto sua própria existência fugidia ${ }^{131}$. Contudo, não podemos deixar de notar, a partir do conjunto documental aqui reunido, uma forte tendência de aceitação da música realizada no Rio de Janeiro setecentista. Juntemos, então, mais uma impressão positiva; pois, além do Juiz de Fora Luiz Antônio Rosado da Cunha, do anônimo oficial da marinha francesa, do "Seleto" Manuel Tavares de Siqueira e Sá, de M. de La Flotte, de Parny, de Pinczon du Sel e do também autor anônimo da Epanáfora, ainda podemos lembrar as boas recordações musicais de Dom Luís Antônio de Sousa Botelho Mourão, Morgado de Mateus, que, vindo de Lisboa para tomar posse do Governo da Capitania de São Paulo, passou, em 1765, pelo Rio de Janeiro e assistiu à ópera Precipício de Faetonte (1738), do "Judeu", Antônio José da Silva (1705-1739), tendo notado em tal espetáculo "excelente música e dança" ${ }^{132}$.

Tal tendência de aceitação nos faz refletir e presumir a existência, nessa época e local, de uma eficiente educação para a música, que permitisse a formação de bons profissionais, uma vez que, apesar da esporádica estada de músicos europeus estranhos ao reino português ${ }^{133} \mathrm{e}$,

1924).

131 O musicólogo alemão Carl Dahlhaus (1928-1989) é da mesma opinião ao enunciar que "dificilmente se pode negar que a música, como afirma Herder, é uma arte 'enérgica', a qual se realiza numa afetividade. O seu caráter de obra é problemático. A música é transitória; passa, em vez de resistir à reflexão" (DAHLHAUS, Carl. Estética musical. Tradução de Artur Mourão. Lisboa: edições 70, 1991, p. 23)

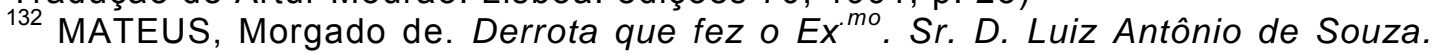
Governador e Capitão-General da Cidade de S. Paulo, indo para a do Rio de Janeiro em a Nau de Guerra N. Sra . da Estrela de que era Comandante. Biblioteca Nacional do Rio de Janeiro, Divisão de Manuscritos, Fundo Morgado de Mateus: 21,4,14-16. Note-se que Nireu Cavalcanti utiliza-se do mesmo texto manuscrito em seu já várias vezes mencionado livro $O$ Rio de Janeiro setecentista (CAVALCANTI, Nireu. Op. cit, p. 183).

${ }^{133}$ Além do já mencionado relato do anônimo oficial da marinha francesa, que dizia haver, em 1748, no Rio, "um inglês que tocava excelentemente a flauta transversal", existe uma outra notícia da provável presença de um exímio músico europeu no Rio de Janeiro setecentista, agora em 1764. Parte dessa informação é do inglês, membro da Academia Real de Ciências de Londres, Richard Twiss (1747-1821), que esteve em Lisboa em 1772. Em seu diário de viagem, intitulado Travels through Portugal and Spain: in 1772 and 1773 e publicado em Londres, em 1775, Twiss afirma ter ouvido, em Lisboa, o primeiro violinista do rei, "Mr. Groeneman" - Jeronimo Groneman - , um teutônico, que havia sido contratado alguns anos antes por "Lord Clive" — o general inglês Robert Clive (1725-1774) - para ir às Índias Orientais. Porém, Groneman acabou sendo deixado no Brasil e, posteriormente, empregou-se em Lisboa: "The first violin was played by Mr. Groeneman, a German, who 
obviamente, de reinóis, a maior parte desses artistas deveria ser originária do próprio Rio de Janeiro, quando não, de outros pólos urbanos da colônia, como Salvador, Recife e as principais urbes mineiras.

É muito provável que, pelo menos até a publicação do Alvará Real de 28 de junho de 1759, parte desses ensinamentos musicais locais tenham sido realizados pelos jesuítas. Basta lembrarmos que o Real Colégio das Artes mantido no Rio pela Coroa e dirigido pela ordem religiosa fundada por Inácio de Loyola foi a mais destacada instituição educacional brasileira da primeira metade do século XVIII, a ponto de quase todos os importantes literatos setecentistas brasileiros terem passado pelos seus ensinamentos. Caso, por exemplo, de Basílio da Gama (1740-1785), Santa Rita Durão (1737-1784), Cláudio Manuel da Costa (1729-1789), Alvarenga Peixoto (1744-1793), Silva Alvarenga (1749-1814) e Domingos Caldas Barbosa (1740-1800) ${ }^{134}$.

Fortalece tal argumento, o geógrafo Adrien Balbi (1782-1848) que nos apresenta, em seu Essai statistique sur le Royaume de Portugal et d'Algarve, de 1822, a informação de que teria existido, nas imediações do Rio - na Fazenda de Santa Cruz -, "uma espécie de conservatório de música", estabelecido pelos jesuítas em época passada não determinada, com o intuito de "formar os negros" na arte dos sons ${ }^{135}$.

was engaged to go with lord Clive to the East Indies some time ago, but left him at the Brasils, and came to Lisbon, where he now is the first violin to the king" (TWISS, Richard: Travels through Portugal and Spain: in 1772 and 1773. London: Robinson, Becket and Robson, 1775, p. 9). Segundo o comodoro inglês John Byron (1723-1786) que esteve no Rio entre setembro e outubro de 1764, Lord Clive ancorou nesse porto, na mesma época, vindo diretamente da Inglaterra (HAWKESWORTH, John. Op. cit., v. 1, p. 6). Daí conjecturarmos que o tal violinista alemão teria estado no Rio, especificamente nesse ano. Como sua admissão na Câmara Real de Lisboa ocorreu apenas em julho de 1766, é possível ainda supor que Groneman tenha permanecido na capital do Estado do Brasil por um ano ou pouco mais - talvez a serviço do Vice-Rei - antes de ir a Portugal e ser contratado como spalla da Câmara Real (SCHERPEREEL, Joseph. A orquestra e os instrumentistas da Real Câmara de Lisboa, de 1764 a 1834. Tradução de Maria Fernanda Cidrais. Lisboa: Fundação Calouste Gulbenkian, 1985, p. 24).

${ }_{134}$ Cf. ROMERO, Silvio. Op. cit., p. 404-485. Valorizando o ensino realizado pelos jesuítas no Brasil colonial, Tito Lívio Ferreira também lembra que, de 1557 a 1822, cerca de 2.500 alunos provenientes dos Reais Colégios brasileiros formaram-se na Universidade de Coimbra, sem contar a Universidade de Évora (FERREIRA, Tito Lívio; FERREIRA, Manoel Rodrigues. História da civilização brasileira. São Paulo, Biblos, 1959, p. 33). Desses 265 anos de ensinamentos e estudos, 202 estiveram sob a responsabilidade da Companhia de Jesus.

135 “Nous croirions n'avoir atteint qu'imparfaitement notre but si nous ne disions ici 
É importante notar que a existência de tal instituição foi fortemente contestada por Francisco Curt Lange em seu já citado artigo que integra a História geral da civilização brasileira ${ }^{136}$. O musicólogo alegou que os exaustivos estudos de Serafim Leite em sua História da Companhia de Jesus no Brasil jamais apontaram para a presença, no Brasil, de músicos profissionais, entre os padres dessa ordem. Lange, no entanto, não se deu conta de que fazer música era uma atividade intrínseca à função sacerdotal. O próprio Padre Serafim Leite, em outro de seus vários estudos sobre a ordem jesuítica no Brasil, afirmou que

... missionários (...) que eram mestres daquela música e daqueles cantos (...) são nomes que em vão se buscariam nos catálogos com estes predicados de cantor e músico; (...). Não era ofício independente, era e é função sacerdotal, porque todo o padre deve estar apto a cantar missa; e requerer-se portanto em todos algum conhecimento de canto ou solfa na expressão daquela época. Por ser comum aos padres, não se menciona ... ${ }^{137}$.

Pouco mais adiante, Serafim Leite listou uma série de nomes de jesuítas que se fizeram notar como músicos por alguma circunstância pessoal. Entre esses, figura, por exemplo, o desconhecido Manuel de Leão

en passant on mot sur une espèce de conservatoire de musique établi depuis longtemps dans les environs de Rio-Janeiro, et qui est destiné uniquement à former des nègres dans la musique. Cette institution est due aux jésuites, ainsi que toutes celles établies du Brésil avant l'arrivée du Roi, que se rattachent à la civilisation et à l'instruction du peuple". (BALBI, Adrien. Essai Statistique sur le royaume de Portugal et d'Algarve. Paris: Rey et Gravier, 1822, v. 2, p. ccxiii). A esse respeito, note-se também o interessante depoimento do já citado abade Blanchardière, que, em 1748, testemunha ter visto, no Rio de Janeiro, negros tocando trompetes "com muito gosto" e ainda violinos e violas de mão para seus senhores, incluindo-se o próprio Governador do Rio, aqui chamado de "General": "Les violons se sont entendre de la plupart des maisons: chaque Maître est curieux de faire apprendre à ses Nègres à jouer de cet instrument. II y a beaucoup de guitares; I'on y entend aussi plusieurs trompettes qui sont des accords assez agréables. Je goûtai surtout un soir ce plaisir, lorsque le Général revenait par eau d'une maison de campagne, située au fond de la Baye, \& passait le long de notre Bord avec deux Noirs placés au-devant de son canot qui jouaient de cet instrument avec assez de goût" (BLANCHARDIĖRE, René Courte de La. Op. cit., p. 190-191).

${ }_{136}$ HOLANDA, Sérgio Buarque de (org.). Op. cit., v. 5, p. 373-374.

${ }^{137}$ LEITE, S. I. Serafim. Op. cit., p. 62 
(1684-1760), natural do Rio de Janeiro, e que é citado em uma passagem por Campos dos Goitacases, em 1730, como "insigne organista" e "diretor de coros e orquestra". Em 1745, estava o mesmo músico no Colégio dos Jesuítas do Rio de Janeiro, onde permaneceu até 1760, quando, expulso de sua terra natal, veio a falecer em Roma, no mesmo ano ${ }^{138}$.

Enfim, além da existência mais provável do que improvável desse conservatório - ou coisa que o valha - podemos contar que o ensino da música no Rio setecentista ainda se deu no Seminário de São Pedro, instituição educacional fundada em 1739139; muito possivelmente nas paróquias - pelos padres seculares —; nos regimentos militares; ou, enfim, por lições particulares de profissionais do ramo, os quais poderiam até mesmo lecionar música a diletantes, como a dama que tocou minuetos ao cravo para os franceses, em 1773. Quanto a essa última condição, lembremos, por exemplo, a figura de Salvador José de Almeida e Faria (c.1732-1799), que, segundo Moreira de Azevedo ${ }^{140}$, teria sido o principal mestre do Padre José Maurício Nunes Garcia, e, para quem, decerto, não faltou trabalho nas mais ricas casas cariocas, já que a análise do Inventário post-mortem desse professor, realizada por Nireu Cavalcanti, levou tal pesquisador a presumir

... que Salvador José havia chegado, através de sua profissão, a uma boa posição social, pois possuía dois imóveis na rua da Cadeia (...), e sete escravos - itens, que indicam um padrão de vida mais elevado ${ }^{141}$.

${ }^{138}$ Ibidem, p. 64 e 202.

139 Em referência a essa instituição, conhecida como "Seminário dos órfãos", Monsenhor Pizarro afirma, peremptoriamente, ter-se ali criado, além de outras aulas, as "de música e de cantochão" (ARAÚJO, José de Sousa Azevedo Pizarro e. Memórias históricas do Rio de Janeiro. Rio de Janeiro: Na Tip. de Silva Porto, 1822, v. 7, p. 219).

140 AZEVEDO, Manuel Duarte Moreira de. Biografia dos brasileiros ilustres por armas, letras, virtudes etc. Padre José Maurício Nunes Garcia. Revista do Instituto Histórico e Geográfico Brasileiro. Rio de Janeiro, v. 43 (t. 34 parte 2), p. 294, 1871.

141 CAVALCANTI, Nireu. Op. cit., p. 185. Note-se que esta informação não prova, por si só, que o ensino musical deu a Salvador José um nível de vida mais elevado. Poderia ter o mestre de José Maurício outros negócios lucrativos, ou, ainda, herdado parte de seu patrimônio. De qualquer forma, a descoberta de Cavalcanti vale como hipótese e é aqui reforçada por uma descoberta similar nossa: outro músico da época, Florentino de Aragão 
Prova mesmo irrefutável de que o Rio de Janeiro já dispunha de uma vida musical evoluída mais de vinte anos antes da chegada da família real portuguesa foi a criação formal, em 1784, de uma organizada corporação de músicos. Referimo-nos à Irmandade da Gloriosa Virgem e Mártir Santa Cecília, ou simplesmente Irmandade de Santa Cecília, que, além de proteger e profissionalizar essa classe de artistas, estabelecendo rígidas regras para o exercício da atividade musical ${ }^{142}$, realizava, com uma "completa orquestra", concertos em sua sede, a Igreja de Nossa Senhora do Parto, como podemos constatar na seguinte notícia, publicada na Gazeta de Lisboa em 10 de maio de 1791:

Da mesma Capital da América também
informam que, constando ali haver o
Excelentíssimo Luiz de Vasconcelos e Sousa
felizmente chegado à Corte, excitou esta grata
notícia em todos aqueles moradores uma tão
viva, e saudosa recordação do governo deste
Fidalgo, que, não podendo mostrá-la de outra
sorte, resolveram dar graças ao Céu na Igreja
de N. Senhora do Parto (com a qual, e seu
Recolhimento praticara Sua Excelência muitas
ações de piedade) fazendo, mediante a
Irmandade de Santa Cecília, cantar um Te
Deum, cuja nova Música foi composta por José
Maurício Nunes Garcia, e executada por uma
completa Orquestra. O Excelentíssimo Vice-Rei
sucessor, o Excelentíssimo Bispo, Nobreza,
Ministros, Militares, e Corpo do Comércio
assistiram a esta gratulatória ação, que,
causando geral devoção e contentamento, ficou

Espanha, segundo seu inventário post-mortem, tombado no Arquivo Nacional (Inventários, maço 466, proc. 8888), possuía ao falecer, em 1808, cinco escravos, o que indica, também, como bem observou Cavalcanti, "um padrão de vida mais elevado".

${ }_{142}$ Segundo Ayres de Andrade, o Arquivo Nacional do Rio de Janeiro guarda o "Compromisso Estatutário" dessa entidade, assinado, a 3 de julho de 1784, por 33 músicos, entre os quais José Maurício Nunes Garcia e os recém mencionados Florentino de Aragão Espanha e Salvador José de Almeida e Faria (ANDRADE, Ayres de. Op. cit., v. 1, p. 77-96). Esse compromisso foi confirmado quase três anos depois, a 8 de outubro de 1787, pelo Vice-Rei do Estado do Brasil, Dom Luís de Vasconcelos conforme nos atesta outro documento tombado no Arquivo Nacional, Conjunto documental Registro Geral de Ordens Régias, Fundo Secretaria de Estado do Brasil (códice 64, v. 20, Fls. 46-63). 
sendo um novo e bem merecido monumento da memória, que conservará aquela Capital de um Vice-Rei, que tanto se distinguiu no seu governo ${ }^{143}$.

Aproveitando a referência aos Vice-Reis, retomemos o importante fato de que, a partir de 1763, o Rio de Janeiro passou a abrigar a sede de governo de todo o Estado do Brasil, e que essa mudança política adicionou ao já centralizado governo e à já diversificada elite social - em que "nobres se distinguiam dos da plebe pelos rostos, e pelos nomes, não pelas galas" 144 —, uma pompa ainda maior, digna, agora, de um governante - de acordo com a impressão do já citado comodoro John Byron, que ancorou, em 1764, na Guanabara - "talvez, de fato, tão absoluto como qualquer outro soberano sobre a Terra"145.

Corcino Medeiros dos Santos, que atentou para o fato de ter havido, após o advento do ouro, uma transformação dos costumes dos cariocas mudança essa sentida sobretudo nos aspectos qualitativos das mercadorias que chegavam à Guanabara, importadas por uma "burguesia, tanto mineira como comercial" que "procurava viver dentro dos padrões europeus,

143 ALMEIDA, Manuel Lopes de. Op. cit., v. 2, p. 222-223. Note-se aí, nessa importante ocasião social, já a presença do "Corpo do Comércio" entre "suas excelências, Nobreza, Ministros e Militares", corroborando a hipótese de que essa elite econômica carioca foi, até fins do século XVIII, conquistando seu espaço social e político da capital do Estado do Brasil.

${ }^{144}$ Testemunha tal fato o autor anônimo da já mencionada Epanáfora Festiva, que conta como foram os festejos realizados no Rio, em 1762, por ocasião do nascimento do Príncipe da Beira, Dom José (Op. cit., p. 6). Eis mais um indício de que uma parte da "plebe" - certamente aqui representada pelos comerciantes - se misturava cada vez mais à nobreza, graças à sua opulência, imitando-a nos costumes civilizados, como, por exemplo, o do trajar.

145 "The city, which is large, and makes a handsome appearance, is governed by the Viceroy of Brazil, who is perhaps, in fact, as absolute a sovereign as any upon earth" (HAWKESWORTH, John. Op. cit., v. 1, p. 6). Destacando a beleza e a extensão da cidade do Rio de Janeiro, o texto do comandante inglês também nos dá uma pequena idéia da pompa cerimonial que o primeiro Vice-Rei a residir no Rio, Conde da Cunha, tinha ao seu dispor, incluindo-se uma guarda pessoal de cerca de sessenta homens muito bem vestidos: "When I visited him, he received me in great form; above sixty officers were drawn up before the palace, as well as a captain's guard, who were men of a good appearance, and extremely well clothed; his Excellency, with a number of persons of the first distinction, belonging to the place, met me at the head of the stairs upon which fifteen guns were fired from the nearest port we then entered the room of state, and after conversing about a quarter of an hour in French, I took my leave, and was dismissed with the same form that 
preocupando-se com a exteriorização de sua opulência" - considera, também, que, aliada ao crescimento do poder aquisitivo, muito teria contribuído para a mudança desses costumes

... a vinda de vice-reis e governadores titulados, com experiência da vida de corte e que tentaram muitas vezes, amenizar as saudades do paço Real criando uma pequena corte em torno de $\mathrm{si}^{146}$.

E não seria apenas aprendendo a falar o bom francês, vestindo veludos, brocados e tafetás indianos, tomando chá em porcelanas chinesas e fazendo música em cravos ingleses que as elites cariocas se aproximariam dos padrões de vida civilizada. Ir à ópera tornava-se igualmente indispensável, pois, além de ser um divertimento típico da corte lisboeta, já era, também, como poderemos verificar, o principal da mais alta autoridade do Brasil; distração que poderia servir como aparato ao seu próprio obséquio $^{147}$ ou a uma digna recepção a ilustres visitantes estrangeiros ${ }^{148}$, antes de uma eventual perseguição política, como ocorreu com o Conde Louis-Antoine de Bougainville (1729-1811), em junho de 1767:

Enquanto isso, a atenção do Vice-Rei conosco
continuou por diversos dias. (...) e ele nos
preparou um camarote na Ópera. Pudemos

had been used at my reception" (Ibidem, p. 6).

${ }^{146}$ SANTOS, Corcino Medeiros dos. Op. cit., p. 187.

${ }^{147}$ Em carta destinada a Bernardino Marques, por exemplo, o Vice-Rei, Marquês do Lavradio, relata que em obséquio a sua posse (1769) foram realizadas no Rio três dias de luminárias, três dias de ópera, e outros três de outeiro, onde havia "uma magnífica orquestra de música" (LAVRADIO, Luiz de Almeida Portugal, Marquês do. Cartas do Rio de Janeiro. Rio de Janeiro: Arquivo Nacional, 1975, p. 35-36). Note-se que parte dos festejos realizados em obséquio aos vice-reis, eram financiados e organizados pelo Senado da Câmara do Rio de Janeiro.

148 São dois os relatos conhecidos de viajantes que, ao passarem pelo Rio de Janeiro, em diferentes épocas ao longo da segunda metade do século XVIII, receberam do Vice-Rei convite para ocuparem um dos camarotes do teatro carioca. O primeiro, mais conhecido, de Bougainville, segue no texto. O segundo, é este, escrito pelo já mencionado major inglês James Lisle, que esteve no Rio em 1797: "The Viceroy (...) sent me the key of a neat house, which I immediately occupied; a few days after which I received the key of a loge in the theatre, from the same generous source of benevolence" (LISLE, James George Semple. Op. cit., p. 270-271). 
então ver, em uma sala bastante bela, as obrasprimas de Metastásio representadas por uma trupe de mulatos, e ouvir trechos divinos dos grandes mestres da Itália, executados por uma orquestra, que dirigia, então, um padre corcunda em hábito eclesiástico ${ }^{149}$.

\section{Detenhamo-nos um pouco nessa célebre anedota do navegante} francês, que, apesar de bastante sucinta, nos oferece diversas informações. Inicialmente, reforça uma característica marcante da atividade artística no período colonial: a mulatice dos espetáculos. Dada a falta de explicações para esse fenômeno, apesar de muito lembrado, tracemos aqui algumas linhas e conjeturas.

Embora não existam dados demográficos muito precisos que apontem para uma correta proporção de mulatos na população brasileira colonial, é de se supor que esses já compusessem boa parte da população no início do século XVIII e que estivessem ocupando os mais diversos espaços na sociedade, fossem livres ou mesmo escravos. Uma leitura da Cultura e opulência do Brasil, de 1711, nos convence plenamente disso:

149 Tradução nossa de: "Cependant les attentions du Vice-roi pour nous, continuèrent plusieurs jours: (...) et il nous fit préparer une loge à l'Opéra. Nous pûmes dans une salle assez belle, y voir les chefs d'oeuvre de Métastasio représentés par une troupe de mulâtres, et entendre ces morceaux divins des grands Maîtres d'Italie, exécutés par un orchestre que dirigeait alors un Prêtre bossu en habit ecclésiastique". (BOUGAINVILLE, Louis-Antoine de. Voyage autour du monde, par la frégate du Roi La Boudeuse, et la flûte L'Etoile, en 1766, 1767, 1768 \& 1769. Paris, Chez Saillant \& Nyon, 1771 , v. 1, p. 77). Essa foi, sem dúvida, de Varnhagen até hoje, a descrição de época referente à atividade teatral e cênico-musical no Rio de Janeiro setecentista mais citada em obras de história geral ou mesmo especializadas em música. Registre-se aqui, no entanto, uma nota a respeito de uma pequena diferença que existe entre o texto impresso na primeira edição, de 1771, aqui traduzido, e o da segunda edição, publicado, um ano depois, pela mesma Saillant \& Nyon. Apenas nessa última versão é que aparece o adjetivo "mauvais" para a "orchestre", qualidade que tanto contribuiu para celebrar a prática musical do Rio setecentista como incipiente. Ora, se tal adjetivo não consta da primeira edição, é possível questioná-lo como expressão verdadeira do gosto de Bougainville. Ainda sobre imprecisões a respeito dessa passagem, é preciso lembrar a difusão bibliográfica de uma tradução desse texto, que substituiu a palavra "divinos" por "diversos" ou "vários" (trocou-se provavelmente, por acidente, "divins" por "divers"). E, enfim, o adjetivo "divins", omitido pelos muitos que reproduziram tal tradução deturpada, poderia até nos oferecer, dependendo da maneira como lemos o texto, ("pudemos ouvir trechos divinos dos grandes mestres da Itália"), um testemunho que desse à execução musical um caráter de aprazamento: ou seja, "trechos divinos" poderiam significar "divinas execuções de trechos". 
... eles e elas da mesma cor, ordinariamente levam no Brasil a melhor sorte, porque com aquela parte de sangue de brancos que têm nas veias, e talvez dos seus mesmos senhores, os enfeitiçam de tal maneira que alguns tudo Ihes sofrem, tudo lhes perdoam e parece que se não atrevem a repreendê-los; antes todos os mimos são seus. E não é fácil coisa decidir se nesta parte são mais remissos os senhores ou as senhoras, pois não falta entre eles e elas quem se deixe governar de mulatos, que não são os melhores, para que se verifique o provérbio que diz que o Brasil é inferno dos negros, purgatório dos brancos e paraíso dos mulatos (...) Bom é valer-se de suas habilidades quando quiserem usar bem delas, como assim o fazem alguns; porém, não se lhes há de dar tanto a mão que peguem no braço e de escravos se façam senhores ${ }^{150}$.

Apesar desse aparente avanço social, não podemos deixar de notar que as autoridades tenham sempre, via legislação, procurado detê-lo, restringindo, para as pessoas com esse "defeito" - como se dizia —, o uso de trajes luxuosos, o porte de arma, a ocupação de funções públicas e eclesiásticas. Em 1751, por exemplo, o Vice-Rei do Estado do Brasil e Conde de Atouguia, Dom Luís Peregrino de Ataíde, fazendo cumprir à risca a Lei, não admitiu que dois mulatos portassem o espadim, mesmo sendo, esses, "homens de negócio de cabedal e bom tratamento"151.

Por outro lado, como o citado Antonil dá a entender, houve, em relação aos mulatos, muita remissão, permitindo-se, a certos deles, escapar

${ }^{150}$ ANTONIL, André João. Cultura e opulência do Brasil. Por suas drogas e minas, com várias notícias curiosas do modo de fazer o açúcar, plantar e beneficiar o tabaco, tirar ouro das minas e descobrir as de prata; e dos grandes emolumentos que esta conquista da América meridional dá ao Reino de Portugal com estes e outros gêneros e contratos reais. Lisboa: Na Oficina Real Deslandesiana, 1711, p. 24.

151 "Logo que tomei posse Deste Governo, mandei publicar a Pragmática de 24 de maio de 1749 e proibindo ela às pessoas de baixa condição, como são aprendizes de ofícios mecânicos, lacaios, mochilas, marinheiros, barqueiros e fragateiros, negros e outras pessoas de igual ou inferior condição o uso do espadim ou espada, recearão dois mulatos, homens de negócio com cabedal e bom tratamento que a dita lei se entendesse com eles naquela proibição; mandarão oferecer 3000 cruzados para a Fazenda Real, se the permitisse trazerem espadim, o que não Ihes admiti" (ANAIS da Biblioteca Nacional. Rio de 
dessas rígidas normas e ascender socialmente. O brasilianista Charles Boxer, por exemplo, lembra o caso do herói da libertação de Pernambuco, João Fernandes Vieira, filho ilegítimo de uma mulata, que chegou a ser um rico senhor de engenho e Governador de Angola e da Paraíba ${ }^{152}$. Uma provisão de Dom João $\mathrm{V}$ ao Governador de Pernambuco, Duarte Sodré Pereira Tibau, de 1731, denota, igualmente, a permissibilidade com a qual o Conselho Ultramarino tratava o assunto, conferindo, duas vezes, a um mulato, o Bacharel Antônio Ferreira Castro, o cargo de Procurador da Coroa:

Me pareceu ordenar-vos que com efeito deis posse ao dito Antônio Ferreira Castro, cumprindo a minha provisão (...), tendo entendido que não tivestes justa razão para replicardes a ela, porquanto o defeito, que dizeis haver no dito provido por ser Pardo, the não obsta para este ministério... ${ }^{153}$

Servindo-se do mesmo exemplo anterior e analisando a questão em Raízes do Brasil, Sérgio Buarque de Holanda alertou que a influência dos "homens de cor" na vida da colônia "penetrava sinuosamente o recesso doméstico, agindo como dissolvente de qualquer idéia de separação de castas ou raças, de qualquer disciplina fundada em tal separação"154; e que, exemplos de esforços, no sentido de reprimir essa influência,

não perturbavam seriamente a tendência da população para um abandono de todas as barreiras sociais, políticas e econômicas entre brancos e homens de cor, livres e escravos ${ }^{155}$.

\footnotetext{
Janeiro, v. 31, p. 6, 1909).

${ }^{152}$ BOXER, Charles R. A idade de ouro do Brasil. Tradução de Nair de Lacerda. Rio de Janeiro: Nova Fronteira, 2000, p. 40-41.

${ }^{153}$ INFORMAÇÃO Geral da Capitania de Pernambuco. Sobre se dar posse ao Doutor Antônio Ferreira Castro do Ofício de Procurador da Coroa, pelo mulatismo lhe não servir de impedimento. Anais da Biblioteca Nacional. Rio de Janeiro, v. 28, p. 352, 1906. 1979, p. 24

154 HOLANDA, Sérgio Buarque de. Raízes do Brasil. Rio de Janeiro: José Olympio,

Ibidem, p. 24.
} 
É de se convir, no entanto, que, via de regra, o mulato não tivesse as mesmas facilidades do branco - ou do caboclo - para adquirir privilégios sociais e obter status de nobreza. Embora alguns deles fossem homens de negócio, bacharéis ou bastardos de fidalgos, podendo, nesse último caso, gozar da nobreza de seus pais, ainda que suas mães fossem escravas, a regra para esses mestiços - ou quando renegados por sua ascendência distinta, ou mesmo uma vez descendentes de brancos sem estirpe - era compor a chamada "mecânica", ou seja, assumir o exercício dos ofícios que já eram, por si próprios, incompatíveis com a nobreza e, conseqüentemente, relegados à plebe. Entre tais ocupações, figuravam, por exemplo, as dos alfaiates, barbeiros, ferreiros, funileiros, livreiros, marceneiros, ourives, pastores, pescadores, moleiros, oleiros, padeiros, relojoeiros, tecelões, vidraceiros, saboeiros, pedreiros, pintores e, também, músicos.

Logo, não é nada estranho que grande parte dos músicos brasileiros fossem mulatos, tanto durante o período em que suas atividades estavam entre aquelas que dependiam "mais do corpo, que do espírito", quanto no momento em que tal ofício foi, aos poucos, alcançando uma estimação superior e conferindo status a seus profissionais. Pois, nesses últimos tempos - grosso modo, final do século XVIII e início do XIX —, era mais uma oportunidade que surgia para o mulato tentar encontrar um melhor lugar no corpo social ${ }^{156}$.

De volta ao relato de Bougainville, podemos averiguar, secundariamente, o tipo de repertório executado no teatro carioca dos tempos do Vice-Rei, Dom Antônio Álvares da Cunha, o Conde da Cunha ${ }^{157}$.

${ }^{156}$ Sobre os aspectos jurídicos da nobreza portuguesa citados, como referências à sua transmissão de pai para filho, ou às profissões com ela incompatíveis, ver, mais uma vez, a obra de Luiz da Silva Pereira, Privilégios da nobreza e fidalguia em Portugal, de 1806. Note-se que esta obra foi fac-similada em 2002 pela Associação da Nobreza Histórica de Portugal e parte de seu conteúdo foi também reproduzido por Tito Lívio Ferreira na sua História da civilização brasileira, de 1959 (p. 307-327). Sobre a evolução social dos músicos - principalmente dos compositores - decorrente das mudanças dos processos sociais e sobretudo econômicos que envolveram a música nos séculos XVIII e XIX, ver SCHERER, Frederic M. Quarter notes and bank notes: the economics of music composition in the eighteenth and nineteenth centuries. Princeton: Princeton University Press, 2004.

157 Note-se que, além de Bougainville, outro tripulante da fragata La Boudeuse 
Nesse caso específico, as "obras-primas", representadas pela "trupe de mulatos", deviam ser, seguramente - apesar de centenas de óperas terem sido escritas com base nos libretti de Pietro Metastásio - solfas do napolitano David Perez (1711-1778), cujo sobrenome de origem espanhola, denota os seculares laços da metrópole natal desse compositor com a Península Ibérica ${ }^{158}$. Perez foi, durante algumas décadas do século XVIII, o mais popular autor de óperas em Lisboa, até porque ele ali esteve radicado, a serviço de Dom José I, desde 1752 até a sua morte ${ }^{159}$. É muito provável, portanto, que, em 1767, no Rio de Janeiro, por influência portuguesa, se executassem algumas de suas óperas ou parte delas, como Adriano in Siria, Alessandro nell'Indie, Artaserse, Demofoonte, L'Eroe Cinese, L'Ipermestra, Olimpiade e II Siroe, todas compostas a partir de textos de Metastásio, e levadas em Lisboa na década de $1750^{160}$.

deixou-nos informações - porém, ainda menos precisas - sobre o teatro carioca dos tempos do Conde da Cunha. Trata-se de Charles Henri Nicolas Othon (1745-1809), Príncipe de Nassau-Siegen. Segundo seu diário, publicado em Bougainville et ses compagnons autour du monde 1766-1769 (Paris: Imprimerie Nationale, 1977, t. 2, p. 371388), num dos dias em que compareceu ao teatro teria sido representado o drama Coriolano.

${ }^{158}$ Nápoles esteve sob domínio ibérico por mais de dois séculos. Ali reinaram as casas de Trastamara (1442-1516), Habsburgo (1516-1700) e Bourbon (1700-1707). Tal relação certamente facilitou o intercâmbio cultural entre essas localidades, o que se reflete na ida de muitos músicos napolitanos, tanto para a Espanha, quanto para Portugal, que, também, de 1580 a 1640, esteve sob o jugo dos Habsburgos.

159 Segundo Charles Burney, David Perez era filho de Juan Perez, espanhol radicado em Nápoles. Fez grande sucesso em Palermo e posteriormente em sua cidade natal, onde recebeu grande aplauso no Teatro di San Carlo. Em 1752, entrou para o serviço de Dom José I, e em Lisboa permaneceu 27 anos como mestre-de-capela e mestre da família real com um salário que excedia £2.000 por ano (Cf. BURNEY, Charles. A general history of music, from the earliest ages to the present period. London: Payne and Son, 1789 , v. 4 , p. $570-572$ ).

${ }_{160}$ Seguindo o mesmo raciocínio e tomando, como base documental, mais de sessenta libretos comemorativos, impressos em Lisboa na segunda metade do século XVIII - edições essas tombadas na Divisão de Música da Biblioteca Nacional do Rio de Janeiro -, aproveitemos para mencionar outros compositores que possivelmente tenham tido suas óperas executadas no Rio setecentista, porém, em décadas posteriores. Iniciamos com o napolitano Niccolò Jommelli (1714-1774), que, na década de 1770, tornou-se, assim como David Perez, muito popular em Lisboa, ao passar a enviar obras para Portugal por encomenda de Dom José I. Para a década seguinte, o compositor português João de Sousa Carvalho (1745-1798) é nome igualmente provável, uma vez que então se destacou, quando a serviço de Dom Pedro III e Dona Maria I. Já, na década de 1790, foi célebre, em Portugal, o italiano Domenico Cimarosa (1749-1801). Ayres de Andrade menciona o fato de uma ópera desse autor - L'Italiana in Londra - ter sido executada no Rio durante o vicereinado de Dom Luiz de Vasconcelos (1779-1790) (ANDRADE, Ayres. Op. cit., v. 1, p. 67). 
Enfim, quanto à referência à sala "bastante bela", trata-se, certamente, daquela edificada ao lado da residência dos Vice-Reis - a mesma, referida no opúsculo português de 1763, publicado por ocasião do nascimento do Príncipe da Beira —, e não mais a "Ópera dos Vivos", situada longe do Palácio do Conde da Cunha, e da qual não temos mais nenhuma informação a partir de 1754.

Qual delas seria, entretanto, a casa de ópera do lendário "Padre Ventura", mencionada, entre outros, por Moreira de Azevedo ${ }^{161}$, e que, segundo as Efemérides do Barão do Rio Branco ${ }^{162}$ teria sido consumida por incêndio, durante o governo do Marquês do Lavradio (1769-1779), quando se encenava Os Encantos de Medéia, peça do "Judeu", Antônio José? Segundo Nireu Cavalcanti ${ }^{163}$, ambos os teatros eram de sua propriedade. Cavalcanti ainda descobriu ser o "Padre Ventura", Boaventura Dias Lopes, um bem sucedido empresário teatral, que até costumava arrendar os seus teatros. Tal exploração terceirizada dos espaços de entretenimento aponta mais uma vez para a existência, no Rio de Janeiro daquela época, de uma expressiva demanda para os espetáculos teatrais, e, conseqüentemente, para a música ligada à cena. Essa hipótese é reforçada por uma carta - já mencionada escrita pelo próprio punho do Capitão-General de Mar e Terra, Dom Luís de Almeida Portugal, pouco mais de um mês após sua chegada ao Rio, a 31 de outubro de 1769. O texto, apesar de irônico e lacônico, nos dá a entender que o teatro se abria com certa periodicidade, já que Dom Luís - o Marquês do Lavradio - ali via "freqüentemente" a figura feminina:

$\ldots$ as senhoras $(\ldots)$, tenho-as visto freqüentemente na Ópera aonde creio que os seus confessores as mandam ir assim a elas como a seus maridos em satisfação das suas culpas, e pecados, porque cada uma delas se

161 AZEVEDO, Manuel Duarte Moreira de. O Rio de Janeiro; sua história, monumentos, homens notáveis, usos e curiosidades. Rio de Janeiro: B.L. Garnier, 1877, v. 2, p. 139 .

${ }^{162}$ RIO BRANCO, José Maria da Silva Paranhos, Barão do. Efemérides brasileiras. Brasília: Senado Federal, 1999, p. 479.

${ }^{163}$ CAVALCANTI, Nireu. Op. cit. p. 173-174. 
acha no seu camarote com o seu marido, ambos em grandíssima melancolia, ele sem se resolver a ir fora nem para as operações a que a humana natureza está sujeita, nem olhar a dar confiança, que ninguém tenha a honra de ir fazer-lhe os seus cumprimentos, neste agradável sistema é que vim achar estas preciosas madamas ... ${ }^{164}$

Quanto ao incêndio, ele deve ter ocorrido, realmente, como afirmou o Barão do Rio Branco, durante o próprio vice-reinado de Dom Luís de Almeida Portugal, já que uma petição manuscrita por nós encontrada no Arquivo Nacional do Rio de Janeiro e redigida, em 1824, pelo então proprietário do Imperial Teatro de São João, Fernando José de Almeida - como parte de uma justificativa para convencer o Imperador a facilitar-lhe a reconstrução dessa última casa, também destruída por um incêndio, naquele ano testemunha, mais uma vez, mesmo que por via indireta, tal acontecimento:

Governando esta cidade o Marquês do Lavradio, sucedeu incendiar-se o teatro e em poucos meses edificar-se outro. Ora, se um Vice-Rei (...) pôde em pouco tempo edificar um teatro para que não cessasse o entretenimento nacional, cuja utilidade é sobremaneira conhecida ...

... O que um longânime Imperador, como Dom Pedro I, não poderia fazer? Essa era a retórica de Fernando José.

A data exata do incêndio é, no entanto, ainda um mistério. Sabemos apenas que, a partir de abril de 1775, conforme documentação descoberta por Nireu Cavalcanti ${ }^{166}$, a segunda casa de ópera do Padre Boaventura passou a ser gerida pelo português Manuel Luiz Ferreira, o mesmo empresário que permaneceria administrando esse teatro até 0 seu

164 LAVRADIO, Luiz de Almeida Portugal, Marquês do. Op. cit., p. 37.

165 ARQUIVO NACIONAL, Rio de Janeiro. Fundo Decretos do Executivo, cx. 19, pc. 34, doc. 7 .

${ }^{166}$ CAVALCANTI, Nireu. Op. cit. p. 174. 
fechamento, em 1813. Tal fato, aliado à referência de que o poeta Alvarenga Peixoto teria recitado, em 1776 - ano em que retornou ao Brasil, vindo de Portugal -, um soneto ${ }^{167}$ em homenagem ao Vice-Rei por ocasião da "inauguração do teatro de Manuel Luiz", nos leva a presumir que o segundo teatro do "Padre Ventura" só pode ter sofrido o incêndio por essa época (1775-1776), quando, após ser reconstruído "em alguns meses", como afirmou Almeida, e reinaugurado, no próprio ano de 1776, passaria, definitivamente, a pertencer a Manuel Luiz Ferreira ${ }^{168}$.

Segundo o Capitão de Fragata espanhol, Don Juan Francisco Aguirre, de passagem pelo Rio, em 1782, o teatro "ainda que pequeno" tinha "uma aparência decente, melhor do que a do de Lisboa", contando ainda com a vantagem de ser o único do Reino em que se permitia a atuação de mulheres, já que em Lisboa, a Rainha, Dona Maria I, as proibia de subir ao palco ${ }^{169}$. É claro que, nessa época, a capital portuguesa ainda se recuperava dos devastadores efeitos do terremoto de 1755. Somente em 1793, um novo teatro - o de São Carlos - substituiria, com certa grandeza, a já referida e suntuosa "Ópera do Tejo", completamente destruída pelo terrível abalo sísmico ${ }^{170}$.

167 "Se armada Macedônia ao Índio assoma / E Augusto a sorte entrega ao imenso lago; / Se o grande Pedro, errando incerto e vago, / Bárbaros duro civiliza e doma: // Grécia de Babilônia exemplos toma, / Aprende Augusto no inimigo estrago, / Ensina a Pedro quem fundou Cartago, / E as leis de Atenas traz ao Lácio e Roma. // Tudo mostra o teatro, tudo encerra; / Nele a cega razão aviva os lumes / Nas artes, nas ciências e na guerra. // E a vós, alto Senhor, que o Rei e os Numes / Deram por fundador à nossa terra, / Compete a nova escola dos costumes" (O BERÇO da arte dramática do Rio de Janeiro. O Teatro de Manuel Luiz. Revista do Instituto Histórico e Geográfico Brasileiro. Rio de Janeiro, v. 255, p. 370,1962$)$.

168 Aliás, note-se que a rápida reconstrução do teatro é mais um indício do quão imprescindível esse já era à vida social carioca.

169 “... el teatro aunque pequeño es de figura adecuada, lo que no sucede en la de Lisboa por lo que es mejor. En el día es el único en que se representan comedias por mujeres, pues en Europa solo las permite la reina con la condición de que todo lo hagan los hombres" (AGUIRRE, Juan Francisco. Op. cit., t. 17, n. 43-44, p. 122, 1949).

$170 \mathrm{O}$ estudioso de teatros lisboetas. Francisco da Fonseca Benevides, afirma que, nos anos decorrentes entre o terremoto de 1755 e a inauguração do São Carlos, em 1793, era no Teatro da Rua dos Condes que mais freqüentemente se davam óperas em Lisboa; um edifício, segundo o mesmo autor "verdadeiramente vergonhoso e mal cheiroso, no qual se ouvia mal, via mal, e se estava acomodado, correndo-se o risco de se morrer assado ou esmagado, se a fatalidade acendesse um fogo que rapidamente se desenvolvesse e que lamberia de certo o mísero barracão em pouco tempo" (BENEVIDES, Francisco da Fonseca, O Real Teatro de S. Carlos de Lisboa desde a sua fundação em 1793 até á 
Conforme documento encontrado por Ayres de Andrade ${ }^{171}$, no Museu Histórico Nacional do Rio de Janeiro, foi organizada no Teatro de Manuel Luiz, a pedido do Vice-Rei, Dom Luiz de Vasconcelos, uma companhia lírica. Dos cantores que aí trabalharam nessa época, destacou-se, sobremaneira, Joaquina Maria da Conceição, a "Lapinha", que chegou a cruzar o Atlântico e encantar o público lisboeta, em 1795, com o seu talento vocal:

A 24 do mês passado houve no Teatro de S. Carlos desta Cidade o maior concurso que ali se tem visto, para ouvir a célebre cantora Americana Joaquina Maria da Conceição Lapinha, a qual na harmoniosa execução do seu canto excedeu a expectação de todos: foram gerais e muito repetidos os aplausos que expressavam a admiração que causou a firmeza, e sonora flexibilidade da sua voz, reconhecida por uma das mais belas, e mais próprias para o Teatro. Por tais testemunhos de aprovação deseja ela por este meio mostrar ao Público o seu reconhecimento ${ }^{172}$.

Nas grandes festas em homenagem à Rainha de Portugal, Dona Maria I, promovidas no Rio de Janeiro pelos Vice-Reis durante a semana do natalício da soberana, era no teatro de Manuel Luiz que também se encerravam as comemorações. Em 1792, por exemplo, passou, o Conde de Resende, Dom José Luiz de Castro, e a condessa, sua esposa,

... a verem a representação da Ópera, ornada com duas Danças, e uma Decoração feita à Soberana: o que tudo foi executado com toda a perfeição, a fim de que este dia fosse o mais plausível, e alegre que se tem visto na Capital do Brasil ${ }^{173}$.

atualidade: estudo histórico. Lisboa: Tip. Castro Irmão, 1883, p. 19).

171 ANDRADE, Ayres de. Op. cit., v.1, p. 67.

172 ALMEIDA, Manuel Lopes de. Op. cit., v. 2, p. 288. Essa notícia, segundo Lopes de Almeida, foi publicada na Gazeta de Lisboa em 06/02/1795. Note-se que, a essa época, a proibição referente à atuação das mulheres nos palcos dos teatros já havia caído, com a ascensão do Príncipe Dom João à Regência.

${ }_{173}$ Ibidem, v. 2, p. 234. Essa notícia, segundo Lopes de Almeida, foi publicada na 
Já, sobre a exata freqüência com que o teatro de Manuel Luiz se abria para o público, encontramos as informações mais precisas em um texto de 1803, portanto, já da época do Vice-Rei, Dom Fernando José de Portugal e Castro, futuro Conde e Marquês de Aguiar. O depoimento que se segue foi escrito pelo Oficial da Marinha Britânica James Tuckey, que esteve de passagem pelo Rio por pouco menos de um mês:

A casa de ópera, que comporta cerca de seiscentas pessoas, abre às quintas-feiras, aos domingos e na maior parte dos feriados ... ${ }^{174}$.

Ou seja, já havia, realmente, no Rio de Janeiro dessa época, uma freqüência semanal de apresentações musicais, coreográficas e cênicas ${ }^{175}$. Continuando sua descrição, Tuckey também registra qual era o repertório de espetáculos do teatro e faz comentários sobre a rígida etiqueta social diante da presença do Vice-Rei; maneiras e reverências típicas de uma verdadeira corte $^{176}$ :

Gazeta de Lisboa em 05/05/1792. Nesse mesmo ano, o já citado embaixador britânico Lord Macartney atenta para a variedade de espetáculos que o teatro de Manuel Luiz proporcionava ao público carioca de ambos os sexos: "Plays, operas, and masquerades were the innocent amusements of both sexes" (STAUNTON, George. Op. cit., p. 59).

${ }^{174}$ Tradução nossa de: "The opera-house, which holds about six hundred persons, is open on Thursdays, Sundays, and most holidays ..." (TUCKEY, James Kingston. An account of a voyage to establish a colony at Port Philip in Bass's Strait, on the south coast of New south Wales. London: Longman, Hurst, Rees, and Orme, 1805, p. 52).

${ }^{175}$ Essa freqüência podia ser observada caso não ocorresse qualquer problema de ordem política ou social que exigisse o fechamento temporário do teatro. Em agosto de 1787, por exemplo, como nos atesta, David Collins, o já citado Governador Phillip não teve a oportunidade de conhecer a ópera, fechada em virtude da recente morte do Rei de Portugal, Dom Pedro III: "Of these buildings the opera-house alone was shut up; and we were informed, that the gloom which was thrown over the court and kingdom of Portugal by the death of the late king, had extended in full force to the colonies also" (COLLINS, David. Op, cit., v. 1, p. 23). Alguns anos mais tarde, em outubro de 1792, foi a vez do também inglês John Barrow encontrar as portas do teatro cerradas, desta vez em virtude da moléstia mental que acometera Dona Maria I e a afastara definitivamente do poder: "... it had been shut up for some time on account of the indisposition of the Queen of Portugal" (BARROW, John. A voyage to Cochinchina, in the years 1792 and 1793 To which is annexed an account of a journey made in the years 1801 and 1802, to the residence of the chief of the Booshuana nation. London: T. Cadell and W. Davies, 1806, p. 97).

${ }^{176}$ Tal proposição - de ter havido na sede da colônia uma verdadeira "sociedade de corte" em torno dos Vice-Reis - torna-se bastante viável diante do conhecimento de 
... os espetáculos levados são, ora tragédias, ora comédias, ora óperas, com alguns interlúdios e farsas. Os diálogos são em português, mas os textos das canções são italianos, assim como a música. (...) O Vice-Rei é esperado, em pessoa, pelo público, todas as noites. Quando da sua chegada ao recinto, todos se levantam, voltam-se para o seu camarote e depois sentam-se ${ }^{177}$.

O navegante norte-americano Richard J. Cleveland (1773-1860), que também esteve por cerca de um mês no Rio de Janeiro, um ano antes de Tuckey - por conseguinte, na mesma época do Vice-Rei, Dom Fernando José de Portugal e Castro - , nos legou, em relação ao teatro, uma descrição muito próxima à do oficial inglês, dando-nos, no entanto, mais alguns detalhes sobre as apresentações que ali ocorriam, como o tempo de duração dos espetáculos e a imprescindibilidade da presença do Vice-Rei:

Nós passamos uma noite no teatro. A
companhia era numerosa, ordeira, bem
arranjada de figurinos, e aparentemente

relatos de época como, por exemplo, o do já mencionado Don Juan Francisco Aguirre, que esteve de passagem pelo Rio em 1782. Além de legar-nos a informação de que havia ali, com etiquetas rígidas, o cerimonial do beija-mão, o espanhol também testemunha que o vice-rei se locomovia pela cidade em uma carruagem puxada por seis cavalos e acompanhado por quatro batedores e sessenta dragões; em suma, "tão absoluto como qualquer outro soberano sobre a Terra", como já havia registrado o Comodoro Byron, dezoito anos antes: "El día de besamanos recibe su llustre Excelencia la corte bajo del dosel en pié (...). Cada sujeto, para cumplimentar S. I. E., hace tres profundas cortesías cada una á dos ó tres pasos de frente y se retira correspondiendo el jefe á la ultima con un leve movimiento. Nosotros presenciamos una corte, Domingo de Resurrección y seguimos en el orden á loa jefes militares antes que la Audiencia porque así nos lo avisó un ayudante de S. E. En esta recibimos una singular bondad de la atención de estos señores, pues nos pusieron en la clase de jefes, única que entra en esta ceremonia, siendo los subalternos solo espectadores. Los mismos días de ceremonia ó que sale el Virrey al público con ella, lleva 4 batidores y 60 hombres de reserva que es una compañía de dragones, de dos que se llaman de su nombre. Su carroza va tirada de 6 caballos y nunca da asiento" (AGUIRRE, Juan Francisco. Op. cit., t. 17, n. 43-44, p. 126, 1949).

177 Tradução nossa de: "the pieces performed are indifferently, tragedies, comedies, or operas, with interludes and after-pieces: the dialogue is in Portuguese, but the words and music of the songs are Italian (...). The Viceroy is expected by the populace, to show himself at the theatre every night: on his entering the house, the audience rise, turn their faces towards his box, and again sit down" (TUCKEY, James Kingston. Op. cit., p. 5253). 
respeitável. Sua perseverança foi colocada à prova por Sua Excelência, o Vice-Rei, de cuja chegada dependia a abertura das cortinas, e que os fez esperar até passadas as oito horas. Quando ele entrou em seu camarote, todos puseram-se de pé, com os rostos voltados para ele; ao mesmo tempo começou-se a tocar uma ária favorita. Depois disto, foi executada uma comédia em cinco atos, sucedida por um balé, que satisfez a todos e que nos deteve até passada a meia-noite ${ }^{178}$.

Enfim, outro viajante inglês — o já citado James Vaux —, alguns anos mais tarde, em 1807, já no governo do último Vice-Rei, Dom Marcos de Noronha e Brito, Conde dos Arcos, registra o mesmo cerimonial austero e necessário, em relação à presença do Capitão-General no teatro, e comenta outros diferentes aspectos dos espetáculos na Ópera de Manuel Luiz, como o aparatoso vestuário das ocupantes dos camarotes, a já tradicional separação de lugares destinados a mulheres e homens, o preço dos ingressos, e mais um elogio à qualidade musical de um conjunto, que, segundo ele, era "numeroso":

A casa é mais ou menos do mesmo tamanho do nosso pequeno teatro, em Haymarket; a platéia é exclusivamente ocupada por homens, mas os camarotes estão cheios de lindas mulheres, vestidas da mais elegante e encantadora maneira e enfeitadas com esplêndidos brincos, braceletes etc. O Vice-Rei tem um elegante camarote no centro da fileira frontal, de modo que ele fique bem diante do palco e seja visto por todo o público. Nunca é permitido que o espetáculo se inicie antes da sua chegada, o que, às vezes, causa atrasos; e quando sua

178 Tradução nossa de: "We passed one evening at the theatre. The company was numerous, orderly, well-dressed, and apparently respectable. Their patience was put to the test by his Excellency the Viceroy, before whose arrival the curtain could not be raised, and who kept them waiting till past eight o'clock. When he entered his box, all rose, with their faces towards him; at the same time the music struck up a favorite air. After this, a comedy in five acts was performed, succeeded by a ballet, which gave general satisfaction, and which detained us till past midnight" (CLEVELAND, Richard J. Voyages and commercial enterprises of the sons of New England. New York: Leavitt \& Allen, 1855, p. 158). 
excelência entra, todos os espectadores levantam-se, demonstrando respeito à sua pessoa. O ingresso para a platéia custa apenas uma pataca ( 2 xelins) por pessoa. Os camarotes são reservados por grupos e custam 12 xelins cada, não importando se o grupo é grande ou pequeno; e não há galeria. A música é excelente, e o conjunto musical, numeroso ${ }^{179}$.

Pois foi esta já antiga casa de espetáculos - cujo respeito e tradição levaram seu proprietário a receber, antes de 1794, a Ordem de São Tiago ${ }^{180}$ - que a realeza e parte de sua corte - agora uma "corte" de verdade encontraram no Rio de Janeiro quando ali aportaram, menos de um ano depois, entre janeiro e março de $1808^{181}$.

179 Tradução nossa de: "The house is about the size of our little theatre in the Haymarket; the pit is solely occupied by the male sex, but the boxes are filled with beautiful women, dressed in the most elegant and bewitching manner, and adorned with brilliant earrings, bracelets etc. The viceroy has an elegant box in the center of the front tiers, so as to be immediately facing the stage, and to be seen by the whole audience. The performance is never suffered to commence till his arrival, which is sometimes protracted; and on his Excellency's entrance, the whole of the spectators rise to testify their respect for his person. The admission to the pit is only a petack (two shillings). The boxes are engaged by parties, at the expense of about twelve shillings each, whether the party is large or small; and there is no gallery. The music is excellent and the band numerous" (VAUX, James Hardy. Op. cit., v. 1, p. 220-221). Tomando-se como base o fato de que durante muito tempo o câmbio entre o dinheiro inglês e o português esteve na proporção de $671 / 2$ pence (ou dinheiros) para $1 \$ 000$ - variando entre 65 e 69 -, é de se calcular que a entrada para a platéia (2 xelins ou 24 dinheiros) custasse mais ou menos o equivalente a uma pataca, como disse Vaux: ou seja, 320 réis (Cf. MONEY of England, reduced into money of Portugal and the money of Portugal reduced into English money, at the exchange of sixty-seven pence halfpenny per mill rea, which is the par of exchange between these kingdoms. Also, the coins, measures, and weights of both kingdoms, compared. Falmouth: M. Allison, 1766).

${ }^{180} \mathrm{O}$ nome de Manuel Luiz Ferreira aparece como Cavaleiro professo na Ordem de São Tiago, com a patente de Capitão no Almanaque do Rio de Janeiro de 1794 (Apud Anais da Biblioteca Nacional. Rio de Janeiro, v. 59, p. 344, 1937).

181 Segundo as Memórias do padre "Perereca", impressas pela primeira vez em 1825, vieram com a família real os seguintes nobres e altos funcionários do governo português (alguns com seus parentes mais próximos): Duque do Cadaval, D. Miguel Álvares Pereira de Melo (que faleceu durante o trajeto); Marquês de Alegrete, Luís Teles da Silva e Menezes; Marquês de Angeja, D. José de Noronha Camões e Albuquerque; Marquês de Belas, D. José de Vasconcelos e Sousa; Marquês do Lavradio, D. Antônio de Almeida Soares e Portugal; Marquês de Pombal, Henrique José de Carvalho; Marquês de Torres Novas, D. Álvaro Antônio de Noronha Abranches; Marquês de Vagos, Nuno Telo da Silva; Marquesa de São Miguel, D. Mariana Xavier Botelho; Marquesa de Lumiares, D. Juliana Xavier Botelho de Lencastre; Conde de Belmonte, D. Vasco Manuel da Câmara; Conde de Caparica, D. Francisco de Menezes da Silveira; Conde de Cavaleiros, D. Gregório Ferreira de Eça e Menezes; Conde de Pombeiro, D. Antônio Maria de Castelo Branco Correia e Cunha Vasconcelos e Sousa; Conde de Redondo, Tomé José de Sousa Coutinho Castelo Branco e Menezes; Visconde de Anadia, João Rodrigues de Sá e 
Sobre o estado geral do Teatro de Manuel Luiz, em 1808, podemos lançar mão, inicialmente, do testemunho do tenente da Marinha Inglesa Thomas O'Neill, que, fazendo parte da tripulação da esquadra de guerra inglesa que acompanhou a família real ao Brasil, permaneceu durante alguns meses desse ano no Rio de Janeiro:

Perto do palácio está a casa de ópera, um edifício de aparência externa pouco nobre; porém o interior é asseado e tem excelentes acomodações ${ }^{182}$.

Mesma "excelente" impressão não teve, no entanto, o comerciante inglês John Luccock, que, além de, ironicamente, fazer pouco da arquitetura e decoração do prédio, censurou veementemente os espetáculos ali representados:

O teatro (...) é uma casa pobre, pequena, escura. Sua forma interior é oval, tendo, de um lado, o palco, e, do outro, o camarote real, que ocupa toda a face norte do edifício. Outros camarotes, abafados e quentes - quase insuportáveis -, sucedem-se ao redor das laterais da casa e têm, na frente, uma grade aberta e deselegante, pintada da forma mais

Menezes; Conselheiros de Estado, Antônio de Azevedo e Araújo, D. Fernando José de Portugal e Castro, D. João de Almeida Melo e Castro e D. Rodrigo de Sousa Coutinho; Tenente-General, João Forbes Skelater; Vice-Almirante, Manuel da Cunha Souto Maior; D. Francisco de Sousa Coutinho; Monsenhores Antônio José da Cunha Almeida e Carvalho, Antônio José da Cunha e Vasconcelos, Joaquim da Nóbrega Cam e Aboim e José Maria Teles e Menezes; Desembargador do Paço, José de Oliveira Pinto Botelho e Mosqueira; Guarda-Jóias, Francisco José Rufino de Sousa Lobato; Marechais, Carlos Antônio Napion, João Batista de Azevedo Coutinho de Montaury; Brigadeiros, João de Sousa de Mendonça Corte Real e Pedro Vieira da Silva Teles; Médicos da Câmara, Doutor Manuel Vieira da Silva, Doutor José Correia Picanço; Tesoureiro da Casa Real, Joaquim José de Azevedo (SANTOS, Luiz Gonçalves dos. Memórias para servir à história do reino do Brasil. Belo Horizonte: Itatiaia, 1981, v. 1, p. 190-191).

182 Tradução nossa de: "Near the palace is the opera house, an edifice of no superior external appearance; but the interior is neat, and has excellent accommodations" (O'NEILL, Thomas. A concise and accurate account of the proceedings of the squadron under the command of Rear Admiral Sir Sydney Smith, K. S. \&c. in effecting the escape of the royal family of Portugal to the Brazils on November 29, 1807; and also the sufferings of the royal fugitives, \&c. during their voyage from Lisbon to Rio Janeiro; with a variety of other interesting and authentic facts. London: J. Barfield, 1810, p. 58). 
berrante. A platéia é dividida em duas partes; uma delas, diante do camarote real, tem bancos, com um encosto de ferro, que serve de apoio para os ombros; a divisão atrás disto - e abaixo do assento da realeza - é separada por uma barreira, e a parte do público que lá fica deve ouvir em pé. A casa é iluminada com candeeiros de latão, fixados nos pilares que suportam os camarotes, e com um lustre de madeira, dotado de braços de latão. Com esta mobília elegante, o cenário e outras decorações correspondem completamente. Sentinelas, com baionetas fixas, são colocados em todas as partes da casa, e em todas as ruas principais que conduzem a ela. Os espetáculos são dignos do lugar e estilo no qual eles são apresentados. A orquestra é pequena, inadequada e precária. Muitas das peças dramáticas contêm representações que um mínimo de bom senso e gosto baniriam para sempre do palco ${ }^{183}$.

Passados mais de trinta anos da sua reinauguração após o incêndio, consta que Manuel Luiz teria realizado no prédio uma série de reformas para melhor acomodar a família real, aumentando o número de lugares e dando maior magnificência à decoração. Ayres de Andrade descreve algumas dessas reformas, sem, contudo, citar as fontes de tais informações:

Para começar, Manuel Luís o remodela a fundo.

${ }^{183}$ Tradução nossa de: "The Theatre (...) is a poor, small, dark house. Its form on the inside is an oval, at one end of which is the stage, and on the other the royal box, which occupies the whole Northern side of the building. Other boxes, cut off from all communication with the air, and hot, almost beyond endurance, extend round the sides of the house, and have an open, clumsily railing in front, most gaudily painted. The pit is divided into two parts; that before the royal box has forms, with a rail, against which the shoulders may be leaned; the division behind this, and beneath the seat of Royalty, is separated by a barrier, and the part of the audience, stationed there, must stand and listen. The house is lighted from tin sconces, fixed to the pillars, which support the boxes, and a chandelier of wood, with tin branches. With this elegant furniture, the scenery and other decorations thoroughly correspond. Sentinels, with fixed bayonets, are placed in every part of the house, and in all the avenues leading to it. The performances are worthy of the place and style in which they are brought out. The orchestra is small, inconvenient, and illsupplied. Many of the dramatic pieces contain representations, which a small portion of good sense and taste would banish for ever from the stage" (LUCCOCK, John. Notes on Rio de Janeiro, and the Southern Parts of Brazil, taken during a residence of ten years in that country, from 1808 to 1818. London: Samuel Leigh, 1820, p. 89). 
Faz construir por cima dos camarotes uma galeria destinada aos servidores do paço. Nova decoração recebia a sala, mais luxuosa, mais digna do público que ia freqüentá-la, dali por diante. José Leandro pinta novo pano de boca, representando, em toda a sua extensão, a baia de Guanabara com Netuno no centro, empunhando o tridente no seu carro puxado por cavalos marinhos, cercado de deuses, sereias e tritões $^{184}$.

Porém, apesar da mobilização de seu proprietário, e da realização, nos primeiros anos da permanência da família real no Rio, de alguns espetáculos operísticos, esse espaço não condizia com a exigência daqueles que cada vez mais chegavam de Lisboa. É preciso levar em conta, novamente, que, desde o tempo de Dom João $V-e$, passados os reinados de Dom José I e Dona Maria I -, a capital portuguesa tornara-se um dos mais aparatados centros musicais da Europa.

Sobre tal afirmação, que, a princípio, poderia parecer um tanto duvidosa aos menos conhecedores, Joaquim de Vasconcelos, um dos mais sérios estudiosos da música portuguesa, assim escreveu a respeito:

\begin{abstract}
Arquitetos de talento, cenógrafos insignes, compositores célebres e cantores eminentes, tudo contribuiu para levar esta cena à altura de primeira da Europa, numa época em que os teatros esplêndidos não eram raros. (...) Não admira, pois, que com estes elementos se pudesse organizar um teatro lírico único na Europa, pela mise en scène, pelos artistas que nele cantavam e pela orquestra poderosa que os auxiliava ${ }^{185}$.
\end{abstract}

Joseph Scherpereel, Professor Emérito da Universidade de Bordeaux, que estudou a fundo a orquestra e os instrumentistas da Real Câmara de Lisboa, de 1764 a 1834, também se surpreendeu, ao descobrir que tal

\footnotetext{
${ }_{184}^{184}$ ANDRADE, Ayres de. Op. cit., v.1, p. 67.

185 VASCONCELOS, Joaquim de. Os músicos portugueses. Porto: Imprensa
} 
conjunto, em número de 51 músicos, no ano de 1782, era muito superior à média das outras orquestras, do mesmo gênero, de eminentes centros musicais europeus, como Mannheim (46), Berlim (40), Esterházy (23) ou Viena $(19)^{186}$

Enfim, outras positivas referências - desta vez de cosmopolitas que viveram a época - nos dão uma idéia mais autêntica de quão magnificente era a atividade musical em Lisboa - sobretudo operística —, entre o reinado de Dom José I e a regência de Dom João. Inicialmente, para termos uma idéia da curta - porém esplendorosa - vida da "Ópera do Tejo", destruída no terremoto que assolou Lisboa em 1755, citemos aqui uma descrição realizada por um autor francês, Chevalier des Courtils, que esteve em Lisboa, poucos meses antes da catástrofe:

O rei mantém uma ópera italiana que lhe custa dois milhões por ano. É um espetáculo majestoso e verdadeiramente pomposo com o qual ele regala sua corte duas ou três vezes por semana. Ele mandou construir para essa ocasião uma sala de espetáculos muito bonita e da maior magnificência. Ela é octogonal com quatro ordens de camarotes. O do rei fica ao fundo, enfeitado com colunas imitando mármore, revestidas de relevos de bronze dourado. Dois outros camarotes com as mesmas características estão situados à direita e à esquerda no sentido longitudinal do teatro. Os outros são ornamentados na frente com balaustradas douradas, isto é, os de primeira e quarta ordem. Os de segunda e terceira ordem são totalmente abertos na frente e magnificamente revestidos de um ouro brilhante que imita o diamante pela luminosidade que reflete. A riqueza, a delicadeza e o bom gosto competem entre si. O teatro é soberbo ${ }^{187}$.

portuguesa, 1870, v. 1, p. 179-181.

186 SCHERPEREEL, Joseph. Op. cit., p. 40-41.

187 Tradução nossa de: "Le roi entretient un opéra italien qui lui coûte deux millions par an. C'est un spectacle majestueux et véritablement pompeux dont il régale sa cour deux ou trois fois par semaine. Il a fait bâtir à cette occasion une salle de spectacle de toute beauté et de la plus grande magnificence. Elle est octogone à quatre rangs de loges. Celle 
Apesar do terrível acontecimento e da inestimável perda desse "soberbo" teatro, construído às margens do Rio Tejo, a música de Lisboa continuou impressionando os estrangeiros que lá estiveram alguns anos mais tarde. Caso, por exemplo, do marechal-de-campo, diplomata e aventureiro francês Charles-François du Périer (1739-1823) - mais conhecido como "Dumouriez" - , que visitou a capital portuguesa em 1766. Para ele, a dança e a música realizada nos teatros era "excelente" e as óperas italianas "muito boas", sendo a do Rei "a melhor da Europa"188.

Outra descrição favorável à ópera real portuguesa foi feita pelo já citado diletante inglês Richard Twiss, que esteve em Lisboa em fins de 1772. Em seu diário, ele narra, entre outros fatos musicais que presenciou, a apresentação de um espetáculo operístico no Palácio Real, em Belém, no qual teria sido levado o drama Ezio, de Metastásio, provavelmente na versão musicada de Niccolò Jommelli ${ }^{189}$. Impressionado com a qualidade da orquestra, Twiss asseverou ser esse conjunto formado por "executantes

du roi est dans le fond, ornée de colonnes en façon de marbre, revêtues de moulures de bronze doré. Deux autres loges dans le même goût sont placées à droite et à gauche au bord du théâtre. Les autres sont revêtues de balustrades dorées qui en forment les devants, savoir celles du premier et quatrième rang; celles du deuxième et troisième rang sont ouvertes en plein sur le devant et dorées magnifiquement d'un or brillant qui imite le diamant par le feu qu'il jette. La richesse, la délicatesse et le bon goût se disputent à l'envie. Le théâtre est superbe" (Apud BRITO, Manuel Carlos de. Opera in Portugal in the eighteenth century. Cambridge: Cambridge University Press, 1989, p. 177). Encômios à "Ópera do Tejo" e aos artistas que ali se apresentavam foram dados também pelo já mencionado musicólogo inglês Charles Burney (1726-1814), autor de uma das mais célebres obras musicológicas do século XVIII, A general history of music, from the earliest ages to the present period: "... the new theatre of his Portuguese Majesty, which was opened on the Queen's birthday, March $31^{\text {st }}, 1755$, surpassed, in magnitude and decorations, all that modern times can boast (...) Besides these splendid decorations, his Portuguese Majesty had assembled together the greatest singers then existing" (BURNEY, Charles. Op. cit., v. 4, p. 570-571).

188 "... les danses \& la musique sont excellentes, \& forment de bons intermèdes qui repartent un peu d'agrément dans les deux théâtres de la ville de Lisbonne, où on donne de fort bons opéras Italiens, outre celui du Roi qui est le mieux composé de l'Europe" (DUMOURIEZ, Charles-François du Périer. État présent du royaume de Portugal, en l'année MDCCLXVI. Lausanne: Chez François Grasset, 1775, p. 171-172). Quanto ao "dois teatros", Dumouriez se refere, provavelmente, ao Teatro do Salitre e ao Teatro da Rua dos Condes, embora houvesse ainda, na capital portuguesa, o Teatro do Bairro Alto.

189 Existe, na Divisão de Música da Biblioteca Nacional do Rio de Janeiro, um libreto desse Dramma per Musica, de Jommelli, publicado em Lisboa, em 1772, por ocasião do aniversário da rainha, Dona Mariana Vitória, esposa de Dom José I. O espetáculo foi 
extremamente meticulosos"190.

Foi, no entanto, a francesa Laure Junot (1784-1838), esposa do general Jean Andoche Junot, que, mencionando nomes de diversos artistas — alguns realmente importantes, como Angelica Catalani ${ }^{191}$ (1779-1849) — nos deixou o mais detalhado panorama da vida operística portuguesa, já da primeira década do século XIX, uma atividade cortesã cuja pompa não se arrefecera e que, à essa época, se transferira definitivamente do pequeno e exclusivo teatro do Real Palácio da Ajuda ${ }^{192}$ — onde apenas os "grandes do reino" podiam entrar - para um nova casa de espetáculos, desta vez um teatro público. Pois, a partir de meados de 1793, graças a um rico grupo de comerciantes locais, Lisboa passava a dispor do Real Teatro de São Carlos, réplica, mesmo que em menores proporções, do mais célebre templo operístico da época, o Scala, de Milão ${ }^{193}$ :

A ópera de Lisboa era, nessa época, a mais famosa da Europa. A Catalani, então em sua

realizado no Real Teatro da Ajuda, tal como descreveu Twiss.

190 "I went on the 17th of November [1772] to the king's palace at Bellem, about five miles from Lisbon, and heard the Italian opera of Ezio performed there. The orchestra consisted of very accurate players" (TWISS, Richard: Op. cit., p. 10).

${ }_{191}$ Angelica Catalani foi, sem dúvida, uma das mais renomadas sopranos de toda a Europa nas duas primeiras décadas do século XIX. Segundo o musicólogo belga FrançoisJoseph Fétis (1784-1871), esta cantatrice célèbre, debutou em Veneza, no la Fenice, em 1795, com 16 anos de idade. Em 1801, já figurava no la Scala, ali sendo considerada um prodígio. De Milão, passou aos teatro de Florença, Trieste, Roma e Nápoles excitando vivo entusiasmo. Chegou em Lisboa em 1804, onde se casou com um diplomata francês. Em 1806, esteve em Paris e Londres. Na capital inglesa chegou a receber duas mil libras por um único concerto. Esteve também, alguns anos depois, em Hamburgo, na Dinamarca, Suécia, Holanda e Bélgica. Em 1816, após um retorno a Paris para dirigir o Teatro Italiano, volta a viajar, desta vez para Munique e Itália, passando por Viena, em 1817. Dez anos mais tarde, faz uma longa turnê pela Polônia, Rússia e é ouvida pela última vez em Berlim, ocasião em que decide parar de cantar (Cf. FÉTIS, François-Joseph. Biographie universelle des musiciens et bibliographie générale de la musique. Paris: Firmin-Didot, 1866-1868, v. 2, p. 210-212).

${ }^{192}$ Twiss deixou-nos uma rápida impressão do pequeno teatro que havia no Real Palácio, em Belém: "This theatre is small, and without any side-boxes; in the pit are ten benches without backs, behind which is the king's box" (TWISS, Richard. Op. cit., p. 11).

193 Segundo Francisco da Fonseca Benevides, autor do mais completo estudo sobre o primeiro século de existência do Real Teatro de São Carlos, o projeto dessa edificação foi desenvolvido pelo arquiteto português José da Costa e Silva, baseado no San Carlo de Nápoles, que acabaria destruído por um incêndio em 1816 (BENEVIDES, Francisco da Fonseca, Op. cit., p. 20). Contudo, vale lembrar que a fachada frontal com as célebres três arcadas, é cópia do Scala, de Milão, inaugurado em 1778. 
melhor fase, era a prima-dona. O soprano era Mattucci, vindo, depois, Crescentini. O pai nobre era Mombelli, excelente ator e bom tenor; Depois, Olivieri, bom baixo cantante. Isso, em se falando de ópera séria. Quanto à ópera-bufa, estrelavam Guaforini, Naldi e um bom tenor, do qual esqueci o nome. Coloquem depois, nessa lista, os nomes de Fioravanti, compositor de ópera-bufa, e de Marcos Portugal, compositor de ópera séria - ajuntando-se ainda o libretista Caravita - e terão uma idéia do que era o teatro de Lisboa em 1805 e $1806^{194}$.

Destarte, para tentar reproduzir, no Rio de Janeiro, a mesma magnificência musical que a corte de Lisboa já conhecia, não houve outra alternativa ao Príncipe Regente, senão propor, à medida em que esse escol cada vez mais cruzava o Atlântico ${ }^{195}$, a construção de um novo espaço de

194 Tradução nossa de: "L’opéra de Lisbonne était a cette époque le plus fameux de L'Europe. La Catalani, alors dans son beau temps, était prima dona. Le soprano était Matucchi, venant après Crescentini, que ne recommença pas l'année théâtrale, et partit pour Madrid après notre arrivée à Lisbonne. Le père noble était Mombelli, excellent acteur et bon ténore. Puis Olivieri, bonne basse-taille. Voilà pour l'opéra seria. La Guaforini, Naldi, un bon ténore dont j'ai oublie le nom, voilà pour l'opéra buffa. Mettez ensuite dans cette liste les noms de Fioravanti, compositeur de l'opéra buffa et Marco Portogallo, compositeur pour l'opéra seria en y ajoutant Caravita pour le libretto, et vous aurez l'idée de ce qu'était le théâtre de Lisbonne en 1805 et 1806" (JUNOT, Laure. Mémoires de la Duchesse D'Abrantes. Paris, 1837, v. 1, p. 166).

${ }^{195}$ A historiografia brasileira (citemos, por exemplo, CALMON, Pedro. Op. cit., v. 4, p. 1366) costumou projetar em cerca de $10 \mathrm{mil}$ (ou até $15 \mathrm{mil}$ ), o número de portugueses que chegaram ao Rio de Janeiro com a família real, entre janeiro e março de 1808. Tal estimativa consagrou-se, tomando como base, entre outras informações ( $O$ jornal Iondrino The times, de 21 de dezembro de 1807, por exemplo, falava em 17.000), aquelas contidas em um opúsculo, editado, em 1810, na Inglaterra, e escrito por Thomas O'Neill, tenente, já citado, que tripulou um dos navios de guerra ingleses (o "London") que escoltaram a frota portuguesa. Nesse relato - diga-se de passagem, com informações de terceiros ("The following circumstances were related to me by an officer in the service of his Royal Highness, a gentleman, in whose veracity I can place the most implicit confidence") -, O'Neill calculou que havia entre 16 e 18 mil súditos portugueses na frota, incluindo-se quatro mil soldados: "There were about four thousand troops of the line on board the fleet, which transported in all from sixteen to eighteen thousand of the subjects of Portugal; all the ships were crowded. On board the Principe Real, there were no less than 412 persons, besides the crew. (...) The fleet was accompanied by about thirty sail of large Portuguese merchantmen" (O'NEILL, Thomas. Op. cit., p. 13-16). Nireu Cavalcanti, no entanto, afirmando, com sua experiência de urbanista, que "Alojar essa multidão, da noite para o dia, representava, caso os números fossem verdadeiros, um insolúvel problema urbano", analisou o movimento dos navios no porto do Rio de Janeiro nos anos de 1808 e 1809 e os processos relativos à Lei de Aposentadoria, que dava ao Governo o poder de tomar posse de moradias. Com base nesses dados, lançou por terra os altos e consagrados números, recalculando em cerca de 500 o número de pessoas vindas de Lisboa acompanhando a 
apresentações, algo que, de preferência, fosse o mais próximo ao que se tivera do outro lado do oceano, ou seja, o Real Teatro de São Carlos, de Lisboa.

Família Real (CAVALCANTI, Nireu. Op. cit., p. 96-97). Em virtude de informações tão díspares (o resultado das contas de Nireu também parece pequeno demais), cabe-nos alimentar ainda mais tal polêmica, conjecturando, com outros dados conflitantes, que a transferência da parte maior e mais diversificada da sociedade portuguesa para o Rio tenha ocorrido ao cabo, não de um ou três meses, mas de um prazo temporal relativamente maior. Lembremos, por exemplo, que Marcos Portugal, o mais insigne músico português, só aportou no Rio de Janeiro em meados de 1811, portanto, passados mais de três anos da chegada do Príncipe Regente. Ainda sobre esse assunto, lancemos nosso olhar para a lista de nobres e funcionários de alto escalão que, segundo o padre "Perereca", teriam chegado ao Rio junto com a família real (vide nota 141 desta parte). São ali citadas apenas 36 pessoas e suas respectivas famílias. Raymundo Faoro já comentara que "os fidalgos de alta linhagem, os que dispunham de meios próprios de vida, não acompanharam, senão excepcionalmente, o regente" (FAORO, Raymundo. Op. cit., v. 1, p. 284). 36 teria sido também o número mais ou menos exato de navios que compunham a frota portuguesa, segundo acreditou Lord Strangford, Ministro de Negócios Estrangeiros Britânico em Portugal: "The fleet consisted of eight sail of the line, four large frigates, several armed brigs, sloops, and corvettes, and a number of Brazil ships, amounting, I believe, to about thirty-six sail in all" (THE TIMES, 23/12/1807). Se imaginarmos que cada um deles pudesse ter trazido, em média, 100 passageiros, teríamos, não 18.000 , mas 3.600 pessoas chegando no Rio entre janeiro e março de 1808. É um numero bem mais razoável, se imaginarmos, igualmente, que, caso tivesse havido uma superlotação, com 500 pessoas, em média, em cada embarcação, parte dessa frota não teria tido a mínima condição de fazer uma escala na Bahia - o que, de fato ocorreu -, enquanto a outra parte ficou por 27 dias ancorada na Guanabara, sem que os membros da família real e da fidalguia desembarcassem, como afirma um opúsculo anônimo da época: "Entre tanto que se preparava esta Cidade para a recepção dos seus Soberanos, apareceu na barra a 17 de janeiro de 1808 uma pequena esquadra composta de duas naus portuguesas, uma fragata, um brigue e quatro naus inglesas. Era a Sereníssima Senhora Princesa Viúva, com duas das Senhoras Infantinhas, filhas de S.A.R.; e neste mesmo dia entrou na barra com 49 de viagem; porém não quis desembarcar enquanto não chegasse S.A.R.; por cujo motivo esteve sempre a bordo, e toda a fidalguia que vinha com ela" (RELAÇÃO das festas: que se fizeram no Rio de Janeiro, quando o Príncipe Regente N. S. e toda a sua real família chegaram pela primeira vez àquela capital. Ajuntando-se algumas particularidades igualmente curiosas, e que dizem respeito ao mesmo objeto. Lisboa: na Impressão Regia, 1810 , p. 6). 


\section{CAPÍTULO III - Uma capela real nos trópicos}

... [o Rei] de maneira alguma é carola

(...) No entanto, freqüenta assiduamente as igrejas, dando muita importância à música sacra e fazendo questão que os outros assistam à mesma $^{196}$.

A observação de época do diplomata prussiano, Conde von Flemming, que esteve no Rio entre 1817 e 1821, resume bem a grande paixão que Dom João tinha pela música sacra. Antes, portanto, de propiciar um espaço de audição de óperas mais digno de si e daqueles que o haviam acompanhado ao Rio de Janeiro, Dom João cuidou logo de organizar a música da Sé do Rio de Janeiro, nova Capela Real. Primeiro, porque, como já dissemos - e era de conhecimento de todos -, o gênero musical de predileção do Príncipe Regente era a música sacra ${ }^{197}$; e, segundo, porque já se achava no Rio, à época da chegada da família real, um exímio compositor, regente e organista dedicado a esse repertório, o padre e mestre-de-capela da Sé, José Maurício Nunes Garcia ${ }^{198}$.

${ }^{196}$ A CORTE de D. João VI no Rio de Janeiro segundo dois relatos do diplomata prussiano Conde von Flemming. Tradução de Carlos H. Oberacker Jr. Revista do Instituto Histórico e Geográfico Brasileiro. Rio de Janeiro, v. 346, p. 260, 1985.

197 Havia até quem recitasse por blague os seguintes versos, em referência ao grande apreço que Dom João tinha pela música eclesiástica: "Temos um rei / Chamado João / Faz o que Ihe dizem / Come o que Ihe dão / E vai para Mafra / Cantar Cantochão" (Cf. ANDRADE, Ayres de. Op. cit., v. 1, p. 13).

198 Como dissemos, da rara documentação que nos permita averiguar algo da atividade musical na Sé Carioca antes de tornar-se Capela Real, restaram-nos apenas algumas obras do Padre José Maurício Nunes Garcia. Considerado o maior compositor brasileiro do período colonial, dentre os que chegaram ao nosso conhecimento, Garcia nasceu em 1767, no Rio de Janeiro. Em 1783, aos 16 anos, escreveu sua mais antiga obra hoje conhecida, a Antífona Tota Pulchra e, no ano seguinte, já músico profissional, assinou o compromisso de fundação da Irmandade de Santa Cecília. Em 1791, como já vimos, a fama de seu talento chega a Lisboa, sendo publicada nota, na gazeta local, sobre a execução de um Te Deum, de sua autoria. Em 1792, foi ordenado padre e cerca de dois anos depois, criou seu "Curso de Música", em uma casa na rua das Marrecas. Em 1798, 
Para tanto, ainda em 1808, Dom João, usando de seus latos poderes, expediu dois importantes alvarás com força de lei. Primeiramente, a 15 de junho, transferiu para o novo templo escolhido como Capela Real - a Igreja do Carmo - José Maurício e seus companheiros, que então trabalhavam na Sé, àquela época, a Igreja do Rosário ${ }^{199}$ :

... não querendo perder nunca o antiquíssimo costume de manter junto ao meu real palácio uma capela real, não só para maior comodidade e edificação de minha real família, mas sobretudo para maior decência e esplendor do culto divino e glória de Deus, em cuja onipotente providência confio que abençoará os meus cuidados e desvelos com que procuro melhorar a sorte de meus vassalos na geral calamidade da Europa; (...) fui servido adotar o plano que nas presentes circunstâncias mais conviesse, ordenando (...) Que o Cabido da Catedral seja logo com a possível brevidade transferido com

passou a ocupar o cargo de mestre-de-capela da Sé (Igreja do Rosário), ao substituir, por falecimento, o também padre João Lopes Ferreira. Em 1801, compôs a música para as solenidades de posse do Vice-Rei, Dom Fernando José de Portugal. Com a chegada da família real, manteve-se como regente e compositor, agora da Capela Real, transferida para a Igreja do Carmo. No ano seguinte, foi agraciado pelo Príncipe Regente com a Ordem de Cristo. Compôs, em 1809, dezenas de obras para a Capela, além da música para a peça O Triunfo da América, apresentada no Real Teatro, no aniversário de Dom João; e uma "peça em música" (talvez Ulissea) no aniversário da Rainha. Em 1816, escreveu, por ocasião do falecimento da Rainha, uma de suas obras-primas, sua terceira Missa de Requiem. Três anos mais tarde, dirigiu importante concerto por ocasião do nascimento da princesa Dona Maria da Glória e preparou o Requiem de Mozart, na Igreja de N. S. do Parto. Em 1822, já com a saúde abalada, deixou de dar aulas em seu curso de música. Em 1826, compôs sua última obra importante, a Missa Festiva, mais conhecida como Missa de Santa Cecília. Morreu a 18 de abril de 1830. (Cf. MATOS, Cleofe Person de. Op. cit., p. 3942).

${ }^{199}$ As Memórias do padre Perereca registram o que teria sido o primeiro encontro do Príncipe Regente com os músicos da Sé: "... uma grande orquestra rompeu em melodiosos cânticos, logo que entrou S. A. R. com a sua augusta família; e ao som dos instrumentos, e vozes, que ressoavam pelo santuário, caminhou o Príncipe Regente Nosso Senhor com muito vagar, e custo, por causa do imenso concurso, que dentro da igreja se achava, até ao altar do Santíssimo Sacramento, e ali, saindo debaixo do pálio juntamente com as mais pessoas reais, se prostrou com a real consorte, e os augustos filhos, e filhas, ante o trono da Majestade Divina; entretanto cantavam os músicos o hino Te Deum Laudamus, e concluído o verso Te ergo etc., se levantou Sua Alteza com a real família, e se dirigiu para o altar mor igualmente debaixo do pálio, onde, pondo-se Suas Altezas outra vez de joelhos sobre almofadas, que também naquele lugar estavam colocadas, renderam as suas homenagens à Santíssima Virgem Nossa Senhora, e ao glorioso mártir São Sebastião, padroeiro da cidade" (SANTOS, Luiz Gonçalves dos. Op. cit., v. 1, p.180). 
todas as pessoas, cantores, e ministros, de que se compõe no estado atual, em que se acha na igreja da Confraria do Rosário, para a igreja que foi dos religiosos do Carmo, contígua ao Real Palácio da minha residência ${ }^{200}$.

Em segundo lugar, a 20 de agosto, com o mesmo argumento de que o culto divino se celebrasse com "decência e esplendor", criou uma pensão para a fábrica da Capela Real, imposta a todas as igrejas das Ordens do Brasil:

Eu o Príncipe Regente como Governador e Perpetuo Administrador das três Ordens Militares, faço saber aos que o presente Alvará com força de Lei virem: que havendo mandado considerar a minha Real Capela como a principal Igreja e cabeça de todas as das ordens; e não tendo ela rendimento, ou patrimônio algum, nem para as despesas do culto, nem para o seu necessário guisamento; e devendo concorrer para isto as Igrejas das Ordens, a fim de que o culto divino se celebre com o esplendor e decência que convém à santidade da religião e sublimidade de sua crença: sou servido determinar que em todas as Igrejas das Ordens, que daqui por diante se proverem neste Estado do Brasil e nos Domínios Ultramarinos, imponha a Mesa da Consciência e Ordens uma módica pensão arbitrada em proporção com lotação delas que será aplicada para a Fábrica de minha Real Capela ${ }^{201}$.

Diga-se de passagem, esse "antiquíssimo costume" cultivado pelos monarcas portugueses de manter a "decência e esplendor do culto divino", propiciara a Lisboa - assim como ocorreu com a ópera -, experimentar uma das mais bem realizadas músicas sacras do continente europeu. Ao conhecer, por exemplo, em agosto de 1787, o trabalho dos músicos da

200 COLEÇÃO das Leis do Brasil de 1808. Cartas de Lei, Alvarás, Decretos e Cartas Régias de 1808. Rio de Janeiro: Imprensa Nacional, 1891, p. 55-57. 
Capela Real de Dona Maria I, o viajante inglês e diletante bem informado William Beckford ${ }^{202}(1760-1844)$ os colocou em patamar superior ao do próprio Papa:

\begin{abstract}
A orquestra da capela da Rainha de Portugal ainda é a primeira da Europa; em excelência de vozes e instrumentos nenhuma outra corporação deste gênero, nem mesmo a do Papa, se pode gabar de ter reunidos tão admiráveis músicos como estes. (...) Os violinos e os violoncelos de Sua Majestade são todos de primeira ordem, e em flautas e oboés a sua ménagerie musical não tem rival ${ }^{203}$.
\end{abstract}

Não era para menos. Desde o reinado de Dom José I, a melhor música ouvida em Portugal era executada, em grande parte, por exímios artistas italianos ${ }^{204}$. E com a vinda da família real e o interesse pessoal do Príncipe Regente em reorganizar sua Capela, o Rio de Janeiro, aos poucos, começou a herdar essa tradicional organização musical. Até 1810, a Catedral manteve-se com praticamente os mesmos músicos nativos ${ }^{205}$. Mas a partir

${ }^{201}$ Idem, p. 101-102.

202 Filho de um influente político inglês de mesmo nome, William Beckford teria recebido lições musicais de Mozart quando ambos eram ainda garotos. Após a morte de sua esposa, uma nobre inglesa, em 1786, viaja no ano seguinte a Portugal, onde se torna um íntimo amigo do Marquês de Marialva e freqüente visitante deste país (Cf. BECKFORD, William. A Corte da Rainha D. Maria I: correspondência de W. Beckford - 1787. Lisboa: Tavares Cardoso, 1901)

${ }_{203}^{203}$ Ibidem, p. 76-77.

${ }^{204}$ Em setembro de 1760, de passagem pela capital portuguesa, o escritor e crítico literário italiano Giuseppe Baretti (1719-1789) ficou muito admirado com a música que ouviu na Sé de Lisboa e achou ainda mais digno de nota ter visto ali quarenta e tantos italianos entre os cantores e instrumentistas: "During the mass the musicians played and sung most gloriously. The King has a good many in his service, and, what is remarkable, more than forty Italians, partly singers and partly players upon several instruments" (BARETTI, Giuseppe Marco Antonio. A journey from London to Genoa, through England, Portugal, Spain, and France. London: T. Davies and L. Davis, 1770, v. 1, p. 111). Note-se que o texto, originalmente escrito em inglês, se deve ao fato de Baretti ter estado a serviço, como correspondente estrangeiro, da Royal Academy of Painting, Sculpture and Anchitecture, de Londres.

${ }^{205}$ André Cardoso, em sua tese de doutorado, menciona apenas dois músicos que teriam vindo para o Rio com a família real: o organista José do Rosário e o padre Francisco de Paula Pereira (CARDOSO, André. A Capela Real e Imperial do Rio de Janeiro - 18081889. Rio de Janeiro, 2001. Tese [Doutorado] - Instituto Villa-Lobos / Universidade Federal do Estado do Rio de Janeiro, p. 89). 
desse ano, a mando de "Sua Alteza Real", começam a chegar muitos componentes da Real Câmara de Lisboa, como Nicolau e Pedro Carlos Heredia. Com eles, viriam também mais quatro músicos pertencentes à Santa Igreja Patriarcal de Lisboa ${ }^{206}$. Talvez pertencessem a esse grupo, José Gori e Antonio Cicconi, dois castrati italianos que, segundo Ayres de Andrade ${ }^{207}$, teriam chegado ao Rio nesse mesmo ano. Outro a chegar, em 1810 seguido de seus irmãos, foi o cantor e compositor Fortunato Mazziotti ${ }^{209}$ (1782-1855), que, alguns anos mais tarde, mais precisamente a partir de $1^{\circ}$ de abril de 1816, incorporaria ao seu salário mensal de cantor da Capela, a quantia de 30 mil réis, por passar a ocupar, por nomeação do rei, "o lugar de Mestre da Sua Real Capela"210.

Em 1811, foi a vez de entrar, pela Guanabara - acompanhado de seu irmão e organista, Simão —, Marcos Antônio da Fonseca Portugal (1762$1830)^{211}$. Logo, o célebre compositor e maestro português assumiu o cargo de professor de música dos Príncipes ${ }^{212}$; e, em outubro do mesmo ano, passaria,

${ }^{206}$ SCHERPEREEL, Joseph. Op. cit., p. 37-38.

207 ANDRADE, Ayres de. Op. cit., v.1, p. 28.

${ }^{208}$ CARDOSO, André. Op. cit., p. 102.

209 Embora tivesse designativos italianos, Fortunato Mazziotti era, muito provavelmente, português de nascimento. Segundo Ernesto Vieira, era filho do cantor italiano Antonio Mazziotti, que fazia parte da companhia lírica organizada para o teatro do Bairro Alto em 1765, dirigida por David Perez (Cf. VIEIRA, Ernesto. Dicionário biográfico de músicos portugueses: história e bibliografia da música em Portugal. Lisboa: Lambertini, 1900).

${ }^{210}$ CARDOSO, André. Op. cit., p. 103.

211 Nascido em 1762, Portugal tinha 9 anos de idade, quando entrou para 0 Seminário Patriarcal, estudando composição com João de Sousa Carvalho. Aos 14, já compunha um Miserere, a 4 vozes e órgão. Aos 21, foi admitido na irmandade de Santa Cecília ao mesmo tempo em que cantava e tocava órgão na Capela Real. Destacando-se pelo talento superior, conseguiu, com a proteção régia, ser enviado à Itália, em 1792, para aperfeiçoar-se. Durante oito anos em que esteve lá, executou, nos principais teatros da península, 21 de suas óperas, obtendo êxito com todas elas. Em 1800, regressou a Lisboa, sendo logo nomeado mestre da Capela Real, diretor do Teatro de São Carlos e professor do Seminário. Apesar da invasão francesa, Marcos Portugal manteve-se em Lisboa e chegou a compor, em 1808, uma ópera em homenagem a Bonaparte. Com a saída dos franceses e a emigração cada vez maior de portugueses ao Rio resolveu partir também para a capital brasileira. Chegou ao Rio de Janeiro em 1811. (Cf. RODRIGUES, Guilherme, PEREIRA, Esteves. Portugal - Dicionário Histórico, Corográfico, Heráldico, Biográfico, Bibliográfico, Numismático e Artístico. Lisboa: João Romano Torres, 1911, v. 5, p. 10131015).

212 Note-se que, segundo Ayres de Andrade, a 23 de junho de 1811, pouco tempo depois de chegar ao Rio de Janeiro, Marcos Portugal teria assumido o cargo de mestre da Real Capela do Rio de Janeiro, cargo que já ocupava em Lisboa (Cf. ANDRADE, Ayres de. 
por decisão do Governo, a inspecionar e dirigir a música do teatro de Manuel Luiz, agora Real Teatro, nos dias em que o Príncipe Regente freqüentasse tais espetáculos ${ }^{213}$.

Op. cit., v.1, p. 30). Estranhamente, notamos a ausência do nome desse compositor em páginas referentes à Capela Real dos Almanaques do Rio de Janeiro de 1811, 1816, 1817, 1824 e 1827 (ver referências individuais mais adiante). Nos três primeiros, apenas é citado, como mestre-de-capela, José Maurício Nunes Garcia; e, nos dois últimos, José Maurício e Fortunato Mazziotti. Portugal irá constar, como mestre-de-capela, apenas do Almanaque de 1829 (Cf. ALMANAQUE imperial do comércio e das corporações civis e militares do Império do Brasil. Rio de Janeiro: Em Casa de P. Plancher-Seignot, 1829, p. 58-59), quando já figura também como tal nos documentos oficiais da Capela. Essa mesma ausência do nome de Marcos como mestre-de-capela também pode ser notada nas muitas notícias que encontramos sobre a Capela Real publicadas na Gazeta do Rio de Janeiro. Nenhuma delas menciona Marcos Portugal como "mestre-de-capela", mas sempre como "Mestre de SS. AA. RR.", ou seja, professor de música dos Príncipes, função que, diga-se a propósito, irá desempenhar mesmo durante o primeiro reinado, como atesta o decreto de 10 de dezembro de 1824: "Tendo resolvido que Marcos Antônio Portugal continue no exercício de mestre de música da Minha Imperial Família (...) com o ordenado de $480 \$ 000$, que já dantes vencia por um igual exercício..." (COLEÇÃO das Leis do Império do Brasil de 1824. Rio de Janeiro: Imprensa Nacional, 1886, parte 2, p 96). Na verdade, como poderemos observar na nota seguinte, Portugal foi oficialmente encarregado pelo Paço, em 1811, de dirigir apenas as funções "de teatro", e, ainda assim, somente quando Sua Alteza estivesse presente nos espetáculos. Nada, portanto, diz respeito às funções de Igreja, estas, como sabemos, já dirigidas - quanto à Capela Real —, desde 1808, pelo padre José Maurício Nunes Garcia.

${ }^{213}$ Eis a decisão, assinada pelo ex-Vice-Rei e então Ministro do Reino, Conde de Aguiar a 9 de outubro de 1811: "Pedindo o decoro e a decência que as peças de música, que se puserem em cena nos teatros públicos desta Corte nos dias em que o Príncipe Real Regente Nosso Senhor faz a honra de ir assistir, sejam executadas com a regularidade e boa ordem que são indispensáveis em tais ocasiões; e concorrendo na pessoa de $\mathrm{Vm}$. todas as circunstâncias de inteligência e préstimo, que se requerem para bem regular e reger semelhantes espetáculos; é o mesmo Senhor servido encarregar Vm. esta inspeção e direção na forma e maneira seguinte; $1^{\circ} \mathrm{A}$ direção e inspeção de $\mathrm{Vm}$. terá tão somente lugar, pelo que respeita às peças de música, que se destinarem para serem representadas na real presença de Sua Alteza Real. $2^{\circ}$ Não se poderá meter em cena nestas ocasiões peça alguma de música, que não seja escolhida e aprovada por $\mathrm{Vm}$. recebendo primeiramente as ordens de Sua Alteza Real para esse fim. $3^{\circ}$ Será também da intendência de $V m$. a distribuição dos caracteres, e a escolha dos músicos instrumentistas, para servirem nos referidos dias, sendo sempre dos mais hábeis, que houverem, e pode $\mathrm{Vm}$. com inteligência do empresário ou proprietário do teatro, despedir alguns dos existentes, que não estiverem nas circunstâncias que se requerem, tomar outros, e ainda aumentar o número, quando a composição da música assim exija. $4^{\circ}$ Procurar $V m$. que os atores e instrumentistas façam aqueles ensaios, que necessários forem, e que, se façam as récitas com a possível perfeição e ordem. $5^{\circ}$ Igualmente ficará à vigilância de $\mathrm{Vm}$. de comum acordo com o empresário ou proprietário do teatro, em fazer aprontar, na forma possível, tudo o que se possa conduzir para a decência dos espetáculos que se houverem de recitar naquelas ocasiões. $6^{\circ}$ Será $\mathrm{Vm}$. obrigado a assistir a todas as representações nos dias em que Sua Alteza Real for ao teatro para observar e providenciar algum descuido, que possa ocorrer. $7^{\circ} \mathrm{E}$ finalmente, acontecendo, que alguns dos empregados nos referidos teatros precise ser corrigido ou castigado pelas faltas que cometer nos referidos dias e ensaios, Vm. dará parte ao Visconde de Vila Nova da Rainha, para este dar as providências que julgar oportunas, segundo as ordens que tiver recebido do mesmo Senhor a este respeito. $\mathrm{O}$ que participo a $\mathrm{Vm}$. para que assim o tenha entendido e nesta conformidade o execute. Deus guarde a Vm. Paço em 9 de outubro de 1811. Conde de Aguiar. Sr. Marcos Antônio 
No ano seguinte, em 1812, alguns músicos que deixam Lisboa rumo ao Rio são Vicente della Corte, Policarpo José de Faria e Eugênio José Farneze, todos instrumentistas da Real Câmara ${ }^{214}$. Assim, pouco a pouco, foise constituindo, sob a égide do Príncipe Regente, um dos melhores conjuntos musicais das Américas de então.

Em 1816, ano da elevação de Dom João a Rei - embora fosse ele coroado apenas em 1818 —, aporta, no Rio de Janeiro, o bem-sucedido castrato bergamasco João Francisco (Giovanni Francesco) Fasciotti ${ }^{215}$, que também integra os quadros da Capela. 1816 é, igualmente, o ano da chegada de Sigismund Neukomm (1778-1858) ${ }^{216}$ :

Portugal" (COLEÇÃO das Leis do Brasil de 1811. Decisões de 1811. Rio de Janeiro: Imprensa Nacional, 1890, p. 30).

214 SCHERPEREEL, Joseph. Op. cit., p. 38.

215 Para esse cantor, Fétis reservou um pequeno verbete em sua Biographie universelle des musiciens: "sopraniste, naquit à Bergame, vers le milieu du dix-huitième siècle. Il fut employé pendant quelques années à la chapelle de Pise, et se livra ensuite à la carrière théâtrale. Après avoir chanté sur les petits théâtres de la Romagne, il fut appelé à Naples, à Turin, à Gènes et à Milan. Il obtint partout du succès par l'expression, la flexibilité et la justesse de sa voix" (FÉTIS, François-Joseph. Op. cit., v. 3, p. 190). De fato, Fasciotti cantou nas principais casas de ópera da Itália, conforme registram alguns libretos lá impressos em 1800, 1802, 1803, 1812, 1813 e 1814: LODOISKA, dramma per musica da rappresentarsi nel Regio-Ducal Teatro alla Scala di Milano il carnevale dell'anno 1800. Dedicato a sua eccellenza il sig. conte Luigi Cocastelli [compositore della musica sig. maestro Simone Majer]. Milano: Gio. Batista Bianchi, [1800] (Biblioteca del Conservatorio di musica Giuseppe Verdi - Milano - MI - Libretti N.52); ZENO, Apostolo. Sesostri, dramma per musica da rappresentarsi nel Real Teatro di S. Carlo nel di' 12 gennaro 1802 festeggiandosi la nascita di Ferdinando 4. nostro amabilissimo sovrano ed alla S. R. M. dedicato [la musica e del signor Gaetano Andreozzi]. Napoli: nella Stamperia Flautina, 1802 (Biblioteca del Conservatorio di musica S. Pietro a Majella - Napoli - NA - Rari 10.8.14/11); PRUNETTI, Michelangelo. La selvaggia del Messico, dramma serio per musica. Da rappresentarsi in Bologna nel teatro della Comune, l'autunno del corrente anno 1803, secondo della Rep. Italiana [la musica e del celebre maestro Giuseppe Nicolini]. Bologna: Stampe del Sassi, 1803 (Biblioteca del Conservatorio di musica S. Pietro a Majella - Napoli - NA - Rari 10.8.15/7); ROMANELLI, Luigi. Coriolano, melodramma serio in due atti del sig. Luigi Romanelli poeta. Da rappresentarsi nel Teatro da S. Agostino nel carnevale dell'anno 1812 [la musica e del sig. Giuseppe Nicolini]. Genova: Stamperia della Marina, e della Gazzetta di Genova, [1812] (Biblioteca del Conservatorio di musica S. Pietro a Majella - Napoli - NA Rari 11.2.3/1); TARDUCCI, Filippo. Amuratte 2., dramma serio per musica. Da rappresentarsi nel nobil teatro a Torre Argentina il carnevale dell'anno 1813 [la poesia e del sig. Filippo Tarducci; la musica e del maestro sig. Pietro Raimondi]. Roma: Stamperia di Crispino Puccinelli, 1813 (Biblioteca del Conservatorio di musica S. Pietro a Majella - Napoli - NA - Rari 10.6.19/1); ANDRIOLI, Luigi. Cesare in Egitto, melodramma serio da rappresentarsi nell'Imperiale Teatro di Torino il carnevale dell'anno 1814 dedicato a Sua Altezza Imperiale il Principe Camillo Duca di Guastalla [la poesia e del sig. Luigi Andrioli; la musica e del Sig. Maestro Ercole Paganini]. Torino: presso Onorato Derossi, [1814?] (Biblioteca del Conservatorio di musica S. Pietro a Majella - Napoli - NA - Rari 10.4 13/10).

${ }^{216}$ Sigismund Neukomm foi um músico de currículo bastante respeitável, em sua 
Em o navio americano Calphe, chegaram do Havre de Grace a este porto as pessoas abaixo nomeadas (...) Neukomm, compositor de música, excelente organista e pianista, e o mais distinto discípulo do célebre Haydn ${ }^{217}$.

época. Nascido em Salzburgo, estudou naquela cidade com Michael Haydn e, aos 18 anos, já era pianista co-repetidor da Ópera. Em Viena, estudou também com Joseph Haydn, o mais famoso músico europeu da segunda metade do século XVIII, ao lado de Mozart. Em 1807, tornou-se membro da Academia de Música de Estocolmo, e, pouco tempo depois, ocupou o cargo de diretor de ópera alemã em São Petersburgo. De volta à Europa Ocidental, em 1809, para despedir-se do moribundo mestre Haydn, Neukomm fixa-se em Paris, onde se torna protegido do Príncipe de Talleyrand. Em 1816, acompanha o Duque de Luxemburgo em sua viagem diplomática ao Brasil, onde fica até 1821, quando retorna novamente a Paris (Cf. FÉTIS, François-Joseph. Op. cit., v. 6, p. 303-305). Apesar de ter permanecido no Rio por quase cinco anos, Neukomm, aparentemente, exerceu um papel bastante informal no meio musical carioca. Segundo Spix e Martius, o "pupilo favorito de Joseph Haydn", teria atuado como "compositor da capela da corte": "Der Lieblingsschüler J. Haydn's, Ritter Neukomm, befand sich damals als Compositeur an der Hofcapelle in Rio" (SPIX, Johann Baptist von; MARTIUS, Karl Friedrich Philip von. Reise in Brasilien auf BefehI Sr. Majestät Maximilian Joseph I., Königs von Bayern in den Jahren 1817 bis 1820 gemacht und beschrieben von Joh. Bapt. von Spix; und Carl Friedr. Phil. von Martius. München: M. Lindauer, 1823, v. 1, p. 106). Contudo, como o próprio compositor afirma em seu "Esquisse biographique", publicado postumamente, em três partes, no jornal francês de música religiosa La maîtrise (15/09/1858, 15/12/1858 e 15/03/1859), sabemos que suas atividades, sem uma função definida, nunca "dependeram pessoalmente da corte ou do estado": "Le Roi m'accorda, sur la demande du comte de Barca, un traitement plus que suffisant pour mes dépenses, et sans me charger d'aucune fonction. Mais je fus heureux d'offrir de donner des leçons de musique à l'infante Dona Maria, ainsi qu'au prince héréditaire, S. A. R. Dom Pedro, et à sa future épouse Léopoldine, archiduchesse d'Autriche; j'offris, de plus, de faire de la musique avec eux, et de leur procurer en même temps l'occasion de s'exercer dans la langue française. Ainsi je vécus pendant tout le temps de mon séjour à Rio-Janeiro, de 1816 à 1821, au milieu de la famille royale, qui me combla de bontés; mais sans dépendre personnellement ni de la Cour, ni de l'État" (LA MAÎTRISE, 15/12/1858). Professor informal dos Príncipes (já que o oficial era Marcos Portugal) com os quais praticava o francês, além da música; hóspede do Conde da Barca e, depois da morte desse último, do Barão de Santo Amaro (José Egídio Alvares de Almeida, depois Visconde e Marquês do mesmo nome), Neukomm deve ter circulado essencialmente, como veremos mais adiante, nos meios musicais de salão (como a casa de Langsdorff), já que, ainda segundo Spix e Martius, a educação musical dos cariocas não estava "reconhecidamente madura" para suas obras, "escritas completamente no estilo dos mais famosos músicos alemães", e, portanto, um tanto distantes do reinante gosto italianizado: "Für seine, ganz im Style der berühmtesten deutschen Musiker geschriebenen, Messen war freilich die musikalische Bildung der Einwohner noch nicht reif" (SPIX, Johann Baptist von; MARTIUS, Karl Friedrich Philip von. Op. cit., v. 1, p. 106).

${ }^{217}$ GAZETA DO RIO DE JANEIRO, 06/04/1816. Curiosamente, Neukomm saiu da França em outra embarcação, como ele próprio nos atesta em seu "Esquisse biographique de Sigismond Neukomm écrite par lui-même": "Nous nous embarquâmes à Brest, le 2 avril 1816, sur la frégate I'Hermione" (LA MAÎTRISE, 15/12/1858). Segundo o padre "Perereca", a fragata l'Hermione aportou no Rio "aos 30 de maio", trazendo o Duque de Luxemburgo, embaixador extraordinário do Rei da França, Luís XVIII (SANTOS, Luiz Gonçalves dos. Op. cit., v. 2, p. 74). O mesmo Esquisse dá como 15/04/1821 a data de retorno de Neukomm para a Europa. 
Nunca se presenciara até então, em terras brasileiras, uma plêiade de tão rico valor musical. O resultado se refletiu na alta qualidade das execuções. Na opinião de quem as ouviu, os mais elogiosos comentários se referem sempre à Capela. Jean Baptiste Debret (1768-1848), por exemplo, artista plástico que chegara com a Missão Artística Francesa, em 1816, assim aludiu a esse conjunto:

O corpo de músicos da Capela é composto por ótimos artistas em todos os gêneros, virtuoses castrados, e outros cantores italianos. A parte instrumental é muito forte ... ${ }^{218}$.

O mineralogista inglês Alexander Caldcleugh, que passou pela Guanabara, em 1819, também dedicou-Ihe linhas elogiosas:

Na opinião da maioria das pessoas, a Capela Real oferece a maior satisfação aos melômanos. Arranjada de forma similar à de Lisboa, em dias normais, nenhuma despesa foi poupada para conferir à performance total notabilidade no assunto $^{219}$.

Louis Claude Desaulces Freycinet (1779-1842), navegador e cientista francês que esteve no Rio entre 1817 e 1818, registra, da mesma forma, em seus escritos a admiração de ouvir, na Capela Real, música nos melhores moldes europeus:

218 Tradução nossa de: "Le corps de musique de la chapelle est composé de trèsbons artistes en tous genres, virtuoses castrats, et autres chanteurs italiens. La partie instrumentale est très-forte ..." (DEBRET, Jean Baptiste. Voyage pittoresque et historique au Brésil, ou Séjour d'un artiste français au Brésil, depuis 1816 jusqu'en 1831 inclusivement. Paris: Firmin Didot frères, 1839, v. 3, p. 5).

${ }^{219}$ Tradução nossa de: "In the opinion of most persons, the Royal Chapel afforded the greatest satisfaction to the lovers of music. Similarly arranged to that the Lisbon in former days, no expense was spared to render the performance fully worthy of the subject" (CALDCLEUGH, Alexander. Travels in South America, during the years 1819-20-21. Containing an account of the present state of Brazil, Buenos Ayres, and Chile. London: John Murray, 1825, v. 1, p. 62). 
Ouvimos, com freqüência e admiração, a música executada pela Capela Real, a qual é constituída quase que inteiramente de artistas negros, e cuja execução não deixa nada a desejar 220 .

Notemos, no entanto, por esse último depoimento, que, apesar da grande concorrência de músicos estrangeiros de reconhecida excelência para o Rio de Janeiro, a presença mais assídua no conjunto da Capela Real, ainda era, em 1817, a do elemento brasileiro, negro ou mulato, que, diga-se a propósito, sempre chamaria a atenção do viajante europeu, às vezes, para comentários preconceituosos, mas, em muitos casos, para observações encomiásticas, o que indica, mais uma vez, a capacidade da colônia de ter gerado - com ou sem um ensino musical organizado - profissionais de talento similar ao dos grandes centros europeus.

Relativo a essa última análise, citemos ainda o conhecido artigo de Sigismund Neukomm - publicado, em julho de 1820, no jornal especializado em música de Leipzig, Allgemeine musikalische Zeitung ${ }^{221}$-, no qual o discípulo de Haydn noticia, com elogiosos comentários, especialmente ao mulato José Maurício Nunes Garcia, uma apresentação do Requiem de Mozart, ocorrida na Igreja de Nossa Senhora do Parto, em dezembro de 1819, e realizada pela Irmandade da Gloriosa Virgem e Mártir Santa Cecília, a já mencionada confraria em que se associavam, oficialmente, desde 1784 , os músicos profissionais do Rio de Janeiro:

O mestre-de-capela da Capela Real, Senhor
José Maurício Nunes Garcia, assumiu todo o

220 Tradução nossa de: "Nous avons entendu souvent avec admiration la musique de la chapelle royale, dont presque tous les artistes étaient nègres, et dont l'exécution ne laissait rien à désirer" (FREYCINET, Louis Claude Desaulces de. Voyage autour du monde, entrepris par ordre du roi exécuté sur les corvettes de S. M. L'Uranie et Le Physicienne. Paris: Chez Pillet aîné, 1826, v. 1, p. 216).

${ }^{221}$ Este periódico semanal, fundado, em 1798, por Johann Friedrich Rochlitz (17691842) e publicado em Leipzig, era uma das mais importantes publicações européias de música. É importante ressaltar que a maioria dos autores que citaram até hoje tal artigo de Neukomm, referem-no, erroneamente, como parte de uma publicação vienense, o homônimo Allgemeine musikalische Zeitung, mit besonderer Rücksicht auf den österreichischen Kaiserstaat. 
empreendimento. O zelo com o qual o Senhor Garcia enfrentou todas as dificuldades para que, finalmente, uma obra-prima de nosso imortal Mozart fosse levada, merece os maiores agradecimentos dos amantes da arte daqui e eu, de minha parte, me sinto obrigado a aproveitar essa oportunidade para chamar a atenção do mundo europeu ligado à arte para um homem que só não é mais conhecido por sua grande modéstia, e que agora, nesta oportunidade, podemos tornar público. Ele tem, além de tudo, todo o direito de receber as maiores distinções pois sua formação é apenas sua própria obra. Nascido no Rio de Janeiro, ele foi admitido subseqüentemente no Seminário Episcopal dessa cidade, onde recebeu a investidura de padre após primoroso estudo, e, finalmente, feito mestre-de-capela da Capela Episcopal. Com a chegada da corte no Brasil, ele recebeu o cargo de mestre-de-capela da Capela Real, a qual, ele dirige gloriosamente, a despeito de sua arruinada saúde.

(...) A execução da obra-prima mozartiana não deixou nada a desejar; todos os talentos se empenharam para que esse desconhecido e genial Mozart fosse muito bem recebido no Novo Mundo. E essa tentativa foi tão bem sucedida em todos os sentidos, que, sem dúvida, não será a última vez que irá ocorrer ${ }^{222}$.

222 Tradução nossa de: "Die Leitung des Ganzen hatte der Kapellmeister der königlich Kapelle Hr. Jozé-Mauricio Nunes Garcia übernommen. Der Eifer, mit dem Hr. Garcia allen Schwierigkeiten entgegengearbeitet hat, um endlich einmal auch hier ein Meisterwerk unseres unsterblichen Mozart's zur Aufführung zu bringen, verdient den wärmsten Dank der hiesigen Kunstfreunde, und ich meinerseits rechne es mir zur Pflicht, diese Gelegenheit zu benutzen, um unsere europäische Kunstwelt auf einem Mann aufmerksam zu machen, der es nur seiner großen Bescheidenheit zuzuschreiben hat, wenn seiner vielleicht erst bei dieser Gelegenheit zum erstenmal öffentlich gedacht wird. Er hat um so mehr die gerechtesten Ansprüche auf ehrenvolle Auszeichnung, da seine Bildung bloß sein eigenes Werk ist. Geboren in Rio de Janeiro, wurde er in der Folge im bischöflichen Seminarium dieser Stadt aufgenommen, wo er nach vollendetem Studium die Priesterweihe empfing und endlich als Kapellmeister bei der bischöflichen Kapelle angestellt wurde. Bei der Ankunft des Hofes in Brasilien erhielt er die Stelle als Kapellmeister der königlich Kapelle, welcher er, seiner zerrütteten Gesundheit ungeachtet, noch immer rühmlichst vorsteht. (...) Die Aufführung des Mozartischen Meisterwerkes ließ nichts zu wünschen übrig; alle Talente wetteiferten, um den genialen Fremdling Mozart in dieser neuen Welt würdig zu empfangen. Dieser erste Versuch ist in jeder Hinsicht so gut gelungen, dass er hoffentlich nicht der letzte in seiner Art sein wird" (ALLGEMEINE 
Valendo-nos do testemunho de Sigismund Neukomm sobre esse brilhante momento da atividade musical do Padre José Maurício Nunes Garcia, ocorrido no final do ano de 1819, julgamos interessante realizar, neste momento, um parêntese em forma de censura à unânime tendência historiográfica, que, ao nosso ver, de forma maniqueísta e superficial, vem, desde Manuel de Araújo Porto Alegre ${ }^{223}$, traçando como prejudicada a presença artística desse importante mestre-de-capela brasileiro, a partir de 1811, em conseqüência exclusiva da presença arrogante, ambiciosa e invejosa de Marcos Antônio da Fonseca Portugal, que nesse ano chegara ao Rio de Janeiro.

Asseveremos, inicialmente, que tal prejuízo tem um fundo de verdade, pois, sabemos, de modo notório, que ocorreu, desde 1808, acirrada disputa de espaços nas mais variadas seções ou divisões governamentais, das quais a Capela Real fazia parte. Porém, embora tenha havido rivalidade, sobretudo entre forasteiros e nativos, por lugares privilegiados no cenário musical carioca, e que Marcos Portugal tenha efetivamente ocupado espaços antes preenchidos por José Maurício ${ }^{224}$, outros fatos, mesmo que pressupostos e, aliás, pouco levados em consideração até hoje como parte integrante dessa história -, permitem-nos, pelo menos, analisar tal episódio de uma forma mais crítica. Apresentemos aqui alguns deles.

Em primeiro lugar, importa constatar que Portugal permaneceu nos "anais" da história musical do Brasil como pessoa de má índole, graças, essencialmente, à utilização de duas fontes um tanto falhas: depoimentos maledicentes de um de seus desafetos, o bibliotecário português Luiz dos Santos Marrocos ${ }^{225}$; e "testemunhos" de Sigismund Neukomm, que nos

MUSIKALISCHE ZEITUNG, 19/07/1820).

${ }^{223}$ Cf. PORTO ALEGRE, Manuel de Araújo. Apontamentos sobre a vida e a obra do padre José Maurício Nunes Garcia. Revista do Instituto Histórico e Geográfico Brasileiro. Rio de Janeiro, t. 19, 1856.

${ }_{224}$ A leitura da Gazeta do Rio de Janeiro, por exemplo, indica uma forte predominância de Portugal apresentando suas obras e regendo a Capela nos aniversários da realeza e datas nacionais, principalmente nos dez anos em que ele esteve a serviço de Dom João.

${ }^{225}$ Cf. MARRocos, Luiz Joaquim dos Santos. Cartas de Luiz Joaquim dos Santos Marrocos escritas do Rio de Janeiro à sua família em Lisboa de 1811 a 1821. Anais da 
chegaram narrados pelo artista Manuel de Araújo Porto Alegre, em uma época de acalorada rixa entre "brasileiros" e "portugueses", na qual, comumente, os primeiros acabavam enaltecidos e os últimos vilipendiados ${ }^{226}$.

Outrossim, se já se constatou, pela precária análise quantitativa das "obras conhecidas" de José Maurício, que a sua produção artística decaiu vertiginosamente a partir de $1811^{227}$, não se leva, no entanto, em consideração, que cerca da metade dessas composições não trazem a marca dos anos em que foram compostas, e que nenhuma das obras mais bemacabadas do padre são de seu período, dito "áureo" (1808-1810), posterior à vinda de Dom João e anterior à chegada de Marcos.

Ademais, se inúmeras atividades da Capela - sobretudo aquelas exclusivamente religiosas, em todas as suas ordens - nunca eram noticiadas nos periódicos e também não sobreviveram nos documentos oficiais dessa instituição, hoje conservados, em sua maioria, no Arquivo Nacional do Rio de Janeiro, não se sabe, em realidade, quem regia e quais obras eram executadas nos serviços musicais de, por exemplo, a Páscoa, o Natal ( $1^{\mathrm{a}}$ ordem), a Circuncisão, o domingo de Ramos ( $2^{\mathrm{a}}$ ordem) e tantas outras funções religiosas de terceira ou quarta ordem. É possível, até mesmo, que a condição eclesiástica de José Maurício lhe desse certa prerrogativa de dirigir a música nessas ocasiões religiosas igualmente importantes.

O fato de a Gazeta do Rio de Janeiro indicar uma segura predominância de Marcos Portugal apresentando suas obras e regendo a Capela nos aniversários, nascimentos e casamentos dos membros da família real também não é indicativo cabal de que José Maurício esteve completamente distanciado das grandes ocasiões, como taxou, por exemplo, Ayres de Andrade ${ }^{228}$. Outras fontes, como as Memórias do Padre "Perereca",

Biblioteca Nacional. Rio de Janeiro, v. 56, 1934.

${ }^{226}$ Cf. PORTO ALEGRE, Manuel de Araújo. Op. cit.

${ }^{227}$ Cf. MATOS, Cleofe Person de. Op. cit.

228 "A presença de Marcos Portugal na Capela Real a tal ponto se fazia sentir absorvente, que José Maurício viu-se relegado a um plano secundário. Nem uma só vez o seu nome vem citado na Gazeta do Rio de Janeiro, jornal oficial, como tendo ele atuado em 
contradizem tal afastamento. Por exemplo: a 21 de janeiro de 1816, como parte das comemorações da elevação do Brasil à condição de Reino, realizou-se, com a presença de toda a corte, uma festividade de ação de graças, a qual, até por ter sido tão grandiosa, teve lugar, não na Capela Real, mas em um local maior, a Igreja de São Francisco de Paula. Segundo o Padre "Perereca", quem dirigiu a função musical em tal vultoso acontecimento não foi Marcos e sim José Maurício:

... seguiu-se o Te Deum Laudamus, que foi cantado, como tinha sido também a missa, pela melhor, e escolhida música, tanto vocal, como instrumental, regida pelo mestre da Capela Real o r. p. José Maurício Nunes. A toda esta grande solenidade assistiu Sua Alteza Real com os seus augustos filhos, os sereníssimos senhores Príncipe, e Infante, o corpo diplomático, os grandes do Reino, o excelentíssimo e reverendíssimo bispo, capelão-mor, e outros bispos eleitos, o senado da Câmara, os cidadãos, outras muitas pessoas distintas de todas as ordens do Estado, e povo quanto podia caber na igreja, onde só entraram os que se achavam vestidos com a decência devida a tão solene e régia festividade ${ }^{229}$.

Quando se afirma, da mesma forma, que a atividade de José Maurício decaiu no momento em que Marcos Portugal supostamente the roubou espaço de atuação, não se apresenta, em contrapartida, um consistente conjunto de ações musicais que o próprio compositor lusitano teria desenvolvido no Rio de Janeiro, além das apresentações de suas obras sacras na Capela, registradas nas esparsas notícias da Gazeta e em alguns depoimentos de viajantes. Aliás, muito se fala e pouco se sabe, como já

cerimônia de vulto" (ANDRADE, Ayres de. Op. cit., v. 1, p. 31-32). Note-se que Ayres de Andrade chega a esboçar certa desconfiança quanto à veracidade das intrigas de Marcos Portugal em relação a José Maurício: "Por mais que se queira considerar válida tal interpretação dos fatos, não é possível deixar de reconhecer que ela se apoia em tradição um tanto precária" (Ibidem, p. 32). Porém, sua crítica nesse sentido não se desenvolve e suas conclusões, baseadas em documentação parcial, acabam corroborando a visão, já consagrada à época, de que a presença de Marcos teria anulado a de José Maurício. 
vimos, sobre a real função e conseqüente peso participativo de Marcos Portugal no cenário musical carioca. Não se tem conhecimento, por exemplo, de que o ex-diretor musical do Teatro de São Carlos, de Lisboa, tenha composto qualquer ópera para o Teatro de São João ou de São Pedro de Alcântara ${ }^{230}$. Se isso for um fato, Portugal até perde para Garcia nesse aspecto, visto que o brasileiro, segundo Porto Alegre, teria composto pelo menos uma ópera para o São João: Le due gemelle ${ }^{231}$.

Enfim, servindo-nos do ponto de partida dessa evasiva - o artigo de Neukomm no Allgemeine musikalische Zeitung —, enquanto se persevera em que a atividade de José Maurício decaiu, conseqüente das intrigas de Portugal, quase não se leva em consideração, como importante componente factual desse declínio produtivo, o estado de saúde do brasileiro, qualificado por Neukomm, já onze anos antes de sua morte, como "arruinado".

Concluído, pois, este desvio, continuemos a relacionar outros dados musicais referentes à Capela Real, futura Capela Imperial. Quanto ao número de músicos envolvidos, a cifra de cem instrumentistas e cinqüenta cantores que essa instituição teria tido por volta de 1815 - apontada por Oliveira Lima em D. João VI no Brasil ${ }^{232}$ - parece-nos um tanto exorbitante; possível ${ }^{233} \mathrm{em}$

${ }^{229}$ SANTOS, Luiz Gonçalves dos. Op. cit., v. 2, p. 33.

${ }^{230}$ Tem-se conhecimento, pelos jornais, ou pelos libretos comemorativos, de que, de 1811 a 1830, apenas quatro óperas de Portugal teriam sido estreadas no Rio de Janeiro, todas composições já conhecidas na Europa: L'oro non compra amore (1811), Artaserse (1812), Merope (1817) e a farsa Le donne cambiate (1826).

${ }^{231}$ PORTO ALEGRE, Manuel de Araújo. Op. cit., p. 361.

232 "Em 1815 possuía a Capela Real um corpo de 50 cantores (...), e de 100 executantes excelentes, dirigidos por dois mestres-de-capela" (LIMA, Manuel de Oliveira. Op. cit., p. 620). Embora não seja citada a fonte, é bem provável que Oliveira Lima tenha apresentado tais números com base em um texto de Manuel de Araújo Porto Alegre, incluído por Debret em sua Voyage pittoresque et historique au Brésil: "Depuis 1815 jusqu'à 1816, I'arrivée de musiciens d'Italie porta l'orchestre de la chapelle royale à cinquante chanteurs et à cent instrumentistes" (DEBRET, Jean Baptiste. Op. cit., v. 3, p. 85). Lembremos, no entanto, que Porto Alegre não viveu a época de Dom João. Nascido no Rio Grande do Sul, em 1806, só mudou-se para o Rio de Janeiro em 1826.

${ }^{233} \mathrm{O}$ já citado viajante inglês Alexander Caldcleugh asseverou, por exemplo, em seu livro Travels in South America, ter contado na Capela, em 1819, "catorze ou quinze sopranos". Se a informação é correta, isso nos possibilita conjecturar, pela distribuição dos naipes, que, ao menos nessa ocasião, o coro estivesse comportando cerca de cinqüenta cantores, o número estipulado por Porto Alegre: "Sopranos, as many as fourteen or fifteen, mingled their peculiar voices in the music of Portogallo an the finest church composers ..." (CALDCLEUGH, Alexander. Op. cit., v. 1, p. 62). 
dias festivos, ou de "Grande Gala", quando músicos extras eram, sem dúvida, contratados $^{234}$. Os números oficiosos dos almanaques da época nos revelam números bem menores, como: 32 para o ano de $1811^{235}$; 38 para $1816^{236}$; e 41 para $1817^{237}$.

Devemos nos lembrar, no entanto, que as cifras impressas nos almanaques de 1811, 1816 e 1817 não computavam, provavelmente, os integrantes exclusivos da Real Câmara, instituição, seja dito de passagem, muito pouco lembrada e estudada, até hoje, como entidade autônoma. Isso ocorre porque são escassos os documentos a seu respeito, e porque há uma certa dificuldade de reconhecer-se seus membros natos, uma vez que alguns ou vários deles também pertenciam à Real Capela ${ }^{238}$. Para piorar esse enleio, em muitas das cerimônias religiosas da realeza se exigia o trabalho, em conjunto, das duas instituições. Daí ser freqüente, nas notícias publicadas na Gazeta do Rio de Janeiro, que os integrantes exclusivos de cada uma, bem como os que trabalhavam simultaneamente nas duas, fossem identificados, todos, genericamente, como "músicos da Real Câmara e Capela":

Então pontificou o Excelentíssimo Bispo de S. Tomé a Missa, que foi cantada pelos melhores professores da Real Câmara e Capela, regidos por Fortunato Mazziotti, mestre da dita

${ }^{234} \mathrm{O}$ relatório do Ministério da Fazenda sobre o estado das finanças do Império em fim do ano de 1825 indica que houve, pelo menos durante o primeiro reinado, verba para eventuais contratações de músicos extras. Segundo o documento, orçou-se para o ano de 1826, além de 57:702\$050 para as despesas ordinárias da Capela, mais 4:800\$000 extras para "Armação nos dias festivos, músicos, e mais despesas" (RELATÓRIO, ou exposição do Ministro da Fazenda sobre o estado da administração respectiva em fim do ano de 1825 , com o orçamento da renda e despesa que poderá ter lugar no corrente ano de 1826. Rio de Janeiro: Na Tipografia Imperial e Nacional, 1826, p. 188).

235 ALMANAQUE da cidade do Rio de Janeiro para o ano de 1811. Revista do Instituto Histórico e Geográfico Brasileiro. Rio de Janeiro, v. 282, p. 132, 1969.

236 ALMANAQUE da cidade do Rio de Janeiro para o ano de 1816. Revista do Instituto Histórico e Geográfico Brasileiro. Rio de Janeiro, v. 268, p. 205, 1965.

237 ALMANAQUE da cidade do Rio de Janeiro para o ano de 1817. Revista do Instituto Histórico e Geográfico Brasileiro. Rio de Janeiro, v. 270, p. 243, 1966.

${ }^{238}$ Sabemos, por exemplo, pelo mesmo e já citado ofício que trata da promoção de Fortunato Mazziotti a mestre-de-capela, que Leonardo da Mota, José Mosman e Alexandre Barret, então, músicos exclusivos da Real Câmara, passariam, a partir daquela data, a integrar também a Capela com um aumento salarial de $12 \$ 800$ por mês (vide nota 170 desta parte). 
Capela ${ }^{239}$.

... e oficiando o Excelentíssimo Bispo Capelãomor, cantaram os músicos da Real Câmara e Capela o hino Te Deum Laudamus, sendo a música da composição do célebre Marcos Portugal, e regida pelo mesmo ${ }^{240}$.

Celebrou em Pontifical o llustríssimo Monsenhor Roque da Silva Moreira. A música foi da composição do célebre Marcos Portugal, executada por muitos Músicos da Real Câmara e Capela, e dirigida pelo Mestre da mesma o Padre José Maurício Nunes Garcia ${ }^{241}$.

Apesar da mistura, sabemos que, desde a vinda da corte ao Rio de Janeiro, a Câmara existiu independentemente da Capela. Suas funções restringiam-se às solenidades da realeza não vinculadas aos ritos sagrados, formalidades que ocorriam ou no Paço, ou na Quinta da Boa Vista, ou ainda na Fazenda de Santa Cruz. Em outra nota da mesma Gazeta, relativa a uma comemoração realizada em razão da chegada da princesa real, Dona Leopoldina, podemos, por exemplo, verificar uma dessas atuações independentes da Real Câmara:

Nesta noite, houve por bem EL-REI Nosso Senhor receber no Paço da Real Quinta da Boa Vista o Corpo Diplomático; e em presença assim deste Respeitável Corpo, como dos Grandes do Reino, Oficiais Mores da Casa, Camareiras Mores, Damas etc. começou uma magnífica Serenata na Casa da Audiência. Deu princípio a esta pomposa solenidade uma sinfonia composta por Inácio de Freitas. Dignou-se então - Sereníssimo Senhor Príncipe Real de cantar uma ária com as formalidades seguidas em semelhantes circunstâncias, repetindo este mesmo obséquio as Sereníssimas Senhoras Princesa D. MARIA TERESA e Infanta D. ISABEL

${ }^{239}$ GAZETA DO RIO DE JANEIRO, 25/04/1818.

${ }^{240}$ Idem, 07/04/1819.

${ }^{241}$ Idem, 19/05/1819. 
MARIA. Depois destas Reais demonstrações de júbilo, seguiu-se a execução do Drama intitulado - Augurio di Felicità, arranjado pelo célebre Marcos Portugal, compositor da excelente música, desempenhada perfeitamente pelos Músicos da Real Câmara; terminando esse mesmo Drama com um Elogio também em Italiano, recitado por um dos mais insignes Músicos da Real Câmara ${ }^{242}$.

Esse conjunto deveria congregar músicos de um nível técnico superior à média da Capela; de preferência, profissionais criativos, compositores e solistas, como era o caso do violinista italiano Francisco Ansaldi ${ }^{243}$. Em 1817 , por exemplo, ele se destacava, tocando solo no Teatro Particular do Rossio ${ }^{244}$ :

... ocuparam o primeiro lugar as belíssimas variações, que executou com a maior perfeição o professor Ansaldi, Músico da Câmara de S. M. ${ }^{245}$.

Em compensação, músicos medianos, como o também violinista Cristóvão Tani, não eram facilmente aceitos nesse seleto grupo. Em 1820, o instrumentista requereu, não pela primeira vez, sua entrada para a Real Câmara. A solicitação foi recusada porque o suplicante não tinha, àquela ocasião,

\footnotetext{
${ }^{242}$ Idem, 12/11/1817.
}

243 "Ansaldi Francesco di Vercelli, nato nel 1785 da Giacomo, fu scolaro di Pietro Sassi che era suo zio e divenne celebre suonatore di violino; onde fu chiamato a dirigere la cappella di S. M. Fedelissima nella qualità di primo violino, e trovavasi a Rio laneiro nel Brasile, allorché la R. Corte colà la sua residenza" (Cf. DIONISOTTI, Carlo. Notizie biografiche dei vercellesi illustri. Biella: Arnaldo Forni Editore, 1862).

${ }^{244}$ Segundo Balbi, o "Teatrinho" Particular do Rossio foi fundado em 1815 por um grupo de ricos comerciantes (BALBI, Adrien. Op. cit., v. 2, p. 226). Essa casa teve, no entanto, vida curta. A 30 de agosto de 1817, portanto pouco mais de um mês após Francisco Ansaldi tocar nessa casa, o Rei, por meio de um decreto, daria ao Teatro de São João dez anos de exclusividade no oferecimento de espetáculos teatrais sem que se pudesse "abrir algum outro teatro na cidade e suas vizinhanças" (COLEÇÃO das Leis do Brasil de 1817. Cartas de Lei, Alvarás, Decretos e Cartas Régias de 1817. Rio de Janeiro: Imprensa Nacional, 1890, p. 54). 
... as circunstâncias e perfeições no seu instrumento, necessárias para se fazer digno de entrar para a Real Câmara; pois se as tivesse já teria entrado... ${ }^{246}$.

Diversos requerimentos tombados no Fundo Documentos Bibliográficos da Seção de Manuscritos da Biblioteca Nacional do Rio de Janeiro também apontam para a forte concorrência por uma estante nessa instituição, que, além de oferecer um ganho extra, certamente dava a seus integrantes um certo status perante os demais profissionais da categoria ${ }^{247}$.

Porém, a partir de 1822, por questões burocráticas, os salários da Câmara passaram a ser pagos pela folha dos músicos da Capela ${ }^{248}$, o que, na prática, uniu administrativamente essas duas instituições. Daí uma provável explicação para o aumento significativo, durante o primeiro reinado, do número de integrantes identificados genericamente, nos almanaques, como "da Capela"249. Para o almanaque de 1824, essa instituição congregava 63 músicos, sem contar com os mestres ${ }^{250}$. Em 1827, idem ${ }^{251}$. Já, a Relação Nominal dos empregados na Capela Imperial e dos seus vencimentos relativos ao $4^{\circ}$ quartel do ano de 1828 apresenta um rol ainda maior. Nesse

${ }^{245}$ GAZETA DO RIO DE JANEIRO, 16/07/1817.

${ }^{246}$ Apud ANDRADE, Ayres de. Op. cit., v. 2, p. 240.

${ }^{247}$ Caso, por exemplo, de Jose Faustino de Lemos, João Isidoro da Silva Nobre, Herculano José de Carvalho, Camilo José de Souza Caldas, José Tibúrcio, Severiano de Castro, Gabriel Fernandes da Trindade, Pedro Teixeira de Seixas, Francisco Domingos, Heliodoro Noberto Florival e Silva, Damião Barbosa de Araújo, Manuel Alves Carneiro e Inácio Pinheiro da Silva, alguns, à época, membros da Capela.

${ }^{248} \mathrm{Na}$ Divisão de Manuscritos da Biblioteca Nacional do Rio de Janeiro há uma Representação dos músicos da Real Câmara e Capela da Corte a S. A. R., pedindo o pagamento dos ordenados vencidos e sua incorporação à folha dos músicos da Real Capela. Ocorre despacho requerendo que todos os músicos da Câmara devem ser pagos pela Capela. Esse documento data de julho de 1822. (Biblioteca Nacional, Divisão de Manuscritos, Fundo/Coleção: Brasil em Geral, II-30, 28, 038).

${ }^{249}$ Menos abrangente na sua análise, Ayres de Andrade acreditava que a diferença entre a cifra mencionada por Oliveira Lima - 150 músicos - e os almanaques estava apenas relacionada à possível - e já comentada - contratação de extras (ANDRADE, Ayres de. Op. cit., v. 1, p. 27).

250 No Almanaque de 1824 , os músicos aparecem discriminados por função ou naipe: são 8 sopranos, 7 contraltos, 11 tenores, 16 baixos, 18 instrumentistas e 3 organistas (ALMANAQUE da cidade do Rio de Janeiro para o ano de 1824. Revista do Instituto Histórico e Geográfico Brasileiro. Rio de Janeiro, v. 278, p. 249, 1968).

251 ALMANAQUE da cidade do Rio de Janeiro para o ano de 1827. Revista do Instituto Histórico e Geográfico Brasileiro. Rio de Janeiro, v. 300, p. 157, 1973. 
manuscrito, são listados 69 músicos, mais dois copistas ${ }^{252}$, ou seja, quase o dobro do registrado no Almanaque de 1816.

Dado o deplorável estado de conservação do citado manuscrito, quando consultado no Arquivo Nacional do Rio de Janeiro - podendo, em pouco tempo, tornar-se imprestável -, julgamos oportuno transcrever seu conteúdo na íntegra para que possamos também divulgar o quanto vencia cada um deles por seus serviços profissionais, desempenhados durante três meses ou um quartel:

\section{ORGANISTAS}

Simão Portugal

$90 \$ 000$

João Jacques

$90 \$ 000$

MESTRES-DE-CAPELA E COMPOSITORES

Marcos Portugal

$156 \$ 250$

José Maurício

$156 \$ 250$

Fortunato Mazziotti

$156 \$ 250$

MÚSICOS [CANTORES]

Antonio Cicconi

$247 \$ 500$

João Francisco Fasciotti

$186 \$ 250$

Angelo Tinelli

$186 \$ 250$

Francisco Reali

$186 \$ 250$

Pascoal Tani

$50 \$ 680$

Marcelo Tani

$50 \$ 680$

Antônio Pedro Gonçalves

$126 \$ 250$

${ }^{252}$ ARQUIVO NACIONAL, Rio de Janeiro. Fundo Casa Real e Imperial, cx. 12, pc. 1, doc. 12 . 
José Maria Dias

$126 \$ 250$

João Mazziotti

$126 \$ 250$

José Mendes Sabino

$81 \$ 250$

Carlos Mazziotti

$81 \$ 250$

Geraldo Inácio Pereira

$95 \$ 250$

Manuel Rodrigues Silva

$56 \$ 250$

João dos Reis Pereira

$130 \$ 450$

Luiz Gabriel Ferreira Lemos

$66 \$ 250$

Manoel Rodrigues e Manso

$31 \$ 250$

Lúcio Antônio Fluminense

$31 \$ 250$

Salvador Salvatori

$180 \$ 000$

Nicolau Majoranini

$180 \$ 000$

Antônio Gomes Cardozo

$23 \$ 750$

Francisco da Luz Pinto

$48 \$ 250$

Elias Antônio da Silva

$56 \$ 250$

José Maria da Silva Rodrigues

$42 \$ 250$

Alexandre José Leite

$18 \$ 750$

Feliciano Joaquim

$16 \$ 250$

José Ferreira

$11 \$ 250$

Augusto César de Assis

$11 \$ 250$

Francisco de Paula Pereira

$126 \$ 250$

INSTRUMENTISTAS

Francisco Ansaldi

[ilegível] ${ }^{253}$

Aleixo Bosh

$65 \$ 112$

253 Felizmente, esse dado não ficou em branco. Segundo outro documento - o orçamento das côngruas e ordenados dos empregados da Capela Imperial para o ano de 1826 - o já mencionado violinista Francisco Ansaldi deveria auferir um ganho anual de $346 \$ 850$, ou seja, $86 \$ 712$ por quartel. Tinha, portanto, um dos maiores ordenados dentre os instrumentistas (RELATÓRIO, ou exposição do Ministro da Fazenda sobre o estado da administração respectiva em fim do ano de 1825, com o orçamento da renda e despesa que poderá ter lugar no corrente ano de 1826. Rio de Janeiro: Na Tipografia Imperial e Nacional, 1826, p. 202). 
Francisco Tani

$21 \$ 104$

Inácio Pinheiro da Silva

$65 \$ 112$

José Joaquim da Silva

$65 \$ 112$

Joaquim de Almeida

$65 \$ 112$

João Liberali

$65 \$ 112$

Luiz Folia

$65 \$ 112$

Manoel Joaquim Correia dos Santos

$65 \$ 112$

Pedro Teixeira de Seixas

$65 \$ 112$

Pedro Laforge

$65 \$ 112$

Quintiliano José de Moura

$65 \$ 112$

Policarpo José de Faria Beltrão*

$65 \$ 112$

Alexandre Barret

$101 \$ 112$

Francisco da Mota

$101 \$ 112$

José Fernandes da Trindade

$103 \$ 512$

Lino José Nunes

$65 \$ 112$

Joaquim Luciano de Araújo

$65 \$ 112$

Francisco Augusto Fremel

$50 \$ 000$

Cristóvão Tani

$65 \$ 112$

Heliodoro Norberto Florival da Silva

$65 \$ 112$

Domingos Francisco

$65 \$ 112$

Francisco Manuel da Silva

$65 \$ 112$

Tertuliano de Sousa Rangel

$30 \$ 000$

José Muraglia

$65 \$ 112$

Nuno Pereira

$65 \$ 112$

Francisco Custódio dos Santos

$65 \$ 112$

Manoel Alvares Carneiro

$65 \$ 112$

Gabriel Fernandes da Trindade

$65 \$ 112$

Antônio Xavier da Cruz

$65 \$ 112$

Francisco José Lopes

$30 \$ 000$

Herculano José de Carvalho

$65 \$ 112$

Francisco Joaquim dos Santos 
Manoel Pimenta Chaves

José de Aragão Espanha

Cláudio Antunes Benedito

* e sua mulher Joana Inácio Beltrão.

(Havia ainda listados dois copistas, com salários trimestrais de 120\$000: Francisco Manoel Chaves e João Antônio da Silva).

Como podemos notar de imediato - observando as cifras contidas nessa relação - , havia grande discrepância entre os ordenados dos diversos músicos. A princípio, poderíamos explicar tal diferença salarial em razão da qualidade técnica - e conseqüentemente funcional -, à qual poderia, ainda, somar-se a reputação internacional de que gozavam, por exemplo, alguns italianos. Por atuarem como solistas, terem técnica especial, e, além do mais, uma fama estendida a diversas nações, alguns castrati - Cicconi, Fasciotti, Tinelli e Reali - recebiam os maiores ordenados.

Porém, um outro fato poderia explicar algumas diferenças salariais entre os demais músicos da Capela: o acúmulo ou não de funções na Câmara. Com base na informação de que, no período de 1764 a 1834, a imensa maioria dos músicos da Real Câmara de Lisboa recebia $260 \$ 450$ por $\mathrm{ano}^{254}$, conjecturamos que o valor correspondente por quartel, $65 \$ 112-$ que,

254 Além de fornecer-nos esse dado, Joseph Scherpereel traça algumas comparações entre o salário dos músicos da Real Câmara de Lisboa e de outros servidores, bem como afere o poder de compra de tais vencimentos de acordo com os vários momentos econômicos compreendidos no longo período que estudou (1764-1834). Achando importante que alguns desses dados venham à tona neste momento, reproduzimos aqui parte do estudo de Scherpereel: "A título de comparação, na Corte, os varredores ganhavam cerca de $64 \$ 000$ rs por ano, os porteiros e os lacaios da Câmara do Rei $80 \$ 000$ rs, os oficiais do guarda-roupa e da baixela de $80 \$ 000$ a $277 \$ 000$ rs, os monteiros de $115 \$ 000$ a $175 \$ 000$ rs, os criados particulares de Sua Majestade de $64 \$ 000$ a $480 \$ 000$ rs. No que se refere aos ordenados fora da Corte, podemos servir-nos das informações recolhidas pelo Professor Vitorino Magalhães Godinho entre 1750 e 1850 . Assim, o salário por dia do trabalhador agrícola varia de 80 réis, nos anos 60 e 70 , a 160 réis, nos anos 80 e 90, passando para 240 réis, na primeira década do século XIX, para 300 e 400 réis, durante a segunda década, voltando depois aos 200 réis no decorrer dos últimos anos que nos interessamos. Em Lisboa, entre 1769 e 1775, na construção civil, os serventes e os aprendizes ganham cerca de 200 réis por dia, os oficiais 300 , os aparelhadores 350 e os mestres 400. O ordenado diário de um músico da Real Câmara permanece, em média, nos 713 réis (correspondendo a $260 \$ 450$ rs por ano), ignorando as inflações e deflações. Este vencimento parece ter sido pois muito respeitável, em 
coincidentemente, é a cifra mais comum na Relação nominal dos empregados na Capela Imperial —, se refere ao ordenado para o músico que exercesse as duas atividades - um valor, aliás, apesar do acúmulo de função, bastante achatado, em 1828, em virtude da crescente desvalorização da moeda ${ }^{255}$ e da quase ausência de aumentos salariais para os músicos.

Para se ter uma idéia, durante a permanência de Dom João no Brasil e todo o primeiro reinado, apenas em 1818 - à época da coroação do Rei houve ligeiro acréscimo em seus vencimentos: um abono de $25 \$ 000^{256}$, integrado ao ordenado anual. Fasciotti, por exemplo, que veio para o Brasil

comparação com outros praticados na Corte, na capital e na província. Mas qual era o poder de compra deste ordenado? Fazendo a redução às unidades francesas de peso e de medida, o litro de trigo custava cerca de 30 réis, o quilo de arroz 65 réis, o quilo de manteiga 240 réis, o litro de azeite 120 réis, o litro de vinho verde 10 réis e podia-se comprar uma galinha por 200 réis e um carneiro por 600 réis, tudo isto durante as duas primeiras décadas do nosso estudo. Cerca de 1790, infelizmente, os preços terão aumentado $50 \%$, cerca de 1801 terão duplicado e triplicado cerca de 1812 . Por volta de 1821, voltarão ao que eram cerca de 1801 e, cerca de 1834, ao que eram ao redor de 1790 . No meio destas enormes variações de preço, pode-se imaginar as dificuldades dos músicos que permaneceram fiéis no seu posto durante os anos de inflação, com o mesmo vencimento. Os melhores anos para os músicos da Real Câmara, do ponto de vista do nível de vida, foram por conseguinte aqueles durante os quais a subida dos preços foi muito lenta, de 1764 a 1782. Notar-se-á que este período corresponde também aos anos em que a orquestra prosperou, atingindo os seus melhores efetivos. É precisamente após 1782, 'quando a subida dos preços começa a acelerar-se', que a curva dos efetivos começa a descer. Notemos ainda que os piores anos correspondem evidentemente às guerras com a Espanha e a França, e o afastamento da família real. O seu regresso em 1821 indica já uma melhoria. Houve pois uma estreita correlação entre os fatos históricos, os fatos econômicos e o nível de vida dos músicos da Real Câmara" (SCHERPEREEL, Joseph. Op. cit., p. 108-109).

${ }^{255}$ A escassez de ouro e prata e a emissão de papel de curso forçado ou dinheiro sem lastro metálico pelo Banco do Brasil, a partir de 1810 - agravando-se sensivelmente a partir de 1814 - , para satisfazer os enormes gastos da corte, contribuiu para a contínua desvalorização do meio circulante e a elevação geral dos preços. Segundo Caio Prado Jr., "Pouco depois da transferência da corte, o ouro terá desaparecido da circulação (...) Substituem-no a princípio os já referidos pesos espanhóis de prata; mesmo estes contudo começarão logo a escassear, e em seu lugar aparecerá uma moeda depreciada de cobre; e finalmente papel-moeda de valor instável e sempre em acelerado declínio (PRADO JR., Caio. História econômica do Brasil. São Paulo: Brasiliense, 1970, p. 133). Sobre esse assunto ver também FRANCO, Afonso Arinos de Melo. História do Banco do Brasil. Rio de Janeiro, 1979, v. 1, p. 65-224.

256 "Querendo que neste faustíssimo dia da minha Real Coroação, os Ministros e Músicos da minha real Capela de Nossa Senhora do Monte do Carmo desta Corte, participem também dos efeitos da minha real munificência; tenho determinado que se the aumentem anualmente os seus vencimentos, a saber: (...) aos Músicos mais $25 \$ 000$ ". (COLEÇÃO das Leis do Brasil de 1818. Cartas de Lei, Alvarás, Decretos e Cartas Régias de 1818. Rio de Janeiro: Imprensa Nacional, 1889, p. 16). 
com um contrato anual de $720 \$ 000^{257}$, passou a vencer $745 \$ 000$ (186\$250 por quartel); José Maurício, mestre-de-capela com salário de 600\$000 por ano, passou a receber $625 \$ 000$ (156\$250 por quartel $)^{258}$.

Felizmente, participar da Capela e da Câmara - ou de ambas - não era a única oportunidade de que o músico dispunha para sobreviver no Rio de Janeiro dos inflacionários tempos de Dom João VI ou de Dom Pedro I. Tais profissionais ainda podiam complementar seus ganhos servindo às irmandades, às igrejas, apresentando-se em concertos, dando aulas particulares, ou, enfim, animando festas de gente endinheirada. Contudo, a oferta de emprego mais cotidiana nesse campo foi, sem dúvida, a que se deu nos teatros públicos ${ }^{259}$, onde corte e soberano se congraçavam ao som de um dos mais aparatosos espetáculos musicais inventados, parte integrante da pompa monárquica européia, desde os Seiscentos: a ópera.

${ }^{257}$ Não era, portanto, 7:020\$000, como reproduziram, em suas já citadas teses de doutorado, André Cardoso (Op. cit., p. 93) e Carlos Eduardo de Azevedo e Souza (Op. cit., p. 59), baseados, ambos, em equívoco possivelmente tipográfico presente na obra de Ayres de Andrade (Op. cit., v. 2, p. 164).

${ }^{258}$ Não obstante a falta de aumentos durante todo esse período, alguns músicos, em especial, gozaram de privilégios junto aos governos de Dom João VI e Dom Pedro I. Caso, por exemplo, de Bernardo José de Sousa Queirós, agraciado em 25 de setembro de 1810 com uma pensão anual de $240 \$ 000$, e José Maurício Nunes Garcia, em 22 de novembro de 1814, com 25\$000 (Cf. DOCUMENTOS com que se instruiu o seu relatório à Assembléia Geral Legislativa do Império do Brasil o Ministro Secretário de Estado dos Negócios da Fazenda, e Presidente do Tesouro Nacional, Miguel Calmon du Pin e Almeida, na sessão de 1829. Rio de Janeiro: Na Tipografia Imperial e Nacional, 1829, p. s/n). Havia também um seleto grupo de galardoados com o "Real Bolsinho". Esta instituição de nome curioso correspondia a pensões com as quais Dom João agraciava diretamente seus servidores prediletos. Entre os músicos que ainda percebiam essa graça, em 1825, figuravam João Francisco Fasciotti (120\$000), Antônio Pedro Gonçalves (120\$000), Angelo Tinelli $(240 \$ 000)$, Francisco Reali $(240 \$ 000)$, João dos Reis Pereira (100\$000), Marcos Portugal (240\$000) Nicolau Majoranini (120\$000) e Salvador Salvatori (120\$000) (Cf. RELATÓRIO, ou exposição do Ministro da Fazenda sobre o estado da administração respectiva em fim do ano de 1825, com o orçamento da renda e despesa que poderá ter lugar no corrente ano de 1826. Rio de Janeiro: Na Tipografia Imperial e Nacional, 1826, p. 197-199).

${ }^{259}$ Note-se: "público" no sentido de "aberto a quaisquer pessoas" e não de "relativo ou pertencente ao governo". 


\title{
CAPÍTULO IV - Uma corte, um teatro decente
}

\author{
O interior do teatro imperial tem muito \\ gosto, e o camarote imperial compete, \\ possivelmente, em elegância com os \\ mais brilhantes camarotes princi- \\ pescos da Alemanha ${ }^{260}$.
}

Como já havíamos dito, até então, o Rio de Janeiro tivera duas casas de espetáculos, nas quais a música muito se fez presente. A última delas, o teatro de Manuel Luiz Ferreira, conhecido, a partir de então, como "Real Teatro", foi, durante os cinco primeiros anos da permanência de Dom João, o único estabelecimento do gênero ${ }^{261}$. Só pode ter ocorrido ali, portanto - e provavelmente pela primeira vez no Rio com a presença da família real ${ }^{262}$-, o teatro "de corte", que complementou, em 1808, as comemorações do natalício do então Príncipe da Beira, Dom Pedro; e da "restauração" de Lisboa, comemorada a 19 de novembro, dois dias após o genetlíaco da Rainha, Dona Maria I. Os testemunhos são mais uma vez do Padre "Perereca":

No fausto dia 12 de outubro, em que o sereníssimo senhor Príncipe da Beira completou nesta Corte do Brasil o décimo ano de sua existência, foi festejado seu natalício com grande prazer público (...). A noite houve teatro de corte com muito luzimento de

260 Tradução nossa de: "Das Innere des Theaters ist in der That geschmackvoll und die kaiserliche Loge wetteifert in Ansehung der Eleganz vielleicht mit den glänzensten Fürstlichen Logen Deutschlands" (BÖSCHE, Eduard Theodor. Op. cit., p. 246).

${ }^{261}$ Luiz dos Santos Marrocos se refere a "uma casa de ópera particular no sítio de Botafogo" que estaria sendo construída (em 1809) "para divertimento de SS. AA." (MARROCOS, Luiz Joaquim dos Santos. Op. cit., v. 56, p. 164, 1934). Não era, no entanto, um casa "pública", na qual qualquer cidadão pudesse entrar, em tendo dinheiro.

262 Não encontramos em nossa pesquisa nenhuma referência a algum espetáculo teatral que tenha ocorrido com a presença da família real entre o seu desembarque, a 8 de março de 1808 , e o $10^{\circ}$ aniversário de Dom Pedro, a 12 de outubro do mesmo ano. É bem possível que, entrementes, o teatro estivesse fechado para as já mencionadas reformas. 
espectadores $^{263}$

Depois de haver festejado o natalício de Sua Majestade Fidelíssima, (...) Na noite desse dia 19 houve teatro de corte, que o Príncipe Regente Nosso Senhor foi servido honrar com a sua augusta presença, e da real família ${ }^{264}$.

Infelizmente, não nos foram deixados quaisquer detalhes sobre a música executada nessas duas ocasiões. Conhecemos, entretanto, alguns outros dados relativos a espetáculos realizados no Real Teatro em anos seguintes. Por exemplo: no natalício da Rainha, em 1809, se representaria, ali, uma "peça em música" do Padre José Maurício Nunes Garcia ${ }^{265}$; no aniversário de Dom João, em 1811, a "peça com música" A União Venturosa, de Fortunato Mazziotti, com destaque para "Lapinha", no papel de América ${ }^{266}$;

${ }^{263}$ SANTOS, Luiz Gonçalves dos. Op. cit., v. 1, p. 219.

264 Ibidem, p. 226.

${ }^{265}$ Tal representação é sugerida por um ofício do Conde de Linhares ao Conde de Aguiar, documento datado de 3 de dezembro de 1809 (e mantido no Arquivo Nacional do Rio de Janeiro), no qual se lê que uma "bela peça em música composta pelo padre José Maurício" seria "posta em cena no augusto dia dos anos de S. M. a Rainha" (Apud ANDRADE, Ayres de. Op. cit., v. 1, p. 68-69). É possível que a "peça em música" em questão seja o Drama Heróico Ulissea, "posto em música por José Maurício Nunes Garcia em 1809 para o dia 24 de junho" (onomástico do Príncipe Regente), tal como está escrito na partitura manuscrita encontrada, em 1967, no Arquivo de Música do Paço Ducal de Vila Viçosa, Portugal. Cleofe Person de Matos argumenta que tal Drama Heróico, não deve ter ido à cena na data programada (MATOS, Cleofe Person de. Op. cit., p. 327), pois, cerca de um mês antes, o Rio de Janeiro recebia a malfadada notícia do saque francês à cidade do Porto (ocorrido em fins de março pelo exército de Soult). Daí a possibilidade de, em um eventual adiamento, ter sido a mesma Ulissea a "peça em música" de José Maurício executada alguns meses depois no natalício da Rainha, quando as notícias de Portugal já eram bem mais animadoras (batido pelo general inglês Wellington, Soult abandonara Portugal em fins de maio, encerrando a 2. ${ }^{a}$ Invasão Francesa). Ayres de Andrade, desconhecendo a existência desse manuscrito de Ulissea, afirmou ser a música em questão, Le due gemelle, única ópera conhecida de José Maurício e cuja partitura se perdeu. Na verdade, tudo indica que Andrade se equivocou, pois, segundo Araújo Porto Alegre, Le due gemelle teria sido composta não para o teatro de Manuel Luiz, mas para o Teatro de São João, portanto, alguns anos depois (PORTO ALEGRE, Manuel de Araújo. Op. cit., p. 361). Já, no natalício de Dom João, de 1810, certamente ouviu-se mais música do padre Garcia no Real Teatro. Tais peças ornavam, desta vez, o drama de Gastão Fausto da Câmara Coutinho, O Triunfo da América, cujo texto e informações adicionais sobre a cena acabou publicado pela Impressão Régia no mesmo ano de 1810. A Divisão de Obras Raras da Biblioteca Nacional do Rio de Janeiro guarda um exemplar dessa publicação (37, $3,19)$, por meio da qual podemos conhecer, também, os nomes dos intérpretes principais escalados para a apresentação: Joaquina Lapinha, Rita Feliciana, Francisca de Assis, Maria Cândida e Domingos Botelho.

266 LEITE, Antonio Bressane. União venturosa. Drama com música para se 
já, nos natalícios da Rainha, de 1811 e 1812, foi a vez de Marcos Portugal fazer ouvir, respectivamente, suas óperas L'Oro non Compra Amore e Artaserse $^{267}$.

Porém, como afirmou John Luccock, o Real Teatro de Manuel Luiz era uma casa "pobre, pequena, escura". Por mais que ela tenha passado por uma reforma, seu tamanho e recursos já não suportavam mais, lá pelos idos de 1810, a grande demanda por diversões que toda uma corte instalada no Rio de Janeiro exigia; ainda mais em se tratando de uma corte composta em boa parte de reinóis, acostumados a experimentar, como já dissemos, em Lisboa, algumas das mais aparatosas encenações operísticas do mundo.

O impasse para esse problema começou a ser resolvido no próprio ano de 1810, quando alguns ricos negociantes locais se uniram - assim como ocorrera na capital portuguesa, em $1792^{268}$ - e ofereceram ao Príncipe Regente o projeto de um novo e suntuoso teatro a ser erguido em um terreno localizado no Largo do Rossio e de propriedade do empreendedor português Fernando José de Almeida. Foi então que, a 28 de maio de 1810, Dom João assinou e mandou publicar o seguinte decreto:

representar no Real Teatro do Rio de Janeiro no faustíssimo dia dos anos de Sua Alteza Real o Príncipe Regente nosso senhor. Rio de Janeiro: Impressão Régia, 1811. Existe, ainda, desse autor, um outro libreto, publicado no mesmo ano: $A$ verdade triunfante, elogio dramático e alegórico feito para ser representado no Real Teatro da corte do Rio de Janeiro, no aniversário da Rainha. Essa peça, com música de autor incógnito, previa, como figuras principais, os cantores Lapinha, Maria Cândida, Francisca de Assis e Antônio Ferreira da Silva.

267 Libretos dessas óperas de Marcos Portugal, editados pela Impressão Régia do Rio de Janeiro em comemoração aos natalícios de Dona Maria I em 1811 e 1812 atestam tais apresentações (CARVALHAIS, Manoel Pereira Peixoto de Almeida. Marcos Portugal na sua música dramática. Lisboa: Tip. Castro Irmão, 1910, p. 35 e p. 168). Não encontrando nenhum deles em acervos de bibliotecas brasileiras, localizamos, no entanto, um exemplar do dito libreto de Artaserse no acervo da Biblioteca Nacional de Lisboa, sob o número L. $87954 \mathrm{P}$ e um do de L'Oro non Compra Amore, no acervo da Library of Congress (Washington, EUA) sob a chamada ML50.P824 O7.

268 De acordo com Francisco da Fonseca Benevides, "Foram os negociantes e capitalistas (...) Joaquim Pedro Quintela, Anselmo José da Cruz Sobral, Jacinto Fernandes Bandeira, Antônio Francisco Machado, João Pereira Caldas e Antônio José Ferreira Sola que dotaram Lisboa com um novo teatro lírico" (BENEVIDES, Francisco da Fonseca. Op. cit., p. 19-20). A generosidade desses negociantes foi, sem dúvida, lembrada por Dom João nas concessões de mercês e títulos. Quintela, por exemplo, foi feito Fidalgo da Casa Real, em 1793, no mesmo ano da inauguração do Teatro de São Carlos. Bandeira, por sua vez, recebeu o mesmo título no ano seguinte. Ambos tornar-se-iam barões em 1805 (Cf. RODRIGUES, Guilherme, PEREIRA, Esteves. Op. cit.). 
Fazendo-se absolutamente necessário nesta Capital que se erija um teatro decente e proporcionado à população e ao maior grau de elevação e grandeza em que hoje se acha pela minha residência nela e pela concorrência de estrangeiros e outras pessoas que vêm das extensas províncias de todos os meus Estados: fui servido encarregar o doutor Paulo Fernandes Viana, do meu Conselho e Intendente da Polícia, do cuidado e diligência de promover todos os meios para ele se erigir; e conservar sem dispêndio das rendas públicas e sem ser por meio de alguma nova contribuição que grave mais os meus fiéis vassalos, a quem antes desejo aliviar de todas elas; e havendo-me proposto o mesmo Intendente que grande parte dos meus vassalos residentes nesta corte me haviam já feito conhecer e que por ser esta obra do meu real agrado e de notória necessidade, se prestavam de boa vontade a dar-me mais uma prova do seu amor e distinta fidelidade, concorrendo por meio de ações a fazer o fundo conveniente, principalmente se eu houvesse por bem de tomar o dito teatro debaixo de minha proteção e de permitir que com relação ao meu real nome se denominasse Real Teatro de $S$. João. Querendo corresponder ao amor que assim prestam à minha real pessoa, e com que tanto se distinguem nesta ação, sou servido honrar o dito teatro com a minha real proteção e com a pretendida invocação, aceitando além disso a oferta que por mão do mesmo Intendente fez Fernando José de Almeida de um terreno a este fim proporcionado, que possui defronte da Igreja da Lampadosa, permitindo que nele se erija o dito teatro, seguindo o plano que me foi presente e que baixará com este assinado pelo mesmo proprietário do dito terreno, que além disso se oferece a concorrer com os seus fundos, indústria, administração e trabalho, não só para a ereção, como para o reger e fazer trabalhar. E sou outrossim servido, para mostrar mais quanto esta oferta me é agradável, conceder que tudo quanto for necessário para o seu fabrico, ornato e 
vestuário, até o dia em que abrir e principiar a trabalhar, se dê livre de todos direitos nas alfândegas onde os deve pagar; que se possa servir da pedra de cantaria que existe na ressalto ou muralha do edifício público que fica contíguo a ele e que de muitos anos se não tem concluído; e que, depois de entrar a trabalhar, para seu maior asseio e mais perfeita conservação, se the permitirão seis loterias, segundo o plano que se houver de aprovar a beneficio do teatro. E porque também é justo e de razão que os acionistas que concorram para o fundo necessário pare a sua ereção fiquem seguros assim dos juros de seus capitais que os vencerem, como dos mesmos capitais, por isso mesmo que os ofertaram sem estipulação de tempo, determino que o mesmo Intendente Geral da Polícia, a cuja particular e privativa inspeção fica a dita obra e o mesmo teatro, faça arrecadar por mão de um tesoureiro, que nomeara, todas as ações e despendê-las por férias por ele assinadas, reservando dos rendimentos aquela porção que se deva recolher ao cofre para o pagamento dos juros e a amortização dos principais, para depois de extintos esses pagamentos, que devem ser certos e de inteiro crédito e confiança, passar o edifício e todos os seus pertences ao domínio e propriedade do proprietário do terreno; ficando entretanto o dito e quanto nele houver com hipoteca legal, especial e privilegiada ao distrito dos referidos fundos ${ }^{269}$.

Conforme tal mandado, o Real Teatro de São João deveria erguer-se sem qualquer desembolso do Erário. $O$ empreendimento partiria apenas de particulares, com algum auxílio de incentivos públicos, como a concessão de seis loterias, e de benefícios alfandegários sobre o material necessário ao fabrico do edifício. A construção contaria ainda com o reaproveitamento de antigos blocos de pedra que haviam sido destinados à nova Sé, mas que, com a interrupção, por décadas, das obras, permaneceram abandonados no

269 COLEÇÃO das Leis do Brasil de 1810. Cartas de Lei, Alvarás, Decretos e Cartas Régias de 1810. Rio de Janeiro: Imprensa Nacional, 1891, p. 112-113. 
terreno vizinho ao do futuro proprietário do teatro, Fernando José de Almeida.

Assim, pouco menos de dois meses após a publicação do decreto, mais precisamente a 20 de julho de 1810, o Intendente Geral da Polícia, Paulo Fernandes Viana, nomeou seu cunhado, o Comendador Fernando Carneiro Leão - importante negociante do Rio de Janeiro e, posteriormente, Barão (1825) e Conde de Vila Nova de São José (1826) - , tesoureiro das ações de todos aqueles que se prestassem a investir na construção do teatro ${ }^{270}$.

Graças às informações contidas em um maço de documentos manuscritos, preservado no Arquivo Nacional, é possível agora divulgarmos a desconhecida relação ${ }^{271}$ de todos os "vassalos" que ofertaram, "sem estipulação de tempo" 272 , fundos necessários para que, em cerca de três anos, Fernando José de Almeida comandasse a ereção, no Rio de Janeiro, de uma casa de espetáculos com dimensões maiores do que a grand Opéra de Paris $^{273}$.

Eram, pois, esses súditos, ricos negociantes, ainda ávidos em adquirir benesses políticas, cargos públicos e títulos de nobreza em troca do seu "amor" e "distinta fidelidade" à realeza. "Provas" iguais a essa - já tradicionais, conforme vimos - haviam se tornado ainda mais corriqueiras e 34, doc. 29.

${ }^{270}$ ARQUIVO NACIONAL, Rio de Janeiro. Fundo Decretos do Executivo, cx. 19, pc.

${ }_{271}$ Ibidem, cx. 19, pc. 34, doc. 31.

272 Segundo consta de um documento tombado no Arquivo Nacional do Rio de Janeiro, somente a $1^{\circ}$ de abril de 1819 os acionistas receberam de Fernando José de Almeida a importância de suas ações no valor de 49:600\$000 (ARQUIVO NACIONAL, Rio de Janeiro. Fundo Decretos do Executivo, cx. 19, pc. 34, doc. 47).

${ }^{273}$ Ferdinand Denis (1798-1890) explorador francês que esteve no Brasil entre 1816 e 1820, assim se referiu ao São João: “... il peut paraître surprenant qu'une cité américaine possède déjà un théâtre égal à celui de Milan, et par conséquent un peu plus vaste que la grand Opéra de Paris" (DENIS, Ferdinand Jean. Histoire et description du Brésil. Paris: F. Didot frères, 1839, v. 1, p. 108). Não sabemos, no entanto, se Denis se referiu à salle le Pelletier, inaugurada em 1821, ou à salle Montansier (1794), demolida após o assassinato do Duque de Berry, a 13 de fevereiro de 1820. Theodore von Leithold achou o São João quase do mesmo tamanho da ópera de Berlim, apenas um pouco menos largo: "Das Schauspielhaus in Rio de Janeiro, aus der Place de Russie, ist beinahe so groß, als das hiesige Opernhaus, nur nicht so breit" (LEITHOLD, Theodor von. Meine Ausflucht nach Brasilien oder reise von Berlin nach Rio de Janeiro und von dort zurück. Berlin: Maurerschen Buchhandlung, 1820, p. 24). 
generosas com a chegada da família real no Rio de Janeiro ${ }^{274}$. Lembremos, por exemplo, a ação do negociante Elias Antônio Lopes ao doar, em 1808, sua imensa Quinta da Boa Vista - avaliada em 160 contos de réis - ao Príncipe Regente, o que lhe rendeu, rapidamente, uma série de nobilitações ${ }^{275}$. Afinal, com a vinda do futuro Rei ao Brasil, tornava-se menos difícil para os riquíssimos negociantes fixados na colônia obterem as dignidades que tanto almejavam, pois estavam muito mais próximos daquele que, unicamente, tinha o poder de concedê-las.

A construção do "absolutamente necessário" teatro "decente", era mais uma excelente oportunidade de barganha para que os negociantes interessados em obter foros demonstrassem seu "amor" e "distinta fidelidade" à realeza, sentimentos, é claro, sempre passíveis de ser traduzidos em altas cifras $^{276}$ como estas:

\section{ACIONISTA}

VALOR

Conselheiro Joaquim José de Azevedo ${ }^{277}$

${ }^{274}$ Ainda sobre esse assunto, ver outros importantes estudos, como: Comércio e política: o enraizamento de interesses mercantis portugueses no Rio de Janeiro, 18081830, de Riva Gorenstein, publicado no volume Negociantes e caixeiros na sociedade da Independência (Rio de Janeiro, 1992); Homens de grossa aventura: acumulação e hierarquia na praça mercantil do Rio de Janeiro, 1790-1830, de João Fragoso (Rio de Janeiro, 1992); e A corte no exílio: civilização e poder no Brasil às vésperas da independência (1808 a 1821), de Jurandir Malerba (São Paulo, 2000).

275 "S.A.R. querendo gratificar a Elias Antônio tão generosa oferta, que os mesmos Fidalgos avaliam em $400 \$$ cruzados, houve por bem nomeá-lo Comendador da Ordem de Cristo, Fidalgo da Casa Real, e Administrador da mesma quinta" (RELAÇÃO das festas: que se fizeram no Rio de Janeiro, quando o Príncipe Regente N. S. e toda a sua real família chegaram pela primeira vez àquela capital. Ajuntando-se algumas particularidades igualmente curiosas, e que dizem respeito ao mesmo objeto. Lisboa: na Impressão Regia, 1810 , p. 13). Informações mais detalhadas sobre a série de benesses obtidas por esse negociante após a chegada de Dom João ao Rio de Janeiro foram reunidas por Manolo Florentino em seu livro Em costas negras (Rio de Janeiro: Arquivo Nacional, 1995, p. 207).

${ }^{276} 400 \$ 000$ réis, a média das contribuições, correspondia aos ganhos anuais de um funcionário de nível médio do funcionalismo público. O bibliotecário Luiz dos Santos Marrocos, por exemplo, ganhava isso (Cf. MARROCOS, Luiz Joaquim dos Santos. Op. cit.).

277 Joaquim José de Azevedo (1761-1835), português de nascimento, era, a esse tempo, um dos mais ricos habitantes do Rio de Janeiro, senão do Brasil. Por sua "generosidade" prestada à realeza, obteve, a 5 de setembro de 1808, seu primeiro privilégio de fidalguia. Em 1810, recebeu a Comenda de Cristo e da Torre e Espada, além de ser nomeado Conselheiro Real. A 12 de outubro de 1812, granjeou o título de Barão do Rio Seco; a 6 de fevereiro de 1818, o de Visconde do Rio Seco; a $1^{\circ}$ de dezembro de 1822 , Visconde do Rio Seco "com honras de grandeza"; e a 12 de outubro de 1826, Marquês de 
José Pereira Guimarães ${ }^{278}$

$1: 200 \$ 000$

Manoel Pinheiro Guimarães

$400 \$ 000$

Antônio Gomes Barroso 279

$800 \$ 000$

Domingos José Loureiro

$1: 200 \$ 000$

José da Mota Pereira

$400 \$ 000$

Fernando Carneiro Leão ${ }^{280}$

2:000\$000

Francisco José Guimarães e João Álvares de Souza

2:000\$000

Guimarães

João da Costa Lima

$400 \$ 000$

Domingos Gonçalves de Azevedo, Paulo Martin Filho e

$1: 200 \$ 000$

Bernardo José de Figueiredo

João Inácio Tavares, José Inácio Vás Vieira ${ }^{281}$ e Joaquim

$1: 200 \$ 000$

José Pereira de Faro ${ }^{282}$

José Luiz Álvares

$1: 000 \$ 000$

José Antônio de Oliveira Guimarães

$400 \$ 000$

Antônio José Ribeiro Guimarães

$400 \$ 000$

Tomás Gonçalves

$1: 200 \$ 000$

Jundiaí. (Nesta e nas notas que se seguem, referentes a alguns dos acionistas do teatro, ver RHEINGANTZ, Carlos G. Titulares do império. Rio de Janeiro: Arquivo Nacional, 1960; e SANCHES DE BAENA, Augusto Romano Sanches de Baena e Farinha de Almeida, Visconde de. Dicionário aristocrático que contém todos os alvarás de foros de fidalgos da casa real, médicos, reposteiros e porteiros da real câmara, títulos e cartas do conselho; fiel extrato dos livros do registro das mercês existentes no arquivo público do Rio de Janeiro; desde 1808 até setembro de 1822. Lisboa: Tip. do Panorama, 1867).

${ }^{278}$ Vereador do Senado da Câmara do Rio de Janeiro, Comendador (SANTOS, Luiz Gonçalves dos. Op. cit., v. 2, p. 30).

${ }^{279}$ Antônio Gomes Barroso (c.1766-1829), negociante do Rio de Janeiro, nascido em Portugal. Fidalgo Cavaleiro, por Alvará de 8 de Maio de 1819. Seu filho, de mesmo nome, natural do Rio de Janeiro, recebeu igual foro a $1^{\circ}$ de julho de 1819.

${ }^{280}$ Como já foi dito, o negociante e Gentil-homem da Câmara de S. M. I. Fernando Carneiro Leão tornou-se a 12 de outubro de 1825, Barão "com honras de grandeza" de Vila Nova de São José, e, exatamente um ano depois, Conde de Vila Nova de São José.

${ }_{281}$ Segundo Jurandir Malerba, José Inácio Vás Vieira era um dos principais traficantes de escravos do Rio de Janeiro, e responsável "por boa parte da comercialização de açúcar, charque e trigo, entre 1802 a 1822". Ainda segundo esse autor, Vieira recebeu o hábito da Ordem de Cristo em 1811 (MALERBA, Jurandir. A corte no exílio: civilização e poder no Brasil às vésperas da independência (1808 a 1821). São Paulo: Companhia das Letras, 2000 , p. 254).

282 O negociante e Coronel Joaquim José Pereira de Faro, português de nascimento, foi um dos primeiros cidadãos a receber do Imperador Dom Pedro II um baronato. A 6 de outubro de 1841, passava a gozar do título de $1^{\circ}$ Barão do Rio Bonito. 
João Lopes Batista

$400 \$ 000$

Manuel Caetano de Brito

$1: 200 \$ 000$

João Rodrigues Pereira de Almeida ${ }^{283}$

$1: 200 \$ 000$

Fernando Joaquim de Matos

$400 \$ 000$

José Agostinho Barbosa

$400 \$ 000$

Joaquim do Babo Pinto

$400 \$ 000$

Caetano José de Almeida

$228 \$ 000$

João Gomes Vale

$400 \$ 000$

Antônio José Airosa

$1: 200 \$ 000$

Manoel Gomes Cardoso 284

$400 \$ 000$

João Gomes Barro

$100 \$ 000$

João Gomes Barroso

$300 \$ 000$

José Antônio da Costa Guimarães

$400 \$ 000$

Manuel Gonçalves de Carvalho

$800 \$ 000$

Francisco José dos Santos

$400 \$ 000$

Manoel Velho da Silva ${ }^{285}$

$1: 200 \$ 000$

Amaro Velho da Silva ${ }^{286}$

$1: 200 \$ 000$

Luiz José de Oliveira

$400 \$ 000$

283 O negociante e Coronel João Rodrigues Pereira de Almeida, natural de Portugal, Deputado da Real Junta do Comércio e Conselheiro do Rei (por carta de 31/03/1821) foi agraciado por Dom Pedro I com o título de $1^{\circ}$ Barão de Ubá, a 12 de outubro de 1828.

${ }^{284}$ Cavaleiro professo na Ordem de Cristo com a patente de Capitão, segundo o Almanaque do Rio de Janeiro de 1794 (Apud Anais da Biblioteca Nacional. Rio de Janeiro, v. 59 , p. 343, 1937).

285 Manuel Velho da Silva, negociante, natural do Rio de Janeiro, consegue a graça de Fidalgo Cavaleiro por Alvará de 14 de junho de 1811. Em 26 de março de 1813, passa a fazer parte do Conselho Real. Seu pai, homônimo, já obtivera o mesmo foro a 22 de agosto de 1812

${ }^{286}$ Amaro Velho da Silva (1780-1845), abastado negociante e capitalista, Tenentecoronel de milícias, sobrinho de comerciante homônimo, morto em 1810. Foi Conselheiro Real, Veador da Imperatriz; agraciado, posteriormente, com os títulos de Barão de Macaé (12/10/1826) e Visconde de Macaé “com honras de grandeza” (18/10/1829). 
José Luiz da Mota

2:000\$000

Antônio Ferreira da Rocha

$1: 200 \$ 000$

Joaquim José de Siqueira ${ }^{287}$

2:000\$000

Domingos Velho da Silva

$1: 200 \$ 000$

Fernando José de Almeida

9:867\$000

João José da Mota

$600 \$ 000$

D. Maria Luiza de Souza Dias

2:000\$000

Baronesa de São Salvador ${ }^{288}$

2:000\$000

TOTAL

47:695\$000

Como ainda previa o Decreto de 28 de maio de 1810, além de utilizar, para a construção do teatro, os quase 48 contos de réis recolhidos por meio do fundo de ações acima discriminado, Fernando José de Almeida ainda poderia lançar mão dos lucros de seis loterias. Surgia, assim - e perduraria com constância até o final do primeiro reinado - um dos mais importantes meios de financiamento da atividade cênico-musical carioca ${ }^{289}$.

Tais planos de loteria tinham por objetivo arrecadar, em cada extração, um fundo de capital bruto que variava, normalmente, de 100 a 150 contos de réis, dos quais $12 \%$ convertiam-se em dotação para o teatro ${ }^{290}$. De

287 Comendador, segundo o padre "Perereca" (SANTOS, Luiz Gonçalves dos. Op. cit., v. 2, p. 30), Joaquim José de Siqueira adquiriu o privilégio de Fidalgo Cavaleiro, por Alvará de 22 de dezembro de 1812. Seu filho, homônimo, recebeu o mesmo foro a 18 de fevereiro de 1813.

288 Dona Ana Francisca Maciel da Costa, viúva do negociante Brás Carneiro Leão recebeu a 17 de dezembro de 1812 o título de Baronesa de São Salvador de Campos dos Goitacazes "pelo serviço por ambos prestado, concorrendo para as urgências do Estado". A 8 de janeiro de 1823, obteve de Dom Pedro I, "honras de grandeza" para o seu baronato.

${ }^{289} \mathrm{Em} \mathrm{1817}$, o decreto de 23 de agosto do mesmo ano concedeu ao Teatro de São João vinte loterias de até 150 contos de réis a serem realizadas no prazo de dez anos (COLEÇÃO das Leis do Brasil de 1817. Cartas de Lei, Alvarás, Decretos e Cartas Régias de 1817. Rio de Janeiro: Imprensa Nacional, 1890, p. 54). Em 1823, Decreto de 17 de janeiro, assinado por José Bonifácio, ratifica a concessão de loterias ao teatro e atesta já terem sido concedidas, àquela época, dez loterias em benefício desse (COLEÇÃO das Leis do Império do Brasil de 1823. Decretos, Cartas e Alvarás de 1823. Rio de Janeiro: Imprensa Nacional, 1887, p. 7). Com o incêndio do São João em 1824, e sua reinauguração, em 1826, com o nome de São Pedro de Alcântara, a concessão de loterias em seu benefício ainda aumentará até o final do primeiro reinado.

290 A despeito das informações contidas nas coleções de leis ou nos periódicos, o reverendo Robert Walsh, que esteve no Rio em 1829, explica com grande concisão como funcionavam as loterias: "The theatre is partly supported by lotteries (...). The benefits are, 
acordo com a Gazeta do Rio de Janeiro de 7 de maio de 1811, os bilhetes para a primeira extração começaram a ser vendidos no dia 15 do mesmo mês. Em carta a seu pai, de 22 de novembro de 1811, Luiz dos Santos Marrocos conta ter comprado bilhetes para as duas extrações iniciais, dandonos também a informação de que, a esse tempo, "o magnífico teatro novo de São João" já estava "a edificar-se" 291 .

Em 1813, mais três loterias extraordinárias foram concedidas com o intuito de complementar os custos da obra e concluí-la ${ }^{292}$. No total, portanto, de nove sorteios, foram arrecadados 62:945\$960; uma média de sete contos de réis por loteria. Além disso, ainda foram necessários mais 27:334\$369, pagos pelo tesoureiro, Fernando Carneiro Leão; sendo esse reembolsado pelo Banco do Brasil, ficou tal quantia debitada ao teatro ${ }^{293}$.

Assim, pouco mais de dois anos e um total de 137:975 $\$ 329$ réis ${ }^{294}$ gastos permitiram à corte encerrar as comemorações do décimo quinto genetlíaco do então Príncipe da Beira, Dom Pedro, na mais avantajada casa de ópera das Américas ${ }^{295}$, traçada pelo Marechal-de-Campo João Manuel da

twelve per cent on the amount of the tickets, which is usually about 7,500 , at twenty milreis each, of which 5,000 are blanks, and 2,500 prizes. The value of the tickets is 150,000 milreis, from which a deduction of twelve per cent. would produce 18,000 milreis for the contractors, leaving 132,000 for prizes; the highest of which is 20,000 , and the lowest twenty" (WALSH, Robert. Op. cit., v. 1, p. 484).

${ }_{291}$ MARROCOS, Luiz Joaquim dos Santos. Op. cit., v. 56, p. 50, 1934.

292 COLEÇÃO das Leis do Brasil de 1813. Decisões de 1813. Rio de Janeiro: Imprensa Nacional, 1890, p. 28.

${ }^{293}$ Esta dívida marcaria, aliás, o início de um longo histórico de débitos do teatro para com o Banco do Brasil, dívidas essas, como veremos, sempre renegociadas ou facilitadas, após a Independência, por ordem de Dom Pedro I.

294 As cifras mencionadas constam de documentos manuscritos tombados no Arquivo Nacional do Rio de Janeiro (Fundo Decretos do Executivo, cx. 19, pc. 34, doc. 30). A título de curiosidade, mencionemos que o São Carlos custou, vinte anos antes, um pouco mais. Segundo, mais uma vez, Francisco da Fonseca Benevides, foram gastos no teatro lisboeta 165:845\$196, dos quais, pouco mais de 34 contos de réis, apenas para serviços de pedreiro e canteiro (BENEVIDES, Francisco da Fonseca, Op. cit., p. 20-22). Isso talvez explique o fato do São Carlos ter custado, vinte anos antes, quase trinta contos de réis a mais do que o São João, já que este último certamente consumiu, em boa parte, mão-deobra escrava.

${ }^{295}$ Não havia, a essa época, nas Américas, teatro que se equiparasse ao São João e seus cerca de 1.800 lugares. Um dos mais próximos em tamanho e suntuosidade era o Park Theatre de Nova lorque, construído entre 1795 e 1798 por Hallam e Hodgkinson. Situado na Chatham Street (hoje Park Row), essa casa abriu suas portas pela primeira vez a 29 de janeiro de $1798 \mathrm{com}$ a peça de Shakespeare As You Like It. Tinha três ordens de camarotes, galeria e platéia, encerrando, todo o conjunto, por volta de 1.200 lugares. O 
Silva à imagem e semelhança do São Carlos de Lisboa, e conseqüentemente do Scala, de Milão. A inauguração do Real Teatro de São João ocorreu a 12 de outubro de 1813, tendo sido levado à cena um texto da pena de Gastão Fausto da Câmara Coutinho (1772-1852), O juramento dos Numes, drama lírico "adornado com muitas peças de música da composição de Bernardo José de Sousa e Queirós, mestre e compositor do mesmo teatro" ${ }^{296}$.

É curiosa a informação de que a música da concorridíssima estréia do Teatro de São João tenha sido escrita por um compositor brasileiro, de quem temos, atualmente, escassas informações ${ }^{297}$. Isso indica mais uma vez o exagero da idéia, fortemente firmada na historiografia, de que Marcos Antônio da Fonseca Portugal teria "monopolizado" o cenário musical carioca - tanto profano como sacro ${ }^{298}$ - enquanto Dom João esteve no Brasil. Há inclusive aqueles que, talvez por conta disso, tenham cometido o equívoco de dar a

teatro incendiou-se em 1820 sendo reconstruído e reaberto em 1821 . Novo incêndio o destruiu definitivamente em 16 de dezembro de 1848 (Cf. HORNBLOW, Arthur. A History of the theatre in America. Philadelphia: J.B. Lippincott Company, 1919; BROWN, T. Allston. A history of the New York stage, from the first performance in 1732 to 1901. New York: B. Blom, 1964). Nova Orleans, principal centro operístico norte-americano da primeira metade do século XIX, tinha, pela mesma época, um teatro também menor do que o carioca. Segundo Henry A. Kmen, o Théâtre d'Orléans, reinaugurado, em 1819, após ser destruído por um incêndio, em 1816, "não era em si nem grande, nem pretensioso, nunca reunindo mais do que 1.300 pessoas!": "... the theater itself was neither large nor pretentious, never seating many over thirteen hundred persons!" (KMEN. Henry A. Music in New Orleans: The Formative Years, 1791-1841. Baton Rouge: Louisiana State University Press, 1966, p. 90). Enfim, em Buenos Aires, onde hoje se acha o monumental Teatro Colón (1889-1908), não havia, igualmente, na década de 1810 , nada que pudesse ser comparado à Ópera do Rio de Janeiro. O principal teatro portenho dessa época era o acanhado Coliseo Provisional construído, em 1804, de frente para a Igreja de la Merced. Foi no Coliseo que se realizou a primeira encenação de ópera completa na Argentina, a 27 de setembro de 1825 (II barbiere di Siviglia), curiosamente com cantores que antes faziam parte da Companhia Italiana do São João, e que, por ocasião do incêndio desse teatro, em 1824, acabaram por radicar-se em Buenos Aires (Cf. GESUALDO, Vicente. Teatros del Buenos Aires Antiguo. Buenos Aires: Ansilta Ediciones, 1990, p. 24-33)

${ }_{296}^{296}$ GAZETA DO RIO DE JANEIRO, 16/10/1813.

297 Segundo a Grande Enciclopédia Portuguesa e Brasileira: "Compositor, n. no Brasil, no séc. XVIII. Vivia no Rio de Janeiro quando ali se estabeleceu a corte portuguesa em 1808" (v. 23, p. 891). A última notícia por nós encontrada sobre esse músico data de 1830, quando este requereu que o Ministério do Império intercedesse em seu nome, solicitando a José Bernardes Monteiro que tornasse a contratá-lo como mestre de música do Teatro de Sao Pedro de Alcantara (BIBLIOTECA NACIONAL, Rio de Janeiro. Seção de Manuscritos, Fundo Documentos biográficos, C-0808,019 n001).

${ }^{298}$ Em relação, por exemplo, à música sacra, André Cardoso chega a intitular um dos subcapítulos de sua tese de doutorado como "Marcos Portugal e o monopólio da música na Capela Real" (CARDOSO, André. Op. cit., p. 96). 
Portugal a autoria e a regência da música de $O$ juramento dos Numes. João de Freitas Branco foi um dos que se enganaram ao afirmar que tanto a composição como a direção musical da peça de estréia do São João teria sido confiada ao músico português ${ }^{299}$. Ora, que a música foi composta por Queirós, o texto da Gazeta "não admite réplica", como, já há algumas décadas, observara Ayres de Andrade ${ }^{300}$. E como se não bastasse a Gazeta, outra fonte da época igualmente cita Queirós como autor de $O$ juramento dos Numes. Trata-se do libreto comemorativo desse drama, impresso no Rio de Janeiro no mesmo ano de $1813^{301}$.

Tal espetáculo de estréia, encerrado com a comédia $O$ combate do Vimeiro, contou com a ilustre presença do Príncipe Regente, que, a partir de então, com a disponibilidade desse "decente teatro", passaria a freqüentar os espetáculos cênicos e musicais profanos com maior assiduidade, conforme nos testemunhou o comerciante John Luccock, em sua segunda estada no Rio, naquele ano:

\begin{abstract}
Os divertimentos do teatro progrediam acompanhando os passos dos assuntos da mais imediata importância. Não só o Regente se dignava a esses espetáculos - o que dava a impressão de forte gosto pessoal, por meio de sua freqüente presença -, como aparecia no teatro acompanhado de sua família. Conseqüentemente, isso se tornou moda para todos aqueles que desejavam se passar por
\end{abstract}

${ }^{299}$ BRANCO, João de Freitas. História da música portuguesa. Lisboa: Publicações Europa-América, 1995, p. 213.

${ }^{300}$ ANDRADE, Ayres de. Op. cit., v. 1, p. 111.

${ }^{301}$ A Divisão de Obras Raras da Biblioteca Nacional do Rio de Janeiro guarda em seu acervo, um exemplar dessa publicação sob o código de localização: $37,6,3$ (COUTINHO, Gastão Fausto da Câmara. O juramento dos Numes, drama. Para se representar na noite da abertura do Real Teatro de S. João em aplausos ao Augusto nome de Sua Alteza Real o Príncipe Regente Nosso Senhor. Rio de Janeiro: Impressão Régia, 1813). Aproveitando, mencionemos mais duas informações: o título completo do libreto nos leva a crer que a inauguração do teatro estava programada, originalmente, para o dia de São João (24/06). Por algum motivo fortuito - o provável atraso nas obras - essa casa acabou abrindo suas portas somente no aniversário de Dom Pedro; o segundo dado é que existe ainda uma partitura manuscrita da Abertura desse drama. Ela se acha atualmente arquivada na Biblioteca Alberto Nepomuceno da Escola de Música da UFRJ sob o número de localização 006-03-000048-2. 
pessoas de relevo, mostrar-se ali. (...) Nas peças representadas, as maneiras, vícios, dialetos e outras peculiaridades da colônia eram ridicularizadas, e o gosto do público apurou-se. As pessoas tinham, certamente, avançado tanto, que passaram a aplaudir desconfiadamente, quando apreciavam algo; mas não tinham confiança suficiente para expressar sua desaprovação ${ }^{302}$.

Voltava, pois, o teatro público a ter, no Rio de Janeiro, seus momentos de maior brilhantismo social, como já ocorrera, embora em dimensões menores, durante o período em que os Governadores e Vice-Reis governaram. Porém, não podemos exatamente concordar que o gosto dos cariocas "apurou-se" ou "retificou-se", como afirmou Luccock; Diríamos que o "gosto" apenas "transformou-se" ${ }^{303}$. Afinal, no que diz respeito à criação musical, por exemplo, de nosso maior compositor do período, o Padre José Maurício Nunes Garcia, é de se notar que o seu estilo "particular" — como mesmo salientou, à época, Araújo Porto Alegre ${ }^{304}$ —, um tanto mais ligado ao estilo centro-europeu de um Haydn ou de um Mozart, sofreu, ao contrário, uma perda estética, ao tornar-se, a partir de 1808, influenciado pelos maneirismos e afetações do estilo italiano da época, que faziam o gosto da corte portuguesa mas que não passavam de modismo; um idiotismo de

302 Tradução nossa de: "Theatrical amusements kept pace in improvement with matters of more immediate importance. Not only did the Regent indulge what seemed a strong personal taste, by his frequent attendance upon them, but he appeared in the Theatre accompanied by his family. Hence it became fashionable for all, who wished to be thought persons of consequence, to show themselves there. (...) In the pieces represented, the manners, vices, dialect, and other peculiarities of the colony were ridiculed; and the public taste, in consequence, amended. The people had even advanced so far as diffidently venturing to applaud, when they were pleased; but had not sufficient confidence to express their disapprobation" (LUCCOCK, John. Op. cit., p. 246).

303 Maurício Monteiro estudou recentemente - em tese de doutorado já mencionada - essas diversas "transformações" de gosto ocorridas no Rio de Janeiro a partir da chegada da corte portuguesa, em 1808 (Cf. MONTEIRO, Maurício Mário. A construção do gosto: música e sociedade na corte do Rio de Janeiro, 1808-1821. São Paulo, 2001. Tese [Doutorado] - FFLCH/USP).

${ }^{304}$ Manoel de Araújo Porto Alegre foi o primeiro a escrever sobre a singularidade do estilo de José Maurício: "Malgré la concurrence des productions italiennes et allemandes, nous possédons un musique brésilienne qui porte le cachet très particulier de l'école de José Mauricio. Son génie extraordinaire sort de la ligne de nos autres musiciens" (DEBRET, Jean Baptiste. Op. cit., v. 3, p. 89). 
linguagem que, como tal, não sobreviveu ao tempo. Quanto a isso, basta dizer que todos os representantes desse estilo, compositores famosíssimos na viragem do século XVIII para o XIX caíram logo no esquecimento, como, Giuseppe Farinelli (1769-1836), Vincenzo Federici (1764-1826), Valentino Fioravanti (1764-1837), Pietro Generali (1773-1832), Pietro Carlo Guglielmi (1772-1817), Luigi Mosca (1775-1824), Giuseppe Mosca (1772-1839), Giuseppe Niccolini (1762-1842), Stefano Pavesi (1779-1850), Antonio Salieri (1750-1825), Nicola Antonio Zingarelli (1752-1837) e o próprio Marcos "Portogallo". Stendhal (1783-1842) - jornalista, romancista e diplomata francês -, ao publicar seu célebre livro, Vie de Rossini, em 1824, já constatava o rápido olvido em que caíram diversos importantes nomes da ópera italiana de fins do século XVIII e princípios do XIX, o que não ocorria com um artista de verdadeiro valor, como Mozart, mesmo passados mais de trinta anos de sua morte:

\begin{abstract}
A cena musical na Itália havia sido ocupada durante os últimos dez anos por Mayer, Paër, Pavesi, Zingarelli, Generali, Fioravanti, Weigl, e por aproximadamente trinta nomes mais ou menos esquecidos hoje, e que ali reinavam tranqüilamente. Esses senhores se julgavam os sucessores de Cimarosa e de Pergolesi, o público também o julgava; Mozart surgiu, de repente, como um colosso no meio de todos esses pequenos compositores italianos, que somente eram grandes pela ausência de grandes homens ${ }^{305}$.
\end{abstract}

É, no entanto, evidente, que a vinda da família real para o Rio de Janeiro, propiciou, em relação à música, um apuramento; não propriamente no gosto musical, mas na prática geral da música, progresso notado pelo

${ }^{305}$ Tradução nossa de: "La scène musicale en Italie était occupée depuis dix ans par MM. Mayer, Paër, Pavesi, Zingarelli, Generali, Fioravanti, Weigl, et par une trentaine de noms plus ou moins oubliés aujourd'hui, et qui y régnaient tranquillement. Ces messieurs se croyaient les successeurs des Cimarosa et des Pergolèse, le public le croyait aussi; Mozart parut tout à coup comme un colosse au milieu de tous ces petits compositeurs italiens, qui n'étaient grands que par l'absence des grands hommes" (STENDHAL. Vie de Rossini. Paris: 
provável crescimento da oferta de instrumentos musicais e partituras; pela presença mais constante de artistas de nacionalidade diversas, que traziam para cá suas experiências diferenciadas, suas técnicas de execução talvez desconhecidas; e, enfim, pela maior demanda de um público pagante por espetáculos - fruto do modismo citada por Luccock - , o que permitiu o estabelecimento de espaços de execução maiores e mais bem equipados e aparatados.

Comportava, pois, o Real Teatro de São João, quase três vezes o público que a antiga Ópera de Manuel Luiz admitia. Segundo as Memórias históricas, do Monsenhor Pizarro, essa "casa esplêndida de representação" acomodava, "sem vexame", na platéia, 1.020 pessoas, sem contar os camarotes, que, divididos em quatro ordens, somavam 112 unidades -30 de primeira, 28 de segunda, 28 de terceira e 26 de quarta ${ }^{306}$-, podendo alojar, quem sabe, mais 600 espectadores, fora as cadeiras extras. Uma vez aberto, em outubro de 1813, organizou-se ali uma companhia de atores e bailarinos. O funcionamento dessa companhia, logo após a abertura do São João, pode ser constatado em uma nota, publicada na Gazeta do Rio de Janeiro de 28 de janeiro de 1814, na qual o proprietário do teatro fazia público

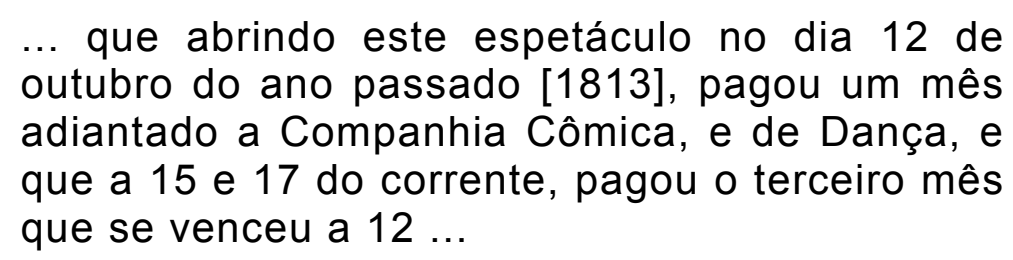

Entre os mais destacados atores, figuravam os reinóis Domingos Botelho, Vítor Porfírio de Borja, Antônio José Pedro ${ }^{307}$ e Mariana Torres, a

\footnotetext{
Le Divan, 1929 , v. 1, p. 37).

${ }^{306}$ ARAÚJO, José de Sousa Azevedo Pizarro e. Op. cit., v. 7, p. 77-78. Ressalte-se aqui uma divergência numérica. Ayres de Andrade, citando o mesmo Monsenhor Pizarro (sem, no entanto, identificar a edição), registra que a platéia do São João acomodava 1.200 pessoas. Na primeira edição, aqui consultada, das Memórias históricas, está impresso 1.020 (ANDRADE, Ayres. Op. cit., v. 1, p. 110).

307 Podemos aproveitar e esclarecer aqui, também, um pequeno equívoco que Maria Beatriz Nizza da Silva cometeu ao considerar que Antônio José Pedro, ator dramático, teria participado da serenata Augurio di Felicità, de Marcos Portugal,
} 
quem, segundo Múcio da Paixão, "Bocage dispensava atenções e amizade" ${ }^{308}$. Entre os dançarinos, o francês Luís (Louis) Lacombe era a principal figura.

Já, quanto ao estabelecimento de uma companhia lírica, ou seja, de cantores de ópera, não há informações muito precisas de quando essa teria sido efetivamente instalada. Embora Galante de Souza, sem revelar as fontes, tenha afirmado, em sua obra O Teatro no Brasil, que "tão depressa foi inaugurado" o teatro, ocupou-o "uma companhia de canto, dirigida por Ruscoli” 309 , o registro documental mais antigo que nos restou, relativo a um espetáculo operístico no Teatro de São João, é posterior cerca de um ano a sua solene inauguração. Sabemos, hoje, graças à Impressão Régia, que, em 1814, no natalício da Rainha, Dona Maria I, era levada à cena a ópera Axur, Re di Ormus, de Antonio Salieri ${ }^{310}$. A Biblioteca Nacional do Rio de Janeiro guarda um libreto comemorativo dessa ópera, por meio do qual podemos ter, também, o conhecimento de que Carlotta D’Aunay, Marianna Scaramelli, João dos Reis Pereira, Luiz Inácio Pereira, João Estremeira, Maria Cândida, Michele Vaccani e Geraldo Inácio Pereira cumpriam, naquela ocasião, os papéis principais ${ }^{311}$. Era, pois, esta "companhia lírica", formada por cantores brasileiros, portugueses e outros estrangeiros, praticamente o mesmo grupo de artistas que, entre 1811 e 1812, interpretara A união venturosa, de Fortunato Mazziotti, e as óperas de Marcos Portugal, no Real Teatro. A

apresentada na Quinta da Boa Vista a 07/11/1817 (SILVA, Maria Beatriz Nizza da. Cultura e sociedade no Rio de Janeiro: 1808-1821. São Paulo, Companhia Editora Nacional, 1977, p. 189). Na verdade, o "Antônio Pedro" em questão era o tenor Antônio Pedro Gonçalves, músico da Real Câmara e Capela e não o ator.

308 PAIXÃO, Múcio da. Do teatro no Brasil. Revista do Instituto Histórico e Geográfico Brasileiro. Rio de Janeiro, tomo especial, parte 5, p. 687,1914.

${ }^{309}$ SOUZA, J. Galante de. O teatro no Brasil. Rio de Janeiro: Instituto Nacional do Livro, 1960 , v. 1, p. 142. Infelizmente não encontramos nenhuma informação a respeito desse "Ruscoli". Aliás, se tal conhecimento tem alguma procedência, o nome não deve ser Ruscoli, mas Rusconi, esse sim, um designativo italiano usual.

${ }^{310}$ Esse drama joco-sério já havia sido encenado em outro natalício da Rainha Dona Maria I. Foi no ano de 1790 , em uma apresentação realizada no Real Teatro da Ajuda. A Biblioteca Nacional do Rio de Janeiro também tem, em sua Divisão de Obras Raras, um libreto comemorativo desta apresentação.

${ }^{311}$ AXUR, Rei de Ormuz. Ópera sério-cômica para representar-se no Real Teatro de S. João no feliz natalício de Sua Majestade Fidelíssima a Senhora D. Maria I, rainha de Portugal a 17 de dezembro. Rio de Janeiro: Impressão Régia, 1814. (Biblioteca Nacional do 
principal novidade do elenco, desta vez, era Miguel (Michele) Vaccani, barítono milanês de certa importância, que atuara na temporada de outono do Scala, em $1799^{312}$, cantara com sucesso em Lisboa na primeira década do século $X I X^{313}$, e que, a partir de então, estrelaria incontáveis espetáculos operísticos no Rio de Janeiro, Montevidéu e Buenos Aires, até encerrar sua longa carreira, provavelmente, na década de $1850^{314}$.

Quanto aos demais cantores, restaram-nos mais interrogações do que dados. O baixo João dos Reis Pereira, por exemplo, é um dos raros nomes que subsistiram, acompanhados de alguma notícia adicional. Citado por Balbi, em seu Essai statistique, de 1822, como um "mulato do Rio de Janeiro" 315 , era, na verdade, mineiro de nascimento, tendo vindo para a capital ainda criança, com seu irmão, Jacinto Reis, que se tornaria médico. De origem pobre, ambos foram educados por um tio abastado e descendente de uma das mais antigas e tradicionais famílias mineiras. O autor dessas informações mais detalhadas é Vieira Fazenda, que, referindo-se a Jacinto

Rio de Janeiro, Divisão de Obras Raras, 37, 9, 8).

${ }^{312}$ Cf. ROMANELLI, Luigi. II trionfo del bel sesso, dramma giocoso in musica da rappresentarsi nel Teatro alla Scala di Milano l'autunno del 1799 [compositore della musica sig. maestro Giuseppe Nicolini]. Milano: per Gio. Batista Bianchi, 1799 (Biblioteca del Conservatorio di musica Giuseppe Verdi - Milano - MI - Legato Somma - Coll. Libr. 227); ROMANELLI, Luigi. II ritratto, dramma giocoso in musica da rappresentarsi nel Teatro alla Scala di Milano l'autunno del 1799 [compositore della musica sig. maestro Nicola Zingarelli]. Milano: per Gio. Batista Banchi, 1799 (Biblioteca del Conservatorio di musica Giuseppe Verdi - Milano - MI - Legato Somma - Coll. Libr. 228).

313 Segundo Francisco da Fonseca Benevides, Michele Vaccani participou da companhia de Jacinto Fernandes da Costa Bandeira e João Pereira de Sousa Caldas (1805-1808), chegando a Lisboa em 1807 (BENEVIDES, Francisco da Fonseca. Op. cit., p. 96).

314 “VACCANI, Miguel. Cantante (barítono). Nació en Milán hacia 1770. (...) era un artista de primera categoría en Europa, habiendo actuado en la Opera de Barcelona en 1805 y en el San Carlos de Lisboa en 1808. También actuó en el teatro de Río de Janeiro (...). En el estreno del "Barbiere" en Buenos Aires (1825) interpretó el rol de Figaro. Desde ese momento se convirtió en uno de los artistas preferidos del público rioplantense. En 1826 actuó en Madrid con una compañía lírica que dirigía el compositor Mercadante. En 1829 estableció en Buenos Aires una Academia de Bailes con su esposa, María Cándida Vaccani y su hijo. En esa época su nombre aparece frecuentemente en los periódicos donde se lo llama 'el gran Vaccani', 'el Buffo sin rival en esta parte del Atlántico'. (...) Después del citado año 1854, no hay más noticias de su actividad en Buenos Aires" (Cf. PETRIELLA, Dionisio; SOSA MIATELLO, Sara. Diccionario biográfico italo-argentino. Buenos Aires: Asociación Dante Alighieri, 1976).

315 "Joao dos Rey [sic], musicien de la chapelle royale. Ce mulâtre de Rio-Janeiro est réputé la première basse-taille des Portugais; aussi le roi le nommait son Mombelli, à cause de la grande ressemblance de sa voix avec celle de ce fameux artiste italien" (BALBI, 
em suas Antiqualhas, abriu-nos, fortuitamente, um parêntese para João dos Reis, reproduzindo mais alguns dados sobre o baixo, entre os quais, uma jocosa anedota, que bem resume seu invulgar talento musical:

Foi celebridade tanto maior quanto nunca foi à Europa, nem freqüentou Conservatórios. Contou-me o mui conhecido Bento Fernandes das Mercês o seguinte fato; certo artista italiano tinha-se em grande conta; ouviu falar da voz excepcional do artista brasileiro e quis conhecelo para se medir com ele. Indagando da residência de Pereira Reis [sic], certa noite bate-lhe à porta e pergunta cantando - mora, aqui, o sr. Pereira Reis? Sim, meu senhor, responde dentro o dono da casa, em voz de baixo-profundo. O italiano não quis saber de histórias. Retirou-se convencido de ter encontrado um indivíduo com voz superior à sua $^{316}$.

Sabemos, também, casualmente, desta vez, graças à Gazeta do Rio de Janeiro, que, Carlotta D'Aunay chegou ao Rio proveniente de Londres, em 1809:

Madama D'Aunay cômica cantora novamente chegada de Londres, em cujos teatros, assim como nos de Paris sempre representou, informa respeitosamente aos cidadãos desta corte que ela pretende dar um concerto de música vocal e instrumental na casa $n .^{\circ} 28$, na praia de $D$. Manuel, no dia 14 do corrente ${ }^{317}$.

\footnotetext{
Adrien. Op. cit., v. 2, p. ccxvi).

${ }^{316}$ FAZENDA, Vieira. Antiqualhas e memórias do Rio de Janeiro. Revista do Instituto Histórico e Geográfico Brasileiro, t. 93, v. 147, p. 295-296, 1923.

${ }^{317}$ GAZETA DO RIO DE JANEIRO, 11/10/1809. De fato, segundo o Times, Madame D'Aunay estivera, pouco mais de um ano antes, em Londres, cantando no principal teatro da capital inglesa, o King's Theatre, ao lado da famosíssima cantora italiana Angelica Catalani: "Tomorrow Evening, June 28, will be performed the last new Comic Opera, in one Act (as performed at Madame Catalani's benefit with universal applause), entitled, GLI AMANTI CONSOLATI, in which Madame Catalani will perform the principal Character and in which Madame D'Aunay will make her third appearance" (THE TIMES, 27/06/1808).
} 
Notícias iguais a essa - com alguns detalhes sobre os músicos que participavam das apresentações musicais realizadas no Rio de Janeiro durante a permanência da família real - eram raras. As notas da Gazeta do Rio de Janeiro, relativas aos espetáculos musicais, traziam, quase sempre, apenas o nome das obras prometidas e, quando muito, de seus respectivos autores. Somente em meados do primeiro reinado - e provavelmente impulsionados pela reabertura, em 1826, do Imperial Teatro, destruído pelo fogo, em 1824 - é que textos mais pormenorizados e concernentes a espetáculos já realizados começaram a ocupar, com maior freqüência, as colunas dos jornais cariocas, que, diga-se a propósito, proliferavam, nesse período, por conta da acirrada conjuntura política.

Porém, mesmo essas críticas ou crônicas teatrais não nos fornecem muitas informações adicionais. Por meio delas, podemos saber apenas que solista vocal desempenhou determinado papel em um ou em outro espetáculo. Os demais músicos - regentes e integrantes da orquestra e do coro - não são quase citados por essas fontes ${ }^{318}$. Os repetidos incêndios ocorridos no Imperial Teatro em 1824, 1851 e 1856 são, também, grandes responsáveis pela atual carência de informações mais detalhadas, relativas aos espetáculos ali realizados. Se ainda existissem, muitos documentos produzidos pelos Teatros de São João e de São Pedro de Alcântara sem

${ }^{318}$ Mencionemos dois raros registros do periódico L'écho de L'Amérique du Sud: journal politique, commercial et littéraire, publicado em francês no Rio de Janeiro pela L'Imprimerie Impériale de Plancher-Seignot entre junho de 1827 e março de 1828 . O primeiro, apesar de iniciar elogioso, reclama dos cortes musicais efetuados pelo Maestro brasileiro Pedro Teixeira de Seixas: "M. Pedro Teixera [sic] a fait de trop bonne musique, et est trop versé dans son art pour ne pas savoir que la moindre coupure, le moindre changement dénature la musique et en détruit tout l'effet" (L'ÉCHO DE L'AMÉRIQUE DU SUD, 30/06/1827). O segundo elogia os esforços do italiano João Liberali diante da curiosa debandada de vários músicos do palco após a ópera e antes da encenação do balé: "La musique du ballet de Jenny est pleine de fraîcheur et d'originalité, et certes on ne s'en douterait pas. Malgré tout le zèle de $M$. Liberali, les musiciens que restent pour accompagner le ballet, sont à peine comparables à de mauvais ménétriers de village; ils ne font pas la moindre attention, et j'ai souvent vu M. Liberali jouer seul toute la partition. Les principaux artistes de l'orchestre se retirent après l'opéra, et les pauvres danseurs sont absolument abandonnés à eux mêmes" (L'ÉCHO DE L'AMÉRIQUE DU SUD, 28/08/1827). Note-se que a atuação de Liberali como Maestro do Teatro de São Pedro era até então desconhecida. Esse músico, nascido em Bolonha, naturalizou-se brasileiro em 1831, conforme decreto de 11 de novembro desse ano (COLEÇÃO das Leis do Império do Brasil de 1831. Rio de Janeiro: Tipografia Nacional, 1875, parte 1, p. 224). 
dúvida nos permitiriam saber, por exemplo, quais e quantos instrumentistas e coristas efetivamente participavam dos espetáculos operísticos, se eram eles os mesmos integrantes da Câmara e da Capela, enfim, quanto recebiam por seus serviços.

Incompletos e escassos, esses dados chegam hoje ao nosso conhecimento, graças, fundamentalmente - além das já comentadas notícias dos principais jornais da época ${ }^{319}$ - a outros dois tipos de fontes: os libretos comemorativos e os testemunhos de contemporâneos, registrados em diários e memórias, em sua maioria, impressos à própria época.

Maria Graham (1785-1842), por exemplo, que esteve no Rio de Janeiro em três ocasiões entre 1821 e 1824 - na última para assumir o cargo de aia da Princesa Dona Maria da Glória -, nos fornece, em seu Diário, informações a respeito de óperas que teriam sido levadas nos dias 10 , 11 , e 12 de agosto de 1823, em comemoração ao restabelecimento da saúde de Dom Pedro I, após sua grave queda de um cavalo ${ }^{320}$. O já mencionado musicólogo Ayres de Andrade, que vasculhou apenas os jornais da época a procura de notícias sobre espetáculos do mesmo gênero, ignora esses três dias de ópera citados por Graham e dá conta apenas de uma única apresentação nesse ano: a 9 de janeiro, dia do "Fico", quando se interpretou

${ }^{319}$ Listemo-los: a Gazeta do Rio de Janeiro, publicada com freqüência bissemanal pela Impressão Régia, foi o primeiro jornal a circular na capital do Brasil. Seu primeiro número data de 10 de setembro de 1808. Circulou até dezembro de 1821, quando surgiu a Gazeta do Rio, publicada pela Imprensa Nacional ainda em 1822. O Diário do Rio de Janeiro, primeiro a propagar-se todos os dias no Rio (exceto aos domingos), iniciou sua publicação a $1^{\circ}$ de junho de 1821 , encerrando suas atividades já na segunda metade do século XIX. O Diário fluminense, também de freqüência diária, surgiu em 1824 e circulou até abril de 1831. O Jornal do comércio, publicado inicialmente pela tipografia de EmileSeignot Plancher surgiu em 1827 (01/10), no lugar do Espectador brasileiro, que havia iniciado tiragem em junho de 1824 e publicou algumas das primeiras crônicas musicais cariocas, entre 1826 e 1827, segundo estudo recente de Luís Antônio Giron (GIRON, Luís Antônio. Minoridade crítica. A ópera e o teatro nos folhetins da corte. São Paulo: Edusp, 2004. p. 78-82).

320 "This day, as well as yesterday and the day before, there have been illuminations and dressed operas on account of the Emperor's recovery" (GRAHAM, Maria. Journal of a voyage to Brazil, and residence there, during part of the years 1821, 1822, 1823. London: Longman, 1824, p. 269). Ainda sobre Maria Graham, uma das pouquíssimas informações que temos a respeito da orquestra do teatro também nos foi dada por ela; de que pelo menos $1 / 3$ de seus integrantes eram mulatos: "The orchestra of the opera-house is composed of at least one-third of mulattos" (GRAHAM, Maria. Op. cit., p. 197) 
Adelaide di Borgogna, de Rossini ${ }^{321}$. Note-se, portanto, mais uma vez, a impossibilidade de se reconstituir cabalmente as temporadas teatrais apenas pelas notícias publicadas nos jornais da época.

Com base nessa documentação falha, podemos, no entanto, conhecer parte importante dos fatos relativos a esse divertimento, que era, sem dúvida, o mais interessante da vida social carioca, sobretudo por oferecer às elites econômicas e aos setores intermediários da sociedade, por meio da compra de ingressos, privilégio igual ao que os "Grandes do Reino" tinham, de cercar seu soberano, fazendo-lhe corte ${ }^{322}$.

As temporadas do São João iniciavam-se - como em outros países de fé cristã - após a quaresma, período no qual o teatro permanecia quase sempre fechado, podendo funcionar para a representação de algum drama de conteúdo sacro. Não é possível saber, com precisão absoluta, quantas vezes por mês as portas se abriam, mas, pelo preço das assinaturas de platéia, para esse mesmo período - $6 \$ 400^{323}$ —, é muito provável que se fizessem, no mínimo, dez récitas, já que o ingresso avulso para este setor correspondia ao patacão de 640 réis. Nada impedia, entretanto, que ocorressem representações quase todos os dias. O Capitão teutônico Johann Gottfried Theodor von Leithold (1771-1826), que esteve no Rio de Janeiro em 1819, falou em até "cinco por semana"324.

Na maior parte das vezes, os espetáculos se iniciavam às sete e meia ou oito da noite e compunham-se de vários números. A orquestra dava princípio à função, executando uma "sinfonia", nome que, na verdade, quase sempre correspondia a uma abertura instrumental de ópera e não a uma sinfonia propriamente dita ${ }^{325}$. Em seguida, vinha a parte principal do

${ }^{321}$ ANDRADE, Ayres. Op. cit., v. 1, p. 122.

322 Esse fato não ocorria, por exemplo, em outros divertimentos, como bailes e saraus com a real presença, para os quais se exigiam convites.

${ }^{323}$ GAZETA DO RIO DE JANEIRO, 07/03/1818.

324 "Es werden darin vier, oder fünfmal wöchentlich Vorstellungen gegeben, welche abwechselnd in Lust, Schau und Trauerspielen in portugiesischer Sprache und in italienischen Opera nebst Balletten bestehen" (LEITHOLD, Theodor von. Op. cit., p. 24).

325 Joaquim de Vasconcelos atenta em sua já citada obra Os músicos portugueses, para a confusão que o termo "sinfonia" cria, na língua portuguesa: "Pode ser que este livro seja lido por algum estrangeiro, e que este ligue à palavra "Sinfonia" uma significação que 
divertimento: o "drama" - relativo quase sempre à tragédia, ou ação séria ou a "comédia", ambas peças recitadas e divididas em vários atos, às vezes entremeados com música. Por fim, encerrava-se o espetáculo com uma "farsa" ou "entremez", de menor duração, cômica - via de regra -, e, em muitos casos, musicada ou "ornada de música", como se costumava dizer. Esse tipo de espetáculo, mais variado, foi visto pelo dramaturgo Jacques Arago (1790-1855), quanto esse esteve pela primeira vez no Rio de Janeiro entre 1817 e 1818. Segundo o autor francês, naquela ocasião, foi à cena, com "belíssima decoração" a tragédia Zaíra, de Voltaire, seguida de uma comédia, intitulada $O$ usurário. Rematou o espetáculo uma farsa, um balé, "e outras duas ou três bagatelas desse gênero". Uma "muito bem executada" sinfonia de Haydn serviu de abertura ${ }^{326}$.

Em outros dias, representavam-se "dramas por música" — ou seja, "óperas" 327 -, quase sempre acompanhados, nos intervalos de algum de seus atos, de bailados, esses, muito apreciados. Tal programa ocorreu, por exemplo, nos natalícios de Dom João VI, em 1818, 1820 e 1821, conforme testemunhou a Gazeta do Rio de Janeiro:

\begin{abstract}
A noite se transportou Sua Majestade, acompanhado de SS. AA. RR. e real família ao Real Teatro de S. João, onde se ofereceu gratuitamente um agradável espetáculo. A
\end{abstract}

ela não tem em Portugal; aqui neste belo país, que em certas coisas é a pátria da confusão, chama-se Sinfonia indistintamente a uma Ouverture de Ópera, a uma Fantasia orquestrada, enfim a qualquer peça mais ou menos desenvolvida que tenha acompanhamento de orquestra; todas estas espécies entram na mesma classificação: é tudo Sinfonia!" (VASCONCELOS, Joaquim de. Op. cit., v. 1, p. 109-110).

326 "On donne Zaïre; une comédie intitulée l'Usurier; une farce, un ballet, et deux ou trois autres bagatelles de ce genre (...) Une symphonie d'Haydn sert d'ouverture: elle est fort bien exécutée. Le rideau se lève: la scène est immense, la décoration fort belle" (ARAGO, Jacques. Promenade autour du monde pendant les années 1817, 1818, 1819 et 1820, sur les corvettes du roi l'Uranie et la Physicienne, commandées par M. Freycinet. Paris: Leblanc, 1822, v. 1, p. 92).

${ }^{327}$ Note-se que as expressões "drama por música" ou mesmo "drama em música", encontradas nas publicações portuguesas e brasileiras da época, não são traduções de opera, mas das expressões italianas, também utilizadas na época, dramma per musica ou dramma in musica, sinônimos, mais especificamente, de opera seria, ópera com tema trágico ou heróico. Para o gênero cômico, a opera buffa, havia os sinônimos dramma giocoso per musica, ou, menos comumente, commedia per musica (Cf. THE New Grove Dictionary of Music and Musicians. London: Macmillan, 2001). 
chegada de Sua Majestade se deram repetidos e unânimes vivas, aos quais se seguiu um elogio alegórico, em que entravam Mercúrio, Amaltéa, Portugal e o Brasil, alusivo, assim, ao faustíssimo dia que se celebrava, como à gloriosa aclamação de Sua Majestade. Seguiuse o drama por música intitulado Coriolano com elegante cenário e rico vestuário. No intervalo do $1^{\circ}$ ao $2^{\circ}$ ato se executou um baile sério pantomimo em um ato intitulado o Prodígio da harmonia, ou o Triunfo do Brasil, inventado e dirigido pelo compositor do mesmo teatro, Luiz Lacombe, acompanhado de nova música, composta por Pedro Teixeira de Seixas ${ }^{328}$.

À noite, dignou-se EL-REI Nosso Senhor honrar
com a sua presença e a de sua real família o
Real Teatro de S. João, que nesta noite excedia
a tudo que ali se tem visto de riqueza e
elegância. (...) Depois de uma agradável
sinfonia, se representou um elogio dramático,
intitulado a Homenagem dos poetas, e, logo que
apareceu o Retrato de S. M. no Templo da
Glória, cantaram os músicos o hino nacional,
estando em pé SS. AA. RR. até findar o mesmo
elogio, o qual terminou com a repetição do
mesmo hino. Seguiu-se a representação do
Drama Aureliano em Palmira, com música do
célebre Rossini, e no intervalo do $1^{\circ}$ ao $2^{\circ}$ ato

${ }^{328}$ GAZETA DO RIO DE JANEIRO, 15/05/1818. Pedro Teixeira de Seixas, autor da música do Bailado, é hoje, assim como Bernardo José de Souza e Queirós, um nome esquecido pela história da música brasileira. Segundo a Enciclopédia da Música Brasileira, "Não se sabe ao certo se era brasileiro ou português, mas antes da chegada de D. João já atuava como músico no Brasil. A 5 de agosto de 1812 foi nomeado segundo violoncelo da Real Câmara. Regente do Real Teatro de São João, logo após sua abertura em 1813, em 1819 constava, ao lado do padre José Maurício Nunes Garcia e outros, como signatário da petição dirigida pela Irmandade de Santa Cecília ao soberano, pleiteando os mesmos favores concedidos à irmandade de Lisboa, Portugal. A 7 de agosto de 1822 foi admitido como músico da Capela Real. Como compositor, dele se conhecem a Missa em mi bemol ou Missa da coroação, além do bailado O Triunfo do amor" (MARCONDES, Marcos Antônio (ed.). Enciclopédia da música brasileira: popular, erudita e folclórica. São Paulo: Art Editora, 1998, p. 722). O nome de Pedro Teixeira consta entre os instrumentistas da Capela Imperial na Relação de membros desta instituição, do último quartel de 1828 , já transcrita em páginas anteriores. A 4 de julho de 1832, foi publicado no periódico O Brasileiro uma notícia relativa ao seu falecimento, o que nos leva a crer, pela linha editorial dessa folha, que o compositor não poderia ser senão brasileiro nato. Quanto ao "drama por música" intitulado Coriolano, deve ser Coriolano, o L'assedio di Roma, composição do italiano Giuseppe Niccolini (1762-1842), cuja estréia mundial ocorreu no Scala de Milão a 26/12/1808. 
se executou um novo baile intitulado Apelles e Campaspe ${ }^{329}$.

\begin{abstract}
SS. AA. RR. O PRÍNCIPE REGENTE e a PRINCESA REAL houveram por bem honrar com as suas augustas presenças o Real Teatro de S. João (...). Representou-se logo um elogio dramático, alusivo à saudade que SUA MAJESTADE deixava em todos os corações (...). A peça por música, Pamella nobile, composição de Generali, foi desempenhada pela Companhia Italiana; e no fim dela se fez uma elegante dança $a^{330}$.
\end{abstract}

Em razão de um fenômeno histórico ainda não muito bem explicado, a ópera, espetáculo de origem e tradição italiana, tornou-se, ao longo dos séculos XVIII e XIX, sinônimo do que de "melhor" — ou, pelo menos, de "mais bem-sucedido" - se fazia em termos de música no mundo ocidental ${ }^{331}$.

${ }^{329}$ GAZETA DO RIO DE JANEIRO, 15/05/1820.

330 Idem, 16/05/1821.

${ }^{331}$ Uma das hipóteses mais aventadas para explicar o sucesso alcançado pela ópera italiana em todo o mundo ocidental nos séculos XVIII e XIX reside na própria funcionalidade dessa música, mais dada a ser "passatempo" do que "arte", em seu sentido mais técnico ou intelectual. Sobre esses assunto, Nicholas Till, biógrafo do compositor Rossini, resume bem o que pensavam a respeito dessa música autores das primeiras décadas do século XIX: "... Stendhal acreditava que a paixão dos italianos pela ópera em particular devia-se 'ao pensamento lógico lhes ter sido negado pela igreja e pelo estado', e continuava com a sugestão de que as autoridades estimulavam ativamente a ópera, uma vez que, como destacou Antonio Gallenga, 'o efeito da música é imediato. Não exige qualquer atividade por parte da mente'. Pode-se rejeitar a generalização dessa afirmativa, mas no que concerne à música italiana ela tem uma certa verdade. 'A música para os italianos', escreveu Berlioz, 'é um prazer sensual e nada mais... Eles querem uma partitura que, como um prato de macarrões, possa ser assimilada imediatamente, sem que tenham que pensar a respeito ou sequer lhe dar qualquer atenção'" (TILL, Nicholas. Rossini. Tradução de Eduardo Francisco Alves. Rio de Janeiro: Ediouro, 1992, p. 27). No entanto, acreditamos que essa "facilidade" - e conseqüente sucesso - da ópera a partir de meados do século XVIIII seja mais uma decorrência das mudanças socioeconômicas operadas nesse período em grande parte da Europa, promovendo a ascensão burguesa de classes comerciais e industriais - e a aproximação dos monarcas desse grupo de novos ricos. Pois, intimamente vinculada, desde os seus primórdios no século XVII, à atividade de corte e à pompa monárquica, a ópera, como símbolo de um "bom gosto" nobre, acabou, aos poucos, sendo copiada pelos círculos burgueses em ascensão e cada vez mais difundida e aprimorada, ao longo do século XVIII, nos teatros públicos, onde, para entrar, bastava pagar. Estes espaços, por sua vez - na medida em que a expansão do setor monetário das economias européias enfraqueciam socialmente as nobrezas, enquanto que o poder das burguesias aumentava -, passaram a ser freqüentados pelos soberanos, despertando ainda maior curiosidade do público, interessado em ver não mais apenas um espetáculo copiado dos ambientes reais, mas o próprio rei, em pessoa, no seu grande 
Assim, os compositores de ópera, em sua maioria, italianos, dominaram a cena musical nas principais cidades européias, como Salieri, em Viena, Paisiello, em São Petersburgo, e Jommelli, em Lisboa. Mesmo autores não italianos acabavam também por compor à moda dos grandes mestres da Península, como foi o caso do germânico Mayer. Enfim, até os franceses, os mais aguerridos adversários do domínio musical italiano - vide a célebre Querelle des Bouffons ${ }^{332}$ —, nunca conseguiram se livrar totalmente dessa influência.

No Brasil, não foi diferente. Herdando-se aqui, desde o reinado de Dom João V, o grande entusiasmo português pelo drama cantado italiano, foi também, esse gênero, o supra-sumo dos espetáculos musicais e teatrais cariocas, sobretudo depois que a família real aqui chegou, e chamou ainda mais a atenção do público para esta diversão, ao passar a honrar o teatro com a sua régia presença. Como ocorrera no período dos Governadores e Vice-Reis, eram, também, as óperas, parte integrante praticamente obrigatória das "grandes galas" ${ }^{333}$. Por exemplo, passado o luto pelo

camarote. Nesse estágio de desenvolvimento, o espetáculo de ópera passa, então, a ser encarado como uma mera desculpa para um outro acontecimento que se passa nos camarotes: uma corte expandida, da qual os setores burgueses mais ricos, alguns adquirindo títulos nobiliárquicos, participam em pé de igualdade com a antiga nobreza. Daí a ópera, pelo seu caráter secundário, decorativo, não exigir mais "qualquer atividade por parte da mente" e obter tanto sucesso entre um público que ainda tinha muito a aprender em termos de "bom gosto".

${ }^{332}$ Polêmica histórica, ocorrida na França entre 1752 e 1754, quando a estada bem-sucedida de uma companhia italiana na ópera de Paris abriu espaço para uma ampla discussão sobre os rumos da música francesa, àquela época considerada superada, por intelectuais, como, por exemplo, o filósofo Jean-Jacques Rousseau.

${ }^{333}$ Os dias de "grande gala" misturavam aniversários principescos, dias santos e datas nacionais importantes. Segundo os já citados almanaques da época, eram 11, por exemplo, em 1817, (ainda durante o reinado de Dom João VI): Reis (06/01), primeira oitava da Páscoa, nascimento da Rainha (25/04), nascimento do Rei (13/05), procissão do Corpo de Deus, nome do Rei (24/06), nascimento da Princesa do Brasil, Dona Maria Francisca Benedita (15/07), nascimento do Príncipe Real, Dom Pedro de Alcântara (12/10), nome da Rainha (04/11), N. S. da Conceição (08/12) e primeira oitava do Natal (26/12). Já, dez anos depois, (no reinado de Dom Pedro I) aumentava-se para 16 o número de festividades de grande gala: Ano Novo (01/01), Reis (06/01), "Fico" (09/01), Juramento da Constituição (25/03), nascimento da Princesa Maria da Glória, Rainha de Portugal (04/04), primeira oitava da Páscoa, nascimento da Rainha Mãe (25/04), dia em que o Imperador aceitou o título de Defensor Perpétuo do Brasil (13/05), procissão do Corpo de Deus, Independência (07/09), aniversário do Imperador (12/10), nome do Imperador (19/10), Coroação (01/12), aniversário do Príncipe Imperial, Dom Pedro de Alcântara (02/12), N. S. da Conceição $(08 / 12)$ e primeira oitava do Natal (26/12). Ainda havia os chamados dias de "pequena gala" 
falecimento da Rainha, ocorrido a 20 de março de $1816^{334}$, quase todos os aniversários de Dom João VI foram comemorados com apresentações de óperas: La Vestale, de Puccita (1817), Coriolano, de Niccolini (1818), Aureliano in Palmira de Rossini (1820) e Pamela nubile, composição de Generali $(1821)^{335}$.

A freqüente e crescente encenação de óperas na Corte, impulsionada, a partir de 1818 pela coroação do $\operatorname{Rei}^{336}$, pelo já citado decreto das loterias de 30 de agosto de 1817 - e pelo interesse cada vez maior da sociedade em imitar os hábitos da realeza, ganha ainda mais fôlego nos anos seguintes, com a chegada de mais e mais cantores líricos estrangeiros, que formariam com os nativos e os aqui já radicados - João Francisco e Maria Teresa Fasciotti, João dos Reis, Vaccani, Geraldo Inácio etc. - uma companhia lírica tão atuante que gerou, em 1822, sérios problemas de divisão de espaço no Teatro de São João com a Companhia Nacional, formada apenas por

ou "simples gala", como, por exemplo, em 1817, o dia 7 de março (dia da chegada de Dom João ao Rio); e, em 1827, o dia 4 de outubro (dia de São Francisco, nome da princesa Dona Francisca Carolina).

334 "Tendo falecido no Rio de Janeiro a Rainha D. Maria I (...) os governadores do reino determinaram que houvesse luto durante um ano (...) e que durante esse ano estivessem fechados os teatros, derrogando assim o que determinava a lei vigente, que era a pragmática decretada por D. João V em 24 de maio de 1749" (BENEVIDES, Francisco da Fonseca. Op. cit., p. 110). A ausência de notícias sobre a atividade teatral na Gazeta do Rio de Janeiro entre meados de 1816 e 1817 nos faz presumir que o mesmo fechamento mencionado por Francisco da Fonseca Benevides, relativo ao São Carlos, de Lisboa, também deva ter ocorrido com o São João.

${ }^{335}$ Apesar de não ter constado do noticiário da Gazeta, certamente houve também ópera a 13 de maio de 1819 , pois, nesse mesmo ano, o alemão Theodor von Leithold garantiu terem sido levados "muito freqüentemente", no Rio, esses espetáculos, referindose, em especial, a Tancredi, ópera de Rossini, possivelmente a primeira desse célebre compositor italiano a ser encenada em terras brasileiras: "So gab man z. B. wahrend meines Aufenthalts daselbst, sehr oft die Oper Tancred..." (LEITHOLD, Theodor von. Op. cit., p. 25). O mesmo autor relata que durante os quatro meses em que permaneceu no Rio, não viu nenhuma vez o Rei ir ao teatro. No entanto, afirma que o monarca ali compareceu "ao menos em oportunidades cerimoniosas, como aniversários": “... und nur bei feierlichen Gelegenheiten, als Geburtstagen" (Ibidem, p. 127).

${ }_{336}$ Houve quem dissesse que o próprio Rei de Portugal teria, àquela época, financiado, "ao custo de uma fragata", a vinda de uma companhia de artistas italianos para o Rio de Janeiro. É o caso do norte-americano H. M. Brackenridge (1786-1871), que esteve nesse porto, em 1818, à época da coroação: "The king has imported a company of opera performers from Italy, at an expensive that would build a frigate. Several of our officers attended the theatre, and spoke highly of their performance" (BRACKENRIDGE, Henry Marie. Voyage to South America: performed by order of the American government, in the years 1817 and 1818, in the frigate Congress. Baltimore: John D. Toy, 1819, v. 1, p. 145). 
atores dramáticos ${ }^{337}$. Entre os novos artistas, quase todos italianos, chegados entre 1819 e 1821, figuraram Caetano e Isabel Ricciolini, os vários membros da família Piacentini - Justina, Carolina, Elisa e Fabrício ${ }^{338}$-, Salvador Salvatori, Nicolau Majoranini e o espanhol Paulo Rosquellas. Esse último, além de ser considerado na Europa um "violinista sem rival" ${ }^{339}$, era compositor, baixo e agente musical, tornando-se um dos representantes da Companhia Italiana na comissão criada em 1822 para dirimir a querela com a Companhia Nacional. Parte desses artistas estrangeiros - inclusive Rosquellas - só deixariam a efervescente temporada lírica carioca, em 1824, quando um incêndio, suspeitosamente ocorrido a 25 de março, dia do Juramento da Constituição, destruiu o Teatro de São João ${ }^{340}$.

${ }^{337}$ A querela envolvendo os cantores da Companhia Italiana com os atores da Companhia Nacional, chegou a exigir até que, a 22 de maio de 1822, o então Ministro José Bonifácio, a pedido do próprio Dom Pedro, baixasse um ato administrativo nomeando uma comissão, composta pelo administrador do teatro e três componentes das companhias, para que, debaixo da presidência do Intendente Geral da Polícia, promovesse "os meios de conciliar assim os interesses do mesmo teatro, e das companhias Nacional e Italiana (COLEÇÃO das Leis do Brasil de 1822. Decisões de 1822. Rio de Janeiro, Imprensa Nacional, 1887, p. 36-37). Sobre esse assunto, ver ainda SOUZA, J. Galante de. Op. cit., v. 1, p. 165-166 e ANDRADE, Ayres. Op. cit., v. 1, p. 120-121.

${ }^{338}$ Encontramos uma única informação a respeito de Fabrizio Piacentini, anterior a sua estada no Rio de Janeiro. Segundo um libreto publicado na Itália, em 1808, o cantor se achava naquele ano, cantando no Teatro di Santa Radegonda, em Milão (Cf. FOPPA, Giuseppe Maria. L' amico dell'uomo, commedia di sentimento in musica da rappresentarsi nel Teatro in Santa Radegonda la state del 1808. Milano: dai torchi Dova, 1808). Tal documento se acha tombado na Biblioteca del Conservatorio di musica Giuseppe Verdi, sob o código ITIICCUIDEI03042401776.

339 "ROSQUELLAS, D. Pablo: natural de Madrid. Juró plaza de cuarto viola de la Real Capilla á 28 de Marzo de 1805; después fue violín de Cámara de S. M., habiéndonos asegurado personas competentes en la música, que Rosquellas no tenia rival en Europa como violinista. Se fue á Rio Janeiro con motivo de la guerra de la Independencia, de donde no quiso volver, y en cuya ciudad es probable que falleciera, à pesar de las instancias que de la corte de España le hacían para que regresara á ella (...) Este gran violinista estaba en 1803 de violín primero en el palacio del Exemo. Señor Duque de Medinaceli, con 16 reales diarios" (Cf. SALDONI Y REMENDO, Baltasar. Diccionario biográfico-bibliográfico de efemérides de músicos españoles. Madrid: Perez Dubrull, 1881 Tomos III-IV). Em seu diário, Maria Graham cita esse músico como "favorito" e "conhecido em ambos os lados do Atlântico": "Having settled every body comfortably, I went ashore to the opera, as it is the benefit night of a favourite musician, Rosquellas, whose name is known on both sides of the Atlantic" (GRAHAM, Maria. Op. cit., p. 173).

${ }^{340}$ Para John Armitage, o incêndio foi categoricamente empreendido como parte de um plano de atentado contra a vida de Dom Pedro I: "In the evening the royal family attended the Theatre. It had been the design of the conspirators against the life of His Majesty, to set fire to the house during the performance, and to assassinate him in the confusion expected to ensue. This plan, however, proved abortive, the Emperor being happily rescued in the beginning of the tumult, without even being aware of the imminence 
Ainda que tenha ocorrido esse infeliz acontecimento - fortuito ou provocado - , o proprietário Fernando José de Almeida decidiu rapidamente reconstruir o grande teatro, o que reforça a idéia - como ainda veremos melhor no capítulo seguinte -, oposta ao que até hoje a historiografia tem validado, de que um movimento musical e teatral em plena ascensão sucedeu durante o primeiro reinado.

Como as estruturas e paredes principais do São João resistiram ao sinistro, o projeto do novo teatro manteve praticamente os mesmos moldes do anterior. Uma vez que a obra duraria pelo menos dois anos e não havia, a esta altura, mais nenhuma outra sala de espetáculos na Corte ${ }^{341}$, ajustou-se, em poucos meses, um pequeno espaço de representações no saguão do antigo. Tal auditório improvisado e o processo de reconstrução do novo

of his danger" (ARMITAGE, John. Op. cit., v. 2, p. 146). O último volume da versão portuguesa aumentada da Histoire du Brésil de Beauchamp, atribuída a Pedro Ciríaco da Silva e Antônio Cândido Cordeiro Pinheiro Furtado é, no entanto, bastante comedida em relação a esse assunto: "Não avançaremos conjecturas sobre a causal do sucesso; uns atribuem ao acaso, outros o dão como prematuro desenvolvimento de uma conjuração, cujo objeto era acabar com o Imperador, e com toda a sua família, e firmar a República; porém como estas são meras hipóteses, e o historiador só deve apresentar como exato aquilo de que possa produzir provas cabais, apontaremos esses rumores vagos sem os darmos como positivos" (HISTÓRIA do Brasil desde 1807 até ao presente: originalmente composta em português para servir de continuação à que se publicou vertida do francês. Lisboa: Tip. de Desidério Marques Leão, 1834, t. 12, p. 154). Enfim, a historiografia mais recente não leva muito à letra a hipótese do atentado. Para Pedro Octávio Carneiro da Cunha, por exemplo, "O incêndio do teatro, a 25 de março, mas depois que Dom Pedro se retirara, não merece mais do que a nota de estranha coincidência" (HOLANDA, Sérgio Buarque de (org.). Op. cit., 1985, v. 3, p. 379).

${ }^{341} \mathrm{O}$ velho teatro de Manuel Luiz já se havia transformado em um anexo do Paço, e os dois teatros particulares, fundados no Rossio e na rua de São Pedro, tinham encerrado suas atividades depois da publicação do já citado decreto de 30 de agosto de 1817, que dava exclusividade de trabalhos cênicos, por 10 anos, ao São João. A atividade desses dois teatrinhos pode ser constatada em uma mesma edição da Gazeta do Rio de Janeiro, de 16/07/1817. A proibição, contudo, não durou dez anos, como previa o decreto real. A 25 de janeiro de 1823, apesar de garantidas vantagens aos trabalhos do São João, teve permissão imperial para abrir suas portas, um teatrinho particular situado na mesma Praça da Constituição: "S. M. o Imperador, deferindo benignamente a súplica que levaram à sua augusta presença os sócios da Companhia do Teatro particular da Praça da Constituição; manda, pela Secretaria de Estado dos Negócios do Império, participar ao Intendente Geral da Polícia, para sua inteligência, que há por bem conceder faculdade, para que possam dar espetáculo duas vezes cada mês, contanto que nunca o façam em noites de representação do teatro de S. João, ainda sendo em dias de gala" (COLEÇÃO das Leis do Brasil de 1823. Decisões de 1823. Rio de Janeiro, Imprensa Nacional, 1887, p. 6-7) Essa casa, que segundo Henrique Marinho ficaria conhecida como "Teatro do Plácido" teve, no entanto, curta existência (MARINHO, Henrique. O teatro brasileiro. Alguns apontamentos para a sua história. Rio de Janeiro: H. Garnier, 1904, p. 52). 
teatro, que passaria a chamar-se, por decreto de 15 de setembro de $1824^{342}$, Imperial Teatro de São Pedro de Alcântara, foram assunto de destaque para o mercenário teutônico e Oficial do Exército Imperial Carl Schlichthorst, que esteve no Rio de Janeiro entre 1825 e 1826 :

O Imperial Teatro de São Pedro de Alcântara
pegou fogo há cerca de um ano e meio e ainda
não foi completamente reconstruído.
Entrementes, representa-se numa grande sala
do mesmo prédio, a qual possui duas filas de
camarotes e uma platéia não elevada, que
comporta apenas algumas centenas de
espectadores (...) A restauração do grande
teatro tem sido realizada com muito zelo ...

Com a exploração de várias loterias ${ }^{344}$ e novos favores pecuniários concedidos pelo Governo por intermédio do Banco do Brasil ${ }^{345}$, Fernando

342 "Atendendo ao que me representou o Coronel Fernando José de Almeida, pedindo-me a permissão de dar ao Teatro, de que é proprietário e que atualmente está reedificando, o título de Imperial Teatro de S. Pedro de Alcântara; Hei por bem ConcederIhe a referida permissão para que tenha o mesmo teatro de agora em diante o referido título. Paço em 15 de setembro de $1824,3^{\circ}$ da Independência e do Império. Com a rubrica de Sua Majestade Imperial" (COLEÇÃO das Leis do Brasil de 1824. Decretos, Cartas Imperiais e Alvarás de 1824. Rio de Janeiro: Imprensa Nacional, 1886, p. 63-64).

343 Tradução nossa de: "Das kaiserliche Theater San Pedro de Alcantare war vor ungefähr anderthalb Jahren abgebrannt und noch nicht ganz wieder aufgebauet. Man spielte unterdessen in einem großen Saale desselben Gebäudes, welcher zwei Logenreihen und ein nicht erhöhtes parterre enthält und überhaupt nur einige hundert Zuschauer faßt. (...) der Wiederherstellung des großen Theaters wurde mit vielem Eifer gearbeitet ..." (SCHLICHTHORST, Carl. Op. cit., p. 79).

${ }_{344}$ Três loterias extraordinárias, com fundo de até 120 contos de réis cada uma, foram concedidas pelo decreto imperial de 26 de agosto de 1824, que, além disso, dispunha também acerca de outros benefícios, dados ao proprietário do teatro para que esse o reedificasse (COLEÇÃO das Leis do Brasil de 1824. Decretos, Cartas Imperiais e Alvarás de 1824. Rio de Janeiro: Imprensa Nacional, 1886, p. 54-55). A primeira loteria extraordinária em benefício das obras do Teatro de São Pedro de Alcântara andou à roda entre 10 e 14 de janeiro de 1825. A segunda foi extraída entre 11 e 15 de abril, e a terceira, entre 27 de junho e 2 de julho do mesmo ano. A Divisão de Obras Raras da Biblioteca Nacional do Rio de Janeiro guarda em seu acervo as listas gerais dos prêmios relativos a essas loterias $\left(088,05,11 n^{\circ} 8\right.$ e 99D, 22, 12). Não sendo suficientes para a reconstrução, novo decreto foi baixado a 4 de julho de 1825 , concedendo a Fernando José de Almeida mais seis loterias (COLEÇÃO de Decretos, Cartas Imperiais e Alvarás do Império do Brasil de 1825. Rio de Janeiro: Imprensa Nacional, 1885, p. 64-65).

${ }^{345}$ Não era a primeira vez que o Banco do Brasil financiava o teatro a pedido de Dom Pedro I, emprestando dinheiro ou deixando de cobrar dívidas passadas. Em 26 de dezembro de 1822, por exemplo, José Bonifácio despachava um decreto obrigando ao Banco fazer entender e cumprir o desejo do Imperador em ajudar Fernando José de 
José de Almeida conseguiu, em menos de dois anos, reabrir o novo teatro, que, mesmo inacabado ${ }^{346}$, causou excelentes impressões aos que o viram, logo em 1826. Para o chevalier francês Alcide d'Orbigny (1802-1857), que esteve de passagem pelo Rio naquele ano, o São Pedro foi definido como "um grande edifício de um estilo uniforme, de acordo com o gosto moderno, aliás, muito bem decorado"347. Hyacinthe Yves Philippe Potentier, capitaine de vaisseau e Baron de Bougainville (1781-1846), que presenciou a reinauguração do teatro logo que terminou a quaresma de 1826 - mais precisamente a 4 de abril, dia do aniversário da Princesa Dona Maria da Glória $^{348}$ - também não Ihe poupou elogios:

\begin{abstract}
A sala de espetáculo é muito bela, e pode comportar de 1600 a 1800 pessoas: a forma é a de uma lira, cujas extremidades, ligeiramente recurvadas, abraçam o palco; disposição favorável para os espectadores, que não perdem nada de vista de qualquer lugar em que estejam sentados... ${ }^{349}$
\end{abstract}

Almeida (COLEÇÃO das Leis do Império do Brasil de 1822. Decretos, Cartas e Alvarás de 1822. Rio de Janeiro: Imprensa Nacional, 1887, p. 105-106).

${ }^{346} \mathrm{O}$ decreto imperial de $1^{\circ}$ de setembro de 1828 prova que, passados mais de quatro anos do incêndio, o teatro ainda não havia sido totalmente reedificado: "... Hei por bem conceder-Ihe três loterias do fundo, que Eu houver por bem aprovar, e que se extrairão em seguimento das que Ihe têm sido concedidas, devendo o dito proprietário concluir sem demora a parte, que ainda falta para completar a reedificação do mesmo teatro a que está obrigado" (COLEÇÃO das Leis do Império do Brasil de 1828. Rio de Janeiro: Imprensa Nacional, 1878, parte 2, p. 133).

${ }^{347}$ Tradução nossa de: "La salle de spectacle est un grand bâtiment d'un style uni, dans le goût moderne, d'ailleurs assez bien décoré ..." (ORBIGNY, Alcide Dessalines d'. Voyage dans l'Amérique Méridionale: le Brésil, la République Orientale de l'Uruguay, la République Argentine, la Patagonie, la République du Chili, la République de Bolivia, la République du Pérou, exécuté pendant les années 1826, 1827, 1828, 1829, 1830, 1831, 1832 et 1833. Paris: Pitois-Levrault, 1835, v. 1, p. 26). Note-se que outro francês, o rico viajante e membro da Société de Géographie de Paris, Jean-Baptiste Douville (1794-1837), que esteve no Rio de Janeiro em 1827, reprovou a acústica da sala: "Le théâtre est grand et bien disposé, mais il est peu favorable pour le son de la voix, qui se perd facilement" (DOUVILLE, Jean-Baptiste. 30 mois de ma vie avant et après mon voyage au Congo, ou ma justification des infamies débitées contre moi; suivie de détails nouveaux et curieux sur les moeurs et les usages des habitants du Brésil et de Buenos-Ayres, et d'une description de la colonie Patagonia. Paris: l'auteur, 1833, p. 237).

${ }^{348} \mathrm{Na}$ realidade, já havia ocorrido uma "pré-inauguração" desse teatro a 22 de janeiro de 1826, dia do aniversário da Imperatriz, Dona Leopoldina, conforme nos testemunha o Diário Fluminense (Apud ANDRADE, Ayres de. Op. cit., v.1, p. 187).

${ }^{349}$ Tradução nossa de: "La salle de spectacle est fort belle, et peut contenir de seize à dix-huit cents personnes: la forme est celle d'une lyre, dont ses extrémités, 
Nesse ano, segundo Ayres de Andrade ${ }^{350}$, novos cantores estrangeiros - entre os quais o tenor Vítor (Vittorio) Isotta - se apresentaram no São Pedro de Alcântara, e nove títulos diferentes de óperas foram à cena, sem contar as diversas repetições. É bem provável, entretanto, que essa temporada tenha sido ainda mais movimentada. Como sempre, as referências de Andrade se limitam aos principais jornais da época - o Diário do Rio de Janeiro, o Diário fluminense e, a partir de 1827, o Jornal do comércio -, e, aliás, esses periódicos muito raramente anunciavam aquilo que se denominava "récitas gerais", ou seja, aquelas que não fossem as dos dias santos, de gala, ou de benefício em favor de algum artista da Companhia Italiana. O testemunho, mais uma vez de Carl Schlichthorst, além de nos permitir incluir nessa estatística uma ópera não mencionada por Andrade Semiramide, de Rossini - enfatiza que esse tipo de espetáculo foi ao palco "até o fastio" naquele singular ano de $1826^{351}$ :

... via de regra, as óperas são cantadas em italiano e repetidas, como na Itália, freqüentemente. Assiste-se, até 0 fastio, Tancredi, Aureliano in Palmira e Semiramide ${ }^{352}$.

Schlichthorst achou também a orquestra do teatro "completa e boa,

légèrement recourbées, embrassent la scène; disposition favorable pour les spectateurs, qui ne perdent rien du coup d'oeil quelque part qu'ils soient placés..." (BOUGAINVILLE, Hyacinthe Yves Philippe Potentien, Baron de. Journal de la navigation autour du globe: de la frégate La Thétis et de la corvette L'Esperance pendant les années 1824, 1825 et 1826. Paris: Arthus Bertrand, 1837, t. 1, p. 612).

350 Ibidem, p. 189.

351 Note-se que os habitantes do Rio de Janeiro presenciaram, no ano de 1826, uma singularidade propícia à atividade social e, conseqüentemente, teatral: com a morte de Dom João VI, a aclamação de Dom Pedro I como Pedro IV de Portugal, e a sua posterior abdicação em sua filha, Dona Maria da Glória, a corte carioca passou a contar, a partir de 2 de maio desse ano, com a presença de nada menos do que dois soberanos.

${ }_{352}$ Tradução nossa de: "Die Opern werden in der Regel italienisch gegeben und wie in Italien häufig wiederholt; Tancred, Aurelian in Palmira, Semiramis sieht man bis zum Überdruß" (SCHLICHTHORST, Carl. Op. cit., p. 153). De fato, as apresentações de ópera eram bastante repetidas. Um ano depois, em 1827, o jornal L'écho de L'Amérique du Sud noticia, por exemplo, que no dia 17 de julho, teria sido realizada a trigésima apresentação de Aureliano in Palmira: "Le spectacle se composait de la trentième représentation de I'Aureliano in Palmira..." (L'ÉCHO DE L'AMÉRIQUE DU SUD, 18/07/1827). 
podendo conter, nas grandes óperas, cerca de cem músicos" 353 . Mais uma informação nova - quanto ao número expressivo de executantes - e outro testemunho de que, também no teatro do Rio de Janeiro, o nível musical ao menos da orquestra - era bom, como Freycinet já havia registrado alguns anos antes, ao declarar que "apesar do fraco desempenho dos atores, distinguiam-se, ali, na música instrumental, alguns notáveis talentos" ${ }^{354}$.

Mesmo com a morte da Imperatriz, Dona Leopoldina, uma guerra em curso com as Províncias Unidas do Rio da Prata - que gerou um déficit ainda maior nas já arruinadas finanças públicas ${ }^{355}$ - e crescentes desavenças políticas entre o Imperador e a Câmara dos Deputados ${ }^{356}$, a

353 "Das Orchester ist vollständig und gut; bei großen Opern mag ungefähr 100 musici enthalten" (SCHLICHTHORST, Carl. Op. cit., p. 151).

354 "... les acteurs, il est vrai, sont pour la plupart fort médiocres; ils jouent alternativement des pièces portugaises, françaises et italiennes, opéras, tragédies, comédies, ballets, \&c. Dans la musique instrumentale, il y a cependant des talents distingués" (FREYCINET, Louis Claude Desaulces de. Op cit., v. 1, p. 212). Não é, no entanto, unânime esta opinião. Críticas negativas à música executada no teatro carioca também existem, como, por exemplo, a de von Leithold, que afirmou ter assistido, em 1819, à ópera Tancredi, de Rossini, mutilada e arruinada por uma má orquestra: "... so jämmerlich ward sie verstümmelt und durch ein schlechtes orchester verhunzt". Leithold ainda garantiu, mais adiante, que a orquestra era "miserável" e que apenas um flautista francês, e um violoncelista haviam chamado a sua atenção: "Das Orchester ist sehr schwach befaßt, mit einem Worte - elend; nur ein Flötenspieler, ein Franzose, und ein Violoncellist erregten meine Aufmerksamkeit" (LEITHOLD, Theodor von. Op. cit., p. 25-26). Quase dez anos depois, o botânico francês Victor Jacquemont (1801-1832) registra uma mesma impressão de que todo o espetáculo era "lamentável": "II n'y a d'autre théâtre que l'Opéra italien, terminé par un exécrable ballet, qui est toujours la partie la plus goûtée de la représentation. J'y ai vu I'Italiana in Algeri; orchestre, chanteurs, spectacle, tout était pitoyable" (JACQUEMONT, Victor. Voyage dans I'Inde. Paris: Firmin Didot, 1841, v. 1, p. 57). Nessa mesma direção, lembremos ainda Spix e Martius, que, durante sua estada (1817-1821), julgaram a ópera italiana, ainda "imperfeita", tanto do ponto de vista dos cantores, como da orquestra: "Die italienische Oper hat bis jetzt, weder von Seite der Sänger noch des Orchesters, etwas Vollkommenes aufzuweisen" (SPIX, Johann Baptist von; MARTIUS, Karl Friedrich Philip von. Op. cit., v. 1, p. 105). Já, as críticas musicais que nos chegaram, publicadas em alguns jornais cariocas dessa época - sobretudo $O$ espectador brasileiro (1824-1827), Astrea (1826-1832), Gazeta do Brasil (1827-1828) e O espelho diamantino (1827-1828) —, ora dão razão a Leithold e Jacquemont, ora corroboram a opinião de Schlichthorst e Freycinet. Quanto a esses últimos periódicos, vide GIRON, Luís Antônio. Op. cit., p. 72-102.

${ }^{355} \mathrm{O}$ déficit das contas públicas, que estava na casa dos 3.600 contos de réis, em 1824 e 1825, saltou para cerca de 5.000 em 1826 e 1827, e quase 11.000 em 1828 (Cf. ANUÁRIO estatístico do Brasil. Rio de Janeiro: IBGE, 1939/1940, v. 5, p. 1410; CARREIRA, Liberato de Castro. História financeira e orçamentária do Império do Brasil desde a sua fundação. Brasília: Senado Federal, 1980, v. 1).

356 "A câmara dos deputados de 1826 foi, como devia ser, tímida. A dissolução da Constituinte e as violências do poder eram disso a causa. Em 1827 e 1828 a câmara começou a tomar alento. Em 1829, quando cheguei ao Rio de Janeiro achava-se 
atividade musical no Teatro não encontrou grandes obstáculos nos anos seguintes. Segundo Ayres de Andrade - com a mesma ressalva anterior à pesquisa desse autor - , em 1827, foram à cena quatorze títulos diferentes de óperas, com destaque para a estréia muito bem aceita da cantora Elisa Barbieri, interpretando L'italiana in Algeri, de Rossini ${ }^{357}$. Em 1828, foram apresentados nove títulos diversos, entre os quais, o primeiro, no Rio, de Gaetano Donizetti: L'Aio nell'Imbarazzo, ópera estreada mundialmente no Teatro Valle, de Roma, em 1824.

O viajante francês Victor Jacquemont, apesar dos comentários maliciosos e preconceituosos em relação a tudo o que viu, quando da sua rápida passagem pela capital brasileira, entre outubro e novembro de 1828 , nos deixou em seus escritos algumas importantes referências sobre a atividade teatral daquele final de ano. Primeiramente, confirma - como Schlichthorst já deixara claro dois anos antes - a grande assiduidade das apresentações operísticas:

Há no Rio um bom teatro, onde uma detestável companhia italiana, com uma orquestra mais execrável ainda, esfola três vezes por semana as obras de Rossini ${ }^{358}$.

Depois, testemunha outra assiduidade - a do público no teatro comentando que, apesar de "muito grande", esse estava "repleto" em uma ocasião em que ouviu L'italiana in Algeri ${ }^{359}$. Em seguida, tece uma minuciosa

funcionando já com certa liberdade a Assembléia Legislativa. A chegada de José Bonifácio contribuiu para reanimar os ânimos. A sessão de 1829 já foi exigente, principalmente no que dizia respeito ao melhoramento da administração financeira" (DRUMMOND, Antônio de Meneses Vasconcelos de. Op. cit., v. 13, p. 189).

357 O sucesso dessa cantora francesa foi tanto que, de seu début, a 21 de setembro de 1827, ao começo do mês de novembro - portanto em pouco mais de um mês -, ela já havia encenado doze vezes L'italiana in Algeri (L'ÉCHO DE L'AMÉRIQUE DU SUD, 03/11/1827).

358 Tradução nossa de: "Il y a à Rio un beau théâtre, ou une détestable troupe italienne, avec un orchestre plus exécrable encore, écorche trois fois par semaine les ouvrages de Rossini" (JACQUEMONT, Victor. Correspondance inédite de Victor Jacquemont avec sa famille et ses amis - 1824-1832. Paris: Librairie de H. Fournier, 1835, v. 1, p. 4559 .

$555^{\circ}$ "... cependant la salle était remplie, et elle est fort grande" (JACQUEMONT, 
e picante descrição social vinculada a este divertimento:

O público parecia entediar-se bastante (...). As mulheres, muito ornadas de enfeites, os homens muito arrumados, todos cobertos de condecorações, acima de 15 a 16 anos, tomando $\mathrm{o}$ ar desdenhoso e exagerado dos dândis de Regent's Street. Eu creio que tudo o que se chama no Rio de "boa companhia" tem camarote na Ópera. O Imperador é lá muito assíduo, porque as dançarinas e figurantes são muito de seu gosto, sem prejuízo das belas damas. Durante a representação, a praça do Teatro fica coberta de seges, nas quais vieram de suas chácaras todos os espectadores dos camarotes; desprendem-se as mulas, que pastam o ralo e poeirento capim, que cresce aqui e ali sobre a praça; os cocheiros dormem por perto ou jogam entre eles e se embriagam. Daí, algumas cenas de desordem, até que, às 11 horas, os patrões, saindo do teatro, não encontram os carros prontos e percebem que seus criados estão, algumas vezes, muito bêbados para os conduzir pela noite, no breu, às suas residências, afastadas geralmente uma a duas léguas. A praça, durante a representação, tem o ar de um acampamento. Há ali não menos do que trezentos ou quatrocentos carros e um milheiro de mulas ou cavalos, mais algumas centenas de negros domésticos. Tudo isso é necessário para o prazer de duzentas ou trezentas famílias. Se ao menos elas se divertissem! A platéia da Ópera, no Rio, me pareceu composta dessa classe burguesa de cor decididamente branca, que aqui exerce os empregos de médico, advogado, e que ocupa os cargos secundários e subalternos da administração. Procurei, em vão, ali, algumas figuras de cor; elas teriam o direito de aparecer ali, mas é provável que fossem mal acolhidas. Pois, é pouca coisa, no Rio, ter para

Victor. Op. cit., 1841, v. 1, p. 57-58). A esse respeito, o também francês e já mencionado Jean-Baptiste Douville dá o mesmo testemunho em relação à freqüência com que o público ia ao teatro, um ano antes (em 1827): "Le théâtre est grand (...) Malgré la chaleur, la salle est ordinairement remplie" (DOUVILLE, Jean-Baptiste. Op. cit., p. 237) 
si o direito legal quando se tem contra si a opinião geral ${ }^{360}$.

\author{
Apesar de nem o capim do velho Rossio - agora Praça da \\ Constituição - escapar aos adjetivos ferinos de Jacquemont, esse parece \\ ser um retrato mais ou menos fiel ${ }^{361}$ do que um espetáculo teatral significava
}

${ }^{360}$ Tradução nossa de: "Le public paraissait s'ennuyer beaucoup. (...) Les femmes parées; les hommes très habillés, tous couverts de plaques, au-dessus de l'âge de 15 à 16 ans, prenaient l'air dédaigneux et excédé des dandys de Regent's street. Je crois que tout ce qu'on appelle à Rio la bonne compagnie a loge à l'Opéra. L'Empereur y est très assidu, parce que les danseuses et les figurantes sont fort de son goût, sans préjudice des belles dames. Pendant la représentation, la place du Théâtre est couverte de chaises de poste, dans lesquelles sont venus de leurs villa tous les spectateurs des loges; on dételle les mules, que broutent le peu d'herbe poudreuse qui croit çà et là sur la place; les postillons dorment auprès, ou jouent entre eux et s'enivrent. De la des scènes de désordre, quand, à 11 heures, les maîtres, sortant du théâtre, ne trouvent pas leurs voitures attelées, et que leurs gens sont quelquefois trop ivres pour les conduire la nuit, dans l'obscurité, à leurs demeures, éloignées généralement d'une ou deux lieues. La place, pendant la représentation, a l'air d'un camp. II n'y a pas moins de trois à quatre cents voitures et d'un millier de mules ou chevaux, outre quelques centaines de Noirs domestiques. Tout cela est nécessaire au plaisir de deux ou trois cents familles. Si encore elles s'amusaient! Le parterre de l'Opéra, à Rio, m'a paru composé de cette classe bourgeoise de couleur décidément blanche, qui exerce les emplois de médecin, d'avocat, et qui occupe les places secondaires et subalternes de l'administration. J'y ai cherché vainement quelques figures de gens de couleur: elles auraient le droit d'y paraître; mais il est probable qu'elles y seraient mal accueillies. Car c'est peu de chose à Rio que d'avoir pour soi le droit légal, quand on a contre soi l'opinion générale" (JACQUEMONT, Victor. Op. cit., 1841, v. 1, p. 57$58)$.

${ }^{361}$ Note-se, a respeito do último item da descrição de Jacquemont - a presença de pessoas de cor no teatro - , uma divergência em relação aos relatos de outros quatro viajantes que estiveram no Rio em épocas anteriores e posteriores: o oficial da marinha russa Otto von Kotzbue (1823), o médico da Marinha norte-americana William Ruschenberger (1831); o também norte-americano, Capitão George Coggeshall (1838); e, enfim, o viajante francês Charles Hubert Lavollée (1844). Kotzbue afirmou em seu livro Neue Reise um die Welt in den Jahren 1823, 24, 25 und 26 que a "platéia permitia uma impressionante vista das mais diversas tonalidades de pele, graduando do preto ao branco, com uma predominância das tonalidades mais escuras": "Das Parterre gewährt einen auffallenden Anblick mit seinen, nach allen Abstufungen vom Schwarzen bis ins Weiße gefärbten Gesichtern, worunter doch die dunkeln Tinten bei weitem überwiegend find" (KOTZEBUE, Otto von. Neue Reise um die Welt in den Jahren 1823, 24, 25 und 26. Weimar: Wilhelm Hoffmann, 1830, p. 32). Ruschenberger também localizou na platéia do teatro "negros e brancos promiscuamente misturados": " $\ldots$ in the pit; negroes and whites were promiscuously mixed"; e, na mesma noite em que compareceu ao teatro, viu pretos e brancos em um café, "alegres e barulhentos, comendo e bebendo juntos, aparentemente na mais íntima condição de igualdade": "This over, we walked into the coffee room. Blacks and whites were gay and noisy, eating and drinking together, apparently on the most intimate terms of equality" (RUSCHENBERGER, W. S. W. Three years in the Pacific: including notices of Brazil, Chile, Bolivia, and Peru. Philadelphia: Carey, Lea \& Blanchard, 1834, p. 43). Coggeshall, por sua vez, viu também, no teatro, "as mais variadas cores, misturadas em perfeita harmonia", só que, desta vez, nos camarotes de primeira ordem: “... in the first boxes in the theatre, I have seen every variety of color, mixed up in perfect harmony..." 
para aqueles que o freqüentavam no Rio de Janeiro das primeiras décadas do século XIX. Assim como ocorria nos principais teatros de ópera do mundo ${ }^{362}$, o divertimento, em si, estava nitidamente em último plano. O oficial

(COGGESHALL, George. Second series of voyages to various parts of the world, made between the years 1802 and 1841. New York: D. Appleton \& company, 1852, p. 303); Enfim, Lavollée afirmou que "todas as raças eram admitidas no teatro", e que "essa mistura, aceita pelos brancos - essa "igualdade momentaneamente tolerada" - , oferecia um "curioso espetáculo" de "mestiços ricos, crendo se vingar do desprezo que sua cor causava através do luxo extravagante de seus enfeites e jóias": "... toutes les races y sont admises, et les riches métisses croient se venger du mépris qui frappe leur couleur par le luxe extravagant de leur parure, par l'or et les bijoux qui scintillent sur leur peau cuivrée. Ce mélange accepté par les blancs, cette égalité de la richesse un instant tolérée présentent un curieux spectacle" (LAVOLLÉE, Charles Hubert. Voyage en Chine - Teneriffe - Rio Janeiro - Le Cap - Ile Bourbon - Malacca - Singapore - Manille - Macao - Canton - Ports chinois. Paris: Just Rovier \& a Ledoyen, 1852, p. 24-25). É bem possível, pois, que, sob esse aspecto, Kotzbue, Ruschenberger, Coggeshall e Lavollée nos tenham deixado testemunhos mais concernente à realidade. Afinal, mestiços de negros e brancos cada vez mais conquistavam espaços na sociedade. Um texto pouco conhecido, publicado alguns anos mais tarde (1847), em Paris, pela Société de Géographie, ilustra bem o avanço social dos mulatos no Brasil ao longo da primeira metade do século XIX: "Les mulâtres provenant des blancs et des nègres, ou des mulâtres eux-mêmes, sont des hommes quelquefois très distingués. Au Brésil, dans toutes les classes de la société, parmi les jurisconsultes ainsi que parmi les médecins, chez les hommes qui s'occupent de la politique du pays comme chez les hommes de lettres, on remarque des mulâtres d'un talent, d'un esprit, d'une perspicacité et d'une instruction qui leur donnent beaucoup d'importance et d'ascendant. Pour les beaux-arts, par exemple, je crois que les mulâtres ont plus de disposition que les autres hommes: les meilleurs musiciens que nous ayons eus au Brésil ont été des mulâtres. Des peintres, des orateurs, des poètes distingués ne sont pas rares parmi eux. Grâce à ces preuves incontestables de capacité et de distinction; un grand nombre d'hommes de couleur se trouvent maintenant admis dans la meilleure société de Rio Janeiro. (LISBOA, M. P. A. de. Notes sur la race noire et la race mulâtre au Brésil. Nouvelles annales des voyages et des sciences géographiques. Paris: Arthur Bertrand, t. 2, p. 65-66, 1847).

${ }_{362}$ Sobre os espetáculos realizados no mais importante teatro de ópera do mundo, o Scala, de Milão, Nicolas Till, com base em depoimentos de autores oitocentistas, traçaIhes um rápido perfil: "Em seus camarotes as pessoas podiam, como observou Byron, conversar, jogar cartas, 'ou qualquer outra coisa', e Samuel Rogers, o poeta inglês que chegou a Milão em 1814, notou que, nos camarotes, 'às vezes as cortinas estão cerradas e pode-se imaginar o que se quiser'. A atividade social na ópera era de fato tão intensa que dificilmente se poderia prestar muita atenção no que ocorria sobre o palco. Stendhal escreveu que 'o silêncio só é observado nas estréias ou, durante as récitas subseqüentes, somente quando uma ou outra das passagens mais memoráveis está sendo executada. Quem quiser se concentrar em assistir à ópera do início ao fim, vai procurar um lugar na platéia'. (...) O compositor alemão Spohr conta a mesma história, ainda que num tom caracteristicamente de desaprovação: 'Essas (as árias populares) eram os únicos trechos a que se concedia alguma atenção. Durante a abertura imponente e um certo número de recitativos acompanhados altamente expressivos, o barulho no teatro era tamanho que dificilmente se podia esperar ouvir a música. Jogavam-se cartas na maioria dos camarotes e conversava-se em voz alta por toda parte. Para um estrangeiro, ansioso por ouvir atentamente, não se pode conceber nada mais insuportável do que esse antro infame. Seria muito difícil, no entanto, se esperar atenção por parte de gente que possivelmente já ouviu a mesma ópera trinta ou quarenta vezes e cujo propósito ao comparecer é exclusivamente social'" (TILL, Nicholas. Op. cit., p. 23-25). 
da marinha russa, Otto von Kotzebue (1787-1846), que passou pelo Rio em 1823, tendo comparecido ao teatro na noite de gala em comemoração ao primeiro aniversário da coroação de Dom Pedro I, também confirma que, durante o espetáculo, embora a platéia estivesse mais quieta e atenta, as "pessoas gradas", presentes nos camarotes, "tinham mais interesse nas visitas que recebiam do que na peça"363. O mesmo ainda nos revela o já citado reverendo irlandês Robert Walsh, que esteve no Rio na mesma época em que Jacquemont. Para ele, o teatro "sozinho" já era "suficiente para atrair os brasileiros para lá, independentemente de boa música e dança" 364 .

De fato, o mais importante não era ouvir alguma coisa, mas ver e ser visto, de preferência em um camarote de segunda ordem, o mais cobiçado por ficar no mesmo plano do camarote imperial, e, desta forma, mais intimamente ligado à realeza ${ }^{365}$. Para as elites econômicas - sobretudo a classe comercial - , em pleno intento de ascender socialmente, de nobilitarse, era a oportunidade de ostentar suas jóias e trajes mais luxuosos, mostrarse inteirados com a última moda ${ }^{366}$; para a nobreza, "antiga" ou "moderna", o

363 "Die Logen waren sämtlich von Honoratioren besetzt; (...) Das Parterre war, so bald der Vorhang aufging, ziemlich ruhig und aufmerksamer als die Logen, denen die Besuche oft interessanter zu sehn schienen, als das Stück" (KOTZEBUE, Otto von. Op. cit., p. 31-32).

364 "... that association alone, is sufficient to draw them there, independent of good music and dancing" (WALSH, Robert. Op. cit., v. 1, p. 483).

${ }^{365} \mathrm{O}$ tenente naval inglês, Charles Brand, que esteve de passagem pelo Rio de Janeiro em princípios de 1828, narra a maneira "promíscua" e "familiar" com a qual Dom Pedro I conversava com ocupantes dos camarotes de segunda ordem vizinhos ao imperial, durante um espetáculo: "... he was talking promiscuously to the ladies and gentlemen in the boxes on each side of him, and they appeared to be very familiar with him..." (BRAND, Charles. Journal of a voyage to Peru: a passage across the cordillera of the Andes, in the winter of 1827 performed on foot in the snow: and a journey across the pampas. London: $\mathrm{H}$. Colburn, 1828, p. 304-305).

${ }^{366}$ Sobre esse aspecto, o Barão de Bougainville nos deixou um curioso relato. Ao ir ao teatro em um dos dias em que permaneceu na capital do Império, em 1826, conta que "as mulheres estavam em trajes de gala e penteadas, em sua maioria, com tufos de plumas brancas". Ao ver este adorno, imaginou "todo um mundo de alta distinção". Porém, prevenido por um oficial que tinha quaisquer relações de negócios com as comerciantes de moda da Rua do Ouvidor, indicou três ou quatro delas "entre as mais empetecadas": "Les femmes étaient en grande toilette et coiffées, pour la plupart, de touffes de plumes blanches. A voir cette parure, je me figurai tout un monde de haute distinction, mais je fus tiré d'erreur par un officier de la division, qui, ayant quelques relations d'affaires avec les marchandes de modes de la rue d'Ouvidor, m'en montra trois ou quatre parmi les plus empanachées" (BOUGAINVILLE, Hyacinthe Yves Philippe Potentien, Baron de. Op. cit., $\mathrm{t}$. 1, p. 625). 
orgulho de usar no peito suas coroas e comendas, de compartilhar do camarote imperial e ser invejada por aqueles que não tinham esse privilégio; e para os homens da platéia - advogados, médicos, funcionários públicos de escalões inferiores ou ainda militares de baixa patente e caixeiros $^{367}$ tentar assistir ao espetáculo ou, talvez, mais interessante, divertir-se com o burburinho das elites nos camarotes. Foi o que Schlichthorst nos confessou fazer:

\begin{abstract}
Involuntariamente, vira-se para o fundo do teatro e diverte-se mais com o diferente intermezzo, desempenhado entre os espectadores. A própria classe ilustre do Rio pode tomar como uma grande ofensa ficar prestando alguma atenção ao palco ${ }^{368}$.
\end{abstract}

Era, pois, o espetáculo cênico e musical, apenas pretexto para um amplo acontecimento social, em que todas as atenções convergiam sempre para a presença, no grande camarote central, do Imperador, ao mesmo tempo, figura primaz da sociedade e primeiro representante político da nação. Daí o teatro assumir também o papel de "termômetro" da popularidade governamental, de um espaço privilegiado para o debate político ${ }^{369}$.

${ }^{367}$ Vasconcelos de Drummond, referindo-se, nas Anotações à sua biografia, aos conturbados momentos que antecederam a partida de Dom João VI do Rio, em 1821, aponta-nos, complementando Jacquemont, quais seriam alguns dos mais assíduos ocupantes da platéia do teatro: "A platéia exercia uma tirania de que não há exemplo e que Ihe fora importada de Lisboa. Nem as senhoras estavam a abrigo dessa tirania. (...) aliás ficariam expostas aos mais grosseiros insultos de uma platéia composta de militares ébrios e caixeiros malcriados e entusiasmados pelas glorias da mãe-pátria. As famílias honestas deixavam de freqüentar o teatro e só compareciam ali aquelas cujos chefes ou parentes pertenciam à sucia dos dominadores do dia, ou procuravam tirar partido da situação" (DRUMMOND, Antônio de Meneses Vasconcelos de. Op. cit., v. 13, p. 14).

${ }^{368}$ Tradução nossa de: "Unwillkürlich wendet man dem Theater den Rücken zu und ergötzt sich mehr an den verschiedenen Zwischenspielen, welche unter den Zuschauern aufgeführt werden. Die eigentliche vornehme Welt von Rio würde es für einen großen Verstoß gegen den Anstand halten, einige Aufmerksamkeit auf die Bühne zu verwenden" (SCHLICHTHORST, Carl. Op. cit., p. 155).

${ }^{369} \mathrm{O}$ historiador Marco Morel, em seu recém publicado livro As transformações dos espaços públicos, que trata das sociabilidades no Rio de Janeiro entre 1820 e 1840, observa alguns aspectos interessantes relativos à importância que o grande teatro carioca tinha como espaço privilegiado de manifestações políticas durante esse período. Porém, a falta de aprofundamento do seu estudo em relação aos já comentados significados sociais da ópera nas principais cortes do mundo ocidental, e à forma socialmente diversificada pela 
Melômano inveterado, como ainda veremos melhor, freqüentador assíduo dos espetáculos de ópera - e talvez, curiosamente, um dos poucos interessados em ouvir música nessas ocasiões - , Dom Pedro era recebido, durante a regência e o início de seu reinado, com muito entusiasmo no teatro, e nos dias de grande relevância política, como o "Fico" - 9 de janeiro de 1822 -, não faltavam recitações de poesias e eloqüentes discursos em sua homenagem, como nos registrou, em seu diário, Maria Graham:

O dia, como de costume em qualquer ocasião de interesse público, terminou na Ópera, mas eu infelizmente não pude desembarcar; entretanto alguns dos oficiais foram. A casa estava iluminada. O Príncipe e a Princesa apareceram em trajes de gala no camarote real, que fica no centro do edifício. Eles foram recebidos com entusiasmo pelos presentes, o hino nacional foi cantado $e$, entre os atos do divertimento, o público recorreu a vários de seus oradores favoritos para discursarem ao Príncipe e aos demais presentes sobre o acontecimento do dia. Este clamor foi atendido por diversos oradores e alguns de seus discursos foram impressos e passados de mão em mão pelo teatro ${ }^{370}$.

qual, àquela época, até no Brasil, os vários pavimentos das casas de ópera eram hierarquicamente ocupados o levou a apresentar hipóteses falhas, tal como a de que "a falta de luxo e solenidade talvez tenha sido um dos fatores que permitiram uma apropriação, pelos espectadores, do Teatro como lugar de manifestação política" (MOREL, Marco. As transformações dos espaços públicos. Imprensa, atores políticos e sociabilidades na cidade imperial, 1820-1840. São Paulo: Hucitec, 2005, p. 234). Na verdade, o que dava ao Teatro a capacidade privilegiada de sediar "diálogos, conflitos e consensos" políticos não foi a ausência ou não de luxo no lugar, mas o fato desse ser o único recinto fechado onde um número expressivo e ao mesmo tempo contrastante de membros da sociedade se reunia, cada qual em seu devido espaço. Ali era possível reunir do general ao tenente, do latifundiário ao profissional liberal, do negociante de grosso trato ao caixeiro, do ministro de estado ao escriturário; todos, é claro, de olho na personalidade máxima da sociedade, o monarca. Como bem resumiu um número do Jornal do comércio, de 1838: "O teatro é a verdadeira distração do povo, a distração nacional que reúne em suas festas todas as classes de espíritos..." (JORNAL DO COMÉRCIO, 30/10/1838).

370 Tradução nossa de: "The day as usual, on any occasion of public interest, was ended at the opera, but I unfortunately could not get ashore; however some of the officers went. The house was illuminated. The Prince and Princess appeared in full dress in the king's box, which is in the centre of the house. They were received with enthusiasm by the people, the national hymn was sung, and between the acts of the play the people called on several of their favourite orators to address the Prince and people, on the event of the day. This call was obeyed by several speakers, and some of their addresses were printed and handed about the theatre" (GRAHAM, Maria. Op. cit., p. 178). 
Otto Kotzbue foi outro que presenciou entusiásticas saudações ao Imperador quando da sua chegada ao grande camarote imperial do Teatro de São João a 2 de dezembro de 1823 - primeiro aniversário da coroação. Note-se, portanto, uma momentânea aceitação, por parte expressiva da opinião pública carioca, da dissolução da Assembléia Constituinte, ocorrida nem um mês antes:

Os chapéus agitaram-se agora novamente, assim como os lenços das damas nos camarotes, e de todos os lados ressoaram: "viva o Imperador, a Imperatriz, a Monarquia!". Um gracioso aceno com a cabeça retribuiu esse entusiasmo ${ }^{371}$.

Já, no terço final do primeiro reinado, Robert Walsh narrou um diferente tipo de recepção ao Imperador no teatro, bastante indicativo da queda de sua popularidade:

O entusiasmo, porém, com o qual ele era geralmente recebido aqui tinha acabado $e$, sempre que eu estive presente, sua entrada jamais foi saudada com qualquer sinal de aplauso $^{372}$.

É inegável, no entanto, que a freqüente presença de Dom Pedro I e dos Príncipes no camarote imperial ainda enchia de pompa um evento essencialmente social, de moda, de conquista ou de manutenção de um status; e, dessa forma, fazia funcionar com todo vigor o teatro, apesar dos tempos de crise política e financeira ${ }^{373} .1829$ seria um ano mais difícil para o

371 Tradução nossa de: "Die Hüte wurden nun wieder geschwenkt, die Schnupftücher der Damen wehten in den Logen, und von allen Seiten ertönte das viva l'Emperador, l'Emperadriza, la Monarchia! Ein gnädiges Kopfnicken lohnte diesem Enthusiasmus" (KOTZEBUE, Otto von. Op. cit., p. 32).

372 Tradução nossa de: "The enthusiasm, however, with which he was generally received here, has passed away, and, whenever I have been present, his entrance was never greeted with any mark of applause" (WALSH, Robert. Op. cit., v. 1, p. 484).

${ }_{373}$ Procurando constatar ainda mais a manutenção da demanda por atividades 
São Pedro, talvez não tanto pelo agravamento dessa crise, mas por conta do falecimento, a 17 de julho, do proprietário da casa, o Coronel Fernando José de Almeida, sem contar, também, com a perda do cantor e agitador cultural Fabrício Piacentini, em outubro do mesmo ano.

Ainda assim, a temporada teatral não se arrefeceu. Impedindo que essa casa paralisasse suas atividades em um momento tão oportuno para a vida cortesã - diante da iminente chegada da nova Imperatriz, Dona Amélia de Beauharnais, e da Rainha de jure de Portugal, Dona Maria II -, o próprio Imperador determinou, logo a 8 de agosto ${ }^{374}$, que o teatro passasse a ser administrado interinamente por uma comissão diretora formada por pessoas de sua plena confiança; e, vinte dias depois, concedeu-lhe mais duas loterias extraordinárias ${ }^{375}$ favorecendo a continuidade dos espetáculos.

No ano seguinte, por exemplo, mais precisamente a 31 de julho, primeiro aniversário da nova Imperatriz passado em terras brasileiras, realizou-se, em grande gala, uma série de festividades, destacando-se a

teatrais - e conseqüentemente musicais - no ano de 1829 , lembremos que é deste mesmo ano a fundação de um outro teatro na capital do Império: o "Teatrinho da rua dos Arcos", que, sobretudo durante o período regencial, como veremos, proporcionou aos cariocas, um espaço alternativo de diversão. Segundo Moreira de Azevedo, a sociedade mantenedora desta casa era "composta por cinqüenta sócios (...) Havia dois espetáculos mensais, e contribuía cada sócio com cinqüenta mil réis de entrada, e dois mil réis mensalmente..." (AZEVEDO, Manuel Duarte Moreira de. Sociedades fundadas no Brasil desde os tempos coloniais até o começo do atual reinado. Revista do Instituto Histórico e Geográfico Brasileiro. Rio de Janeiro, v. 48 (segunda parte), p. 290, 1885.

374 COLEÇÃO das Decisões do Império do Brasil de 1829. Rio de Janeiro: Tipografia Nacional, 1877, p. 124.

${ }^{375}$ Em 01/09/1828, Dom Pedro I concedera, por decreto, a Fernando José de Almeida, mais três loterias para o sustento do São Pedro de Alcântara (vide nota 306 desta parte). No entanto, como o proprietário do Teatro morreu antes de extrair-se a última dessas três loterias, foi expedido novo decreto, a 28/08/1829, que cancelava a última loteria relativa ao primeiro Decreto e concedia mais três (de 120 contos de réis) "aos atuais administradores D. Dionísio Orioste, Inácio Ratton, Joaquim Gonçalves Ledo, Joaquim José de Siqueira e José Bernardes Monteiro Guimarães" (COLEÇÃO das Leis do Império do Brasil de 1829. Rio de Janeiro: Imprensa Nacional, 1877, parte 2, p. 288). A 27/09/1830, novo decreto de Dom Pedro agraciava o Teatro com mais três loterias: "Atendendo ao que me representou José Bernardes Monteiro na qualidade de Diretor do Imperial Teatro de São Pedro de Alcântara sobre o aumento excessivo das despesas indispensáveis com os seus espetáculos e a falta de meios suficientes para supri-las: Hei por bem conceder-Ihe a faculdade necessária para a extração de três loterias de cento e vinte contos de réis cada uma (...) com a declaração de que o produto líquido dos 12 por cento das mesma três loterias e o rendimento dos espetáculos servirão não só para o pagamento de todas as despesas precisas na sustentação deles até o carnaval do ano futuro ..." (COLEÇÃO das Leis do Império do Brasil de 1830. Rio de Janeiro: Tipografia Nacional, 1876, parte 2, p. 
recepção no Paço e, à noite, é claro, um suntuoso divertimento no São Pedro de Alcântara. Tal ocasião é narrada, com detalhes, pelo General Tomás Guido - Ministro Plenipotenciário da República das Províncias Unidas do Rio da Prata junto ao governo brasileiro - em carta à sua esposa, de 2 de agosto de 1830:

Às sete e meia, concorreu ao teatro toda a família imperial: o Imperador dava a direita à Rainha de Portugal, sua esquerda à Imperatriz e ao lado desta se sentaram as Princesas e o Príncipe (...). O Teatro estava iluminado com esplêndidos lustres e com o triplo de lanternas de cristal normalmente usadas (...). As damas da corte, todas, sem exceção, com plumagens brancas, e os personagens do império cobertos de bordados, produziam uma perspectiva verdadeiramente magnífica. Cantou-se a ópera La Gazza Ladra, em que brilhou Vaccani, como de costume. Um bailado novo e preciosas decorações foram à cena pela primeira vez naquela noite. Nos entreatos, alguns dos presentes às cadeiras do teatro chamaram a atenção do público e recitaram odes em obséquio à Imperatriz; e o Oficial Maior da Secretaria do Senado leu de seu camarote o soneto que te envio, composto pelo Imperador em honra de sua esposa. O evento findou-se à uma e meia da madrugada ${ }^{376}$.

44).

${ }^{376}$ Tradução nossa de: "A las siete y media, concurrió al teatro toda la familia imperial: el Emperador daba la derecha a la Reina de Portugal, su izquierda a la Emperatriz y a la de esta se sentaron las Princesas y el Príncipe (...). El Teatro estaba iluminado con ricas arañas, y triple numero de bombas de cristal que el que se acostumbra a diario (...). Las damas de la corte, todas sin excepción con plumaje blancos y los personajes del imperio cubiertos de bordados, formaban e, verdad una perspectiva magnifica. Se cantó la opera de la Gazza Ladra, en que se lució Bacani como acostumbra. Un Baile Nuevo y preciosas decoraciones se exhibieron por primera vez en aquella noche. En los entre actos algunos de los asistentes a las Lunetas Ilamaron la atención, y recitaron odas en obsequio de la Emperatriz: y el oficial Mayor de la Secretaria del Senado leyó desde su Palco el soneto que te acompaño, compuesto por el Emperador en honor de su Esposa. La función concluyo a la una y media de la mañana". O original manuscrito desta correspondência se acha sob a custódia do Archivo General de la Nación, de Buenos Aires, e foi reproduzido sem tradução pelo Anuário do Museu Imperial (SODRÉ, Alcindo. Um dia de gala no primeiro reinado. Anuário do Museu Imperial. Rio de Janeiro, v. 13, p. 10-11, 1952). 
O cantor citado, Michele Vaccani, que se afastara do Rio, em 1824, quando o São João se incendiou, estava de volta, após uma longa e bemsucedida temporada pelo Prata e um regresso à Europa, no final da década, para cantar em Madri e Lisboa -, nesta última, sob a direção de Saverio Mercadante (1795-1870), compositor italiano de certa relevância à época e autor de um dos mais conhecidos concertos para flauta e orquestra executados ainda hoje ${ }^{377}$. O retorno de Vaccani ao Rio de Janeiro indica o quanto a nova diretoria do Teatro de São Pedro, nomeada pelo Imperador, procurou manter acesa a temporada operística de 1830, a qual se encerrou no domingo de Carnaval, 13 de fevereiro de 1831, conforme anúncio do Jornal do comércio:

\section{IMPERIAL TEATRO}

Domingo 13 do corrente vai a cena pela última vez neste ano teatral, a Companhia Italiana representará a muito bem aceita Peça em música A Gazza Ladra. No intervalo de seus atos a Dança a Pupila mal Guardada ${ }^{378}$.

Mal sabiam os amantes da ópera que, encerrado o ano teatral de 1830, quase treze anos seriam necessários para que as temporadas líricas no Rio de Janeiro se normalizassem, após a Abdicação.

377 A célebre Revue musicale, de Paris, publicada por Fétis, registra, em suas Nouvelles étrangères de um número de agosto de 1828, a presença de Vaccani em Lisboa interpretando II posto abbandonato, de Mercadante, ao lado de $\mathrm{M}^{\frac{\mathrm{me}}{}}$. Glossop-Démeri

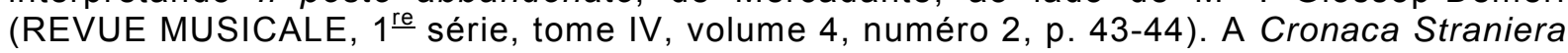
de um número de 1830 do jornal milanês I teatri, também menciona Vaccani em Madri, interpretando Gli Arabi nelle Gallie, de Pacini, com la Tosi, Trezzini, e la Lorenzani (I TEATRI, Parte II, Fasc. 42, p. 678-679).

378 JORNAL DO COMÉRCIO, 11/02/1831. 


\section{CAPÍTULO V - Outros sons}

As reuniões sociais são freqüentes
(...) No baile, o costume manda que
seja o dono da casa o responsável
pela escolha das damas que devem
dançar com os senhores, e que ele
mesmo os conduza a elas. São quase
sempre as danças francesas e
inglesas que se executam nos
salões $^{379}$.

Antes de encerrarmos esta primeira parte e chegarmos, agora, de fato, ao cerne de nosso estudo, inicialmente acerca da depressão musical ocorrida após a renúncia de Dom Pedro I e sua saída do Rio de Janeiro, tracemos, ainda, rapidamente, algumas linhas a respeito da música realizada fora do âmbito religioso e teatral nos tempos de Dom João e de Dom Pedro.

As festas da realeza, que ocorriam na Quinta da Boa Vista, ou no Paço, contavam sempre com a participação da Real Câmara, posterior Imperial Câmara, que, como já dissemos, congregava a nata da ópera e da Capela, em suma, os melhores executantes da Corte. Já, nos divertimentos organizados pelos mais destacados membros da nobreza emigrada, como Francisco José Rufino de Sousa Lobato, Visconde de Vila Nova da Rainha, a música também não deixou de receber atenção toda especial, como nos testemunhou Luiz dos Santos Marrocos em mais uma de suas cartas:

A excelente orquestra vocal e instrumental, dança, refrescos, e tudo o mais que deveria solenizar aquele dia, de tudo o dito visconde lançou mão para se distinguir mais do conde da Lousã... ${ }^{380}$

379 Tradução nossa de: "Les réunions de société sont fréquentes (...) Au bal, l'usage veut que ce soit le maître de la maison qui désigne aux messieurs les dames avec lesquelles ils doivent danser, et qui les conduise lui-même auprès d'elles. Ce sont ordinairement les danses françaises et anglaises que l'on exécute dans les salons" (FREYCINET, Louis Claude Desaulces de. Op cit., v. 1, p. 211-212).

${ }_{380}$ MARROCOS, Luiz Joaquim dos Santos. Op. cit., v. 56, p. 260, 1934. 
Porém, não foram os exilados nobres portugueses, mas os diplomatas estrangeiros e os membros da elite social emergente carioca - os negociantes de grosso trato - que se destacaram como os maiores organizadores de bailes e saraus do Rio de Janeiro desses tempos ${ }^{381}$. A 15 de setembro de 1815 , era aprovado, com a licença real ${ }^{382}$, um projeto de estabelecimento de uma sociedade de até cem pessoas "de certa representação pública" - dita "Assembléia Portuguesa" - que tinha por finalidade a realização semanal de passatempos - jogos carteados, música e dança - em uma sede especialmente alugada e asseada para abrigar tais reuniões sociais. Assinaram o projeto grandes negociantes do Rio de Janeiro, alguns deles os mesmos beneméritos acionistas do Teatro de São João, como Manoel Pinheiro Guimarães, Fernando Carneiro Leão, Amaro Velho da Silva e Joaquim José de Siqueira ${ }^{383}$.

Também nas próprias chácaras desses negociantes - alguns, já detentores de títulos de nobreza, como Dona Ana Francisca Maciel da Costa, a Baronesa de São Salvador dos Campos dos Goitacazes -, e, igualmente, nas residências dos diplomatas, a maior parte localizada no Catete e em Botafogo, eram comuns os encontros sociais, muitos deles dançantes. A música, necessária para o baile, acabava, quase sempre, sendo executada por membros contratados da orquestra do Teatro, como testemunhou von Leithold, em 1819:

Teve este baile lugar na chácara ou casa de campo que ocupa o Sr. Langsdorff, perto, ou melhor, ainda na cidade, e começou às sete

${ }^{381}$ É também de Marrocos outro depoimento dessa época sobre um baile, desta vez ocorrido na casa de Lord Strangford, representante diplomático da Inglaterra. Segundo o português, no dia dos anos do Príncipe Regente da Inglaterra, fez no Rio o inglês "uma função esplendidíssima, consistindo esta em baile e ceia, a que foi toda a corte..." (Ibidem, p. 163).

${ }^{382}$ As quantias de contribuição para a sociedade denotam o seu elitismo: a jóia de admissão era de $40 \$ 000$ e a mensalidade de $8 \$ 000$ (COLEÇÃO das Leis do Brasil de 1815. Decisões de 1815. Rio de Janeiro, Imprensa Nacional, 1890, p. 25-28).

${ }_{383}$ Segundo Ayres de Andrade, tal documento manuscrito acha-se tombado no Arquivo Nacional do Rio de Janeiro (ANDRADE, Ayres. Op. cit., v. 1, p. 128-130). Infelizmente, não restaram maiores informações sobre o destino dessa sociedade, quanto tempo durou e quantos bailes realizou. 
horas da noite. (..) O grupo de músicos consistiu em quatro componentes da orquestra do teatro, entre os quais, um mulato, que tocou o primeiro violino ${ }^{384}$.

Maria Graham, em 1822, também relata a participação dos músicos do Teatro de São João em um baile particular, desta vez, realizado à bordo de um navio de bandeira inglesa:

Nosso baile correu muito bem; nós tivemos mais estrangeiros do que ingleses; e, como havia excelente música da orquestra da ópera e muita dança, a juventude se divertiu bastante com isso ${ }^{385}$.

A periodicidade dos encontros musicais realizados nas residências de alguns dos mais abastados cidadãos do Rio de Janeiro, como as da família da Baronesa de São Salvador ou de Joaquim José de Azevedo - que, em pouco tempo, de Barão do Rio Seco galgou a Marquês de Jundiaí - devia ser freqüente, pois, em ambas as casas, havia salas especialmente destinadas à dança e à música ${ }^{386}$, incluindo no mobiliário, o ainda raro piano,

384 Tradução nossa de: "Dieser Ball wurde aus der Chacre oder dem Landhause des Herrn v. Langsdorff, dicht neben oder vielmehr noch in der Stadt, des Abends um sieben Uhr eröffnet. (...) Das Chor Musici bestand aus vier Personen aus dem Orchester des Theaters, unter denen ein Mulatte die erste Geige spielte" (LEITHOLD, Theodor von. Op. cit., p. 158).

385 Tradução nossa de: "Our ball went off very well: we had more foreigners than English; and as there was excellent music from the opera-orchestra, and a great deal of dancing, the young people enjoyed it much" (GRAHAM, Maria. Op. cit., p. 187).

386 "I spent the day with Madame do Rio Seco. Her house is really a magnificent one; it has its ball-room, and its music-room..." (Ibidem, p. 226). Sobre a vida musical nas casas das famílias mais abastadas cariocas, Maria Graham ainda menciona, em seu diário, uma passagem pela casa de Dona Ana Vidal Carneiro da Costa, casada com Luiz José de Carvalho e Melo (depois Visconde da Cachoeira), e que era filha de Brás Carneiro Leão e da Baronesa de São Salvador: "I spent the day with Miss Hayne, and accompanied her in the evening to compliment Dona Ana, the wife of Senhor Luis Jose de Cavalho e Mello, on her birthday. The family were at their country-house at Botafogo; (...) The daughter of the house, Dona Carlota, is distinguished here by talent and cultivation beyond her to the music-room, where the music-master attended to accompany the ladies, many of whom sang extremely well ..." (Ibidem, p. 224). O mestre de música em questão, citado em nota por Graham como "irmão do instrutor de Catalani”, esta, uma soprano renomada internacionalmente que cantara alguns anos no São Carlos de Lisboa (vide nota 151 desta parte), era, sem dúvida, Simão Portugal, irmão do ex-diretor do teatro lisboeta, Marcos Portugal, e para quem, segundo Luiz dos Santos Marrocos, não faltavam alunos: "Simão 
instrumento moderno que, aos poucos, ia substituindo o velho cravo ${ }^{387}$. Na citada chácara do Cônsul-Geral da Rússia na corte no Rio de Janeiro, Barão Georg Heinrich von Langsdorff (1774-1852), por exemplo, von Leithold conta que havia "um grande fortepiano inglês"388, freqüentemente usado pela Senhora Langdorff, e por músicos ilustres, como Sigismund Neukomm:

A hospitaleira casa do Sr. von Langsdorff era, para muitos europeus presentes no Rio de Janeiro, um prezadíssimo ponto de encontro noturno. Ali dominava sempre o alegre e animado entretenimento, o qual era elevado pelo talento musical da dona da casa, ainda mais com a colaboração de Neukomm ${ }^{389}$.

\section{Outros músicos convidados freqüentemente para esses encontros} particulares no Rio de Janeiro eram os castrati da Capela. Essa foi pelo menos a impressão que nos deixou A. P. D. G., o autor incógnito do livro Sketches of Portuguese life, manners, costume, and character, ao relatar que "nunca assistiu a um sarau no Rio sem notar a presença de um ou dois

Portugal é organista da Capela R. com os seus $300 \$ 000$ réis e apêndices, ignoro se com ração; porém o irmão tem-no introduzido com seus conhecimentos de sorte que tem granjeado muitos discípulos e discípulas, que lhe mandam suas seges a casa buscá-lo: eu tenho-o visto mil vezes nas ditas seges ..." (MARROCOS, Luiz Joaquim dos Santos. Op. cit., v. 56, p. 159, 1934).

${ }^{38}$ Spix e Martius comentam que, ao tempo de sua estada no Brasil (1817-1821), o piano era um móvel raro e só se encontrava nas casas mais ricas: “... Fortepiano zu den seltensten Meubles und wird nur in reichen Häusern angetroffen" (SPIX, Johann Baptist von; MARTIUS, Karl Friedrich Philip von. Op. cit., v. 1, p. 107)

388 "... auf einem großen englischen Fortepiano im Saale ..." (LEITHOLD, Theodor von. Op. cit., p. 158). A essa época, destacava-se como negociante de pianos e outros instrumentos no Rio, o inglês John Ferguson. Eram comuns na Gazeta do Rio de Janeiro seus anúncios. Em 19/03/1817, por exemplo, fazia saber ao público que tinha "uma grande porção de pianos fortes muito modernos, e de bom autor, e também um órgão muito bom para qualquer igreja, e uma porção de rabecas e solfas, e encordoação de pianos e rabecas, e afinador de pianos e órgão ...". Quase três anos depois, a 12/01/1820, anunciava "uma nova partida de pianos chegados de próximo do melhor autor, que se intitula $\mathrm{G}^{\mathrm{me}}$. Stodart, aprovado por todos os melhores mestres em música; e o mesmo promete ter sempre bom sortimento de pianos, e mais instrumentos". Passada uma década do primeiro anúncio mencionado, dizia outro jornal carioca: “... não há casa onde não se ouça tocar piano" (O ESPELHO DIAMANTINO, 01/10/1827).

${ }_{389}$ Tradução nossa de: "Das gastfreie Haus des Hrn. v. Langsdorff war für viele in Rio de Janeiro anwesende Europäer am Abend ein sehr angenehmer Vereinigungspunkt. Es herrschte hier stets der Geist froher und belebter Unterhaltung, die durch das musikalische Talent der Hausfrau und die Mitwirkung Neukomm's noch mehr erhöht wurde" (SPIX, 
desses castrati”390.

Enfim, além de animar bailes e soirées de gente graúda, os músicos cariocas ou residentes no Rio ainda se apresentavam em concertos e recitais públicos ou "academias", como melhor se conhecia esse tipo de divertimento àquela época. Em outubro de 1809, por exemplo, a já mencionada cantora Carlotta D'Aunay, recém chegada de Londres, anunciava na Gazeta do Rio de Janeiro, ao salgado preço de $4 \$ 000$ réis, um concerto de música vocal e instrumental a ser realizado no dia 14 daquele mês, um sábado, na casa $n{ }^{\circ}$ 28 na praia de Dom Manuel. Nele, cantariam, além de D'Aunay, a brasileira Joaquina Lapinha, e executariam os senhores "Lansaldi" e "Lami" "concertos de rabeca". Para finalizar, uma "grande orquestra" executaria "as melhores aberturas de Mozart" ${ }^{391}$.

No entanto, pelos poucos fatos que nos restaram dos anúncios dos jornais, estima-se que não fossem muito freqüentes as "academias". Uma razão sócio-histórica bastante plausível para o fato desses encontros musicais não terem sido tão populares como os espetáculos realizados no teatro foi bem aventada por Ayres de Andrade:

O teatro era, como a igreja, um ponto obrigatório de reunião social. Sua Alteza ia ao teatro e ia à igreja. Era o quanto bastava para que todo mundo fosse ao teatro e à igreja. Sua Alteza não ia a concertos. Todo mundo julgavase, por isso, dispensado de ir a concertos. E por que haveria Sua Alteza de ir a concertos se os tinha a domicílio, executados pelos músicos de sua Real Câmara, à hora que lhe conviesse? ${ }^{392}$

Esporádicas, as "academias" tiveram sua primeira tentativa mais

Johann Baptist von; MARTIUS, Karl Friedrich Philip von. Op. cit., v. 1, p. 105).

390 "I never attended a soirée at Rio without seeing at it one or two of these castrati" (A. P. D. G. Sketches of Portuguese life, manners, costume, and character: illustrated by twenty colored plates. London: Printed for G. B. Whittaker, 1826, p. 180).

391 GAZETA DO RIO DE JANEIRO, 11/10/1809 (originalmente esta grafado "overturas de Mozart"). O senhor "Lansaldi", citado nesta notícia, deve ser, sem dúvida, o já mencionado violinista italiano Francisco Ansaldi, que foi, durante muitos anos, destacado membro da Câmara e da Capela. 
organizada de funcionar com freqüência e assinantes em agosto de 1823, quando o cantor do Teatro de São João, Fabrício Piacentini, apresentava ao público carioca os chamados "Acadêmicos Filarmônicos". Tal iniciativa, fracassada em um primeiro momento, acabou vingando dois anos depois, quando o público carioca, por ocasião do incêndio do Teatro de São João, se viu desfalcado de sua diversão musical principal, a ópera. Segundo Ayres de Andrade ${ }^{393}$, em 1825, os "Acadêmicos" anunciaram 21 concertos entre abril e julho. No ano seguinte, no entanto, ao que tudo indica, a reabertura da ópera voltou a dispersar essas iniciativas particulares dos músicos, que só seriam retomadas com maior força já durante o período regencial, quando, ir ao grande teatro público, como veremos, tornou-se um programa arriscado e fora de moda. 


\title{
PARTE II - INTERREGNUM
}

\section{CAPÍTULO VI - $O$ adeus do príncipe filarmônico}

\begin{abstract}
Dizem que mal o Imperador subiu a bordo da fragata inglesa e mal soube que seus tesouros estavam em segurança, apanhou um violino e uma das mais repugnantes canções populares brasileiras surgiu ${ }^{394}$.
\end{abstract}

Tal singular relato, que Carl Seidler imortalizou em suas memórias faz parte de um conjunto de anedotas que surgiram nos dias subseqüentes à Abdicação, urdidas por alguns dos não raros desafetos políticos de Dom Pedro I com o intuito de ridicularizá-lo. Contudo, como o próprio alemão admitiu ${ }^{395}$, não seria nada inverossímil acreditar que, apesar do calor dos acontecimentos, o agora apenas Duque de Bragança tivesse realmente manifestado seus dotes musicais a bordo do H. B. M. Warspite e dito essas menoscabadoras palavras após meter-se dentro do navio de guerra inglês e ver-se livre da horda de revoltosos que se aglomerava no Campo da Aclamação, rebatizado, alguns dias depois, de Campo da Honra:

394 Tradução nossa de: “Kaum war, behauptete man, der Kaiser an Bord der englischen Fregatte angekommen, kaum wußte er seine Schätze in Sicherheit, als er eine Geige ergriff, und das allergemeinste brasilianische Volkslied darauf absiedelte" (SEIDLER, Carl. Op. cit., p. 191). Ainda sobre esse anedótico fato — fictício ou não —, segundo o imortal Viriato Correia, autor da crônica histórica baseada em oralidades, Brasil dos meus avós, Dom Pedro I não teria tocado alegremente um violino logo que subiu a bordo da Warspite, como afirmou Seidler, mas apenas ao cair da tarde do dia 12 de abril, véspera da sua partida definitiva do Brasil, ao ter tido a agradável notícia de que a Regência havia Ihe concedido vantagens financeiras, além de assegurar-lhe seus bens deixados em terra (CORREIA, Viriato. Brasil dos meus avós. Rio de Janeiro: Companhia Editora Nacional, 1927, p. 190-191). Parece mais razoável, realmente, que a piada, provocativa como era em relação aos dotes artísticos do Imperador, tenha surgido em contrapartida ao conhecimento público desse seu último golpe nas finanças do Império.

395 Mesmo não respondendo pela veracidade da cena, Seidler admitiu dar-lhe fé, por ela "corresponder completamente ao caráter do ex-Imperador": "Man erzählte sich zu jener Zeit in Rio de Janeiro verschiedene Anekdoten, für deren Wahrheit ich freilich nicht einstehen kann, da ich nicht Augenzeuge gewesen bin, denen man aber schon deshalb Glauben beimessen muß, weil sie so ganz dem Charakter des Exkaisers entsprechen" (SEIDLER, Carl. Op. cit., p. 191). 
"Ah!" (...) "que grande coisa eu perdi; tinha de afligir-me em governar, e na Europa viverei futuramente em feliz Far niente e quando muito tocarei para mim e meus chegados um Miudinho" 396 .

Em verdade, é muito provável que Dom Pedro, naquele exato momento, jamais tivesse esperado tal futuro tranqüilo para si. Se não vislumbrava retomar em algum tempo a coroa brasileira, com o apoio político dos Andradas - com quem se reconciliara, nomeando José Bonifácio, Tutor de Dom Pedro II -, tinha, ao menos, dali por diante, uma longa e difícil missão a cumprir na Europa: reentronizar a filha, Dona Maria II, expulsando, à força, do poder português, o irmão, Dom Miguel ${ }^{397}$.

${ }^{396}$ Tradução nossa de: “'Ach!' gab Dom Pedro (...), 'was habe ich Großes verloren; dort musste ich mich mit Regierungsformen abquälen, und in Europa lebe ich für die Zukunft im seligen Far niente, und spiele mir und meiner Umgebung höchstens einen Miudinho dazu auf'" (Ibidem, p. 192).

${ }^{397}$ Note-se, a esse respeito, que, em meados de 1833, logo após reconquistar o trono português para a sua filha, e, provocado por boatos referentes à presença de Antônio Carlos de Andrada na Europa, como representante do grupo político que defendia abertamente a sua restauração no trono brasileiro, Dom Pedro chegou a declarar, publicamente, algo similar ao que teria dito quando deixou o Brasil, ou seja, que "desejava encontrar na Europa o repouso de uma vida privada para a qual ele estava ansioso em retornar assim que a restauração de sua filha no trono português fosse efetivada". Foi o que asseverou, por exemplo, o The times, com base em notícias parisienses: "Don Pedro himself acknowledged that it was impossible for him to continue to reign, and voluntarily resigned the crown, in order to find in Europe that repose in private life for which he was anxious, and to which he will return as soon as the restoration of his daughter to the throne of Portugal is accomplished" (THE TIMES, 15/08/1833). Se isso era um refolho diante da notória presença de Antônio Carlos na Europa, ou o real desejo de alguém resignado, já consciente, talvez, de ter contraído uma doença incurável e, com o tempo, mortal - a tuberculose - , ninguém saberá com certeza absoluta. Uma carta de 14 de dezembro de 1833 de Dom Pedro a Antônio Carlos tende a apoiar a primeira hipótese, uma vez que o Duque de Bragança tinha, sim, ao se ver livre dos compromissos portugueses, a intenção de retornar ao Brasil; mas não para recuperar o trono e o título de Imperador. Tencionava apenas reassumir temporariamente o poder máximo do Brasil na qualidade de Regente como o fez em Portugal -, a fim de assegurá-lo a seu filho, enquanto durasse a menoridade deste, diga-se de passagem, bem mais longa e periclitante do que a de sua irmã, Dona Maria da Glória, seis anos e meio mais velha. Eis um trecho da mencionada carta, atualmente tombada no Arquivo Histórico do Museu Imperial de Petrópolis: “... poderei ir prestar, ao Brasil, os serviços que de mim exigir a nação; mas para que isto tenha lugar, será mister, como eu marcho sempre conforme com a lei, e desejo respeitar, como sempre respeitei, a Constituição Brasileira, que as Municipalidades expressem a vontade Nacional, que a Assembléia Nacional declare, solenemente, que convém que eu volte ao Brasil, para na qualidade de Regente o governar durante a menoridade do Imperador meu filho..." (Apud VIANA, Hélio. D. Pedro I e D. Pedro II: acréscimos as suas biografias. São Paulo: Companhia Editora Nacional, 1966, p. 48). Assim, talvez em 1843, quando Dom Pedro II completasse 18 anos, o nosso primeiro imperador pudesse, enfim, ter 
No que diz respeito à música, no entanto, reforça a verossimilhança de tal chiste, uma notícia, desta vez séria, impressa em um dos mais prestigiosos periódicos musicais europeus da época, a Revue musicale, de François-Joseph Fétis. A publicação parisiense atesta que o ex-Imperador, mal chegado a Londres ${ }^{398}$ - e mesmo antes de iniciar as primeiras articulações políticas com o intuito de tratar da "questão portuguesa" 399 —, já participava de encontros de amadores de música na capital inglesa, apresentando, com muito sucesso, composições de sua lavra:

LONDRES. Lê-se no Court journal de 9 de julho: "Siroe, ópera da estimada senhorita Marianne Jervis. Uma segunda repetição desta interessante e notável produção teve lugar, terça-feira passada, nos salões de madame Cuthbert, praça Grovenor. Ela foi honrada com a presença de Dom Pedro e de um numeroso círculo de amadores distintos. (...) A noitada terminou com o hino constitucional da composição de Dom Pedro, que produziu uma ótima impressão...."400.

ao lado de sua esposa, Dona Amélia, a desejada vida privada tranqüila, com direito, sem dúvida, a muita música. A história, é claro, como todos sabemos, foi outra.

${ }^{398} \mathrm{O}$ The times de 27 de junho de 1831, segunda-feira, deu como o domingo anterior - portanto, 26 de junho - a data da chegada de Dom Pedro a Londres: "His Majesty Don Pedro, Duke of Braganza, accompanied by the Marquis d'Arenze, Major Webster, Mr. Pinto, and Mr. Gomez de Silva, arrived at the Clarendon Hotel, Bond-street, on Sunday evening, at 6 o'clock" (THE TIMES, 27/06/1831).

399 Segundo Tarquínio de Souza, embora Dom Pedro tenha tratado do "negócio político da filha" logo que encontrou com o Rei Guilherme IV, a 29 de junho, apenas em fins de julho é que o ex-Imperador teria realizado reuniões significativas para tratar dessa questão: "Novo convite dirigiu o rei a D. Pedro, desta vez para passar um dia em sua casa de campo, em Windsor, lá dormindo a noite de 21 para 22 de julho. Houve uma reunião a que compareceram todos os ministros e é de se presumir que se tenha tratado da questão portuguesa, à vista do que fez o ex-Imperador mal regressou ao Hotel Clarendon: convocar para o dia 23 todos os negociantes portugueses estabelecidos em Londres, a fim de obter os recursos necessários à sonhada expedição contra o governo usurpador" (SOUZA, Octavio Tarquinio de. Op. cit., v. 4, t. 3, p. 981). Algum tempo depois, já em Paris, Dom Pedro, como logo adiante ainda veremos melhor, iria despertar ainda mais seus interesses mundanos, chegando a deixar alguns portugueses verdadeiramente preocupados. Ainda segundo Tarquínio de Souza, "Enquanto não se conseguia o tão desejado empréstimo [para a campanha militar], D. Pedro dava a muitos dos adeptos da filha a impressão de dubiedade e incerteza. Mais: de alheamento e inclinação a vadiar. (...) a Condessa de Ficalho profetizava: 'Se o Imperador continuar a passear e mais nada, Portugal acabou-se'" (Ibidem, v. 4, t. 3, p. 999).

400 Tradução nossa de: "LONDRES. On lit dans le Court journal du 9 juillet: 'Siroe, opéra de l'honorable miss Marianne Jervis. Une seconde répétition de cette intéressante et 
E não fora um caso isolado. Passados alguns meses, como certifica mais uma vez a Revue musicale, essa situação se estenderia, igualmente, à estada do Duque em Paris:

\begin{abstract}
Uma representação extraordinária foi dada domingo passado [no teatro italiano]. Ela se compunha de La prova d'un opera seria, na qual M. ${ }^{\text {me }}$ Pasta se despediu do público de Paris; e de um concerto em que se escutou a maioria dos hábeis cantores desse teatro. A parte do concerto mais digna de nota foi uma abertura composta por S. M. Dom Pedro, Imperador do Brasil, e que foi executada pelo conjunto da orquestra. Essa abertura em mi bemol é de uma feitura correta e mostra que seu autor tem um amplo conhecimento dos recursos da orquestra. Ela foi muito aplaudida. É bom ver um soberano se consolar dos desgostos da política na cultura das artes, e de obter nela um sucesso que artistas poderiam ambicionar ${ }^{401}$.
\end{abstract}

remarquable production a eu lieu, mardi dernier, dans les salons de madame Cuthbert, Grovenor square. Elle a été honorée de la présence de don Pedro et d'un nombreux cercle d'amateurs distingués. (...) La soirée s'est terminée par l'hymne constitutionnelle de la composition de don Pedro, qui a produit un très grand effet..." (REVUE MUSICALE, 06/10/1831).

${ }^{401}$ Tradução nossa de: "Une représentation extraordinaire a été donnée dimanche dernier. Elle se composait de La prova d'un opera seria, dans laquelle Mme. Pasta a fait ses adieux au public de Paris; et d'un concert où l'on a entendu la plupart des habiles chanteurs de ce théâtre. La partie la plus remarquable de ce concert était une ouverture composée par S. M. Don Pedro, empereur du Brésil, et qui a été exécutée avec ensemble par l'orchestre. Cette ouverture en mi bémol est d'une facture correcte et annonce dans son auteur une connaissance étendue des effets de l'orchestre. Elle a été fort applaudie. II est beau de voir un souverain se consoler des chagrins de la politique dans la culture des arts, et d'obtenir dans ceux-ci des succès que des artistes pourraient ambitionner (Idem, 05/11/1831). Note-se ainda que Tarquínio de Souza, na minuciosa biografia que realizou de Dom Pedro I, nos fornece vários outros detalhes sobre o vivo interesse do ex-Imperador pela música, durante a sua estada em Paris. A 12 de setembro, por exemplo, ia Dom Pedro à ópera, ocupando o camarote do Rei Luís Felipe. Nesse mesmo mês, conheceu pessoalmente Gioacchino Rossini, que o convidou a apresentar, a 30 de outubro, uma de suas composições no Théâtre des Italiens. Pelo que se sabe, a obra tocada foi, mais uma vez, a ouverture. Em novembro, ainda segundo Tarquínio, com a chegada do frio, o Duque passou muitos dias em casa. Em um deles, "divertiu-se tocando clarineta e flauta". Em outro, ocupou-se, à noite, "em tirar para música de pianoforte as marchas de sua composição, tocadas durante as paradas imperiais no Rio de Janeiro", oferecendo-as posteriormente às filhas de Luís Felipe. Finalmente, a 11 de dezembro de 1831, aparentemente comemorando um acerto da expedição militar contra seu irmão, fez em sua casa "uma sessão de música"; uma semana depois, foi mais uma vez à ópera assistir a 
Foi, pois, Dom Pedro I, mesmo depois de abandonar o Brasil, e até mesmo nos seus últimos e piores momentos de vida ${ }^{402}$, um melômano inveterado; provavelmente, de todos os Duques de Bragança - tradicionais protetores da música - , aquele que mais intimamente se relacionou com a arte dos sons, não apenas apreciando-a e protegendo-a, como seus antepassados já o tinham feito, mas também experimentando-a de todas as formas, como executante de diversos instrumentos, regente de orquestra, ou, ainda, como autor de obras sacras e profanas. Nessa última atividade graças especialmente às lições de Marcos Portugal ${ }^{403}$ — obteve alguns bons resultados, como Fétis já observara à época, e como mesmo demonstram algumas partituras de suas obras que subsistiram ao tempo, entre as quais, o Hino constitucional, oferecido à nação portuguesa, de 1821404; o Hino

Guilherme Tell (SOUZA, Octavio Tarquinio de. Op. cit., v. 4, t. 3, p. 1002-1019).

${ }^{402} \mathrm{Na}$ noite de 27 de maio de 1834, dia de grande exaltação dos ânimos em Lisboa, em resposta ao decreto regencial de Dom Pedro que concedia aos miguelistas anistia geral, o Duque, já valetudinário, foi, ainda assim, à noite, ao Teatro de São Carlos, assistir à ópera $O$ Pirata, de Bellini. Segundo Alberto Pimentel, baseado em fontes orais, quando o Regente apareceu no camarote real "... foi recebido com uma pateada estrondosa. Perante esta nova manifestação de hostilidade, D. Pedro teve um ímpeto de indignação. Diz-se que proferira a palavra canalhas. O tumulto aumentou na platéia, onde eram distribuídos impressos contra o Imperador; e ouviam-se insultos, ameaças à sua pessoa, cara a cara, vozes repetidas de - Fora, fora - que alguns vivas não podiam abafar. No parapeito do camarote real chofravam patacos arremessados por escárnio, por afronta. (...) O Imperador, após a exaltação, teve um ataque de tosse violenta, uma onda de sangue, vermelho e escumoso, enodoou o seu lenço. Viu-se isso da platéia, de toda a parte. A pateada, o tumulto cessou. O regente da orquestra e todos os outros músicos não sabiam que fazer. Mas D. Pedro, curvando-se para o maestro, disse com energia, que a palidez do seu rosto contrastava: - Continue..." (PIMENTEL, Alberto Augusto de Almeida. A Corte de Dom Pedro IV. Lisboa: Guimarães, 1914, p. 215-216).

${ }^{403}$ Lembremos que Dom Pedro não apenas recebeu lições musicais de Marcos Portugal, a partir de 1811, mas também de Sigismund Neukomm, enquanto este esteve no Rio de Janeiro de 1816 a 1821. Não foi, no entanto, Neukomm um professor muito presente. Tanto em sua autobiografia como em carta a uma amiga parisiense, de 12 de agosto de 1817, o compositor austríaco deixa patente não contar o Príncipe Real como um de seus verdadeiros alunos: “... j'ai deux Elèves (je n'y compte pas le Prince royal, qui s'occupe de la musique en Prince)" (Apud ANGERMÜLLER, Rudolph. Sigismund Neukomm Werkverzeichnis Autobiographie Beziehung zu seinen Zeitgenossen. München-Salzburg: Musikverlag Emil Katzbichler, 1977, p. 38-39). Ainda sobre a formação musical de Dom Pedro, vale mencionar a existência de documentação que apresenta um destacado músico carioca, Januário da Silva Arvelos - o pai - como o " $1^{\circ}$ compositor brasileiro que foi mestre do Sr. D. Pedro I" (Apud MúsıCA no Rio de Janeiro imperial. Rio de Janeiro: Biblioteca Nacional, 1962, p. 13).

${ }^{404}$ Este hino, composto por Dom Pedro em 1821, para celebrar a Constituição que seria elaborada pelas Cortes de Lisboa, que tinha, como primeiros versos, "Ó Pátria, ó Rei, 
imperial e constitucional - mais tarde conhecido como o nosso Hino da Independência —, composto possivelmente em $1824^{405}$; e duas partituras sacras: um Credo, de época desconhecida, e um Te Deum, escrito em $1820^{406}$.

Não se sabe, ao certo, quando Dom Pedro teria começado a se interessar por música. Presume-se apenas que, durante seus dez primeiros anos de permanência no Rio de Janeiro - enquanto os assuntos de governo ainda não o "afligiam" —, tenha tido tempo de sobra para dedicar-se à arte dos sons. A inglesa Maria Graham, em seu "Escorço biográfico de Dom Pedro I", traduzido e publicado pelos Anais da Biblioteca Nacional do Rio de Janeiro, em 1938, assim relata a esse respeito:

Na ocasião da chegada da família real ao Brasil,
seguiu-se o sistema do costume entre os
Braganças: os jovens príncipes foram afastados,

ó Povo / ama a tua Religião / observa e guarda sempre / Divinal Constituição // Viva, viva, viva o Rei / Viva a Santa Religião! / Viva os Lusos valorosos / Divinal Constituição!", passou posteriormente, já no reinado de Dona Maria II, a ser conhecido como hino constitucional português, com os versos "Quanto ó Pedro generoso / te deve a Lusa Nação / por teu valor possuímos / Liberal Constituição // Viva, viva, viva Pedro / Viva a Santa Religião / Viva Maria segunda / Liberal Constituição!". Existem algumas edições desse hino, impressas em Portugal, na França e na Alemanha. A Österreichische Nationalbibliothek, por exemplo, guarda uma edição de Hamburgo intitulada Portugiesische Constitutions Hymne, gedichtet und componirt von Don Pedro I, Kaiser von Brasilien e uma edição parisiense, em português, com o título Hino constitucional da Nação Portuguesa. Composto por Dom Pedro, Dugue de Bragança.

${ }_{405}$ Foi com esse título, pelo menos, que Robert Walsh publicou, em 1830, uma partitura, de autoria de Dom Pedro I, para piano e canto, que corresponde, com algumas pequenas diferenças de letra e melodia, ao hino conhecido hoje como Hino da Independência (WALSH, Robert. Op. cit., v. 2, p. 533-534). O fato, porém, do Diário mercantil ter publicado, a 13 de dezembro de 1824, que naqueles dias saía à luz, impresso, o tal Hino imperial e constitucional de autoria de Dom Pedro I nos faz crer que esta seja a verdadeira época de sua composição, e não os momentos que sucederam o 7 de setembro de 1822, como até hoje muito se propagou. Sobre tal polêmica, ver ainda a opinião de Ayres de Andrade (ANDRADE, Ayres de. Op. cit., v. 1, p. 155-158).

${ }^{406}$ A partitura manuscrita desse Te Deum laudamus, datada de 1820 , que fazia parte do acervo da Capela Imperial e hoje se acha tombada no Arquivo do Cabido Metropolitano do Rio de Janeiro (Fundo Capela Real e Imperial, Seção Musical, cx. 55), é oferecida a "EI-Rei D. João VI por seu filho, o Príncipe Real D. Pedro de Alcântara, Duque de Bragança". Este é provavelmente o mesmo Te Deum referido por Dona Leopoldina em carta de 19 de fevereiro de 1821 a seu pai, o Imperador Francisco I da Áustria (Apud NORTON, Luís. A corte de Portugal no Brasil. São Paulo: Editora Nacional, 1979, p. 316). Quanto à partitura do Credo, manuscrito não datado, também se acha no Arquivo do Cabido Metropolitano do Rio de Janeiro (Fundo Capela Real e Imperial, Seção Musical, cx. $54)$. 
quanto possível, de todo conhecimento dos negócios públicos e casos do Estado. Passavam o tempo principalmente no apartamentos da velha aia, que os acompanhara de Portugal, ou numa espécie de caçadas ligeiras que se permitem aos príncipes do Sul da Europa, ou em divertimentos, dos quais o único respeitável era a música ${ }^{407}$.

Documentos da época atestam, também, que, em princípios de 1818 , o então Príncipe Real, com dezenove anos, já dominava vários instrumentos, compunha, e até regia. Uma carta de sua esposa, Dona Leopoldina, é fonte de algumas dessas informações. Escrevendo à tia, Marie Amélie, GrãoDuquesa da Toscana, a Princesa conta que, como Dom Pedro tocava "muito bem quase todos os instrumentos", passava parte do dia ocupada, acompanhando-o ao piano, e, tendo assim, "a satisfação de estar sempre perto da pessoa querida" ${ }^{408 ;}$ o que, em outras palavras, significa que o Príncipe Real deveria praticar seus dotes de multiinstrumentista regularmente, para não dizer diariamente. Reforça tal devotamento, outra missiva do mesmo ano, do diplomata prussiano Conde von Flemming. Ele também ressalta, em meio a severas críticas, a surpreendente capacidade de Dom Pedro executar diversos instrumentos, além de compor e "ocupar-se muito" com uma pequena orquestra de músicos negros:

Os príncipes receberam uma educação
extremamente desleixada. D. Pedro (...)
entregue totalmente à satisfação de desejos
libertinos, não adquiriu nem caráter nem
conhecimentos, nem postura externa. Somente
a música possui algum encanto para ele: dizem
que tem bom juízo a respeito dela, conhecendo

${ }^{407}$ GRAHAM, Maria. Escorço biográfico de Dom Pedro I com uma notícia do Brasil e do Rio de Janeiro. Tradução de Américo Jacobina Lacombe. Anais da Biblioteca Nacional. Rio de Janeiro, v. 60, p. 75, 1938.

408 "Toute la journée je suis occupée à écrire, lire et faire la musique. Comme mon époux joue presque tous les instruments très bien, je l'accompagne avec le Piano et de cette manière j'ai la satisfaction d'être toujours près de la personne chérit" (LEOPOLDINA, Imperatriz consorte de Dom Pedro I. Carta a sua tia. São Cristóvão, 24/01/1818. Biblioteca Nacional, Rio de Janeiro, Seção de Manuscritos, I-35,02,058). 
a amplitude de todos os instrumentos e até algo da composição. Organizou ele próprio uma banda composta de negros e ocupa-se muito dela ${ }^{409}$.

Este último e inusitado fato também é divulgado, embora com outras palavras, por Spix e Martius em seu livro Reise in Brasilien:

... um pequeno conjunto privado de música instrumental e vocal, o qual o próprio príncipe herdeiro criou com mestiços nativos e pretos, fala, todavia, muito em favor do senso musical dos brasileiros. Dom Pedro, que de seu antepassado D. João IV parece ter herdado excelente vocação para a música, conduz até mesmo de vez em quando esta orquestra que, estimulada por isto, toca com grande diligência ${ }^{410}$.

É claro que essa plena dedicação não se sustentaria após a volta de Dom João VI para Portugal. Atarefado com os negócios do Reino ao entrar no exercício da Regência, Dom Pedro teria de dividir-se cada vez mais entre suas paixões e obrigações, sobretudo quando assumiu definitivamente o poder, em 1822, como Imperador. Ao contrário, porém, do que taxou Vasco Mariz, em sua História da música no Brasil, documentação aqui reunida nos permite demonstrar que o impacto da política nos interesses musicais de Dom Pedro I não foi assim tão forte ${ }^{411}$. E mais importante: fica provado,

${ }^{409}$ A CORTE de D. João VI no Rio de Janeiro segundo dois relatos do diplomata prussiano Conde von Flemming. Tradução de Carlos H. Oberacker Jr. Revista do Instituto Histórico e Geográfico Brasileiro. Rio de Janeiro, v. 346, p. 261, 1985.

410 Tradução nossa de: "... eine Privat Kapelle von Instrumental und Vokalmusik jedoch, welche sich der Kronprinz aus eingeborener Mestizen und Schwarzen errichtet hat, spricht sehr für den musikalischen Sinn der Brasilianer. Don Pedro, der von seinem Ahnherrn D. Johann IV. ein ausgezeichnetes Talent für Musik ererbt zu haben scheint, leitet bisweilen selbst dieses Orchester, welches dadurch belebt die ausgaben mit großem Fleiß ausführt" (SPIX, Johann Baptist von; MARTIUS, Karl Friedrich Philip von. Op. cit., v. 1, p. 105-106)

... sua formação musical e grande parte de sua produção como compositor atam de antes da partida do rei, seu pai, para Lisboa, em 1821. Depois da Independência não Ihe sobrou muito tempo para a música..." (MARIZ, Vasco. Op. cit., p. 61). Note-se que a primeira assertiva é também duvidosa, uma vez que, das raras obras que subsistiram de Dom Pedro, algumas nem sequer foram datadas como Mortuus est (Responsório para São 
igualmente, que, graças ao interesse não arrefecido desse monarca pela música, como ouvinte e protetor, e à sua imprudência quanto à administração financeira do Império - que contou inclusive com a conivência do Legislativo em relação, por exemplo, ao descontrole das despesas relativas ao aparato monárquico, do qual a música da Câmara e da Capela Imperiais, faziam parte - a década 1821-1831 foi um período propício a essa atividade artística e cultural, tanto quanto ou mais do que o período histórico anterior, dito “joanino" (1808-1821), desmontando-se tese contrária, unanimemente defendida até hoje pela historiografia especializada, de que os abalos político-econômicos da Independência teriam enfraquecido o movimento artístico e cultural, e, por conseqüência, a atividade musical na capital do Brasil $^{412}$.

Primeiramente, em relação às alegadas dificuldades do Império nascente, vale relembrar que entre a fase "joanina" e o governo de Dom Pedro I, não houve grandes mudanças do ponto de vista econômico, financeiro e tributário. Existiu, sim, aquilo que Caio Prado Jr. chamou de

Pedro de Alcântara, em dó maior), Sub tuum præsidium (Antífona de Nossa Senhora, em dó maior) e o já mencionado Credo, em dó maior. Essas três partituras, manuscritas, estão tombadas no Fundo Capela Real e Imperial (Seção Musical) do Arquivo do Cabido Metropolitano do Rio de Janeiro (caixas 53 e 54).

412 Para Mário de Andrade, “... a independência política faz com que a vida brasileira principie de novo. Também a música sofre o abalo da mudança e no Primeiro Império se empobrece bem" (ANDRADE, Mário de. Pequena história da música. Belo Horizonte: Itatiaia, 1987, p. 158). Renato Almeida faz-Ihe coro: "... depois da partida de D. João VI e da Independência, cessou o amor pela música que tanto dominara a época anterior da nossa vida. A nação independente, embriagada pela liberdade, sofria os primeiros reveses da glória" (ALMEIDA, Renato. Op. cit., p. 337). Ayres de Andrade não segue outra linha: "O período histórico que começa com a Independência, por corresponder a uma fase de adaptação do País a condições políticas para as quais ele não estava preparado, teria forçosamente que trazer o enfraquecimento de suas atividades, inclusive artísticas. A época de D. João VI havia sido para a música na Capela uma época de esplendor. Na de D. Pedro I o quadro não será o mesmo. Bem que o imperador esforçavase para que tudo continuasse como antes na sua Capela, já agora Imperial por força das circunstâncias. Tinha, no entanto, as mãos atadas. Aos seus esforços opunham-se, não só um ambiente tumultuado pelas lutas partidárias, como as desmanteladas finanças do país" (ANDRADE, Ayres de. Op. cit., v. 1, p. 161). Enfim, Vasco Mariz, foi, de todos, o mais radical: “... o regresso à Lisboa do rei Dom João VI foi um desastre para a música no Brasil. O nível das atividades musicais na Capela Real, e depois Imperial, baixou bruscamente. A música profana também sofreu muito, com a agravante de que o Teatro de São João, no Rio de Janeiro, incendiou-se em 1824" (MARIZ, Vasco. Op. cit., p. 65). Note-se que esse último texto, embora já tenha algumas décadas, foi revisto, ampliado e reeditado recentemente em 2000 e 2005. 
"prolongamento da situação". Segundo o mesmo autor,

... desde a transferência da corte em 1808, pelos anos afora, as contas públicas saldar-seão cada ano, quase sem exceção, em débito. Isso se resolverá em regra pelo não pagamento sumário dos compromissos. Funcionalismo em atraso, dívidas proteladas, são fatos não somente comuns na vida financeira do país mas antes a regra poucas vezes infringida. Outro expediente serão as emissões de papel-moeda de curso forçado que se sucedem a jato contínuo... ${ }^{413}$

De fato, o Banco do Brasil, e, paralelamente, todos aqueles que aceitaram seus papéis de curso forçado como meio de pagamento - em suma, toda a população - , bancaram quase que integralmente os excessos de despesas sobre receitas contabilizados ano após ano pelo Erário ou Tesouro, desde 1810. Durante o reinado de Dom Pedro I, além de empréstimos externos realizados, essas emissões de notas ainda aumentaram ${ }^{414}$, satisfazendo os mais abusivos gastos do Governo, fossem civis, militares, ou relacionados à chamada "dotação", ou seja, à manutenção de um aparato magnífico exclusivamente destinado ao "decoro" do monarca. Isso incluía, evidentemente, como já dissemos, gastos com manifestações artísticas, entre as quais, a predileta do Imperador: a música.

A respeito da dotação, é importante mencionar que essa verba, com ou sem a aprovação do Legislativo ${ }^{415}$, só aumentou, durante o primeiro

\footnotetext{
${ }^{413}$ PRADO JR., Caio. Op. cit., 1970, p. 138-139.

414 Segundo o ex-Ministro do Supremo Tribunal Federal, Amaro Cavalcanti (18491922), em seu minucioso e esclarecedor trabalho $O$ meio circulante nacional: resenha e compilação cronológica de legislação e de fatos, de 1893, durante o período joanino, as emissões de notas do Banco do Brasil alcançaram, de 1810 a 1820 , inclusive (11 anos, portanto), o total de $8.826,45$ contos de réis, dos quais apenas 260 foram resgatados, conservando-se em circulação mais de 8.500. Durante um período menor do governo de Dom Pedro (até a extinção do Banco em 1829, ou seja 9 anos a partir de 1821), o "empréstimo" foi ainda maior. Do total de emissões - 20.900 contos de réis - foram resgatados 10.291,53, ficando o Governo devendo ao Banco, nesse período, mais de 10 mil contos de réis. Ao ser extinta essa instituição, estavam circulando em papéis, mais de 19 mil contos de réis (CAVALCANTI, Amaro. Op. cit., p. 78).

${ }^{415}$ Note-se que a Carta de Lei de 1824 , em seus artigo 107, dava à Assembléia
} 
reinado. Até 1827, ficou arbitrada em duzentos contos de réis, pelo Decreto de 7 de julho de $1824^{416}$, do próprio Imperador. Com o funcionamento da Assembléia Geral, a partir de 1826 - quando os gastos anuais de Dom Pedro I, à total revelia do mencionado Decreto, já giravam em torno dos 700:000\$000 417 , a dotação passou a ser discutida em plenário, tendo sido votado, em 1827, o aumento a que se referia o Artigo 108 da Constituição ${ }^{418}$, para valer a partir do ano seguinte, 1828. Ali, os gastos pessoais do Imperador passaram à ordem da fantástica quantia de mil contos de réis ${ }^{419}$. Sobre essa questão, é de vital importância a leitura da longa discussão que se travou no plenário da Câmara dos Deputados, na sessão de 28 de julho de 1827, em torno da proposta de aumento da dotação, que havia principiado, em 1826, nessa casa, e que o Senado elevara, no ano seguinte, de iniciais quatrocentos contos de réis para mil, fazendo-a retornar à Câmara. Mesmo patenteando-se o estado lastimável das finanças públicas - uma iminente "bancarrota", como alertou Vergueiro -, venceu-se, entre os Deputados, pela

Geral a incumbência de assinar ao Imperador e a sua esposa "uma dotação correspondente ao decoro de Sua Alta Dignidade" (COLEÇÃO das Leis do Império do Brasil de 1824. Constituição Política do Império do Brasil. Rio de Janeiro, Imprensa Nacional, 1886, parte 1, p. 23).

${ }^{416}$ COLEÇÃO das Leis do Império do Brasil de 1824. Decretos, Cartas Imperiais e Alvarás. Rio de Janeiro, Imprensa Nacional, 1886, parte 2, p. 43.

417 DEMONSTRAÇÃO da receita e despesa do Tesouro Nacional, divida ativa e passiva, orçamentos para o ano futuro. Rio de Janeiro: Na Tipografia Imperial e Nacional, 1827 , p. 20. Desses pouco mais de 700 contos de réis - gastos em $1826-, 76: 896 \$ 679$ o foram com a Capela Imperial, que, à época, congregava, entre seus empregados, quase 70 músicos.

418 "Art. 108. A dotação assinada ao presente Imperador, e a sua Augusta Esposa, deverá ser aumentada, visto que as circunstâncias atuais não permitem que se fixe desde já uma soma adequada ao decoro de Suas Augustas Pessoas, e Dignidade da Nação" (COLEÇÃO das Leis do Império do Brasil de 1824. Constituição Política do Império do Brasil. Rio de Janeiro, Imprensa Nacional, 1886, parte 1, p. 23).

419 Durante o ano de 1827, mesmo antes de entrar em vigor a lei - de 11 de agosto - que elevava a verba pessoal do imperador para 1.000 contos de réis, a despesa da Casa Imperial já chegava, na prática, a essa cifra: mais precisamente a 1.051:627\$562. Note-se, que esse valor já não mais englobava - segundo mesmo mandava a lei - os gastos com a Capela Imperial, que, nesse ano, chegaram a quase 103 contos de réis (DOCUMENTOS com que se instruiu o seu relatório à Assembléia Geral Legislativa do Império do Brasil o Ministro Secretário de Estado dos Negócios da Fazenda, e Presidente do Tesouro Nacional, Miguel Calmon du Pin e Almeida, na Sessão de 1828. Rio de Janeiro: $\mathrm{Na}$ Tipografia Imperial e Nacional, 1828, p. s/n.). Para se ter uma vaga idéia do que representava essa fortuna - mil contos de réis - basta imaginar que o Governo poderia contratar, com essa verba, mais de 6.500 professores de primeiras letras, cujo salário anual, à mesma época, era de $150 \$ 000$ (COLEÇÃO das Leis do Império do Brasil de 1827. 
expressiva diferença de 58 votos a 24 , a idéia de que pela "dignidade da Nação" - como sustentou Batista Pereira, parafraseando o próprio Artigo 108 da Carta de Lei - era "mister" - completou Miguel Calmon - "fornecer ao trono, por meio de uma suficiente dotação os meios de sustentar o esplendor" ${ }^{\prime 20}$. Assim se venceu, e assim os artistas que dependiam da pompa imperial certamente agradeceram aos mandatários do povo. Mantinha-se ou mesmo incrementava-se - o aparato; ao menos até 7 de abril de 1831, quando a necessária assinatura de uma nova dotação, uma vez que a Constituição assim mandava, permitiu ao Legislativo rever radicalmente as suas decisões, como melhor veremos adiante.

Em segundo lugar, paralelamente a essa momentânea conivência do Legislativo com o aumento do déficit das contas públicas, patrocinando uma pompa que, por mais algum tempo, nem mais a emissão de papel de curso forçado suportaria ${ }^{421}$, Dom Pedro I não deixou de participar de eventos musicais como compositor e instrumentista, segundo se supôs. Ao contrário - e dispondo, como vimos, de folgadas verbas —, era regular a freqüência com que reunia em São Cristóvão sua Imperial Câmara - da qual faziam parte os melhores músicos da Ópera e da Capela - para que esta executasse suas composições ou o acompanhasse em algum solo. Testemunha, com conviç̧ão, esse fato, o médico da Marinha norteamericana William Samuel Waithman Ruschenberger que esteve algumas vezes no Rio de Janeiro, entre as quais, em 1826, e em 1831, logo após a Abdicação:

Antes do jantar passamos o tempo conversando e ouvindo música; diversas peças, das quais DOM PEDRO I é o compositor, e que falam bem em favor de seu gosto, foram tocadas. Ele é apaixonadamente aficionado por música, e há

\footnotetext{
Rio de Janeiro: Tipografia Nacional, 1878, parte 1, p. 1).

${ }_{420}$ ANAIS do Parlamento brasileiro. Câmara dos Srs. Deputados. Segundo ano da primeira legislatura. Rio de Janeiro: Tipografia de H. J. Pinto, 1875, t. 3, p. 291-308.

${ }^{421}$ Relembremos que, acossado pela Assembléia Geral, a 14 setembro de 1829 Dom Pedro I sancionou a extinção do Banco do Brasil. A partir daí, apenas os empréstimos externos acudiriam as deficitárias finanças do Império.
} 
pouquíssimos instrumentos que ele não toca bem. A companhia de ópera, ou, mais propriamente, os músicos, não raramente eram levados a São Cristóvão para acompanhar o Imperador em seus concertos, ou tocar suas composições ${ }^{422}$.

Teriam pois, essas "diversas peças", ouvidas pelo norte-americano em 1831 - certamente pianísticas - sido compostas durante o primeiro reinado? Infelizmente, isso não é possível assegurar. Porém, uma coisa é certa: o monarca não deixou de compor após assumir o trono. O Hino da Independência é a maior prova disso. Como se não bastasse, textos completamente desconhecidos de nossa historiografia e aqui revelados também nos asseguram que Dom Pedro I se dedicou à composição enquanto "chave de toda a organização política" ${ }^{423}$.

Um deles, da pena de William Tudor (1779-1830) - Encarregado de Negócios dos Estados Unidos no Rio de Janeiro, entre 1827 e 1830 - e publicado no periódico nova-iorquino The naval magazine, em 1837, nos traz a notícia de que o Imperador teria escrito, por ocasião das suas segundas bodas, em 1829 - e estreado sob a direção de Marcos Antônio Portugal —, um "belo" Te Deum ${ }^{424}$. Outras notícias, igualmente publicadas em 1837 -

422 Tradução nossa de: "Before dinner the time was passed in conversation and listening to music; several pieces, of which DOM PEDRO $\mathrm{I}$. is the composer, and which speak well for his taste, were played. He is passionately fond of music, and there are very few instruments which he does not play well. The opera company, or rather the musicians, were not unfrequently brought to San Christovão to accompany the emperor in his concerts, or to play his compositions" (RUSCHENBERGER, W. S. W. Op. cit., p. 55).

${ }_{424}$ Vide nota 3 da introdução.

${ }^{424}$ Note-se que essa é a ultima notícia que se tem da atividade do então mestrede-capela Marcos Portugal, alguns meses antes de sua morte. Embora Cleofe Person de Matos, presuma que tenha sido Fortunato Mazziotti o responsável pelo serviço musical nas segundas núpcias de Dom Pedro I (MATOS, Cleofe Person. José Maurício Nunes Garcia biografia. Rio de Janeiro: Biblioteca Nacional, 1997, p. 175) o norte-americano, testemunha ocular do fato, é taxativo: "Portugello [sic], who must be one of the oldest of living composers, is the conductor. The music of this 'TE DEUM' was beautiful, and composed by the Emperor himself, for this occasion" (THE NAVAL MAGAZINE, 11/1837, p. 538). Já, quanto à partitura deste Te Deum, de 1829, embora atualmente encontre-se extraviada, deve ela ter pertencido, até o início do século XX, ao antigo acervo da Capela Imperial, pois, em um catálogo manuscrito de partituras desse conjunto documental, de 1902, atualmente tombado no Arquivo do Cabido Metropolitano do Rio de Janeiro (Fundo Capela Real e Imperial, Seção Musical, cx. 46), são listados, como composições de Dom Pedro I, dois te-déuns (ARCOVERDE. Dom Joaquim. Catálogo da música da Capela Imperial 
desta vez no principal diário do Rio de Janeiro, o Jornal do comércio também nos revelam um Dom Pedro I, compositor de duas peças pianísticas, uma delas, ao menos, comprovadamente composta durante o primeiro reinado:

$\mathrm{Na}$ imprensa de música de $\mathrm{P}$. Laforge rua da Cadeia n. 89 (...) Acha-se também reimpressa a bela marcha fúnebre de $\mathrm{D}$. Pedro I, para piano, corrigida do erro tipográfico que havia na primeira edição... ${ }^{425}$

... Souvenir filial ou divertimento para piano forte; composto em 1828 na imperial quinta da Boa Vista, por S. M. I. o Sr. D. Pedro $1^{\circ}$, impresso pela primeira vez por ordem do seu augusto filho o Sr. D. Pedro $2^{\circ}$ (...) Previne-se que estas interessantes peças de música, apesar de sua barateza, estão impressas em bom papel, e que o tipo não é inferior em beleza ao que vem da Europa: vendem-se na Imprensa de música de $\mathrm{P}$. Laforge, Rua da Cadea, $\mathrm{n}$. $89^{426}$.

Além disso, a realidade de que Dom Pedro I, durante todo o seu governo, freqüentou com assiduidade o camarote central do grande teatro

atualmente Catedral Metropolitana do Rio de Janeiro. Rio de Janeiro, 1902, p. 22). Um deles é o de 1820, em dó maior, já mencionado. O outro, talvez seja esse, de 1829.

425 JORNAL DO COMÉRCIO, 02/05/1837.

${ }^{426}$ Idem, 02/08/1837. O oboísta Pierre Laforge, natural de Perpignan, França, chegou ao Rio de Janeiro em 1817 e logo passou a integrar a Câmara e Capela de Dom João VI, onde permaneceu até 1831. Três anos depois, funda na Rua do Ouvidor tradicional reduto de comerciantes franceses - sua "imprensa de música", a primeira da capital do Império exclusivamente voltada a esse tipo de mercado editorial. Em janeiro de 1835, anunciava o início de seus trabalhos, como nos testemunha, mais uma vez, o Jornal do comércio: "MARCHA FÚNEBRE, composta em Lisboa na ocasião do funeral de S. M. I. o Duque de Bragança, e reimpressa nesta corte com muita nitidez, acha-se à venda na casa de Seignot-Plancher e Comp. Esta peça faz-se recomendável ao público tanto por seu nobre e saudoso objeto, como por ser o primeiro ensaio de um novo ramo de indústria no Brasil, qual a música aberta em chapas de cobre com tanta perfeição e nitidez, que em nada se diferencia da que nos vem da Europa. Mr. P. Laforge, a quem devemos a impressão desta excelente peça, incumbe-se de abrir com prontidão e corretamente toda a música que se Ihe confiar. Dirigir-se à rua do Ouvidor, n. 154" (Idem, 10/01/1835). Pierre Laforge morreu em 1853 (Cf. CAPEILLE, J. Dictionnaire de biographies roussillonnaises. Perpignan: Imprimerie-Librairie Catalane de J. Comet, 1914). 
para assistir - com interesse ${ }^{427}$ - às óperas e aos bailados também torna evidente que, mesmo ocupado em exercer seus latos poderes, ele continuava gastando tempo com a arte dos sons, auxiliando-a muito, inclusive - desta vez de forma indireta, sem para isso forçar a emissão de uma nota sequer do Banco do Brasil -, na medida em que sua presença constante no teatro incitava toda a corte a acompanhá-lo em sua diversão cênica, coreográfica e musical, fazendo dela moda, como já ocorrera nos tempos dos vice-reis e de Dom João. A 18 de julho de 1827, por exemplo, o jornal de Plancher-Seignot, L'écho de L'Amérique du Sud, publicado em francês no Rio de Janeiro, noticia a ida do Imperador e de sua filha, a Rainha de jure de Portugal, ao teatro no dia anterior para assistirem à trigésima apresentação de Aureliano in Palmira, ópera de Rossini. Mesmo não sendo um dia de gala, o teatro esteve, segundo o cronista do jornal, "completamente lotado" oferecendo "a reunião mais brilhante da elite da sociedade brasileira" ${ }^{428}$.

O Barão de Bougainville, que esteve ali presente em uma apresentação de ópera, seguida de um bailado, em 1826, nos legou uma das mais detalhadas narrativas acerca da presença de Dom Pedro I nesse divertimento. Ela nos mostra, entre outra coisas, como era concorrido o camarote imperial - tal qual um "salão deslumbrante" - e como a presença do Imperador determinava, não apenas o início, mas também o encerramento do espetáculo:

${ }^{427}$ Em 23 de setembro de 1830, Dom Pedro I chegou até a advertir, por carta, seu então Ministro dos Negócios Estrangeiros, Miguel Calmon du Pin e Almeida, para que esse não Ihe levasse notícias de governo quando estivesse no teatro: "...vou ao Teatro só para ouvir a ópera, e que, para me serem comunicadas notícias, e tão interessantes como estas que acabam de chegar, estou no Meu Palácio, digo-Ihe-o [sic] já" (Apud VIANA, Helio. Op. cit, p. 71). Segundo Viana, este documento manuscrito se acha tombado no Arquivo Histórico do Museu Imperial de Petrópolis.

428 "Hier, S. M. l'Empereur, accompagné de son auguste Fille, à honoré le théâtre de sa présence. La salle, entièrement remplie, offrait la réunion la plus brillante de l'élite de la société brésilienne" (L'ÉCHO DE L'AMÉRIQUE DU SUD, 18/07/1827). Note-se ainda que essa verdadeira "atração" não apenas levava, em massa, ao teatro, a "elite da sociedade brasileira". Estrangeiros, de passagem, também faziam questão de ir à ópera apenas pela curiosidade de ver o Imperador em pessoa. Esse foi o caso do já mencionado tenente da Marinha inglesa Charles Brand, que esteve de passagem pelo Rio de Janeiro em princípios de 1828: “... I visited the opera for the purpose of getting sight of the Emperor, who happened to be there, accompanied by his two daughters, the Queen of Portugal and the Infanta" (BRAND, Charles. Op. cit., p. 302-303). A infanta referida era Dona Januária, então 
A ópera Tancredi seria representada à noite no teatro e a família imperial devia assistir a essa representação. M. de Gestas ofereceu seu camarote ao almirante. Chegamos no momento em que o público, em pé e sem chapéus, escutava em silêncio os versos dirigidos ao príncipe por um espectador dos camarotes de segunda ordem; cópias da poesia caíam esvoaçando sobre a platéia, lenços eram agitados e vivas ecoavam de todos os lados; em seguida, todos retomaram seus lugares, depois que o Imperador deu o exemplo, sentando-se. (...) O camarote imperial, que fica defronte ao palco e ocupa quase todo o fundo do teatro, forrado de espelhos, tinha o aspecto de um salão deslumbrante. O Imperador, a Imperatriz e a princesinha, acomodados na parte da frente do camarote, estavam com as mesmas roupas do beija-mão e, atrás, permaneciam em pé em torno de vinte pessoas da Casa de S. M., entre as quais me fizeram notar o confessor do príncipe (...) O balé do segundo ato ainda não tinha terminado quando o príncipe se retirou, saudando o público, que se levantou ao mesmo tempo. Após sua saída esperava-se que 0 espetáculo continuasse, mas depois de um quarto de hora de incerteza, a extinção das luzes do palco deu o sinal de retirada e o povo se esvaiu sem o menor murmúrio, persuadido, sem dúvida, de que essa era a vontade suprema ${ }^{429}$.

com 6 anos, por fazer.

${ }^{429}$ Tradução nossa de: "On représentait le soir au théâtre l'opéra de Tancredi, et la famille Impériale devait assister à cette représentation. M. de Gestas offrit sa loge à l'amiral. Nous y arrivâmes à l'instant où le public, debout et découvert, écoutait en silence des vers adressés au prince par un spectateur des secondes loges; des copies de ce morceau de poésie descendirent en voltigeant sur le parterre; les mouchoirs furent agités, et des vivat multipliés se firent entendre de toute part; puis chacun reprit place après que l'Empereur en eut donné l'exemple en s'asseyant. (...) La loge impériale, qui fait face au théâtre et occupe presque tout le fond de la salle, lambrissée de glaces, présentait l'aspect d'un salon éblouissant de lumière. L'Empereur, I'Impératrice et la petite princesse, placés sur le devant de la loge, étaient dans le même costume qu'au baisemain, et derrière se tenaient debout une vingtaine de personnes de la maison de S. M., parmi lesquelles on me fit remarquer le confesseur du prince (...) Le ballet du second acte n'était pas encore achevé, lorsque le prince se retira en saluant le public, qui s'était levé en même temps. Après son départ on s'attendait à voir continuer la pièce; mais au bout d'un quart d'heure d'incertitude, l'extinction des rampes donna le signal de la retraite, et la foule s'écoula sans 
Maria Graham e Antônio de Meneses Vasconcelos de Drummond testemunharam algumas vezes a invariável presença do Príncipe Regente e posterior Imperador no Teatro de São João entre os anos de 1821 e $1824^{430}$. Do mesmo fato nos certificam Victor Jacquemont e Robert Walsh, entre os anos de 1828 e 1829, demonstrando que não houve atenuação desse hábito imperial, mesmo em uma época em que os assuntos políticos se fizeram mais do que soberanos. O primeiro foi taxativo: "Há no Rio de Janeiro um belo teatro (...). O Imperador está sempre lá" ${ }^{431}$. Já, o reverendo irlandês, corrobora, tanto o depoimento de Jacquemont, como, com palavras idênticas, o relato anterior, de Ruschenberger, confirmando que Dom Pedro I era "apaixonadamente aficionado" pela Ópera e seu "constante espectador" 432.

Finalmente, lancemos nosso olhar para a atividade musical em si, durante o domínio de Dom Pedro I. Se a Imperial Câmara, como vimos, formada pelos melhores músicos do Rio de Janeiro, manteve-se ativa, acompanhando o Imperador em seus concertos e bailes particulares em São Cristóvão, a atividade da Capela, apesar de alegadas dificuldades sobretudo relacionadas à estagnação salarial dos músicos ${ }^{433}$ —, também não sofreu, aparentemente, nenhum impacto negativo após o regresso de Dom

le plus petit murmure persuadée sans doute que telle était la volonté suprême" (BOUGAINVILLE, Hyacinthe Yves Philippe Potentien, Baron de. Op. cit., t. 1, p. 625-626). Quanto ao "M. de Gestas" mencionado, trata-se do Comte de Gestas, Jacques-Marie Aymard (1786-1858), à época cônsul-geral da França no Rio de Janeiro.

${ }_{430}$ Corroborando, aliás, o relato de Bougainville, Drummond, em uma de suas anotações referentes a um fato ocorrido em 1821, deixa transparecer um mesmo "movimento inercial" do público — ou pelo menos de parte dele — em relação à saída precoce do Imperador de um espetáculo realizado no teatro: "O Príncipe deixou o teatro mais cedo do que de costume. Nós seguimos o exemplo..." (DRUMMOND, Antônio de Meneses Vasconcelos de. Op. cit., v. 13, p. 16).

431 "Il y a à Rio un beau théâtre. (...) L'Empereur est toujours là" (JACQUEMONT, Victor. Op. cit., 1835, v. 1, p. 45).

Robert. Op. cit., v. 1, p. 484).

${ }_{433}$ Ayres de Andrade sustentou - sem mencionar, no entanto, um nome sequer que, após a volta de Dom João VI para Portugal, "não poucos músicos haviam abandonado seus postos em busca de trabalho mais lucrativo". Apresentou, também, como sustentáculo de uma situação "dramática" dos músicos da Capela, um único documento, de 1828, no qual esses profissionais pediam o aumento de seus salários (ANDRADE, Ayres de. Op. cit., v. 1, p. 161-162). No entanto, o fato de os músicos estarem insatisfeitos com seus vencimentos não significa que a qualidade ou a assiduidade do serviço tenham piorado. 
João VI à Lisboa ou mesmo a proclamação da Independência ${ }^{434}$. Em referência a essa hipótese, um fato irretorquível chama-nos a atenção logo de saída: os melhores profissionais que prestaram serviços a Dom João muitos deles trazidos da Europa, como os já mencionados Giovanni Francesco Fasciotti, Antonio Cicconi, Angelo Tinelli, Francesco Reali, Marcos Portugal, Antônio Pedro Gonçalves e Francesco Ansaldi; ou mesmo brasileiros, como João dos Reis Pereira, José Maurício Nunes Garcia e Pedro Teixeira de Seixas - permaneceram no Rio de Janeiro durante o primeiro reinado, alguns deles, inclusive, mantendo as pensões que recebiam do "Real Bolsinho" 435 . Números oficiais dos gastos públicos com essa repartição, contidos nos relatórios do Ministério e Secretaria de Estado da Fazenda, também não apresentam, em média, grandes diferenças entre um período e outro. Em 1820, por exemplo, a Capela Real consumiu 83:030 $\$ 537^{436}$; mais do que em $1824(58: 445 \$ 898)^{437}$; porém, menos do que em 1827 $(102: 856 \$ 871)^{438}$. Além disso, testemunhos de viajantes são unânimes quanto à manutenção do nível de excelência musical da Capela durante todo o reinado de Dom Pedro I. A já mencionada Maria Graham registra, por exemplo, em seu diário que, em 1822, o coro era "mantido de maneira que

${ }^{434}$ André Cardoso, em sua tese de doutorado, que mostra exclusivamente a atividade musical da Capela entre 1808 e 1889, chegou a afirmar, com base na análise da documentação manuscrita do Arquivo Nacional, que a Independência "não representou uma mudança substancial na sistemática de trabalho estabelecida em 1808". Porém, procurando não se contrapor à historiografia, e citando o mesmo documento de 1828 usado por Andrade, também concluiu, sem demais argumentos e provas, que "os problemas econômicos (...) abriram um período de crise na Capela Imperial, que refletiu no esplendor do culto..." (CARDOSO, André. Op. cit., p. 106).

${ }^{435}$ Vide nota 218 da primeira parte.

436 RELATÓRIO, ou exposição do Ministro da Fazenda sobre o estado da administração respectiva em fim do ano de 1825, com o orçamento da renda e despesa que poderá ter lugar no corrente ano de 1826. Rio de Janeiro: Na Tipografia Imperial e Nacional, 1826 , p. 152. Outros dados relativos aos gastos anuais com a Capela nos tempos de Dom João ainda podem ser observados no já citado Essai statistique sur le royaume de Portugal et d'Algarve de Balbi. Números ali compilados também mostram que essas despesas não foram superiores às dos tempos de Dom Pedro. Em 1811, por exemplo, a Capela teria gasto 43:563\$536 (BALBI, Adrien. Op. cit., v. 1, p. 307).

437 Idem, p. 140.

438 DOCUMENTOS com que se instruiu o seu relatório à Assembléia Geral Legislativa do Império do Brasil o Ministro Secretário de Estado dos Negócios da Fazenda, e Presidente do Tesouro Nacional, Miguel Calmon du Pin e Almeida, na Sessão de 1828. Rio de Janeiro: Na Tipografia Imperial e Nacional, 1828, p. s/n. 
não envergonharia a Itália". E que, "assistindo às vésperas, raramente se satisfizera tanto quanto com essa música" ${ }^{439}$. Peter Heinrich Schumacher, que coordenou a vinda de alguns imigrantes alemães para o Brasil, em 1824, foi ainda mais preciso nos seus elogios à qualidade da música da Capela. Afirmou ser esta "muito bem executada", destacando o "excelente" canto dos castrados $^{440}$. Seu conterrâneo, Carl Schlichthorst, que morou no Rio de Janeiro entre 1825 e 1826, achou-a toda "excelente"441; mesma impressão que teve o Barão de Bougainville - nobre francês, acostumado, sem dúvida, a ouvir os melhores artistas europeus - ao presenciar, na Capela, um Te Deum, em $1826^{442}$. Não desmente os anteriores, o Encarregado de Negócios dos Estados Unidos no Brasil, William Tudor, ao descrever o casamento de Dom Pedro I com Dona Amélia de Beauharnais, em 1829. O norte-americano afirmou que a música executada naquela ocasião era "muito refinada"443. Enfim, exempli gratia, em relação ao mesmo ano, outro americano, o capelão da Marinha Charles Samuel Stewart (1795-1870), deixou-nos depoimento igualmente favorável ao serviço musical da Capela Imperial:

A música, realizada por um conjunto completo, compreendendo os mais distintos intérpretes da Ópera, foi admirável, o canto, refinado, e o acompanhamento instrumental, deleitável ${ }^{444}$.

439 "The choir is served in a manner that would not disgrace Italy. I attended at vespers, and have seldom been more gratified with the music of the evening service" (GRAHAM, Maria. Op. cit., p. 168).

440 "Nachdem die ganze Suite in der Kirche angekommen war, begann die Musik, welche sehr gut exekutiert wurde, und wobei einige, auf die Feier des Tages sich beziehende Hymnen von Kastraten vortrefflich gesungen wurden" (SCHUMACHER, Peter Heinrich. Beschreibung meiner Reiser von Hamburg nach Brasilien Juni 1824 nebst Nachrichten über Brasilien bis zum Sommer 1825 über die Auswanderung dahin, der Wahrheit gemäß und zur Warnung niedergeschrieben. Braunschweig: Bei Friedrich Vieweg, 1826, p. 48).

441 "Die Musik in der kaiserlichen Capelle ist vortrefflich" (SCHLICHTHORST, Carl. Op. cit., p. 137).

442 "Le Te Deum fut entonné aussitôt que LL. M.M. eurent pris place au bruit des salves d'artillerie et de mousqueterie tirées à la porte de l'église. La musique était excellente..." (BOUGAINVILLE, Hyacinthe Yves Philippe Potentien, Baron de. Op. cit., t. 1, p. 623).

443 "The music of the Royal [sic] chapel is very fine..." (THE NAVAL MAGAZINE, 11/1837, p. 538).

dradução nossa de: "The music, by a full orchestra, embracing the most distinguished performers of the opera, was admirable, the singing fine, and the instrumental 
Falando-se em ópera, quanto a ela - não se levando em conta o período de cerca de dois anos em que o Imperial Teatro teve de ser reconstruído após um incêndio (1824-1826) —, nunca se vira, até então, no Rio de Janeiro, temporadas tão movimentadas. Se durante a época de Dom João as apresentações de óperas não foram senão dispersas - ao menos até $1819^{445}$ —, a partir de 1822, o São João iria transformar-se em um verdadeiro centro operístico, promovendo até mesmo uma dura concorrência entre as companhias Italiana e Nacional - esta última apenas de atores dramáticos - e provocando desentendimentos entre os artistas ${ }^{446}$.

Favoreceu, sem dúvida, o desenvolvimento das temporadas líricas, sempre mais dispendiosas do que as meramente teatrais, a ação governamental paternalista de Dom Pedro I para com essa casa de espetáculos. Um dos primeiros decretos assinados pelo Imperador após a sua coroação - o de 26 de dezembro de 1822 - já concedia ao proprietário do Teatro de São João, Fernando José de Almeida, uma loteria para que este legalizasse suas dívidas com o Banco do Brasil, e pudesse assim voltar a pôr em cena espetáculos "dignos" de serem oferecidos ao público carioca:

Tendo reconhecido a impossibilidade que tem o proprietário do Teatro de S. João de continuar a pôr em cena espetáculos, que sejam dignos de oferecer-se ao público desta corte, não só pelo alcance em que ele se acha para com os seus

accompaniment delightful" (STEWART, Charles Samuel. A visit to the South Seas, in the U.S. ship Vincennes, during the years 1829 and 1830; with notices of Brazil, Peru, Manilla, the Cape of Good Hope, and St. Helena. London: Fisher, son, \& Jackson, 1832, p. 27).

${ }_{445}$ Segundo Ayres de Andrade, que realizou minudente pesquisa nos jornais da época, poucos títulos operísticos teriam sido encenados durante a permanência de Dom João no Rio de Janeiro (ANDRADE, Ayres de. Op. cit., v. 1, p. 112-126). Sabemos, no entanto, que essa documentação não revela toda a amplitude do movimento teatral e que depoimentos, como, por exemplo, o do já citado von Leithold, referente ao ano de 1819, contradizem tal carência de espetáculos. Tudo indica que a entrada de Paulo Rosquellas na cena musical carioca a partir desse ano teria alavancado a temporada lírica, fazendo-a crescer substancialmente nos anos subseqüentes.

${ }_{446}$ Documenta o fato a já mencionada portaria do Ministério dos Negócios do Reino de 22 de maio de 1822, mediante a qual José Bonifácio, a pedido de Dom Pedro, procurou promover os meios de conciliar os interesses das duas companhias (Coleção das Leis do Brasil de 1822. Decisões de 1822. Rio de Janeiro, Imprensa Nacional, 1887, p. 36-37) 
credores, mas pelos diminutos interesses que Ihe provém das representações; e Desejando Eu proteger este estabelecimento pelos atendíveis e conhecidos motivos por que os teatros são favorecidos em todas as Nações civilizadas: Hei por bem, Tendo em vista a Sua necessária conservação, que o Banco do Brasil concorra a tão justos fins, e tome a seu cargo formar sobre o fundo competente o plano de uma loteria, cuja administração e regulamento Sou Servido incumbir-lhe; devendo o mesmo Banco legalizar as contas do sobredito proprietário, Fernando José de Almeida, e suprir igualmente do produto da nova loteria o excedente das despesas do Teatro, conservando em caixa, o resto liquido para o aplicar no futuro ao mesmo fim do suprimento dos gastos, a que não chegarem os lucros procedentes das representações ${ }^{447}$.

Note-se que esta loteria, segundo o decreto de 7 de janeiro de 1823, era extraordinária, ou seja, não fazia parte da concessão que, em agosto de 1817, já havia dado ao teatro o direito de extrair, por uma década, duas loterias anuais ${ }^{448}$. Um ano e meio depois - a 26 de agosto de 1824 -, outro decreto do Imperador concedendo ao teatro, antecipadamente, o produto líquido de mais três loterias extraordinárias - cerca de 43 contos de réis ${ }^{449}$ - socorreria mais uma vez Fernando José de Almeida, ajudando-o, agora, a reedificar o teatro, após o incêndio de 25 de março daquele ano:

${ }^{447}$ COLEÇÃO das Leis do Império do Brasil de 1822. Rio de Janeiro: Imprensa Nacional, 1887, parte 2, p. 105-106. Uma hipótese ainda a ser confirmada por documentação: em querendo sempre espetáculos "dignos" no Teatro, como confirma a intenção desse Decreto, Dom Pedro I certamente forçou o proprietário Fernando José de Almeida a investir ao máximo na mise en scène, incluindo-se, é claro, o que se gastava com música. Em contrapartida aos investimentos, o Imperador concedia-Ihe loterias e certamente Ihe facilitava créditos no Banco do Brasil. Isso justifica, talvez, o constante déficit do Teatro e a sua dívida obrigada, não a seus fornecedores, mas sempre ao Banco do Brasil.

${ }^{448}$ Aliás o mesmo decreto atesta que, até aquele momento, o São João já havia desfrutado de dez delas (COLEÇÃO das Leis do Império do Brasil de 1823. Rio de Janeiro: Imprensa Nacional, 1887, parte 2, p. 7).

${ }_{449}$ Estipula-se que este tenha sido o valor que o Banco do Brasil antecipou a Fernando José de Almeida, mais precisamente 43:200\$000, que correspondia a $12 \%$ de três loterias de 120:000\$000. 
Tomando em consideração que os Teatros são em todas as Nações cultas protegidos pelos Governos, como estabelecimentos próprios para dar aos povos lícitas recreações e até saudáveis exemplos das desastrosas conseqüências dos vícios, com que se despertem em seus ânimos o amor a honra e a virtude; e Desejando por isso facilitar a reedificação do Teatro desta capital, infelizmente incendiado na noite de 25 de março do presente ano: Hei por bem, depois de ter ouvido a esse respeito a Junta do Banco do Brasil, Encarregá-la em benefício do Coronel Fernando José de Almeida, proprietário daquele Teatro, da administração de três novas loterias (que não terão de fundo mais de 120:000\$000 cada uma), para se extraírem antes das mais já concedidas ao dito Coronel, a quem se entregará logo o produto destas ... ${ }^{450}$

Jamais, em tão pouco tempo, a Ópera - agora denominada, em homenagem ao seu protetor, "Imperial Teatro de São Pedro de Alcântara" teve tantas concessões de loterias. Do incêndio, em 1824, até meados de 1831, andaram à roda vinte delas ${ }^{451}$, sem contar as três últimas, concedidas pelo decreto de 27 de setembro de $1830^{452}$, que só seriam extraídas, como ainda veremos, entre 1834 e 1835. Dessa proteção, resultaram temporadas líricas de movimento bastante expressivo, já em parte visto, no primeiro capítulo, mediante as informações parciais, colhidas por Ayres de Andrade. Aproveitando essa retomada de assunto, complementemos os dados relativos às temporadas líricas do tempos de Dom Pedro I com o resgate de uma preciosa informação: uma "lista dos dias em que as companhias italianas e de dança darão espetáculo", publicada, em 1828, em O espelho diamantino: periódico de política, literatura, belas artes, teatro e modas, "dedicado às

${ }^{450}$ COLEÇÃO das Leis do Brasil de 1824. Decretos, Cartas Imperiais e Alvarás de 1824. Rio de Janeiro: Imprensa Nacional, 1886, p. 54-55. No total, até 1831,

${ }^{451}$ No dia 7 de setembro de 1831, o Jornal do comércio anunciava: "A vigésima primeira loteria do Teatro, continua a vender-se no banco e nas lojas de livros de João Pedro da Veiga (...) O prêmio maior é de vinte contos de réis líquidos, já há uma porção de bilhetes vendidos e breve se anunciará quando deve andar a roda".

${ }^{452}$ COLEÇÃO das Leis do Império do Brasil de 1830. Rio de Janeiro: Tipografia Nacional, 1876, parte 2, p. 44. 
senhoras brasileiras" ${ }^{453}$. Reproduzida aqui, pela primeira vez, ela nos permite redimensionar a totalidade de um ano teatral da Companhia Italiana durante o primeiro reinado, incluindo-se, nesse cálculo, não apenas os "benefícios" e os "dias de gala" - mais comumente noticiados nos principais jornais, e que, em grande parte, já haviam sido resgatados por Ayres de Andrade -, mas, também, as pouco referidas "récitas gerais", que ocorriam, quase sempre, aos domingos e às quintas-feiras, e correspondiam a mais da metade do total de récitas prometidas. Embora tal documento não prove que todos esses espetáculos tenham efetivamente ido à cena, eis o que, ao menos, se planejava para o ano teatral de 1828, encerrado na terça-feira de carnaval de 1829, 3 de março: 69 récitas gerais, vinte benefícios e 35 récitas de gala e (ou) de dia santo, totalizando a vultosa cifra de 124 espetáculos ${ }^{454}$. Esse

${ }^{453}$ A publicação desse periódico, bimensal e realizada pela tipografia de PlancherSeignot, teve inicio em setembro de 1827 e terminou em abril de 1928. Alguns números apresentam parte do texto em francês.

454 "Dias em que deve haver espetáculo no Imperial Teatro de S. Pedro de Alcântara, principiando em 7 de abril do corrente ano, até o dia 3 de março de 1829. Abril: 7 segunda-feira, dia santo e de gala -8 terça-feira, dia santo -13 domingo -17 quintafeira -20 domingo -24 quinta-feira -27 domingo; maio: 1 quinta-feira -3 sábado, dia santo e de gala -4 domingo -8 quinta-feira -11 domingo -13 terça-feira, dia de gala -15 quinta-feira, dia santo -18 domingo -22 quinta-feira -26 segunda-feira, dia santo - 27 terça-feira, dia santo; junho: 1 domingo - 5 quinta-feira, dia santo e de gala -8 domingo - 13 sexta-feira, dia santo -15 domingo -19 quinta-feira, dia santo -22 domingo -24 terça-feira, dia santo -28 sábado, benefício -29 domingo; julho: 3 quintafeira -5 sábado, benefício -6 domingo -10 quinta-feira -12 sábado, benefício -13 domingo -17 quinta-feira -19 sábado, benefício -20 domingo -25 sexta-feira, dia santo - 27 domingo - 29 terça-feira, benefício; agosto: 2 sábado, dia de gala -3 domingo -5 terça-feira, benefício -7 quinta-feira -10 domingo -12 terça-feira, benefício -15 sexta-feira, dia santo -17 domingo -19 terça-feira, benefício -21 quinta-feira -24 domingo -26 terça-feira, benefício -28 quinta-feira -31 domingo; setembro: 4 quinta-feira -7 domingo, dia de gala -8 segunda-feira, dia santo -11 quinta-feira -13 sábado, benefício -14 domingo, e dia de gala -19 sexta-feira, dia santo -21 domingo -23 terça-feira, benefício -25 quinta-feira -28 domingo -29 segunda-feira, dia santo; outubro: 4 sábado, dia de gala -5 domingo - 9 quinta-feira 12 domingo, e dia de gala -16 quinta-feira -19 domingo, dia de gala -21 terça-feira, benefício -23 quinta-feira -26 domingo -28 terça-feira, dia santo -30 quinta-feira; novembro: 4 terça-feira -6 quinta-feira -8 sábado, benefício -9 domingo -13 quintafeira - 15 sábado, benefício - 16 domingo - 20 quinta-feira -22 sábado, benefício 23 domingo -27 quinta-feira -29 sábado, benefício -30 domingo; dezembro: 1 segunda-feira, dia de gala -2 terça-feira, dia de gala -6 sábado, benefício -8 segundafeira, dia santo e de gala -11 quinta-feira -14 domingo -16 terça-feira, benefício -18 quinta-feira -21 domingo -26 sexta-feira, dia santo e de gala -27 sábado, dia santo 28 domingo - 31 quarta-feira, dia santo; janeiro de 1829: 1 quinta-feira, dia santo e de gala -4 domingo -6 terça-feira, dia santo e de gala -10 sábado, benefício -11 domingo -15 quinta-feira -18 domingo -20 terça-feira, dia santo -25 domingo -27 
movimento correspondia, praticamente, a três récitas por semana, como já mencionara Victor Jacquemont, em relação a essa mesma temporada de $1828^{455}$. Em suma, era uma previsão tão otimista quanto o seguinte comentário, publicado no mesmo $O$ espelho diamantino, em fins do ano teatral de 1827 , e que também nos confirma quais seriam os principais "elementos" desse "sucesso":

Sim, Senhor, nós teremos no Rio de Janeiro um teatro digno do nome que carrega, digno da sociedade que ali se reúne: pois temos agora todos os elementos de sucesso; espectadores todos os dias prontos a pagar, (...), um governo generoso, e uma população muito disposta à jogar na loteria cinco ou seis vezes por ano ${ }^{456}$.

E como se não bastassem o público atraído pela presença do Imperador e as "generosas" concessões de loterias, a proteção de Dom Pedro I em relação ao Teatro chegou a sair da esfera oficial e adentrou na particular, ao menos, comprovadamente, quando o proprietário Fernando José de Almeida faleceu, em julho de 1829. Encabeçando, com vultosos dez contos de réis, uma lista de 24 subscritores, da qual participavam muitos de seus amigos mais íntimos - como Plácido Antônio Pereira de Abreu, João da Rocha Pinto e Francisco Gomes da Silva, o "Chalaça" - , políticos e grandes negociantes da praça do Rio de Janeiro, sempre ávidos em agradar o monarca em troca de honrarias e vantagens, o Imperador auferiu 79:000\$000 457 , arrematando o prédio de seus principal credor, o Banco do

terça-feira, dia santo; fevereiro: 1 domingo -2 segunda-feira, dia santo -8 domingo -10 terça-feira, benefício -15 domingo -19 quinta-feira -22 domingo -24 terça-feira, dia santo; março: 1 domingo -2 segunda-feira -3 terça-feira" (O ESPELHO DIAMANTINO, 05/04/1828).

${ }^{455}$ Vide nota 318 da primeira parte.

456 Tradução nossa de: "Oui, Monsieur, nous aurons à Rio de Janeiro un théâtre digne du nom qu'il porte, digne de la société qui s'y rassemble: car nous avons ici tous les élemens de succès; des spectateurs toujours prêts à payer (...) un gouvernement généreux, et une population fort disposée à mettre à la loterie cinq ou six fois par an" (O ESPELHO DIAMANTINO, 18/02/1828).

457 O Arquivo Histórico do Museu Imperial de Petrópolis preserva um inédito documento manuscrito, não datado, com assinaturas de 24 "subscritores para a compra e 
Brasil, extinto à mesma época ${ }^{458}$. Em seguida, indicou para a sala uma nova direção de sua total confiança, formada por cinco dos subscritores - Dionísio Orioste, Inácio Ratton, Joaquim Gonçalves Ledo, Joaquim José de Siqueira e José Bernardes Monteiro Guimarães -, os quais, com interesse digno de permanecer na memória dos cariocas como a "direção por parte do Governo", deram continuidade aos trabalhos cênicos até meados de $1831^{459}$.

Destarte, diante de tais provas e ilações não nos resta mais nada senão devolver a Dom Pedro I - a despeito da completa irresponsabilidade financeira de seu governo ${ }^{460}$ - o esquecido e merecido epíteto que os

arrematação do Teatro de São Pedro de Alcântara". Essa operação financeira ocorreu provavelmente em 1829, quando o proprietário do Teatro faleceu e o seu principal credor, o Banco do Brasil, foi liquidado. Tal manuscrito contém, igualmente, os valores das contribuições de cada acionista (totalizando 79:000\$000), os quais, seguem, entre parêntesis, os nomes dos ditos subscritores, tal como assinaram o documento: "Sua Majestade o Imperador (10:000\$000), Marquês de Jundiaí (8:000\$000), João Fernandes Lopes (4:000\$000), Antônio José Meireles (4:000\$000), Francisco José Guimarães $(4: 000 \$ 000)$, Samuel Philips $(4: 000 \$ 000)$, Dionísio Orioste $(4: 000 \$ 000)$ José Buschenthal $(4: 000 \$ 000)$, Guilherme Young (3:000\$000), Pedro José Bernardes (2:000\$000), José Fortunato de Brito (2:000\$000), Diogo Gomes Barroso (2:000\$000), Inácio Ratton (4:000\$000), José Bernardes Monteiro Guimarães (4:000\$000), Plácido Antônio Pereira de Abreu (2:000\$000), Lourenço Antônio do Rego (2:000\$000), João Batista Hutchens (2:000\$000), Joaquim José de Siqueira (2:000\$000), Joaquim Gonçalves Ledo (2:000\$000), Francisco Gomes da Silva (2:000\$000), Manuel Gomes de Oliveira Couto (1:000\$000), José Clemente Pereira (2:000\$000), João da Rocha Pinto (1:000\$000), Albino Gomes Guerra (4:000\$000)" (ARQUIVO HISTÓRICO DO MUSEU IMPERIAL, II-POB-[1822-1831]-Tea.rç).

${ }^{458}$ Essa operação deve ter arrematado apenas parte da dívida, pois, segundo Henrique Marinho, o Teatro ainda se achava hipotecado ao Banco, em 1831, quando o filho de Fernando José de Almeida assumiu, como arrendatário, a propriedade do falecido pai (MARINHO, Henrique. Op. cit., p. 58). Uma pesquisa mais demorada no Arquivo Nacional do Rio de Janeiro certamente poderá estabelecer os pormenores desta operação, bem como da relação promíscua que se nota ter havido entre o Teatro de São Pedro de Alcântara e o Banco do Brasil. Por ora, sabemos apenas, pela leitura do Diário do Rio de Janeiro, que em agosto de 1836, a comissão liquidadora do Banco dava por encerrada a questão com o Teatro, assumindo-o e indenizando, em parte, mediante acordo, os seus acionistas (DIÁRIO DO RIO DE JANEIRO, 13/08/1836). Algum tempo depois, provavelmente leiloado, passou, conforme ainda veremos, à propriedade dos negociantes Manoel Maria Bregaro e Joaquim Valério Tavares.

${ }^{459} \mathrm{Um}$ comentário publicado no Jornal do comércio quase cinco anos depois, mais precisamente a 14 de maio de 1833, relembra o competente trabalho dessa administração: "Por esta ocasião não podemos deixar de tributar nossos louvores e agradecimentos à atual Sociedade do Teatro Imperial, pelo cuidado que tem prestado a organização de belos divertimentos e devemos confessar com franqueza que depois da direção por parte do governo em 1829 e 1830 (...) o teatro não esteve tão interessante como no corrente ano".

${ }_{460}$ A esse respeito, reproduzamos aqui um fragmento do relatório do Ministro da Fazenda José Inácio Borges, apresentado à Assembléia Geral em maio de 1831. Além de nos testemunhar que a situação financeira do Império nascente não era tão lastimosa como tanto se propagou, resume, em dura crítica, o que foi o Governo de Dom Pedro I do ponto de vista puramente financeiro: "Por duas vezes havemos conquistado a nossa 
próprios cariocas, mediante um de seus principais jornais - o Diário do Rio de Janeiro -, Ihe atribuíram à época em que constatou, em definitivo, aquilo que o Sete de Abril, provisoriamente, já antecipara em alguns anos: o adeus do "Príncipe Filarmônico"461.

\begin{abstract}
Em 12 do corrente, na Igreja de N. S. do Parto, a Irmandade de S. Cecília dos Professores de Música cumpriu o anual dever da comemoração do óbito de seus falecidos irmãos com solene ofício de defuntos e sacrifício e missa cantada, e esplêndida orquestra. Ainda que pareça casualidade inconsiderável, contudo, excitou viva reminiscência do protetor dessa instituição pia, o ex-Imperador do Brasil, D. Pedro I, por ser em dia imediato ao do nojo e encerramento de seu augusto filho, o Senhor Dom Pedro II, pela notícia do falecimento de um pai, que deixou à Capela Imperial memorial de sua perícia na angélica arte e ciência da harmonia
\end{abstract}

\footnotetext{
emancipação: a primeira no dia 7 de setembro de 1822, e a segunda no dia 7 de abril deste ano. Naquela ganhamos o Império com o legado de uma administração ressentida dos defeitos do feudalismo, e já viciada, mas não carregada de embaraços financeiros, porque não tínhamos divida externa, e a interna que nos pesava era de pouca monta, e tanto que o Ministro da Fazenda de então pôde, sem o socorro das Províncias, nem a operação de ruinosos empréstimos estrangeiros, ocorrer às despesas do Estado que aliás não foram pequenas. Agora ganhamos o Império ulcerado de uma administração perturbada, e corrompida em todos os seus ramos, e dependências; mas ganhou-se a grande causa da Nacionalidade, e tanto basta para sofrer de bom grado os sacrifícios que convém fazer a fim de restabelecer nossa independência iludida, e abafada. Sobre uma dívida de 50.980:344\$643 externa, e interna, experimentamos a calamidade de ver substituídas as espécies metálicas por um papel depreciado, e por uma moeda fraca, moeda que tem provocado a imoralidade dos Cidadãos a falsificá-la, e animado o interesse dos Estrangeiros a introduzi-la, resultando de uma tal crise monetária a carestia dos gêneros, a aflição das famílias, os embaraços do Governo, o apuro dos Empregados, e, para dizer tudo de uma vez, a miséria Pública" (RELATÓRIO do Ministro e Secretário de Estado dos Negócios da Fazenda José Inácio Borges na Sessão de 1831. Rio de Janeiro: Na Tipografia de Gueffier, 1831, p. 15).

${ }^{461}$ Essa reputação de Dom Pedro como "filarmônico", ou seja, "amigo da música", era tão reconhecida à época, que dois estrangeiros, de passagem pelo Rio durante o primeiro reinado, chegaram a relatar sumariamente, em seus escritos de viagem - embora isso não corresponda exatamente à realidade —, que o Imperador teria, ele próprio, organizado as duas principais instituições musicais cariocas, a Companhia Italiana da Ópera e o serviço musical da Capela. Um deles foi o Barão de Bougainville: "Le prince est grand amateur de musique, et même compositeur; les musiciens de sa chapelle ont été formés par lui..." (BOUGAINVILLE, Hyacinthe Yves Philippe Potentien, Baron de. Op. cit., t. 1, p. 612); o outro, o médico norte-americano William Ruschenberger: "The company is composed of Italians, brought here by the Emperor, Pedro I" (RUSCHENBERGER, W. S. W. Op. cit., p. 42).
} 
pela composição do cântico $T e$ Deum e da música do Hino Nacional. O devoto e generoso povo fluminense terá, só por isso, urgente razão para, em sufrágio da sua alma oferecer orações ao céu suplicando a graça da bem-aventurança eterna ao Príncipe Filarmônico.... ${ }^{462}$ 


\section{CAPÍTULO VII - A corte silente}

Já nós tivemos uma boa companhia italiana; já o nosso teatro esteve em um pé, senão maravilhoso ao menos como o comportavam as nossas circunstâncias; e tudo acabou ${ }^{463}$.

Quando Dom Pedro I ouviu, como protesto ao seu governo, gritos de "viva Dom Pedro II" ecoarem pelo templo de São Francisco de Paula na tarde de 25 de março de 1831, dia em que se comemorava o sétimo aniversário do juramento da Constituição, teria, segundo Armitage, respondido com desfaçatez à provocação: "Ele é, por ora, apenas uma criança" ${ }^{464}$. Todavia, essa idéia que, a princípio, lhe pareceu absurda, transformou-se, pouco mais de duas semanas depois, em boa escapatória, quando suas condições políticas estertoraram.

O Imperador sabia que, ao abdicar "mui voluntariamente" em seu filho menor, uma atoleimada e frágil criança de cinco anos e poucos meses de idade, deixava, na verdade, seu trono temporariamente vago, podendo, esfriados os ânimos, recuperá-lo - ainda que na condição de Regente, como faria mais tarde em Portugal - apoiado pelo núcleo político de José Bonifácio, com quem, aliás — de propósito ou não - se reconciliou definitivamente no mesmo dia em que abdicou, ao escolhê-lo Tutor de Dom Pedro II. Fundavam-se, pois, ali, as bases de uma terceira via partidária entre a ordem e a liberdade liberais, o chamado partido "caramuru" ${ }^{465}$, que, até o conhecimento da morte do ex-Imperador, ocorrida a 24 de setembro de 1834, em Queluz, acalentaria o sonho de ver novamente o "Príncipe Filarmônico" empolgar o mando no Brasil.

463 JORNAL DO COMÉRCIO, 22/09/1835.

464 "'He is but a child yet;'" (ARMITAGE, John. Op. cit., v. 1, p. 125)

465 Assim ficou conhecido esse partido em referência ao seu primeiro órgão de manifestação pública, criado em março de 1832: o periódico O caramuru, cujo redator era David da Fonseca Pinto. Essa publicação circulou de 02 de marco de 1832 (n 1) a 10 de abril de 1833 ( $n^{\circ}$ 64). A Biblioteca Nacional do Rio de Janeiro possui toda a coleção microfilmada sob o código PR SOR 00483. 
Como todos sabemos, não houve, no entanto, forças suficientes para tal empreitada. Mesmo escudados pelo "Patriarca" - que se não foi o chefe de fato desse movimento, emprestou o prestígio de seu nome a ele - os restauradores só conseguiram abalar um pouco mais a segurança pública da corte, já perturbada pelas freqüentes sedições "exaltadas", e transformar o Palácio de São Cristóvão em um pequeno arsenal de armas de baixo calibre $^{466}$. A possibilidade, discutida no parlamento, em meados de 1833 , de que o Duque de Bragança estaria planejando retomar o poder no Brasil usando a força das tropas que arregimentara para liberar Portugal do jugo de seu irmão ${ }^{467}$, aliada à ida de Antônio Carlos de Andrada à Europa, na mesma época, para encontrar e tentar convencer o ex-Imperador a voltar ao Rio de Janeiro, também não passaram de um espantalho, justificante do abuso de poder que a Regência cometeria, em fins desse último ano, ao eliminar de uma vez por todas José Bonifácio do cenário político brasileiro suspendendoo arbitrariamente do exercício da tutela imperial. $O$ fato é que o desaparecimento precoce de Dom Pedro I enterrou por completo o sonho da sua volta ao posto de primeiro representante da nação, e a corte brasileira permaneceu mesmo, um longo tempo, acéfala, destituída de um centro de gravidade social verdadeiramente ativo, e, por conseqüência, minimizada na sua etiqueta, nos seus rituais, dos quais, sobretudo uma pomposa música

${ }^{466} \mathrm{O}$ incidente mais grave envolvendo os caramurus ocorreu a 17 de abril de 1832 , no Rio de Janeiro, quando um grupo de cerca de 250 homens marcharam de São Cristóvão para a cidade sob o comando de um aventureiro alemão, conhecido como "Barão de Bulow". Esse ajuntamento foi debelado sem grandes esforços pelo batalhão da freguesia do Sacramento, comandado pelo então major Luiz Alves de Lima, posteriormente, Barão, Conde, Marquês e, finalmente, Duque de Caxias (Cf. AZEVEDO, Manuel Duarte Moreira de. Motim político de 17 de abril de 1832 no Rio de Janeiro. Revista do Instituto Histórico e Geográfico Brasileiro. Rio de Janeiro, v. 51 [t. 38 parte 2], p. 127-141, 1875).

467 Eis um trecho do relatório que o Ministério dos Negócios Estrangeiros enviou à Câmara para ser lido na sessão em 19 de junho de 1833 e posteriormente discutido: “... o Brasil deve sondar com tato as intenções próximas ou remotas do seu natural inimigo, para saber malograr com destreza seus projetos ambiciosos. (...) D. Pedro já se acha em Portugal; o seu desembarque foi operado com felicidade, e os primeiros sucessos das suas armas agouram feliz resultado à sua tentativa. Senhor daquele reino, tendo à sua disposição dois exércitos, um vitorioso e outro submetido, rivais em opiniões, mas concordes em tudo que for contra o Brasil, e uma marinha bem organizada, D. Pedro renunciará por ventura os sentimentos de vingança e ambição, assaz dominantes em todas as suas ações? Embora proteste o contrário, ele nunca fez o que disse nem o que jurou" (ANAIS do Parlamento brasileiro. Câmara dos Srs. Deputados. Quarto ano da segunda 
sacra e a ópera, faziam parte.

Como já foi dito, à época em que herdou o trono, Dom Pedro II era uma criança de pouco mais de cinco anos de idade, e, dadas as precárias condições medicinais e de saúde pública de então, esse estado não lhe assegurava um futuro muito certo. Em 1833, mesmo ano em que perdeu, logo em janeiro, uma de suas irmãs mais velhas, a Princesa Dona Paula, caiu repentina e gravemente enfermo, deixando o Império em grande apreensão ${ }^{468}$. Ainda estava fresco na memória dos cariocas o precoce desaparecimento de outros dois varões, herdeiros do trono do então Reino Unido: Dom Miguel, segundo filho de Dom Pedro I, morto no mesmo dia em que nasceu, a 26 de Abril de 1820; e Dom João Carlos, que chegou a ser aclamado Príncipe da Beira, em 1821, mas faleceu com um ano incompleto de vida a 4 de Fevereiro de 1822. Assim sendo, os excessivos cuidados com a saúde do Imperador já o tornavam, por si só, um prisioneiro ${ }^{469}$. Somava-se

legislatura. Rio de Janeiro: Tipografia de viúva Pinto e filho, 1887, t. 1, p. 292).

468 Esta foi mais uma justificativa para o afastamento de José Bonifácio do exercício da tutela imperial, já que a grave doença de Dom Pedro II gerou uma série de boatos, entre os quais a de que o Imperador tivesse sido vítima de envenenamento (Cf. RANGEL, Alberto. A educação do príncipe: esboço histórico e crítico sobre o ensino de $D$. Pedro II. Rio de Janeiro: Agir Editora, 1945, p. 147).

${ }_{469}$ Curiosamente, esse confinamento e conseqüente sedentarismo, segundo relatos do cônsul francês da época, Conde de St. Priest, poderia até ter sido a causa da falta de saúde do Imperador durante parte da sua infância, na medida em que lhe faltaram exercícios físicos, banhos de sol e bons ares. Em correspondência à Chancelaria de seu país, de 9 de setembro de 1833, o representante estrangeiro assim descreveu o que então vira: "L'Empereur ne me paraît pas manquer de vivacité (...) mais la pâleur de son teint n'annonce pas la santé (...) Ces enfants ne font aucun exercice pendant les six mois de l'année qu'ils passent dans la ville" (Apud Rangel, Op. cit., p. 150). Outro a fazer praticamente as mesma críticas foi o cônsul napolitano Gennaro Merolla, em correspondência a seu superior, de abril de 1834: "Trovano in generale al giovane imperatore un'aria di languidezza e di debolezza straordinaria; il modo di vivere che gli fanno osservare, come ancora alle Sue Auguste Sorelle, disgraziatamente è conforme agli errori dell'educazione Brasiliana. Delle abitudini troppo sedentarie, l'abuso dello Zucchero e l'uso dei liquori, ritardano lo sviluppo di questi Ragazzi; ne nasce che la loro crescenza è tardiva per la loro età" (MEROLLA, Gennaro. Correspondência brasileira (1832-1834). São Paulo: Instituto Cultural Italo-Brasileiro, 1963, p. 104). Somente em 1835, já sob a tutela do Marquês de Itanhaém, é que exercícios físicos, como a equitação, iriam tratar de desenvolver as qualidades exteriores e materiais do jovem monarca, buscando a melhoria de sua saúde. Outro relatório do consulado francês, desta vez assinado por Edouard Pontois, de 17 de setembro de 1835, chama a atenção para essa novidade, elogiando a administração de Itanhaém: "Sous le rapport des soins physiques il n'y a que des éloges à donner à l'administration du tuteur actuel. Grâce à l'influence d'un exercice régulier, dans air plus vif et plus par que celui de la ville, et d'une Résidence favorable aux amusements de son âge, la santé du jeune Empereur s'est beaucoup amélioré" (RANGEL, Alberto. Op. 
a isso a enorme preocupação dos estadistas da época em fazer, desse novo monarca a antítese do anterior, ou seja, alguém polido, contido, educado e, sobretudo, afastado da mundanalidade, resguardado de qualquer labéu.

Passada a fase do "colosso" 470 , que, como Tutor, decerto, não se furtou, em nenhum momento, a inculcar, na cabeça do infantil soberano, seus ideais políticos, os donos do poder àquele momento, como os Ministros Aureliano de Sousa Oliveira Coutinho e Antônio Pinto Chichorro da Gama, preocupados em neutralizar quaisquer outras influências na educação de Dom Pedro II que viessem a torná-lo enérgico como o pai ou Bonifácio, ambos defensores de um governo fundado nos princípios de uma liberdade garantida pela segurança de uma efetiva autoridade, acharam, por bem, que não apenas o novo Tutor fosse alguém apartidário e sem grandes ambições de poder - caso típico do Marquês de Itanhaém ${ }^{471}$ - como que o Imperador passasse a sofrer influências diretas de um preceptor, ao mesmo tempo rígido, moralmente, e desprovido de opiniões políticas ${ }^{472}$. Escolheu-se, pois, para essa missão, Frei Pedro de Santa Mariana, seu então professor de latim e matemática. "De espírito limitado, de uma carolice minuciosa" - como salientou o Cônsul francês, Saint Georges, em $1842^{473}$ —, esse carmelita seria o principal responsável por tornar Dom Pedro II ainda mais recluso em seus estudos e por dar indeléveis contornos ao seu modo de ser, tido por todos como "retraído" e "distante dos prazeres fúteis", diametralmente

cit., p. 213).

Assim o então Ministro da Justiça, Aureliano Coutinho, se referiu a José Bonifácio, em carta à Primeira Dama de Dom Pedro II, Dona Mariana de Verna, logo após a remoção do Tutor de São Cristóvão: "Parabéns, minha Sra., custou mas demos com o colosso em terra" (Apud RANGEL, Alberto. Op. cit., p. 159).

471 O Marquês de Itanhaém. Manuel Inácio de Andrade Souto Maior Pinto Coelho (1782-1867), figura permanentemente apagada entre os principais titulares do Império, foi efetivado no cargo de Tutor de Dom Pedro II e suas irmãs no mesmo dia 14 de dezembro de 1833 em que José Bonifácio foi afastado.

${ }_{472}$ Essa visão, diga-se a propósito, não seria mais modificada por nenhum outro governante até o final do período regencial, nem mesmo pelo próprio Dom Pedro II, durante seus primeiros anos de reinado.

473 "Frey Pedro (...) est d'un esprit borné, d'une bigoterie minutieuse qu'il a communiqué à son élève, d'une indifférence absolue sur les choses de ce monde et d'une ignorance profonde en politique" (Apud RANGEL, Alberto. Op. cit., p. 197). 
contrário, portanto, ao exemplo — "a fugir" — da vida de seu pai ${ }^{474}$.

Apesar, no entanto, dos excessivos cuidados médicos e desse rigor estudantil "monástico", o distanciamento físico do Imperador com seus súditos jamais foi completo. Como símbolo máximo da continuidade monárquica, fazia-se necessário que o pequeno monarca, de tempos em tempos, fosse exposto publicamente. Nada, é claro, que se comparasse aos tempos de Dom Pedro I, em que os bailes e saraus em São Cristóvão, as audiências públicas no Paço e a presença do Imperador no Teatro - ou mesmo nas ruas do Rio de Janeiro - eram freqüentes ${ }^{475}$. Pelo que foi possível apurar, o contato de Dom Pedro II com a corte nos anos da Regência resumiu-se quase que apenas aos dias de grande gala, como o aniversário do juramento da Constituição — 25 de março —, o Sete de Abril, o Sete de Setembro e o próprio natalício do Imperador -2 de dezembro ${ }^{476}$. Nessas ocasiões, seguindo uma rotina igualmente rígida, S. M. I. saía de São Cristóvão apenas para assistir à missa na Capela Imperial e receber os principais membros da corte e o Corpo Diplomático no Paço da cidade. À noite, caso fosse conveniente e seguro - como ainda veremos com mais detalhes - ocorria, no teatro, um encontro mais amplo com a sociedade. A reunião, no entanto, não durava muito, como ocorreu no dia 2 de dezembro de 1831, quando o Imperador completou seis anos de idade. Às dez da noite, chegava a hora da imperial criança ir para a cama:

${ }^{474}$ A esse respeito, testemunha outro cônsul francês, Conde Ney, em despacho ao Ministério dos Negócios Estrangeiros da França de 26 de maio de 1844: "Les dispositions qui portent l'Empereur à la retraite et à l'éloignement, des plaisirs futiles du monde, sont le fruit des insinuations du Fray Pedro, moine placé auprès de lui dès son enfance; (...) La vie de son père, qui ne fut pas exemple de reproche sous le rapport des moeurs, lui a été représenté comme un exemple à fuir..." (Apud RANGEL, Alberto. Op. cit., p. 200-201).

475 A esse último respeito, eis, e. g., o testemunho do inglês Charles Brand, referente ao ano de 1828: "... he is frequently to be seen driving about the town in his tilbury, or riding on horseback..." (BRAND, Charles. Op. cit., p. 305).

${ }^{476} \mathrm{~A}$ informação de que Dom Pedro II, nesses anos de Regência, só recebia a corte no Paço "em grandes galas" nos é fornecida pelo Almirante inglês Grahan Eden Hamond (1779-1862), que morou no Rio de Janeiro entre 1834 e 1838 (Cf. HAMOND, Graham Eden. Os diários do Almirante Graham Eden Hamond. Tradução de Paulo Fontainha Geyer. Rio de Janeiro: Ed. JB, 1984, p. 55). Note-se que os diários manuscritos de Hamond, atualmente tombados no National Maritime Museum, de Londres - e aqui traduzidos por Paulo Geyer, que os microfilmou -, formam, possivelmente, o mais detalhado relato de época conhecido da vida social carioca da década de 1830. 
A noite, S. M. imperial e as $\mathrm{Sr}^{\text {as }}$ Princesas foram ao teatro, e igualmente a excelentíssima regência, que se achava à direita de $S$. M. Imperial, sendo recebidos com grande aplauso. Deu-se princípio ao espetáculo pela representação de um drama alegórico (...). Às 10 horas S. M. I. e suas augustas irmãs se retiraram ficando na tribuna a excelentíssima Regência ${ }^{477}$.

Passados os anos, com o desenvolver físico do jovem monarca, a sua permanência no camarote imperial iria, evidentemente, prolongar-se, embora esse espaço privilegiado, que fora, como vimos, um "salão esplêndido" nos tempos de Dom Pedro I, continuasse muito pouco utilizado durante todo o período regencial, como nos chamou a atenção o professor de matemática da marinha norte-americana Joshua Sidney Henshaw (1811-1859), que esteve de passagem pelo Rio de Janeiro, em julho de 1838. Aproveitando a oportunidade, Henshaw destacou, ainda, em seu testemunho de época, o grave contraste entre essa época de menoridade e o período em que Dom Pedro I governou:

... nós prosseguimos em direção a um limpo e grande edifício, construído por Dom Pedro I, para o estímulo da ópera onde, soubemos, os melhores cantores europeus e uma grande orquestra foram empregados, e, principalmente, patrocinados pelo Imperador, para satisfazer seu gosto luxuoso, e despertar entre seu povo a inclinação para esse mesmo sentimento. Porém, a organização da Ópera tem agora dado lugar às palhaçadas de meros charlatões, e, embora os principais camarotes sempre estejam reservados para a família real [sic], até o exato momento, o presente jovem que ocupa o trono raramente comparece ao teatro; e o local reservado é mantido encoberto por uma rica cortina de veludo verde ${ }^{478}$.

477 JORNAL DO COMÉRCIO, 5/12/1831.

478 Tradução nossa de: "... we passed on toward a neat and large edifice built by 
Ao contrário, pois, do que ocorreu no primeiro reinado, quando a freqüente presença de Dom Pedro I garantia ao São Pedro de Alcântara um público cativo e, conseqüentemente, receita - além das loterias - para a sustentação de espetáculos "dignos de oferecer-se ao público" esporádica e alheia no teatro desse "verdadeiro fantoche, dirigido pelos homens ambiciosos" ${ }^{480}$, apesar de, nessas raras ocasiões, promover a lotação da sala e causar grandes sentimentos de júbilo nos presentes, não assegurava o adequado funcionamento dos espetáculos nem mesmo nessas importantes ocasiões. Outro norte-americano, um viajante anônimo, que estava no Rio em 1838 e compareceu ao espetáculo teatral de gala que comemorou os treze anos do monarca, ao relatar o fato, não encontrou outro tom senão o irônico para fazê-lo:

À noite, o Imperador, as princesas, e eu, fomos ao teatro. (...) ele e suas irmãs, aparentando muito cansaço e sonolência, levantaram-se para ser aplaudidos e bombardeados com pétalas de rosas que caiam abundantemente de todos os lados da galeria. A peça era muito fraca e

Don Pedro 1st, for the encouragement of the opera, where, it is said, the best European singers and a grand orchestra were employed, and mostly supported by the emperor, to gratify his luxurious taste, and to foster a fondness for the same among his people. But the opera arrangements have now given place to the buffooneries of mere mountebanks, and, although the front boxes are always reserved for the royal family, yet even the present youth upon the throne seldom attends the theatre; and the reserved part is kept screened by a rich green velvet curtain" (HENSHAW, Joshua Sidney. Around the world: a narrative of a voyage in the East India Squadron under Commodore George C. Read. New York: Charles S. Francis, 1840 , v. 1, p. 128). É claro que este depoimento, dado por um estrangeiro de passagem e baseado no "ouviu dizer", é mais um daqueles nos quais, embora haja, como já vimos, um fundo de verdade, os fatos são simplificados, como, por exemplo, o de que Dom Pedro I teria "construído" o teatro.

${ }_{479}$ Vide nota 54 desta parte.

480 Essa foi a descrição que fez de Dom Pedro II o Capitão de Fragata francês Cyrille Laplace (1793-1875), de passagem pelo Rio de Janeiro em 1832: "Le souverain actuel est un enfant, véritable mannequin dirigé par des hommes ambitieux..." (LAPLACE, Cyrille Pierre Theodore. Voyage autour du monde, par les mers de l'Inde et de la Chine, exécuté sur la corvette de l'État La Favorite pendant les années 1830, 1831, 1832. Paris: Imprimerie Royale, 1835 , t. 4, p. 118). Três anos depois, corroboraria Laplace, o já mencionado inglês Eden Hamond: "O Imperador é um menino de 10 anos (...). Seu semblante é pálido e inexpressivo (...) O Imperador nunca fala. É claro que não the permitem fazê-lo, enquanto for uma criança" (HAMOND, Graham Eden. Op. cit., p. 61). 
estúpida, a sala muito cheia e quente, e eu, sentindo-me muito mal, saí com tal rapidez depois do primeiro ato, que acabei esquecendo de apresentar minhas desculpas à sua majestade. Nessa noite, a cidade esteve brilhantemente iluminada, e o Imperador tomou seu transporte para casa por volta da meianoite ${ }^{481}$.

E se existe alguma dúvida quanto à validade dessa descrição - seja pelo tom menoscabado de, certamente, um republicano convicto, seja pelo fato de, em 1838, o espetáculo teatral de gala ter ocorrido, não no grande teatro, então em reformas, mas no São Januário - eis, pois, aqui, outra, exatamente dois anos posterior, escrita, desta vez, pelo próprio Dom Pedro II, em seu Diário, no dia em que completou quinze anos de idade e referente a uma récita ocorrida no já reformado e reaberto São Pedro de Alcântara. É uma boa mostra de que o estrago cultural dos anos de menoridade ainda repercutia na qualidade dos espetáculos teatrais em pleno fulgor do nascente reinado. A falta de músicos e cantores líricos profissionais obrigava atores dramáticos de renome, como Ludovina Soares da Costa, a fazer papel de ridículo no palco:

... às sete e $3 / 4$ parti para o Teatro; depois de tocarem a sinfonia ouvi palmas, num camarote. Disse cá comigo — "Lá vai verso!" (...) foram outros piores, enfim, foram os últimos, péssimos. Depois de longo intervalo e desafinadas aberturas, apareceram Os Dois Renegados, drama de engenho, mas muito mal executado, pois, devendo uma pessoa cantar lá

${ }^{481}$ Tradução nossa de: "In the evening, the Emperor, the princesses, and I, went to the theatre. (...) he and his sisters looking fagged and sleepy, stood up to be applauded and pelted with rose leaves which were showered down plentifully on all sides from the gallery. The play was very dull and stupid, the house very crowded and hot, and I becoming very uncomfortable, took my leave after the first act, in such haste that I forgot to apologize to his majesty. In the evening the city was brilliantly illuminated, and the Emperor rode home about midnight" (THE LADY'S BOOK. 07/1839, v. 19, p. 36). O periódico The Lady's Book (1830-1839), publicado em Filadélfia por Louis Antoine Godey (1804-1878) foi a primeiro de sucesso voltado ao público feminino norte-americano (Cf. MOTT, Frank Luther, A History of American Magazines: 1741-1850. New York: D. Appleton and Company, 1930, p. 580-594). 
dentro, afim de parecer que a Ludovina, desengraçada Isabel, cantava; foi ela mesma que tocou na harpa e cantou com um tom áspero (...). Acabada a peça, dormindo fui para casa, dormindo me despi e dormindo me deitei. Agora, façam-me o favor de me deixarem dormir. Estou muito cansado, não é pequena a maçada $^{482}$.

Do ambiente teatral, passemos rapidamente a São Cristóvão. Palco de saraus e concertos da Imperial Câmara, durante o primeiro reinado ${ }^{483}$, este foi, a partir da Abdicação, um local de reunião cortesã a ser esquecido por um bom tempo, tanto para resguardar a privacidade, a segurança, o bom prosseguimento dos estudos e a estabilidade da saúde do pequeno monarca, quanto para, durante a tutela de José Bonifácio (1831-1833), manter em segredo os planos restauradores do partido "caramuru". O primeiro baile imperial na Quinta, após o Sete de Abril, como veremos mais à frente, só ocorreria cinco anos e meio depois da Abdicação, mais precisamente a 8 de dezembro de 1836; e, ainda assim, por motivo fortuito.

Detenhamo-nos agora às recepções imperiais no Paço da cidade, que, com o fim das audiências públicas de Dom Pedro I, sempre às sextasfeiras $^{484}$, se resumiram, durante o período regencial, aos dias de grande

${ }^{482}$ Apud VIANA, Helio. Op. cit., p. 117-118. Curiosamente, a crítica mordaz do jovem Imperador não é corroborada pela do Jornal do comércio. Esse elogia muito a apresentação de Ludovina na peça apresentada no $15^{\circ}$ aniversário de Dom Pedro II, incluindo-se o seu desempenho musical: "A Sra. Ludovina representou excelentemente o seu papel, sobretudo no $5^{\circ}$ ato. Deu-nos ali uma mostra de seus talentos músicos. Cantou com muita expressão a xácara do renegado; a sua voz de contralto animada, forte e vibradora, parecia exprimir excelentemente as amarguras de sua situação. O último verso - Morte, afronte ao Renegado - produziu muito efeito" (JORNAL DO COMÉRCIO, 07/12/1840). Veja-se que não é nada fácil, para um historiador dessa época, aferir a qualidade de artes precárias como as das interpretações teatral e musical.

${ }^{483}$ Lembremos que o último desses encontros sociais e musicais ocorreu a 4 de abril de 1831, três dias antes da Abdicação, quando Dom Pedro preparou um concerto para sua filha aniversariante, a então Rainha destronada de Portugal, Dona Maria II (Cf. SOUZA, Octavio Tarquinio. Op. cit. v. 4, t. 3, p. 914).

${ }^{484}$ A informação de que Dom Pedro I, além das reuniões de gala, ocupava sempre o Paço da cidade às sextas-feiras para dar audiências é de Carl Schlichthorst: "Außer den Gallatagen hält er jeden Freitag Audienz in der Stadt..." (SCHLICHTHORST, Carl. Op. cit., p. 50). Note-se que as audiências públicas continuaram durante o interregno, sob a presidência dos Regentes. Porém, é de se imaginar que a pompa dessas ocasiões tenha se arrefecido completamente. 
festividade nacional. Debret imortalizou, em uma de suas célebres gravuras, a primeira aparição pública de Dom Pedro II no Paço, uma cena curiosa, em que o pequenino monarca, em pé, sobre uma cadeira, acena com um lenço para o público e a tropa do principal balcão do largo edifício, ao lado de suas três irmãs mais velhas, as Princesas Dona Januária, Dona Paula e Dona Francisca ${ }^{485}$. Nesse dia, 9 de abril de 1831, houve, também, estando o serviço musical da Capela Imperial ainda em pleno funcionamento - embora por pouco tempo - , um "solene Te Deum" ${ }^{486}$ na Catedral, ao qual foram convidados os membros da Assembléia Geral. A poética imagem produzida por Debret, não revela, porém, o pavor que a imperial criança e os seu nobre séquito sentiram, momentos antes, ao se depararem, na saída da Missa segundo o viajante inglês Joseph William Moore -, com uma turba de cerca de vinte mil pessoas, das quais muitas - entre "pretos e mulatos" - queriam aproximar-se do Imperador e demonstrar seu "intenso amor e respeito" a esse "sagrado objeto da sua patriótica veneração"487, criando um terrível empurra-empurra ${ }^{488}$. É provável, portanto, que situações análogas tenham sido evitadas enquanto os ânimos ainda estivessem exaltados.

Quanto ao cerimonial que ocorria no interior do Paço, nesses primeiros tempos de regência, embora refletisse a saúde frágil e a completa indiferença de Dom Pedro II em relação a tudo o que acontecia, ainda guardava alguns resquícios dos beija-mãos que se realizavam nos tempos de Dom Pedro I. Ainda que o beija-mão, em si, tivesse sido temporariamente abolido, a etiqueta continuava, em parte, bastante rígida, e as personagens

${ }^{485}$ DEBRET, Jean Baptiste. Op. cit., v. 3, planche 51.

${ }^{486}$ ANAIS do Parlamento brasileiro. Câmara dos Srs. Deputados. Segundo ano da segunda legislatura. Rio de Janeiro: Tipografia de H. J. Pinto, 1878, t. 1, p. 2.

${ }^{487}$ Assim se referiu a Regência aos acontecimentos de 9 de abril, na Fala do Trono da Sessão Imperial da Abertura da Assembléia Geral, a 3 de maio de 1831 (Idem, t. 1, p. 7).

488 "April 9th. Sunday. (...) I suppose there were about twenty thousand people all rending the air with their vivas. (...) After Service the pressure to kiss his hand was so great that a Nobleman was obliged to carry him in his arms. The poor little boy was so terrified that I observed he was crying thinking no doubt he was going to be worried, a large crowd of blacks and mulattos pressing on him and roaring out 'Viva Emperador' (...). The little Emperor then went to the Palace and the troops and cannon all defiled before him. The Emperor waving his handkerchief and his three little sisters curtsying all the time and evidently in the greatest fear" (MOORE, Joseph William. Op. cit., p. s/n). 
eram todas as mesmas: diplomatas, clérigos e cortesãos de todos os tipos, cada qual com sua insígnia: de Titulares do Império, com ou sem honras de grandeza - marqueses, condes, viscondes, barões - a cavaleiros de alguma ordem honorífica. Retrato detalhado de uma dessas ocasiões, que, note-se, ainda não dispensava a presença de uma "banda completa" de música, nos legou o já mencionado norte-americano William Ruschenberger, testemunha de uma recepção imperial ocorrida em 1831, na grande gala da Independência, a 7 de setembro, quando, então, o Imperador não tinha, como o próprio autor sublinha, "seis anos completos":

Ao meio dia e meia a Legação Americana chegou à entrada lateral do Palácio, e, apeando das caleças, encaminhou-se diretamente do portão para a escada. Chegando em cima, fui informado por um dos nossos que, na presença imperial, luvas ou chapéus eram contrários à etiqueta. (...) $\mathrm{Na}$ primeira sala, que era elegantemente mobiliada, estavam vários cavalheiros do corpo diplomático estrangeiro, e, entre eles, o Núncio do Papa. Claro que todos estavam em seus trajes de corte. Daí, nós passamos para uma sala maior, mobiliada de uma maneira muito mais elegante. (...) Dom Pedro II estava acompanhado de suas irmãs e da Regência. Os trajes dos membros da corte eram esplêndidos; o do jovem Imperador era asseado e simples. Enquanto eles atravessavam as salas, todos se curvavam em reverência. Então uma fanfarra de trompetes, seguida de uma grande marcha, executada por uma banda completa, proclamou a abertura da corte. Todos nós seguimos para a ante-sala. Em alguns momentos o camareiro-mor informou o corpo diplomático de que Sua Alteza Imperial estava pronto para recebê-lo. Os mais antigos na corte eram recebidos primeiro, e seguiam 0 camareiro-mor pela porta da esquerda. A legação americana era a última. Nosso Encarregado foi primeiro e os Oficiais o seguiram de acordo com sua importância, distanciando-se cerca de três metros um do outro. Entrando na presença Imperial, todos nos 
curvamos; o que se repetiu a meio caminho do dossel e imediatamente em frente a Sua Alteza. Retiramo-nos, então, com nossas faces voltadas para o trono, e, fazendo três reverências, saímos pela porta da direita. (...) A sala do trono era ricamente forrada com veludo verde, pontilhado com ouro e estrelas de prata, e o assoalho estava coberto com um tapete de colorido vivo com a figura de um medalhão no centro. Dom Pedro II, que tem uma notável semelhança com seu pai, levantou-se no dossel - uma elevação de um degrau em que o trono normalmente é colocado - com a Regência à sua direita, e suas duas jovens irmãs à sua esquerda. Seus olhos, grandes e claros, vagavam de uma pessoa a outra, com uma expressão que beirava a indiferença. Suas saudações eram formais, e as princesas, que são mais velhas (ele não tem seis anos), pareciam sofrer algum tipo de embaraço. Nobres de ambos os sexos, e oficiais ostentando suas respectivas insígnias estavam em pé, próximos às paredes, por todos os lados. Muitos dos cortesãos ostentavam ricos trajes de veludo de uma moda antiquada, e usavam essas condecorações de honra que são concedidas aos que agradam a realeza. Então, a multidão começou a sair do palácio para as suas carruagens. A música continuou; a conversa era alegre; todos tinham uma aparência de "estado de graça", e a satisfação poderia ser notada em todos os semblantes! ${ }^{489}$

${ }^{489}$ Tradução nossa de: "At half past twelve the American Legation reached the side entrance of the palace, and alighting from the caleças, made way through the gate to the stair. As we ascended, I learned from one of our party, that wearing gloves or hats in the imperial presence was equally contrary to etiquette. (...) In the first room, which was handsomely furnished, were several gentlemen of the foreign corps diplomatique, and among them, a Nuncio from the Pope. Of course all were in their court dresses. From this, we passed into a larger room, fitted up in a much more elegant manner. (...) Dom Pedro II was accompanied by his sisters and the regency. The dresses of the members of the court were splendid; that of the young emperor was neat and simple. As they passed through the rooms, every head was bowed in salutation. Presently a flourish of trumpets, followed by a grand march by a full band, proclaimed the opening of the Court. We had all followed into the anteroom. In a few moments the chamberlain informed the corps diplomatique that his imperial Highness was ready to receive them. Those who had resided longest near this court, took precedence, and followed the chamberlain through the left hand door. The American Legation was last. Our Charge preceded, and the officers followed according to rank, at about three yards from each other. On entering the presence, we all bowed; and again, when half way up to the dais, and repeated the reverence immediately before his 
Intriga-nos saber de que constava essa "banda completa" referida pelo cirurgião norte-americano. A esse tempo, a imensa maioria dos músicos da orquestra da Capela Imperial, da qual faziam parte os da Câmara, já haviam sido demitidos - como veremos adiante, com maiores detalhes. Resta imaginar que essa "banda" fosse composta de escravos ou de profissionais, contratados especialmente para a ocasião, utilizando-se para isso, restos da vultosa dotação de mais de 1.100 contos de réis, assinada, em 1830, pela Assembléia Geral a Dom Pedro I, para ser gozada no período de $1^{\circ}$ de julho de 1831 a 30 de junho de $1832^{490}$.

A primeira hipótese parece ser, no entanto, a mais razoável, já que, pouco mais de um mês depois, mais precisamente a 23 de outubro de 1831 , Dona Mariana de Verna, Primeira Dama de Dom Pedro II, se queixava, em carta ao Duque de Bragança, do fato de já estarem vivendo, em São Cristóvão, um período de "economias" em virtude da "pequena" dotação que o novo monarca recebera ${ }^{491}$. Certamente, por essa época, o Executivo, nas mãos de adversários de José Bonifácio - que, como Tutor, seria o responsável por administrar a dotação - já tivesse cortado parte da eventual verba remanescente de Dom Pedro I. No Legislativo, as manobras políticas nesse mesmo sentido não demoraram a surgir. A $1^{\circ}$ de outubro de

Highness, Then retreating, with our faces towards the throne, and making three bows, we made our exit through the right hand door (...). The throne room was richly hung with green velvet, sprinkled with gold and silver stars, and the floor was covered with a bright colored carpet, with a center medallion figure. Dom Pedro II who bears a striking resemblance to his father, stood upon the dais - an elevation of one step, on which the throne is usually placed - with the regency on his right, and his two younger sisters on his left hand. His large, liquid eyes, wandered from one person to another with an expression of half indifference. His salutations were stiff, and the princesses, who are his seniors (he is not six years old), seemed to suffer a kind of mauvaise honte. Ladies and lords, and officers bearing their respective insignia, stood along the walls on either hand. Many of the courtiers were arrayed in rich suits of velvet of. antiquated fashion, and wore those decorations of honor which it may have pleased royalty to bestow upon them. The crowd soon began to move out of the palace towards their carriages. The music continued; conversation was gay; everybody wore a holy-day face, and self approbation might be read in every countenance!" (RUSCHENBERGER, W. S. W. Op. cit., p. 49-51).

490 COLEÇÃO das Leis do Império do Brasil de 1830. Rio de Janeiro: Tipografia Nacional, 1878, parte 1, p. 127.

491 “... tem sido preciso algumas economias porquanto a dotação que the deram é muito pequena" (Apud RANGEL, Alberto. Op. cit., p. 118). 
1831, era lido, no plenário da Câmara dos Deputados, um Projeto de Lei de Honório Hermeto Carneiro Leão, que, embora não tenha sido aprovado, previa a diminuição drástica da dotação de Dom Pedro II, propondo que, durante a menoridade do Imperador, esta fosse de 160:000\$000 anuais; e, chegando a sua maioridade, de 365:000\$000 anuais. De forma similar à lei de 11 de agosto de 1827, da qual ainda falaremos, previa-se, igualmente, que nesta despesa se compreendesse

... todas as despesas da imperial casa, reparos de palácios e quintas, serviço de decoro do trono, à exceção somente da capela imperial, biblioteca pública, mestres e das aquisições de palácios que a nação julgar convenientes para a decência e recreio do imperador e de sua augusta família... ${ }^{492}$

Menos ainda propunha o projeto do orçamento de 1832-1833: cem contos de réis, incluindo-se o salário do Tutor $(4,8)$ e dos mestres $(8,3)$, restando, para os gastos gerais com o decoro de Dom Pedro II, menos de 87 contos de réis. Na defesa de uma dotação maior, a 29 de agosto de 1831, José Bonifácio, que, à época, também era Deputado, atentou para o fato de que essa cifra não era

correspondente ao decoro de tão alta dignidade, e que era perfeitamente ilusória, como se podia ver melhor pelas contas que existiam no Tesouro com toda a especificação necessária das quais se via que apesar de terem-se já diminuído muito os gastos, e de haver-se despedido muita gente do serviço da casa imperial, a despesa mensal andava por 14, 15, $16: 000 \$$ e às vezes mais ${ }^{493}$.

Alguns dias depois, a $1^{\circ}$ de setembro, Antônio Carlos Ribeiro de

${ }^{492}$ ANAIS do Parlamento brasileiro. Câmara dos Srs. Deputados. Segundo ano da segunda legislatura. Rio de Janeiro: Tipografia de H. J. Pinto, 1870, t. 2, p. 216

${ }^{493}$ Idem, t. 2, p. 73. 
Andrada, irmão do Tutor e então Presidente da Câmara dos Deputados, também discursaria em favor de uma dotação maior:

Seria vergonhoso, senhores, que a nação brasileira tirasse todos os meios de subsistência ao monarca que acaba de aclamar. (...) a quantia que se lhe pretende dar digo que é pequena (...) deduzido o ordenado dos mestres vem a ficar o Imperador com quase nada ${ }^{494}$.

Todavia, os tempos eram outros. O Governo, nas mãos de José Lino Coutinho na pasta do Império, Diogo Antônio Feijó na da Justiça e Bernardo Pereira de Vasconcelos na da Fazenda, não queria se comprometer a fazer o que muito se criticara na Administração anterior: despesas maiores do que receitas. Estando Lino Coutinho no plenário, naquela sessão, ele assim respondeu ao Deputado Ribeiro de Andrada:

Concordo com as idéias gerais que acaba de enunciar o nobre Deputado, mas tenho de fazer uma advertência sobre as suas reflexões. Nós devemos calcular a despesa que temos para fazer, segundo as rendas do Império, para não haver déficit; por isso não convém aumentar despesas ainda que sejam muito filantrópicas e muito recomendáveis, senão dentro dos limites da nossa renda; porque quem gasta mais do que ganha faz bancarrota ${ }^{495}$.

A discussão prosseguiu por outras sessões, e a opinião da maioria dos Deputados, singularmente oposta à de 1827 , foi a de que o Imperador "deveria ser tratado com simplicidade" e não "com o luxo com que viera para o Brasil o Sr. D. João VI". Este foi, por exemplo, parte do discurso proferido por Carneiro da Cunha. Outro Deputado, Costa Ferreira, desejava "que o Imperador menor fosse tratado com toda a dignidade mas não que se the dessem superfluidades porque a nação estava carregada de muitas dívidas

\footnotetext{
${ }^{494}$ Idem, t. 2, p. 107.

495 Idem, t. 2, p. 107.
} 
que a acabrunhavam". Tentando contornar as dissensões, Custódio Dias sugeriu 120 contos de réis. Caetano de Almeida, imaginando que "com economia" a conta mensal do Imperador pudesse chegar a doze contos de réis, foi um pouco mais generoso: 144 contos de réis ${ }^{496}$. Enfim, após ser discutida e votada na Câmara e no Senado, venceu a proposta de uma dotação de duzentos contos de réis - mais doze para os ordenados do Tutor e dos Mestres ${ }^{497}$ —, que, apesar de acalmar um pouco os nervos de José Bonifácio, não chegava a $20 \%$ da soma que Dom Pedro I tivera em mãos durante, pelo menos, seus últimos quatro anos de reinado. Isso, evidentemente, haveria de repercutir no aparato imperial, simplificando-o, e, conseqüentemente, no que se investia em música com tal finalidade durante todo o período regencial, já que esse valor continuou a ser aprovado pela Assembléia Geral sem alterações - mesmo após a mudança na tutela imperial - até a Maioridade, em $1840^{498}$. Acenam para esta possibilidade, as contas da Casa Imperial de 1835-1836, apresentadas à Assembléia Geral, que registram, referentes à música, apenas gastos com o mestre de Suas Altezas e com "comedorias aos escravos músicos", passando, o total de

${ }^{496}$ As discussões sobre o orçamento do Ministério do Império, no qual a dotação do Imperador estava incluída, se estenderam pelas sessões de $1^{\circ}, 2,3,5$ e 6 de setembro de 1831 (Cf. Idem, t. 2, p. 106-126).

${ }^{99}$ COLEÇÃ̃ das Leis do Império do Brasil de 1831. Rio de Janeiro: Tipografia Nacional, 1875, parte 1, p. 229.

498 De 1832 a 1840 , a dotação imperial não foi aprovada por uma lei particular, como previa o mencionado projeto de Carneiro Leão, mas apenas pelas leis orçamentárias, promulgadas anualmente pela Assembléia Geral: em 1832, pela lei de $24 / 10$ que orçava a receita e fixava a despesa para o ano financeiro de 1833-1834 (COLEÇÃO das Leis do Império do Brasil de 1832. Rio de Janeiro: Tipografia Nacional, 1874, parte 1, p. 132); em 1833, pela lei de 08/10, para 1834-1835 (COLEÇÃO das Leis do Império do Brasil de 1833. Rio de Janeiro: Tipografia Nacional, 1872, parte 1, p. 67); em 1834, pela lei de 03/10, para 1835-1836 (COLEÇÃO das Leis do Império do Brasil de 1834. Rio de Janeiro: Tipografia Nacional, 1866, parte 1, p. 44); em 1835, pela lei de 31/10, para 1836-1837 (COLEÇÃO das Leis do Império do Brasil de 1835. Rio de Janeiro: Tipografia Nacional, 1864, parte 1, p. 102); em 1836, pela lei de 22/10, para 1837-1838 (COLEÇÃO das Leis do Império do Brasil de 1836. Rio de Janeiro: Tipografia Nacional, 1861, parte 1, p. 43); em 1837, pela lei de 11/10, para 1838-1839 (COLEÇÃO das Leis do Império do Brasil de 1837. Rio de Janeiro: Tipografia Nacional, 1861, parte 1, p. 67); em 1838, pela lei de 20/10, para 1839-1840 (COLEÇÃO das Leis do Império do Brasil de 1838. Rio de Janeiro: Tipografia Nacional, 1838, parte 1, p. 49). Decretada a maioridade, a 23 de julho de 1840 , a dotação foi finalmente assinada por decreto particular em 28/08 do mesmo ano, que a elevou à quantia de 800 contos de réis (COLEÇÃO das Leis do Império do Brasil de 1840. Rio de Janeiro: Tipografia Nacional, 1863, parte 1, p. 37). 
despesas anuais, a pouco mais de um conto e meio de réis ${ }^{499}$.

Passados exatos quatro anos depois que Ruschenberger presenciou a recepção de gala da Independência, em 1831, ou seja, a 7 de setembro de 1835, o Vice-Almirante inglês Graham Eden Hamond observava a última recepção de gala dada nos tempos da Regência trina, chamando a atenção para o fato de que esta era a primeira vez que via, desde que chegara, em 1834, uma corte "tão brilhante" ${ }^{500}$. É de se imaginar, apesar das limitações impostas pelo orçamento, que, com o natural crescimento físico do Imperador, houvesse, a cada ano que passava, um pequeno aumento de suntuosidade e magnificência no cerimonial imperial, preparando o próprio monarca e seus súditos para a maioridade, que ocorreria, segundo a Constituição, a 2 de dezembro de 1843.

É de se constatar, também, que, nesse exato momento do período regencial, o Império estava apenas sob o comando do Brigadeiro Francisco de Lima e Silva. O Deputado João Bráulio Muniz ficou, a esse tempo, gravemente doente - morrendo em setembro de 1835 -, e o ex-Presidente da Câmara dos Deputados, José da Costa Carvalho, desde julho de 1833, por razões pessoais, já não mais assinava nenhum ato oficial do Governo como Regente, retirando-se para São Paulo. É possível que na ausência desses dois combativos membros da Regência - ambos contrários, como Deputados da Primeira Legislatura, aos abusos dos gastos da Casa Imperial ${ }^{501}$ —, Lima e Silva, até pela sua postura de monarquista convicto e de ex-membro íntimo da corte de Dom Pedro I, tivesse tido o propósito, em relação ao Imperador, de preservar o seu brilho ${ }^{502}$.

499 Apud INFÂNCIA e Adolescência de D. Pedro II; Documentos interessantes publicados para comemorar o primeiro centenário do nascimento do grande brasileiro, ocorrido em 2 de dezembro de 1825. Rio de Janeiro: Arquivo Nacional, 1925, p. 87.

${ }_{500}$ HAMOND, Graham Eden. Op. cit., p. 93.

${ }^{501}$ Costa Carvalho e Bráulio Muniz, assim como outros poucos deputados - entre os quais, Feijó, Vergueiro, Paula e Sousa, Custódio Dias e Souza França - haviam sido contrários ao já mencionado aumento, para mil contos de réis, da dotação de Dom Pedro I (Cf. ANAIS do Parlamento brasileiro. Câmara dos Srs. Deputados. Segundo ano da primeira legis/atura. Rio de Janeiro: Tipografia de H. J. Pinto, 1875, t. 3, p. 308).

${ }_{502}$ Comendador das Ordens de Aviz e da Rosa, Grão-cruz da do Cruzeiro, gentilhomem da câmara imperial, veador da Imperatriz Leopoldina, Francisco de Lima e Silva teve a honra de apresentar à corte, carregando em seus próprios braços, o recém-nascido 
Esse natural e possível engrandecimento, mesmo que sutil, da pompa monárquica, entre 1831 e 1834, enfrentou, no entanto, a partir de 1835, outros obstáculos que não os decorrentes da situação especial do Imperador menor ou os insolúveis problemas de ordem orçamentária. Como se sabe, a vigência do Ato Adicional de 12 de agosto de 1834 levou o Império do Brasil a experimentar, no ano seguinte, o clima de uma "quase república", uma vez que a reforma na Carta de Lei de 1824, inspirada, em parte, no sistema político norte-americano, trazia a novidade de uma regência una, temporária - com mandato de quatro anos - e escolhida por todos os eleitores da respectiva legislatura ${ }^{503}$.

Como se não bastassem as novas regras do jogo, a eleição de 7 de abril de 1835 fez vencedor, escolhido sobretudo pelos eleitores dos rincões do país, o então Senador Diogo Antônio Feijó, um presbítero paulista de grande simplicidade e despretensão - segundo ele próprio, "criado pois na roça, onde só se fala a linguagem do coração, desconhecendo as etiquetas da corte..." ${ }^{504}$ - e que, talvez, por não ter tido acesso a uma educação

Príncipe Imperial Dom Pedro de Alcântara, a 2 de dezembro de 1825. Segundo a Galeria dos brasileiros ilustres, "O Regente Lima tinha um amor particular ao Senhor D. Pedro II, tinha-lhe uma afeição paternal. Contar-se-lhe os progressos intelectuais do imperador, suas boas ações, era uma delícia indizível para ele; e logo acudia cheio de ufania: 'Aqui, aqui nestes braços o apresentei à corte no dia do seu nascimento; com esta boca o aclamei no campo de Santana, e com este coração leal fiz tudo quanto devia para conservar-Ihe a coroa" (Cf. SISSON, S. A. (editor). Galeria dos brasileiros ilustres. Brasília: Senado Federal, 1999, v. 1, p. 359-367). Ainda sobre a convicta posição monarquista do Regente Lima e Silva, note-se que em fins de 1834, em carta ao então Conde de Valença, Estevão Ribeiro de Resende, o Brigadeiro cogitava resistir no cargo a entregar o Governo a alguém que, possivelmente, pudesse levar o Império à proclamação da República: "O Padre Feijó descaradamente pretende; Vasconcelos solicita votos em Minas, e, no norte, é candidato Manuel de Carvalho e Barata; veja V. Ex. ${ }^{a}$ em que mãos irá cair isto, e o inocente Imperador... (...) tomara ver-me livre destes ingratos; porém não desejo ver o Brasil em república, o que sucederá, se qualquer dos acima indigitados empolgar o mando" (Apud MARTINS, Amélia de Rezende. Um idealista realizador, Barão Geraldo de Resende. Rio de Janeiro: Oficinas Gráficas do Almanak Laemmert, 1939, p. 47).

${ }_{503}$ Note-se que no projeto original da reforma, apresentado pela comissão formada por Vasconcelos, Limpo de Abreu e Paula Araújo, a eleição temporária, de quatro em quatro anos, não era admitida. A idéia da temporalidade foi apresentada em emenda substitutiva pelo deputado pela Bahia, Cornélio Ferreira França, e, após longas discussões nos dias 12 e 14 de julho de 1834, foi aprovada por 50 votos, vencidos 35 deputados (ANAIS do Parlamento brasileiro. Câmara dos Srs. Deputados. Primeiro ano da terceira legislatura. Rio de Janeiro: Tipografia de H. J. Pinto, 1879, t. 2, p. 80-89).

${ }^{504}$ Foi desta forma que Feijó se autodefiniu em uma sessão da Câmara dos Deputados de 1832 (16/05, quando ainda era Ministro da Justiça), ao rebater críticas de 
exemplar, com direito a uma passagem pela Universidade de Coimbra, guardava, pessoalmente, certos ressentimentos com a civilização urbana e seus principais valores de distinção política e social, como o diploma de bacharel e os títulos honoríficos ${ }^{505}$.

Embora defendesse, em tese, o sistema monárquico, esse "homem da fazenda e da floresta" ${ }^{\text {506 }}$ era totalmente avesso aos velhos e aparatosos rituais de corte. Como fica clara a sua posição no periódico O justiceiro que redigiu, em São Paulo, entre novembro de 1834 e abril de 1835 —, Feijó defendia uma monarquia "barata e destituída de aparatos supérfluos, pesados e odiosos à Nação"; em suma, um império sem pompa, sem corte, sem aristocracia. O Regente, então, seria "alguma coisa menos que o Presidente dos Estados Unidos"

Autêntico, personalista, "não propenso às ostentações e intolerante em relação às alheias" ${ }^{508}$, o padre não teve dúvidas, ao assumir a Regência, alguns meses depois: no que esteve ao seu alcance, enfraqueceu como nunca o cerimonial monárquico, jamais adulando servilmente o jovem Imperador, e, principalmente, não aceitando, em hipótese alguma, bajulações públicas em torno de si, tirando da corte, qualquer opção, mesmo que remota, de tomar a sua figura como centro das atenções sociais. A esse respeito, inestimáveis são os testemunhos que nos legou o Comandante das Forças Navais Britânicas no Atlântico Sul, o já mencionado Almirante Graham Eden Hamond, ao registrar com detalhes, em seus diários, diversos eventos

Martim Francisco de Andrada. Nessa ocasião, dissera também: "nunca quis ser Ministro" (ANAIS do Parlamento brasileiro. Câmara dos Srs. Deputados. Terceiro ano da segunda legislatura. Rio de Janeiro: Tipografia de H. J. Pinto, 1878, t. 1, p. 16).

${ }^{505}$ Cf. HOLANDA, Sérgio Buarque de (org.). Op. cit., 1985, v. 3, p. 43-44.

506 Assim, em ofício enviado à França em 14 de dezembro de 1835, o representante de Paris no Rio de Janeiro, Edouard Pontois, caracterizava o Regente Feijó: "homme de la ferme et de la forêt" (Apud RANGEL, Alberto. No rolar do tempo: opiniões e testemunhos respigados no arquivo do Orsay-Paris. Rio de Janeiro: José Olympio, 1937, p. 146).

${ }_{508}^{507}$ O JUSTICEIRO, 05/03/1835.

508 A respeito da personalidade de Feijó, assim comentou o reverendo norteamericano Daniel Kidder (1815-1891), que chegou à capital do Império pouco antes do Regente renunciar: "Disinclined to ostentation himself, he did not countenance it in others" (KIDDER, Daniel Parish. Sketches of residence and travels in Brazil: embracing historical and geographical notices of the empire and its several provinces. Philadelphia: Sorin \& Ball; 
sociais ocorridos na corte durante o governo de Feijó, incluindo-se o próprio comportamento pouco cortês do Regente.

Não obstante ter referendado, como Ministro da Justiça, em 1831, uma lei que declarava livres os escravos que aportassem no Império, cuja inaplicabilidade logo a tornou conhecida como "lei para inglês ver", Feijó punha em prática, agora, a "corte para inglês não ver". Explicamos a paródia: segundo Hamond, a primeira grande gala do ano de $1836-1^{\circ}$ de janeiro já começou causando estranhezas, sem a recepção imperial ao Corpo Diplomático e aos principais membros da comunidade estrangeira ${ }^{509}$. Mais adiante, a 7 de abril, naquele tempo o principal dia de festividade nacional, o comandante da Marinha inglesa também não deixou de notar que a reunião da corte no Paço foi "ridícula", sobretudo quanto aos esforços de alguns presentes em aclamar o pequeno Imperador ${ }^{510}$, dando-nos a entender que, nesse clima de "monarquia republicana", o cerimonial herdado do Antigo Regime português começava, sensivelmente, a perder o seu significado. Em junho, na procissão de Corpus Christi, que percorria alguns quarteirões do centro da capital saindo da Capela Imperial e terminando no Paço, Hamond também espantou-se ao ver, naquela que era uma solenidade tradicional e pomposa, Dom Pedro II sozinho, ou seja, desacompanhado dos Ministros e do Regente. Então desabafou:

... seria muito natural que ele [Feijó] tomasse parte (...). Suas idéias no entanto, são muito liberais, como são chamadas nos tempos atuais. (...) Ele não deveria abster-se de comparecer a essa procissão nacional, ou pessoalmente ou através de um dos ministros, como também não deixar de apoiar o pobre Imperador que desfilou sozinho pela sarjeta sem que ele estivesse ao seu lado - o que deveria ter feito, tendo em

London: Wiley \& Putnam, 1845, v. 1, p. 64).

${ }^{509}$ HAMOND, Graham Eden. Op. cit., p. 115. Esse mesmo fato se repetiria no ano seguinte com a mesma estranheza do inglês: "O Imperador e as Princesas recebem hoje, no Palácio da cidade, cumprimentos pelo Ano Novo. Os estrangeiros não deverão estar presentes. Por que, eu não sei" (Ibidem, p. 153).

${ }_{510}$ Ibidem, p. 120. 
vista seu cargo ${ }^{511}$

A 7 de setembro, outra das mais importantes festividades nacionais, Hamond comenta que "o ambiente no Palácio era o usual da ocasião". Porém, notou que "a farsa" de reverenciar o Imperador, as Princesas e o Regente, "havia terminado"512. Nesse caso, fica ainda mais evidente que ocorria, ao longo daquele ano de 1836 - e provavelmente por ordem expressa de Feijó ou de seus ministros, como Limpo de Abreu, acusado na Câmara de "não simpatizar com as idéias monarquistas" processo de esvaziamento dos costumes cortesãos e do prestígio imperial, o que nos faz presumir também que o aparato, incluindo-se a música para tal fim, estivesse sendo igualmente banalizado às últimas conseqüências ${ }^{514}$.

Único respiro diante dessa "asfixia monárquica", que obrigou os "ximangos de plantão" a improvisar uma momentânea retomada da pompa imperial, foi a chegada, no Rio de janeiro, a 29 de novembro de 1836, da fragata holandesa Bellona, que trazia, entre seus oficiais, um príncipe holandês, Henrique de Orange. Afinal, não seria nada adequado ao Governo brasileiro, "ainda" reconhecido internacionalmente como uma monarquia, recepcionar um membro de uma das principais casas dinásticas européias sem um mínimo de aparato. Assim, aproveitou-se o aniversário de Dom Pedro II -2 de dezembro - e o próprio natalício do Príncipe, quatro dias depois, para que algo de diferente e necessário fosse arranjado.

Segundo Eden Hamond, nessa primeira data, as tropas foram passadas em revista "para dar melhor impressão ao Príncipe" e, "de longe", teria sido esta a "corte mais brilhante" que havia visto até então. À noite, o teatro ficou "repleto" para ver o Príncipe e a família imperial. No palco,

\footnotetext{
511 Ibidem, p. 124.

12 Ibidem, p. 131.

${ }^{513}$ O CRONISTA, 09/07/1836.
}

${ }^{514}$ Note-se que, durante o governo de Feijó, as longas e apologéticas notícias do Jornal do comércio, referentes às "grandes galas", deram lugar ao laconismo de textos como esse, referente ao sexto aniversário da ascensão de Dom Pedro II ao trono: "Ontem, sete de abril, festejou-se com as formalidades do estilo, 0 aniversário da nossa regeneração política" (JORNAL DO COMÉRCIO, 08/04/1837). 
porém, mais uma vez, um espetáculo "sem graça"515. Desta vez, Feijó se fez presente, como também não deixou de visitar, dois dias depois, "com toda a pompa", o príncipe a bordo da Bellona ${ }^{516}$.

Contudo, o mais importante progresso da vida social carioca após o Sete de Abril se deu nos dias 7 e 8 de dezembro de 1836, quando dois bailes, com a presença inédita do jovem Imperador mobilizaram toda a corte. Inicialmente, no primeiro dia, ocorreu um baile particular, patrocinado pela "Assembléia Estrangeira" - sociedade da qual trataremos com mais vagar em páginas posteriores. Inusitado o fato, o Jornal do comércio chegou a por dúvidas quanto à presença imperial:

À noite S. A. assistirá ao baile da Assembléia Estrangeira, que S. M. o Imperador, dizem, se dignará honrar com sua presença ${ }^{517}$.

Pois, honrou. E segundo o Almirante Eden Hamond, além do Imperador,

${ }^{515}$ A presença do Imperador - e desta vez do Príncipe de Orange -, garantindo ao Teatro uma renda incomum com a venda de ingressos, chegou a fazer com que a Companhia do Constitucional Fluminense especulasse, nessa ocasião, obrigando os interessados em assistir à récita de gala a comprar bilhetes para mais uma récita comum. Noticiando tal iniciativa, o jornal O Cronista criticou-a com certa ironia: "... a solenidade de um dia tão festivo, e sobretudo, no Teatro Constitucional Fluminense, a presença de S. M. Imperial, de cuja vista a população do Rio de Janeiro se mostra tão justamente sequiosa, atrairão por certo numeroso concurso. Desejaremos que a Companhia do Teatro Constitucional seja feliz na sua especulação de obrigar a comprar um bilhete para outra récita a todos os que quiserem assistir a esse festejo: no entanto não sabemos se lhe é muito decoroso servir-se da presença de S. M. Imperial como de chamariz, e especular sobre o amor que Lhe temos, e desejo de O ver que nos anima..." (O CRONISTA, 02/12/1836). Aí torna-se claro que, pela falta de um atrativo social - como a presença freqüente do imperador - o público estivesse plenamente desinteressado pelos espetáculos ordinários do Teatro, o que acabava por diminuir a receita da casa, e, conseqüentemente o nível daquilo que se punha em cena. A esse respeito, aliás, uma nota da Companhia do Teatro Constitucional Fluminense publicada no Jornal do comércio, justificando a venda combinada de ingressos para o dia 2 de dezembro de 1836, confirma que o fazia "por seus interesses", por se achar "isolada, falta de todos os recursos", em contraposição aos tempos mais "felizes", em que o Teatro tinha "grande número de assinantes, bons protetores, loterias, e o auxílio do finado Senhor D. Pedro I e do seu Governo" (JORNAL DO COMÉRCIO, 01/12/1836).

${ }^{516}$ HAMOND, Graham Eden. Op. cit., p. 143-144.

517 JORNAL DO COMÉRCIO, 03/12/1836. 
Toda a elite da cidade, o Regente, e toda a Corte, estavam presentes. As princesas, lindamente vestidas, com uma enorme quantidade de jóias, diamantes e todas com a maior condecoração brasileira. (...) O baile foi honrado pelos reais visitantes até quase meianoite, quando todos foram embora, exceto o príncipe de Orange que perdeu toda cerimônia e dançou até quando quis ${ }^{518}$.

Ressurgia, pois, com muita música, o encontro dançante e gastronômico da sociedade carioca com sua mais alta autoridade moral, mesmo que por uma razão fortuita e passageira. Durante cerca de três horas, alguns brasileiros afortunados puderam ter a "honra", segundo Hamond, "de ver Sua Majestade Imperial comer!"519. Como se não bastasse, no dia seguinte, realizou-se, no Palácio de São Cristóvão, a "primeira festa no seu gênero depois da subida ao trono de Dom Pedro II"520. Tal como a ave mitológica Fênix, o brilho dos salões da Boa Vista, espaço tantas vezes usado por Dom Pedro I para seus saraus, jantares e bailes, renascia das cinzas, mesmo que a elas voltasse no dia seguinte. Segundo o Jornal do comércio, após um jantar, servido para 58 pessoas "com toda a profusão e delicadeza", às oito horas, juntou-se a esse escol "um grande número de senhoras e mais convidados". A banda imperial - não se sabe se formada apenas pelos músicos escravos do Imperador ou por profissionais especialmente arregimentados para a ocasião - tocou, então, o "Hino Nacional Brasileiro" ${ }^{21}$. E, findo este e mais uma "sinfonia",

${ }^{518}$ HAMOND, Graham Eden. Op. cit., p. 145-146.

519 Ibidem, p. 146.

520 A informação é do jornalista Escragnolle Dória, apurada na transcrição de um ofício de 19 de dezembro de 1836 do cônsul Pontois à Chancelaria Francesa (ARQUIVO NACIONAL, Rio de Janeiro. Fundo Luis Gastão d'Escragnolle Dória, cx. 232, v. 5, p. 376).

${ }_{521}$ Aí fica a dúvida em relação a que "hino nacional" seria esse. Se era, ainda, o Hino imperial e constitucional, de Dom Pedro I - futuro Hino da Independência -, ou se já era o atual, de Francisco Manuel da Silva. A questão permanece viva porque, segundo pesquisa de Ayres de Andrade, o documento mais antigo que constata veementemente o hino de Francisco Manuel como "hino nacional" é de dezembro de 1837, portanto um ano posterior ao mencionado evento envolvendo o Príncipe de Orange (Cf. ANDRADE, Ayres de. Op. cit., v. 1, p. 174-175). Ainda assim, três textos aqui revelados, de 1834, 1837 e 1850 nos atestam que o hino de Dom Pedro I com a letra de Evaristo da Veiga ("Já podeis filhos da pátria...") ainda foi executado e conhecido nesses tempos como "o hino nacional". 
... os quatro Príncipes romperam o baile por uma quadrilha; e assim durou este magnífico espetáculo até 1 hora da noite quando se retirou o Príncipe, com os da sua comitiva, sendo acompanhado da mesma forma porque havia sido recebido ${ }^{522}$.

Além dos ilustres convidados para o jantar, entre os quais, o Regente, os Ministros de Estado, os Presidentes do Senado Imperial e da Câmara dos Deputados, o Tutor, vários chefes de legações estrangeiras, membros da comitiva holandesa e, curiosamente, José Bonifácio de Andrada - para provável desgosto de seu arquiinimigo Feijó -, estiveram, também, presentes no baile,

... todos os Titulares, Gentis-homens, Veadores, Damas, Açafatas, Guarda-roupas, Moços fidalgos, e Moços da Câmara; os Secretários e Adidos ao Corpo Diplomático, e os Comandantes dos vasos de guerra estrangeiros surtos no porto; os Senadores e Deputados, os Membros de todos os Tribunais da Corte, os

A primeira é um número do Diário do Rio de Janeiro (vide nota 69 desta parte); a segunda, o livro de Daniel Kidder, publicado em 1845, porém referente a uma excursão que esse reverendo norte-americano realizou nos arredores do Rio de Janeiro entre 1837 e 1838: "Among the other patriotic songs which were that evening made to echo over the stillness of these woods and waters, was the national hymn, generally attributed to Don Pedro I, but said to have been actually composed by Evaristo Ferreira da Veiga, a distinguished patriot at the time of the revolution. Já podeis, filhos da patria, / Ver contente a mai gentil / Já raiou a liberdade, / No horizonte do Brazil..." (KIDDER, Daniel Parish. Op. cit., v. 1, p. 191); enfim, a última, um livro de Charles Stewart, de 1856, que narra mais uma passagem desse capelão da Marinha norte-americana pelo Rio de Janeiro, em 1850. No dia 2 de dezembro desse ano - o $25^{\circ}$ aniversário de Dom Pedro II - Stewart assevera ter ouvido pelas ruas da capital do Império o mesmo "já podeis, filhos da pátria". Note-se que mais uma vez a letra, de Evaristo da Veiga, é erroneamente atribuída a Dom Pedro I: "The vivas of the multitudes were tolerably loyal, and the spirited strains of the national air, caught, as the cortege approached, from band to band, stationed at various points on the route, quite spirit-stirring. The music of this air is a composition of Don Pedro I., who was a master in the science. It is one of the most animated, spirit-moving national airs I know - equal almost in this respect to the Marseillaise. The words of the anthem to which it is set are said to be also from the pen of his late Majesty; and, in the native language, are scarce less incisive than the tune, to emotions of patriotism and valor - Já podeis, filhos da patria..." (STEWART, Charles Samuel. Brazil and La Plata: the personal record of a cruise. New York: G.P. Putnam, 1856, p. 152).

522 JORNAL DO COMÉRCIO, 10/12/1836. 
Chefes de todas as Repartições Públicas, o Presidente da Assembléia Provincial, todos os Oficiais Generais de Mar e Terra, os Comandantes dos Corpos de Primeira Linha, os Chefes de Legião da Guarda Nacional, os Diretores da Assembléia Estrangeira, cujo baile tinha o Imperador honrado com sua presença; dois dos Diretores da Caixa da Amortização, e dois negociantes matriculados; e bem assim as respectivas famílias ${ }^{523}$.

Ou seja, em uma oportunidade única, mais descontraída e íntima em relação aos circunspectos encontros imperiais no Paço da cidade, a corte inteira se reuniu em torno do soberano, mesmo sendo esse monarca alguém ainda bastante inexpressivo socialmente, como notou Eden Hamond, em referência a um dos piores momentos desse dia tão especial:

Nunca houve nada mais tedioso do que o Imperador e o Príncipe; ali estão sentados lado a lado, completamente em silêncio. Nenhuma palavra se diz entre os dois. Duas estátuas ${ }^{524}$.

O fato é que três dias depois desse acontecimento - por pior ou melhor que tenha sido - , a fragata Bellona levantou ferro e, dando suas costas a ela, Feijó continuou, na sua concepção "barata" de monarquia, a obscurecer a figura imperial e, conseqüentemente, a apagar a si próprio. Afinal, como disse certa vez, em 1832, um deputado: "na regência reflete toda a luz que brilha no Imperador..."525

Sem, pois, brunir seu cargo, no que se refere à sociabilidade, e levando constante desvantagem política na indissolúvel queda de braço que travava com o Legislativo ${ }^{526}$, a 19 de setembro de 1837 , esse Senador - que

${ }^{523}$ Idem.

${ }^{524}$ HAMOND, Graham Eden. Op. cit., p. 146-147.

${ }^{525}$ ANAIS do Parlamento brasileiro. Câmara dos Srs. Deputados. Terceiro ano da segunda legislatura. Rio de Janeiro: Tipografia de H. J. Pinto, 1878, t. 1, p. 167.

${ }^{526}$ Desde o início de seu governo, Feijó sempre ignorou a opinião da maioria parlamentar. Achava que o fato de ter sido alçado à mais alta magistratura do Império "pelo voto nacional" - como fez questão de sublinhar já na Fala do Trono da Abertura da Sessão Legislativa de 1836 - , Ihe daria prerrogativas suficientes para poder exercer um mando 
ainda seria Presidente da sua casa legislativa em 1839 - demitia-se do posto de Regente. Como podemos observar na descrição que o Jornal dos debates políticos e literários fez da grande gala de 7 de setembro daquele ano, a firmeza de caráter de Feijó, magnética até os últimos suspiros de seu governo, não repercutiu apenas na escolha de seu sucessor ${ }^{527}$. Até o fim, não quis pompa, não quis bajulações; foi o que teve:

Nunca este dia glorioso da nossa Independência raiou tão melancólico no horizonte brasileiro. (...) Toda a manhã passou-se em silêncio; $O$ modesto festejo começou de tarde (...); e de noite com a sua presença tão cara e desejada concorreu para maior realce do Teatro nacional fluminense. Alguns vivas ressoaram ao Imperador, a Sua Augusta Família, à Independência, e dando-se também alguns vivas ao Herói, e ao Patriarca da Independência, nem um só viva deu-se ao venerável Regente, com surpresa, e pesar nosso ${ }^{528}$.

Ao assumir interinamente a Regência, o recém nomeado Senador e Ministro do Império, Pedro de Araújo Lima - futuro Visconde e Marquês de

pessoal sem o voto de confiança da Assembléia - em especial, da Câmara dos Deputados. Dependendo, no entanto, dela para efetivar diversos de seus projetos de governo, e sem poder, a princípio, dissolvê-la, Feijó acabou, com sua teima - ajudada por uma legislação mal escrita e mal interpretada -, fazendo do Império um nó górdio, aliás, muito bem anedotizado, à época, por Justiniano José da Rocha, em um de seus escritos publicados no jornal O Cronista, em meados de 1836: "Parece-nos que aqui está o ponto da questão: a Câmara dos Deputados diz ao Regente: 'Nós, que somos representantes da vontade nacional, julgamos que o Ministério, ou que tal ou tal Ministro não convém aos interesses nacionais, e que o povo não está com ele contente, portanto demiti o Ministério, ou o Ministro'. E o Regente responde: 'Eu, que também sou representante da vontade nacional, julgo que este Ministério é o que melhor quadra com os interesses nacionais, e que o povo está contente com ele, portanto não demito o Ministério'. Eis aqui a luta em que se empenha a Câmara com o chefe do Poder Executivo, e o meio de terminá-la não é outra senão a já indicada: o povo é quem deve decidir. Como?" (O CRONISTA, 20/08/1836).

${ }_{527}$ Visando a efetivar uma transmissão direcionada de poder, escolhendo deliberadamente seu sucessor, Feijó nomeou o recém nomeado Senador e então Presidente da Câmara dos Deputados, Pedro de Araújo Lima como Ministro do Império um dia antes de demitir-se. Como estabelecia o artigo 30 do Ato Adicional de 12 de agosto de 1834, na falta e impedimentos do Regente, governaria o Ministro do Império (COLEÇÃO das Leis do Império do Brasil de 1834. Rio de Janeiro: Tipografia Nacional, 1866, parte 1, p. 22).

528 JORNAL DOS DEBATES POLÍTICOS E LITERÁRIOS, 13/09/1837. 
Olinda -, sabia que a sua sustentação, tanto momentânea, como efetiva nesse posto - tendo em vista um vindouro sufrágio, em abril de 1838, e a difícil concorrência de seu conterrâneo, o Deputado Holanda Cavalcanti ${ }^{529}$-, dependeria, necessariamente, de um afastamento diametral em relação aos desígnios políticos cumpridos, com alto grau de impopularidade, pelo padre paulista. Sua preocupação imediata foi buscar uma reconciliação entre o Executivo e o Legislativo, nomeando um gabinete composto por algumas das principais lideranças da Câmara, como Bernardo Pereira de Vasconcelos e Miguel Calmon du Pin e Almeida. Como se isso não bastasse, passou ainda seguindo uma postura absolutamente oposta à de seu antecessor - a prestigiar a figura imperial, na medida em que a ostentação monárquica, como se provou depois, na época da maioridade, ainda satisfazia, e muito, o gosto geral do "povo", como afirmou o Reverendo Daniel Kidder:

Uma nova política foi adotada com respeito ao
imperador menino. Feijó havia sido reservado e
avesso a cerimônias; a nova administração
tornou-se excessivamente cortês. As ocasiões
públicas passaram a ter um maior aparato, e as
inclinações de um povo apaixonadamente
aficionado pela pompa e circunstância da
realeza começaram a ser inteiramente

529 A expressiva votação do Deputado Antônio Francisco de Paula e Holanda Cavalcanti de Albuquerque no pleito eleitoral de 1835, perdendo para Feijó por margem pequena de votos, e a falta de meios de apurar as intenções de votos, o colocavam como favorito à vitória no pleito de 22 de abril de 1838. Assim caía no erro, por exemplo, o Jornal do comércio, poucos mais de um mês antes da eleição: "Com dados tais, fácil é prever quem será o Regente: se o decidido amor à pátria, o sincero respeito às instituições nacionais, integridade e atividade apoiados no voto consciencioso, já pronunciado, de tão grande número de eleitores, pode servir de base para se ajuizar quem será esse Regente, é o Sr. Holanda Cavalcanti decididamente o que tem de ser escolhido" (JORNAL DO COMÉRCIO, 17/03/1838). Não contavam, no entanto, os especuladores eleitorais, com a grande aceitação da política conciliadora de Araújo Lima, que, em poucos meses de governo, convenceu a grande maioria dos eleitores a efetivá-lo no cargo. Sua vitória, proferida na sessão da Assembléia Geral de 6 de outubro de 1838, se deu, ao contrário da de Feijó, por larga margem de votos em relação a Cavalcanti: 4308 a 1981. O restante dos votos pulverizou-se em diversos nomes, entre os quais, Antônio Carlos Ribeiro de Andrada, 597; Costa Carvalho, 581; Lima e Silva, 443; Arcebispo da Bahia, 432; Feijó, 414; Vasconcelos, 298; Rafael Tobias de Aguiar, 180; e, curiosamente, José Bonifácio, 164, que no dia da eleição já havia falecido (Cf. ANAIS do Parlamento brasileiro. Câmara dos Srs. Deputados. Primeiro ano da quarta legislatura. Rio de Janeiro: Tipografia da viúva Pinto \& Filho, 1886, t. 2, p. 610). 
satisfeitas $^{530}$

Sem poder, no entanto, em virtude da austeridade orçamentária ${ }^{531}$, contar com grandes somas, essa política de engrandecimento do Imperador e de fortalecimento das instituições monárquicas foi feita à base de sutilezas. A 2 de dezembro de 1837, por exemplo, dia do aniversário de Dom Pedro II, o Governo o homenageava convertendo o Seminário de São Joaquim tradicional instituição educacional carioca - em "Colégio de Pedro II"532. O mesmo ocorreria, de forma oficiosa, com o Teatro Constitucional Fluminense, que, em junho de 1838, voltaria a chamar-se, em homenagem ao santo nome do Imperador - e como na época de Dom Pedro I —, de "Imperial Teatro de São Pedro de Alcântara"533.

Nesse mesmo sentido, outra estratégia utilizada pelo novo Regente foi

${ }^{530}$ Tradução nossa de: "A new policy was adopted towards the boy Emperor. Feijo had been distant and unceremonious; the new administration became over-attentive. More display was made on public occasions, and the inclinations of a people, passionately fond of the pomp and circumstance of royalty, began to be fully gratified" (KIDDER, Daniel Parish. Op. cit., v. 1, p. 64-65).

${ }^{531}$ O projeto de orçamento para 1839-1840 apresentado pelo Ministro da Fazenda, Miguel Calmon, na sessão de 8 de maio de 1838 não contemplaria uma dotação maior para - Imperador (ANAIS do Parlamento brasileiro. Câmara dos Srs. Deputados. Primeiro ano da quarta legis/atura. Rio de Janeiro: Tipografia da viúva Pinto \& Filho, 1886, t. 1, p. 55). Permaneciam os mesmos duzentos contos de réis, aprovados, posteriormente, sem alteração, pela já mencionada lei de 20 de outubro de 1838.

${ }_{532}$ COLEÇÃO das Leis do Império do Brasil de 1837. Rio de Janeiro: Tipografia Nacional, 1861, parte 2, p. 59-60.

${ }^{533} \mathrm{Em}$ setembro do mesmo ano, a mesma idéia de homenagear o Imperador se estenderia também à Princesa Imperial, Dona Januária: o Teatro da Praia de Dom Manuel, construído, em 1833, por uma sociedade de atores, passaria a denominar-se "Teatro de São Januário" (JORNAL DO COMÉRCIO, 26/09/1838). Aliás, note-se que as atenções do Governo de Araújo Lima quanto ao fortalecimento das instituições monárquicas não apenas se faziam presentes em relação ao Imperador, mas à toda família imperial. Na fala do trono da Sessão Imperial da Abertura da Assembléia Geral de 1839, o Regente já se mostrava preocupado em tratar do casamento de Dona Januária: "O consórcio de Sua Alteza Imperial é um dos grandes objetos que ocupam minha atenção; e eu vos recomendo, em nome do Imperador, que o tomeis em muito particular consideração, para que ele seja levado a efeito de um modo digno do Brasil e do trono" (ANAIS do Parlamento brasileiro. Câmara dos Srs. Deputados. Segundo ano da quarta legislatura. Rio de Janeiro: Tipografia da viúva Pinto \& Filho, 1884, t. 1, p. 13). Curiosamente, esse tema, discutido na Sessão de 1840, levaria alguns Senadores da oposição - como Holanda Cavalcanti - a colocar novamente em pauta a antecipação da maioridade de Dom Pedro II, tendo-se em vista a determinação constitucional (art. 120) de que o casamento da herdeira presuntiva da coroa - à época, Dona Januária - fosse feito "a aprazimento do Imperador" (Cf. COLEÇÃO das Leis do Império do Brasil de 1824. Constituição Política do Império do Brasil. Rio de Janeiro, Imprensa Nacional, 1886, parte 1, p. 24). 
a de tirar, o máximo possível, o Imperador de sua rotina claustral, em São Cristóvão, o que, em um primeiro momento, dada a novidade da situação, criou até situações vexatórias, como a que ocorreu em outubro de 1837 , quando Dom Pedro II foi levado, de surpresa, ao Paço da cidade para assistir ao desfile das tropas que partiriam para o Rio Grande do Sul dando combate aos "farrapos". Nessa ocasião, o Comandante do Exército, inseguro quanto a que atitude tomar, diante da augusta presença, acabou por não saudar o Imperador ${ }^{534}$. Algum tempo depois, em novembro do mesmo ano, o imperial menino visitava os arredores da Fazenda de Santa Cruz, acompanhado de diversos membros da alta sociedade ${ }^{535}$. Dias antes, estivera inspecionando o Arsenal de Guerra ${ }^{536}$. Na grande gala de 25 de março de 1838, o monarca novamente excedia o seu já não mais tão rigoroso itinerário, participando da inauguração do Colégio Pedro ${ }{ }^{537}$, instituição para a qual doaria, na mesma época, dois contos de réis a título de filantropia ${ }^{538}$. No dia 5 de abril de 1838 , assistia acompanhado de suas irmãs, do Regente e dos Ministros de Estado, a um Te Deum, na Capela Imperial, em homenagem à restauração da Bahia $^{539}$. Naquele mesmo mês, comparecia ao Teatro da Praia de Dom Manuel para a comemoração do aniversário da sua irmã mais velha, a Rainha de Portugal, Dona Maria II. Nessa ocasião, foi estreada uma grandiosa abertura instrumental de Januário da Silva Arvelos, escrita para a ocasião e baseada em peça pianística portuguesa "A batalha da Ilha Terceira", de Francisco de Paula Santiago ${ }^{540}$. Enfim, com essas e outras incursões, o

534 "S. M. I., o Ex. ${ }^{\text {mo }}$ Regente interino, e os Ministros de Estado assistiram nas janelas do Palácio da cidade as evoluções da tropa no Largo do Paço. Algum desgosto houve entre as pessoas que estiveram presentes a estas evoluções por se não darem vivas a S. M. I.: pensamos que os devia dar o Ex. ${ }^{\mathrm{mo}}$ General das armas, talvez que o não fizesse por acanhamento" (O CRONISTA, 07/10/1837).

535 JORNAL DO COMÉRCIO, 17/11/1837.

536 O CRONISTA, 28/10/1837.

537 Idem, 27/03/1838.

538 JORNAL DO COMÉRCIO, 04/04/1838.

539 Idem, 06/04/1838.

540 Um manuscrito de 134 páginas dessa partitura orquestral, copiada em 1838 pelo músico Francisco da Mota, se acha tombado na Seção de Música da Biblioteca Nacional do Rio de Janeiro (Cf. MÚSICA no Rio de Janeiro Imperial. Rio de Janeiro: Biblioteca Nacional, 1962, p. 13). Uma cópia xerográfica de um manuscrito, sem título, da peça pianística homônima, de autoria de Francisco de Paula Santiago, foi por nós 
pequeno Imperador, operado de perto pelo Regente, insinuava-se na vida social carioca, para o prazer geral de seus súditos e, certamente, dos músicos cariocas.

Todavia, o que mais simbolizou a nova política de Araújo Lima para com o monarca, inspirando calorosos debates na sociedade e no parlamento, foi a restauração, no aniversário de Dom Pedro II de 1837, do cerimonial do beija-mão. As discussões sobre a retomada desse hábito nas solenidades imperiais, realizadas entre parlamentares da situação e da oposição na Câmara dos Deputados, não apenas nos permitem confirmar que, desde 1831, ele havia sido realmente abolido, como também especular sobre as possíveis razões que teriam levado essa prática ao desuso. Vejamos parte do discurso que Honório Hermeto Carneiro Leão proferiu, na sessão do dia 10 de maio de 1838, respondendo à acusação - de Teófilo Ottoni - de que o Governo, ao promover a restituição do beija-mão no aniversário do Imperador, havia se prostrado "ao modo oriental perante o trono", restaurando-se, assim, usos que o "antigo despotismo estabelecera":

Eu estive aqui em 1831, quando o falecido Sr. D. Pedro I, ex-Imperador do Brasil abdicou, e foi aclamado o Sr. D. Pedro II; (...) Vi que, com efeito, nessa época não se beijava a mão do monarca. Dirá o nobre deputado que esse ato foi então proscrito, como pouco digno do povo brasileiro (...) não creio, digo, que se desonrasse com isso (numerosos apoiados); mas como uma medida de cautela. O monarca era então infante: contava apenas cinco anos (...) havia alguns indivíduos tão fanáticos pelo sistema republicano que apregoavam nos periódicos a conveniência de uma espécie de deportação para o monarca. Conseqüentemente podia-se, devia mesmo proibir-se então o beijamão, quer para evitar que se aproximassem ao monarca pessoas que podiam suscitar desconfianças: quer porque um infante não

identificada em 2002 entre as doações de partituras ao acervo do infelizmente extinto Núcleo de Música Brasileira da Fundação Padre Anchieta, à época sob a direção do musicólogo Maurício Monteiro. 
poderia suportar a fadiga de estar a dar beijamão... 541

Essa versão foi, no entanto, rebatida pelo deputado Alvares Machado na sessão do dia seguinte, 11 de maio. Eis parte do rechaço:

O senhor D. Pedro II não correu pois o menor perigo; e não foi esta, portanto, a causa da suspensão dos beija-mãos. Já no tempo do senhor D. Pedro I se falava contra esse uso, notando-se que uns se ajoelhavam, outros andavam de joelhos a sala inteira (risadas) etc. Veio o 7 de abril, e assentou-se que era chegada a época de deixar em desuso este costume, porque se entendeu que era um tanto servil, e não convinha... ${ }^{542}$

Enfim, como se não bastasse, complementaram o resgate da pompa imperial $^{543}$, naquela mesma ocasião de retomada do beija-mão - 2 de dezembro de 1837 - o uso de novas carruagens de gala, feitas com fino material importado de Londres ${ }^{544}$; e a contratação esporádica, por $46 \$ 900$, de

${ }^{541}$ ANAIS do Parlamento brasileiro. Câmara dos Srs. Deputados. Primeiro ano da quarta legislatura. Rio de Janeiro: tipografia da viúva Pinto \& Filho, 1886, t. 1, p. 76-78.

542 Idem, p. 90.

${ }^{543} \mathrm{Em}$ contraposição ao tempo da regência de Feijó (vide nota 121 desta parte), o Jornal do comércio voltava a publicar no governo de Araújo Lima, longas e laudatórias notas referentes às festividades de "grande gala", como a que saiu à luz, no que diz respeito ao dia 2 de dezembro, aniversário de Dom Pedro II: "De novo raiou um dos mais belos dias do Brasil; de novo a alegria e as esperanças de um povo inteiro vieram mesclarse às recordações de glória que o haviam embalado no seu berço, e que pareciam tê-lo abandonado: o entusiasmo hoje renasce e abre as páginas de um porvir brilhante, superior a todos os desejos, a todas as esperanças, a todos os sonhos e a todas as ilusões..." (JORNAL DO COMÉRCIO, 05/12/1837). Dois anos depois, o mesmo Jornal do comércio ampliaria ainda mais seus comentários encomiásticos a esse respeito publicando, durante todo o mês de dezembro, informações sobre as diversas manifestações de regozijo que teriam ocorrido nas províncias do Império por ocasião do décimo quarto aniversário do Imperador.

${ }^{544}$ O Jornal do comércio descreve a sua beleza: "Partiu dali o préstito que se compunha de uma carruagem a seis, trazendo o porteiro da imperial câmara e o padre frei Pedro. Seguia um piquete de cavalaria, seis moços da estribeira, e logo depois o magnífico coche, todo guarnecido de prata, em que vinha S. M. I. acompanhado pelos Ex. ${ }^{\text {mos }}$ Regente, Tutor, e Mordomo Mor. Vinha então o esquadrão de cavalaria comandado pelo tenente coronel Gusmão, que precedia outro coche que como o primeiro era puxado a oito cavalos, guarnecidos de ricos arreios de imitação de ouro, e no qual se achavam SS. AA. acompanhadas de suas damas e escoltadas por um piquete de cavalaria. Tanto esse coche 
dez músicos instrumentistas para a Missa cantada na Capela. Tombado no Arquivo Nacional, um inédito manuscrito de prestação de contas dos músicos, que comprova o pagamento dessa despesa pelo Governo, é o mais antigo de todo o período em estudo. Se não houve perda de documentação anterior, tudo indica que esse tipo de contratação esporádica de instrumentistas para o serviço musical da Capela após o Sete de Abril, tendo em vista o aumento do aparato imperial, tenha sido instituído, também, pela regência de Araújo Lima, embora se tornasse efetivamente usual, como veremos, apenas a partir da Maioridade ${ }^{545}$.

No que diz respeito ao Teatro Constitucional Fluminense, local de visita imperial praticamente obrigatória nas grandes galas, o novo Governo mostrou-se, ao menos, preocupado com o melhoramento do nível dos seus espetáculos e a correta aplicação dos subsídios que esse estabelecimento, a pedido de seus acionistas, acabava de conquistar, mediante resolução da Assembléia Geral: duas loterias anuais de duzentos contos de réis por um espaço de seis anos ${ }^{546}$. Segundo um número do Jornal dos debates políticos e literários, posterior cerca de um mês à posse interina de Araújo Lima, seu Ministério "das capacidades" cogitava, àquele momento, a viabilidade de transformar o Constitucional Fluminense em "Teatro Nacional”, dando sanção às loterias autorizadas pelo Legislativo "com a condição de receber a

como o de S. M. são de uma riqueza e elegância extraordinárias, e asseguram-nos que se empregaram na sua confecção para mais de quatro mil onças de prata" (JORNAL DO COMÉRCIO, 04/12/1837). Segundo Eden Hamond, as carruagens teriam custado £15.000, ou pouco mais do que 120 contos de réis (HAMOND, Graham Eden. Op. cit., p. 176). Era uma quantia bastante alta, à época, equivalente a mais da metade da dotação anual do Imperador. Não sendo paga por recursos extraordinários do orçamento, é possível que o montante tenha sido reunido ao longo dos anos, economizando-se uma parte dos duzentos contos de réis anuais. Corrobora tal hipótese, outro texto publicado no Jornal do comércio a mando da Casa Imperial, dando conta que a sua administração tinha por hábito reservar uma parte da sua verba anual para o "crescimento do patrimônio pessoal de Sua Majestade" (JORNAL DO COMÉRCIO, 24/10/1838). No que se refere, portanto, à compra das carruagens, não foi obra, nem de Araújo Lima, nem de Feijó, mas uma realização da tutela ou da mordomia-mor. É provável, no entanto, que Araújo Lima tenha usado politicamente essa novidade como marca de seu Governo. 1 , doc. 60 .

${ }^{545}$ ARQUIVO NACIONAL, Rio de Janeiro. Fundo Casa Real e Imperial, cx. 13, pc.

546 Essa resolução acabou transformando-se, após a sanção do Regente, referendado pelo Ministro do Império, em Decreto de 30 de novembro de 1837 (COLEÇÃO das Leis do Império do Brasil de 1837. Rio de Janeiro: Tipografia Nacional, 1861, parte 1, 
companhia uma diretoria de nomeação do Governo"547. Por razões desconhecidas - talvez pela cautela do Executivo em não se confrontar com a Assembléia - acabou-se deixando tudo como estava, e o Teatro, embora entrasse em uma fase ligeiramente melhor, em 1838, com a extração das primeiras loterias concedidas no ano anterior, permaneceria ainda vários anos sem uma companhia italiana de ópera ${ }^{548}$.

Note-se, pois, mais uma vez, que a ação política do governo de Araújo Lima, favorecendo o decoro imperial e procurando colocar o Imperador em evidência, foi mais baseada no improviso de ações propagandistas do que em efetivas mudanças materiais. Deveras dependente do Legislativo, sobretudo no que diz respeito ao Orçamento, não havia muito o que o Executivo pudesse fazer, nem mesmo em relação ao luxo dos já decadentes palácios ${ }^{549}$.

p. 109).

547 JORNAL DOS DEBATES POLÍTICOS E LITERÁRIOS, 28/10/1837.

${ }^{548}$ A ligeira melhora do nível dos espetáculos do Teatro Constitucional Fluminense - novamente renomeado São Pedro de Alcântara, em junho de 1838 —, graças, provavelmente, às loterias, é constatada em coluna do Jornal do comércio de outubro desse ano: "O ano que está a findar-se, foi o menos desfavorável à existência desse teatro. Desde 1831 ele tinha decaído em uma espécie de abandono; a atenção pública estava muito absorvida no espetáculo dos acontecimentos políticos para entregar-se aos prazeres dramáticos. Por outro lado os atores desalentados negligenciavam a arte; as representações estiveram, por muito tempo, sem interesse algum, já pela natureza das peças, já pela falta de atores, e sobretudo pela carência de subsídios..." (JORNAL DO COMÉRCIO, 30/10/1838).

549 Prova de que o Governo de Araújo Lima teve sempre as mãos atadas em relação a esse assunto é encontrada no relatório apresentado pelo Ministério do Império a 14 de maio de 1840, poucos meses, portanto, de ser declarado maior o Imperador. Ali se tentava justificar à Assembléia - diante de uma situação financeira pouco favorável - o aumento de quarenta contos de réis na dotação imperial pedido pelo Ministro da Fazenda uma semana antes, a 8 de maio (PROPOSTA e relatório apresentados à Assembléia Geral Legislativa na Sessão Ordinária de 1840, pelo ministro e secretário de estado dos Negócios da Fazenda Manuel Alves Branco. Rio de Janeiro: Na Tipografia Nacional, 1840, p. 3). Assim se expressava Francisco Ramiro de Assis Coelho, então Ministro interino do Império: "O Governo tributando à Augusta Família, que a Providência se dignou de colocar à frente dos destinos do Brasil, o mais profundo acatamento, e respeito; desejando que em torno Dela tudo respire o decoro, e mesmo a magnificência correspondente à Sua Alta Hierarquia; julga do seu rigoroso dever oferecer à vossa consideração a necessidade de votardes com urgência uma consignação suficiente para as obras, e reparos dos Paços Imperiais. Quem tem viajado, e visto a residência dos Monarcas estrangeiros, ainda entre as Nações menos poderosas, e menos favorecidas em elementos de riqueza, não pode deixar de ter um sentimento pungente, quando, aportando à Capital do Império do Brasil, lança os olhos aos edifícios, que servem de residência ao seu Monarca, e às Augustas Princesas, que com Ele constituem a garantia mais firme da nossa união, da nossa paz, e da nossa futura prosperidade; entretanto um desses mesmos edifícios acha-se em estado 
Em princípios de 1838, a chegada, ao Rio de Janeiro, do vaso de guerra Hercule, trazendo a bordo o terceiro filho do Rei francês Luís Felipe, Francisco Ferdinando d'Orléans, iria demonstrar o quanto o Palácio ainda carecia de luxo, e mesmo, de um verdadeiro monarca, que não um préadolescente educado por mestres medíocres ${ }^{550}$. Eis, aqui, retratando esse momento histórico, algumas observações que o Príncipe de Joinville realizou dos vários encontros que teve com a família imperial. São páginas de puro escárnio, mas que não devem fugir muito à realidade dos fatos ${ }^{551}$.

Primeiramente, além do desdém à arquitetura de São Cristóvão, notemos como a pouca idade do Imperador e a sua inexpressividade ainda ocasionavam grandes embaraços, praticamente os mesmos relatados por Graham Eden Hamond, referentes à visita do Príncipe de Orange ao Rio de Janeiro, pouco mais de um ano antes:

... partimos para São Cristóvão a galope. (...) Passamos, então, por um gradil e subindo uma avenida curva chegamos ao pátio de um castelo, sem muita aparência, ao pé de uma escadaria como a de Fontainebleau mas mil vezes menor. Fui lá recebido por uma nuvem de

deplorável de decadência, o outro esta ainda por concluir. O Paço da Cidade ameaça em alguns dos repartimentos da sua frente voltada ao mar tão iminente ruína, que se julgou de absoluta necessidade transferir-se para outro lugar a sala dos Cortejos: no Paço de S. Cristóvão ainda não está concluído o segundo torreão, e as obras foram suspensas por falta de meios para a sua continuação. Deixando de chamar por agora as vossas vistas sobre a mobília, e os ornatos, que decoram o interior daqueles Paços, e que, além de estarem muito distantes do gosto, que entre todas as Nações civilizadas se encontra nas habitações dos Príncipes, acham-se em estado de não deverem continuar a servir, eu as concentro unicamente naquele primeiro objeto, em atenção às pouco favoráveis circunstâncias, em que nos encontramos pelos esforços, que tem sido necessário pôr em pratica para restabelecer a ordem nas Províncias, em que homens ambiciosos, e perdidos, a tem subvertido; o Governo espera que o torneis na devida consideração" (RELATÓRIO apresentado à Assembléia Geral Legislativa na Sessão Ordinária de 1840, pelo Ministro e Secretário de Estado dos Negócios da Justiça, e interinamente do Império Francisco Ramiro de Assis Coelho. Rio de Janeiro: Na Tipografia Nacional, 1840, p. 3-4).

550 Toda a ridicularização que se segue, de Joinville, corrobora a tese, defendida por Alberto Rangel em seu livro A educação do Príncipe, de que os mestres de Dom Pedro II, incluindo-se o de dança, Lourenço Lacombe, e o de música, Fortunato Mazziotti, eram todos verdadeiras mediocridades (Cf. RANGEL, Alberto. Op. cit., 1945).

${ }^{551}$ Note-se que muitos dos acontecimentos narrados pelo Príncipe francês também o foram, de forma quase idêntica, pelo Almirante Hamond (Cf. HAMOND, Graham Eden. Op. cit., p. 179-180) 
camareiros, subi entre uma ala de alabardeiros, atravessei inúmeros apartamentos cheios de ministros etc. etc. O Regente, Marquês de Lima, veio também ao meu encontro. $\mathrm{Vi}$, enfim, um garotinho, da altura de minha coxa, rígido, teso, hirto; era Sua Majestade. Fiz-lhe uma profunda reverência, que ele me devolveu, e Ihe dirigi meu cumprimento de chegada: ele não me disse nada. Eu tinha preparado minha mão para o caso em que houvesse um aperto de mãos, o que houve, com efeito, mas ele segurou minha mão e nós entramos dando-nos as mãos direitas e meu sabre, que eu não podia segurar, batendo-Ihe nas pernas. Sentamo-nos e ele, sempre sem dizer nada, se pôs a contemplarme; por Deus que aquilo não me agradava; eu construía frases para estabelecer uma conversação e isso não ia adiante. O Regente, vendo o embaraço geral, quis livrar-nos da situação e se pôs a falar comigo. Mas foi uma desgraça porque ele era surdo como uma porta e eu também e assim fizemos completas cacofonias $^{552}$.

Posteriormente, referindo-se a um jantar, também realizado em São Cristóvão, Joinville ressalta a falta, em geral, de modos dos Ministros, testemunha a audição de uma música "desafinada", executada por escravos,

552 Tradução nossa de: “... nous sommes partis pour St. Christophe au galop (...) Enfin nous passons une grille et montant une avenue tournante nous arrivons dans la cour d'un château d'une petite apparence au pied d'un escalier comme celui de Fontainebleau, mais mille fois plus petit. Là je suis reçu par une nuée de chambellans, je monte entre une haie de hallebardiers je traverse plusieurs appartements remplis de ministres etc. etc. Le Régent Marquis de Lima vient aussi au devant de moi. Enfin j'aperçois un petit mirloret haut comme ma jambe, raide, pincé, patarafé, c'est Sa Majesté. Je lui fais un profond salut qu'il me rend, et je lui tourne mon compliment d'arrivée; il ne me répond rien. J'avais préparé ma main pour le cas où il y aurait poignée de main, ce qui a eu lieu en effet, mais il a gardé ma main et nous sommes entrés en nous donnant la main droite et mon sabre que je ne pouvais pas tenir lui battant dans les jambes. Nous nous sommes assis et lui, toujours sans rien dire, s'est mis à me contempler; ma foi cela ne m'amusait pas, je faisais des phrases pour nouer la conversation et cela ne réussissait pas. Le Régent voyant l'embarras général a voulu nous en tirer, et s'est mis à me parler, mais il y avait un malheur, c'est qu'il est sourd comme un pot et moi aussi, aussi nous avons fait des cacophonies complètes" (Apud DIÁRIO do Príncipe de Joinville. Anuário do Museu Imperial. Notas de Lourenço Luís Lacombe. Rio de Janeiro, v. 11, p. 182-183, 1950). Ressalve-se, assim como também notou Lacombe, que o Príncipe faz uma pequena confusão, chamando o Regente, Pedro de Araújo Lima, de "Marquês" (De fato o seria, mas apenas em 1854!). Provavelmente o erro de Joinville está relacionado ao fato do Tutor de Dom Pedro II ser, à época, o Marquês de 
e conclui suas observações do dia destacando a falta de meios, digna de "pena", da imperial família:

Eu estava entre o Imperador e o Ministro dos Negócios Estrangeiros que é, de longe, o que há de melhor aqui pois que ele foi estudante de medicina em Paris. (...) havia uma música executada por negros escravos do Imperador. Não se faz idéia do que ela é. O ministro, meu vizinho, nela encontrava algo de oriental, devia ser a desafinação (...) Eu me retirei cheio de pena dessas pobres crianças abandonadas às quais se dá apenas o que é necessário para viver... ${ }^{53}$.

A mais preciosa descrição de Joinville acerca do que viu em São Cristóvão, se refere, no entanto, a um baile, ali realizado em sua honra. É uma verdadeira pilhéria:

Á noite fui a um jantar de cerimônia em São Cristóvão. (...) Quando já havia chegado bastante gente, o Imperador tomou suas duas irmãs pela mão, se sentaram ao piano e começaram uma sonata a seis mãos; 0 Imperador tocava com admirável aplicação mas o professor de piano, velho apoplético com uniforme de gala e condecoração de cavaleiro de não sei quê, tendo virado duas páginas em lugar de uma, provocou uma cacofonia completa. Foi muito chato. Houve, em seguida, uma segunda sonata, tocada pela Princesa Januária e depois começou-se a dançar. $O$ Imperador tomou a mais velha e eu a caçula e nos colocamos no meio da sala. Pensei que viria mais gente mas nos deixaram sós, os quatro, e foi necessário dançar. Eu tinha uma

Itanhaém.

Tradução nossa de: "J'étais entre l'Empereur et le ministre des affaires étrangères, qui est de beaucoup ce qu'il y a de mieux ici, car il a été étudiant en Médecine à Paris. (...) il y avait une musique composée de nègres esclaves de l'Empereur. On ne se fait pas d'idée de ce que c'est; le ministre, mon voisin lui trouvait quelque chose d'oriental, se devait être la discordance (...) Je me suis bientôt retiré plein de pitié pour ces pauvres enfants abandonnés à qui on donne tout juste ce qu'il faut pour vivre..." (Idem, p. 185-186) 
vontade incontrolável de rir que, a custo, conseguia controlar pois o Imperador, sem luvas e com um grande lenço flutuando na mão, executava passos tão extraordinários que, verdadeiramente, era para cair na gargalhada 554

Em suma, dadas as circunstâncias, não se poderia esperar outra opinião de alguém plenamente acostumado à pompa e à etiqueta de uma das maiores potências econômicas e culturais da época, a França. Felizmente, para a alegria geral do Governo, as galhofas do Príncipe não caíram na boca do povo e, para a opinião pública, valeu a descrição encomiástica do Jornal do comércio, o que, em última análise, não passou de mais uma propaganda em benefício do ideal monárquico de Araújo Lima:

Às 8 horas começou o baile na sala grande de Flora que estava magnífica e elegantemente ornada. (...) Sua Alteza Real dançou com ambas as Princesas. Compunha-se a reunião de duzentas a trezentas pessoas: as senhoras apresentaram-se com muito luxo e os homens todos em uniforme ou em trajo de corte. (...) Durou o baile até as duas horas ${ }^{555}$.

Paralelamente à ação de elevar o jovem monarca e suas irmã mais velha e herdeira, Dona Januária ${ }^{556}$, ao primeiro plano social, Araújo Lima mostrou-se, também, desde então, profundamente solícito em assumir, numa corte sedenta por aparências e ostentações, o lugar social para o qual o

554 Tradução nossa de: “Le soir je suis allé dîner en grande cérémonie à St. Christophe (...) Quand il y a eu assez de monde d'arrivé l'Empereur a pris ses deux soeurs par la main, ils se sont assis au piano, et ont commencé une sonate à six mains; l'Empereur y mettait une applications étonnante, mais le maître de piano, vieillard apoplectique en grand uniforme et cordon de commandeur de je ne sais quoi ayant tourné deux feuilles au lieu d'une, il y a eu une cacophonie complète. C'était assommant. II y a eu ensuite une seconde sonate pour la Princesse Januaria, puis on a été danser. L'Empereur a pris l'aînée moi la cadette et nous sommes allés nous placer au milieu de la salle, je croyais qu'il allait venir plus de monde, mais on nous a laissés tous quatre seuls et il a fallu danser, j'avais une envie de rire inextinguible que je pouvais à peine contenir car l'Empereur sans gants et un grand mouchoir flottant à la main faisait des pas si extraordinaires que vraiment c'était à en pouffer..." (Idem, p. 189).

555 JORNAL DO COMÉRCIO, 11/01/1838. 
Senador Francisco de Paula Sousa achou que serviria: o de "rei constitucional" ${ }^{557}$. Sua presença marcante nos eventos da sociedade - como nos atesta o diário do Almirante inglês Eden Hamond - decerto o auxiliou a granjear parte da estima geral constatada no resultado do pleito de 22 de abril de 1838 que o efetivou na Regência com larga vantagem sobre seus concorrentes ${ }^{558}$ :

[27 de setembro de 1837] Fui ao baile do Catete, que estava bem concorrido e com três dos novos ministros presentes (...) Quando me retirava, chegou o Regente que, com os outros três, mostrava-se extremamente popular ${ }^{559}$.

Araújo Lima, portanto, não se recolhia deliberadamente "à penumbra" permitindo que o "Príncipe fizesse esquecida a sua própria posição", como afirmou Paulo Pereira de Castro na História geral da civilização brasileira ${ }^{560}$, baseado, certamente, em um hesitante depoimento histórico de Daniel Kidder. A dúvida expressa pelo presbítero norte-americano - tendo ele vivido no Rio de Janeiro na época do governo do futuro Marquês de Olinda nos parece, sob a ótica histórico-social, deslindar-se, justamente, no sentido contrário, ou seja, no de que a política de elevação da imagem do imperador visava ao fortalecimento da Regência como instituição e não ao seu obscurecimento. O fato é que, como escreveu Kidder,

Quer o Regente esperasse ou não tal resultado, tornou-se logo óbvio, que a distinção de seu posto estava completamente eclipsada pelas

\footnotetext{
${ }^{556}$ Vide nota 140 desta parte.

557 Segundo Victor de Azevedo essas teriam sido as palavras de Feijó, ao comentar a sua renúncia em favor de Araújo Lima: "- Chamei os amigos, pedindo-lhes conselho. E como não consultava se devia abdicar, porque isto estava por mim resolvido, mas sim a quem devia entregar o governo, e Paula Sousa disse na última conferência que o Pedro de Araújo podia ser um bom rei constitucional, a ele entreguei a regência" (AZEVEDO, Victor de. Feijó: vida, paixão e morte de um chimango. São Paulo: Editora Anchieta limitada, 1942, p. 207).

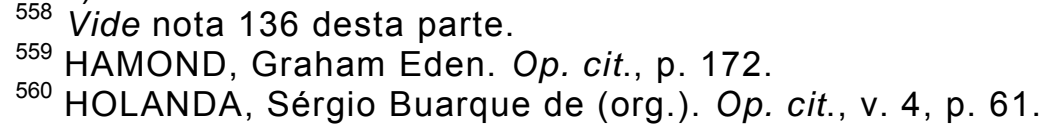


novas honras com as quais o jovem soberano foi lisonjeado ${ }^{561}$.

E foi essa ousada e bem-sucedida ação de libertar das amarras de São Cristóvão "a esperança do povo brasileiro", "o alívio de seus males", aliada à descrença geral com o Governo - sobretudo em relação à continuidade das revoltas provinciais no Sul e no Norte $e^{562}$ - e ao oportunismo daqueles que haviam perdido, tanto as rédeas da Administração, em 1837, como a disputa eleitoral, no ano seguinte, que levariam Araújo Lima a perder a metade do seu mandato regencial. A 23 de julho de 1840, após grave pressão popular, devidamente conduzida pelo "Clube da Maioridade", a Assembléia Geral, "pisando" na Carta de $\mathrm{Lei}^{563}$, dava por findo o interregno, curiosamente da mesma forma inconstitucional com que o iniciara, no Sete de Abril $^{564}$.

Para a atividade musical carioca, os resultados desse Golpe de Estado se refletiram imediatamente, na restauração, mesmo que ainda esporádica e não oficial, das atividades da orquestra da Capela Imperial, interrompida desde junho de 1831. Após uma lacuna de mais de dois anos, a documentação manuscrita dessa repartição, tombada no Arquivo Nacional ${ }^{565}$, nos evidencia que, três dias depois de aclamada a maioridade de Dom Pedro

561 Tradução nossa de: "Whether the regent himself expected such a result or not, it soon became apparent that the dignity of his office was quite eclipsed by the new honors with which the young sovereign was complimented" (KIDDER, Daniel Parish. Op. cit., v. 1, p. 64-65).

562 Embora tenha pacificado a Bahia, Araújo Lima não conseguiu debelar a Farroupilha no Sul e a Cabanagem no Pará. Como se não bastasse, em fins de 1838, estourava nova revolta, agora no Maranhão: a Balaiada.

563 Como bem afirmou Kidder, a respeito da Maioridade, "A revolution has indeed transpired; the constitution has been trampled under foot; but it is a popular revolution, in accordance with the inclination of the people, and therefore it is a glorious event" (KIDDER, Daniel Parish. Op. cit., v. 2, p. 367).

${ }^{564}$ Lembremos que a eleição e a posse da Regência provisória a 7 de abril de 1831 também foi inconstitucional na medida em que desrespeitava o artigo 124 da Carta de Lei. Segundo tal determinação imperativa, enquanto a Regência permanente não se elegesse, governaria o Império uma "Regência provisional composta dos Ministros de Estado do Império, e da Justiça; e dos dois Conselheiros de Estado mais antigos em exercício" (COLEÇÃO das Leis do Império do Brasil de 1824. Constituição Política do Império do Brasil. Rio de Janeiro, Imprensa Nacional, 1886, parte 1, p. 25). Foi, no entanto, justamente a presença de alguns destes personagens no Governo, o "dínamo" da Revolução.

${ }^{565}$ Vide nota 152 desta parte. 
II, ela já contratava, à considerável despesa de 357\$000 - para um Te Deum comemorativo a ser realizado naquele dia -, 28 instrumentistas, entre os quais alguns dos mais competentes músicos do Rio de Janeiro, como Manoel Joaquim Correia dos Santos, Gabriel Fernandes da Trindade e Januário da Silva Arvelos ${ }^{566}$. Tal iniciativa se repetiria a 7 de setembro, com a arregimentação de vinte instrumentistas ${ }^{567}$; a 19 de outubro, dia de São Pedro de Alcântara, com 22 "professores"568; e, finalmente, a 2 de dezembro, natalício do Imperador, quando se ouviu, na Capela, uma orquestra composta de trinta instrumentistas e ao custo de $382 \$ 500^{569}$. Segundo relatos do próprio Dom Pedro II, em seu Diário, teria sido ali interpretado um Te Deum de autoria de Dom Pedro ${ }^{570}$.

Preocupado com a nova situação do Império e as necessidades dela decorrentes, o Inspetor Fabriqueiro da Capela Imperial, Monsenhor Fidalgo, não tardou uma semana sequer, após o Te Deum de 26 de julho, em enviar ao novo Ministro da Justiça e futuro Visconde de Abaeté, Antônio Paulino Limpo de Abreu - que já ocupara esta pasta durante a regência de Feijó —, ofício, pedindo-lhe providências em relação ao serviço musical da Capela. Além de solicitar mais alguns elementos para o coro, que não deixara de funcionar durante todo o período regencial, opinava o padre:

Agora é ocasião de tornarem-se a chamar os
músicos instrumentistas que foram despedidos
da Capela logo depois do Sete de Abril, pois
que V. Ex. sabe que S. M. o Imperador é muito
apaixonado de música e quer as suas funções
com todo o esplendor. Continuando-se alguma
vez a chamar músicos de fora instrumentistas,
vem certamente a fazer maior despesa do que
se eles forem admitidos, porque servem a todas

${ }^{566}$ ARQUIVO NACIONAL, Rio de Janeiro. Fundo Casa Real e Imperial, cx. 13, pc. 2, doc. 1, fl. 35 .

${ }_{567}$ Idem, fl. 36.
568 Idem, fl. 33.
569 Idem, fl. 34.

570 "Chegando ao Paço, descansei um pouco, depois fui para o Te Deum, grandezinho, mas suportável, por ser composto por meu pai..." (Apud VIANA, Helio. Op. cit., p. 116). Note-se aí o pouco interesse de Dom Pedro II pela arte dos sons. 
as funções que forem necessárias, quer ordinárias, quer extraordinárias ${ }^{571}$.

Todavia, Dom Pedro II não era, propriamente, "um apaixonado de música" ${ }^{572}$. Se havia qualquer vínculo especial entre o jovem monarca e arte dos sons voltada aos ritos sagrados da Religião Católica, este estava mais para o lado da carolice do que para o da melomania; algo, de certa forma, mais semelhante à relação que Dom João VI tinha com a música sacra do que à paixão inveterada que Dom Pedro I sentia pela ciência das combinações sonoras. Além disso, questões orçamentárias e o recolhimento do novo monarca durante os primeiros anos do segundo reinado - fatores dos quais trataremos, com mais precisão, em páginas seguintes — iriam também, certamente, motivar o Ministério da Justiça a não investir cabalmente no serviço musical da Capela Imperial e procrastinar, por cerca de três anos, o aceite da sugestão de Monsenhor Fidalgo.

De pronto, essa repartição continuou a contratar os instrumentistas por evento, como se constata mediante documentação manuscrita, inédita e tombada no Arquivo Nacional do Rio de Janeiro. Segundo ela, em 1841, ano marcado pela coroação de Dom Pedro II, houve contratações nos dias: 25 de março, dia do juramento da Constituição (20 instrumentistas); sábado de Aleluia (19); domingo de Páscoa (19); segunda-feira de Páscoa (19); 7 de setembro, dia da Independência (19); 19 de outubro, nome do Imperador (19); $1^{\circ}$ de dezembro, Coroação de Dom Pedro I (20); e 2 de dezembro, aniversário do Imperador (20). Já, em 1842, encontramos documentos que comprovam a contratação de instrumentistas nos dias: 6 de janeiro, festividade dos Reis (18); 9 de janeiro, dia do "Fico" (19); 25 de março (19); 7 de abril, elevação de Dom Pedro II ao Trono (19); 18 de julho, Coroação (22); 23 de julho, Maioridade (20); 7 de setembro (19); $1^{\circ}$ de dezembro (20); e 2 de dezembro $(14)^{573}$. 1, doc. 88 .

${ }^{571}$ ARQUIVO NACIONAL, Rio de Janeiro. Fundo Casa Real e Imperial, cx. 13, pc.

${ }^{572}$ Vide nota 177 desta parte.

573 Toda essa documentação se acha guardada na caixa 13, pacote 2 do Fundo 
A documentação é, no entanto, sem dúvida, parcial, uma vez que o calendário de festividades de 1841 não bate, em grande parte, com o de 1842. Não há coerência, por exemplo, em ter-se comemorado, com suntuosidade, o domingo de Páscoa, apenas em 1841, e o Sete de Abril, apenas em 1842. Outro manuscrito guardado nas enferrujadas caixas do Arquivo Nacional, datado desse último ano, também nos dá conta de que, durante $\mathrm{o}$ ano financeiro de 1842-1843, a Capela teria, dos 78:711\$000 orçados $^{574}$, cinco contos de réis para as contratações esporádicas de instrumentistas ${ }^{575}$. Dado que esses ajustes envolviam, em média, vinte músicos a $12 \$ 750$ cada, cinco contos de réis seriam suficientes para vinte deles, em um ano; mais do que o dobro, portanto, da relação de contratações anteriormente apresentada, referente ao ano de 1842.

Contando, pois, com esse orçamento anual de cinco contos de réis para contratar músicos extras, Monsenhor Fidalgo enviou a 31 de janeiro de 1843 ao recém empossado Ministro da Justiça, Honório Hermeto Carneiro Leão, um plano de reestruturação da orquestra da Capela, argumentando que, com a mesma quantia já orçada, poder-se-ia contratar um efetivo musical de 24 instrumentistas ${ }^{576}$. Pouco mais de um mês antes, os mestresde-capela Francisco Manuel da Silva e Fortunato Mazziotti já haviam enviado ao Ministério outro plano similar — de 6:240\$000 para 26 instrumentistas não aceito. Parece-nos, portanto, que a diplomacia insistente do velho Inspetor, convencendo os músicos a desfazerem-se de duas vagas pretendidas e a baixarem seus ordenados até que se chegasse à quantia redonda de cinco contos de réis é que fez a diferença na delicada negociação com o Ministério da Justiça, buscando-se a reincorporação definitiva de todos

\footnotetext{
Casa Real e Imperial do Arquivo Nacional do Rio de Janeiro.

${ }^{574}$ COLEÇÃO das Leis do Império do Brasil de 1841. Rio de Janeiro: Tipografia nacional, 1842, parte 1, p. 75.

575 "Pelo orçamento apresentado pelo Monsenhor Inspetor, é calculada em 5:000\$000 a quantia necessária para pagamento dos professores convidados para a execução desses dias..." (ARQUIVO NACIONAL, Rio de Janeiro. Fundo Casa Real e Imperial, cx. 13, pc. 2, doc. 53) 2, doc. 57.

${ }^{576}$ ARQUIVO NACIONAL, Rio de Janeiro. Fundo Casa Real e Imperial, cx. 13, pc.
} 
esses músicos na folha da Capela ${ }^{577}$. Esta, já contando com quatro "instrumentistas de baixo", passaria então a reunir 28 instrumentistas além dos vinte cantores, dois organistas e dois mestres de capela. Em setembro de 1843, com a chegada da Imperatriz, Dona Teresa Cristina, o serviço musical da Capela ganharia ainda um integrante a mais, o baixo napolitano Arcângelo Fiorito ${ }^{578}$. Assim, o conjunto ficaria, no segundo quartel de 18431844, com 53 integrantes, no total: Fortunato Mazziotti e Francisco Manuel da Silva (mestres-de-capela); João Jacques e Carlos de Castro Lobo (organistas); João dos Reis Pereira, José Maria Dias, João Mazziotti, Antônio Pedro Gonçalves, Geraldo José Pereira, Carlos Maziotti, Francisco da Luz Pinto, Firmino Reis Silva, José Maria da Silva Rodrigues, Lúcio Antônio Fluminense, João Rodrigues de Araújo, Alexandre José Leite, Feliciano Joaquim, Joaquim José de Mendanha, Bento Fernandes das Mercês, Luís Gabriel Ferreira Lemos, Dionísio Veiga, Gabriel Fernandes da Trindade, Manuel Teixeira da Costa, Francisco Pamplona de Ave e Maria e Archangelo Fiorito (cantores); Alexandre Baret, Francisco da Mota, Lino José Nunes, José Jacinto Fernandes da Trindade, Manuel Joaquim Correia dos Santos, João Antônio da Mata, José Joaquim dos Reis, Heliodoro Norberto Florival,

${ }^{577}$ Note-se que outros autores, como Ayres de Andrade e André Cardoso, os quais também pesquisaram os documentos da Capela, não mencionam esse plano e apontam o anterior, de Francisco Manuel da Silva e Fortunato Mazziotti como aquele que teria dado margem à reestruturação da orquestra (Cf. ANDRADE, Ayres de. Op. cit., v. 1, p. 215-217; e CARDOSO, André. Op. cit., p. 118-120). De qualquer forma, quaisquer que tenham sido os principais agentes dessa negociação, o que, sem dúvida, pesou efetivamente na reestruturação do serviço musical da Capela foi a chegada de Dona Teresa Cristina e a consumação do matrimonio imperial. O próprio e já referido projeto de Mazziotti e Silva demonstra tal fato na medida em que no memorial do projeto, surge o seguinte argumento em defesa da reestruturação da orquestra: “... aproximando-se o feliz consórcio de S. M. I. necessariamente deve aumentar o número de festividades solenes, e talvez que os 5:000\$000 orçados sejam insuficientes para ocorrer a estas despesas extraordinárias: é por isso o engajamento de reconhecida utilidade e economia" (ARQUIVO NACIONAL, Rio de Janeiro. Fundo Casa Real e Imperial, cx. 13, pc. 2, doc. 53).

${ }_{578}$ Não citado por Fétis em sua Biographie universelle des musiciens Arcangelo Fiorito esteve, segundo libretos comemorativos italianos do final da década de 1830, cantando à essa época em Nápoles, tanto no Teatro di San Carlo, como em eventos sacros à serviço da realeza local (Cf. TARANTINI, Leopoldo. Antonio Foscarini: tragedia lirica in due atti da rappresentarsi nel Reale Teatro S. Carlo nell'inverno del 1839. Napoli: dalla Tipografia Flautina, 1839. [obra localizada na Biblioteca del Conservatorio di musica S. Pietro a Majella, em Nápoles, sob o código "Rari 10.6.6/10"]; SARMIENTO, Giulio. Te Deum espressamente composto $p$. la Cappella di Capo di Monte nell'occasione del felice parto di S. Al. La Regina. Napoli, 1839 [Idem, "Casa Reale - 77.4.2 (25-61)"]). 
João Vítor Ribas, José Martins Ferreira, José Francisco Martins, Francisco Bosch, Manuel Alves Carneiro, Timóteo Eleutério da Fonseca, Severiano Joaquim de Castro, Bernardo Antônio da Silva, João Bartolomeu Klier, João de Carvalho da Cunha e Silva, Cláudio Antunes Benedito, Luís José da Cunha, Carlos Justo Cavalier, Mariano José Nunes, Antônio Xavier da Cruz Lima, Francisco Duarte Bracarense, Desidério Dorison, Manuel Francisco Tavares, Antônio Diogo Gomes da Silva e Francisco Manuel Chaves (instrumentistas) $)^{579}$.

Diferentemente, porém, dos sucessos em pouco tempo obtidos pela música religiosa, a atividade musical no principal palco da corte -0 do Teatro de São Pedro de Alcântara - não surtiu melhoras imediatas com a ascensão de Dom Pedro II ao Poder. Embora a presença da família imperial nessa casa de espetáculos tenha aumentado sensivelmente, a partir de meados de 1840 , superando as tradicionais e obrigatórias idas nos dias de grande gala, outro palco, o do São Januário, se mostrou, de início, mais atraente ao jovem Imperador, oferecendo-lhe peças representadas em francês. Notando, já em dezembro de 1840, a preferência de Dom Pedro II pelos espetáculos da Companhia Dramática Francesa do São Januário, o Jornal do comércio profetizou o bom êxito do negócio, pela mesma razão que o São Pedro de Alcântara fora próspero nos tempos de Dom Pedro I:

... a augusta presença da família imperial a quase todas as representações do Teatro de $S$. Januário é penhor de prosperidade, porque um dia ou outro lembrar-se-ão os fidalgos e mais pessoas que tem a fortuna de aproximarem-se do monarca brasileiro, que S. M. I. deve desejar encontrar no teatro rostos conhecidos, e ver-se ali rodeado, como no paço, de todos aqueles que pertencem à sua casa, ou que tem a honra de ser admitidos a fazerem-Ihe a corte ${ }^{580}$.

\footnotetext{
2, doc. 77 .

580 JORNAL DO COMÉRCIO, 27/12/1840. Porém, como veremos melhor nas páginas seguintes, o caráter anti-social de Dom Pedro II acabou não favorecendo nem um pouco o São Januário, quanto mais o São Pedro. Ao não fazer a mínima questão de ser
}

${ }^{579}$ ARQUIVO NACIONAL, Rio de Janeiro. Fundo Casa Real e Imperial, cx. 13, pc. 
As aparições de Dom Pedro II no Teatro de São Januário não tinham, no entanto, um caráter social. Se assim o fosse, preferiria o monarca se exibir no São Pedro, que além de comportar maior público, havia sido recentemente reformado, era mais luxuoso, menos quente, enfim, possuía as melhores acomodações. A predileção do Imperador pelos espetáculos do São Januário se deu, muito provavelmente, pela oportunidade que esse teatro the oferecia de aperfeiçoar os seus conhecimentos da língua francesa.

A verdade é que, mesmo investido e coroado, Dom Pedro II não deixou de ser o mesmo estudante aplicado dos anos anteriores, o véritable mannequin, mudo, inexpressivo, tímido e fervorosamente carola, moldado por Frei Pedro de Santa Mariana. Relatos de estrangeiros referentes a esse início de segundo reinado são unânimes em constatar o caráter sério e anti-social do Imperador. Continuava, pois, ele, apaixonado por seus livros e avesso à mundanalidade das festas ${ }^{581}$. O sobrinho de Frederico III da Prússia, Príncipe

cortejado, o jovem Imperador acabou também ignorado pela corte nos seus primeiros anos de reinado, como nos testemunhou o jornal O Brasil, pouco antes da coroação: "Nada há que mais nos aflija de que ver o pouco interesse que tomam a nossa corte, os nossos cidadãos mais opulentos, e até mesmo o corpo diplomático aqui residente, pelo teatro $\mathrm{S}$. Januário a quem S. M. I. honra constantemente com sua presença e proteção. Embora a companhia multiplique esforços para dar sempre variados, sempre ótimos divertimentos, embora o zelo incansável de seu diretor ainda ultimamente conseguisse, sem que padecesse o crédito de seu estabelecimento, vencer uma crise, a que poucos esperam que não sucumbisse, a sala está deserta, e S. M. I. levando os olhos em redor de si não acha decerto nos camarotes, nem mesmo da ordem nobre, uma só cara conhecida. Já em outra ocasião escrevemos a este respeito, e sentimos que ainda hoje sejam justas nossas censuras. Parece que nossos comendadores, titulares, camaristas, moços da câmara, que a nossa aristocracia de títulos ou de empregos, bem como os nossos deputados, senadores, altos funcionários públicos, não conhecem que é quase um dever deles aproveitar todas as ocasiões em que S. M. I. está visível, para o rodearem com o aparato e brilho que Ihe são devidos. Parece que não sabem que é dever seu apreciar e proteger as belas-artes, e especialmente quando, se o fizerem, só terão a honra de concorrer para fazerem efetiva a proteção do monarca, e para sustentarem no país um divertimento que tanto é por S. M. I. apreciado. Outro tanto não acontecia antigamente..." (O BRASIL, 19/06/1841).

${ }^{581}$ Note-se que a freqüência mais cotidiana de bailes e banquetes em São Cristóvão - uma das principais inovações sociais ocorridas a partir da Maioridade, em relação ao período regencial -, se limitavam, ainda, neste princípio de segundo reinado, apenas às galas, como os aniversários dos membros da família imperial e das datas nacionais. É, pelo menos o que se pode presumir a partir das notícias publicadas no Jornal do comércio entre os anos de 1840 e 1843. O relato do Conde de Suzannet referente a sua passagem pelo Rio, em 1842, embora um tanto irônico, corrobora a idéia de que essa esporadicidade era ocasionada pela falta de interesse de Dom Pedro II pela vida social: 
Guilherme Adalberto (1811-1873), que esteve no Rio em setembro de 1842, escreveu, por exemplo, em seu diário de viagem, que "além de se dedicar com todas as suas energias aos negócios do Estado", Dom Pedro II "ocupava o restante de seu tempo disponível particularmente com a leitura"582.

O mesmo hábito de ler em qualquer situação é narrado por outra visitante da corte brasileira, Victorine Emilie de Sainte-Aulaire, esposa do Barão de Langsdorff, diplomata francês que tratou do casamento do Príncipe de Joinville com a Princesa Dona Francisca, e que esteve no Rio de Janeiro praticamente à mesma época em que o Príncipe Adalberto da Prússia. O relato da Baronesa se refere a um baile realizado pelo comitê diplomático francês em homenagem à família Imperial:

Em geral, após a ceia, o baile terminava em São Cristóvão, mas as princesas disseram-me muito amavelmente: - Esta noite, dançaremos ainda após a ceia; o meu irmão nos disse que, se ele se aborrecesse demais, iria ler em um quarto...583

\footnotetext{
"L'Empereur (...) évite le monde, et ne donne des fêtes que dans de grandes solennités; les courtisans imitent son exemple, et la cour d'un empereur qui n'a pas vingt ans, mais dont les goûts, les habitudes sont ceux d'un vieillard, a l'incontestable supériorité d'être la plus triste de l'univers" (SUZANNET, Comte de. Souvenirs de voyages: Les provinces du Cawcase, l'empire au Brésil. Paris: G. A. Dentu, 1846, p. 211). Essa falta de interesse também pode ser medida pela forma com que a música era executada em São Cristóvão nessa época. Enquanto as partidas particulares, como ainda veremos, chegavam a congregar orquestras inteiras, de quarenta músicos - entre os quais figuravam os mais destacados da cidade -, os salões da Quinta da Boa Vista ainda se limitavam, aparentemente, à banda de escravos do Imperador, composta por menos de quinze elementos. O testemunho a esse respeito é do médico norte-americano Gustavus Horner (1804-1892), que esteve, em 1842, no baile em comemoração ao aniversário de Dona Januária, com a ilustre presença do Príncipe Adalberto, da Prússia: “... a band of thirteen of fourteen black musicians, dressed in suits of red velvet, trimmed and striped with gold lace, began to play a lively waltz at the foot of the hall" (HORNER, Gustavus Richard Brown. Medical topography of Brazil and Uruguay: with incidental remarks. Philadelphia: Lindsay \& Blakiston, 1845, p. 266).

582 "Schon um sechs Uhr Morgens steht der Kaiser auf, um sich mit allen Kräften den Staatsgeschäften zu widmen. In der Zeit, welche inm übrig bleibt, beschäftigt der junge Monarch sich besonders mit Lesen..." (PREUSSEN, Heinrich Wilhelm Adalbert, Prinz von. Aus meinem tagebuche 1842-1843. Berlin: Deckerschen Geh Oberhofbuchdruckerei, 1847, p. 294).

583 LANGSDORFF, Victorine Emilie de Sainte-Aulaire, Baronesa de. Diário da Baronesa E. de Langsdorf: relatando sua viagem ao Brasil por ocasião do casamento de S. A. R. o Príncipe de Joinville, 1842-1843. Tradução de Patrícia Chittoni Ramos e Marco Antõnio Toledo Neder. Florianópolis: Editora Mulheres, 1999, p. 169.
} 
Jules Itier (1802-1877), que esteve de passagem pela corte brasileira em princípios de 1844 não fez também comentário diferente. Após ter tido, em São Cristóvão, um rápido encontro pessoal com o Imperador - cuja "arrogante expressão de dignidade" procurava esconder "uma grande timidez" relação a o que teria ido fazer Dom Pedro II ao deixar tão bruscamente a comitiva francesa, durante a recepção:

Ele provavelmente estava com pressa de retornar aos seus livros no meio dos quais passa a sua vida; as ciências e a literatura são suas mais agradáveis ocupações; com elas ele esquece as preocupações do trono e, quem sabe, o próprio trono... ${ }^{585}$

Em suma, eis, aqui, um perfil quase completo desse jovem monarca, realizado pelo Conde de Suzannet, Monsieur Louis de Chavagnes, a partir das impressões parciais que esse nobre francês também teve do jovem monarca quando de sua estada no Rio de Janeiro, em fins de 1842:

D. Pedro II é de saúde delicada e de aparência
doentia; uma timidez excessiva é a possível
causa da rigidez e do constrangimento que se
notam na atitude do jovem Imperador. O gênero
de vida que ele se impôs seria suficiente para
explicar essa falta de espontaneidade e de
abandono das boas maneiras. De pouca altura e
dotado de uma robustez precoce, Dom Pedro
faz pouco exercício e dificilmente monta a
cavalo. (...) Somos, entretanto, reduzidos a

584 "A peine étions-nous rangés dans le salon de réception, que la porte s'ouvrit à deux battants pour donner passage à un homme jeune, d'une figure régulière, très blond, à l'air sérieux et froid, cherchant à cacher sous une expression de dignité fière une grande timidité; nous étions en face de l'empereur du Brésil" (ITIER, Jules. Journal d'un voyage en Chine en 1843, 1844, 1845, 1846. Paris: Chez Dauvin et Fontaine, 1848, v. 1, p. 65).

${ }^{585}$ Tradução nossa de: "Il avait hâte, probablement, de retourner à ses livres au milieu desquels il passe sa vie; les sciences et la littérature sont ses plus douces occupations; avec elles il oublie les soucis du trône et peut-être le trône lui-même..." (Ibidem, v. 1, p. 65). 
conjeturas em relação ao caráter de Dom Pedro II pois uma apresentação não é suficiente para que nos asseguremos de que sua impassibilidade e a sua aparente simplicidade de maneiras não escondem certa vivacidade de espírito. O Imperador jamais fala; ele dirige às pessoas um olhar fixo e sem expressão; saúda e responde por um sinal de cabeça ou um movimento de mão, e deixamos com uma impressão penosa esse príncipe de vinte anos que parece tão triste e tão infeliz. A gravidade desse jovem não inspira respeito, mas, sim, um sentimento quase vizinho da compaixão ${ }^{586}$.

Apesar da ressalva do autor quanto às convicções mais íntimas de Dom Pedro II, fica claro a partir desse e dos demais depoimentos que não se podia esperar do jovem Imperador a mesma sociabilidade que tinha seu pai, e que muito favorecera o monumental São Pedro de Alcântara a, pelo menos, quitar parte de suas dívidas com a venda de ingressos. Sem preencher constantemente os seus mais de 1.600 lugares, e tendo um alto custo de manutenção — só a iluminação, por dia, custava-Ihe mais de $70 \$ 000^{587}$ —, o grande teatro da Praça da Constituição continuou sem montante para investir na contratação de uma custosa companhia italiana de ópera. Nem mesmo as diversas loterias concedidas a partir de fins de $1837^{588}$ seriam, sozinhas, suficientes para tal empreitada, fato que inclusive levou a Assembléia Geral a

${ }^{586}$ Tradução nossa de: "Don Pedro II est d'une santé délicate et d'une apparence maladive; on attribue à une excessive timidité la raideur et la gêne qu'on remarque dans le maintien du jeune empereur. Le genre de vie qu'il s'est imposé suffirait à expliquer ce défaut d'aisance et d'abandon dans les manières. D'une petite taille et doué d'un précoce embonpoint, don Pedro prend peu d'exercice, et c'est à peine s'il monte à cheval. (...) On est réduit toutefois à des conjectures sur le caractère de don Pedro II, car une présentation à l'empereur n'offre pas l'occasion de s'assurer si son impassibilité, sa bonhomie apparente, cachent une certaine vivacité d'esprit. L'empereur ne parle jamais; il attache sur vous un regard fixe et sans expression; il salue et répond par un signe de tête ou un mouvement de main, et vous quittez avec une impression pénible ce prince de vingt ans, qui paraît si triste et si malheureux. La gravité de ce jeune homme n'inspire pas le respect, mais un sentiment presque voisin de la compassion" (CHAVAGNES, M. L. de. Le Brésil en 1844. Revue des deux mondes. Paris: Au Bureau de la revue des deux mondes, t. 7, p. 88, 1844). Note-se que à época em que Suzannet conheceu Dom Pedro II, ele tinha, na verdade, 17 anos.

${ }_{587}$ Cf. JORNAL DO COMÉRCIO, 16/07/1840.

${ }^{588}$ De acordo com o Jornal do comércio, de 1837 até a Coroação, já haviam sido extraídas nove loterias em benefício do Teatro de São Pedro de Alcântara. 
amenizar, logo em setembro de 1838, a caução, prescrita no Decreto de 30 de novembro de 1837, que obrigava a Sociedade do Teatro de São Pedro a manter, como contrapartida à concessão dos jogos, três companhias: uma dramática, uma de baile e uma de ópera italiana ${ }^{589}$. Como questionou o Jornal do comércio, em março de 1839 - diante da informação de que não se poderia contratar uma companhia italiana "sofrível" por menos de setenta contos de réis e "passagem paga" — , que "rendimentos" teria o Teatro "para poder carregar com esse enormíssimo peso?"590. Sem o interesse do Imperador e o incentivo da sua presença, capazes de reestabelecer, na sociedade carioca, a moda de ir ao Teatro e de protegê-lo com convicção, este espaço permaneceria mesmo, por mais algum tempo, "aos tropeços sem conta" ${ }^{591}$.

Curiosamente, ainda assim foi possível comemorar a coroação de Dom Pedro II com uma improvisada e parcial apresentação de ópera no Teatro de São Pedro de Alcântara. Ali foi encenado, no dia seguinte a esse fausto acontecimento, o primeiro ato de A italiana em Argel, de Rossini, demonstrando que o drama cantado italiano ainda era considerado o suprasumo dos espetáculos teatrais, o tipo de evento mais adequado para uma comemoração de tal magnitude. Contribuiu para essa parcial apresentação operística a chegada, em abril de 1841, de dois cantores de ópera italianos, o barítono Livio Tosini e a contralto Rosa Baldoni ${ }^{592}$. Diante da falta de bons

589 "O Regente Interino, em Nome do Imperador o Senhor Dom Pedro II, Tem Sancionado, e Manda que se execute a Resolução seguinte da Assembléia Geral Legislativa: Art. $1^{\circ}$. A Sociedade do Teatro Constitucional Fluminense fica desonerada da obrigação de prestar a caução determinada no Artigo segundo do Decreto de trinta de novembro de mil oitocentos e trinta e sete, devendo receber o produto das loterias já extraídas, e que se extraírem em virtude do referido Decreto, sem dependência da dita caução..." (COLEÇÃO das Leis do Império do Brasil de 1838. Rio de Janeiro: Tipografia Nacional, 1838, parte 1, p. 34).

590 Idem, 07/03/1839.

591 "Triste sorte é a do malfadado Teatro de S. Pedro! Tudo parece conspirar contra ele e baldar os esforços dos que procuram avivar-lhe a existência. Aos tropeços sem conta, aos embaraços que por toda a parte formigam, acrescem cotidianamente circunstâncias que mais complicam a situação difícil em que se acha o pobre teatro" (JORNAL DO COMÉRCIO, 14/01/1841).

592 Uma única informação sobre Rosa Baldoni Tosini nos foi encontrada a respeito de sua carreira na Itália. Em 1822, estava em Milão cantando o papel de Edoardo em Matilde Shabran, de Rossini, ao lado de artistas de renome, como a célebre soprano Rosa 
cantores líricos na cidade, o Jornal do comércio tratou com grande entusiasmo a estréia do casal:

A julgarmos pelo dueto que devem cantar hoje os novos artistas, somos levados a crer que devem ser cantores de talento. O dueto do Esule di Granata, do grande Meyerbeer, é obra primorosa, mas da maior dificuldade; esperamos que os novos cantores o executarão de uma maneira satisfatória, e que teremos motivo de congratular-nos com os dilettanti que abundam nesta cidade pela nova aquisição do Teatro de S. Pedro ${ }^{593}$.

E imaginou que tal estréia prenunciasse uma nova e tão esperada temporada de óperas:

A aparição do Sr. e da Sra. Tosini desperta nos amantes da música idéias lisonjeiras, e faz entrever a possibilidade da organização de uma companhia italiana. Já temos um soprano, a Sra. Lemos, que tem feito ultimamente muitos progressos; o Sr. José Cândido tem talento para bufo; chegam agora um contralto e um barítono, pouco falta. Eia! mais um esforço, e a empresa do teatro adquirirá um título aos elogios das pessoas de gosto, e terá prestado um grande serviço às artes e ao público desta corte ${ }^{594}$.

O prenúncio, no entanto, não se confirmou, mesmo tendo sido o espetáculo operístico do dia 19 de julho recebido com grande entusiasmo:

A sensação produzida no auditório foi imensa; despertaram-se nos amadores as recordações saudosas da soberba companhia de canto que

Morandi, e sob a direção musical do violinista Alessandro Rolla (1757-1841), professor do Conservatório de Milão e mestre de Paganini (Cf. FERRETTI, Jacopo. Matilde Shabran: Dramma Per Musica. Milano: Pirola Giacomo, 1822 [Localização: Biblioteca nazionale Marciana - Venezia - VE - DRAMM 861.3]). É de se imaginar, no entanto, que, em 1841, Baldoni já estivesse em fim de carreira.

593 JORNAL DO COMÉRCIO, 29/04/1841.

${ }^{594}$ Idem, 29/04/1841. 
outrora fizera as delícias do povo elegante desta capital; o teatro como que achou sua bela voz, e recuperou por um momento a glória de seus belos dias. Se não fora esse costume indesculpável de se não aplaudir o talento em presença de S. M. como se acoroçoar o merecimento fosse delito de desobediência, ou falta de respeito, explosão de palmas teria recompensado os esforços de mais um $\operatorname{artista}^{595}$.

Depois de algumas poucas repetições de $A$ italiana em Argel e mais algumas apresentações - também apenas do primeira ato - da Cenerentola, o casal Tosini, se tinha alguma intenção de permanecer no Rio de Janeiro e participar de uma companhia lírica, não viu conjuntura favorável para isso, pois, em pouco tempo, tomou seu rumo em direção a outros portos. Desta forma, o Teatro de São Pedro de Alcântara adiou por mais um tempo a retomada de sua temporada lírica. O ano teatral de 1842 acabou por privilegiar a reestruturação da companhia de baile, sob a direção de Luís Montani, e as datas mais importantes do Império foram comemoradas com apresentações coreográficas.

Como dissemos, mesmo com o incentivo governamental da concessão de loterias, faltava público, para que os altos investimentos do Teatro de São Pedro em uma companhia de ópera se justificassem ${ }^{596}$. E não se tratava da ausência dos dilettanti — que, como se dizia, "abundavam" —, mas de um público especial, de uma elite, que, não apenas fizesse reluzir os camarotes com suas mulheres empetecadas - atraindo a curiosidade geral - como auxiliasse, mediante incentivos financeiros, o Teatro a investir nos espetáculos.

Pois, enquanto "Sua Majestade" não se mostrasse interessado em

${ }^{595}$ Idem, 21/07/1841.

596 Eis o questionamento do Jornal do comércio, pouco antes da chegada da Imperatriz ao Rio de Janeiro: "Não terminaremos este pequeno tributo ao verdadeiro talento sem levantarmos mais uma vez a voz para reclamar a organização de uma pequena companhia italiana. A coisa é tão fácil! O pessoal aqui existe: Fasciotti, Ribas, Majoranini, Ricco, Toselli, Lemos, José Cândido etc., e para dar vida ou harmonizar estas forças dispersas, a atividade e grande talento do nosso Francisco Manuel. O que falta pois? $\mathrm{O}$ 
ópera e em sociabilizar-se, é certo que o topo da sociedade, e, com ela, o restante dos estados, também não estariam dispostos a se comprometer. Monsieur de Chavagnes achava que a "vida monótona" dos cortesãos que cercavam Dom Pedro II, em 1842, só poderia sofrer uma "feliz mudança" com a chegada de uma jovem imperatriz, "acostumada com os prazeres de uma corte mais alegre" ${ }^{297}$. Pois, a restauração operística ocorrida em fins de 1843 , quando uma companhia de cantores italianos finalmente desembarcou no Rio de Janeiro a fim de promover no São Pedro de Alcântara uma temporada lírica de pelo menos quatro meses -24 récitas, cinco títulos - só pode ter sido motivada e ampliada no anos seguintes pela novidade - além de um amplo avanço conservador no campo político, que, aos poucos, ia reforçando o poder imperial — da presença de uma "outra Majestade" na corte carioca, Dona Teresa Cristina, terceira Imperatriz do Brasil, que, não podemos nos esquecer, era uma princesa napolitana, proveniente, portanto, da capital da ópera ${ }^{598}$, e, ela mesma, uma cantora lírica diletante, como nos testemunhou Jules Itier, ao visitar, em 1844, o Palácio de São Cristóvão:

... parei sob uma janela entreaberta para ouvir a ária do Barbeiro: Una voce poco fa, cantada ao piano, com uma deliciosa expressão; as últimas notas ecoavam ainda em meus ouvidos e, em meu deslumbramento, minhas mãos, indiscretamente, iam aplaudir, quando uma senhora apareceu à janela. Fui apanhado em flagrante delito de curiosidade; retirei-me, então, precipitadamente, mas, em minha confusão, mereci todas as penas do mundo para arrepender-me por tê-la ouvido. Peço, aqui, respeitosamente, perdão por isso, a S. M. a

público?" (JORNAL DO COMÉRCIO, 27/08/1843).

597 "J'espère que la présence d'une jeune impératrice habituée aux plaisirs d'une cour plus gaie aura amené un heureux changement dans la vie monotone des courtisans qui entourent l'empereur" (CHAVAGNES, M. L. de. Le Brésil en 1844. Op. cit., t. 7, p. 63, 1844).

${ }^{598}$ Como bem resumiu Kurt Pahlen em sua célebre Musikgeschichte der Welt, "Em Nápoles, a ópera dá os passos decisivos para o que o mundo chama hoje de 'ópera italiana' (...) Nápoles tornou-se a cidade dos mais famosos cantores do mundo, a pátria do canto de ópera, como Cremona é a do violino, Viena a da valsa..." (PAHLEN, Kurt. História Universal da Música. Tradução de A. Della Nina. São Paulo: Melhoramentos, p. 65). 
Imperatriz do Brasil ${ }^{599}$.

Segundo Ayres de Andrade, a Companhia Italiana que chegou ao Rio de Janeiro, em fins de 1843 , foi formada em fevereiro de 1840 , pelo capitão sardo Pedro Pittaluga, já com o intuito de, àquela época, atravessar o Atlântico e reanimar a temporada operística do São Pedro de Alcântara ${ }^{600}$. É possível que essa iniciativa tenha surgido ainda em 1839, por incentivo do Governo Araújo Lima e aproveitando-se da longa presença, àquele ano, na capital do Império, do membro da casa real sardo-piemontesa, Eugenio Emanuele di Savoia (1816-1888), Príncipe de Carignano, que chegou a ser pretendente da então Princesa Imperial - e herdeira presuntiva do trono -, Dona Januária ${ }^{601}$. Em dezembro de 1839, o Jornal do comércio publicava a seguinte nota:

O Teatro de S. Pedro acaba de receber notícia de se estar engajando a companhia italiana que ele mandou buscar à Europa. A companhia

${ }^{599}$ Tradução nossa de: “... je m'arrêtai sous une fenêtre entrouverte pour écouter l'air d'll Barbiere: Una voce poco fà, chanté au piano, avec une délicieuse expression; les dernières notes retentissaient encore à mon oreille, et, dans mon ravissement, mes mains allaient indiscrètement applaudir, lorsqu'une dame parut à la fenêtre; j'étais pris en flagrant délit de curiosité, aussi me retirais-je précipitamment, mais, dans ma confusion, j'eus toute les peines du monde à me repentir d'avoir écouté! J'en demande ici respectueusement pardon à S. M. l'impératrice du Brésil" (ITIER, Jules. Op. cit., v. 1, p. 50-51).

600 ANDRADE, Ayres de. Op. cit., v. 1, p. 196.

601 Dona Januária, diga-se de passagem, era, dos filhos de Dom Pedro I, a mais dada à música. Uma das referências positivas ao seu talento musical nos foi dado, curiosamente, pelo impiedoso Príncipe de Joinville, no seu Diário, de 1838: "La petite Januaria a joué assez bien une longue, très longue sonate sur le piano..." (Apud DIÁRIO do Príncipe de Joinville. Anuário do Museu Imperial. Notas de Lourenço Luís Lacombe. Rio de Janeiro, v. 11, p. 188, 1950). Outra opinião, um tanto mais suspeita - embora corrobore a de Joinville -, é a do mestre de música da Casa Imperial, Fortunato Mazziotti. Em 1836, o dito mestre, principal da Capela Imperial, assim se referiu aos dotes musicais da Princesa, em relatório enviado ao Tutor, Marquês de Itanhaém: "A Princesa, a Senhora D. Januária tem adquirido conhecimentos grandes no pianoforte. S. A. Imperial, já não lhe é estranho para os seus estudos, os diferentes autores que escrevem. Ela combina todas estas idéias estranhas perfeitamente; tem ganhado muito gosto no que toca; como também perfeição, e destreza, e promete com a continuação do estudo, ser grande tocadora de pianoforte; tenho mais a informar a V. Ex. ${ }^{a}$ que esta Princesa, vai na cantoria dando muitas boas esperanças; ainda a sua voz não é grande, porem é harmônica, e espero que em pouco tempo, mostre fruto do seu trabalho com satisfação." (Apud INFÂNCIA e Adolescência de D. Pedro II; Documentos interessantes publicados para comemorar o primeiro centenário do nascimento do grande brasileiro, ocorrido em 2 de dezembro de 1825. Rio de Janeiro: Arquivo Nacional, 1925, p. 54). 
estará aqui em março ou abril ${ }^{602}$.

Pela coincidência de datas, era, provavelmente, essa companhia, a mesma que, em fevereiro de 1840, já se achava arregimentada na Itália e que demorou quase quatro anos para resolver aportar nos trópicos. A razão de tanta tardança? É possível que, entrementes, Candiani, Ricci, Depperini, Ghisoni e os demais componentes dessa sociedade de cantores, assim como o casal Tosini, também não tivessem tido a certeza de encontrar no Rio de Janeiro uma conjuntura favorável para realizar o seu trabalho, ainda mais depois que as negociações em torno do casamento do Príncipe de Carignano com Dona Januária romperam-se. Foi necessário, pois, esperar que Dom Pedro II se casasse com uma princesa napolitana - e apaixonada por ópera -, em 1843, para que esses italianos tomassem coragem, e, com seus próprios meios, arriscassem uma vinda à corte brasileira ${ }^{603}$. A estréia de tal companhia - com a ópera Norma, de Vincenzo Bellini - ocorreu a $17 \mathrm{de}$ janeiro de 1844, como documenta o "Folhetim" do Jornal do comércio:

... Foi esta a peça com que a nova companhia italiana estreou a sua carreira, quarta-feira p. p. perante um público numeroso e escolhido, que se apinhava na sala de S. Pedro. A Imperial família assistia a esta representação. No juízo que temos de fazer da nova companhia, devemos ser indulgentes, e fora rematada loucura queremos estabelecer uma comparação entre ela e os primeiros artistas da Europa, cuja reputação enche o mundo e que são pagos a peso de ouro. Isto posto, confessaremos

602 JORNAL DO COMÉRCIO, 06/12/1839.

603 A informação de que, em 1843, essa companhia acabou vindo ao Brasil por seus próprios meios, sem a interferência de nenhum empresário teatral ou do governo brasileiro, nos é dada pelo Jornal do comércio: "A companhia italiana é digna por muitos títulos dos favores do público; e não podemos desconhecer que a sua aparição nesta corte é um ato que tem seu quê de generosidade. Embarcou ao acaso; veio aqui sem contrato, sem garantia alguma; nada mais a guiou do que a esperança; submeteu-se a uma prova da qual saiu-se bem, na verdade, mas que ainda poderia ser lhe fatal, se the viesse a faltar a pública concorrência. Longe vá o agouro! Não; não é esta a sorte que espera uma companhia que nos memora os belos dias das Barbieri, Piacentini, Majoranini e tantos outros cujas saudosas recordações conserva ainda um público tão apaixonado pela música como é o público brasileiro" (Idem, 20/01/1844). 
francamente que no todo a companhia italiana nos parece melhor do que podíamos esperar, e vimos com prazer geralmente partilhada a agradável surpresa que experimentamos. Como seja difícil ajuizar dos talentos peculiares dos cantores em uma primeira representação na qual tem grande influência a emoção, não individualizaremos por hoje, e limitar-nos-emos a algumas observações gerais, depois de declarar que o desempenho da peça foi em geral muito satisfatório. (...) Mas não sejamos exigentes; devemos agradecimentos e louvores ao teatro de S. Pedro por ter contratado, nas críticas circunstâncias em que se acha esta companhia; e apesar dos defeitos que apontamos, foi todavia muito grande a sensação produzida quarta-feira pela composição de um dos mais brilhantes gênios da Itália, e é com sinceridade que convidamos o público a ir esta noite ao teatro de S. Pedro aplaudir a Norma. Estão preenchidos os mais ardentes votos dos dilettanti do Rio de Janeiro. Temos uma companhia italiana que nos promete deliciosas noites. Cumpre agora que o público a sustente, cumpre que não esfrie o entusiasmo de hoje... 604

Apesar de não ter sido tão festejada pela crítica, menos por seus artistas principais e mais pelo restante da encenação, um tanto improvisada ${ }^{605}$, a Companhia Italiana levaria de volta a corte, ao teatro, propiciando uma bem sucedida temporada, que, segundo Ayres de Andrade,

604 Idem, 20/01/1844.

605 O viajante francês Charles Hubert Lavollée, que esteve no Rio em 1844 descreve uma das apresentações de Norma, elogiando os cantores italianos e criticando o restante posto em cena: "Les premiers sujets de la troupe sont assez bons, mais le reste et surtout les choeurs, composés de mulâtres, sont pitoyables. Ce sont deux petits nègres, à cheveux crépus et au ventre rebondi qui représentent les fils de Norma. A chaque instant il faut rire de la mise en scène..." (LAVOLLÉE, Charles Hubert. Op. cit., p. 24). A opinião crítica do Jornal do comércio é similar: "Os coros muito deixam a desejar, e é pena que as circunstâncias apuradas do teatro não permitiram a administração fazer algumas despesas mais com coros, comparsas e aparato. Os guerreiros e soldados gauleses, por exemplo, que acodem ao chamamento de Norma no templo de Irminsul, não passam de uma dúzia de basbaques vestidos a romana ou coisa que o valha! A crítica teria também muito que dizer acerca dos Druidas, Bardos, Eubages, sacerdotisas, sacrificadores etc. Quão bela, quão magnífica, quão sublime, deve ser esta Norma, tendo por intérpretes os primeiros talentos, e acompanhada com todos os coros e com todo o luxo e aparato teatrais!" (JORNAL DO COMÉRCIO, 20/01/1844). 
chegou a somar 74 récitas $^{606}$, somente naquele ano de 1844. Contribuiu, sem dúvida, para isso, a presença mais constante do Imperador na tribuna, acompanhando sua diletante esposa napolitana. Assim, o público seria reconquistado e tal iniciativa daria início a uma nova fase da atividade cênico-musical carioca, que de tão sólida e duradoura, veio a causar forte impacto na produção musical nacional por toda a segunda metade do século XIX, como, por exemplo, transformar nosso maior talento musical do período, Antônio Carlos Gomes, não por acaso, em um dos maiores compositores de ópera do mundo, à época.

É interessante ressaltar que a ida de Carlos Gomes à Itália, em 1863, para aperfeiçoar seus estudos musicais - o que the possibilitou, posteriormente, estabelecer uma importante carreira nesse país e compor diversas de suas óperas mais célebres, a partir de libretos escritos em língua italiana - foi motivada justamente por Dona Teresa Cristina, dando-nos mais elementos para propor a hipótese de que a presença da Imperatriz no Rio de Janeiro foi fundamental nesse processo de reestruturação da produção operística no Rio de Janeiro, já em $1844^{607}$.

${ }^{606}$ ANDRADE, Ayres de. Op. cit., v. 1, p. 197.

${ }^{607} \mathrm{De}$ acordo com vários autores, entre os quais Gaspare Nello Vetro, a idéia inicial de Dom Pedro II, ao promover os estudos de Carlos Gomes na Europa, era mandá-lo à Alemanha. A interferência da Imperatriz é que o teria levado a fixar-se na Itália (VETRO, Gaspare Nello. Antônio Carlos Gomes. Rio de Janeiro: Cátedra, 1982, p. 12). 


\section{CAPÍTULO VIII - Mais do que republicana, uma experiência "soberana"}

Infelizmente, em nosso país, a arte da
música marcha em direção à
decadência em que a meteu o nosso
governo, pelo desmantelamento da
música da Capela Imperial; única flor
digna rival da Europa e que nos
distinguia em toda a América. Mas
fechados em um sistema de reformas
e economias, o abismo das
necessidades está aberto e clamante
de ouro. Demole-se o muro, cujo
entulho, hoje esparso, esteriliza o
terreno que cobre... 608

Não é nova a tese que estabelece a ascensão das Regências ao comando político do Império como causa da má situação em que se viu a música da Capela Imperial, a partir de meados de 1831. A esse respeito, a historiografia musical brasileira - embora muito superficialmente - tem sido, até o momento, unânime ${ }^{609}$. Destaquemos a mais recente consideração ao tema, a de Carlos Eduardo de Azevedo e Souza, em sua já mencionada tese

${ }^{608}$ Aproveitando-se de um texto de seu pupilo, Manoel de Araújo Porto Alegre, assim Debret definiu a situação da Capela Imperial, após a Abdicação, em sua Voyage pittoresque et historique au Brésil. Tradução nossa de: "Hélas, chez nous, l'art de la musique marche vers la décadence où l'a mis notre gouvernement par le démembrement de la musique de la chapelle impériale; unique fleur digne rivale de l'Europe, et qui nous distinguait dans toute l'Amérique. Mais renfermés dans un système de réformes et d'économies, le gouffre des besoins est ouvert et clamante de l'or. On abat un mur dont les débris, épars aujourd'hui, stérilisent le terrain qu'ils couvrent..." (DEBRET, Jean Baptiste. Op. cit., v. 3, p. 89).

${ }^{609}$ Ayres de Andrade, apesar de sucinto, foi o mais preciso em relação ao assunto: "1831 foi um ano fatídico para ela [a Capela]. A 7 de abril D. Pedro I abdicava em favor do filho criança. Cerca de dois meses depois, por medida de economia, o ministro da Justiça, Manuel José de Souza França, assinava portaria extinguindo a orquestra da capela" (ANDRADE, Ayres de. Op. cit., v. 1, p. 163). Já Cleofe Person de Matos, ainda mais breve, afirmou que a "Regência foi impiedosa com a Catedral", como se, naquilo que ela chamou de "golpe final no conjunto famoso", houvesse um ato de má vontade do novo governo para com essa instituição (MATOS, Cleofe Person de. Op. cit., 1997, p. 187). Já, André Cardoso, em seu doutoramento, limitou-se apenas a repetir as informações dos dois autores ora mencionados, acrescentando ainda dados históricos errôneos, como o de que Dom Pedro I teria partido "para Lisboa para assumir o trono português" (CARDOSO, André. Op. cit., p. 112). 
de doutorado Dimensões da vida musical no Rio de Janeiro: de José Maurício a Gottschalk e além, 1808-1889:

Curta de numerário por conta das despesas com as operações militares para conter os diversos movimentos rebeldes que surgiram de norte a sul, ameaçando a integridade do território, e desconfiada de qualquer instituição que lembrasse o despotismo do filho de D. João VI ou as ligações com Portugal, a Regência despediu todos os músicos da Capela alguns meses depois do 7 de abril ${ }^{610}$.

De fato, como ainda veremos mais detalhadamente, a situação financeira e econômica precária do Império e o ódio generalizado pelas coisas próprias de Portugal contribuíram para que, durante um bom tempo, o Rio de Janeiro esquecesse que teve algum dia um serviço musical sacro com qualidade similar à dos grandes centros europeus. Entretanto, não foram propriamente as "despesas com as operações militares para conter os diversos movimentos rebeldes que surgiram de norte a sul"611, muito menos a "impiedade" ou a "desconfiança" da "Regência" que ocasionaram a demissão em massa dos músicos da Capela em fins de junho de 1831. Um

${ }^{610}$ SOUZA, Carlos Eduardo de Azevedo e. Op. cit., p. 72.

611 Inicialmente, é preciso notar que embora tenham ocorrido nas diversas províncias do Império, desde abril de 1831, inúmeras perturbações da ordem pública, presumimos que Souza, quando fala em "movimentos rebeldes que surgiram de norte a sul" esteja referindo-se às mais renitentes e expressivas do período: a Farroupilha, no Sul (1835-1845); a Sabinada, na Bahia (1837-1838); a Balaiada, no Maranhão (1838-1841); e a Cabanagem, no Pará (1835-1840). Elas, sem dúvida, causariam estragos nos cofres do Império, mas apenas alguns anos após o Sete de Abril, não sendo, portanto, admissível vinculá-las à demissão dos músicos da Capela em junho de 1831. Ademais, lembremos que, em períodos anteriores, graças sobretudo à larga emissão de papel de curso forçado, pelo Banco do Brasil, o serviço musical da Capela e outros luxos principescos não deixaram de ter suas verbas garantidas por conta de guerras e revoluções. Dom João teve de enfrentar graves problemas militares, como a guerra com a França, a questão do Prata e a Revolução Pernambucana. No governo de Dom Pedro I, igualmente, houve enormes gastos militares com a resistência das tropas portuguesas no Maranhão e na Bahia, a Confederação do Equador, em Pernambuco, e, sobretudo, a Guerra da Cisplatina, que, segundo o publicista José Dias da Cruz Lima, custou aos cofres públicos a fantástica quantia de 22 milhões de cruzados, ou 8.800 contos de réis (LIMA, José Dias da Cruz. Reflexões sobre o estado atual das finanças do Brasil: proposta de alguns melhoramentos e medidas que Ihe podem ser aplicadas. Rio de Janeiro: Tip. Americana de I. P. Da Costa, 1843, p. 9). 
aprofundamento na documentação nos permitiu identificar uma causa precisa, sobre a qual já chegamos a tratar, en passant, em páginas anteriores: o rígido cumprimento, por parte do Poder Executivo, de uma novidade legislativa, a lei orçamentária.

Prevista no artigo 15, inciso X, da Carta de Lei de 25 de março de 1824, a fixação anual das despesas públicas do Império - atribuída ao Poder Legislativo, na figura da Assembléia Geral — foi, no entanto, letra morta até 1827, quando as primeiras tentativas de se conter a completa desordem das contas imperiais finalmente ocorreram ${ }^{612}$. Naquele ano, foi votada, de forma provisória, a dotação de "Suas Majestades Imperiais" 613 (Lei de 11 de agosto) e surgiu, também, um primeiro esboço de lei orçamentária, aprovando, genericamente, para o ano de 1828, as despesas do Tesouro Público, apenas da Província do Rio de Janeiro (Lei de 14 de novembro) ${ }^{614}$. No ano seguinte, 1828, um novo mandado (Lei de 8 de outubro), um pouco mais detalhado, restabelecia o mesmo orçamento preliminar da corte e da província fluminense, e exigia do Executivo um controle mais rígido das receitas e das despesas, preparando o Império para a votação de um primeiro orçamento geral em 1829615. Isso, de fato, pelo demasiado prolongamento das discussões e conseqüente perda do prazo de votação ${ }^{616}$,

${ }^{612}$ Até então, apenas se debatera no Legislativo, os relatórios do Ministério dos Negócios da Fazenda, que o artigo 172 da Carta de Lei obrigava. Não foi sancionada, no entanto, nenhuma lei em relação aos orçamentos gerais apresentados em 1826, 1827, 1828 e 1829.

613 COLEÇÃO das Leis do Império do Brasil de 1827. Rio de Janeiro: Tipografia Nacional, 1878, parte 1, p. 3-4.

${ }^{614}$ Idem, p. $99-101$

${ }^{615}$ COLEÇÃO das Leis do Império do Brasil de 1828. Rio de Janeiro: Tipografia Nacional, 1878, parte 1, p. 92-96.

616 A esse respeito, John Armitage nos legou um excelente resumo dos acontecimentos: "The time appointed by law for the termination of the Session was, in the meantime, fast approaching; and, notwithstanding that nothing had as yet been decided relative to the budget, and that the actual Session was the fourth mid last of the existing House of Deputies, no intimation had as yet been conveyed of any intention to prolong the term of its duration. Vasconcelos, on the 27th of August, proposed that a deputation should be sent to the Throne, for the purpose of communicating the state of various affairs of public interest, and of praying that the House might be permitted to terminate the labors in which its members were actually engaged. But this indication was overruled, on the ground that the head of the State was already well acquainted with these circumstances, and that it therefore behooved the House to abstain from all interference, to conduct themselves according to the Constitution, and to proceed in their labors until the expiration of the 
não ocorreu senão no ano seguinte, 1830 , quando, já em sua $2^{\mathrm{a}}$ legislatura, a Assembléia Geral finalmente discutiu, e, desta vez, conseguindo do Poder Moderador duas prorrogações ${ }^{617}$, aprovou o primeiro orçamento geral do Império, sancionado por Dom Pedro I a 15 de dezembro, para viger "do $1^{\circ}$ de julho de 1831 ao último de junho de 1832"618.

A leitura de uma das mais importantes fontes para o estudo histórico do pensamento político brasileiro, os Anais da Câmara do Deputados, nos dá uma idéia de como eram, em 1830, completamente obscuras as contas de certas repartições públicas, como a da Capela Imperial, e do que pensavam alguns Deputados a respeito de suas despesas, entre as quais, as da manutenção pública de um efetivo musical destinado unicamente ao fausto imperial. Na sessão de 7 de agosto, quando se discutiu parte do orçamento do Ministério dos Negócios da Justiça e Eclesiásticos - ao qual, a princípio,

appointed time" (ARMITAGE, John. Op. cit., v. 2, p. 60-61). De fato, de acordo com os Anais da Câmara dos Deputados, a 27 de agosto foi aprovado requerimento de Bernardo Pereira de Vasconcelos para que se enviasse uma deputação ao Imperador, para informálo de que ainda não estava concluída a discussão da lei do orçamento. O discurso de Vasconcelos, defendendo o seu requerimento é digno de ser aqui, em parte, reproduzido, pela sutileza com que afronta o Imperador: "É axioma nos governos monárquicorepresentativos, que o monarca é inviolável, que nenhum mal pode fazer, ou como dizem os ingleses nossos mestres, o rei é o princípio e fonte de todo o bem; o mal não é obra senão de seus ministros. Ao monarca compete, pela nossa Constituição, prorrogar a Assembléia Geral; se esta atribuição competisse ao corpo legislativo, nenhum de nos duvidaria votar pela prorrogação nas circunstâncias em que nos achamos. Mas esta atribuição é, como disse, da exclusiva competência do monarca; que motivo pode ocorrer, para que não levemos ao seu conhecimento a necessidade que temos de alguns dias para se ultimar tão importante trabalho? A reflexão de que o monarca bem sabe desta demonstrada necessidade não é atendível e eu declaro que o monarca a ignora, porquanto sendo ele a fonte do bem, não podendo fazer mal, não é presumível que encerre a Sessão antes de ultimada a lei do orçamento, do que podem resultar gravíssimas desgraças a nossa pátria" (ANAIS do Parlamento brasileiro. Câmara dos Srs. Deputados. Quarto ano da primeira legislatura. Rio de Janeiro: Tipografia de H. J. Pinto, 1877, t. 5, p. 76). Em resposta a essa e outras provocações, Dom Pedro I não apenas indeferiu o pedido de prorrogação, como, no dia 3 de setembro - Sessão Imperial do Encerramento da Assembléia -, proferiu a célebre e lacônica fala do trono: "Augustos e digníssimos Srs. representantes da nação brasileira: está fechada a Sessão" (Idem, p. s/n).

$617 \mathrm{Em} \mathrm{1830,}$, diferentemente do que ocorrera no ano anterior, Dom Pedro I prorrogou em duas oportunidades a Sessão Legislativa. A 3 de setembro, "por assim o pedir o bem do Estado", convocou extraordinariamente a Assembléia Geral até 30 de outubro (COLEÇÃO das Leis do Império do Brasil de 1830. Rio de Janeiro: Tipografia Nacional, parte 2, p. 43). Não sendo suficiente esse prazo, novo decreto, de 21 de outubro, procrastinou o encerramento da Sessão para 30 de novembro (Idem, parte 2, p. 46).

${ }^{618}$ COLEÇÃO das Leis do Império do Brasil de 1830. Rio de Janeiro: Tipografia Nacional, 1878, parte 1, p. 100-139. 
a Capela deveria estar vinculada desde $1822^{619}$-, o combativo Deputado Bernardo Pereira de Vasconcelos inquiriu do Ministro da Justiça, na época o Visconde de Alcântara, informações a respeito dessas contas:

Esse negócio da Capela está muito
desarranjado; por que motivo o provedor não
tem dado contas da Capela? Rogo ao Sr.
Ministro para explicar a razão disso ${ }^{620}$.

A resposta tergiversante do Visconde é digna de uma anedotário político:

\begin{abstract}
Os negócios da Capela Imperial até agora nunca estiveram sob a inspeção do Ministro, era de inspeção particular. Qual é a razão de se não tomarem contas, cumpre dizer que a jurisdição do inspetor da Capela é proveniente do direito de catedral, como o têm as outras estabelecidas no Brasil; o provedor da Capela Imperial não só tem autoridade geral, mas até está autorizado por uma bula para isto, fundada na mesma base em que os bispos entram com autoridade em todos aqueles casos chamados de direito geral. A Capela Imperial tem o mesmo privilégio da Santa Casa da Misericórdia, é separada da jurisdição ordinária ${ }^{621}$.
\end{abstract}

Mais adiante, novo texto taquigrafado denuncia que, em alguns

${ }^{619}$ Foi o Decreto de 3 de julho de 1822 que criou, no Brasil, a Secretaria de Estado dos Negócios da Justiça. Tal mandado baseava-se na Lei de 23 de agosto de 1821, promulgada pelas Cortes de Lisboa, na qual "todos os objetos de Justiça civil e criminal, todos os Negócios Eclesiásticos, a expedição das nomeações de todos os lugares de Magistratura, Ofícios e Empregos (...), a inspeção das prisões e quanto é relativo à segurança pública" passavam a pertencer a essa repartição (COLEÇÃO das Leis do Brasil de 1821. Rio de Janeiro: Imprensa Nacional, 1889, parte 1, p. 31-32). No entanto, segundo os relatórios do Ministério dos Negócios da Fazenda de 1825, 1826, 1827, 1828 e 1829, a Capela Imperial - como parte da enorme confusão orçamentária que vigorou durante todo o primeiro reinado - , ora esteve discriminada como repartição vinculada ao Ministério dos Negócios da Justiça, ora ao dos Negócios do Império, e mais especificamente à Casa Imperial, o que acabou sendo vedado pela lei de 11 de agosto de 1827.

620 ANAIS do Parlamento brasileiro. Câmara dos Srs. Deputados. Primeiro ano da segunda legislatura. Rio de Janeiro: Tipografia de H. J. Pinto, 1878, t. 2, p. 331.

${ }^{621}$ Idem, t. 2, p. 331-332. 
minutos, outra explicação - um pouco menos excêntrica - foi ali cogitada para o fato de a Capela Imperial até então não dar contas à Assembléia: a de que esses lançamentos estariam, na verdade, vinculados à Casa Imperial. Tal esclarecimento foi, no entanto, instantaneamente contestado pelo mesmo Deputado - e brilhante jurista - Vasconcelos, bem lembrando ele da já mencionada Lei de 11 de agosto de 1827 - por ele referida como "lei da dotação" - , a qual proibia que os gastos com a manutenção da Capela Imperial entrassem como despesa vinculada à Casa Imperial ${ }^{622}$ :

... um ilustre deputado respondeu ao Sr. Ministro da Justiça que disse que a Capela Imperial não estava obrigada a apresentar ao corpo legislativo as suas contas porque era uma despesa da Casa Imperial e que a Câmara não tinha autoridade de examinar as despesas da Casa Imperial. A Câmara nem algum dos Srs. Deputados se consideram com direito de fiscalizar as despesas da Casa Imperial, mas esta despesa não é da Casa Imperial; está separada da Casa Imperial pela lei da dotação, isto é inquestionável ${ }^{623}$.

A falta de clareza em relação ao assunto, gerou, então, protestos veementes, como o discurso mordaz do Deputado e Padre, José Custódio Dias:

Eu quisera que o Ex. ${ }^{\text {mo }}$. Sr. Ministro da Justiça me dissesse se há algum inventário dos utensílios desta catedral; se há algum livro de receita, porque me consta que há abusos que se podem conhecer; e é preciso que haja um livro da catedral do império onde reina tanto luxo. $O$ que dá Deus louvor não é a pompa. Para se darem louvores a Deus não é necessário que se consumam tantos contos em músicas e adornos inúteis. Seremos agora obrigados a sustentar

${ }^{622}$ COLEÇÃO das Leis do Império do Brasil de 1827. Rio de Janeiro: Tipografia Nacional, 1878, parte 1, p. 3.

${ }^{623}$ ANAIS do Parlamento brasileiro. Câmara dos Srs. Deputados. Primeiro ano da segunda legislatura. Rio de Janeiro: Tipografia de H. J. Pinto, 1878, t. 2, p. 334. 
um coro de castrados para dar louvores a Deus, quando um órgão é o mais próprio para o louvor divino? (...) O meu voto é para que se recomende ao Governo melhor modo de governar de que tem governado até agora, porque no estado em que nos achamos só Deus é que nos pode valer ${ }^{624}$.

Ou, ainda, o voto de Vasconcelos:

Fala-se em música: porventura os músicos, assim como muitos outros que lá vão ganhar o seu dinheiro, são empregados vitalícios? Há lei que fixe o número? Mesmo pagando-se a estes músicos a $600 \$$ e a $700 \$$, a quantia de 56:000\$ é mais que suficiente (...) Votarei por 58:000\$ para que se não diga que a Câmara não quer concorrer para o brilhantismo do culto; mas protesto já, que para o ano futuro não darei, por meu voto, nem um real se a administração da Capela não tiver dado contas ao Tesouro ${ }^{625}$.

Resultado: da verba de quase 74 contos de réis inicialmente pedida pelo Ministério para a "Santa Igreja Catedral e Imperial Capela", a Câmara Ihe destinou, no final da discussão - que passou sem alterações pelo Senado, antes de subir à sanção do Imperador —, pouco mais do que 56 contos de réis. Essa cifra, ao contrário do que supôs Vasconcelos, era claramente insuficiente para manter, além do corpo religioso, um efetivo musical de cerca de setenta músicos, o qual, àquele tempo, consumia ordinariamente algo em torno de 23 contos de réis por ano, ou seja, quase a metade do orçamento então votado para a Capela, ou pouco mais do que a diferença de verba que a Assembléia deixara de conceder a essa repartição ${ }^{626}$.

${ }^{624}$ Idem, t. 2, p. 333.

${ }^{625}$ Idem, t. 2, p. 334.

${ }^{626}$ Note-se que, além da verba orçamentária, a Capela ainda recebia, teoricamente, uma pensão de todas as igrejas das Ordens, imposta pelo Alvará de 20 de agosto de 1808 (vide nota 161 da primeira parte). Esse valor, no entanto, não chegava a suprir nem $5 \%$ dos gastos ordinários dessa repartição. Segundo, por exemplo, o Relatório 
Para termos uma idéia do que consumiu a Capela em anos anteriores, incluindo-se todas as côngruas dos religiosos e os ordenados dos músicos e demais empregados, vejamos algumas cifras: em 1826, foram gastos $76: 896 \$ 679^{627}$; em $1827,102: 856 \$ 871^{628}$. No relatório do Ministério da Fazenda de 1827 foram orçados $72: 190 \$ 000$ para $1828^{629}$; e no de 28 , $73: 920 \$ 000$ para $1829^{630}$. No relatório de 1829 , orçou-se 108:000\$000, como despesa para o primeiro semestre de 1830 e todo o ano financeiro de 1830$1831(01 / 07 \text { a 30/06) })^{631}$, o que, proporcionalmente, para um ano inteiro, correspondia aos mesmos setenta e poucos contos de réis, agora, não mais aceitos pela Assembléia Geral. Enfim, graças ao relatório de 1830 - o mais detalhado de todos - não apenas foi possível saber que a capela gastara, de fato, $80: 413 \$ 224$, em 1829 , como se previa, para o ano financeiro de 18311832 , um orçamento de precisos $73: 821 \$ 850$, dos quais $22: 268 \$ 650$ seriam destinados à musica ${ }^{632}$.

Assim sendo, não foi por "desconfiança" ou "impiedade", mas por acatamento aos ditames emanados de leis discutidas e aprovadas por um

do Ministério da Fazenda de 1826 , teriam sido arrecadados, com esse imposto, 5:357\$714 durante os anos de 1823, 1824 e 1825, uma média, portanto, de menos de um conto e oitocentos mil réis por ano para fazer face a uma despesa que chegaria, em anos posteriores, a mais de cem contos de réis (RELATÓRIO, ou exposição do Ministro da Fazenda sobre o estado da administração respectiva em fim do ano de 1825, com o orçamento da renda e despesa que poderá ter lugar no corrente ano de 1826. Rio de Janeiro: Na Tipografia Imperial e Nacional, 1826, p. 197).

627 DEMONSTRAÇÃO da receita e despesa do Tesouro Nacional, divida ativa e passiva, orçamentos para o ano futuro. Rio de Janeiro: Na Tipografia Imperial e Nacional, 1827, p. 20.

${ }_{629}^{628}$ Vide nota 45 desta parte.

${ }^{629}$ DEMONSTRAÇÃO da receita e despesa do Tesouro Nacional, divida ativa e passiva, orçamentos para o ano futuro. Rio de Janeiro: Na Tipografia Imperial e Nacional, 1827 , p. 37.

${ }_{630}$ DOCUMENTOS com que se instruiu o seu relatório à Assembléia Geral Legislativa do Império do Brasil o Ministro Secretário de Estado dos Negócios da Fazenda, e Presidente do Tesouro Nacional, Miguel Calmon du Pin e Almeida, na Sessão de 1828. Rio de Janeiro: Na Tipografia Imperial e Nacional, 1828, p. s/n.

631 DOCUMENTOS com que se instruiu o seu relatório à Assembléia Geral Legislativa do Império do Brasil o Ministro Secretário de Estado dos Negócios da Fazenda, e Presidente do Tesouro Nacional, Miguel Calmon du Pin e Almeida, na Sessão de 1829. Rio de Janeiro: Na Tipografia Imperial e Nacional, 1829, p. s/n.

$632720 \$ 000$ para 2 organistas, 1:250\$000 para 2 mestres-de-capela, 10:095\$800 para 26 cantores, 9:242\$850 para 34 instrumentistas e $960 \$ 000$ para 2 copistas (RELATÓRIO do Ministro, e Secretário de Estado dos Negócios da Fazenda na sessão de 15 de maio de 1830. Rio de Janeiro: Na tipografia imperial e nacional, 1830, p. s/n). 
parlamento, que a Regência - ou mais especificamente o Ministério da Justiça - aproximando-se a data da vigência da lei orçamentária $-1^{\circ}$ de julho de 1831 — , tenha deliberado excluir da folha de pagamento da Capela Imperial mais da metade de seus músicos ${ }^{633}$. A documentação manuscrita da Capela, tombada no Arquivo Nacional, é prova de que a decisão, embora contextualizada às circunstâncias sociais já descritas, foi baseada em números. A 14 de junho de 1831 - não coincidentemente apenas duas semanas antes de vigorar a nova lei —, o já mencionado Monsenhor Fidalgo apontava em seus relatórios, "Conforme a quantia (...) concedida pela Lei do Orçamento" ${ }^{634}$, um novo e reduzido montante anual para os gastos com a música: 10:929\$900. Isso diminuía o conjunto a 23 cantores, dois rabecões (contrabaixos) e dois fagotes - a 8:959\$900 -; dois organistas - a $720 \$ 000$-; e dois mestres-de-capela, Fortunato Mazziotti e Simão Portugal - a $1: 250 \$ 000$.

Como já foi dito, essa situação permaneceria praticamente inalterada, com algumas mudanças para melhor ou pior, conforme as circunstâncias políticas, econômicas e sociais, até meados de 1843, quando, só então, a

${ }^{633}$ Nesse momento, importa imaginar o que teria ocorrido com a Capela se Dom Pedro I não tivesse abdicado a coroa e partido para a Europa, cerca de uma semana depois. Visto que o serviço musical dessa instituição era uma de suas paixões, não seria impossível sustentar a hipótese de que ele pudesse fazer vistas grossas a esse item da lei orçamentária, como já o fizera com as normas relacionadas a seus gastos pessoais e os orçamentos parciais de anos anteriores. A edição de uma da últimas decisões do seu governo - uma portaria do Ministério da Guerra de 7 de março de 1831 -, deixa, no entanto, dúvidas quanto à sua disposição, àquelas alturas, de desrespeitar um mandado do parlamento, ainda que esse pusesse em xeque sua tão amada arte dos sons. Dizia a portaria: "Sendo preciso, em conformidade do $\S 44$ do art. 19 da Lei da fixação da receita e despesa do Império para o ano financeiro de 1831-1832, e art. 12 da fixação das forças de terra ordinárias para o mesmo ano, diminuir a despesa com a música dos corpos; Determina Sua Majestade o Imperador: $10^{\circ}$ que seja dissolvida a música do $1 .^{\circ}$ corpo de artilharia de posição de $1 .^{a}$ linha, por não ser própria dessa arma (..) $2 .^{\circ}$ que a música do batalhão do Imperador fique reduzida, como a de qualquer outro batalhão, ao número de dezesseis indivíduos..." (COLEÇÃO das decisões do Império do Brasil de 1831. Rio de Janeiro: Tipografia Nacional, 1876, p. 25). Em vista disso, resta-nos, ao menos, especular que Dom Pedro I pudesse cobrir o déficit orçamentário da Capela Imperial, utilizando-se da sua vultosa dotação de mais de mil contos de réis; afinal, diante do que já foi exposto, fica difícil supor que o "Príncipe Filarmônico" aceitasse passivamente a decisão, tomada por seu Ministro da Justiça, Manuel José de Sousa França, em junho de 1831, de exonerar quase todos os instrumentistas da Capela.

${ }^{634}$ ARQUIVO NACIONAL, Rio de Janeiro. Fundo Casa Real e Imperial, cx. 12, pc. 1 , doc. 12 , fl. 27. 
Capela Imperial - motivada, possivelmente, pelo casamento de Dom Pedro II — conseguiu, graças à tenacidade de Monsenhor Fidalgo, reorganizar o seu efetivo musical em moldes mais próximos aos dos tempos de Dom João VI e Dom Pedro I. O resgate de informações relacionadas à Capela e ao orçamento imperiais existentes em alguns dos relatórios dos Ministérios da Fazenda e da Justiça desses doze anos (1831-1843), as discussões sobre essa matéria, realizadas na Assembléia, e a legislação orçamentária do mesmo período nos permitem reconstituir, em parte, além dos já estudados fenômenos político-sociais, outros, político-econômicos ou meramente políticos, que igualmente desfavoreceram o Governo a investir, durante esse período, em um serviço musical sacro de qualidade similar ao dos períodos precedentes.

Inicialmente, além do absurdo endividamento do Estado, herdado de Dom Pedro $1^{635}$, salta-nos à vista a paralisação geral da Economia e a conseqüente queda drástica da Receita. Bernardo Pereira de Vasconcelos, que foi o Ministro da Fazenda entre 1831 e 1832, bem se lembrou deste crucial problema financeiro, em seu relatório, apresentado à Assembléia Geral, a 8 de maio de 1832:

Para que possais avaliar justamente a conduta do Governo, releva chamar à vossa lembrança o deplorável estado do País, quando a Administração atual entrou na sempre difícil, e então perigosa direção dos Negócios do Império. Freqüentes comoções em diversos pontos, bem que terminadas a favor da ordem estabelecida, de maneira tinham aterrado a indústria, e propriedade, que todos os trabalhos úteis, todos os serviços produtivos caíram em um mortal torpor. A agricultora desfaleceu; o Comércio paralisou-se; a confiança estremeceu; e o crédito público, e particular abalou-se; só havia atividade em apurar fundos para a emigração. Neste estado de violência não é para admirar que as nossas Rendas fossem

${ }^{635}$ Vide nota 67 desta parte. 
reduzidas à metade, e em algumas Províncias á terça parte do seu produto ordinário ${ }^{636}$.

É verdade que essa situação, entre altos e baixos, melhoraria um pouco nos anos seguintes, mas não o suficiente para permitir ao Executivo gastar com o que não fosse estritamente necessário ${ }^{637}$. Foi comum nesses tempos, o Jornal do comércio publicar, a respeito das comemorações de gala do Império, comentários como este:

O oitavo aniversário do juramento da Constituição Política do Império, dia de festa nacional para os brasileiros foi solenizado na capital com a pompa possível... ${ }^{638}$

Acrescente-se a isso, a nova ordem institucional do Império após a vigência da Lei de 14 de junho de 1831. Como mandava o artigo 15 da Constituição, na falta ou impedimentos do Imperador, cabia à Assembléia Geral, não apenas eleger três regentes, como também marcar os limites da

\footnotetext{
${ }^{636}$ RELATÓRIO apresentado à Câmara dos Senhores Deputados pelo Ministro e Secretário de Estado dos Negócios da Fazenda Bernardo Pereira de Vasconcelos na Sessão de 1832. Rio de Janeiro: Na Tipografia Nacional, 1832, p. 23-24.

637 O The times londrino é uma fonte interessante de informações acerca da situação econômica e financeira do Brasil nesses tempos. Com grandes interesses comerciais no Brasil, os ingleses acompanhavam atentamente a conjuntura brasileira procurando obter as informações mais fidedignas. Assim, é possível, por exemplo, constatar que em fins de 1831, o comércio começava a reviver, aproveitando certa tranqüilidade política: "The political aspect of the country was favorable. The utmost vigilance appears to have been kept up by the Government for the preservation of public tranquility. Trade was beginning to revive..." (THE TIMES, 07/01/1832) Nessa ocasião o câmbio entre as moedas inglesa e brasileira estava em $281 / 2$ pence para $1 \$ 000$. Já em meados de 1834, a tranqüilidade pública e a melhoria dos negócios elevou o valor da moeda brasileira: "The country was quiet, and business improving. The exchange on England was 40..." (Idem, 06/06/1834). Dois anos depois, a notícia da Guerra dos Farrapos e a falta de habilidade do legislativo em tratar do problema monetário brasileiro voltava a indicar dificuldades para a economia brasileira: "The circumstances of the currency, disorders at Rio Grande, and general want of confidence, offer obstacles of such magnitude to the free current of business as to prohibit all expectation or hope of a better state of things for some time to come. (...) The legislative bodies are entirely indifferent to the currency question, and advices from Rio Grande are unpromising" (Idem, 04/10/1836). Note-se que a melhoria dos negócios relacionados ao comércio internacional, tanto de importação como de exportação era de vital importância para o Governo, na medida em que grande parte das receitas do Império eram arrecadadas nas alfândegas.

638 JORNAL DO COMÉRCIO, 27/03/1832.
} 
sua autoridade 639 . A lei referida veio a regulamentar esse artigo, estabelecendo, entre outras normas restritivas, a impossibilidade da Regência exercitar o Poder Moderador no que dizia respeito à dissolução da Câmara dos Deputados ${ }^{640}$.

A partir daí - e desestabilizando-se, temporariamente, a engendrada concepção de equilíbrio dos Poderes preconizada por Benjamin Constant ${ }^{641}$ - a Câmara assumiu, durante todo o período regencial, um papel preponderante entre os Poderes Políticos do Império, exercendo, pela voz de seus líderes e pelo voto de suas maiorias, uma crítica sem limites àqueles que ousaram comandar o Império sem uma coroa sobre a cabeça. E o maior expediente de que os Deputados lançaram mão para exercer tal censura foi sempre a discussão do Orçamento, na medida em que era de sua prerrogativa abrir as discussões legislativas sobre esse tema ${ }^{642}$. Assim,

639 COLEÇÃO das Leis do Império do Brasil de 1824. Constituição Política do Império do Brasil. Rio de Janeiro, Imprensa Nacional, 1886, parte 1, p. 9.

640 COLEÇÃO das Leis do Império do Brasil de 1831. Rio de Janeiro: Tipografia Nacional, 1875, parte 1, p. 19-23. É bem verdade que, uma vez empossado o primeiro Regente uno temporário - Feijó - a 12 de outubro de 1835, essa norma poderia ter sido considerada nula, uma vez que, contendo disposições expressamente relacionadas à Regência trina, contrariava uma norma superior, o Ato Adicional. No entanto, nem Feijó, nem Araújo Lima tiveram condições políticas de aprofundar essa delicada discussão, permanecendo a Câmara intacta, apesar de toda a crise desses dois governos. Sobre esse assunto ver também HOLANDA, Sérgio Buarque de (org.). Op. cit., 1985, v. 4, p. 49.

${ }^{641} \mathrm{O}$ suíço Benjamin Constant foi um dos principais publicistas europeus, assim como Clermont-Tonnerre, a defender a idéia fundamental de distinguir-se o Poder Executivo do Poder Real, dando a esse último "a chave de toda organização política", na medida em que assumisse, com plena influência de opinião e autoridade política, uma força "neutra", contudo dotada de prerrogativas largas o suficiente para pôr termo a quaisquer desequilíbrios que, porventura, ocorressem entre os três poderes tradicionais. Em seus Principes de politique, de 1815, encontramos exemplos práticos de como o Poder Real poderia ser empregado: "L'action du pouvoir exécutif est-elle dangereuse, le roi destitue les ministres. L'action de la chambre héréditaire devient-elle funeste, le roi lui donne une tendance nouvelle, en créant de nouveaux pairs. L'action de la chambre élective s'annoncet-elle comme menaçante, le roi fait usage de son veto, ou il dissout la chambre élective. Enfin l'action même du pouvoir judiciaire est-elle fâcheuse, en tant qu'elle applique à des actions individuelles des peines générales trop sévères, le roi tempère cette action par son droit de faire grâce" (CONSTANT, Benjamin. Op. cit., p. 20). Essas idéias de Constant foram, em grande parte, aproveitadas na Constituição de 1824 , sobretudo no que diz respeito ao Poder Moderador e suas atribuições.

642 Vide Artigos 37, inciso II e 172 da Carta de Lei de 1824 (Cf. COLEÇÃO das Leis do Império do Brasil de 1824. Constituição Política do Império do Brasil. Rio de Janeiro, Imprensa Nacional, 1886, parte 1). Isso fazia com que o Senado tivesse papel secundário em grande parte das discussões orçamentárias, já que os primeiros e mais longos debates ocorriam na Câmara. 
esteve, como nunca, nas mãos do "Soberano" - cognome dado por Dom Pedro I à Câmara dos Deputados ${ }^{643}$ —, o poder de apreciar, suprimir ou emendar as propostas orçamentárias do Império, formuladas pelo Executivo, quase sempre resultando, de suas intervenções, diminuição sumária de despesas e conseqüente minimização da ação governamental ${ }^{644}$, fosse ou não ela propensa a cumprir um papel de incentivadora das artes ${ }^{645}$. Como bem resumiu Eden Hamond, em seu Diário de 1837, era “impossível levar adiante qualquer governo com as mãos do Executivo tão amarradas [pela Câmara dos Deputados]". Na visão do Almirante inglês, parecia o Brasil "uma república da pior qualidade, com um imperador apenas nominal”646.

${ }^{643}$ HOLANDA, Sérgio Buarque de (org.). Op. cit., 1985, v. 3, p. 400.

644 Já em 1834, o então Ministro da Fazenda, Cândido José de Araújo Viana, criticava, em seu relatório, a disposição contumaz dos parlamentares em oferecer apenas sugestões de cortes no orçamento, como solução ao déficit das contas públicas: "O cerceamento nas despesas dos diferentes ramos do serviço público tem sido mais de uma vez recomendado por Vós à Administração, como o meio mais próprio e econômico de fazer desaparecer um déficit, que se apresentou com o caráter de ordinário. É porém de mister ponderar-vos que semelhante recurso (..) pode ao contrário ser nocivo (...) A administração, de que tenho a honra de fazer parte, tem feito infrutíferos esforços nesse sentido, não tendo podido efetuar no estado atual do serviço público redução alguma, que pudesse dar um resultado satisfatório, sem prejudicar gravemente o mesmo serviço" (RELATÓRIO da Repartição dos Negócios da Fazenda apresentado à Assembléia Geral Legislativa na Sessão Ordinária de 1834; pelo respectivo Ministro e Secretário de Estado Cândido José de Araújo Viana. Rio de Janeiro: Na Tipografia Nacional, 1834, p. 5-6).

${ }^{645}$ Vê-se, pela crítica do Jornal dos debates políticos e literários, que não apenas Feijó podia ser responsabilizado pela até então negligente ação do Governo no favorecimento das artes. A "Câmara" também recebeu parcela da culpa: "A Câmara e o Governo passado foram insensíveis às artes, uma minoria de homens que possuem idéias generosas e grandes não pôde estender os braços à música..." (JORNAL DOS DEBATES POLÍTICOS E LITERÁRIOS, 18/10/1837). Alguns anos depois, outro periódico, O Brasil, voltava a criticar o Legislativo pela falta de apoio governamental à música: "Todos os interesses, ainda os mais insignificantes e mesquinhos, têm encontrado calorosos defensores nas nossas câmaras, no entanto a música, cuja influência civilizadora de ninguém é desconhecida, ainda não encontrou uma voz eloqüente e generosa que defendesse seus interesses" (O BRASIL, 08/07/1841).

${ }^{646}$ HAMOND, Graham Eden. Op. cit., p. 162. Note-se que o Almirante inglês se refere ao Governo de Feijó, de todos do período regencial, o mais severamente perseguido pela Câmara. É de se notar, no entanto, que essa Casa tenha, também, durante a Regência trina permanente e o governo de Araújo Lima, procurado sempre mostrar-se, como bem denominou Pedro Calmon, "irresistível" (CALMON, Pedro. Op. cit., v. 5, p. 1587). A respeito desse último período, reproduzamos parte de um discurso proferido por Feijó, em 1839. Naquele momento, o então Presidente do Senado saía em defesa da governabilidade do Império, sugerindo novamente reformas radicais na Constituição e pedindo encarecidamente à Câmara dos Deputados que deixasse de "anarquizar o povo, declamando, injuriando, envenenando as intenções dos ministros, imputando-lhes prevaricações verdadeiras e supostas, desconsiderando-os na opinião pública, ensinando ao povo a ter em desprezo estes altos funcionários" (JORNAL DO COMÉRCIO, 
No que diz respeito especificamente às despesas da Capela Imperial, para o ano financeiro de 1832-1833, o julgamento da Câmara, em 1831, foi ainda mais implacável do que em 1830. Na sessão do dia 17 de setembro daquele ano, o orçamento, já reduzido, de 56 contos de réis, enviado pelo Ministério da Justiça - cifra igual à aprovada no ano anterior - foi diminuído para cinqüenta contos de réis, por emenda do Deputado Castro e Silva. Como se não bastasse, outra emenda, desta vez do Deputado Lobo de Sousa, na medida em que autorizava o Governo a fazer todas as reduções que julgasse conveniente no pessoal e no material da Capela Imperial e a suspender o provimento dos lugares ou empregos que ali vagassem, exigia que o Ministério dos Negócios da Justiça e Eclesiásticos desse conta, na Sessão futura, do estado daquela repartição ${ }^{647}$. Essas diretivas, passando sem quaisquer modificações pelo Senado e sancionadas pela Regência, converteram-se na Lei de 15 de novembro de $1831^{648}$ e foram fielmente reproduzidas no orçamento do exercício financeiro seguinte (1833-1834), sancionado a 24 de outubro de $1832^{649}$.

Conforme previam tais mandados, o Ministro da Justiça, em 1833 então Honório Hermeto Carneiro Leão, que ocupava pela primeira vez esse cargo, desde setembro de 1832 -, dando conta à Assembléia do estado da Capela, relatou que, com a jubilação de alguns empregados dessa repartição, os seus gastos anuais cairiam a pouco mais de 48 contos de réis. Ainda assim, o futuro Marquês de Paraná sugeriu à Assembléia Geral que mantivesse os 50 contos de réis dos dois anos anteriores, "visto que a música", nesse momento com 29 integrantes, tinha "falta de vozes" e que poderiam ocorrer também alguns gastos extraordinários com o conserto do edifício, além da necessidade de compra de paramentos e roupas novas ${ }^{650}$.

24/08/1839).

${ }^{647}$ ANAIS do Parlamento brasileiro. Câmara dos Srs. Deputados. Segundo ano da segunda legislatura. Rio de Janeiro: Tipografia de H. J. Pinto, 1870, t. 2, p. 173.

${ }_{648}$ COLEÇÃO das Leis do Império do Brasil de 1831. Rio de Janeiro: Tipografia Nacional, 1875, parte 1, p. 237.

649 COLEÇÃO das Leis do Império do Brasil de 1832. Rio de Janeiro: Tipografia Nacional, 1874, parte 1, p. 134.

${ }_{650}$ RELATÓRIO da Repartição dos Negócios da Justiça apresentado à Assembléia 
Na sessões de 11 e 12 de julho de 1833, no entanto, a Câmara aprovou, para o exercício financeiro de 1834-1835, apenas aquilo que se previa de gastos ordinários - 48:395\$800 — , sendo ainda apoiada uma emenda que retirava do orçamento a quantia de trezentos mil réis para o "encrespamento de roupas da Capela"651. Por aí se vê até que ponto ia a avareza de alguns deputados em propor emendas para tentar reduzir - em coisa de 0,6\% um orçamento já bastante despojado de superfluidades.

Para os anos financeiros seguintes (1835-1836 e 1836-1837) o Legislativo foi, no entanto, mais benevolente. A lei de 3 de outubro de 1834 liberou a mesma verba do ano anterior, não obstante a Capela ter diminuído a sua folha em sete empregados, entre os quais, três músicos. Diante das constantes censuras do Legislativo, o Ministro da Justiça da época, Aureliano de Sousa e Oliveira Coutinho, justificava antecipadamente que, apesar da diminuição do pessoal, pretendia manter o mesmo orçamento para que, extraordinariamente, promovesse o conserto de partes do templo que ameaçavam vir abaixo ${ }^{652}$. Todavia, em 1835, o próprio Ministério da Justiça, na figura de seu novo titular, Manuel Alves Branco, retirava essa verba "extraordinária", diminuindo ainda mais o orçamento da Capela. Um montante de 44 contos de réis foi apresentado à Câmara dos Deputados na sessão de 29 de julho e aprovado, sem alterações, por ambas as casas legislativas. Essa resolução seria sancionada a 31 de outubro, pelo recém empossado Regente Feijó.

A administração seguinte - a primeira de Antônio Paulino Limpo de Abreu à frente da pasta da Justiça - não apresentou no Relatório de 1836 um orçamento para a Capela pelo fato desta achar-se "em muitas partes em estado de ameaçar ruína, tendo-se por isso mandado proceder a uma

Geral Legislativa na Sessão Ordinária de 1833; pelo respectivo Ministro e Secretário de Estado Honório Hermeto Carneiro Leão. Rio de Janeiro: Na Tipografia Nacional, 1833, p. 42.

651 ANAIS do Parlamento brasileiro. Câmara dos Srs. Deputados. Quarto ano da segunda legislatura. Rio de Janeiro: Tipografia de viúva Pinto \& Filho, 1887, t. 2, p. 61.

${ }^{652}$ RELATÓRIO da Repartição dos Negócios da Justiça apresentado à Assembléia Geral Legislativa na Sessão Ordinária de 1834; pelo respectivo Ministro e Secretário de Estado Aureliano de Sousa e Oliveira Coutinho. Rio de Janeiro: Na Tipografia Nacional, 
vistoria, para depois orçar-se a despesa" ${ }^{653}$. A 12 de julho, estando já o Ministério sob outro comando, o de Gustavo Adolfo de Aguilar Pantoja, este apresentou, possivelmente a título improvisatório - dada a recentidade da sua posse - um orçamento de 43:373\$900 para $1837-1838^{654}$. Era o menor de todo o período regencial, e portanto não contemplava orçamento algum para as necessárias reformas estruturais da Igreja. Como se não bastasse, diversos Deputados, àquele momento, hostis ao Governo - entre os quais, Vasconcelos e Honório Hermeto - realizaram uma duríssima argüição a Pantoja, e apresentaram uma série de restrições e emendas ao seu projeto de orçamento, entre as quais, uma, do Arcebispo da Bahia - possivelmente em uma afronta pessoal a Feijó - , aumentando as côngruas dos cônegos e monsenhores da Capela ${ }^{655}$. Disso resultou um curioso aumento do orçamento da Capela, retornando ele à casa dos 50 contos de réis — mais especificamente 50:673\$900656 —, ainda que nada melhorasse em relação ao serviço musical, a essas alturas, segundo relatório do Monsenhor Fidalgo, limitado à quantia de 9:737\$700 para 27 integrantes, entre os quais vinte cantores, três instrumentistas, dois organistas e dois mestres-de-capela ${ }^{657}$.

A 2 de agosto de 1837, o Ministério da Justiça, na pessoa do último titular dessa pasta nomeado por Feijó, Francisco Gê Acaiaba de Montezuma, voltava a apresentar à Câmara a proposta de orçamento da Capela para o ano financeiro de 1838-1839: 54:873\$000. O aumento de mais de quatro contos de réis em relação ao orçamento anterior se devia à premência de obras estruturais ainda não realizadas, sobretudo na torre da Catedral, que

\section{4 , p. 25.}

${ }^{653}$ RELATÓRIO da Repartição dos Negócios da Justiça apresentado à Assembléia Geral Legislativa na Sessão Ordinária de 1836, pelo respectivo Ministro e Secretário de Estado Antônio Paulino Limpo de Abreu. Rio de Janeiro: Na Tipografia Nacional, 1836, p. 40 .

654 ANAIS do Parlamento brasileiro. Câmara dos Srs. Deputados. Terceiro ano da terceira legislatura. Rio de Janeiro: Tipografia de viúva Pinto \& Filho, 1887, t. 2, p. 65 ${ }^{655}$ Idem, t. 2, p. 65-83.

${ }^{656}$ COLEÇÃO das Leis do Império do Brasil de 1836. Rio de Janeiro: Tipografia Nacional, 1861, parte 1, p. 45.

657 Este documento manuscrito, datado de 15 de fevereiro de 1836 marca as despesas ordinárias com a música para o ano financeiro de 1837-1838 (ARQUIVO NACIONAL, Rio de Janeiro. Fundo Casa Real e Imperial, cx. 13, pc. 1, doc. 28, fl. 2). 
ameaçava desabar. Dizia o Ministro: "Essa obra é evidentissimamente precisa, e até o decoro nacional exige que ela se faça" — ou seja, o "até o decoro" indicava que este estava, realmente, no limite das ações, em suma, em último plano, durante o governo de Feijó. Como se não bastasse, a animosidade da Câmara persistia. Honório Hermeto, por exemplo, dizia estar "persuadido" quanto ao fato da Capela necessitar de "algum reparo", porém, incitou os Deputados a não estabelecerem quantia alguma para essa despesa sem que antes fossa apresentado à Câmara, um orçamento respectivo. Como bom líder da oposição, Honório ainda terminou o seu discurso ameaçando que, se aparecesse alguma emenda suprimindo a quantia destinada aos reparos da Capela Imperial, ela teria o seu voto. Porém, Montezuma, futuro Visconde de Jequitinhonha, era um político experiente. Com uma mistura de cortesia e astúcia, saiu-se bem na defesa de sua gestão, e, apresentando até o fim daquele dia um enorme orçamento de 48 contos de réis para a necessária reforma da torre da Capela, minimizou os 4:000\$000 a mais pretendidos e conseguiu aprovar, sem alterações, esse e outros itens de seu orçamento ${ }^{658}$.

É claro que, diante de tantos apertos, a grande reforma estrutural da Igreja ficaria para depois, tornando-se cada vez mais prioritária, e, conseqüentemente, deixando em plano inferior a possibilidade de um eventual melhoramento no serviço musical. Nem mesmo a ascensão de um dos mais eminentes líderes da Câmara dos Deputados, Bernardo Pereira de Vasconcelos, ao Ministério da Justiça iria proporcionar a essa repartição, para o exercício de 1839-1840, verbas mais folgadas, que permitissem um efetivo restabelecimento da pompa religiosa, ajudando-se, assim, a política de engrandecimento do Imperador delineada por Araújo Lima ${ }^{659}$. Houve um

${ }^{658}$ Cf. ANAIS do Parlamento brasileiro. Câmara dos Srs. Deputados. Quarto ano da terceira legislatura. Rio de Janeiro: Tipografia de viúva Pinto \& Filho, 1887, t. 2, p. 231-241

${ }^{659}$ Não faltou, pois, discurso para isso. Foram com essas demagógicas palavras que Vasconcelos tentou convencer seus antigos pares a fazer o contrário do que ele próprio fizera, como Deputado oposicionista, ou seja, votar contra a liberação de verbas para o esplendor da Capela Imperial: "Apresento-vos, Senhores, debaixo deste título, um objeto digno da vossa atenção. A Capela Imperial, que é ao mesmo tempo a Santa Sé desta grande, e opulenta Capital, existe hoje em um estado lastimoso, quer no seu pessoal, 
aumento, é verdade, no orçamento, para pouco mais de sessenta contos de réis - seis a mais do que a quantia prevista no anterior ${ }^{660}$. Porém ela já estaria comprometida com o provimento dos lugares vagos de monsenhores, cônegos e capelães ${ }^{661}$.

Em 1839, ano de crise no Governo, com o queda do "gabinete parlamentar", também conhecido como "ministério das capacidades", o orçamento do ano financeiro 1840-1841 acabou não sendo votado, ficando para a Sessão Legislativa seguinte, de 1840. O substituto de Vasconcelos, Francisco de Paula de Almeida e Albuquerque, atentava, em seu relatório, ainda em 1839, para o "estado de ruína" da Catedral, orçando gastos extraordinários de doze contos de réis para o seu reparo emergencial ${ }^{662}$. Isso não veio a se concretizar, dado que a lei orçamentária, sancionada a 26 de maio de 1840, acabou reduzindo de vinte para oito contos de réis as despesas extraordinárias do Ministério e consignando à Capela uma verba menor do que a do ano anterior: 57:083\$100663. Pelo orçamento apresentado pelo Inspetor Fabriqueiro da Capela ao Ministério da Justiça, para o ano

quer no seu material. (...) Os Ofícios Religiosos já não podem aí ser celebrados com a majestade, e esplendor, que o Culto Nacional exige, e é indispensável a esta Igreja debaixo de qualquer de seus títulos. A piedade, e até direi, a curiosidade mesmo, quando para ali se dirige, escandaliza-se de ver o abandono, em que está, e recorda-se com dor da sua passada grandeza. (...) o Grande Templo da Nação está inferior a muitos respeitos a vários Templos particulares, e em todos aos das Ordens Religiosas, que existem nesta Cidade. Não é possível, Senhores, que deixeis continuar por mais tempo este estado de nudez, em que se acha a Santa Igreja Fluminense. Não Ihe deis o aparato magnifico, que ela teve aos dias do Senhor Rei D. João Sexto; mas restitui-Ihe o decoro, o asseio, o esplendor mesmo, que é indispensável à Casa do Senhor, e que é digno dos Legisladores Brasileiros (...) O Governo por vós habilitado dar-se-á com fervor a este importante assunto, do qual ele espera valiosa influência sobre a moral, e Religião do nosso povo" (RELATÓRIO da Repartição dos Negócios da Justiça apresentado à Assembléia Geral Legislativa na Sessão Ordinária de 1838, pelo respectivo Ministro e Secretário de Estado Bernardo Pereira de Vasconcelos. Rio de Janeiro: Na Tipografia Nacional, 1838, p. 18-19).

${ }^{660} \mathrm{O}$ orçamento proposto foi de 60:253\$100. Aprovado na Câmara sem alterações, recebeu emenda do Senado, incluindo-se um aumento de $200 \$ 000$ ao Inspetor (COLEÇÃO das Leis do Império do Brasil de 1838. Rio de Janeiro: Tipografia Nacional, 1838, parte 1, p. 52).

${ }^{661}$ Cf. ANAIS do Parlamento brasileiro. Câmara dos Srs. Deputados. Primeiro ano da quarta legislatura. Rio de Janeiro: Tipografia de viúva Pinto \& Filho, 1887, t. 2, p. 298311.

${ }^{662}$ RELATÓRIO apresentado à Assembléia Geral Legislativa na Sessão Ordinária de 1839, pelo Ministro e Secretário de Estado dos Negócios da Justiça. Rio de Janeiro: $\mathrm{Na}$ Tipografia Nacional, 1839, p. 13.

${ }^{663}$ COLEÇÃO das Leis do Império do Brasil de 1840. Rio de Janeiro: Tipografia 
financeiro de 1840-1841, é possível notar igualmente que a previsão de vagas para o serviço musical da Capela permanecia praticamente a mesma de três anos antes: 26 integrantes, entre os quais 22 "músicos", dois organistas e dois mestres-de-capela. A quantia orçada era também praticamente igual à de 1837-1838: 9:896\$900664.

No ano que encerraria a regência de Araújo Lima, 1840, o então Ministro da Justiça, Francisco Ramiro de Assis Coelho, tentou, em um discurso apologético, convencer o parlamento da necessidade da retomada da pompa na Capela. Há ali uma especial lembrança à questão musical, ressentida, segundo o Ministro, "de uma simplicidade menos edificante". O incessante trabalho dos organistas da Capela, que, desde 1831, acabaram fazendo as vezes da extinta orquestra, ao lado de três ou quatro instrumentistas de baixo também foi especialmente lembrado. Pedia Assis Coelho, nessa ocasião, um aumento de seus ordenados, de $360 \$ 000$ para $500 \$ 000^{665}$. Como o orçamento apresentado para 1841-1842 - o maior de todo o período regencial - passou praticamente incólume pela Assembléia, apesar de a Comissão da Câmara dos Deputados ter mais uma vez tentado diminuí-lo por não achar o gasto "indispensável" ${ }^{666}$, foi possível, pela primeira

\footnotetext{
Nacional, 1863, parte 1, p. 10-11.

664 ARQUIVO NACIONAL, Rio de Janeiro. Fundo Casa Real e Imperial, cx. 13, pc. 1 , doc. 60 , fl. 2 .

665 "Incumbências há mal remuneradas na Capela, e a dos Organistas merece aqui ser enumerada; sem o vencimento de quinhentos mil réis ânuos não serão compensados aqueles operários do serviço, que prestam. Por esplendor do culto, e por uma louvável efusão do espírito devoto, é geralmente a celebração dos Ofícios Santos da Religião acompanhada de Cânticos sonoros, e acordes instrumentos; assim costuma a piedade enunciar-se! Nossos Monarcas imprimiram nos atos da Capela Imperial esse caracter de solenidade externa, que igualmente exprimia o fervor, de que eram incendidos; mas com o andar dos tempos tem diminuído nesta parte o esplendor; e os hinos, que se entoam ao Altíssimo, ressentem-se de uma simplicidade menos edificante. Habilitai pois o Governo a restituir ao Grande Templo da Capital do Império a majestade do seu antigo culto, convencidos, como vos considero, de que o fumo do incenso, que elevardes ao Todo Poderoso, muito contribuíra para dissipar as impuridades de nossa moral publica" (RELATÓRIO apresentado à Assembléia Geral Legislativa na Sessão Ordinária de 1840, pelo Ministro e Secretário de Estado dos Negócios da Justiça Francisco Ramiro de Assis Coelho. Rio de Janeiro: Na Tipografia Nacional, 1840, p. 29).

${ }_{666} \mathrm{Na}$ sessão de 23 de junho de 1840 , a Comissão do Orçamento da Câmara reduzia para sessenta contos de réis a verba de 63:113\$900 pedida pelo Ministério da Justiça para a Capela, por entender que naquela circunstância se deveria restringir a despesa ao que fosse "absolutamente indispensável"; e portanto, "que não conviria dar toda a quantia pedida para reparos e melhoramentos da Capela Imperial" (ANAIS do
} 
vez, desde a Coroação de Dom João VI, em 1818, que integrantes do serviço musical da Capela percebessem um aumento em seus ordenados. Não ocorreu, no entanto, durante o restante do ano financeiro de 1840-1841, nenhuma mudança substantiva no efetivo musical da Capela, nem mesmo após a aclamação da Maioridade de Dom Pedro II. A partir daí, apenas em dia de grande gala, o serviço musical, como já vimos, contou com a contratação esporádica de músicos extras, sobretudo instrumentistas.

Apesar das adversidades, como a continuação da guerra no Sul, o fim do período regencial e o início das preparações para a coroação de Dom Pedro II fizeram entrar definitivamente na pauta das discussões políticas o aumento dos gastos públicos com o luxo imperial ${ }^{667}$. Já em 1840, a Assembléia, após longas discussões, assinava nova dotação ao Imperador, elevando-a em quatro vezes, para a considerável quantia de oitocentos contos de réis ${ }^{668}$. A lei, no entanto, nos mesmos moldes da anterior, de 1827 ,

Parlamento brasileiro. Câmara dos Srs. Deputados. Terceiro ano da quarta legislatura. Rio de Janeiro: Tipografia de viúva Pinto \& Filho, 1884, t. 1, p. 826).

${ }_{667}$ Assim se dirigia o então Ministro do Império Cândido José de Araújo Viana futuro Visconde e Marquês de Sapucaí - à Assembléia Geral a respeito dos gastos extraordinários necessários à Coroação de Dom Pedro II: "A pompa, com que deve proceder-se nesta Cerimonia festiva, e majestosa, requer despesas extraordinárias, diante das quais não esmoreceu o Governo, confiado em vosso patriotismo, e esperançado de que serão por vós aprovadas. A regra que o Governo tem prescrito a si mesmo, como parte do programa Administrativo, que adotara, de guardar severa economia não é por certo violada, quando a despesa, que decreta, é destinada a rodear o Trono de esplendor; condição essencial do Sistema, que abraçamos, e numa época singular na vida do Monarca" (RELATÓRIO apresentado à Assembléia Geral Legislativa na Sessão Ordinária de 1841, pelo Ministro e Secretário de Estado dos Negócios do Império Cândido José de Araújo Viana. Rio de Janeiro: Na Tipografia Nacional, 1841, p. 3-4).

${ }_{668}$ O projeto de dotação foi apresentado pelo deputado paulista Álvares Machado no dia seguinte à aclamação da Maioridade de Dom Pedro II, ou seja, a 24 de julho de 1840. Essa proposta apresentava, inicialmente, uma dotação de quinhentos contos de réis. Alguns dias depois, a Comissão do Orçamento da Câmara apresentou emenda ao projeto aumentando a dotação para 730 contos de réis. Houve ainda outras propostas: de seiscentos contos de réis, de Montezuma, e oitocentos contos de réis, de Coelho Bastos. O discurso do Deputado Carneiro da Cunha na sessão de 4 de agosto, defendendo a quantia menor demonstra a preocupação com o equilíbrio das contas em um momento delicado das finanças públicas. Outros deputados, no entanto, como Lopes Gama, trazendo à discussão a quantia de mil contos de réis que já se dera a Dom Pedro I, votam pela maior, desejando "a manutenção, o esplendor, o prestígio a glória do trono brasileiro". Posta em votação no dia seguinte, foi aprovada "por grande maioria de votos" a dotação de 800:000\$000. Discutidos outros pontos e passando pelo Senado, o decreto subiu à sanção imperial a 28 de agosto de 1840 (Cf. ANAIS do Parlamento brasileiro. Câmara dos Srs. Deputados. Terceiro ano da quarta legislatura. Rio de Janeiro: Tipografia de viúva Pinto \& Filho, 1884, t. 2, p. $356-503)$. 
excluía dessa consignação, os gastos com a manutenção da Capela imperial $^{669}$. Esta continuaria dependente de um orçamento ânuo, variável ao sabor das circunstâncias políticas e econômicas.

Algum tempo após assumir o Ministério da Justiça, em março de 1841 - e portanto a poucos meses da Coroação — o futuro Visconde do Uruguai, Paulino José Soares de Sousa, apresentava à Câmara a situação da Capela Imperial. Justificando uma consignação de quarenta contos de réis a mais no orçamento a ser votado naquele ano, Paulino dizia que o seu estado era "o mais lastimoso", sendo-Ihe precisas "várias obras", como o assoalhamento, a reparação do teto da sacristia e a reconstituição do corredor por detrás do trono, cuja parede pendia, ameaçando ruína. O estado dos seus paramentos também era tido como "o mais deplorável” e o da armação "vergonhoso". Por fim o Ministro ainda fez menção ao serviço musical:

O Coro dos Músicos sente grande falta; porém não insistirei por ora sobre este ponto por me parecer que primeiro que tudo, cumpre reparar a Capela, e provê-la de paramentos, o que terá de absorver avultadas quantias ${ }^{670}$.

Ou seja, nem a maioridade de Dom Pedro Il e a sua iminente coroação seriam suficientes para concretizar o sonho de Monsenhor Fidalgo - e de muitos músicos - de ver renovado o coro e reestruturada a orquestra da Capela. Depois de dez anos de privações, eram tantas e prementes as necessidades materiais da Catedral que a situação do seu efetivo musical, prejudicada desde 1831, foi por mais algum tempo posta de lado. A verba ordinária continuaria na casa dos dez contos de réis, para uma configuração de 24 músicos, dois organistas e dois mestres-de-capela ${ }^{671}$.

${ }^{669}$ COLEÇÃO das Leis do Império do Brasil de 1840. Rio de Janeiro: Tipografia Nacional, 1863, parte 1, p. 37-38.

${ }^{670}$ RELATÓRIO da Repartição dos Negócios da Justiça apresentado à Assembléia Geral Legislativa na Sessão Ordinária de 1841, pelo respectivo Ministro e Secretário de

Estado Paulino José Soares de Sousa. Rio de Janeiro: Na Tipografia Nacional, 1841, p. 40.
671 ARQUIVO NACIONAL, Rio de Janeiro. Fundo Casa Real e Imperial, cx. 13, pc. 2, doc. 3, fl. 2. 
Como se não bastassem as múltiplas necessidades da Capela, tornavam ainda mais distante esse sonho de reestruturação musical, o pesado aumento da dotação imperial e a conjuntura ainda bastante desfavorável das finanças públicas, que obrigaram inclusive o Ministério da Fazenda a realizar novo empréstimo em setembro de 1840. Apesar da ampla defesa do Orçamento realizada pelo Governo, dos $101: 511 \$ 200^{672}$ previstos pelo Ministério da Justiça para a Capela no exercício de 1842-1843, apenas $78: 711 \$ \$ 000$ foram devidamente aprovados pela lei de 30 de novembro de $1841^{673}$. Os cortes, mais uma vez, emanaram do "Soberano". Ainda assim, já seria possível aumentar a despesa total com a música na Capela para cerca de treze contos de réis, dos quais 6:090\$700 correspondiam aos gastos ordinários com dezesseis cantores e três instrumentistas ${ }^{674}$. Com um pouco mais, em 1843-1844 - 15:423\$304 —, foi possível finalmente reestruturar, em meados de 1843, a orquestra e aumentar o conjunto de músicos efetivos para 53 integrantes: dois mestres de capela, 21 cantores, 28 instrumentistas e 2 organistas ${ }^{675}$.

Paralelamente às incursões constantes contra as despesas que não fossem "absolutamente indispensáveis", a Câmara dos Deputados foi, também, durante o período regencial - e sobretudo nos primeiros anos subseqüentes à revolução de 7 de abril de 1831 — um baluarte da crítica ao Governo anterior. Antes mesmo da Abdicação, a Sessão de 1830,

${ }^{672}$ PROPOSTA e relatório apresentados à Assembléia Geral Legislativa na Sessão Ordinária de 1841, pelo Ministro e Secretário de Estado dos Negócios da Fazenda Miguel Calmon du Pin e Almeida. Rio de Janeiro: Tipografia Nacional, 1841, p. 5.

673 COLEÇÃO das Leis do Império do Brasil de 1841. Rio de Janeiro: Tipografia Nacional, 1842 , parte 1, p. 75

${ }^{674}$ ARQUIVO NACIONAL, Rio de Janeiro. Fundo Casa Real e Imperial, cx. 13, pc. 2, doc. 44. Esse documento, uma lista dos músicos que existiam na Capela, em setembro de 1842, nos permite saber que, embora o grupo de músicos efetivos tivesse diminuído, alguns de seus salários haviam sido aumentados. Isso pôde ter lugar provavelmente pelo falecimento, do castrato João Francisco Fasciotti, que sozinho consumia um salário de $745 \$ 000$ mais extras (Fasciotti morreu em meados de outubro de 1840, como atesta o Jornal do comércio do dia 15 desse mês, anunciando o seu enterro na Igreja dos religiosos de Santo Antônio). O cantor Francisco da Luz Pinto que, por exemplo, ganhava, por ano, $193 \$ 000$ em 1828 (Vide nota 212 da primeira parte), à essa época já percebia $300 \$ 000$ anuais. João dos Reis Pereira, no entanto, continuava a receber o mesmo ordenado de 1828: $521 \$ 800$.

${ }^{675}$ ARQUIVO NACIONAL, Rio de Janeiro. Fundo Casa Real e Imperial, cx. 13, pc. 
inaugurando a Segunda Legislatura, já demonstrava que viera para sofrear definitivamente os abusos de Dom Pedro I em diversas áreas da administração pública. Uma das propostas apresentadas nesse ano legislativo, mais precisamente na sessão do dia 27 de setembro, foi o projeto de lei do Deputado José Custódio Dias que proibia as loterias "debaixo de qualquer pretexto" 676 .

Desde a vinda da família real para o Rio de Janeiro, em 1808, esse jogo de azar já havia sido diversas vezes autorizado por meio de alvarás e decretos com o intuito de financiar obras, a princípio, de interesse público, sem, no entanto, onerar a sociedade com mais impostos ${ }^{677}$. A população, interessada em lucrar com os diversos prêmios distribuídos por cerca de $1 / 3$ do total de bilhetes, concorria livremente para formar um montante normalmente de cem a duzentos contos de réis - do qual $12 \%$ seriam, então, destinados ao seu fim. Na maior parte das vezes, os beneficiários das loterias eram estabelecimentos pios ligados à Igreja, como as santas casas de misericórdia e os seminários. Em outros casos, as próprias paróquias eram favorecidas para a construção e reforma de seus templos. Houve, no entanto, durante o reinado de Dom Pedro I, concessões suspeitas de loterias em benefício de particulares, como, por exemplo, as fábricas de estamparia e de papel do sítio de Andaraí, de propriedade do negociante Joaquim José da Silva. Esse recebera, a 26 de julho de 1826, direito de explorar o lucro de dez loterias de 120 contos de réis para "conservação e melhoramento" do seu negócio ${ }^{678}$. Outro estabelecimento particular diversas vezes beneficiado com a concessão de loterias foi, como já vimos, o Real Teatro de São João, posteriormente Imperial Teatro de São Pedro de Alcântara, que, até 1829, pertenceu ao Coronel Fernando José de Almeida e, depois da sua morte,

\footnotetext{
2, doc. 77.

${ }^{676}$ ANAIS do Parlamento brasileiro. Câmara dos Srs. Deputados. Terceiro ano da quarta legislatura. Rio de Janeiro: Tipografia de H. J. Pinto, 1878, t. 2, p. 563.

677 Vide e. g. o Decreto de 28 de maio de 1810, que concedeu a Fernando José de Almeida seis loterias para a construção do Real Teatro de São João (nota 229 da primeira parte).

${ }^{678}$ COLEÇÃO das Leis do Império do Brasil de 1826. Rio de Janeiro: Tipografia Nacional, 1880, parte 2, p. 61.
} 
passou a ser gerido por um grupo de acionistas do qual faziam parte o próprio Imperador e alguns de seus mais fiéis amigos ${ }^{679}$. Foi, sem dúvida, esse obscuro favorecimento estatal a particulares que motivou a apresentação, em 1830, na Câmara, de um projeto de lei que proibisse as loterias $^{680}$. A gota d'água deve ter sido, muito provavelmente, a concessão de quatro delas "em socorro" aos emigrados portugueses fugidos do absolutismo de Dom Miguel, que Dom Pedro I decretou a 22 de dezembro de 1829 para serem extraídas antes de "quaisquer outras já concedidas" ${ }^{681}$, numa época em que a promiscuidade entre o Governo brasileiro e os interesses de Portugal e de seus cidadãos aqui residentes já era vista com muita desconfiança e ódio pela maioria da população nativa ${ }^{682}$.

O autor do projeto, José Custódio Dias, que havia sido Deputado por

${ }^{679}$ Vide nota 64 desta parte.

${ }^{680}$ Nos Anais da Câmara dos Deputados, não permaneceu, infelizmente, nenhuma discussão sobre esse projeto. É pela discussão realizada no Senado, já em 1831, que podemos ter a idéia de que o interesse maior dos parlamentares em aprovar tal projeto estava mais relacionado ao abuso com que o Governo havia concedido loterias a particulares do que qualquer outro argumento, como a própria imoralidade do jogo em si, idéia apresentada pelo Marquês de Barbacena. Eis, por exemplo, o discurso do Senador Luiz José de Oliveira Mendes - futuro Barão de Monte Santo - em favor do projeto, proferido na sessão de 18 de maio de 1831: "O que eu sinto é que esta lei não possa ter efeito retroativo, porque vejo loterias concedidas para uma fábrica de papel, que nada tem feito, para a fábrica das chitas, que creio nenhum andamento tem tido; para o Teatro, que cada vez está mais empenhado etc., e o povo incauto tem concorrido com grossas somas, que não podem deixar de lhe ser pesadas, e o benefício é destes que têm obtido tão abusivas concessões; mas passe a lei, para evitar o mal futuro, já que o passado se não pode remediar" (ANAIS do Senado do Império do Brasil. Segunda Sessão da Primeira Legislatura. Rio de Janeiro, 1914, t. 1, p. 161). Na sessão de 26 de maio de 1831, outros Senadores ainda fariam pronunciamentos semelhantes. Manoel Caetano de Almeida e Albuquerque, por exemplo, criticou com veemência o excesso de loterias dadas ao Teatro de São Pedro de Alcântara: "Há algumas loterias concedidas sem motivo, que justifique a concessão; porque só para o Teatro se contam duas, ou três, com duas, ou três aplicações diferentes; e quem come esse dinheiro? Talvez seja alguém que por nenhum título o mereça. Estes abusos são de um efeito mais terrível do que muitas pessoas julgam, e eu desejava desde já vê-los cortados..." (Idem, p. 222).

681 "Sendo incompatível com os sentimentos de humanidade, e com o brio e honra nacional, que se deixem perecer à míngua os emigrados portugueses, que recorrendo a este Império, procuraram nele um asilo: E reconhecendo-se a mais urgente necessidade de se Ihes prestar um pronto socorro, sem prejuízo das rendas nacionais, que não devem distrair-se do destino legal, a que se acham aplicadas: Hei por bem, enquanto a Assembléia Geral Legislativa não providenciar a este respeito, conceder a extração de quatro loterias, do capital de cem contos de réis cada uma, para deles se deduzirem doze por cento a beneficio dos referidos emigrados; preferindo-se a extração destas a quaisquer outras já concedidas..." (COLEÇÃO das Leis do Império do Brasil de 1829. Rio de Janeiro: Tipografia Nacional, 1877, parte 2, p. 327). 
Minas na Constituinte de 1823 e na Primeira Legislatura (1826-1829), pertencia ao grupo de parlamentares que mais cedo exerceu oposição aberta a Dom Pedro I. Em seus discursos e apartes - considerados por Robert Walsh "às vezes, os mais violentos" da Câmara -, esse "franzino pardo de nervosa vivacidade de modos", que vestia uma "desbotada batina de lã preta" e "jamais havia saído do Brasil" 683 , defendia com radicalismo suas idéias liberais e nativistas, tratadas de "subversivas" por governistas, como o "adotivo" José Clemente Pereira ${ }^{684}$. Já em 1827, ano em que a maioria dos Deputados ainda demonstrava subserviência ao monarca, aprovando, por exemplo, a desmedida dotação de mil contos de réis para a Casa Imperial, foi Custódio Dias um severo crítico do servilismo de seus pares, acusando-os, veladamente, àquela ocasião, de "aduladores" daquele que, na sua visão liberal, não passava de um mero "cidadão" para quem a nação dera "parte de sua soberania"685.

Não é, portanto, de se estranhar, que da pena desse padre tivesse saído um projeto de lei que afrontava o Imperador, cerceando os seus poderes e deixando a sua menina-dos-olhos, o Teatro de São Pedro de Alcântara, sem uma de suas principais fontes de financiamento. Dado o estado de descrédito do Governo perante a opinião pública e a conseqüente e forte oposição formada na Câmara dos Deputados, o projeto não demorou muito mais do que um mês para tramitar nessa casa e ser aprovado a 3 de novembro de 1830. Enviado ao Senado, acabaria ali passando apenas após a Abdicação, na sessão de 26 de maio de 1831. O possível veto imperial a essa matéria não seria, pois, um empecilho. Subindo à sanção da Regência provisória, a 6 de junho, o Ministro da Justiça, Manoel José de Sousa França, fez imprimir, publicar e correr a nova Lei — talvez uma das mais lacônicas de

${ }^{682}$ Sobre esse assunto, vide nota 14 da introdução.

683 "Custodio Dias (...) a thin brown man, with sharp prominent features, of a nervous quickness of manner; (...) He dresses in a frock of rusty black stuff (...). He told me, he never was out of Brazil (...) He is one of the most constant speakers in the chamber, and sometimes the most violent" (WALSH, Robert. Op. cit., v. 2, p. 431).

${ }^{684}$ ANAIS do Parlamento brasileiro. Câmara dos Srs. Deputados. Quarto ano da primeira legislatura. Rio de Janeiro: Tipografia de H. J. Pinto, 1877, t. 1, p. 25.

${ }^{685}$ ANAIS do Parlamento brasileiro. Câmara dos Srs. Deputados. Segundo ano da 
todo o Império - que assim mandava em seu artigo único: "Fica proibido a concessão de loterias".

Tal ordenamento caiu, certamente, como um raio sobre a administração do Teatro de São Pedro de Alcântara. Renomeado, àquela mesma semana, "Teatro Constitucional Fluminense", esse estabelecimento tentava reorganizar-se diante da ausência de seu principal protetor e de uma situação de segurança pública precária - da qual trataremos mais adiante que ajudou a afugentar parte de seu público fiel. Até então movida por esse público, e pelo lucro das constantes extrações lotéricas concedidas por Dom Pedro I, essa casa passaria a ter ainda mais dificuldades para manter-se em pleno funcionamento, investindo em espetáculos dispendiosos, como as óperas. Sem o crédito fácil do Banco do Brasil, desde 1829, e, agora, sem as loterias, vinte dias após a publicação da Lei, a Sociedade Teatral dirigia-se ao "respeitável público", rogando-Ihe, como nunca, a sua proteção, e, de certa forma, desculpando-se antecipadamente de uma inevitável diminuição na qualidade dos espetáculos:

A Sociedade sem auxílios e entregue tão somente à proteção do respeitável público continuará a apresentar espetáculos novos e compatíveis com as suas diminutas forças ${ }^{686}$.

$\mathrm{Na}$ prática, ao proibir a concessão de loterias, a Assembléia não apenas cerceava uma ação cotidiana e, até então, desregrada do Poder Executivo, como reservava para si o poder de concedê-las a qualquer tempo - ou de permitir que o Governo voltasse a facilitá-las _ , mediante nova lei que revogasse as "disposições em contrário". Isso, no entanto, não se deu durante mais do que quatro anos, a partir de junho de 1831. Até fins de outubro de 1835 , nenhuma loteria foi permitida no Império, além daquelas que já haviam sido concedidas antes de promulgada a Lei. Como essa não tinha efeito retroativo, o Teatro Constitucional Fluminense ainda pôde gozar 
de algumas esparsas extrações atrasadas, entre as quais, as três que lhe haviam sido concedidas pelo decreto de 27 de setembro de 1830 e que acabaram indo à roda apenas entre 1834 e $1835^{687}$.

Foi somente quando os interesses de uma corporação forte como a dos comerciantes do Rio de Janeiro se fizeram patentes, em meados de 1835, que a Câmara resolveu pôr novamente em pauta a questão lotérica, apresentando e discutindo uma resolução que autorizava o Governo a conceder duas extrações desse jogo de azar para a conclusão das obras da Praça do Comércio da corte. As opiniões dos Deputados foram, como sempre, divergentes, e a votação no plenário, apertada, em favor da resolução. Houve quem a achasse despropositada, ao favorecer "homens ricos", como os negociantes do Rio de Janeiro. Na última discussão, realizada a 2 de outubro de 1835, chegou-se até a cogitar que, em passando tal resolução, a Assembléia acabaria obrigando-se, mais cedo ou mais tarde, a fazer outras concessões, como para os teatros, igrejas etc ${ }^{688}$. De fato, a 29 de outubro de 1835, seriam sancionados em lei, não um, mas três decretos da Assembléia nesse sentido, desfazendo-se, de uma vez por todas, o jejum de concessões de loterias ${ }^{689}$. O Teatro Constitucional Fluminense não figurou, entretanto, entre os outros dois beneficiários. Esse só seria lembrado pelos “augustos e digníssimos senhores representantes da nação" em 1837, quando, talvez no auge da sua decadência - em pleno Governo Feijó uma sociedade de acionistas organizou-se com o fim de restaurá-lo e reavivar as suas temporadas. Segundo um documento manuscrito de 1850 , tombado na Biblioteca Nacional, que rememora a ação dessa sociedade em 1837, achava-se o Teatro Constitucional Fluminense "abandonado naquele tempo ao descuido e à ausência absoluta de todos os embelezamentos

${ }^{687}$ Como atestam as notícias do Diário do Rio de Janeiro, as extrações da primeira loteria referente ao decreto de 27 de setembro de 1830 ocorreram entre $1^{\circ}$ e 7 de julho de 1834. A 16 de maio de 1835, o mesmo Diário anunciava a venda de bilhetes da "terceira e última loteria para pagamento das despesas feitas com a sustentação dos espetáculos do Imperial Teatro".

${ }^{688}$ ANAIS do Parlamento brasileiro. Câmara dos Srs. Deputados. Segundo ano da terceira legislatura. Rio de Janeiro: Tipografia de H. J. Pinto, 1875, t. 2, p. 129 e p. 349.

${ }^{689}$ COLEÇÃO das Leis do Império do Brasil de 1835. Rio de Janeiro: Tipografia 
teatrais" ${ }^{690}$. Para garantir ao Teatro, após a reforma, o funcionamento de uma companhia nacional e outra "de cantoria com um corpo de baile", essa sociedade requereu da Assembléia, a concessão de duas loterias anuais ${ }^{691}$. Em maio de 1837, o Jornal dos debates políticos e literários assim noticiava a novidade, tomando-Ihe partido:

Acha-se organizada uma companhia, cujo fim é o elevar o Teatro Constitucional Fluminense de S. Pedro à altura das exigências da nossa civilização, enriquecendo-o com a presença dos melhores artistas estrangeiros, tanto na dança, como nas óperas. O capital reunido para este objeto orça à 30:000\$000 de rs. A sociedade acaba de dirigir à Câmara dos Deputados uma petição para a concessão de duas loterias anuais. Nós cremos que a Câmara dará a devida importância à esta petição; quando tão belas missões têm os Teatros em todas as nações cultas, não deve o Brasil pôr-se fora da linha, negligenciando um tal objeto. Não só no Brasil, como nas nações as mais ricas, a grandeza das empresas de Teatro sobrepujam de muito as forças individuais, e a maior parte dos Governos as animam e mantêm com largos subsídios (...) Todos eles com razão consideram os Teatros, quando bem organizados, como um poderoso instrumento de civilização, como um meio de moralidade, e instrução popular, como uma carreira aberta diante o gênio das artes, e enfim como um meio de prender mais energicamente os cidadãos à pátria, pelos prazeres que realçam a vida social e douram a existência ${ }^{692}$.

A decisão favorável, no entanto - transformada em lei a 30 de

Nacional, 1864, parte 1, p. 91-93.

690 SÁ, José Bernardino de. Requerimento da diretoria do Teatro de São Pedro de Alcântara a S. M. I., descrevendo as dificuldades financeiras por que passava aquele teatro e apresentando as soluções cabíveis à situação. Rio de Janeiro, 23/10/1850 e 13/12/1850. BIBLIOTECA NACIONAL, Rio de Janeiro, Seção de Manuscritos, II-34,25,31.

${ }^{691}$ ANAIS do Parlamento brasileiro. Câmara dos Srs. Deputados. Quarto ano da terceira legislatura. Rio de Janeiro: Tipografia de viúva Pinto \& Filho, 1887, t. 1, p. 112.

692 JORNAL DOS DEBATES POLITICOS E LITERÁRIOS, 27/05/1837. 
novembro de 1837 - não teve um caráter meramente cultural. A concessão desse benefício ao Teatro e outros estabelecimentos fazia parte de mais um "pacote econômico" de medidas políticas visando a diminuir o enorme volume de papel-moeda ainda em circulação no país. Para tanto, foram criados pela lei de 11 de outubro de 1837 dois novos impostos para a amortização do papel de curso forçado, entre os quais, um de $8 \%$ sobre todas as loterias concedidas a partir de então. A lei ainda previa que, quando o número de loterias concedidas fosse menor do que doze a cada ano, o Governo ficaria automaticamente obrigado a completar esse número, deduzindo-se do montante arrecadado para essas extrações sem fim determinado, $20 \%$ - os $12 \%$, tradicionalmente reservados ao benefício, mais os $8 \%$ de imposto - a favor da amortização ${ }^{693}$.

Assim, a partir de 1838, o Teatro voltou a ter duas loterias anuais garantidas, e, em outubro desse ano, fechou suas portas para uma primeira grande reforma, desde a sua reinauguração, em 1826. Como já vimos, no entanto, as loterias sozinhas - embora a sua proibição temporária tenha, com certeza, prejudicado o negócio teatral - não seriam suficientes para que o "São Pedro de Alcântara" se estabilizasse financeiramente e voltasse a contratar uma companhia italiana de ópera. Faltava também a esse estabelecimento, a proteção mecênica que os teatros de ópera do mundo tradicionalmente tiveram desde o surgimento desse gênero musical.

Da Itália para o mundo, a ópera desenvolveu-se no início do século XVII, vinculada exclusivamente aos círculos cortesãos, e financiada, a princípio, pelos soberanos locais, com a finalidade ideológica de exaltar o seu poder forte ${ }^{694}$. Todavia, pouco tempo foi necessário para que esse

${ }^{693}$ COLEÇÃO das Leis do Império do Brasil de 1837. Rio de Janeiro: Tipografia Nacional, 1861, parte 1, p. 81-82.

694 "The first operas were produced under noble auspices. Organizing opera in a house financed and controlled by the local sovereign continued to be the custom in Naples, Turin, Paris, Vienna (until the Napoleonic wars), St. Petersburg, and German capital cities such as Berlin (where Frederick the Great built an opera house in 1742), Dresden, Darmstadt, Stuttgart/Ludwigsburg, Munich, and Mannheim/Schwetzingen. Under this organizational mode, the local king or duke built the opera house with money from the state treasury, appointed an official or committee to manage the program, intervened frequently in artistic decisions to impose his own artistic tastes, and provided generous subsidies to keep 
oneroso espetáculo, um dos símbolos máximos da pompa monárquica, passasse a difundir-se mais largamente nas sociedades - dentro dos teatros públicos $^{695}$ - , ainda que de forma deficitária, bancado quase sempre por uma rica burguesia ou uma elite econômica sem status de nobreza, não apenas interessada em imitar os hábitos de corte, como em realizar atos de cortesia - investir nos espetáculos, participar de uma sociedade de acionistas do teatro e até assumir parte da administração dessas verdadeiras instituições cívicas, instrumentos de civilização e símbolos da monarquia —, passíveis de ser recompensados com títulos e insígnias de ordens militares ou religiosas, enfim, símbolos do ingresso no convívio com o monarca, e na administração da coisa pública.

No Rio de Janeiro, não foi diferente. Como já vimos, desde antes dos tempos dos Vice-Reis, os "homens de negócio" já concorriam "com mão larga" obsequiando óperas ao monarca e a seus principais representantes na colônia - como ocorreu em 1762, no nascimento do Príncipe da Beira certamente em vista de reconhecimento e, conseqüentemente, de um penduricalho e privilégios políticos. Com a vinda do Príncipe Regente, Dom João, ao Brasil, essa "troca"696 cresceu consideravelmente, haja vista as

the costly enterprise afloat. In some cases admission was restricted to members of the court and guests invited by the sovereign..." (SCHERER, Frederic M. Op. cit., p. 41-42). A esse respeito, e mais especificamente sobre as origens da ópera na Itália, ver também BIANCONI, Lorenzo (org). Storia dell'opera italiana: II Sistema produttivo e le sue competenze. Torino: EdT, 1987, v. 4.

695 "As pesadas cargas financeiras indispensáveis à manutenção de uma companhia de ópera permanente podiam ser aliviadas por um outro tipo de tratamento da questão que veio a responder, no século XVII, à demanda de um público mais vasto, formado principalmente pela pequena nobreza, e que seguia uma fórmula menos onerosa: a ópera suntuosa foi transformada em espetáculo público e pago, aberto a todos, sem exceção, com a condição de pagar a entrada e assistir ao espetáculo convenientemente vestido, o que, evidentemente, não era viável para todos. A ópera paga, comercializada, solicitada pela ampliação de um público interessado, foi criada em Veneza em 1637, no Teatro di San Cassiano. O exemplo foi seguido em Londres, em 1639, por William d'Avenant; em Paris, em 1669, por Cambert e Perrin; e em outras cidades, como Hamburgo (1687) e Nápoles. Essas iniciativas eram apoiadas por burgueses ricos, desejosos também de ir ao espetáculo" (SUPICIC, Ivo. Situação sócio-histórica da música no século XVII. In: MASSIN, Jean (org.). Op. cit., p. 321). Note-se que, com o tempo - e sobretudo durante o século XVIII — os espetáculos de ópera nos teatros públicos passaram a contar cada vez mais com a presença dos soberanos, tornando-se, enfim, o rico espaço de sociabilidades do qual já falamos anteriormente.

${ }^{696}$ Como bem analisou Théo Lobarinhas Piñeiro, "o dinheiro desses Negociantes era extremamente bem-vindo à Coroa, que dele muito necessitava. (...) É verdade que 
enormes somas que, após 1808, o Real Erário recebeu das elites econômicas cariocas e a profusão de ordens honoríficas e títulos nobiliárquicos concedidos, a partir da mesma época. Somente em relação às Ordens de Cristo, de São Bento de Avis e de São Tiago da Espada, foram distribuídas, durante a permanência de Dom João no Rio de Janeiro, de 1808 a 1821 , 5.610 condecorações: 4.998 ordens de cavalaria, 591 comendas e 21 grãocruzes $^{697}$, essas últimas, normalmente concedidas apenas a grandes titulares, ministros, generais ou bispos ${ }^{698}$. Baronatos, foram catorze, nesse mesmo período ${ }^{699}$. No primeiro reinado, então, não somente aumentaram as oportunidades de nobilitação ${ }^{700}$, como, proporcionalmente ao tempo de

gastaram muito dinheiro em favores e doações, mas tal dinheiro voltava sob a forma de vantagens e bons negócios; de propriedades e privilégios" (Cf. PIÑEIRO, Théo Lobarinhas. A Construção da Autonomia: o Corpo de Commercio do Rio de Janeiro. In: V CONGRESSO BRASILEIRO DE HISTÓRIA ECONÔMICA E $6^{\text {a }}$ CONFERÊNCIA INTERNACIONAL DE HISTÓRIA DE EMPRESAS, 2003, Caxambu (MG). Anais Eletrônicos do $V$ Congresso Brasileiro de História Econômica e $6^{a}$ Conferência Internacional de História de Empresas. Caxambu: Associação Brasileira de Pesquisadores em História Econômica, 2003). Foi certamente 0 abuso de privilégios e vantagens concedidos a esses "beneméritos", resultando em inevitáveis casos de corrupção governamental, que criou, com o tempo, um curioso estigma nesses que também eram agraciados por títulos e condecorações. Ao invés de serem tratados como heróis, acabaram vilipendiados, tidos como "inimigos da pátria", "sevandijas", "réus de alta traição" e outros depreciativos, como ainda veremos adiante, em alguns discursos, transcritos dos Anais da Câmara dos Deputados.

697 POLIANO, Luiz Marques. Ordens honoríficas do Brasil: história, organização, padrões, legislação. Rio de Janeiro: Imprensa Nacional, 1943, p. 103 (Cf. PINHEIRO, Artidoro Augusto Xavier. Organização das ordens honoríficas do Império do Brasil. São Paulo: Tip. a Vapor de Jorge Seckler, 1884).

${ }^{698}$ Nos tempos de Dom João, eram principais insígnias de nobreza no Reino, três condecorações (de cinco qualidades, a partir de 1818), e cinco títulos. As condecorações das Ordens de Nossa Senhora da Conceição de Vila Viçosa, da Torre e Espada, de Cristo, de São Bento de Avis e de São Tiago da Espada, tinham três graus: cavaleiro, comendador e grão-cruz. Já, os títulos de nobreza hierarquizavam-se na seguinte ordem de titulares: barão, visconde, conde, marquês e duque. Em 1811, de acordo com o Almanaque do Rio de Janeiro, havia, nessa nova corte, 29 titulares, a saber: Aguiar (Conde), Agrado (Viscondessa), Alegrete (Marquês), Angeja (Marquês), Andaluz (Barão), Arcos (Conde), Belas (Marquês) Belmonte (Conde), Cadaval (Duque), Caparica (Conde), Cavaleiros (Conde), Condeixa (Barão), Figueira (Conde), Galveas (Conde), Lavradio (Marquês), Linhares (Conde), Lumiares (Marquesa), Majé (Barão), Palma (Conde), Pombal (Marquês), Pombeiro (Condessa), Ponte (Conde), Redondo (Conde), São Miguel (Marquesa), Torres Novas (Marquês), Vagos (Marquês), Valadares (Conde), Viana (Conde) e Vila Nova da Rainha (Visconde) (ALMANAQUE da cidade do Rio de Janeiro para o ano de 1811. Revista do Instituto Histórico e Geográfico Brasileiro. Rio de Janeiro, v. 282, p. 116-119, 1969).

${ }^{699}$ ANUÁRIO do Museu Imperial. Rio de Janeiro, v. 6, p. 9-10, 1945.

${ }^{700}$ Com a proclamação da Independência, Dom Pedro I ampliou as possibilidades de nobilitação. Manteve as ordens portuguesas de Cristo, de São Tiago da Espada e de São Bento de Avis, estabeleceu que baronatos e viscondados poderiam ser de dois tipos (com ou sem honras de grandeza) e, ao longo do seu reinado, criou três novas ordens 
governo, as concessões de hábitos e títulos. Em menos de nove anos, Dom Pedro I outorgou 4.592 condecorações, entre ordens de cavalaria e grãocruzes $^{701}$. Quanto aos títulos, foram criados mais de cem, entre baronatos, viscondados, condados, marquesados e ducados ${ }^{702}$.

Caso dos mais bem sucedidos de cortesia ligada à escalada nobiliárquica, tanto no governo de Dom João como no de Dom Pedro I, foi o de Joaquim José de Azevedo (1761-1835) ${ }^{703}$, uma das éminences grises do período, beneficiário de diversos cargos e privilégios, e nome muitas vezes envolvido em suspeitas de corrupção ${ }^{704}$. Do grau de cavaleiro, recebido a 5

honoríficas: a do Cruzeiro, em 1822, a de Dom Pedro I, em 1826, e a da Rosa, em 1829. A Ordem do Cruzeiro tinha quatro graus: cavaleiro, oficial, dignitário e grão-cruz; a de Dom Pedro I, três: cavaleiro, comendador e grão-cruz; e a da Rosa, seis: cavaleiro, oficial, comendador, dignitário, grande dignitário e grão-cruz. Em 1829, de acordo com o Almanaque imperial do comércio, havia, no Império, 68 titulares, a saber: Alcântara (Visconde), Aracati (Marquês), Baipendi (Marquês), Baipendi (Visconde), Bajé (Barão), Barbacena (Marquês), Cachoeira (Visconde), Caeté (Visconde), Camamu (Visconde), Cantagalo (Marquês), Caravelas (Marquês), Carreira (Barão), Cairu (Visconde), Congonhas do Campo (Visconde), Cunha (Marquês), Jericinó (Visconde), Jacarepaguá (Marquês), Jagaripe (Barão), Inhambupe (Marquês), Inhomirim (Barão), Itabaiana (Visconde), Itanhaém (Marquês), Itapagipe (Condessa), Itaparica (Barão), Itapicuru de Cima (Barão), Itapuã (Barão), Itapororoca (Barão), Jundiaí (Marquês), Lajes (Conde), Laguna (Visconde), Macaé (Barão), Maceió (Marquês), Maragojipe (Barão), Maranhão (Marquês), Maricá (Marquês), Mirandela (Visconde), Paranaguá (Marquês), Parnaíba (Barão), Pedra Branca (Visconde), Pelotas (Visconde), Pirajá (Barão), Queluz (Marquês), Quixeramobi (Marquês), Recife (Marquês), Resende (Marquês), Rio das Contas (Barão), Rio da Prata (Barão), Rio de São Francisco (Barão), Rio Pardo (Conde), Santo Amaro (Marquês), Santos (Marquesa), Saúde (Barão), São João das duas Barras (Conde), São João Marcos (Marquês), São João da Palma (Marquês), São Leopoldo (Visconde), São Salvador dos Campos (Baronesa), São Simão (Conde), Sorocaba (Barão), Souzel (Conde), Taguaí (Marquesa), Taubaté (Marquês), Torre de Garcia d'Ávila (Visconde), Ubá (Barão), Valença (Conde), Vila Bela (Barão), Vila Nova de São José (Conde) e Vila Real da Praia Grande (Visconde) (ALMANAQUE imperial do comércio e das corporações civis e militares do Império do Brasil. Rio de Janeiro: Em Casa de P. Plancher-Seignot, 1829, p. 34-40). Essa relação não inclui os títulos remanescentes de viúvas de titulares.

${ }_{701}^{70}$ C. POLIANO, Luiz Marques. Op. cit.

${ }^{702}$ Cf. RHEINGANTZ, Carlos G. Op. cit.

${ }^{703}$ Eis algumas das graças que Joaquim José de Azevedo recebeu: Fidalgo Cavaleiro, Conselheiro, Escrivão dos Filhamentos, Tesoureiro da Casa Real, Senhor de Macaé, Alcaide-Mor de Santos, Comendador de Cristo, da Torre e Espada, do Cruzeiro e da Rosa, Porteiro-Mór, Barão do Rio Seco, Visconde do Rio Seco, Visconde do Rio Seco com honras de grandeza e Marquês de Jundiaí (VASCONCELOS, Rodolfo Smith de Vasconcelos, Barão de. Arquivo nobiliárquico brasileiro. Lausanne: La Concorde, 1918, p. 245-246)

${ }^{704}$ Em carta ao pai, de 29 de fevereiro de 1812, o já mencionado Luís dos Santos Marrocos transcreve uma quadra que circulava, à época, no Rio de Janeiro, referente a possíveis casos de peculato envolvendo Joaquim José de Azevedo e Bento Maria Targini, este último, outro negociante, então Barão de São Lourenço: "Furta Azevedo no Paço, I Targini rouba no Erário; / E o povo aflito carrega / Pesada cruz ao Calvário..." 
de Setembro de 1808, até o título de Marquês de Jundiaí, outorgado a 12 de outubro de 1826, foram inúmeras as ações desse negociante milionário, natural de Leiria, Portugal, em prol da ostentação monárquica ${ }^{705}$. No que diz respeito especificamente à Ópera, Azevedo não apenas encabeçou - com vultosos dois contos de réis - a lista dos acionistas que financiaram a construção do São João entre 1810 e 1813, como subscreveu uma quantia ainda maior - oito contos de réis - , para a compra e arrematação do São Pedro de Alcântara, em 1829 ${ }^{706}$. Em 1832, seu nome também aparecia entre os acionistas, donos de camarotes, do Teatro Constitucional Fluminense ${ }^{707}$.

Ter um lugar cativo no principal teatro da corte, especialmente em um camarote de segunda ordem - ou de "ordem nobre" como também era conhecido -, foi, não apenas no Rio de Janeiro, um importante símbolo de status. Desde o surgimento dos teatros públicos, na Itália e, posteriormente, por toda a Europa, negociantes, capitalistas, industriais, em plena ascensão social e sedentos por prestígio, investiram nesse que foi o principal local de encontro da sociedade da época, capaz de envolver, hierarquicamente, em seus diversos espaços de ocupação, do monarca - em seu grande camarote central - aos funcionários públicos subalternos - na platéia.

Comprar um camarote não apenas dava aos seus proprietários a faculdade de usufruir, com segurança, de um local privilegiado para ver e ser visto. Ser "acionista", significava ser também benemérito perante a sociedade, na medida em que, além de participar do capital social do teatro e assinar antecipadamente as temporadas de récitas gerais, em dadas ocasiões - nos benefícios ao Teatro ou a artistas escriturados -, Ihes era facultado pagar duplamente por seus lugares ou ceder graciosamente a sua propriedade para a revenda. Na Itália - berço da ópera e dos teatros

(MARROCOS, Luiz Joaquim dos Santos. Op. cit., v. 56, p. 64, 1934).

${ }^{705}$ Cf. MALERBA, Jurandir. Op. cit., p. 284-292.

706 Vide, mais uma vez, a nota 64 desta parte. É bem verdade que, em 1829, a moeda brasileira havia depreciado muito, sobretudo quanto ao poder de compra de mercadorias importadas. Contudo, oito contos de réis era ainda dinheiro suficiente para manter funcionando por um ano uma orquestra de 30 músicos. Tomamos como base desse cálculo o salário anual médio dos instrumentistas da Capela Imperial, que era de $260 \$ 450$ (Vide lista de músicos e salários, apresentados no primeiro capítulo). 
públicos -, foi praxe, entre os séculos XVIII e XIX, que os empresários de ópera recebessem, como "doação", em récitas extraordinárias, o direito de revender os camarotes cativos, ou de receber dos acionistas somas em espécie pelo uso não ordinário, nessas ocasiões, de seus tradicionais lugares de ocupação ${ }^{708}$. Tratava-se, pois, de um esquema de mecenato, sem o qual, diga-se a propósito, os teatros dificilmente sobreviviam ${ }^{709}$.

No grande teatro do Rio de Janeiro - São João, São Pedro de Alcântara, Constitucional Fluminense, e, por fim, novamente, São Pedro de Alcântara - não foi diferente. Membros de uma elite econômica, em grande parte formada por negociantes ${ }^{710}$ — interessados em ser reconhecidos como "doadores", dignos de honras -, investiram, como já vimos, o seu dinheiro nas obras de 1810-1813 e 1824-1826, adquiriram camarotes, pagaram anualmente as jóias das temporadas de récitas gerais ${ }^{711}$, e, nos dias de

707 JORNAL DO COMÉRCIO, 17/08/1832.

708 "Selon une conception courante en Italie entre le XVIII" et le $\mathrm{XIX}$ " siècle, toute saison théâtrale donnée en adjudication à un impresario comportait une donation. La donation pouvait être une somme en espèces ou un privilège (généralement celui de tenir des jeux et des tombolas); elle pouvait aussi représenter le droit de revendre des loges. La somme en espèces pouvait provenir de la redevance payée par les propriétaires de loges..." (BIANCONI, Lorenzo (org.). Histoire de L'opéra italien. Traduit de l'italien par Bernardette Delcomminette. Liège: Mardaga, 1992, v. 4, p. 96). Note-se que somente nos foi possível ter acesso à tradução francesa da já referida Storia dell'opera italiana, organizada por Lorenzo Bianconi, um dos raros estudos publicados sobre o sistema de produção dos espetáculos operísticos desde o seu surgimento, no século XVII até os nossos dias.

709 "La conclusion était claire: 'L'expérience prouve malheureusement', écrivit en 1825 le spécialiste Carlo Ritorni, que les spectacles d'opera seria 'ne peuvent subsister sans donation'..." (Ibidem, p. 102). Sobre esse assunto, ver também ROSSELLI, John. Opera Industry in Italy From Cimarosa to Verdi: The Role of the Impresario. Cambridge: Cambridge Univ. Press, 1984.

${ }_{110}$ A 17 de agosto de 1832, o Jornal do comércio publicou uma preciosa lista de nomes de acionistas do Teatro Constitucional Fluminense, possivelmente alguns dos mesmos cidadãos que ajudaram Fernando José de Almeida a reconstruir, entre 1824 e 1826, o Teatro incendiado. De forma similar à lista de 1810, de acionistas do Teatro de São João (Vide primeiro capítulo), faziam parte desse novo rol, diversos negociantes, como Antônio José de Brito, Francisco José Guimarães, Frutuoso Luís da Mota, João Pereira de Andrade e Lourenço Antônio do Rego (ALMANAQUE imperial do comércio e das corporações civis e militares do Império do Brasil. Rio de Janeiro: Em Casa de P. PlancherSeignot, 1829, p. 162-169).

${ }^{711} \mathrm{Em}$ relação às jóias dos acionistas, documentação tombada no IHGB demonstra o seu pleno funcionamento. Em 1842, por exemplo, o Senador - e ex-Regente - Pedro de Araújo Lima era convidado pelo então Presidente da Sociedade Teatral, Joaquim Valério Tavares, a participar da assembléia da dita sociedade, o que confirma a sua posição de acionista do Teatro. Ainda assim, no mesmo ano, o então Visconde de Olinda pagou $320 \$ 000$ ao inspetor do São Pedro de Alcântara, José Antônio Tomás Romeiro, pelo uso, por cinqüenta récitas, de seu camarote de segunda ordem (ARQUIVO DO INSTITUTO 
"benefício", em que perdiam temporariamente os seus direitos de propriedade, ou recompravam seus camarotes, ou permitiam a sua venda a outros interessados, incrementando, de qualquer forma, a receita do Teatro.

A partir de abril de 1831, no entanto, essa situação modificou-se diametralmente. Não apenas a família imperial deixou de comparecer com assiduidade às récitas, esvaziando o interesse social pelo evento, como iniciou-se, no Império, um processo de perseguição política aos títulos e demais insígnias de nobreza tão cobiçadas por quem tinha dinheiro mas não tinha nome. O auge de tal encarniçamento se deu com a aprovação, na Câmara dos Deputados, na sessão de 20 de junho de 1831, de um projeto de lei que declarava nulos todos os títulos e ordens militares portuguesas concedidas depois de proclamada a Independência do Brasil.

Argumentavam alguns deputados favoráveis à medida que o artigo $102 \S 11$ da Constituição permitira ao Poder Executivo "conceder" títulos, ordens etc. e não "criá-los", uma vez que a própria Carta de Lei não designava que títulos e ordens eram esses. A idéia, portanto, era a de que tais honrarias dependiam de lei regulamentar, decretada pela Assembléia, o que nunca fora realizado. Nesse polêmico dia, destacaram-se mais uma vez os discursos de alguns dos mais eminentes membros da antiga oposição a Dom Pedro I, como o de Bernardo Pereira de Vasconcelos:

Está reconhecido que o direito de conceder títulos, sendo uma das atribuições do Poder Executivo forma artigo constitucional; mas temse igualmente reconhecido que não havendo lei para os criar foram nulamente conferidos pelo mesmo Poder Executivo. Sou também deste parecer (...) Eu entendo que a Assembléia pode declarar nulos esses títulos. visto achar-se autorizada a reformar todos os abusos da administração passada. Na Constituição muito expressamente se declarou ( $\S 6^{\circ}$ do art. 15) que na vacância do trono ou por morte do Imperador se instituirá exame da administração passada, e

HISTÓRICO E GEOGRÁFICO BRASILEIRO, Coleção Marquês de Olinda, Lata 214, pasta 49). 
que se reformarão os abusos nela introduzidos. Em que consiste o desempenho deste encargo da Constituição? Em acusar o Ministério? Não. Mas em declarar que não tem vigor tudo quanto foi feito por abuso. Conseguintemente, a Assembléia, nas circunstâncias em que se acha, tem autoridade para declarar nulos os títulos, ordens militares, condecorações etc., por isso não ha inconstitucionalidade no projeto de lei, e voto, a favor dele porque entendo que a Assembléia agora tem este direito ${ }^{712}$.

O orador mais inflamado em favor do projeto, recebendo, apoio geral do plenário, foi, no entanto, o Deputado maranhense Manuel Odorico Mendes:

Não tenho receio, como um ilustre deputado, de que a nossa gloriosa revolução não vá adiante por causa dos queixumes e pranto amargo dos titulares (muitos apoiados) que houverem de ser destituídos de seus títulos, principalmente quando considero que a maior parte deles são réus de alta traição, e que têm levado a nação ao precipício pelo lado das finanças. (Apoiados.) Entretanto, quero ver se respondo a alguns argumentos de um $\mathrm{Sr}$. deputado que mais tomou a peito a defesa destas góticas instituições. Disse ele que não faria mal que houvessem [sic] estes títulos, porque eles nada valiam, e por conseqüência não fora justo tirá-los; porém o Sr. deputado esquece-se de que o povo ou massa da nação, por mais ilustrada que seja, esta não é composta de homens instruídos e que tenham juízo, os quais nenhum caso fazem de tais distinções e títulos; mas para os ignorantes e que não têm juízo valem alguma coisa; há até velhacos que procuram persuadir ao povo que elas têm algum valor; pois nós vemos que uma parte da representação nacional se prevalece destas idéias para chamar-se representante da parte da nobreza. Com o objeto de evitar que se procure iludir o povo é que eu voto contra os

${ }^{712}$ ANAIS do Parlamento brasileiro. Câmara dos Srs. Deputados. Segundo ano da segunda legislatura. Rio de Janeiro: Tipografia de H. J. Pinto, 1878, t. 1, p. 163. 
títulos. (...) Demais creio que todo o Brasil quer esta reforma. Se há alguém a quem ela não agrade ou a quem incomode, seria poucos, porque os titulares que mais merecem sê-lo são aqueles que não fazem caso de semelhantes títulos (apoiados), e os outros os estimam porque não tendo qualidades que os distingam querem figurar como os pavões pelas cores. (Muitos apoiados) $^{713}$.

Apesar de supostamente querido por "todo o Brasil" - como cria o Deputado Odorico Mendes - e aprovado ainda com uma emenda que ampliava a extinção das condecorações à Ordem Imperial do Cruzeiro, este projeto acabou, no entanto, engavetado pelo Senado, onde se achavam assentados, muitos dos titulares ou detentores dos mais altos graus das ordens honoríficas ${ }^{714}$. Àquela época, subia, no entanto, à sanção da Regência - embora dela não necessitasse para viger - , um outro decreto legislativo, a já mencionada Lei de 14 de junho de 1831, que veio a marcar os limites dos poderes regenciais. Entre as ações defesas, impostas ao Executivo por tal mandado, figurava a proibição de se "conceder títulos, honras, ordens militares e distinções" ${ }^{715}$. Na Câmara dos Deputados, onde o projeto da "Lei da Regência" nasceu - pelas mãos de Honório Hermeto, Costa Carvalho e Paula Sousa - discutiu-se longamente essa idéia. O discurso, resumido pela taquigrafia, do baiano Paula Araújo, apoiando a emenda vencedora do Deputado pernambucano Ernesto Ferreira França, ilustra bem o momentâneo sentimento de repulsa às "tetéias", como assim eram conhecidas as insígnias

\footnotetext{
${ }^{713}$ Idem, p. 165.

${ }^{714} \mathrm{Em} 1832$ - ano em que o polêmico projeto de extinção dos títulos de nobreza acabou "esquecido" diante de toda a crise de poderes que se instaurou entre a Câmara e o Senado em torno de uma ampla reforma constitucional, que não saiu, senão muito parcialmente, em 1834, com o Ato Adicional - faziam quorum nessa última casa os seguintes titulares: Marquês de Inhambupe, Visconde do Rio Vermelho, Conde de Valença, Marquês de Barbacena, Visconde de São Leopoldo, Marquês de Jacarepaguá, Marquês de Paranaguá, Marquês de Aracati, Visconde de Alcântara, Marquês de Queluz, Conde de Lajes, Visconde de Cairu, Marquês de Santo Amaro, Marquês de Caravelas, Visconde de Caeté, Visconde de Congonhas do Campo, Marquês de Maricá, Marquês de São João da Palma, Barão de Itapuã, Marquês de Baependi e Marquês de Santo Amaro.

${ }^{715}$ COLEÇÃO das Leis do Império do Brasil de 1831. Rio de Janeiro: Tipografia Nacional, 1875, parte 1, p. 22.
} 
de nobreza:

Apoiou a emenda do Sr. Ernesto a fim de que a regência não pudesse conceder condecorações etc., das quais se tinha feito até agora um tão grande abuso; em razão de poder-se recear que - mesmo abuso continuasse; porquanto nascendo ele de terem os ex-ministros e o governo passado muitos afilhados, também poderia tê-los a Regência, e ainda com mais razão por serem três pessoas em lugar de uma: e concluiu dizendo que era necessário que os brasileiros começassem a desprezar estes enfeites e exterioridades que nada significavam e que preferissem a honra, bom conceito e estima dos seus concidadãos, baseada em serviços prestados a bem da pátria, a estas tetéias com que no governo antigo raras vezes era premiado o mérito, mas serviam unicamente para ataviar $o$ vicio e ornar o crime. $(\text { Apoiados })^{716}$.

Na mesma sessão da Câmara, de 26 de maio de 1831, o Deputado José Lino Coutinho ainda nos testemunha que, àquele instante, era enorme a antipatia da população pelas insígnias de nobreza, ao ponto de seus dignitários, segundo ele, já não mais saírem às ruas com estes "aparatosos distintivos, andando todos com as casaquinhas muito limpas, sem sinal algum de hábitos ou condecorações"717. O discurso imediatamente posterior, entretanto, desdiz a opinião de Coutinho, e, contrariando o modo de pensar da maioria, defende a manutenção dessa "moeda" para o bem do Estado. Segundo o resumo publicado nos Anais da Câmara, o Deputado baiano e advogado, Antônio Rebouças

... advertiu que grandes publicistas assentavam que esta moeda era indispensável nos governos monárquico-representativos, por ser o meio de

${ }^{716}$ ANAIS do Parlamento brasileiro. Câmara dos Srs. Deputados. Segundo ano da segunda legislatura. Rio de Janeiro: Tipografia de H. J. Pinto, 1878, t. 1, p. 97.

${ }^{717}$ Idem, p. 98. 
pagar certos serviços do Estado sem despender o dinheiro do mesmo Estado; sustentou que a abolição de tais condecorações não era da vontade geral da nação; pois muitos ainda continuavam a apresentar-se com elas em público, e faziam grande apreço delas, gastando dinheiro em profissões etc.; e apontou o fato de haverem [sic] na secretaria muitos requerimentos pedindo condecorações ainda neste tempo em que se dizem tão desapreciadas. Declarou-se contra a purificação de que se falara, do qual poderia resultar mais mal do que bem; porque os costumes públicos não se levam a golpes de espada, podendo acontecer que na Câmara mesmo houvesse alguém que tivesse sua condecoraçãozinha, e já estivesse assustado com medo de a perder. (...) Concluiu finalmente, que havendo-se concedido estes títulos a tanta gente que os não merecia era injusto que não possam para o futuro ser obtidos por aqueles que tiverem direito a eles ${ }^{718}$.

É possível que ambas as idéias representassem, em parte, a realidade geral, uma vez que as opiniões sobre o assunto, no âmago da sociedade, deveriam estar divididas. O fato é que, àquele momento e na Câmara, o pensamento majoritário pendeu para a abolição das insígnias de nobreza; e embora derrotado quanto ao projeto que anulava todos os títulos e condecorações já conferidos, venceu, quanto à idéia da proibição temporária das mercês, pelo menos enquanto durasse a menoridade de Dom Pedro $\mathrm{II}^{719}$.

${ }_{719}^{718}$ Idem, p. 99.

719 Note-se que além desses dois projetos mencionados, contrários aos títulos e ordens honoríficas, a Câmara dos Deputados ainda propôs, em 1831, no projeto de reforma constitucional, uma substancial mudança no inciso XI do artigo 102 da Constituição, que outorgava ao Imperador, como chefe do Poder Executivo, a faculdade de "Conceder Títulos, Honras, Ordens Militares, e Distinções em recompensa de serviços feitos ao Estado..." (COLEÇÃO das Leis do Império do Brasil de 1824. Constituição Política do Império do Brasil. Rio de Janeiro, Imprensa Nacional, 1886, parte 1, p. 22). Passava, pois, ele a ter a seguinte redação: "Conceder remunerações, honras, e distinções em recompensa de serviços feitos ao Estado: na conformidade porém das leis que hão de regular esta matéria, e precedendo a aprovação da Assembléia Nacional, se as remunerações forem pecuniárias" (ANAIS do Parlamento brasileiro. Câmara dos Srs. Deputados. Primeiro ano da terceira legislatura. Rio de Janeiro: Tipografia de H. J. Pinto, 1879 , t. 1, p. 20). Ou seja, saíam do texto constitucional as palavras "títulos" e "ordens militares", e tudo o que dissesse respeito a "honras" e "distinções" passaria, antes de mais 
Ao contrário, pois, do que vinha ocorrendo durante os governos anteriores - em que o Estado teve à mão artifícios capazes de convencer as elites econômicas a socorrê-lo, ou a prestar serviços em seu nome -, a ausência deles resultou certamente em mais esvaziamento da ação governamental. Da mesma forma, instituições de interesse público, comumente auxiliadas pela filantropia dessa elites, também, muito provavelmente, sofreram revezes com a extinção temporária de mercês ${ }^{720}$. Em 22 de agosto de 1831, por exemplo, o Jornal do comércio publicava a seguinte nota a respeito do Teatro Constitucional Fluminense:

\begin{abstract}
A Companhia Nacional reunida em sociedade, animada dos mais puros sentimentos, e desejosa de preencher sempre seus deveres, pretende celebrar o fausto e memorável dia sete de setembro, aniversário da feliz Independência deste Império, com um espetáculo inteiramente novo para cuja prontificação não se poupará as despesas ainda que superiores às suas diminutas forças, pois que além de não ter auxílio algum para a sustentação dos espetáculos, é de mais a mais prejudicada em seus interesses por causa de um grande número de camarotes existirem pensionados, dos quais em récita alguma se tem aproveitado. (...) A Sociedade aproveita esta ocasião para agradecer ao Sr. acionista, Inácio Ratton, o obséquio que lhe tem feito de haver cedido em todas as récitas.
\end{abstract}

\footnotetext{
nada, a ser regulado por leis, devidamente aprovadas pela "Assembléia Nacional" (e não mais "Assembléia Geral"). Como já dissemos, no entanto, esse projeto também não chegou a ser promulgado.

${ }^{720}$ Por conta, provavelmente, da forte crença religiosa da época, talvez menos ou pouco - tenham sofrido as instituições de cunho pio ou eclesial. Dados levantados por Francisco Curt Lange em uma das mais ricas irmandades do Rio de Janeiro, a do Santíssimo Sacramento da Paróquia de Nossa Senhora da Candelária - sustentada por ricos negociantes da região -, não demonstram que os gastos com música nas solenidades da Páscoa e de Corpus Christi tenham tido qualquer repercussão negativa após a promulgação da Lei da Regência e a extinção temporária das mercês. Ali se gastou, por exemplo, entre 1831 e 1834, 388\$000 em cada ano; mais até do que em tempos anteriores, quando ser filantropo poderia significar uma "tetéia" no peito (LANGE, Francisco Curt. Op. cit., v. 4, p. 140-142, 1968). O mesmo não poderemos dizer da música profana executada no Teatro Imperial.
} 
Por aí, é possível notar que os acionistas do Teatro não apenas haviam deixado de comparecer com assiduidade aos espetáculos, como, à exceção de um único nome - o Conselheiro Inácio Ratton ${ }^{721}$ —, não estavam nem um pouco preocupados em demonstrar procedimentos notáveis, dignos de aplausos, cedendo suas propriedades em benefício da Companhia Nacional. Aliás, a relação entre a sociedade de atores dramáticos e os donos de camarotes do Teatro iria ainda exasperar-se, dali por diante. Em 1832, quando esse público aparentemente retomou certo interesse pelos espetáculos, uma série de notas publicadas no Jornal do comércio demonstram que os artistas, buscando honrar as despesas "de uma Sociedade exausta de meios e sem a esperança de alcançar uma pequena parte dos grandes auxílios concedidos a este teatro desde a sua fundação"722, procuraram tomar posse dos camarotes em dias não estabelecidos nos acordos com os acionistas, causando "escandalosas desordens" ${ }^{723}$ e outras queixas, como esta, ao Governo:

Os abaixo assinados acionistas do teatro desta corte, não podem prescindir de queixar-se a $\mathrm{V}$. M. I. da franqueza com que se permitiu a uma companhia cômica a abertura do mesmo teatro sem que os suplicantes fossem ouvidos, resultando que esta companhia continuamente sob estudados motivos abusa do direito que compete aos acionistas pelas condições de contrato justo chegando a ponto tal de mesmo aos domingos fazerem récitas que intitulam de

${ }^{721}$ O negociante Inácio Ratton foi uma das grandes fortunas cariocas da primeira metade do século XIX. Pessoa de influência no comércio do Rio de Janeiro participou, em 1834, de uma comissão para organizar um projeto de Código Comercial. Quatro anos mais tarde, fundou o Banco Comercial do Rio de Janeiro, do qual foi presidente. Em 1845, segundo o Almanaque Laemmert, encabeçava a comissão da Praça do Comércio. Ainda de acordo com essa mesma publicação, tinha o título de Conselheiro, a Comenda da Ordem de Cristo, e o Hábito de Cavaleiro da Ordem Imperial do Cruzeiro, mercês provavelmente concedidas ainda no primeiro reinado (ALMANAQUE administrativo mercantil e industrial do Rio de Janeiro para o ano de 1845. Rio de Janeiro: Eduardo e Henrique Laemmert, 1844, p. 230). Ao lado de Dom Pedro I, do Marquês de Jundiaí e de outros 21 subscritores, Ratton participou da compra e arrematação do Teatro de São Pedro de Alcântara, em 1829, com 4:000\$000 (Vide nota 64 desta parte).

${ }_{722}^{723}$ JORNAL DO COMÉRCIO, 27/08/1832.

${ }^{723}$ Idem, 11/08/1832. 
benefício seu a que chamam da casa ou de indivíduos que não fazem parte da companhia com manifesta violação das condições com que os suplicantes contribuíram para a construção do teatro, e só para os privarem do direito que têm a gozarem de seus lugares... ${ }^{724}$

Isso não significa que todos os acionistas estivessem em desacordo com o "abuso" dos atores, plenamente justificável, aliás, pela carência de auxílios, como as loterias, proibidas em 1831. Em nota posterior a essa reclamação, a Companhia Cômica afirmou que "alguns dos ditos senhores (...) não só cederam os seus camarotes, como nobremente concorreram com a paga deles para gozarem o espetáculo" ${ }^{\prime 25}$. Eram, no entanto, apenas "alguns senhores" que continuavam, ao contribuir duas vezes por seus lugares, praticando o tradicional mecenato, mesmo não podendo mais, por vários anos, ganhar pontos como beneméritos cortesãos e ser reconhecidos pelo Império com uma ordem de cavalaria, comenda ou qualquer outra insígnia de nobreza.

Para não dizer que durante os 3.394 dias que perfizeram o período regencial - quase trezentos a mais do que o reinado de Dom Pedro $\mathrm{I}^{726}$ nenhuma graça foi concedida, vale lembrar que três condecorações foram autorizadas por decreto da Assembléia Geral, revogando-se, para este efeito, "as leis e disposições em contrário". Em 1835, era dada a permissão para o governo de Feijó condecorar o ex-Regente José da Costa Carvalho com a Grão-Cruz da Ordem Imperial do Cruzeiro ${ }^{727}$. Dois anos depois, Araújo Lima teria a permissão do Legislativo para fazer mercê a dois altos funcionários do

${ }^{724}$ Idem, 17/08/1832.

725 Idem, 27/08/1832.

${ }^{726}$ De 12 de outubro de 1822 - dia em que Dom Pedro foi aclamado Imperador a 6 de abril de 1831, correram 3.098 dias, portanto 296 a menos do que o período regencial, inaugurado a 7 de abril de 1831 e encerrado no dia 22 de junho de 1840, véspera da Maioridade.

727 COLEÇÃO das Leis do Império do Brasil de 1835. Rio de Janeiro: Tipografia Nacional, 1864, parte 1, p. 121-122. Apesar de o trabalho de Luiz Marques Poliano pôr dúvidas quanto à efetivação dessa mercê, o Almanaque Laemmert de 1845 confirma que o já titulado José da Costa Carvalho - então Visconde de Monte Alegre - possuía a Grãocruz do Cruzeiro (ALMANAQUE administrativo mercantil e industrial do Rio de Janeiro para $o$ ano de 1845. Rio de Janeiro: Eduardo e Henrique Laemmert, 1844, p. 39). 
governo belga com insígnias dessa mesma $\operatorname{Ordem}^{728}$. Não entram nessa conta, pouco mais de uma dúzia de Hábitos de Cavalaria da Ordem de São Bento de Avis, concedidos automaticamente, nesse período, aos Majores de milícias que passavam a contar vinte anos de serviço na $1^{\text {a }}$ e $2^{\mathrm{a}}$ linhas ${ }^{729}$.

Os números dessa estatística, no entanto, representam o mesmo que nada se comparados aos dos tempos de Dom Pedro I, em que, em média, mais de quinhentas condecorações foram distribuídas por $a^{730}{ }^{730}$. E se durante os agitados momentos subseqüentes à Abdicação alguns cidadãos andaram escondendo seus penduricalhos e saindo às ruas da corte "com as casaquinhas muito limpas" - como afirmou Lino Coutinho - , passado certo tempo e acalmados os ânimos mais exaltados, a proibição de concessões de títulos e condecorações, durante os anos subseqüentes, provocou um efeito oposto àquele que ocorrera no final do primeiro reinado, em que esses símbolos de prestigio social, de tão fartamente concedidos, acabaram banalizados e veementemente criticados por intelectuais e políticos da época. Apesar de continuarem combatidos por um Evaristo da Veiga ${ }^{731}$ ou um

${ }^{728}$ COLEÇÃO das Leis do Império do Brasil de 1837. Rio de Janeiro: Tipografia Nacional, 1861, parte 1, p. 97.

${ }_{729}$ Cf. POLIANO, Luiz Marques. Op. cit.

${ }^{730}$ Vejamos alguns números: em 1823, Dom Pedro I outorgou 342 condecorações; em 1824, 440; em 1825, 660; em 1826, 531; em 1827, 340; em 1828, 504; em 1829, 772; e em 1830, 568 (Cf. POLIANO, Luiz Marques. Op. cit).

${ }_{731}$ Em princípios de 1835, mesma época em que Feijó pregava a sua "monarquia barata" no jornal O justiceiro, Evaristo da Veiga fazia, na Aurora fluminense, dura crítica à manutenção, no Brasil, de uma nobreza titulada. Tal investida gerou uma veemente resposta no Diário do Rio de Janeiro, demonstrando-se que não apenas no parlamento, mas na sociedade as opiniões ainda estavam bastante divididas a esse respeito. Eis parte da resposta do Diário: "A nobreza titular no Brasil foi criada por D. Pedro I, por ser a isso autorizado pela Constituição, que concedeu ao Imperador a prerrogativa de dar títulos e condecorações. Na reforma da constituição foi ileso esse artigo e a Assembléia Geral Legislativa elegeu para tutor dos augustos pupilos imperiais ao Marquês de Itanhaém. Isto basta para confundir ao detrator da inofensiva nobreza titular de seu país, contra a qual ele não imputa mal algum. Ele diz: "A nobreza titular, pelo menos, é inutilidade". E para que hostiliza a uma sombra? Pelo menos ela serve para cortejo do Imperador ao templo e no paço nos dias de festa nacional e de grande gala. Quer-se espoliar ao chefe supremo da nação da homenagem pública que então the rende o corpo aristocrático bem como o corpo diplomático? Os titulares, na maior parte, são dos notáveis proprietários do Império; portanto, são os máximos guardas da propriedade geral, e vigilantes sentinelas contra os abusos dos agentes do poder e dos demagogos da plebe. Constituem por isso um corpo intermédio entre o trono e o povo para não exorbitarem da respectiva esfera. São enfim os mais interessados na boa ordem constitucional. Diz o redator da Aurora que em país nascente a nobreza titular é obstáculo ao desenvolvimento industrial. É o contrário. Os 
Feijón $^{732}$, os títulos e condecorações valorizaram-se durante o período regencial, e, como bem ponderou Luiz Marques Poliano, "vieram a prestar assinalados serviços a Dom Pedro II"733.

Com a Maioridade, em junho de 1840, era de se prever que toda uma enchente de interesses nos títulos e condecorações, represada durante mais de nove anos, iria, com certa força, defluir. Estando o Imperador em pleno gozo de suas prerrogativas constitucionais, e dada a modorra em se legislar sobre o tema, deu-se continuidade à concessão de honrarias tal e qual se fizera no governo de Dom Pedro I, ou seja, à revelia de uma lei complementar. Estrategicamente, no entanto, o ano de 1840 viu poucas honras serem distribuídas. Assumindo um Estado ainda com sérios problemas financeiros e, ao mesmo tempo, carecido de oferecer ao povo uma demonstração menos simbólica e mais real do alto poder político e do prestígio social do novo monarca, o Governo de Dom Pedro II soube reservar uma enorme onda de novas concessões de mercês para depois da Coroação e transformar novamente essa prerrogativa do Poder Executivo, em forte moeda de troca com as elites.

Documentação da época nos permite notar que o aparato montado para o evento da Coroação, em julho de 1841 - um dos mais suntuosos e magníficos jamais visto no Novo Mundo ${ }^{734}$-, não foi apenas financiado com

principais titulares, pelas suas propriedades territoriais, necessariamente são os promotores das indústrias dos campos e não menos promovem as indústrias superiores das cidades, como os seus grandes consumidores pela faculdade de pagar a seus produtos. A indústria com que se edificam palácios e se fazem seges, imóveis e vestidos esplêndidos se sustenta pela aristocracia. Com razão disse Montesquieu: 'se os ricos não despenderem muito, os pobres morrerão de fome'" (DIÁRIO DO RIO DE JANEIRO, 03/03/1835).

${ }_{732}$ Vide nota 114 desta parte.

${ }^{733}$ POLIANO, Luiz Marques. Op. cit., p. 76.

${ }^{734}$ Eis, e. g. O depoimento de Daniel Kidder a respeito: "The splendor of the day itself - the unnumbered thousands of citizens and strangers that thronged the streets the tasteful and costly decorations displayed in the public squares, and in front of private houses - the triumphal arches - the pealing salutes of music and of cannon - the perfect order and tranquillity that prevailed in the public processions and ceremonies of the day, together with nearly everything else that could be imagined or wished, seemed to combine and make the occasion one at the most imposing that ever transpired in the new world" (KIDDER, Daniel Parish. Op. cit., v. 2, p. 371-372). Outro a mencionar a Coroação de Dom Pedro II como algo jamais visto no Rio de Janeiro foi o Barão Leopoldo de Daiser, Ministro do Imperador da Áustria junto à corte do Brasil, em carta ao Príncipe de Metternich: "Devo dizer, a bem da verdade, que a Corte ostentou nessa ocasião um luxo em équipages, em 
dinheiro público, mas auxiliado por setores da sociedade civil. A $1^{\circ}$ de abril daquele ano, por exemplo, a "benemérita" Praça do Comércio do Rio de Janeiro lançava uma subscrição, que, de partida, já juntava 44 assinaturas de $100 \$ 000$, para "dignamente solenizar a coroação de S. M. I." com "Luminárias, fogos artificiais, danças de mascarados, arcos triunfais", prevendo-se consumir, para isso, "centenas de contos de réis" ${ }^{735}$. Não seria estranho, pois, conjecturar que o espetáculo de ópera da noite de 19 de julho daquele ano - mesmo que improvisado e parcial - também tenha sido financiado por membros de uma elite financeira, ainda ávidos por status, por ter seus nomes inseridos em alguma das listas de mercês, fartamente publicadas pelo Governo àquele ano. Somente uma "troca" fora de série de recursos privados por honrarias justifica, só de ordens, 1.585 concessões, em 1841 , tendo em vista uma distribuição muito inferior - 198 - em 1840. O mesmo se pode concluir a respeito dos títulos. Ao passo, por exemplo, que, em 1840, nenhum baronato foi concedido, em 1841, o Império passou a contar com treze novos barões, entre os quais, o negociante Joaquim José Pereira de Faro, ex-acionista do Teatro de São João, e já várias vezes agraciado com graças honoríficas, em reconhecimento de seus serviços beneficentes $^{736}$. Outro exemplo similar é o de José Francisco de Mesquita, "capitalista abastado e banqueiro cuja bolsa muitas vezes abriu-se para acudir o Estado" ${ }^{737}$, e que, na mesma data da Coroação de Dom Pedro II,

librés e em mobiliário de toda espécie, realmente espantoso neste país, onde os recursos são muito limitados, onde outrora tudo faltava, e onde há pouco e, por assim dizer, nenhum precedente; porque tudo que se tinha feito ao tempo de Dom Pedro I, não se aproximava nem de longe do que vimos atualmente, nem da riqueza, nem em bom gosto, nem em dignidade..." (Apud SCHWARCZ, Lilia Moritz. As barbas do imperador: D. Pedro II, um monarca nos trópicos. São Paulo: Companhia das Letras, 1998, p. 83).

${ }_{736}^{735}$ JORNAL DO COMÉRCIO, 01/04/1841.

${ }^{736}$ Segundo o Arquivo nobiliárquico brasileiro, Joaquim José Pereira de Faro era Coronel reformado do extinto $1^{\circ}$ Regimento de infantaria de $2^{\mathrm{a}}$ linha do Exército. Fidalgo Cavaleiro da Casa Imperial, Cavaleiro e Comendador da Imperial Ordem de Cristo e Cavaleiro da Imperial Ordem do Cruzeiro (VASCONCELOS, Rodolfo Smith de Vasconcelos, Barão de . Op. cit., p. 387-388).

${ }_{737}$ Ibidem, p. 84. Em 1845, Bonfim possuía, segundo o Almanaque Laemmert, a comenda da Ordem de Cristo e o oficialato da Ordem do Cruzeiro (ALMANAQUE administrativo mercantil e industrial do Rio de Janeiro para o ano de 1845. Rio de Janeiro: Eduardo e Henrique Laemmert, 1844, p. 231). 
recebeu o título de Barão de Bonfim ${ }^{738}$.

A presença do mecenato teatral na soma de ações beneméritas de ricaços sem estirpe, normalmente ligados ao comércio de grosso trato - e ainda ao tráfico negreiro - em busca de ascensão social é uma realidade incontestável. Não pode ser mera coincidência que dos dezoito Comendadores da Ordem de Cristo presentes entre os 160 negociantes listados no Almanaque Laemmert de 1845, dois fossem os atuais donos do Teatro de São Pedro de Alcântara - Manoel Maria Bregaro e Joaquim Valério Tavares - e outros dois - Inácio Ratton e João Pereira de Andrade -, acionistas desse mesmo estabelecimento ${ }^{739}$.

Bregaro e Tavares encabeçaram a "sociedade de trinta negociantes" que, em 1837, subscreveu um capital de trinta contos de réis ${ }^{740} \mathrm{e}$, propondo ao Legislativo elevar o Teatro Constitucional Fluminense, "enriquecendo-o com a presença dos melhores artistas estrangeiros, tanto na dança, como nas óperas" ${ }^{741}$, conseguiu, para tal fim - e conforme já vimos -, a concessão de duas loterias anuais, por seis anos. De início, tal sociedade reformou o prédio, dando-Ihe nova magnificência depois de vários anos de abandono. A fachada do Teatro foi remodelada, tornando-se ainda mais parecida com a do Scala, de Milão. Um novo lustre de cem luzes, numeração para as cadeiras da platéia, melhores acomodações para os músicos no

${ }^{738}$ Durante o segundo reinado, José Francisco de Mesquita ainda receberia honras de grandeza para o seu baronato (1846), e os títulos de Visconde com honras de grandeza (1854), Conde (1866) e Marquês de Bonfim (1872) (RHEINGANTZ, Carlos G. Op. cit., p. 69).

739 Cf. ALMANAQUE administrativo mercantil e industrial do Rio de Janeiro para o ano de 1845. Rio de Janeiro: Eduardo e Henrique Laemmert, 1844, p. 230-234.

740 Note-se que há conflitos de fontes em relação ao valor desse capital e ao número exato de acionistas envolvidos. Enquanto o Jornal dos debates políticos e literários (vide nota 299 desta parte) assevera que o montante captado pela sociedade de acionistas foi de 30 contos de réis, um manuscrito tombado na Biblioteca Nacional (vide nota 297 desta parte), de 1850, apresenta-nos um outro valor: 40 contos de réis. E a despeito do Jornal do comércio ter publicado, a 30 de outubro de 1838, nota referindo-se a uma "sociedade de trinta negociantes", existe no Arquivo Histórico do Museu Imperial de Petrópolis uma apólice no capital de 1:000\$000 em nome do Deputado José Clemente Pereira, correspondente a uma ação de "n. 37" do Teatro (ARQUIVO HISTÓRICO DO MUSEU IMPERIAL, III-DSM-1840-Soc.rç). Como esse documento é de 1840, é possível que ao longo do tempo, ou mesmo durante as reformas do São Pedro, entre 1838 e 1839 , o capital e o número de acionistas tenha aumentado de trinta para quarenta.

741 Vide nota 298 desta parte. 
fosso da orquestra foram outros melhoramentos, além do "insano trabalho dos insignes artistas Porto Alegre, Olivier, Carvalho, Malivert e outros" ${ }^{\text {"742, }}$ empenhado nos novos afrescos e pano de boca. Terminada a obra, e reaberto o Teatro a 7 de setembro de 1839, a direção do Teatro, como já vimos, não tardou em mandar buscar na Europa, cantores de ópera. $O$ fato desses artistas só terem chegado em fins de 1843 - pelas razões já especuladas - não tira o mérito desses "negociantes" terem tentado melhorar o estado do principal espaço de divertimento público da capital do Império sem aparentes benefícios pessoais, a não ser o de contar pontos para uma eventual condecoração futura ${ }^{743}$.

Enfim, ainda sobre a questão da suspensão temporária de mercês, estabelecida pela Lei de 14 de junho de 1831, além de provavelmente ocasionar a interrupção ou o enfraquecimento do patrocínio às artes, também despojou os primeiros magistrados do Império - os Regentes - do prestígio social inerente ao poder de nobilitar. Esses, ao invés de serem bajulados por possuírem tal prerrogativa, acabaram sendo tratados publicamente - como Marco Morel constatou, com base em relatórios dos diplomatas franceses residentes no Rio de Janeiro entre 1833 e 1834 - "com desprezo", sobretudo pelos "titulados" 744 . Corrobora tal idéia o já muitas vezes mencionado testemunho de época do Almirante inglês Graham Eden Hamond, que, a respeito desse fato, narra, em seu diário de 1835, a ocasião de um baile no qual o Regente Francisco de Lima e Silva esteve, alguns dias antes de deixar o cargo:

As famílias mais seletas estavam presentes e, entre elas, estava o Regente, senhor Francisco de Lima e Silva, geralmente chamado Sr. Lima.

742 JORNAL DO COMÉRCIO, 10/09/1839.

${ }^{743}$ Nesse sentido é possível especular que a atuação dos trinta (ou quarenta) negociantes em benefício da recuperação do Teatro, em 1837, tenha sido, em parte, motivada pela movimentação política que, durante todo o governo de Feijó, alardeou a idéia de, em primeiro lugar, elevar a Princesa Dona Januária a Regente; e, posteriormente, já em 1837, conceder a maioridade ao próprio Dom Pedro II, restaurando-se, em qualquer das duas situações, a retomada da concessão de mercês.

${ }^{744}$ MOREL, Marco. Op. cit., p. 196-197. 
Pobre homem - parecia muito infeliz - quase sozinho, com toda sua "grandeur"

Vejamos que, não obstante o que já foi dito acerca de Feijó e sua particular sociopatia, houve, por conta da coarctação disposta na Lei de 14 de junho de 1831, um esvaziamento generalizado das sociabilidades em torno da figura dos Regentes durante todo o período em que esses exerceram o mando. Mesmo Pedro de Araújo Lima, o mais festejado de todos os substitutos políticos de Dom Pedro II, acabou, como já vimos, sucumbindo à própria fraqueza sociopolítica de seu cargo, incapaz de seduzir a sociedade da época a gravitar em torno de si e a promover acontecimentos de especial interesse, em sua homenagem, como, por exemplo, óperas.

${ }^{745}$ HAMOND, Graham Eden. Op. cit., p. 90. 


\section{CAPÍTULO IX - Muito barulho, pouca música}

A pedra rolou do alto da montanha e não se sabe onde irá parar... ${ }^{746}$

O movimento social que sacudiu a capital do Império em 1831, promovendo, no ápice de seu incitamento, a renúncia de Dom Pedro I, não foi senão, como analisou Teófilo Otoni, mais uma journée des dupes ${ }^{747}$. Camadas baixas e numerosas da população - incluindo-se as rasas patentes das tropas - , persuadidas pelas elites oposicionistas ao Imperador com a demagógica propaganda antilusitana e a promessa de reformas sociais, políticas e econômicas, expuseram-se à frente de um movimento revolucionário, e, duplamente enganadas, viram seus líderes, uma vez no poder, assumirem uma posição reacionária e de congraçamento com antigos setores adversários. O freio moral e objetivo imposto às massas pela nova situação logo após o Sete de Abril não impediu, no entanto, a inércia do movimento revolucionário, e o Rio de Janeiro, ao longo de um bom tempo, ainda foi palco de inúmeras desordens e crimes, cometidos por membros da massa enganada contra os mais fiéis cortesãos de Dom Pedro I - em grande parte, comerciantes lusos ou "adotivos" —, seja dito de passagem, assíduos vizinhos de camarote do Imperador no Teatro de São Pedro de Alcântara.

No dia 27 de abril de 1831, por exemplo, o viajante inglês William Moore testemunhou que "todas as lojas fecharam na cidade e multidões de negros e mulatos, andavam por todas as partes munidos de porretes $\mathrm{e}$ pedras". Às nove horas da noite desse mesmo dia, um "considerável" número de pessoas também se ajuntou no Campo da Honra para forçar "os

746 Frase de Evaristo da Veiga a respeito da revolução de 7 de abril (Apud AZEVEDO, Manuel Duarte Moreira de. Motim político de 3 de abril de 1832 no Rio de Janeiro. Revista do Instituto Histórico e Geográfico Brasileiro. Rio de Janeiro, v. 49 [t. 37 parte 2], p. 367, 1874).

47 Apud PRADO JR., Caio. Op. cit., 1969, p. 59. Cf. OTTONI, Teófilo Benedito. Circular dedicada aos Srs. eleitores de senadores pela província de Minas Gerais no quatriênio atual e especialmente dirigida aos Srs. eleitores de deputados pelo $2^{\circ}$ Distrito Eleitoral da mesma província para a próxima legislatura. Rio de Janeiro: Correio Mercantil de M. Barreto, Filhos, 1860. 
portugueses não naturalizados a sair da cidade" ${ }^{748}$. A bem da verdade, segundo o mercenário Eduard Theodor Bösche, muitos "portugueses" sobretudo alguns dos mais abastados - já haviam, a esse tempo, deixado a corte, acompanhando o ex-Imperador. Com eles, "um enorme volume de capital saiu do país, dificultaram-se as operações de comércio, até então florescentes, muitas casas faliram ou, tendo seus negócios estancados, retiraram-se para a Europa"749. Sem abastecimento, sem dinheiro em circulação, com mais e mais desocupados nas ruas, a insatisfação social e a violência certamente agravaram-se.

Em meados de julho, quando ocorreu o mais importante levante na capital depois da Abdicação, os insurretos - povo e tropa, mais uma vez reclamaram ao Governo a deportação de 89 "indivíduos" 750 : clérigos de importância, como o Bispo de Anemuria; deputados, como José Clemente Pereira; militares de alta patente, como o Tenente General José da Nóbrega Botelho, diversos "titulares" - alguns, Senadores —, como o Marquês de Aracati, o Conde do Rio Pardo, o Conde de Lajes e o Marquês de Baipendi; grandes negociantes, como Antônio José Meireles e Fernando Carneiro Leão; magistrados, como Gustavo Adolfo de Aguilar; e outros tantos nomes de menor ou maior relevância, em sua maioria "portugueses" ou "adotivos". Embora a representação dos rebeldes não tenha tido qualquer aceitação e,

748 "We found all the shops shut in the city and mobs of blacks and mulattos parading about with clubs and stones in the presence of soldiers. The city was under great excitement during the whole day. (...) About nine o'clock considerable numbers assembled in the Campo for the purpose of compelling all the Portuguese who were not naturalized to leave the city..." (MOORE, Joseph William. Op. cit., p. s/n).

749 "Der Abgang Dom Pedro's zog den meisten und reichsten Portugiesen nach sich, wodurch ungeheure Kapitalien aus dem Lande gezogen wurden. Dieses hatte einen bisher nie gekannten Geldmangel zur Folge: der Handel, vor kurzer Zeit noch so blühend, lag gänzlich darnieder, das so nöthige Bertrauen im Handelsstande hatte sich gänzlich verloren und keine bedeutenden Geschäfte wurden mehr gemacht. Viele Häuser fallirten, oder stellten ihre Geschäfte ganz ein, und zogen sich nach Europa zurück" (BÖSCHE, Eduard Theodor. Op. cit., p. 227). De fato, uma análise dos livros do Tribunal da Junta do Comércio, de 1831, tombados no Arquivo Nacional nos mostra uma sensível queda, durante esse período, no número de matrículas de negociantes de grosso trato na praça do Rio de Janeiro. Enquanto que ao longo de 1830 aparecem 21 inscrições e nos três primeiros meses de 1831, treze, serão apenas três, no restante desse último ano. Em 1832, as matrículas não chegam a dez (Cf. ARQUIVO NACIONAL, Rio de Janeiro. Fundo Junta do Comércio, Agricultura, Fábricas e Navegação, Códice 170, v. 2).

${ }_{750}$ ANAIS do Parlamento brasileiro. Câmara dos Srs. Deputados. Segundo ano da 
em pouco tempo, tal revolta acabasse debelada, sob o comando firme do então Ministro Feijó, esses e outros nomes de pessoas ligadas a Dom Pedro I ficaram por mais um bom tempo marcados como "inimigos do Brasil"751. Muitos, temendo a própria segurança, deixaram o Rio de Janeiro mesmo antes de julho de 1831, como foi o caso do Barão de Inhomirim, Dr. Vicente Navarro de Andrade. Em carta à Condessa de Itapagipe, de junho desse ano, o médico da Casa Imperial dizia partir "sem vontade e sem crimes" para a França, forçado por "alguns inimigos", que, aproveitando a ocasião da revolução, haviam maculado a sua "reputação política"752.

No mês seguinte, após o levante, estimava-se em cerca de dez mil o número de "portugueses" que, até aquele momento, já haviam abandonado a cidade, por mar, ou por terra, em direção ao interior ${ }^{753}$. Carta do Cônsul Geral de Portugal no Rio de Janeiro, João Batista Moreira a Dom Pedro I, de 18 de setembro de 1831, também ilustra essa contínua debandada:

Participo Vossa Majestade que no dia 13 do corrente, consegui, depois de indefesos trabalhos, fazer sair deste porto em direção ao da ilha terceira o brigue de guerra Conde de Vila Flor e a barca Regência de Portugal levando a seu bordo todos os emigrados portugueses que aqui se achavam (...) Um sem número de infelizes perseguidos, a despeito da justiça... ${ }^{754}$

Quem ficou, corria diariamente o risco, sobretudo à noite, de se ver em maus lençóis diante de um grupo fora-da-lei. Manchetes como essa, corriam os oceanos:

\footnotetext{
segunda legislatura. Rio de Janeiro: Tipografia de H. J. Pinto, 1878, t. 1, p. 244.

${ }_{751}$ Mais de dois anos depois, em novembro de 1833, essa lista, de "fidalgos inimigos do Brasil", ainda era publicada em um dos primeiros exemplos da "imprensa negra" brasileira, o $\mathrm{n}^{\circ} 1$ do jornal $O$ cabrito (07/11/1833).

752 BIBLIOTECA NACIONAL, Rio de Janeiro. Seção de Manuscritos, I-9,11,38.

753 Esse número nos foi dado pelo The times, de Londres, ao publicar uma informação de 20 de julho, proveniente do Rio de Janeiro: "In the meanwhile, nearly 10,000 Portuguese have fled, either on board of the shipping, or into the country..." (THE TIMES, 21/09/1831). Embora tal cifra não seja de todo confiável sua expressividade demonstra, no entanto, certa verossimilhança.

${ }^{754}$ ARQUIVO HISTÓRICO DO MUSEU IMPERIAL, II-POB-[1831]-PI.B.do 1-6.
} 
Relatos provenientes do Rio de Janeiro de 5 de agosto foram recebidos em Baltimore. Uma insurreição de pretos foi contida. Um eminente negociante português foi recentemente assassinado por um escravo e assassínios de portugueses têm sido freqüentes ${ }^{755}$.

Outro testemunho dessa sangrenta época, o do alemão Carl Seidler, também nos apresenta, mais uma vez, como vítima, um "filho do reino":

Um jovem português, promissor filho de pais afetuosos, estava, um dia, um pouco atrasado por conta de um encontro social e voltava para casa por volta de 11 horas da noite. Tão logo chegou à rua $S$. José, um pouco estreita e escura, um robusto mulato cruza seu caminho, gritando: "Quem viva?". O rapaz, animado e um pouco alcoolizado pelo vinho do porto, que no meio da escuridão não foi capaz de reconhecer imediatamente quem fez a pergunta, e, imaginando que fosse uma patrulha, respondeu tranqüilamente: "Amigo!". Rápido, chegando imediatamente mais perto, e, de cacetete em riste, o mulato repete a inconveniente pergunta. O português reconhece o seu erro e agora compreende o sentido da funesta palavra; porém como não se sente obrigado a manifestar seu credo político a um vagabundo desacompanhado, também ostenta cheio de coragem sua bengala e exige do mulato, com poucas e sérias palavras, que saia do caminho. Todavia, o brasileiro sans culotte desata a pancada e em um instante ambos se agarram da forma mais vulgar. A habilidade do jovem contrabalança com a força superior de seu inimigo e a luta parece incerta; então, saltam dois outros de tocaia e, depois de cinco

755 Tradução nossa de: "Accounts from Rio Janeiro to the 5th Aug. have been received at Baltimore. An insurrection of the blacks was apprehended. An eminent Portuguese merchant had been recently murdered by a negro slave, and assassinations of the Portuguese were frequent" (THE LIBERATOR, 08/10/1831). O jornal semanal abolicionista The Liberator começou a ser publicado em 1831, em Boston, Massachusetts, EUA, pelo jornalista William Lloyd Garrison. 
mortíferos golpes de faca, o infeliz rapaz cai no chão sangrando e sem vida. Depois disso, os patrióticos assassinos ainda pegam o pouco dinheiro, o chapéu e o relógio da vítima atrozmente mutilada e saem caminhando, muito calmamente, e dizendo: "Um filho do reino de menos!"756

Não obstante tamanha violência, havia ainda quem se arriscasse a sair de casa à noite em busca de - como notou Seidler - "um encontro social". Dos mais tradicionais da cidade, a ópera, diante de todas as dificuldades, tentava manter-se viva. Sem o apoio de Dom Pedro I, sem loterias, sem muitos dos seus principais mecenas dispostos a aparecer nos camarotes, já por falta de interesse social ou mesmo por insegurança ${ }^{757}$, a

756 Tradução nossa de: "Ein junger Portugiese, der einzige hoffnungsvolle Sohn liebender Eltern, hatte sich eines Tages in einer fröhlichen Gesellschaft etwas verspätet, und kehrte erst gegen $11 \mathrm{Uhr}$ Abends in seine Wohnung zurück. Als er nun auf dem Heimwege in die Rua St. Jozé, eine etwas enge und dunkle Strasse, gelangte, tritt ihm plötzlich ein stämmiger Mulatte mit dem Geschrei: 'Quem viva!' entgegen. Der junge, vom Portwein belebte und etwas benebelte Mann, der in der Dunkelheit nicht sogleich den Fragenden zu erkennen vermag, und in der Meinung steht, dass inn eine Patrouille anrufe, antwortet ruhig: 'Amigo!' (Freund). Rasch tritt jener sodann auf ihn zu und wiederholt mit aufgehobenem Knüttel seine ungebührliche Frage. Der Portugiese erkennt seinen Irrtum und begreift jetzt, in welchem Sinne das verhängnisvolle Wort zu nehmen; da er sich aber nicht verpflichtet fühlt, einem einzelnen Vagabunden sein politisches Glaubensbekenntnis abzulegen, so erhebt er ebenfalls muthvoll seinen Spazierstock, und fordert den Mulatten mit wenigen, ernsten Worten auf, inn ruhig seiner Wege ziehen zu lassen. Doch der brasilianische Sansculotte schlägt augenblicklich auf inn los, und im $\mathrm{Nu}$ find beide handgemein geworden. Die Gewandtheit des jungen Mannes balanciert die überlegene Kraft seines Gegners, und der Kampf scheint zweifelhaft; - da stürzen zwei Andere aus ihrem Hinterhalte hervor, und von fünf meuchel mörderischen Messerstichen durchbohrt, sinkt der unglückliche Jüngling blutend und leblos zu Boden. Hierauf nehmen die patriotischen Mörder ihrem grässlich verstümmelten Schlachtopfer noch die wenige Barschaft, Hut und Uhr ab, und wandern dann mit den Worten: 'Um filho do reino de menos!' (ein Kind des Königreichs weniger) sehr ruhig und gelassen von dannen" (SEIDLER, Carl. Zehn Jahre in Brasilien während der Regierung Dom Pedro's und nach dessen Entthronung. Leipzig: Gottfr. Basse, 1835, v. 2, p. 219-220).

757 Jornais da época noticiam a falta de segurança dentro do Teatro, já alguns dias depois da Abdicação e notam a ausência desse público específico, como havíamos comentado em páginas anteriores. Segundo Marco Morel, A nova luz brasileira de 19 de abril de 1831 noticia, por exemplo, que "a platéia do Teatro estava dominada por 'Bravos Defensores da Pátria' e que 'a canalha da cascaduraverde-negra que aluga os camarotes da Gávea' (isto é, os portugueses abastados) sequer havia comparecido ao local habitualmente freqüentado". Por sua vez, O repúblico de 9 de junho do mesmo ano traz à luz uma desordem ocorrida dias antes no Teatro, com direito a cadeiras quebradas, gritarias e insultos às autoridades (Apud MOREL, Marco. Papéis incendiários, gritos e gestos: a cena pública e a construção nacional nos anos 1820-1830. TOPOI. Revista de história. Rio de Janeiro: PPGHIS/UFRJ, n. 4, p. 52, 2002). Note-se, portanto, mais uma vez 
companhia italiana, mesmo assim, iniciou sua temporada de récitas, talvez confiante na proteção do ainda fiel público estrangeiro - ingleses, franceses, alemães, norte-americanos, que pouco sofreram com a animosidade nativista - e na maior tranqüilidade urbana, uma vez posto em prática o recrutamento paramilitar, aprovado pelo decreto de 17 de julho e complementado pela Lei de 18 de agosto de 1831, que daria, principalmente à capital do Império, um novo e mais eficiente método de segurança pública, a Guarda Nacional.

Constava dessa nova temporada lírica, quatro títulos de Rossini. Ao que tudo indica, os espetáculos se iniciaram a 11 de agosto, com uma primeira execução de La Cenerentola ${ }^{758}$. Vinte dias depois, alterando-se o cronograma inicial, ia à cena, em benefício da primeira dama da Companhia, Justina Piascentini, A italiana em Argel. Segundo o médico norte-americano William Ruschenberger, que assistiu a esse espetáculo, elogiando-o muito, "a casa estava cheia" e a ordem, "mantida por diversos soldados pretos, espalhados por toda a platéia"759. A paz dos dilettanti não durou, no entanto, muito tempo. Local em que tradicionalmente ocorriam eventos políticos, como já vimos, o São Pedro de Alcântara - agora "Constitucional Fluminense", em homenagem aos novos tempos - tornou-se, em fins de setembro de 1831 , palco de uma cruenta sublevação.

A versão oficial do acontecimento, publicada no Jornal do comércio dias depois, foi dada pelo então Juiz de Paz da Freguesia do Sacramento e futuro Senador, Saturnino de Sousa e Oliveira, que estava presente ao

a informação de que os camarotes do Teatro de São Pedro de Alcântara eram majoritariamente ocupado por "portugueses" - certamente, a grande maioria, negociantes - que bajulavam Dom Pedro I e muito o agraciavam oferecendo subsídios à ópera. Aliás, é de se conjecturar que a manifesta lusofobia pós 7 de abril tenha, ao menos durante os primeiros meses seguintes da revolução, promovido dificuldades às encenações operísticas, tão vinculadas a Dom Pedro e seus asseclas. Como ainda veremos adiante, a "casa cheia" notada por um viajante norte-americano em uma apresentação de ópera, em setembro de 1831, indica que esse tipo de espetáculo, se foi alvo de represálias, não permaneceu nessa situação por muito tempo.

758 JORNAL DO COMÉRCIO, 03/08/1831. Novo espetáculo foi anunciado a $18 \mathrm{de}$ agosto, embora não se possa afirmar que tenham, ambos, ido à cena (Idem, 18/08/1831).

759 "The night on which I visited the opera, 'La italiana in Algeri' was performed in a masterly style. The scenery was good an the orchestra full and efficient. (...) Order is preserved and enforced by a number of black soldiers, distributed through the pit. The house was full, which argued much in favor of the musical taste of Brazil" 
espetáculo dramático, em seu camarote, e protagonizou o acontecido, quando, pelas dez horas da noite do dia 28 de setembro, foi chamado por alguns cidadãos para "acomodar uma desordem que havia no Largo, junto aos arcos do Teatro", envolvendo dois oficiais militares, um "nato" e outro "adotivo". Chegando ao local e ouvidas as partes, Saturnino deu voz de prisão a ambos os oficiais. Porém, um "grupo do povo" que os rodeava começou a gritar que o "brasileiro" — de nome Antônio Caetano — "não iria preso", e, à força, o puxou para dentro do Teatro ao mesmo tempo em que o outro oficial - chamado Paiva - escafedeu-se. Levado Antônio Caetano para a platéia, começou-se aí a gritar que ele estava preso por causa de um "chumbo que o atacou, mas que este fora solto", o que resultou imediatamente em "um espantoso alarido". Ainda assim, Saturnino ordenou novamente ao comandante da guarda do Teatro - o Major Miguel de Frias, futuro protagonista de outro $\operatorname{motim}^{760}$ - que efetuasse a prisão. Esse, no entanto, respondeu que o "brasileiro" não haveria de ir preso porque "a populaça não queria" e essa "podia mais" do que o juiz. Diante de tal desacato, Saturnino saiu do Teatro e fez pôr em ordem, à certa distância da entrada da Ópera, as rondas municipais, que, em pouco tempo, formaram um batalhão de "para mais de duzentos homens". Do saguão, e mesmo debaixo das arcadas, vários indivíduos vaiavam a força militar, lançando-lhes, igualmente, "os maiores insultos e palavras obscenas". Enfim, o juiz ordenou que quatro municipais prendessem os primeiros que chegassem do saguão a insultar e provocar; logo apareceram quatro, à testa dos quais estava "um pardo escuro com um cacetete na mão". Apenas os quatro guardas os quiseram prender, esses Ihes lançaram as mãos às armas para as tomarem. Enquanto lutavam, dispararam do saguão para fora um tiro. Provocada "ao último ponto", a força de mais de duzentos homens começou, então, a fazer fogo "desconcertadamente", disparando por volta de trinta tiros, "ficando

(RUSCHENBERGER, W. S. W. Op. cit., p. 42-43).

${ }^{760}$ Trata-se do motim ocorrido de 2 para 3 de abril de 1832 (Cf. AZEVEDO, Manuel Duarte Moreira de. Motim político de 3 de abril de 1832 no Rio de Janeiro. Revista do Instituto Histórico e Geográfico Brasileiro. Rio de Janeiro, v. 49 [t. 37 parte 2], p. 367-381, 1874). 
mortos três indivíduos, dois feridos e também alguns muito poucos dos guardas municipais" ${ }^{\prime 761}$.

Moreira de Azevedo, ao historiar, muito tempo depois, esse ocorrido em um artigo da Revista do IHGB, deu plena validade à versão oficial, comentando que os periódicos do "partido exaltado" exageraram na narração dos fatos, "para impressionar vivamente o público", tornando "feia e horrorosa a descrição de tais acontecimentos". Mencionou, por exemplo, a Nova luz brasileira, a qual publicou que "quando o povo e famílias quiseram sair, acharam o teatro circulado por guardas municipais, as portas todas tomadas, proibindo-se a saída a quem estava dentro" ${ }^{762}$. Ainda segundo Moreira de Azevedo, outro periódico ainda "elevou o número dos mortos a mais de vinte" 763 .

Curiosamente, as informações dos jornais "exaltados" se aproximam dos depoimentos que nos legaram os alemães Carl Seidler e Eduard Bösche, em seus livros de memórias, publicados, alguns anos depois, na Europa. Ambos os escritos foram ignorados por Moreira de Azevedo em seu trabalho, e mostram diferente ângulo sobre esse acontecimento, talvez menos parcial, não apenas pelo distanciamento desses estrangeiros em relação às questões política locais mas, também pelo fato de o primeiro desses - segundo ele próprio - ter sido testemunha ocular do fato ${ }^{764}$.

Conta, pois, Carl Seidler, que havia ido àquela noite - de 28 de setembro - ao Teatro, animado pela apresentação, "depois de longa ausência", da dançarina Ricardina Soares, de quem era um incondicional fã. Confessa o alemão que, adormecendo na parte do espetáculo destinada à peça principal, acordou sobressaltado com gritos "muito consideráveis e,

761 JORNAL DO COMÉRCIO, 03/10/1831.

762 AZEVEDO, Manuel Duarte Moreira de. Os tiros no Teatro: motim popular no Rio de Janeiro. Revista do Instituto Histórico e Geográfico Brasileiro. Rio de Janeiro, t. 36, parte 2, p. $357,1873$.

763 Ibidem, p. 357, 1873. Note-se que, algumas semanas depois, o The times encampou, embora ressalvando a falta de pormenores, a informação de que cerca de vinte pessoas haviam perdido suas vidas nesse levante: “... some disturbances had occurred at the theatre, by which about 20 persons had lost their lives. No time was left, however, to obtain particulars" (THE TIMES, 21/11/1831). A fonte primária das informações não foi, no entanto, mencionada pelo jornal londrino. 
mais tarde, desacreditados" de "viva a república". Interrompido o espetáculo e ouvidos também, em contrapartida, vivas "a Dom Pedro II" e a "Dom Pedro I", entrou em cena o Juiz de Paz - Saturnino de Sousa e Oliveira - , que reclamou silêncio, sendo respondido com obscenidades por um dos primeiros jovens que gritara contra a monarquia. Afrontado, o juiz deu então ordem para que a guarda "carregasse suas armas e ocupasse triplamente as portas do prédio, de maneira que nenhum dos criminosos pudesse escapar". No momento em que os soldados entraram na sala de espetáculos de baionetas armadas, foram recebidos à bala; tiros de pistola que partiam "da platéia e dos camarotes". Saturnino então, "trêmulo, escondido de pé atrás de um pilar de seu camarote", deu ordem para que a guarda fizesse fogo. Uma única descarga em direção ao público teriam feito, segundo o alemão, "em um segundo, mais de trinta mortos e feridos"765.

Por sua vez, o depoimento de Eduard Bösche, embora mais sucinto e dado com base no "ouvi dizer", corrobora a visão de Seidler, de que o acontecido fora um tanto diferente - ocorrido dentro e não fora do Teatro -

${ }^{764}$ SEIDLER, Carl. Op. cit., 1835, v. 1, p. 53.

765 "Ein Neues, populaires Mulattendrama war angekündigt; das hätte mich nicht gereizt; aber Madem. Ricardine wollte nach längerer Abwesenheit endlich einmal wieder tanzen. (...) Ich war, offenherzig gestanden, sanft eingeschlafen, und meine Gedanken tanzten den Fandango des Traumes. Da erweckte mich plötzlich der Ruf: "Es lebe die Republik!" - "Die Republik! Die Republik!" hallte es von hundert Stimmen wieder; es war ein vielbedeutendes Echo, das später zu Schänden wurde. - "Es lebe Dom Pedro der Zweite!" tönte von der linken Seite der Ruf der Stutzer, das Schreien der Dämchen. - Viva Dom Pedro primeiro!" erscholl es in den Logen, wie im Parterre. Der Vorhang fiel, die Gaslampen erloschen allmählich; Blicke flogen hin und her, - Dolche blitzten heller als die Bajonette; der Tumult war da. Im ersten Range streckte ein Juiz de Paz (Friedensrichter) seine imponierende Wohlbeleibtheit über das Sammetgitter, und gebot gähnend, mit den früher angeführten portugiesischen Galanterien, Ruhe. Zur Antwort präsentierte derselbe junge Mann, der zuerst die Republik hatte leben lassen, mit herabgelassenen Hosenträgern, auf unanständige Weise das, was hier nicht zu präsentieren war, und sprach dazu einen kurzen Monolog. Der Friedensrichter nahm die Ausforderung an, und erteilte dem wachhabenden Offiziere den Befehl, 'sogleich die Gewehre laden und die Türen des Theaters dreifach besetzen zu lassen, damit von den vielen Missetätern (denn ein Einziger ließ sich nicht herausfinden) keiner entfliehe!' In dem Augenblicke aber, dass sich die Soldaten mit aufgepflanztem Gewehr in den weit geöffneten Türen zeigten, knallten ihren auch schon aus Parterre und Logen mehre Pistolenschüsse entgegen, und die wütende Menge drang wie eine sturmbewegte Flut unaufhaltsam auf sie ein. Der Juiz de Paz verlor endlich Geduld und Contenance; zitternd stand er da, gegen einen Pfeiler seiner Loge gelehnt; stolz wie ein General nach einer gewonnenen Schlacht, gab er den Befehl, zu schießen. 'Fogo!' donnerte der Offizier seinen Leuten zu. Die Kugeln schlugen in den dichtensten Menschenhausen, und in einer Sekunde lagen mehr denn dreissig Tote und Verwundete am Boden" (Ibidem, p. 
e bem mais violento do que o retratado pela versão oficial:

Tiros de pistola e punhaladas ocorreram em uma noite de casa cheia nos camarotes e na platéia, a saber que muitos dos mais respeitáveis portugueses e brasileiros perderam suas vidas nessa oportunidade. A determinação do magistrado Dr. Saturnino Oliveira impediu um derramamento de sangue ainda maior. Esse homem apareceu dentro do teatro acompanhado de vinte homens da Guarda Nacional, deu-lhes ordem para carregar suas armas debaixo dos olhos do espectadores e exigiu que todos abandonassem a sala. Como sua ordem não foi atendida por duas vezes, repetiu-a então pela terceira vez, ameaçando abrir fogo. Como esta terceira intimação também não foi bemsucedida, autorizou de sua parte a ameaça. Com isso, várias pessoas foram mortas; o que, no entanto, permitiu a imediata evacuação do teatro. (...) $O$ teatro permaneceu fechado durante alguns meses ${ }^{766}$.

Diante de tamanho constrangimento físico e moral, eis a provável gota d'água que levou a Companhia Italiana do Teatro Constitucional Fluminense ao desmantelamento, após anos de atividade ininterrupta. Sem os "elementos de sucesso" dos anos anteriores e, ademais, acossados por uma situação de segurança pública periclitante, capaz de obrigar o Governo a fechar "temporariamente" ${ }^{\text {"67 }}$ as portas da principal casa de espetáculos da corte, não

53-55).

766 Tradução nossa de: "Es kam nämlich eines Abends bei vollem Hause im Parterre und in den Logen zu Pistolenschüssen und Dolchstichen, bei welcher Gelegenheit mehrere der angesehensten Portugiesen und Brasilier das Leben verloren. Die Entschlossenheit des Friedensrichters Dr. Saturnio Oliveira verhütete ein noch größeres Blutbad. Dieser Mann erschien nämlich mit zwanzig Mann der Nationalgarde auf der Bühne, ließ vor den Augen des Publikums scharf laden und forderte die Zuschauer auf, das Haus zu verlassen. Als seiner zweimaligen Aufforderung kein Genüge geleistet wurde, wiederholte er dieselbe nochmals unter der Androhung Feuer geben zu lassen. Als auch diese dritte Aufforderung erfolglos blieb, ließ er seine Drohung ins Leben treten. Durch dieses Verfahren wurden nun zwar mehrere Menschen getödtet, aber es hatte doch die unmittelbare Räumung des Hauses zur Folge, wodurch größerm Unglück vorgebeugt wurde. (...) Das Schauspiel wurde auf mehrere Monate Geschlossen" (BÖSCHE, Eduard Theodor. Op. cit., p. 228).

767 "A Sociedade do Teatro Constitucional Fluminense, participam ao respeitável 
houve aos cantores italianos outra alternativa senão dissolver a sociedade e procurar outros meios de sobrevivência, ainda no Rio de Janeiro ou fora dele $^{768}$. A 13 de outubro de 1831 , o Jornal do comércio publicava a seguinte nota:

\begin{abstract}
A Companhia Italiana, não podendo preencher, por se achar fechado o teatro, as condições, a que se obrigam para com aqueles Srs., que generosamente concorreram com as suas assinaturas para a sustentação de seus trabalhos cênicos; (...) convida a todos aqueles Srs. Assinantes que quiserem receber a parte de suas assinaturas correspondentes às récitas que a Companhia, não por culpa sua deixa de fazer, a dirigirem-se para (...) no espaço de seis dias $^{769}$.
\end{abstract}

Sabiam, os italianos, que seu último baluarte - os "estrangeiros acostumados a assistir a tais reuniões com aquela seriedade, característica de um povo civilizado"770 —, mesmo que o Teatro logo voltasse a reabrir suas portas, já não se sujeitariam, como antes, aos azares da sorte. A 2 de dezembro, aniversário de Dom Pedro II - portanto, pouco mais de dois meses depois do motim -, o Constitucional Fluminense reiniciava suas atividades. Todavia, o trauma do sangue derramado, sem dúvida, afastou por bom tempo seus fiéis espectadores, tornando ainda mais inviável a continuidade dos custosos espetáculos líricos ${ }^{771}$.

público, que o referido teatro se acha fechado por ordem superior (temporariamente), assim como participam a todas as pessoas que têm transações com a referida Sociedade tenham a bondade de comparecer ao escritório do referido teatro desde às 9 horas da manhã até o meio-dia, com os seus documentos, a fim de ser pagos prontamente" (JORNAL DO COMÉRCIO, 01/10/1831).

${ }_{768}$ A 9 de março de 1832, despachava-se para Montevidéu e Buenos Aires a família Piascentini, incluindo-se a primeira dama da Companhia Italiana, Justina Piascentini (Idem, 10/03/1832). No mês anterior, Miguel Vaccani já deixara o Rio de Janeiro em direção ao mesmo destino (Idem, 24/02/1832).

769 Idem, 13/10/1831.

770 Idem, 16/11/1831.

${ }^{771}$ Para se ter uma idéia de como a notícia do levante de 1831 no grande teatro carioca permaneceu ainda muito tempo em voga, chegando, inclusive, a portos do outro hemisfério, citemos aqui um trecho de um artigo publicado três lustros depois, em um 
almanaque nova-iorquino. Note-se que, segundo o autor do texto, "a Friend of the Editor" provavelmente algum norte-americano radicado no Rio de Janeiro -, o funesto ocorrido teria sido a causa do desmantelamento da companhia de ópera, conforme conjecturamos. Note-se também que a informação sobre o número de mortos - três ou quatro - foi provavelmente baseada em fontes oficiais: "The Opera House is also well conducted but an unhappy political disturbance having occurred there, in which three or four lives were lost, caused it to be shut up and the company disbanded" (RIO Janeiro and the adjacent country. Fisher's national magazine and industrial record. New York: Redwood Fisher, 1846, v. 1, p. 451). 


\title{
CAPÍTULO X - Outros sons, agora amplificados
}

\begin{abstract}
Desde meio século a música tem sido o florão mais belo do Brasil, o seu mais brilhante ornato, e que até mesmo o caracterizava e distinguia entre todas as nações do novo mundo, já pela vocação e talento natural de seus filhos, já pela eficaz proteção que recebera sempre dos diferentes governos até 1831, e hoje caminha a passos rápidos para a decadência, ou talvez para a sua total extinção, se a mão daqueles a quem foi cometida a direção dos destinos públicos, a não suster [sic] e reanimar ${ }^{772}$.
\end{abstract}

Se, por um lado, alguns músicos - sobretudo cantores de ópera deixaram o Rio de Janeiro em direção ao Prata, como já ocorrera em 1824, à época do incêndio do Teatro de São João, a imensa maioria desses profissionais, residentes na capital do Império, ali permaneceu após os acontecimentos de 1831, e buscou reagir às dificuldades apresentadas sobretudo à falta de ação governamental já vista e acima referida estabelecendo novas oportunidades de trabalho, em parceria ou não com uma sociedade civil, a qual, mesmo diante de uma corte esvaziada, não dispensou em momento algum a música como forma de entretenimento ou atividade cultural, capaz de oferecer status a seus iniciados e protetores.

Diante do enfraquecimento das atividades na Capela Imperial em julho de 1831 e no Teatro Constitucional Fluminense em outubro do mesmo ano, a primeira iniciativa musical que se vê - empreendimento esse levado, muito provavelmente, ao cabo, pelos próprios músicos - é a proliferação de

772 MAZZIOTTI, Fortunato et alii. Requerimento encaminhado ao Ministério do Império por Fortunato Mazziotti e outros professores de música, solicitando a criação de um conservatório de música e a concessão de duas loterias anuais, por espaço de oito anos, em nome da Sociedade Musical. [S.I.], 1841 (Biblioteca Nacional, Rio de Janeiro, Seção de Manuscritos, Fundo Documentos biográficos, C-0774,035). São signatários desse documento, além de Fortunato Mazziotti: Francisco Manuel da Silva, José Joaquim dos Reis, João Bartolomeu Klier, Manuel Alves Carneiro, Francisco da Mota e Firmino 
concertos ou "academias" - como se dizia - em recintos alternativos, de menor capacidade, e mais seguros, portanto, em relação a eventuais desordens. Somente nos dois primeiros meses de 1832, ao mesmo tempo em que se observa a saída da cidade de alguns dos principais membros da extinta Companhia Italiana, três importantes instrumentistas da cidade organizam, em diferentes locais, academias em seu benefício. A 9 de janeiro, o francês Pedro (Pierre) Laforge, ex-flautista e oboísta da Câmara e Capela, anunciava uma academia no salão da casa n. 82 da Rua da Quitanda, contando com a presença de uma orquestra e dos solistas Cândido Inácio da Silva, João Bartolomeu Klier, Francisco da Mota, Salvador Salvatori e Miguel Vaccani ${ }^{773}$. No dia 3 de fevereiro, era a vez de José de Aragão Espanha, exviolinista da Capela ${ }^{774}$. Um dia depois, o mesmo João Bartolomeu Klier, clarinetista alemão, também dava ao conhecimento público que promoveria um concerto na casa n. 330 da rua do Alecrim; salão, segundo anúncio do Jornal do comércio, "muito decente"

Outro espaço que caiu como uma luva para a produção de "academias" em benefício de alguns dos mais destacados músicos do Rio de Janeiro foi o "Teatrinho da Rua dos Arcos", criado em 1829 e reformado em 1832, na medida em que as elites cariocas deixavam claramente de comparecer e investir no Teatro Constitucional Fluminense para concentrar suas atenções em outros espaços sociais menores e de freqüência mais "escolhida"776. A reabertura desse espaço é registrada mais uma vez pelo Jornal do comércio:

Na noite de 3 do corrente de novo se abriu o

\footnotetext{
Rodrigues Silva.

${ }^{773}$ Idem, 09/01/1832. Em dezembro, Laforge anunciava nova academia em seu benefício, desta vez na Rua do Ouvidor, n. 215 (Idem, 03/12/1832).

774 Idem, 03/02/1832.

775 “... os Srs. que quiserem concorrer, sem embargo de não terem bilhetes, podem ir, e gratificarão com aquilo que for do agrado das pessoas; e os que quiserem levar as pessoas de sua família, pois o lugar é muito decente, no salão da rua do alecrim n. 330 , travessa de S. Jorge" (Idem, 23/02/1832).

${ }^{776}$ Nesse local, em fins de agosto de 1832, era anunciada, por exemplo, uma "grande academia de música vocal e instrumental dividida em dois atos", em benefício do multiinstrumentista Antônio Xavier da Cruz Lima (Idem, 29/08/1832)
} 
Teatro particular da Rua dos Arcos, cujas representações se haviam interrompido a 4 meses, pouco mais ou menos em razão dos preparativos que se the estavam fazendo a fim de o tornar digno do objeto para que fora instituído. Graças ao zelo dos sócios, que se não forraram a trabalhos nem a despesas, a sala não só admite agora mais crescido número de espectadores, como que se acha pintada com o maior asseio e bom gosto. Segundo o nosso cálculo a platéia pode receber até 500 convidados e a tribuna que circunda a sala e unicamente reservada para as Sr.as., 160 a 200. (...) Devemos notar, que reinou sempre grande harmonia e seriedade entre os convidados de um e outro sexo, por isso que todos eram pessoas escolhidas. Enfim, merecem todo o louvor os sócios deste elegante teatrinho, que, buscando distrair-nos da insipidez que a todos atormenta hoje em dia, procuram-nos um passatempo tão agradável, como honesto ${ }^{777}$.

A forte demanda por novos e menores espaços de entretenimento e sociabilização no Rio de Janeiro desses anos é notada também pela iniciativa de um grupo de atores, que, desde 1829, se apresentava com sucesso no grande teatro. Em 1833, Ludovina Soares da Costa, Maria Soares do Nascimento, Teresa Soares, Ricardina Soares, Vítor Porfírio de Borja, João Evangelista da Costa, José Jacó Quezado, Manoel Soares, Bento José Fernando Caqueirada, Camilo José do Rosário Guedes, José Maria do Nascimento, João Evangelista Júnior e Antônio Soares se uniram em sociedade e, apoiados por alguns "protetores" ${ }^{778}$, construíram uma nova casa

777 Idem, 07/07/1832. Segundo o Regulamento da Sociedade do Teatrinho da Rua dos Arcos, também conhecido como "Teatro Particular da Rua dos Arcos" - denotando a exclusividade do público que o freqüentava - esta agremiação compunha-se de 50 sócios e seu único objetivo era a "recreação de seus membros por meio de representações de cenas perante os convidados", esses, por sua vez, "pessoas de probidade". Os sócios entravam para a sociedade mediante contribuição de, no mínimo, $50 \$ 000$ e mensalidade de $2 \$ 000$ (COLEÇÃO das Decisões do Império do Brasil de 1829. Rio de Janeiro: Tipografia Nacional, 1877 , p. 94-100).

${ }_{778}$ "A Sociedade que está construindo o supradito teatro, ansiosa por concluir um edifício o mais bem apropriado para a representação dramática, tem a honra de anunciar ao respeitável público que o andamento da obra tem ido em progresso, devido sem dúvida 
de espetáculos na corte, o Teatro da Praia de Dom Manuel, que mais tarde em 1838 - passaria a chamar-se Teatro de São Januário, em homenagem à Princesa Imperial. Durante a construção, o elenco animou, sempre acompanhado de música orquestral, os sócios e convidados do já mencionado Teatrinho da Rua dos $\operatorname{Arcos}^{779}$.

Por outro lado, o retorno, na mesma época, ao Rio de Janeiro, de dois importantes cantores da extinta Companhia Italiana - o barítono Miguel Vaccani e o tenor Vítor Isotta - trouxe ao Constitucional Fluminense um novo fôlego musical ${ }^{780}$. Curiosamente, a companhia de atores que permaneceu na Ópera e que jamais tivera um bom relacionamento com os italianos pela acirrada disputa de espaços nessa casa acabou por unir-se a eles a partir de abril de 1833, promovendo uma pequena retomada do canto lírico, cujo maior empreendimento se deu em meados de agosto desse ano, quando, em benefício de Isotta, anunciou-se um "brilhante espetáculo", que entre outras coisas, levaria à cena "o grande final todo completo" do primeiro ato do Barbeiro de Sevilha, ópera de Rossini. A iniciativa, no entanto, apesar do amplo apoio da imprensa ${ }^{781}$, não surtiu grandes efeitos, e o Teatro

aos esforços de alguns indivíduos da mesma Sociedade e aos de outras pessoas, seus protetores..." (JORNAL DO COMÉRCIO, 28/08/1833)

${ }^{779}$ E. g.: "Domingo, 16 do corrente subirá a cena um espetáculo novo neste teatro (...) Os professores da orquestra continuarão a executar brilhantes peças de música dos melhores autores" (Idem, 12/06/1833). Note-se que à época da abertura das portas do Teatro da Praia de Dom Manuel, em 1834, o Teatrinho da Rua dos Arcos, menor e menos aparatado, caiu no olvido, muito provavelmente pela concorrência que o novo espaço lhe fez.

780 "A aquisição dos Srs. Miguel Vaccani e Vítor Isotta veio aliviar as saudades dos amadores da música e já temos gozado o prazer de ouvir bocados dela. O benefício que temos anunciado nos oferece uma noite bem satisfatória" (Idem, 14/05/1833).

${ }_{781}$ "A escolha do espetáculo que nos oferece o Sr. Vítor Isotta é suficiente para nos persuadirmos que haverá grande concurso de espectadores. (...) Na verdade, os nossos costumes tornam-se cada dia mais austeros: tertúlias, galas, funções, bailes, noites voluptuosas de contradanças, e harmonia, desvaneceu-se tudo como sonhos, como visões encantadas! De Atenas passamos para Esparta: mudamos a vida de Péricles para a de Licurgo (...) Mas o Sr. Vítor Isotta nos pretende tirar do estúpido letargo em que nos deixamos cair; o arco do rabequista é a varinha mágica com que nos há de acordar; felizes, se ao ouvir os nossos aplausos a bela música do Barbeiro, resolver-se a Administração atual a introduzir algumas reformas no seu sistema soporífero de representações dramáticas; não pedimos inovações. Deus nos livre! contentar-nos-emos com o avivar o passado. Benévolo, e generoso, seguramente o Público concorrerá para o benefício do Sr. Isotta não somente pelo motivo dos divertimentos anunciados como que movido pela justiça, pela lembrança dos serviços de um ator, que tantas vezes aplaudiu" (Idem, 
Constitucional Fluminense, sem preencher sequer $1 / 3$ de seus lugares ${ }^{782}$ não tinha mais qualquer condição de sonhar com o retorno das temporadas líricas. Como já foi dito, é muito provável que apenas nos dias de gala, com a presença da família imperial, esse grande casa de espetáculos revivesse seus outrora freqüentes dias de lotação esgotada ${ }^{783}$. Ainda assim, dadas as delicadas circunstâncias políticas daquele fim de ano de 1833 - a queda de braço entre a Regência e o Tutor, José Bonifácio -, nem se poderia dizer que o divertimento valesse a pena. A 2 de dezembro de 1833, dia do aniversário de Dom Pedro II, um tumulto dentro da Ópera acossou novamente os espectadores, incluindo-se, entre eles, o próprio monarca ${ }^{784}$. Diante disso, não tardou a circular nos jornais a desagradável notícia aos diletantes de que Vaccani e Isotta ameaçavam, mais uma vez, retirar-se dos palcos cariocas:

07/08/1833).

782 Dada a escassez de documentação específica sobre essa casa - três vezes vítima de grandes incêndios — uma prova produzida pelo acaso nos permite especular que os espetáculos do Teatro Constitucional Fluminense, a essa época, mesmo com o reforço da dupla de cantores de ópera, Vaccani e Isotta, não preenchiam mais do que um terço de seus lugares. No dia 21 de junho de 1833, uma das mais importantes figuras da remanescente companhia de atores do Constitucional, João Clímaco da Gama, realizava seu benefício. Ocorreu que, naquela noite, todo o dinheiro arrecadado com a venda dos ingressos foi roubado da bilheteria. Acusado, o responsável pela guarda do montante, o bilheteiro Francisco Antônio de Oliveira e Silva, se viu obrigado a relatar o fato publicamente, mandando imprimir nos jornais uma nota em sua defesa. Uma das informações arroladas diz respeito à renda e ao público desse espetáculo: "na noite de 21 do p.p. no benefício do Sr. João Clímaco, fiz a venda de 9 camarotes, de cento e tantas cadeiras, e trezentos e tantas gerais fazendo a conta pelos bilhetes que sobejaram a quantia de 404\$200" (Idem, 04/07/1833). Ou seja, um teatro com mais de cem camarotes e mil lugares na platéia não teve, nesse dia, sequer um terço de sua lotação comprometida. Os setores menos procurados foram os camarotes (menos de 10\%) reforçando-se a idéia de que as elites do Rio de Janeiro haviam realmente se afastado do grande teatro, direcionando suas atenções a outros divertimentos e espaços de sociabilização.

${ }^{783}$ Sobre o espetáculo teatral realizado a 2 de dezembro de 1833, natalício de Dom Pedro II, o Jornal do comércio atesta a "grande concorrência de espectadores" (Idem, 03/12/1833).

${ }^{784}$ O caso, abafado pelos jornais oficiosos, não deixou de ser comentado nos pareceres diplomáticos. Um que mencionou o assunto - em seu relatório de 19 de dezembro de 1833 - foi Gennaro Merolla, cônsul napolitano: "Nel Teatro la sera del 2 ci furono dei tumulti nonostante la presenza di Sua Maestà I'Imperatore" (MEROLLA, Gennaro. Op. cit., p. 81). Outro testemunho é o do cônsul francês, Conde de St. Priest. Segundo o historiador Marco Morel, que teve acesso a essa documentação, em Paris, "os gritos e palavras de ordem, de um e outro lado, foram num crescendo e acabaram abafando não só o espetáculo, mas a própria presença de D. Pedro. O tumulto foi grande - o que era evidente desrespeito à autoridade do jovem monarca - e do lado de fora do Teatro uma multidão reproduzia e aumentava o barulho" (MOREL, Marco. Op. cit., 2005, p. 238). 
Quinta-feira, 5 de dezembro de 1833, em benefício do primeiro tenor VÍTOR ISOTTA (...) Logo que a orquestra tiver executado uma sinfonia do mestre Rossini, começará a grande ÁRIA DA CENERENTOLA, acompanhada de coros, e cantada pelo beneficiado; depois seguir-se-á a representação do muito aplaudido drama dividido em 4 atos que se denomina OS PORTUGUESES CATIVOS EM ARGEL OU O VALOR E HEROÍSMO PORTUGUÉS. (...) Os atos serão divididos com agradáveis sinfonias. No fim do drama, seguir-se-á o grande final todo completo da ÓPERA Barbeiro de Sevilha (...) farsa que se denomina $O$ Enredador. É com o descrito entretenimento que o beneficiado vai desafiar (quem sabe pela última vez) a generosidade do iluminado público da Capital do Império, pois que fora do seu elemento, pela falta de Ópera Italiana, se vê forçado a procurar noutro país a precisa subsistência... ${ }^{785}$

Mesmo para os que não viviam apenas dos grandes espetáculos operísticos, esses também não foram tempos fáceis. Apesar das iniciativas particulares das academias e do surgimento de novos palcos, onde sobretudo a música instrumental encontrava acolhida, espaços de apresentação menores significavam orquestras menores; ou seja, menos oportunidades de trabalho. Parcerias com atores dramáticos constituíam também uma forma de dependência em relação aos colegas artistas e, possivelmente, desvalorização profissional; perda pecuniária.

Não foi, pois, à toa que a 18 de novembro de $1833^{786}$ eram aprovadas,

785 Idem, 29/11/1833. Na verdade, ambos ainda permaneceriam animando, entre idas e vindas, a vida teatral do Rio de Janeiro dos anos seguintes. Em novembro de 1836, por exemplo, Vaccani se destacava em um espetáculo realizado no Teatro da Praia de Dom Manuel. Mas ao que tudo indica, sua voz já não tinha mais a potência de anos anteriores: "Pelo que diz respeito à orquestra, faltaríamos ao nosso dever se espaçássemos o elogio; confessaremos pois que não esperávamos uma execução tão varonil e tão bem sustentada. Sobretudo o acompanhamento da ária cantada, com mais arte do que voz, pelo Sr. Vaccani, foi perfeitamente executado (O SETE DE ABRIL, 23/11/1836).

${ }_{786}$ Segundo o CEHB - Catálogo da Exposição de História do Brasil —, publicado no volume IX dos Anais da Biblioteca Nacional do Rio de Janeiro, havia, tombado, nessa instituição, um documento, publicado em 1833 pela Tipografia Nacional com o seguinte título: Bases para a Sociedade Beneficência Musical, aprovadas pelos professores de música, em 18 de novembro de 1833 (t. 2, p. 1172, 1881). Foi por aí que pudemos 
no Rio de Janeiro, por uma congregação de músicos, as bases para uma entidade cultural voltada à promoção de "academias", e, acima de tudo, uma associação de classe capaz de fortalecer os interesses profissionais dos músicos e protegê-los dos infortúnios, mediante benefícios, pagos por uma caixa beneficente. Surgia a "Sociedade Beneficência Musical", também conhecida como "Sociedade de Música", que, de certa forma, veio a substituir a já mencionada Irmandade de Santa Cecília com novo nome e regras profissionais e previdenciárias mais bem estabelecidas ${ }^{787}$.

Tal como ocorria com a velha Irmandade, a sustentação financeira da Sociedade de Música se baseava na contribuição individual de seus sócios à caixa beneficente. De cada pataca - 320 réis - ganha no serviço profissional, o músico deveria repassar um vintém - vinte réis - à Sociedade. Havia ainda uma jóia de admissão, cujo valor dependia da idade do músico, e uma mensalidade geral de mil réis. Em contrapartida a esses deveres, os músicos, quando enfermos, tinham direito a receber, por dia, os mesmos mil réis pagos mensalmente. $E$, caso fosse-lhes constatada inabilidade definitiva de exercer a arte, tinham direito a uma pensão pecuniária, que poderia ser paga, igualmente, por uma vida, às viúvas, filhas, mães ou irmãs do associado, em razão de falecimento ${ }^{788}$. Depois de quatro anos de existência da Sociedade, sua movimentação financeira produzia, conforme comentário publicado no Cronista, "os mais favoráveis resultados":

constatar a data da fundação da sociedade, uma vez que o documento em si infelizmente não foi localizado na Biblioteca Nacional por seus funcionários, quando de nossa demorada visita a essa instituição, em novembro de 2003.

${ }^{787}$ Note-se que, na verdade, não se sabe até hoje, ao certo, quando se deram, definitivamente, por encerradas as atividades da Irmandade de Santa Cecília do Rio de Janeiro. Segundo um número do Diário do Rio de Janeiro (vide nota 69 desta parte), esta instituição ainda se mantinha ativa, em fins de 1834, mesmo já tendo sido fundada a Sociedade Beneficência Musical. No entanto, dada a total falta de notícias a respeito da Irmandade desde então, é bem possível que, justamente por essa época, ela tenha dado lugar à nova Sociedade, até porque, segundo Ayres de Andrade, essa última funcionou, durante um tempo, no mesmo endereço da Irmandade, ou seja, o consistório da Igreja de Nossa Senhora do Parto (ANDRADE, Ayres de. Op. cit., v. 1, p. 176).

${ }^{788}$ Cf. ESTATUTOS da Sociedade de Música. Rio de Janeiro: Tip. de Paula Brito, 1854. Note-se que este é o mais antigo exemplar dos estatutos da Sociedade Beneficência Musical por nós encontrado no acervo da Biblioteca Nacional do Rio de Janeiro. Ali existe ainda um outro, de 1868, publicado pela Tipografia Nacional. Dada a pouca diferença encontrada entre o texto de 1854 e o de 1868 , é de se imaginar que tais regras, à época da 
catorze contos de réis de entradas e um saldo de 9:400\$000 ${ }^{789}$.

Contudo, mais importante do que promover a seguridade de seus associados, a Sociedade Beneficência Musical atuou também como verdadeiro sindicato, resguardando $-\mathrm{e}$ até aumentando $-\mathrm{o}$ valor econômico do serviço musical em um momento de maior instabilidade desse exercício profissional. Entre as obrigações estatutárias dos sócios, figurava a de "não exercer a arte em atos públicos sem ser por convite dos Diretores da Sociedade" ${ }^{790}$. O resultado prático desse artigo pode ser notado claramente nos diversos recibos de pagamentos da Capela a instrumentistas avulsos, contratados, entre 1840 e 1843, para solenidades de gala do Império manuscritos esses tombados no Arquivo Nacional do Rio de Janeiro ${ }^{791}$. Todos são assinados por um único músico, Francisco da Luz Pinto, diretor da Sociedade Beneficência Musical, e o valor dos cachês individuais é sempre o mesmo: $12 \$ 750$, uma cifra bastante elevada para uma única apresentação, se imaginarmos que um músico efetivo da Capela, como o próprio Francisco da Luz Pinto - então cantor dessa instituição, em 1842 -, ganhava, por mês, $25 \$ 000-300 \$ 000$ por ano ${ }^{792}$-, tendo de trabalhar bem mais do que uma vez a cada quinzena.

A prova cabal da força da Sociedade Beneficência Musical como sindicato, embora tácita, aparece em um manuscrito alguns anos posterior da mesma documentação relativa à Capela Imperial — um relatório de 1849 -, que rememora os tempos da menoridade.

Quando no princípio da Menoridade de Sua Majestade, o Imperador, foram dispensados do serviço da Capela os músicos instrumentistas, fizeram um convênio, no qual se assentou, que nenhum músico tocaria na Capela Imperial por

\footnotetext{
fundação, entre 1833 e 1834, também não fossem muito divergentes.

${ }_{789}$ O CRONISTA, 13/01/1838.

790 ESTATUTOS da Sociedade de Música. Rio de Janeiro: Tip. de Paula Brito, 1854 , p. 5.

${ }^{791}$ ARQUIVO NACIONAL, Rio de Janeiro. Fundo Casa Real e Imperial, cx. 13, pc. 1 e 2.

${ }^{792}$ Idem, cx. 13, pc. 2, doc. 44.
} 
menos de $12 \$ 000$ rs. por cada ação diferente e distinta, e por tal modo se coligarão, tão religiosamente cumprirão o seu convênio, que uma só vez o não quebrarão... ${ }^{793}$

O "convênio" ao qual o Inspetor da Capela se refere não pode ser outro, senão, o compromisso estatutário dos membros da Sociedade Beneficência Musical, guardiã dos interesses dessa classe profissional.

Enfim, além dos aspectos beneficentes e sindicais dessa entidade, devemos ressaltar também os importantes serviços que ela prestou ao movimento artístico e cultural da época. Durante um dos mais estagnados momentos da política cultural brasileira, a Sociedade Beneficência Musical promoveu, periodicamente, grandes "academias" em seu benefício, congregando os mais seletos músicos do Rio de Janeiro e executando repertório novo, tanto nacional, como europeu, esse último, curiosamente menos voltado à ópera italiana e mais à música instrumental então em voga nas capitais francesa e inglesa. No dia 4 de novembro de 1834, por exemplo, o Teatro Constitucional Fluminense, abrigando a Sociedade, abria suas portas aos diletantes, prometendo, em seus anúncios, a interpretação, entre outras peças, de aberturas de Auber e Hérold, um concerto para duas clarinetas de Cramer, e obras instrumentais de Cândido Inácio da Silva e Januário da Silva Arvelos ${ }^{794}$. Três anos depois, a mesma Sociedade fazia saber a apresentação, entre indefectíveis composições de Rossini, de um concerto para piano de Kalkbrenner, das "novas" aberturas Lestocq e Le cheval de bronze, de Auber e das "novas" variações para corneta de chaves de Cândido Inácio da Silva ${ }^{795}$.

A importância dessas atividades, incluindo-se a audição de peças de autores nacionais - como Cândido Inácio - foi plenamente reconhecida pela crítica contemporânea. Segundo o Jornal dos debates políticos e

${ }^{793}$ Idem, cx. 13, pc. 3, doc. 305.

${ }^{794}$ DIÁRIO DO RIO DE JANEIRO, 04/11/1834.

795 JORNAL DO COMÉRCIO, 11/10/1837. Quanto à "novidade" do repertório, notese que Le Cheval de bronze, de Auber, estreou em Paris, em 1835 e Lestocq, do mesmo autor, um ano antes. Já, Kalkbrenner era um dos mais celebrados pianistas residentes na 
literários, publicação carioca de fins da década de 1830, a Sociedade Beneficência Musical foi considerada "a âncora que suspendeu o naufrágio desta arte" e dois de seus principais integrantes, Francisco Manuel da Silva e Cândido Inácio da Silva,

... os anjos que governaram a arca possuidora dos códices que deviam transportar à geração vindoura uma arte que tem sido consagrada por todas as nações... ${ }^{966}$

Maior influência ainda teria a Sociedade Beneficência Musical no "transporte" dessa arte "à geração vindoura" quando, quase quatro anos depois, mais precisamente a 23 de junho de 1841, sete "professores de música", em nome da Sociedade, entregaram à Câmara dos Deputados as bases para a criação de um conservatório de música na capital do Império, a ser instituído mediante a obtenção, pelo espaço de oito anos, de duas loterias anuais ou subsídio equivalente. Eis o principal argumento dos requerentes, transcrito da inédita petição original, conservada no acervo da Biblioteca Nacional do Rio de Janeiro:

A capital do Império, senhores, terá de ver bem depressa a época em que para a Capela Imperial não hajam os professores precisos, e que igualmente se não possa entreter o Teatro Nacional, se um conservatório não for imediatamente criado a fim de abrir mais uma carreira a nossa mocidade talentosa de ambos os sexos, e promover assim a moralidade pública; um conservatório onde se possam aproveitar as excelentes disposições dos brasileiros, e onde se façam ótimos artistas que

capital francesa durante a década de 1830.

796 JORNAL DOS DEBATES POLÍTICOS E LITERÁRIOS, 30/09/1837. Em contrapartida, na crítica ao concerto da Sociedade, publicado duas semanas depois, só restou o desprezo aos políticos: "O teatro tem uma enchente completa, e nós desejamos saber a vista de tal entusiasmo, o que diriam certos Senadores e certos Deputados, que por falta do órgão da música desprezam semelhante arte: queixem-se de sua má organização e insensibilidade, e não menosprezem a arte, que tantos homens civilizados adoram" (Idem, 18/10/1837). 
vão enriquecer o teatro, mesmo como cantores, visto que estes só podem vir da Europa por imensos sacrifícios. Se, pois, um conservatório não vier como âncora das artes no Brasil, abrilhantar o culto e iluminar o teatro, qual será o nosso estado relativo à música quando mais alguns anos forem passados? A Sociedade Musical já impediu, senhores, a ruína total da música e apesar de seus esforços não pode de maneira alguma fazê-la progredir sem o vosso auxílio. A missão de conservar está realizada mas esta não pode durar se a criação de novos artistas não vierem substituir aqueles que desaparecem para sempre ${ }^{797}$.

De fato, a atividade musical no Rio de Janeiro vivia, pelos idos dos anos de 1830, um momento crucial. Desde o desaparecimento de José Maurício Nunes Garcia e de sua aula pública - pela qual passaram os mais destacados músicos brasileiros da geração posterior à do padre, como Francisco Manuel da Silva, Cândido Inácio da Silva, Francisco da Luz Pinto e Francisco da Mota -, o ensino dessa profissão quase que não mais se viabilizara, na capital do Império, de forma gratuita ou subsidiada, voltado aos talentos sem recursos financeiros ${ }^{798}$. Vinculadas ao diletantismo das elites, as aulas de música, durante esse período, mesmo que oferecidas a alunos hábeis por alguns dos melhores músicos da corte ${ }^{799}$, não permitiam

${ }^{797}$ MAZZIOTTI, Fortunato et alii. Op. cit.

798 A esse respeito, assim nos testemunha o jornal O Brasil, em 1841: "A música tem sido entregue a seus destinos; hoje só é lícito gozar de seu ensino às pessoas abastadas que podem pagar mestres; ao povo nada se concede..." (O BRASIL, 08/07/1841). Na verdade, havia ao menos um local público, na capital do Império, onde se ensinava algo de música: o Colégio de Pedro II. Em 1843, ocupava a cátedra dessa disciplina, o cantor da Capela e diretor da Sociedade Beneficência Musical, o já mencionado Francisco da Luz Pinto (ALMANAQUE administrativo mercantil e industrial do Rio de Janeiro para o ano de 1844. Rio de Janeiro: Eduardo e Henrique Laemmert, 1843, p. 74). A esse respeito vale notar também que, em 1839, o então Comandante do Corpo Municipal Permanente da corte, Luís Alves de Lima - Futuro Barão, Conde, Marquês e Duque de Caxias - pretendia instalar no quartel, na Rua dos Barbonos, uma aula pública e gratuita "tanto de música vocal como instrumental de sopro" sob a direção do maestro e compositor Januário da Silva Arvelos (JORNAL DO COMÉRCIO, 16/01/1839). Infelizmente nada sabemos sobre a real concretização dessa iniciativa. Ayres de Andrade, sem mencionar fontes e demais detalhes, comentou apenas que "gratuitos esses cursos, logo tiveram grande procura” (ANDRADE, Ayres de. Op. cit., v. 2, p. 140).

${ }_{799}$ Não são raros os anúncios que apresentam, durante a década de 1830 , alguns 
qualquer oportunidade de desenvolvimento artístico profissional, uma vez que o preconceito da sociedade ainda bem distinguia o gosto da obrigação ${ }^{800}$. Além disso, esses principais profissionais vinham desaparecendo ano após ano. Em 1830, e. g., expiraram Marcos Portugal e José Maurício Nunes Garcia; em 1832, Pedro Teixeira de Seixas; em 1839, Cândido Inácio da Silva; em 1840, João Francisco Fasciotti.

Diante da evidência de tal situação, não causa espanto o fato de o Legislativo ter aceito, sem dificuldades, os argumentos da Sociedade Beneficência Musical e, com presteza, aprovado o requerimento. A 27 de novembro de 1841 era sancionado por Dom Pedro II um decreto da Assembléia Geral concedendo à dita associação de músicos duas loterias anuais por espaço de oito anos a fim de que ela estabelecesse na corte um conservatório de música ${ }^{801}$. E apesar da lentidão do Governo em promover o pleno funcionamento dessa escola nos anos subseqüentes, regulamentando

dos mais renomados músicos do Rio de Janeiro oferecendo aulas de música. Esta foi uma época, inclusive, que, pela diminuição das principais atividades musicais na corte, não faltaram profissionais interessados em reforçar sua renda, lecionando. Caso, por exemplo, da antiga integrante da Companhia Italiana do São Pedro de Alcântara, Madame Fasciotti, agora professora de "piano e cantoria" (ALMANAQUE geral do Império do Brasil. Rio de Janeiro. Tip. Comercial Fluminense de S. F. Surigué, 1836, p. 285); do cantor aposentado da Capela, Salvador Salvatori, que prometia "ensinar a Arte de Cantar pelo método mais moderno e adotado na Europa, que diligenciou adquirir durante a sua última viagem à Itália" (CORREIO DAS MODAS, 19/07/1840); ou ainda de José Joaquim dos Reis. Este último, então spalla do Teatro de São Pedro de Alcântara, oferecia aulas de música vocal teórica e prática segundo método "adotado pelo Conservatório de Paris". Para tanto, cobrava, por mês, de $6 \$ 000$ a $10 \$ 000$, uma quantia, seja dito de passagem, nada desprezível, o que reforça ainda mais a idéia de que o aprendizado musical, à época, na capital do Império, era apenas privilégio de uma elite econômica (JORNAL DO COMÉRCIO, 18/02/1840).

${ }_{800}$ Araújo Porto Alegre, em texto publicado por Debret em sua Voyage pittoresque et historique au Brésil faz menção ao preconceito social - um "certo desprezo" - que ainda havia em relação aos profissionais da música, no Brasil: "On s'étonne cependant que les Brésiliens, passionnés pour la musique, conservent un certain mépris pour les musiciens de profession; et c'est à un tel point, que l'homme riche qui paye généreusement la leçon qu'il reçoit de son professeur de musique, serait intérieurement honteux d'être son ami” (DEBRET, Jean Baptiste. Op. cit., v. 3, p. 88). Um texto contemporâneo do Jornal do comércio, referente à decadência do teatro carioca, também retrata esse desprezo da sociedade da época por seus artistas dramáticos: "Quais têm sido as causas do pouco aumento do nosso teatro? A meu ver muitas. Em primeiro lugar, nós não damos apreço a um artista dramático. (...) Um rapaz que entre nós dedica-se ao teatro, ainda que seja um verdadeiro artista, sabe que vai ficar desprezado. (...) Este desprezo tem sido a causa de não termos mais atrizes brasileiras. Quais as mulheres que se dedicam ao teatro? Com poucas exceções, só as de uma classe..." (JORNAL DO COMÉRCIO, 07/03/1839).

801 COLEÇÃO das Leis do Império do Brasil de 1841. Rio de Janeiro: Tipografia nacional, 1842, parte 1, p. 63. 
seus estatutos e concedendo na prática as referidas loterias para a sua sustentação, a Capital do Império, em um espaço de cerca de vinte anos, viu frutificar, indiscutivelmente graças ao plantio dessa semente cultural, uma nova geração de competentes músicos, da qual se sobressaiu o maior compositor brasileiro de todo o século XIX, Antônio Carlos Gomes.

Enfim, é também à Sociedade Beneficência Musical que se deve, muito provavelmente, a organização e a viabilização das atividades arquitetadas por outras três associações, criadas pouco tempo depois, e intimamente voltadas ao cultivo dessa arte, seja sob a forma de academias de música vocal e instrumental, seja sob a forma de bailes. Tratemos, em primeiro lugar, da única delas cuja data precisa de fundação nosso estudo conseguiu revelar.

"Instalada a 24 de agosto de 1835 "802, a "Sociedade Filarmônica" tinha por finalidade, segundo seus estatutos, publicados em 1840, reunir "pessoas nacionais e estrangeiras de um ou outro sexo, destinadas a promover a execução de música vocal e instrumental, afim de se instruírem e recrearem mutuamente" ${ }^{803}$. Como o próprio nome denuncia, essa entidade foi estabelecida por amadores de música, entusiastas das mais privilegiadas classes da sociedade carioca que se dedicavam à essa arte, por gosto ou por moda, sendo, muitos deles, provavelmente, alunos particulares dos mais renomados professores da corte ${ }^{804}$. Suas atividades consistiam de apresentações musicais dos sócios, em reuniões assistidas pelos demais associados e convidados. O caráter instrutivo da agremiação era garantido pela participação, no próprio quadro social, de músicos profissionais, que dirigiam artisticamente os saraus, quando não participavam efetivamente das

${ }^{802}$ ALMANAQUE administrativo mercantil e industrial do Rio de Janeiro para o ano de 1848. Rio de Janeiro: Eduardo e Henrique Laemmert, 1847, p. 276.

1840 , p. s/n. ${ }_{804}$ Ao comentar, certa vez, em 1851, na revista Guanabara, sobre o importante ingresso de Francisco Manuel da Silva nos quadros da Sociedade Filarmônica, Manuel de Araújo Porto Alegre deixa a entender que já faziam parte de tal grêmio, muitas das alunas do destacado músico carioca: "À entrada do Sr. Francisco Manuel da Silva ao concurso de suas admiráveis discípulas e ao gosto e aos aplausos dos sócios se deveram aquelas noites admiráveis..." (Apud ANDRADE, Ayres de. Op. cit., v. 1, p. 177). 
apresentações, acompanhando os amadores.

Em 1837, a Sociedade Filarmônica já despertava grande afluência de interessados, tanto que, na reunião mensal de junho desse ano, não foi permitida a entrada de convidados "em conseqüência do grande número de sócios e da pequena capacidade da sala" ${ }^{805}$, situada, à essa época, segundo Manoel de Araújo Porto Alegre, na Rua de São Pedro ${ }^{806}$. Informações de anos posteriores, contidas em diferentes edições do Almanaque Laemmert indicam, entretanto, que houve mudança da sede para a Rua do Conde, provavelmente pela necessidade de mais espaço ${ }^{807}$. À época da coroação de Dom Pedro II, em meados de 1841, as atividades da Filarmônica já eram muito bem consideradas, tanto pela enorme curiosidade que os seus saraus ainda provocavam, como pela sua importante função de propagar o conhecimento da arte musical. Assim declarava, a respeito, o Jornal do comércio:

... ninguém há que ignore o alto preço em que é tida a Sociedade Filarmônica na opinião dos amadores; não há reunião cujos convites sejam cobiçados com tanta ânsia e que mais satisfaça a expectativa dos convidados. A elegância e beleza do estilo, a harmonia angélica das vozes, a expressão do canto e profundo conhecimento dos mistérios da arte, tudo se encontra nesses belos saraus tão desejados, que inundam a alma de harmonias celestes, e nelas gravam recordações que nunca se podem esquecer. $A$ instituição da Filarmônica foi uma bela idéia.

805 JORNAL DO COMÉRCIO, 16/06/1837.
806 MINERVA BRASILIENSE, 01/01/1844.
807 ALMANAQUE administrativo mercantil e industrial do Rio de Janeiro para o ano de 1848. Rio de Janeiro: Eduardo e Henrique Laemmert, 1847, p. 276. Nem assim, a sede dessa sociedade deixou de permanecer completamente cheia durante as reuniões. Eis o comentário de um concerto da Filarmônica realizado três anos depois, já na Rua do Conde: "O dia ameaçava noite chuvosa, o céu entretanto parecia ter compaixão dos amadores da boa música e do belo canto. A noite vestiu-se de gala, rodeou-se de estrelas, reassumiu seu poderio, e à Sociedade Filarmônica concorreu tão grande número de sócios e convidados, que nenhum lugar ficou vazio, que as salas e os corredores se apinharam de gente, e até pelo Largo do Rossio lá se desfilava linha imensa de cadeiras, lá se perdiam mil curiosos diletantes, que não respeitaram as lamas da rua, nem tiveram medo da fria atmosfera deste mês" (CORREIO DAS MODAS, 23/07/1840). 
Reunindo em seu seio nossas celebridades musicais, sob a direção de um professor tão distinto, como o Sr. Francisco Manuel, forma como um centro de bom tom artístico, cuja imitação deve produzir extraordinária influência sobre o cultivo dessa bela arte que, despertando os doces sentimentos do coração humano, contribui tanto para a civilização dos povos. Além disto, os talentos se acrisolam pelo contato, e está fora de dúvida que as sociedades em que se reúnem os talentos eminentes sempre exercem uma influência salutar sobre o espírito público na esfera de sua atividade. Não será, talvez, possível avaliar devidamente quanto terá a Filarmônica contribuído para aperfeiçoar o gosto e incitar o desejo de cultivar o estudo da música, mas o que não se pode duvidar é que para o futuro se façam poderosamente sentir esses resultados $^{808}$.

Apesar da importância que a Filarmônica teve para a vida musical carioca do período regencial e dos primeiros anos do segundo reinado, são muito raros os vestígios de informações que o pesquisador hoje encontra a seu respeito ${ }^{809}$. Contudo, podemos presumir, por notícias esparsas publicadas nos periódicos, que, até 1844, as reuniões eram, via de regra, mensais, e o repertório executado, dominantemente operístico, tanto pela quantidade de sócias mulheres - muito dadas, à época, ao estudo do canto - quanto pela gosto geral, ainda contaminado pela maciça influência italiana, herdada de Portugal ${ }^{810}$.

\footnotetext{
808 JORNAL DO COMÉRCIO, 25/07/1841.

809 É possível que no Arquivo Nacional - e sobretudo nos fundos que guardam os antigos papéis dos quatro primeiros Ofícios de Notas do Rio de Janeiro - ainda se encontre a ata de fundação da Sociedade Filarmônica e outras informações relevantes sobre ela, como o rol completo de nomes dos seus fundadores, os primeiros estatutos etc. Infelizmente, a exiguidade do tempo de nossa pesquisa e as dificuldades de acesso a essa documentação inviabilizaram quaisquer descobertas nesse sentido. Esperamos em um futuro próximo complementar essas informações.

${ }_{810} \mathrm{~A}$ apresentação que a Sociedade Filarmônica realizou em homenagem à coroação de Dom Pedro II, em julho de 1841, por exemplo, não deixa dúvidas quanto à preponderância do diletantismo feminino, quase sempre vocal. Eis o programa da referida apresentação: "O concerto principiou pela execução do hino composto e dedicado a S. M. I. pelo Sr. Francisco Manuel da Silva, depois do que seguiram-se: a introdução da ópera
} 
Do ponto de vista social, os poucos dados encontrados confirmam que a Filarmônica congregou uma ampla variedade de indivíduos: proprietários, negociantes, funcionários públicos, intelectuais, artistas. Em 1840, por exemplo, participavam de sua diretoria: como $1^{\circ}$ Secretário, servindo de Presidente, o Oficial Maior do Tribunal do Conselho Supremo Militar e de Justiça, João Jacques da Silva Lisboa; como $2^{\circ}$ Secretário, o Professor da Academia Imperial das Belas Artes, Manuel de Araújo Porto Alegre; e como Conselheiro, o músico, Padre Firmino Rodrigues Silva ${ }^{811}$. Em 1847, tomava parte da diretoria da entidade como Presidente, o negociante João Pedro da Veiga ${ }^{812}$. Um ano depois, a Filarmônica passava a contar com um "Presidente Honorário", o Maestro Francisco Manuel da Silva ${ }^{813}$. Outro nome que também

Cenerentola, de Rossini, executada pelas Sras. Maria Henriqueta Graça, D. Henriqueta Carolina dos Santos, D. Maria Carolina Nunes e pelo Sr. Antônio Severino da Costa; a cavatina da ópera Gianni di Calais, de Donizetti, executada pela Sra. D. Amália Maria Firmo; o quarteto da ópera Mosé in Egitto de Rossini, executado pelas Sr.as D. Teresa Joaquina Nunes, D. Mariana Henriqueta e Srs. José Rufino Rodrigues de Vasconcelos e Salvador Fabregas; a cavatina da Pia de Tolomei, de Donizetti, executada pela Sra. D. Paulina Porto Alegre; o dueto da ópera Belisário, de Donizetti, executado pela Sra. D. Delfina Rosa da Silva Vasconcelos e pelo Sr. Dionísio Vega; o rondó da ópera Cenerentola, de Rossini, executado por D. Mariana Henriqueta Graça; a introdução da ópera Aureliano in Palmira, de Rossini, executada pelas Sras. D. Amália Maria Firmo e D. Paulina Porto Alegre. Desnecessário parece-nos dizer que este concerto foi o mais bem desempenhado possível" (JORNAL DO COMÉRCIO, 25/07/1841). Quase que exatamente um ano antes, o Correio das modas também nos testemunha um concerto similar da Filarmônica: "Depois de uma abertura de Rossini, teve lugar o dueto dos Cruzados no Egito do famoso Meyerbeer. Era essa música gigantesca, e melancólica, sonora e majestosa, grande prelúdio de Roberto do Diabo. (...) A segunda parte do concerto conteve, além de outras músicas, o dueto da Norma, dessa bela sacerdotisa dos Gaulos, casta, pura e nobre inspiração desse Deus da música, que se chamava Bellini (...). As senhoras, que o cantaram, rivalizavam com o célebre maestro, E os músicos bem o secundaram" (CORREIO DAS MODAS, 23/07/1840).

${ }^{811}$ Cf. ESTATUTOS da Sociedade Filarmônica. Rio de Janeiro: Imprensa Americana, 1840.

${ }_{812}$ ALMANAQUE administrativo mercantil e industrial do Rio de Janeiro para o ano de 1848. Rio de Janeiro: Eduardo e Henrique Laemmert, 1847, p. 276. João Pedro da Veiga era irmão do falecido Deputado Evaristo da Veiga. Foi Vereador do Senado da Câmara do Rio de Janeiro.

${ }^{813}$ ALMANAQUE administrativo mercantil e industrial do Rio de Janeiro para o ano de 1849. Rio de Janeiro: Eduardo e Henrique Laemmert, 1848, p. 228. Aliás, é de se considerar que foi provavelmente esse ambiente "democrático" - de harmonia entre classes - da Sociedade Filarmônica o responsável por permitir a certos músicos ali associados, mesmo de pouco brilho artístico, como Francisco Manuel da Silva e Cândido Inácio da Silva, ascender econômica e socialmente. Em 1837, essa "mudança de posição" já era notada publicamente: “... ambos mudaram de posição, e o que é mais espantoso, entre nós, é que apesar disso seus nobres corações palpitam pelas artes com aquela força perseverante de que o entusiasmo é o apanágio" (JORNAL DOS DEBATES POLÍTICOS E 
participou, com destaque, dos quadros de tal sociedade - possivelmente como importante mecenas - foi o de Henriqueta Carolina dos Santos (18251897). Ainda bastante jovem, essa abastada filha de fazendeiros - futura Baronesa de Três Barras e Viscondessa de Jaguari - brilhava nos saraus da Sociedade como diletante, cantando árias de óperas. Dez anos mais tarde, em 1852, sua "ausência”, segundo um documento da época, assinado pelo então Presidente da entidade, o Desembargador João Antônio de Miranda, teria feito "cessar os pagamentos e as reuniões" da Filarmônica, ocasionando naquele mesmo ano, o seu $\mathrm{fim}^{814}$.

A par das academias, promovidas por artistas isolados ${ }^{815}$ ou por sociedades, como a Beneficência Musical e a Filarmônica, é de se notar, também, nesse período em foco, um desenvolvimento jamais visto no Rio de Janeiro de atividades musicais relacionadas à coreografia e precisamente vinculadas às sociedades de baile. Como já vimos, apesar das "sociedades privadas", descritas pelo inglês James George Semple Lisle ${ }^{816}$ nos revelarem

LITERÁRIOS, 30/09/1837). Francisco Manuel, que ainda viveria por muitos anos Cândido Inácio morreu em 1839 - , era um músico de fundo de palco da Capela Imperial quando foi demitido com os demais instrumentistas dessa repartição, em 1831. Dez anos depois, em 1841, era nomeado compositor da Câmara Imperial e, em 1842, mestre-decapela da Capela Imperial. Tempos depois, em 1845, recebeu também de Dom Pedro II o grau de Cavaleiro da Ordem da Rosa. Em 1844, comentando um concerto da Sociedade Filarmônica, Araújo Porto Alegre denota o respeito e estima social que Francisco Manuel adquirira nesses tempos: "Quantos sacrifícios não tem feito este honrado brasileiro para sustentar e fazer progredir uma arte que tem atravessado todos os séculos fazendo as delícias do gênero humano e conduzido o homem a atos de heróísmo! Mas todos estes sacrifícios são compensados pela estima e veneração que goza de seus concidadãos, e pela idolatria que the consagram os membros agraciados da Sociedade Filarmônica" (MINERVA BRASILIENSE, 01/01/1844).

${ }_{814}^{814}$ Apud ANDRADE, Ayres de. Op. cit., v. 1, p. 178.

815 Depois da criação da Sociedade Beneficência Musical, em fins de 1833, e a provável melhoria das relações de trabalho para os muitos profissionais a ela associados, as academias em seu benefício diminuíram. A maior parte delas, a partir de então, passa a ser realizada por empreendimento direto da Sociedade - e em seu benefício - ou por artistas estrangeiros de passagem pela capital do Império, e, portanto, não vinculados à Sociedade. E. g.: em 1834, apresentava-se na corte o "professor de rabeca" Carlos Bassini, prometendo a execução de obras de Paganini, entre as quais, um "grande capriccio" (DIÁRIO DO RIO DE JANEIRO, 03/10/1834). Já, em abril de 1839, um grupo de estrangeiros, do qual fazia parte o violinista italiano José Crocco, prometia a realização de uma academia vocal e instrumental no Hotel da Itália, localizado na Praça da Constituição (JORNAL DO COMÉRCIO, 19/04/1839). Alguns anos depois, em 1842, o clarinetista Dionísio Trucci convidava o público carioca para uma academia em seu benefício no Teatro de São Francisco (Idem, 11/04/1842).

${ }^{816}$ Vide nota 76 da primeira parte. 
indícios do estabelecimento ali, ainda durante o período colonial, desse tipo de agremiação, a primeira experiência nesse sentido, notadamente "oficializada", ocorreu, como já vimos, apenas no período joanino, mais precisamente em 1815, quando um projeto de sociedade recreativa, apresentado ao Governo por grandes negociantes, foi instituído legalmente sob o nome de "Assembléia Portuguesa". A quase completa ausência de informações a respeito dessa entidade nos faz presumir que sua iniciativa não perdurou. Durante o primeiro reinado, não se tem também qualquer notícia da criação de semelhantes associações.

Isto não significa que os bailes não configurassem uma prática social freqüente. A sua realização ocorria, sim; porém, em ambientes ainda mais privados do que as sociedades recreativas: as residências, incluindo-se o Palácio de São Cristóvão ${ }^{817}$. Ao que tudo indica, os clubes de dança não prosperaram durante essa época porque o teatro, enquanto divertimento de maior interesse do monarca e da sociedade - e elevado ao seu auge nesse período -, eclipsou qualquer outro tipo de entretenimento que pudesse envolver um certa quantidade de pessoas e que exigisse uma sede especialmente criada para tal fim. Não é nada estranho pensar, portanto, que o vácuo da decadência da ópera e do espetáculo dramático ${ }^{818}$ a partir de

817 Esta é a razão maior para que a prova sobre esse tipo de evento seja rara. Encontros sociais ocorridos em ambientes pequenos deixam sempre poucas testemunhas. $\mathrm{E}$ as fontes dessas ocasiões, quase sempre manuscritas, são, portanto, mais passíveis de extravio.

${ }^{818}$ Note-se que, assim como a ópera, o espetáculo puramente dramático também sofreu uma grande decadência durante esse período; porém, menos pela falta de bons executantes - entre os quais figuravam o mais relevante ator brasileiro do século XIX, João Caetano dos Santos - e mais pela baixa qualidade dos textos, além, é claro, da falta de público, de subsídios governamentais, e de segurança, durante os tempos de maior embate político na corte. O alemão Carl Seidler, apesar do seu repugnante preconceito contra os mulatos, trata bem desse assunto em seu livro de memórias Zehn Jahre in Brasilien, mencionando a retirada das peças portuguesas de cartaz — menos pela lusofobia e mais pelo excesso de estudos e despesas que demandavam - e o surgimento, após a abdicação de Dom Pedro I, de um "drama popular", produzido a partir de traduções "terríveis" de peças francesas, inglesas e alemãs, e "intoleravelmente alusivo às heróicas proezas perpetradas no agourento 7 de abril de 1831, de carnavalesca memória": "Die alten portugiesischen Schauspiele erforderten zu viel Studium und Kostenaufwand; außerdem musste eine so gewaltige Revolution notwendig mit den vielen ungelegten Eiern sogleich ein volkstümliches Drama zur Welt bringen. Die Mulatten find schon von Geburt nur ein Flickwerk der Mutter Natur, sie verstehen das Flickwerk vortrefflich. Die ältern und neuern dramatischen Erzeugnisse Frankreichs, Englands und Deutschlands wurden in einer 
1831 tenha sido o principal fator motivador do surgimento, nos anos seguintes, de pelo menos duas importantes sociedades de baile na corte, capazes de congregar em seus eventos, não apenas a nata da sociedade, como também grandes orquestras, formadas pelos melhores músicos, e, conseqüentemente, produzir divertimentos de alto nível.

Os primórdios dessas sociedades de baile parecem estar vinculados à própria proliferação das associações civis, de um modo geral, a partir de 1831 119 . De todas elas, destacou-se sobremaneira a "Sociedade Defensora da Liberdade e Independência Nacional", que, unindo em seu quadro de sócios as principais lideranças políticas da época, tornou-se, em pouco tempo, como é de notório conhecimento, um "Estado no Estado"; e sua ação, "mais poderosa que a do Governo" ${ }^{220}$. Pouco se sabe, no entanto, que a célebre "Defensora", além de conduzir os rumos do Império, realizou

wahrhaft schrecklichen Transformation wiedergegeben, und die fadesten Witze, die unerträglichsten Anspielungen auf die am verhängnisvollen 7. Apriltage des Jahres 1831 verübten Heldentaten, carnavalischen Andenkens, nahmen kein Ende" (SEIDLER, Carl. Op. cit., 1835 , v. 1 , p. 54-55). De fato, a leitura dos jornais da época nos revelam curiosos títulos de peças teatrais como: "O dia de júbilo para os amantes da liberdade ou a queda do tirano", prometido para 3 de maio de 1831; "O patriotismo no seu auge ou América triunfante" (06/06/1831); "Memorável dia sete de abril no campo da honra ou a nova regeneração do Brasil" (02/07/1831). Em 1838, no entanto, seis anos antes da retomada das temporadas líricas, o texto dramático já dava seus sinais de recuperação no Rio de Janeiro, com o surgimento de peças como Antônio José, de Gonçalves de Magalhães e $O$ Juiz de Paz da roça, de Martins Pena. Segundo um número do Jornal do comércio, de fins desse mesmo ano, a crescente melhora no nível das peças dramáticas representadas no Rio de Janeiro teria ocorrido já a partir de 1837: "Nestes últimos dois anos, porém, o teatro começou a surgir pouco a pouco do seu abatimento, a melhorar a sua sorte, a tornar-se mais digno, enfim, da civilização da capital do Império. O primeiro ator de S. Pedro de Alcântara fez progressos que lisonjearam os mais difíceis amadores da arte; o vestuário tornou-se mais verdadeiro, mais fiel; as decorações mais belas. A nova importância que o público deu ao teatro, fez aparecer algumas peças de composição nacional, e excelentes traduções do teatro europeu" (JORNAL DO COMÉRCIO, 30/10/1838). Note-se aí o grande destaque dado a João Caetano dos Santos, que além de "primeiro ator", dirigia as montagens e escolhia o repertório a ser representado. Muito a ele, certamente, se deve esse "ressurgimento" do teatro no Rio de Janeiro, incluindo-se a volta de um público interessado.

${ }^{819}$ Marco Morel, em seu já mencionado livro As transformações dos espaços públicos, analisou quantitativamente a criação de associações entre os anos de 1820 e 1840. E é justamente no período regencial que ocorrem os maiores picos (MOREL, Marco. Op. cit., 2005, p. 261).

820 "[a Defensora] foi em realidade outro Estado no Estado, porque sua influência era a única que predominava no Gabinete e nas Câmaras, e sua ação, mais poderosa que a do Governo, se estendia por todos os ângulos do Império" (ABREU E LIMA, José Ignácio de. Compêndio da história do Brasil. Rio de Janeiro: E. e H. Laemmert, 1843, v. 2, p. 88). 
concorridos bailes, como o que de fato ocorreu, segundo o Jornal do comércio, no primeiro aniversário do Sete de Abril:

A noite houve teatro, e a Sociedade Defensora da Independência e Liberdade Nacional deu um esplêndido baile na Secretaria da Guerra no Campo da Honra a que foram convidados todos os sócios que avultam a mais de 800 pessoas... ${ }^{82}$

Dois anos depois, o jornal $O$ Sete de abril também anunciava o programa - com começo, meio e fim - de uma "reunião festiva" da Sociedade Defensora, mais uma vez em homenagem ao "glorioso" dia:

O entretenimento principiará às $8: 30(\ldots)$ terá
primeiramente lugar uma boa abertura, ou
sinfonia; imediatamente o Hino, findo o qual
dará o presidente da sociedade os vivas.
Seguir-se-á tudo o que houver de cantoria, que
nunca deverá exceder das $11 \mathrm{~h}$ da noite.
Terminada a cantoria começarão as
contradanças...

É possível que esses bailes comemorativos realizados pela Defensora - que não deixam de configurar uma resposta cultural ao desvario do "povo", que enxotara as elites do seu antigo local de confluência social, o teatro tenham animado alguns de seus freqüentadores a reviver a experiência da Assembléia Portuguesa. Pois, passado esse último evento, não tardaram muito mais do que dois meses para que uma "Sociedade de Recreação estabelecida no Catete" anunciasse pela primeira vez, no Diário do Rio de

821 JORNAL DO COMÉRCIO, 09/04/1832. No dia do baile, ainda segundo esse mesmo número do Jornal do comércio, teria sido cantado - talvez pela primeira vez - o hino de Francisco Manuel da Silva, mais tarde adotado pelo Império como Hino Nacional. Assim se dava a notícia: "Saiu à luz litografado o hino para canto e piano por F. M. da Silva, que foi cantado no dia 7 de abril no começo do divertimento dado pela Sociedade Defensora cujo hino foi cantado pelos Sr.as. e Sócios da mesma sociedade, acha-se à venda na Litografia da rua da Quitanda n. 111" (Idem).

822 O SETE DE ABRIL, 29/03/1834. 
Janeiro, uma "partida"823. Ao longo desse ano, outras notícias no mesmo jornal já denotam a periodicidade das atividades daquele que começaria a ficar conhecido, simplesmente, como "baile do Catete". A reunião era promovida por uma sociedade privada, que, assim como a Filarmônica, só admitia a entrada de sócios e convidados ${ }^{824}$.

O Diário do Almirante inglês Graham Eden Hamond nos dá alguns indícios de quem seriam, precisamente, essas pessoas. Tendo ido ao baile do Catete algumas vezes, entre 1836 e 1837, ele nos afirma, por exemplo, que em uma dessas ocasiões - em que o salão estava "repleto" encontrou o mais alto representante do governo francês, Edouard Pontois ${ }^{825}$. Em outra, foi convidado pessoalmente pelo então Presidente da Sociedade, Diogo Soares da Silva de Bivar, um ilustre profissional liberal da corte ${ }^{826}$. A passagem seguinte nos revela que o baile era freqüentado por "todas as classes de gente. Desde o marquês até o lojista" ${ }^{827}$. Seu último relato menciona, finalmente, a presença de três Ministros de Estado e do Regente, Araújo Lima ${ }^{828}$. Em suma, reunia-se ali o mesmo público que freqüentou outrora o teatro, excluídos, é claro, quaisquer indivíduos de índole ou credo político suspeitos. Afinal, não havia ingressos; apenas convites.

Houve, no entanto, na capital do Império dessa mesma época, uma outra agremiação voltada às reuniões sociais e recreativas, com direito a muito boa música, e que mereceu ainda maior destaque do Almirante Eden Hamond em seus Diários. Referimo-nos à "Assembléia Estrangeira", que,

${ }^{823}$ DIÁRIO DO RIO DE JANEIRO, 13/05/1834.

824 A informação é mais uma vez dada pelo Diário do Rio de Janeiro, e, curiosamente, de forma fortuita: "O sócio ou convidado do Baile do Catete, que na noite de 25 do corrente levou por engano (...) um chapéu francês (...) queira mandar à Rua do Conde n. 21 para se desfazer a troca (Idem, 28/10/1834).

${ }_{826}^{825}$ HAMOND, Graham Eden. Op. cit., p. 139.

826 Ibidem, p. 158. O Conselheiro Diogo Soares da Silva de Bivar (1785-1865), português de nascimento, era advogado respeitado nas rodas sociais e políticas do Rio de Janeiro e teve papel importante na administração cultural da capital do Império entre os anos de 1830 e 1840. Primeiro Orador do IHGB, primeiro Presidente do Conservatório Dramático Brasileiro, possuía, em 1846, segundo o Almanaque Laemmert, os graus de cavaleiro das ordens de Cristo e da Rosa (ALMANAQUE administrativo mercantil e industrial do Rio de Janeiro para o ano de 1847. Rio de Janeiro: Eduardo e Henrique Laemmert, 1846, p. 280).

${ }^{827}$ HAMOND, Graham Eden. Op. cit., p. 123. 
pela similaridade do nome, bem poderia ser "uma reminiscência da Assembléia Portuguesa de 1815", como notou Ayres de Andrade ${ }^{829}$. A data certa de sua fundação é ainda uma incógnita ${ }^{830}$. Mas muito provavelmente surgiu na mesma época do "Baile do Catete", ou um pouco depois.

Hamond esteve pela primeira vez nesse salão - uma ampla casa, alugada do Marquês de Barbacena - na noite do dia 2 de agosto de 1835, após ter sido convidado, dois dias antes pelo próprio Presidente da Assembléia, Marcelino José Coelho ${ }^{831}$. Segundo o Almirante, esse grêmio era "de natureza muito privada" e seus estatutos impunham certas regras de admissão dos convidados "a fim de evitar excesso de freqüentadores". Ainda assim, Hamond calculou ter visto ali reunidas de trezentas a quatrocentas pessoas, "de todas as classes". Suas observações ainda deram conta de que o número de brasileiros excedia o de estrangeiros. Enfim, eis um resumo da festa, que contou também com a presença de um dos Regentes:

Foram servidos refrescos, bolos, sorvetes, água gelada, e, por fim, lá por perto da meia-noite, um chocolate com que me deliciei. Vi toucados de plumas da melhor qualidade, em algumas das senhoras brasileiras. As famílias mais seletas estavam presentes e, entre elas, estava o Regente, senhor Francisco de Lima e Silva (...) Quase todos os ingleses compareceram e os americanos não acabavam mais... ${ }^{832}$

Em outra ocasião, dois meses depois, Hamond novamente

${ }^{828}$ Ibidem, p. 172.

${ }^{829}$ ANDRADE, Ayres de. Op. cit., v. 1, p. 237.

${ }^{830}$ A esse respeito, vale o mesmo comentário da nota 416 desta parte.

${ }^{831}$ Marcelino José Coelho foi um destacado negociante da praça do Rio de Janeiro na década de 1830. Segundo Théo Lobarinhas Piñeiro, "recebeu a incumbência de redigir o Regulamento para a Praça Comercial. A proposta de Coelho foi submetida à outra comissão, com ele próprio, os três primeiros da responsável pelos Estatutos e outros membros do comércio, que a aprovou e enviou ao governo. Em 9 de setembro de 1834, o governo aprovou o Regulamento. Estava criada a Sociedade dos Assinantes da Praça, sucessora e institucionalização formal do antigo Corpo de Commercio, sendo Felipe Néri de Carvalho o seu primeiro presidente e tendo como diretores Francisco José da Rocha, Jorge Naylor, Henrique Riedly, William Moon, Guilherme Theremin, Diogo Birckhead, Marcelino José Coelho e Andrés de Lisauer" (Cf. PIÑEIRO, Théo Lobarinhas. Op. cit.).

${ }^{832}$ HAMOND, Graham Eden. Op. cit., p. 90. 
compareceu à "Assembléia", comentando tomar parte de um baile que se organizava "todos os meses" ${ }^{833}$. Desta vez, embora confessasse, em outro ponto de seus Diários, que não tinha sensibilidade qualquer para a apreciação musical, o Almirante fez questão de anotar: "A música era extremamente boa e a organização perfeita. (...) Dançaram até 1,00 hora da madrugada e terminaram com um tremendo "galope'”. Outra observação realizada pelo inglês diz respeito ao público: "Todos os homens importantes estavam presentes e as condecorações brilhavam por todos os lados" 834 .

Maior ocasião, no entanto, ainda estava por vir. Como já vimos em páginas anteriores, a "organização perfeita" dos "Estrangeiros" 835 iria contribuir para que a incursão do Príncipe de Orange na corte brasileira, em

833 Ibidem, p. 100. Essa informação é confirmada pelo diplomata e naturalista Francis de La Porte, Comte de Castelnau (1812-1880), que esteve no Rio alguns anos depois, mais precisamente em 1843: "Nous assisterons aussi régulièrement aux jolis bals du Catete et des Etrangers, qui ont lieu tous les mois" (CASTELNAU, Francis, Comte de. Expédition dan les parties centrales de l'Amérique du Sud, de Rio de Janeiro à Lima, et de Lima au Para: exécutée par ordre du gouvernement français pendant les annés 1843 à 1847, sous la direction de Francis de Castelnau. Histoire du voyage. Paris: P. Bertrand, 1850 , v. 1, p. 121). Na verdade, isso não significa que havia bailes exatamente o ano inteiro. Hamond comenta que os da Assembléia iniciavam-se em abril e encerravam-se em novembro. Ao que tudo indica, a interrupção ocorria por conta do verão, época em que o abafado calor, as grossas chuvas e a proliferação de insetos certamente criavam uma série de embaraços ao bom funcionamento dessas reuniões. A esse respeito, ver LEITHOLD, Theodor von. Op. cit., p. 158-159.

${ }^{834}$ HAMOND, Graham Eden. Op. cit., p. 100. Por aí se nota que, a despeito da perseguição política exaltada dos primeiros anos do período regencial e do ideal "republicano" dos tempos de Feijó, as "tetéias", dentro dos ambientes privados, jamais deixaram de ter seu forte significado social. Sobre esse mesmo assunto, recordemos também o depoimento do cirurgião norte-americano William Ruschenberger, que, ainda em 1831, viu no Paço Imperial "muitos dos cortesãos" ostentando "essas condecorações de honra que são concedidas aos que agradam a realeza" (vide nota 96 desta parte).

${ }^{835}$ Assim a Assembléia Estrangeira era também conhecida: como baile "dos estrangeiros" (Ibidem, p. 120). De fato, em 1836, segundo Hamond, além da constante freqüência de diplomatas e cidadãos de nações européias, a própria direção da Assembléia recaíra sobre os ombros de estrangeiros: Mr. Freese (Presidente), Mr. G. Naylor e Sr. Faria (Ibidem, p. 146). "G. Naylor" era George Naylor, inglês, dono de uma firma de comércio cuja sede, em 1843, situava-se na Rua dos Pescadores, n. 16. Nesse mesmo ano ocupava o cargo de membro estrangeiro da comissão da Praça do Comércio da corte (ALMANAQUE administrativo mercantil e industrial do Rio de Janeiro para o ano de 1844. Rio de Janeiro: Eduardo e Henrique Laemmert, 1843, p. 216). Já, o "Sr. Faria" deve referir-se, provavelmente, a um dos irmãos Farias - talvez Joaquim Pereira de Faria —, portugueses, donos da firma "Faria e irmão", não por coincidência localizada às vizinhanças de Mr. Naylor, na Rua dos Pescadores, n. 13 (Idem, p. 220). Por fim, "Mr. Freese" era também, ao que tudo indica, negociante. O Almanaque do Rio de 1829 lista, entre os estabelecimentos comerciais estrangeiros instaladas na corte, "Freese Mutter e C. ${ }^{a}$, Rua da Alfândega, n. 32" (ALMANAQUE imperial do comércio e das corporações civis e militares do Império do 
fins de 1836, não tivesse se resumido ao então decadente Palácio de São Cristóvão. A presença, no salão da Assembléia Estrangeira, do ilustre visitante, bem como da família imperial na noite do dia 7 de dezembro desse último ano não deixam dúvidas quanto ao fato de que esse era, àquele tempo, o principal espaço de sociabilização do Rio de Janeiro, superando inclusive 0 então Teatro Constitucional Fluminense, ambiente social igualmente em franca decadência, com suas peças de teatro desinteressantes. Isso nos permite conjecturar - encerrando nossa exposição de fatos - que, se por um lado a proliferação dessas sociedades particulares de recreação e de baile — incluindo-se a própria "Filarmônica" favoreceu a atividade musical no Rio de Janeiro, abrindo ofertas de trabalho ao músicos profissionais, revalorizando a música como parte integrante dos eventos sociais, e, em parte, renovando o repertório tão calcado em anos anteriores na ópera e no canto sacro com uma ênfase maior à música coreográfica e puramente instrumental ${ }^{836}$, por outro lado subtraiu forças e

Brasil. Rio de Janeiro: Em Casa de P. Plancher-Seignot, 1829, p. 170).

${ }_{836}$ Note-se que, além de "bonitos" bailes, a Casa do Catete e a Assembléia Estrangeira também, a partir de certa época, passaram a organizar concertos, privilegiando um repertório ainda pouco difundido no Rio de Janeiro: a música instrumental. Segundo o Correio das modas, um concerto realizado nos "salões do Catete", ao qual assistiram "espectadores de ambos os sexos, que subiam ao número de 400" teria sido "um dos primeiros divertimentos deste gênero dado nesta corte" (CORREIO DAS MODAS, 19/01/1839). Pouco mais de dois meses depois, o mesmo jornal narrava, com os mesmos detalhes, outro divertimento semelhante, desta vez na sede da Assembléia Estrangeira, "executado por perto de cinqüenta artistas". Ali, em vez dos mais do que conhecidos trechos de óperas de Rossini se pôde ouvir, por exemplo, uma rara audição de uma obra instrumental de Beethoven, sua primeira sinfonia, em dó maior. Eis parte da crítica publicada: "No meio da desolação, da escassez, ou antes da inteira falta de divertimentos na presente estação, veio a Assembléia Estrangeira oferecer a seus sócios e convidados um concerto de excelente escolha (...). A grande concorrência do sócios da Assembléia foi correspondida pelos desejos dos convidados que com grande ânsia procuravam obter bilhetes para tão agradável reunião, onde reinou a sem-cerimônia de uma sociedade particular, o brilhante de uma grande função e o gosto da divina música dos grandes mestres conforme as inclinações de cada um! (...) Podemos afirmar que a noite do concerto se pode chamar cheia, e não receamos fazer voto em nome de todos os assistentes, que tais divertimentos inocentes se repitam entre nós freqüentemente. A música foi em geral bem executada, principalmente as riquíssimas aberturas de Roberto Diabo e de Guilherme Tell; a valsa de Strauss não correspondeu à expectação geral, parecia mal ensaiada e tocada com um vagar e uma frieza estranhos à música daquele compositor. Beethoven, o imortal compositor das mais belas sinfonias não foi compreendido pela orquestra, pouco acostumada a executar tão sublime música: possa a freqüente execução das suas composições animar os nossos artistas a estudarem o seu gênio e as suas obras e a fazerem-nos as sublimes emoções de que são capazes!!" (Idem, 23/03/1839). 
atenções do teatro, como espaço privilegiado de reunião da sociedade, e conseqüentemente dificultou ainda mais a retomada das temporadas de ópera, como vimos, plenamente dependentes de um público fiel e benemérito, formado sobretudo por integrantes das elites econômicas ainda em processo de nobilitação, as quais, por acaso, formavam também a mais assídua freqüência dessas sociedades privadas, bem como suas diretorias. 


\section{CONCLUSÃO}

Ao concluirmos este trabalho, após incontáveis e pacientes horas de perscrutação, compilação, análise e redação, nos sentimos, de um modo geral, satisfeitos com o resultado obtido. lluminamos uma série de novos fatos, atacamos diversos pontos pacíficos mal resolvidos de nossa historiografia, fizemos reviver um instigante - por vezes malfadado passado social, político, econômico e cultural, nítido substrato de nossa realidade hodierna.

Um mergulho no melindroso terreno da história geral foi, ao mesmo tempo, alívio para uma curiosidade quase insaciável e um problema metodológico de infrutífera resolução, que se refletiu nas extensas digressões do corpo e das notas, e diminuiu, tanto a fluência textual como a objetividade do estudo. Confessamos: abrimos inúmeras gavetas desnecessárias ao entendimento de nosso objeto principal, mas que os ensejos da crítica bibliográfica ou da inédita descoberta, acreditamos, indultam. Não quisemos aqui repetir, mas inovar. E quando repetimos, o fizemos buscando, sempre, um novo olhar investigativo e a mais precisa referência documental.

A espinha dorsal deste estudo já foi bastante explorada, com sólidas bases, por alguns dos mais brilhantes estudiosos da Idade Moderna, como Norbert Elias e Peter Burke. Escoramo-nos nela ao afirmarmos que o ataviado som de óperas e pomposas obras musicais sacras - como parte de um ritual aparatoso e carregado de etiquetas - esteve, em determinado tempo e local, intimamente vinculado à exaltação de um poder monárquico forte e à efetivação de uma sociedade de corte. E daí a recíproca, ou seja, a existência de um poder centralizado nas mãos de um soberano, e de súditos capazes de sustentar a majestade monárquica em troca de um lugar social privilegiado, nos permite, também, vislumbrar, no mesmo tempo e local, a ocorrência de uma atividade musical voltada a esse tipo de repertório.

É o que acontece no Rio de Janeiro, e mesmo muito antes da vinda 
da família real portuguesa. Desde princípios do século XVIII, a pujança do ciclo do ouro não apenas enriqueceu sobremaneira uma classe de comerciantes sediada na Guanabara, asseando suas residências com os mais finos móveis e utensílios orientais e permitindo-lhes vestir-se à última moda francesa. A busca por prestígio social e poder político, única coisa que Ihes faltava ter, os levou também a promover, na colônia, a sustentação da pompa monárquica, tanto nos aniversários e nascimentos dos membros da família real, como em outros eventos, locais, muitos deles em obséquio aos Governadores e Vice-Reis. Estes, com o centralismo político necessário ao controle do ouro e tal apoio financeiro das elites mercantis, tornam-se "tão absolutos como qualquer outro soberano sobre a Terra", como afirmou o comodoro John Byron, em 1764, ao retratar o grande aparato que envolvia a etiqueta vice-real. Esta última, por sua vez, desenvolvida, como vimos, incluiu música variada e executada tanto no palácio e na igreja, como, sobretudo, no teatro, onde a sociedade carioca colonial se reunia, quase que como uma verdadeira "corte", em torno de seu "monarca", e onde até mesmo obras especialmente compostas em homenagem a esses "soberanos", foram executadas, como, por exemplo, a Abertura Zemira, do Padre José Maurício Nunes Garcia.

É muito provável que a vinda da realeza, de Portugal, tenha amplificado, e muito, todo esse princípio de relação entre a música e a pompa monárquica, embora o ciclo econômico do ouro já estivesse em plena decadência, diga-se de passagem, quando Dom João e muitos grandes do Reino aportaram no Rio de Janeiro, em 1808. A dificuldade financeira do momento - agravada pelos gastos militares na guerra com a França e pela abertura dos portos - é, no entanto, contornada pela criação do Banco do Brasil, instituição que irá tomar de empréstimo da população, entre $1810 \mathrm{e}$ 1829, quase três dezenas de milhares de contos de réis, cifra mais do que suficiente para, entre muitas coisas, manter-se no Rio de Janeiro, durante esses quase vinte anos, uma pompa digna do mais alto poder monárquico.

Ainda assim, Dom João e Dom Pedro utilizaram, como nunca, a velha 
- e muito eficaz - magnanimidade de derivar a dignidade principesca, mediante a concessão de títulos, honras, ordens militares e distinções, em troca de doações, sobretudo de negociantes de grosso trato, muitos deles sem qualquer estirpe, vinculados ao abjeto tráfico negreiro, e ávidos por insígnias de nobreza, capazes, talvez, de os purificar de tal pecha, perante uma sociedade de corte e seus rígidos códigos de conduta.

É de uma forma ou de outra que se possibilita, no Rio de Janeiro dos anos de 1808 a 1831, a existência de uma Capela com qualidade musical equivalente a de importantes cidades européias e de um teatro maior do que a Ópera de Paris, onde o esplendor dos espetáculos, sobretudo nos dias de grande gala, foi garantido pela presença de executantes de excelência internacionalmente reconhecida, como Giovanni Francesco Fasciotti e Pablo Rosquellas. Disse um viajante inglês que Dom João teria gasto, à época de sua coroação, em 1818, "uma fragata" para financiar uma companhia lírica no Teatro de São João. Pois não foi propriamente o Rei, o investidor, mas o próprio estabelecimento, financiado pelo Governo; de forma direta, pelo Banco do Brasil; e, indiretamente, por seus acionistas, muitos deles magnatas do comércio carioca, como Joaquim José de Azevedo, beneficiário, em poucos anos, graças à sua "generosidade em ocorrer às urgências do Estado" - e urgia à monarquia ter, para sediar seus rituais, um teatro e uma capela "decentes" -, de inúmeros cargos, condecorações e títulos nobiliárquicos.

Durante o governo de Dom Pedro I, a continuidade desse processo é quase total, pelo menos até 1829, quando a Câmara dos Deputados e a própria situação financeira insustentável do Império levam o Imperador a aceitar a liquidação do Banco do Brasil. Um ano depois, outra ofensiva legislativa iria apertar o cerco em relação aos abusivos gastos governamentais: o Orçamento. Ainda assim, é possível notar uma certa resistência, somente possível em uma forma de governo, que, embora constitucional, dava ao monarca autoridade quase absoluta, capaz de intimidar os demais poderes políticos. O luxo, assim como a atividade 
musical, mantêm-se, escorados pela enorme dotação imperial — fruto da "aduladora" política do Legislativo em relação ao Poder Moderador — e pela fiel camarilha de Dona Maria II e de Dom Pedro I, feliz dona de muitos títulos nobiliárquicos e cargos na burocracia.

Tudo isso, no entanto, desmoronará com a Abdicação de Dom Pedro I. A partir de 7 de abril de 1831, o Brasil - e mais especificamente o Rio de Janeiro, capital do Império - entra em um momento de fortes mudanças políticas e sociais. Crucial é o fato de que, durante quase uma década, não houve quem preenchesse o lugar político e social do monarca. Dom Pedro II, ao ser alçado em Imperador, era uma criança de menos de seis anos de idade, desprovida de discernimento, e, já, antes de mais nada, impedida, pelas regras constitucionais vigentes e pelas próprias circunstâncias, de exercer o mando político e o prestígio social. Este último, em verdade, o tinha desde 1831; porém, de uma forma muito mais imaginária, afetiva e popular do que objetiva, prática e cortesã. Até o fim do governo Feijó, em setembro de 1837, o jovem Imperador foi praticamente um prisioneiro de São Cristóvão. Já, durante a regência de Araújo Lima, houve, até, buscando-se fortalecer o regime monárquico, um certo alteamento da figura imperial, embora as amarras orçamentárias e o desinteresse das elites em cortejar o ainda imberbe e arredio monarca, tenham de certa forma anulado tal empreendimento. Posteriormente, já em pleno gozo do poder, em 1840, Dom Pedro II não fez nenhuma questão de assumir imediatamente seu papel social de monarca, tornando-se centro efetivo de uma corte, função que só desempenharia com maior ênfase após seu casamento, em 1843, quando o forte apelo social do momento e a plena retomada do poder político imperial, depois de dois anos de governo dominado pelos conservadores, voltam a fortalecer a atividade de corte, e, conseqüentemente, a música a esse fim vinculada.

Outrossim, na ausência, durante o interregno, de membros da família imperial em condições de substituir o monarca política e socialmente, mantendo-se, assim, com certo vigor, a pompa da realeza, tomaram o seu 
lugar Regentes eletivos, não apenas defensores, alguns deles, de um sistema de representação política sem aparatos — incluindo-se a música com esse fim -, como privados: a priori, do status próprio dos príncipes; e, a posteriori, de algumas das mais importantes atribuições constitucionais conferidas ao Imperador e que sustentavam o próprio carisma monárquico, entre as quais, a concessão de títulos, honras, ordens militares e distinções, tão usada em tempos anteriores.

É neste último aspecto - do cerceamento dos poderes regenciais, estabelecido pela Lei de 14 de junho de 1831 - que reconhecemos, também, uma outra importante e ignorada personagem dessa "história da música": o multíplice Poder Legislativo, que, poderoso como nunca com a ausência, no jogo político, da figura imperial, definiu, pela maioria de seus membros, não apenas essa privação de poderes aos Regentes, o que acarretará sensíveis mudanças em mecanismos socioculturais até então vigentes - como a cortesia e o mecenato - , mas todas as regras que governarão o Império, incluindo-se a edição de normas eminentemente contrárias ao bom funcionamento dos principais organismos musicais da capital imperial, tais quais a proibição de concessão de loterias - fonte importante de financiamento da ópera - e a diminuição das despesas com o luxo imperial, incluindo-se aí, a música da Câmara e da Capela.

Diante de tudo isso, notemos ainda fatos acessórios ou pontuais, como a participação dos vários setores da sociedade carioca nesse processo decadencial: o "povo", que estorva, em dados momentos, o bom funcionamento do principal espaço público de espetáculos musicais - o Teatro da Praça da Constituição, agora "Teatro Constitucional Fluminense" e as "elites" dali freqüentadoras - sobretudo comerciantes estrangeiros e "portugueses" - , que, por sua vez, se isolam, ao lado da elite "brasileira", em sociedades privadas, consumindo outros gêneros musicais de menor aparato - como a música de salão e os concertos - e desistindo, temporariamente, daqueles que antes os faziam, na presença do monarca, uma verdadeira corte. 
Enfim, cabe ressaltar que a virada do Sete de Abril retirou também de cena uma importante personagem dessa história musical. Pois, muito além do que já se explorara a respeito da pitoresca habilidade de Dom Pedro I como compositor e instrumentista, foi possível determinarmos um papel um tanto mais largo do Príncipe Regente e Imperador no processo de manutenção e de desenvolvimento da música na corte carioca, durante os dez anos em que ele comandou o Brasil, progresso, diga-se a propósito, negado até então, sem demonstrações evidentes, pela historiografia.

Concluir, é, pois, terminar, pôr fim, acabar, findar. Findemos, então, com os célebres versos de Fernando Pessoa, inspiradores desse longo e extenuante trabalho:

"Tudo vale a pena

se a alma não é pequena". 


\section{FONTES E BIBLIOGRAFIA}

\section{FONTES MANUSCRITAS}

\section{Arquivo Nacional (RJ)}

Anotações do jornalista Escragnolle Dória, apurada na transcrição de um ofício de 19 de dezembro de 1836 do cônsul Edouard Pontois à Chancelaria Francesa, referente a um baile realizado em São Cristóvão no dia 8 do mesmo mês (Fundo Luis Gastão d'Escragnolle Dória, cx. 232, v. 5, p. 376).

Compromisso da Irmandade da Gloriosa Virgem e Mártir Santa Cecília do Rio de Janeiro, confirmado a 8 de outubro de 1787, pelo Vice-Rei do Estado do Brasil, Dom Luís de Vasconcelos (Fundo Secretaria de Estado do Brasil, códice 64 , v. 20, Fls. 46-63).

Conta dos músicos instrumentistas de fora que se convidaram para tocarem na Imperial Capela no dia 2 de dezembro de 1837 (Fundo Casa Real e Imperial, cx. 13, pc. 1, doc. 60).

Conta dos músicos instrumentistas de fora que se convidaram para tocarem na Imperial Capela no dia 7 de abril de 1842 (Fundo Casa Real e Imperial, cx. 13, pc. 2, doc. 39).

Contas dos músicos instrumentistas de fora que se convidaram para tocarem na Imperial Capela nos dias 26 de julho, 7 de setembro, 19 de outubro, 2 de dezembro de 1840; 25 de março, Semana Santa e 7 de setembro de 1841 (Fundo Casa Real e Imperial, cx. 13, pc. 2, doc. 01).

Contas dos músicos instrumentistas de fora que se convidaram para tocarem na Imperial Capela nos dias 6 de janeiro, 9 de janeiro, Semana Santa e 25 de março de 1842 (Fundo Casa Real e Imperial, cx. 13, pc. 2, doc. 34).

Contas dos músicos instrumentistas de fora que se convidaram para tocarem na Imperial Capela nos dias 19 de outubro, $1^{\circ}$ de dezembro e 2 de dezembro de 1841 (Fundo Casa Real e Imperial, cx. 13, pc. 2, doc. 31).

Contas dos músicos instrumentistas de fora que se convidaram para tocarem na Imperial Capela nos dias 26 de julho, 7 de setembro, 19 de outubro, 2 de dezembro de 1840; 25 de março, Semana Santa e 7 de setembro de 1841 (Fundo Casa Real e Imperial, cx. 13, pc. 2, doc. 01).

Contas dos músicos instrumentistas de fora que se convidaram para tocarem na Imperial Capela nos dias 18 de julho, 23 de julho e 7 de setembro de 1842 (Fundo Casa Real e Imperial, cx. 13, pc. 2, doc. 47). 
Contas dos músicos instrumentistas de fora que se convidaram para tocarem na Imperial Capela nos dias $1^{\circ}$ de dezembro e 2 de dezembro de 1842 (Fundo Casa Real e Imperial, cx. 13, pc. 2, doc. 55).

Despacho do Intendente Geral da Polícia, Paulo Fernandes Viana, nomeando seu cunhado, o Comendador Fernando Carneiro Leão, tesoureiro das ações de todos aqueles que se prestassem a investir na construção do teatro (Fundo Decretos do Executivo, cx. 19, pc. 34, doc. 29).

Inventário post-mortem de Florentino de Aragão Espanha (Fundo Inventários, maço 466 , proc. 8888 ).

Lista dos músicos que existem na Capela, de 16 de setembro de 1842 (Fundo Casa Real e Imperial, cx. 13, pc. 2, doc. 44).

Matrículas de negociantes de grosso trato da praça do Rio de Janeiro, 18281839 (Fundo Junta do Comércio, Agricultura, Fábricas e Navegação, Códice 170 , v. 2).

Ofício do proprietário do Teatro de São João, Fernando José de Almeida, ao Imperador, Dom Pedro I, pedindo-Ihe auxílio para a reconstrução do dito teatro, incendiado a 25 de março de 1824 (Fundo Decretos do Executivo, cx. 19, pc. 34 , doc. 7 ).

Ofício, de 10 de dezembro de 1842, de Fortunato Mazziotti e Francisco Manuel da Silva, ao Ministro da Justiça, Paulino José Soares de Sousa, pedindo-lhe a contratação de instrumentistas para o serviço musical da Capela (Fundo Casa Real e Imperial, cx. 13, pc. 2, doc. 53).

Ofício, de $1^{\circ}$ de agosto de 1840 , do Inspetor da Capela Imperial, Monsenhor Fidalgo, ao Ministro da Justiça, Antônio Paulino Limpo de Abreu, pedindo-Ihe providências em relação ao serviço musical da Capela (Fundo Casa Real e Imperial, cx. 13, pc. 1, doc. 88).

Ofício, de 31 de janeiro de 1843, de Inspetor da Capela Imperial, Monsenhor Fidalgo, ao Ministro da Justiça, Honório Hermeto Carneiro Leão, pedindo-Ihe a contratação de instrumentistas para o serviço musical da Capela (Fundo Casa Real e Imperial, cx. 13, pc. 2, doc. 57).

Orçamento da Capela Imperial para o ano financeiro de 1840-1841, datado de 3 de janeiro de 1839 (Fundo Casa Real e Imperial, cx. 13, pc. 1, doc. 60, fl. 2).

Orçamento da Capela Imperial para o ano financeiro de 1842-1843, datado de 13 de janeiro de 1841 (Fundo Casa Real e Imperial, cx. 13, pc. 2, doc. 3, fl. 2).

Relação do que se recebeu dos acionistas para as obras do Teatro de São 
João, do Rio de Janeiro, no valor total de 47:695\$000; e outros dados (Fundo Decretos do Executivo, cx. 19, pc. 34, doc. 31).

Relação dos acionistas que receberam de Fernando José de Almeida a importância de suas ações, no valor total de 49:600\$000 até $1^{\circ}$ de abril de 1819 (Fundo Decretos do Executivo, cx. 19, pc. 34, doc. 47).

Relação Nominal dos empregados na Capela Imperial e dos seus vencimentos relativos ao $4^{\circ}$ quartel do ano de 1828 (Fundo Casa Real e Imperial, cx. 12, pc. 1, doc. 12).

Relação, de 2 de janeiro de 1844, dos vencimentos que tiveram os empregados da Capela no $2^{\circ}$ quartel do ano financeiro de 1843 a 1844 (Fundo Casa Real e Imperial, cx. 13, pc. 2, doc. 77).

Relatório do tesoureiro das ações do Teatro de São João, Fernando Carneiro Leão, apresentando as contas finais da obra e os débitos do proprietário Fernando José de Almeida com o Banco do Brasil (Fundo Decretos do Executivo, cx. 19, pc. 34, doc. 30).

Relatório, de 14 de junho de 1831, da despesa com o serviço musical da Capela Imperial (Fundo Casa Real e Imperial, cx. 12, pc. 1, doc. 12, fl. 27).

Relatório, de 15 de fevereiro de 1836, das despesas ordinárias com a música para o ano financeiro de 1837-1838 (Fundo Casa Real e Imperial, cx. 13, pc. 1 , doc. 28 , fl. 2).

\section{Biblioteca Nacional (RJ) - Divisão de Manuscritos}

Carta da Princesa Leopoldina, consorte de Dom Pedro I, a sua tia Marie Amélie de Napoli de 24 de janeiro de 1818 (I-35,02,058).

Carta do Barão de Inhomirim, Dr. Vicente Navarro de Andrade à Condessa de Itapagipe, de 12 de junho de 1831 (I-9,11,38).

Derrota que fez o Ex. ${ }^{\text {mo }}$. Sr. D. Luiz Antônio de Souza. Governador e CapitãoGeneral da Cidade de S. Paulo, indo para a do Rio de Janeiro em a Nau de Guerra N. Sra. da Estrela de que era Comandante (Fundo Morgado de Mateus, 21,4,14-16).

Representação dos músicos da Real Câmara e Capela da Corte a S. A. R., em julho de 1822, pedindo o pagamento dos ordenados vencidos e sua incorporação à folha dos músicos da Real Capela (Fundo Brasil em Geral, II$30,28,038)$.

Requerimento da diretoria do Teatro de São Pedro de Alcântara a S. M. I., descrevendo as dificuldades financeiras por que passava aquele teatro e apresentando as soluções cabíveis à situação. Rio de Janeiro, 23/10/1850 e 
13/12/1850 (II-34,25,31).

Requerimento de Bernardo José de Sousa Queirós encaminhado ao Ministério do Império, solicitando que José Bernardes Monteiro torne a contratá-lo como mestre de música do Teatro de São Pedro de Alcântara. 1830. (Fundo Documentos biográficos, C-0808,019 n001).

Requerimento de Camilo José de Sousa Caldas, encaminhado ao Ministério do Império, solicitando ser nomeado músico de rabeca, da Casa Imperial. 1828 (Fundo Documentos biográficos C-0428,048 $n^{\circ} 001$ ).

Requerimento de Damião Barbosa de Araújo, encaminhado ao Ministério, solicitando nomeação para músico da Real Câmara (Fundo Documentos biográficos, C-0853,008 $\mathrm{n}^{\circ} 002$ ).

Requerimento de Francisco Domingos, encaminhado ao Ministério do Império, solicitando ser nomeado músico da Câmara, no lugar de $2^{\circ}$ Oboé (Fundo Documentos biográficos, C-0828,005).

Requerimento de Gabriel Fernandes da Trindade, encaminhado ao Ministério do Império, solicitando lugar de músico na Câmara Imperial. 1825-1827 (Fundo Documentos biográficos, C-0566,022).

Requerimento de Heliodoro Noberto Florival e Silva, músico da Capela Real, rabeca, encaminhado ao Ministério, solicitando ser admitido como Músico da Câmara Real (Fundo Documentos biográficos, C-0835,047).

Requerimento de Herculano José de Carvalho, músico violoncelo na Capela Imperial, encaminhado ao Ministério do Império, solicitando ser nomeado músico da Câmara (Fundo Documentos biográficos, C-0111,020 n002).

Requerimento de Inácio Pinheiro da Silva, mestre dos escravos da Fazenda de Santa Cruz, encaminhado ao Ministério do Reino, solicitando ser nomeado Músico da Câmara Real. 1814 (Fundo Documentos biográficos, C-0929,042).

Requerimento de João Isidoro da Silva Nobre, encaminhado ao Ministério do Reino, solicitando alvará de sua provisão como charamela da Casa Real. Solicita também lugar de músico da Real Orquestra. 1813-1816 (Fundo Documentos biográficos, C-0239,013).

Requerimento de José Faustino de Lemos, encaminhado ao Ministério do Reino, solicitando passar para a repartição dos Músicos da Real Câmara. 1812-1813 (Fundo Documentos biográficos, C-0379,034).

Requerimento de José Tibúrcio, encaminhado ao Ministério do Reino, solicitando ser nomeado músico instrumentista (violoncelo) da Câmara Real. 1817-1818 (Fundo Documentos biográficos C-0452,005). 
Requerimento de Pedro Teixeira de Seixas, violoncelista, encaminhado ao Ministério do Reino, solicitando ser admitido músico instrumentista da Câmara Real. 1811-1812 (Fundo Documentos biográficos, C-0827,016).

Requerimento de Severiano de Castro, músico, segundo fagote, encaminhado ao Ministério do Império, solicitando ser nomeado músico da Câmara Imperial. 1830 (Fundo Documentos biográficos, C-0556,030).

Requerimento do Padre Manuel Alves Carneiro, professor de música, instrumentista de rabeca e violeta, encaminhado ao Ministério do Reino, solicitando ser nomeado músico da Câmara Real (Fundo Documentos biográficos, C-0896,020).

Requerimento, de 23 de junho de 1841, encaminhado ao Ministério do Império por Fortunato Mazziotti e outros professores de música, solicitando a criação de um conservatório de música e a concessão de duas loterias anuais, por espaço de oito anos, em nome da Sociedade Musical (Fundo Documentos biográficos, C-0774,035).

\section{Arquivo Histórico do Museu Imperial de Petrópolis}

Apólice no capital de 1:000\$000 em nome do Deputado José Clemente Pereira, correspondente a uma ação de "n. 37" do Teatro de São Pedro de Alcântara para o ano de 1840 (III-DSM-1840-Soc.rç).

Carta do Cônsul Geral de Portugal no Rio de Janeiro, João Batista Moreira a Dom Pedro I, de 18 de setembro de 1831, comunicando a partida de duas naus, o brigue Conde de Vila-Flor e a barca Regência de Portugal, levando emigrados portugueses para a Ilha Terceira (II-POB-[1831]-PI.B.do 1-6).

Relação dos subscritores para a compra e arrematação do Teatro de S. Pedro de Alcântara (II-POB-[1822-1831]-Tea.rç).

\section{Arquivo do Instituto Histórico e Geográfico Brasileiro}

Recibo no valor de $320 \$ 000$ assinado pelo inspetor do Teatro de São Pedro de Alcântara, José Antônio Tomás Romeiro, ao Visconde de Olinda, em relação ao uso, por cinqüenta récitas, de seu camarote de segunda ordem (Coleção Marquês de Olinda, Lata 214, pasta 49).

\section{Arquivo do Cabido Metropolitano do Rio de Janeiro}

Catálogo da música da Capela Imperial atualmente Catedral Metropolitana do Rio de Janeiro. 1902 (Fundo Capela Real e Imperial, Seção Musical, cx. 46).

Credo in unum Deum, Credo, Sanctus e Agnus Dei da Missa de Nossa Senhora do Carmo, em dó maior (Fundo Capela Real e Imperial, Seção 
Musical, cx. 054).

Mortuus est, Responsório para São Pedro de Alcântara, em dó maior (Fundo Capela Real e Imperial, Seção Musical, cx. 053).

Sub tuum præsidium, Antífona de Nossa Senhora, em dó maior (Fundo Capela Real e Imperial, Seção Musical, cx. 053).

Te Deum laudamus, Hino de Ação de Graças, em dó maior. 1820 (Fundo Capela Real e Imperial, Seção Musical, cx. 055).

\section{FONTES IMPRESSAS}

\section{Jornais}

Allgemeine musikalische Zeitung (Leipzig)

Correio das modas: jornal crítico e literário das modas, bailes, teatros (Rio de Janeiro)

Correio mercantil e econômico de Portugal (Lisboa)

Diário do Rio de Janeiro (Rio de Janeiro)

Gazeta do Rio de Janeiro (Rio de Janeiro)

I Teatri: giornale drammatico musicale e coreografico (Milano)

Jornal do comércio (Rio de Janeiro)

Jornal dos debates políticos e literários (Rio de Janeiro)

L'écho de L'Amérique du Sud: journal politique, commercial et litteraire

(Rio de Janeiro)

La maîtrise (Paris)

Minerva brasiliense: jornal de ciências, letras e artes (Rio de Janeiro)

O Brasil (Rio de Janeiro)

O brasileiro (Rio de Janeiro)

O cabrito (Rio de Janeiro)

O cronista (Rio de Janeiro)

O espelho diamantino: periódico de política, literatura, belas artes, teatro e modas (Rio de Janeiro) 


\section{O justiceiro (São Paulo)}

O Sete de Abril (Rio de Janeiro)

Revue musicale (Paris)

The lady's book (Filadélfia)

The liberator (Boston)

The naval magazine (New York)

The times (London)

\section{Demais fontes impressas}

A CORTE de D. João VI no Rio de Janeiro segundo dois relatos do diplomata prussiano Conde von Flemming. Tradução de Carlos H. Oberacker Jr.. Revista do Instituto Histórico e Geográfico Brasileiro. Rio de Janeiro, v. 346, 1985.

A MISSIONARY voyage to the Southern Pacific Ocean, performed in the years 1796, 1797, 1798, in the ship Duff, commanded by Captain James Wilson: compiled from journals of the officers and the missionaries: and illustrated with maps, charts, and views. London: T. Gillet, 1799.

A. P. D. G.. Sketches of Portuguese life, manners, costume, and character: illustrated by twenty colored plates. London: Printed for G. B. Whittaker, 1826.

ABREU E LIMA, José Ignácio de. Compêndio da história do Brasil. Rio de Janeiro: E. e H. Laemmert, 1843.

AGUIRRE, Juan Francisco. Diario del Capitán de Fragata D. Juan Francisco Aguirre. Revista de la Biblioteca Nacional. Buenos Aires: Imprenta de Ministerio de Educación, t. 17, n. 43-44, 1949.

ALMANAQUE administrativo mercantil e industrial do Rio de Janeiro para o ano de 1844. Rio de Janeiro: Eduardo e Henrique Laemmert, 1843.

ALMANAQUE administrativo mercantil e industrial do Rio de Janeiro para o ano de 1845. Rio de Janeiro: Eduardo e Henrique Laemmert, 1844.

ALMANAQUE administrativo mercantil e industrial do Rio de Janeiro para o ano de 1847. Rio de Janeiro: Eduardo e Henrique Laemmert, 1846.

ALMANAQUE administrativo mercantil e industrial do Rio de Janeiro para o ano de 1848. Rio de Janeiro: Eduardo e Henrique Laemmert, 1847.

ALMANAQUE administrativo mercantil e industrial do Rio de Janeiro para o ano de 1849. Rio de Janeiro: Eduardo e Henrique Laemmert, 1848.

ALMANAQUE da cidade do Rio de Janeiro para o ano de 1811. Revista do 
Instituto Histórico e Geográfico Brasileiro. Rio de Janeiro, v. 282, 1969.

ALMANAQUE da cidade do Rio de Janeiro para o ano de 1816. Revista do Instituto Histórico e Geográfico Brasileiro. Rio de Janeiro, v. 268, 1965.

ALMANAQUE da cidade do Rio de Janeiro para o ano de 1817. Revista do Instituto Histórico e Geográfico Brasileiro. Rio de Janeiro, v. 270, 1966.

ALMANAQUE da cidade do Rio de Janeiro para o ano de 1824. Revista do Instituto Histórico e Geográfico Brasileiro. Rio de Janeiro, v. 278, 1968.

ALMANAQUE da cidade do Rio de Janeiro para o ano de 1827. Revista do Instituto Histórico e Geográfico Brasileiro. Rio de Janeiro, v. 300, 1973.

ALMANAQUE do Rio de Janeiro de 1794. Anais da Biblioteca Nacional. Rio de Janeiro, v. 59, 1937.

ALMANAQUE geral do Império do Brasil. Rio de Janeiro. Tip. Comercial Fluminense de S. F. Surigué, 1836.

ALMANAQUE imperial do comércio e das corporações civis e militares do Império do Brasil. Rio de Janeiro: Em Casa de P. Plancher-Seignot, 1829.

ALMEIDA, Manuel Lopes de. Notícias históricas de Portugal e Brasil. Coimbra, 1961.

ALMEIDA, Renato. História da música brasileira. Rio de Janeiro: Briguiet, 1942.

ANAIS da Biblioteca Nacional. Rio de Janeiro, v. 2, 1877.

ANAIS da Biblioteca Nacional. Rio de Janeiro, v. 31, 1909.

ANAIS da Biblioteca Nacional. Rio de Janeiro, v. 46, 1924.

ANAIS do Parlamento brasileiro. Câmara dos Srs. Deputados. Segundo ano da primeira legislatura. Rio de Janeiro: Tipografia de H. J. Pinto, 1875.

ANAIS do Parlamento brasileiro. Câmara dos Srs. Deputados. Quarto ano da primeira legislatura. Rio de Janeiro: Tipografia de H. J. Pinto, 1877.

ANAIS do Parlamento brasileiro. Câmara dos Srs. Deputados. Primeiro ano da segunda legislatura. Rio de Janeiro: Tipografia de H. J. Pinto, 1878.

ANAIS do Parlamento brasileiro. Câmara dos Srs. Deputados. Segundo ano da segunda legislatura. Rio de Janeiro: Tipografia de H. J. Pinto, 1878.

ANAIS do Parlamento brasileiro. Câmara dos Srs. Deputados. Terceiro ano 
da segunda legislatura. Rio de Janeiro: Tipografia de H. J. Pinto, 1878.

ANAIS do Parlamento brasileiro. Câmara dos Srs. Deputados. Quarto ano da segunda legislatura. Rio de Janeiro: Tipografia de viúva Pinto e filho, 1887.

ANAIS do Parlamento brasileiro. Câmara dos Srs. Deputados. Primeiro ano da terceira legislatura. Rio de Janeiro: Tipografia de H. J. Pinto, 1879.

ANAIS do Parlamento brasileiro. Câmara dos Srs. Deputados. Segundo ano da terceira legislatura. Rio de Janeiro: Tipografia de H. J. Pinto, 1875.

ANAIS do Parlamento brasileiro. Câmara dos Srs. Deputados. Terceiro ano da terceira legislatura. Rio de Janeiro: Tipografia de viúva Pinto \& Filho, 1887.

ANAIS do Parlamento brasileiro. Câmara dos Srs. Deputados. Quarto ano da terceira legislatura. Rio de Janeiro: Tipografia de viúva Pinto \& Filho, 1887.

ANAIS do Parlamento brasileiro. Câmara dos Srs. Deputados. Primeiro ano da quarta legislatura. Rio de Janeiro: Tipografia da viúva Pinto \& Filho, 1886.

ANAIS do Parlamento brasileiro. Câmara dos Srs. Deputados. Segundo ano da quarta legislatura. Rio de Janeiro: Tipografia da viúva Pinto \& Filho, 1884.

ANAIS do Parlamento brasileiro. Câmara dos Srs. Deputados. Terceiro ano da quarta legislatura. Rio de Janeiro: Tipografia de viúva Pinto \& Filho, 1884.

ANAIS do Senado do Império do Brasil. Segunda Sessão da Primeira Legislatura. Rio de Janeiro, 1914.

ANDRADE, Ayres de. Francisco Manuel da Silva e seu tempo. 1808-1865. Uma fase do passado musical do Rio de janeiro à luz de novos documentos. Rio de Janeiro: Tempo brasileiro, 1967.

ANDRADE, Mário de. Aspectos da música brasileira. São Paulo: Martins, 1975.

Pequena história da música. Belo Horizonte: Itatiaia, 1987.

ANDRIOLI, Luigi. Cesare in Egitto, melodramma serio da rappresentarsi nell'Imperiale Teatro di Torino il carnevale dell'anno 1814 dedicato a Sua Altezza Imperiale il Principe Camillo Duca di Guastalla. Torino: presso Onorato Derossi, [1814?].

ANGERMÜLLER, Rudolph. Sigismund Neukomm Werkverzeichnis Autobiographie Beziehung $z u$ seinen Zeitgenossen. MünchenSalzburg: Musikverlag Emil Katzbichler, 1977.

ANTONIL, André João. Cultura e opulência do Brasil. Por suas drogas e 
minas, com várias notícias curiosas do modo de fazer o açúcar, plantar e beneficiar o tabaco, tirar ouro das minas e descobrir as de prata; e dos grandes emolumentos que esta conquista da América meridional dá ao Reino de Portugal com estes e outros gêneros e contratos reais. Lisboa: Na Oficina Real Deslandesiana, 1711.

ANUÁRIO do Museu Imperial. Rio de Janeiro, v. 6, 1945.

ANUÁRIO estatístico do Brasil. Rio de Janeiro: IBGE, 1939/1940.

ARAGO, Jacques. Promenade autour du monde pendant les années 1817, 1818, 1819 et 1820, sur les corvettes du roi l'Uranie et la Physicienne, commandées par M. Freycinet. Paris: Leblanc, 1822.

ARAÚJO, José de Sousa Azevedo Pizarro e. Memórias históricas do Rio de Janeiro. Rio de Janeiro: Na Tip. de Silva Porto, 1822.

ARMITAGE, John. The history of Brazil: from the period of the arrival of the Braganza family in 1808, to the abdication of Don Pedro the First in 1831. London: Smith, Elder and co., 1836.

AXUR, Rei de Ormuz. Ópera sério-cômica para representar-se no Real Teatro de S. João no feliz natalício de Sua Majestade Fidelíssima a Senhora D. Maria I, rainha de Portugal a 17 de dezembro. Rio de Janeiro: Impressão Régia, 1814.

AZEVEDO, Fernando de. A cultura brasileira. Brasília: Editora Universidade de Brasília, 1963.

AZEVEDO, Manuel Duarte Moreira de. Biografia dos brasileiros ilustres por armas, letras, virtudes, etc. Padre José Maurício Nunes Garcia. Revista do Instituto Histórico e Geográfico Brasileiro. Rio de Janeiro, v. 43 (t. 34 parte 2), 1871.

. Motim político de 17 de abril de 1832 no Rio de Janeiro. Revista do Instituto Histórico e Geográfico Brasileiro. Rio de Janeiro, v. 51 (t. 38 parte 2), 1875.

Motim político de 3 de abril de 1832 no Rio de Janeiro. Revista do Instituto Histórico e Geográfico Brasileiro. Rio de Janeiro, v. 49 [t. 37 parte 2], 1874.

. O Rio de Janeiro; sua história, monumentos, homens notáveis, usos e curiosidades. Rio de Janeiro: B.L. Garnier, 1877.

Os tiros no Teatro: motim popular no Rio de Janeiro. Revista do Instituto Histórico e Geográfico Brasileiro. Rio de Janeiro, t. 36, parte 2, 1873.

Sociedades fundadas no Brasil desde os tempos coloniais até o começo do atual reinado. Revista do Instituto Histórico e Geográfico Brasileiro. Rio de Janeiro, v. 48 (segunda parte), 1885.

AZEVEDO, Victor de. Feijó: vida, paixão e morte de um chimango. São Paulo: Editora Anchieta limitada, 1942. 
BALBI, Adrien. Essai Statistique sur le royaume de Portugal et d'Algarve. Paris: Rey et Gravier, 1822.

BARETTI, Giuseppe Marco Antonio. A journey from London to Genoa, through England, Portugal, Spain, and France. London: T. Davies and L. Davis, 1770.

BARROW, John. A voyage to Cochinchina, in the years 1792 and 1793 To which is annexed an account of a journey made in the years 1801 and 1802, to the residence of the chief of the Booshuana nation. London: T. Cadell and W. Davies, 1806.

BECKFORD, William. A Corte da Rainha D. Maria I: correspondência de W. Beckford - 1787. Lisboa: Tavares Cardoso, 1901.

BELVIANES, Marcel. Sociologie de la musique. Paris: Payot, 1951.

BENEVIDES, Francisco da Fonseca, O Real Teatro de S. Carlos de Lisboa desde a sua fundação em 1793 até á atualidade: estudo histórico. Lisboa: Tip. Castro Irmão, 1883.

BIANCONI, Lorenzo (org.). Histoire de L'opéra italien. Traduit de l'italien par Bernardette Delcomminette. Liège: Mardaga, 1992.

BICALHO, Maria Fernanda. As Câmaras Municipais no império português: o exemplo do Rio de Janeiro. Revista Brasileira de História. São Paulo: ANPUH, v.18, n. 36, 1998.

BLANCHARDIĖRE, René Courte de La. Nouveau voyage fait au Pérou. Paris: De l'imprimérie de Delaguette, 1751.

BOISANGER, Béatrice de. Mémoires des Isles. Paris: O. Orban, 1986.

BÖSCHE, Eduard Theodor. Wechselbilder von land-und Seereisen, Abenteuern, Begebenheiten, staatsereignissen, volks-und sittenschilderungen während einer fahrt nach Brasilien und eines zehnjährigen Aufenthalts daselbst, in den Jahren 1825 bis 1834. Hamburg: Hoffmann und Campe, 1836.

BOUGAINVILLE et ses compagnons autour du monde 1766-1769. Paris: Imprimerie Nationale, 1977.

BOUGAINVILLE, Hyacinthe Yves Philippe Potentien, Baron de. Journal de la navigation autour du globe: de la frégate La Thétis et de la corvette L'Esperance pendant les années 1824, 1825 et 1826. Paris: Arthus Bertrand, 1837.

BOUGAINVILLE, Louis-Antoine de. Voyage autour du monde, par la frégate du Roi La Boudeuse, et la flûte L'Etoile, en 1766, 1767, 1768 \& 1769. Paris, Chez Saillant \& Nyon, 1771.

BOXER, Charles R. A idade de ouro do Brasil. Tradução de Nair de Lacerda. Rio de Janeiro: Nova Fronteira, 2000.

BRACKENRIDGE, Henry Marie. Voyage to South America: performed by 
order of the American government, in the years 1817 and 1818, in the frigate Congress. Baltimore: John D. Toy, 1819.

BRAGA, Teófilo. História do teatro português: a comédia clássica e as tragicomédias. Séculos XVI e XVII. Porto: Imprensa Portuguesa, 1870.

BRANCO, João de Freitas. História da música portuguesa. Lisboa: Publicações Europa-América, 1995.

BRANCO, Luiz Maria da Costa de Freitas. Música em Portugal. Lisboa: Imprensa Nacional, 1929.

BRAND, Charles. Journal of a voyage to Peru: a passage across the cordillera of the Andes, in the winter of 1827 performed on foot in the snow: and a journey across the pampas. London: H. Colburn, 1828.

BRITO, Manuel Carlos de. Opera in Portugal in the eighteenth century. Cambridge: Cambridge University Press, 1989.

BROWN, T. Allston. A history of the New York stage, from the first performance in 1732 to 1901. New York: B. Blom, 1964.

BURNEY, Charles. A general history of music, from the earliest ages to the present period. London: Payne and Son, 1789.

CALDCLEUGH, Alexander. Travels in South America, during the years 181920-21. Containing an account of the present state of Brazil, Buenos Ayres, and Chile. London: John Murray, 1825.

CALMON, Pedro. História do Brasil. Rio de Janeiro: José Olympio, 1959.

CÂMARA, J. M. B. da. O lugar de $D$. João $V$ na História da música portuguesa. Revista ICALP, Lisboa: Instituto de Cultura e Língua Portuguesa, v. 16 e 17, jun./set. 1989.

CANDIDO, Antônio. Formação da literatura brasileira. São Paulo: EDUSP, 1975.

CAPEILLE, J.. Dictionnaire de biographies roussillonnaises. Perpignan: Imprimerie-Librairie Catalane de J. Comet, 1914.

CARDOSO, André. A Capela Real e Imperial do Rio de Janeiro - 1808-1889. Rio de Janeiro, 2001. Tese (Doutorado) - Instituto Villa-Lobos / Universidade Federal do Estado do Rio de Janeiro.

CARREIRA, Liberato de Castro. História financeira e orçamentária do Império do Brasil desde a sua fundação. Brasília: Senado Federal, 1980.

CARTAS Andradinas. Anais da Biblioteca Nacional. Rio de Janeiro, v. 14, p. 11, 1890.

CARVALHAIS, Manoel Pereira Peixoto de Almeida. Marcos Portugal na sua música dramática. Lisboa: Tip. Castro Irmão, 1910.

CASTELNAU, Francis, Comte de. Expédition dan les parties centrales de l'Amérique du Sud, de Rio de Janeiro à Lima, et de Lima au Para: 
exécutée par ordre du gouvernement français pendant les annés 1843 à 1847, sous la direction de Francis de Castelnau. Histoire du voyage. Paris: P. Bertrand, 1850.

CATÁLOGO da Exposição de História do Brasil. Anais da Biblioteca Nacional. Rio de Janeiro, v. 9, t. 2, 1881.

CAVALCANTI, Amaro. O meio circulante nacional. Brasília: Editora da Universidade de Brasília, 1983.

CAVALCANTI, Nireu. O Rio de Janeiro setecentista: a vida e a construção da cidade da invasão francesa até a chegada da corte. Rio de Janeiro: Jorge Zahar, 2004.

CHAPELLE, Claude Emmanuel Lhuillier et alii. Voyage de Chapelle et Bachaumont, suivi de quelques autres voyages dans le même genre. Londres [i.e. Paris], 1782.

ChAVAGNES, M. L. de. Le Brésil en 1844. Revue des deux mondes. Paris: Au Bureau de la revue des deux mondes, t. 7, 1844.

CLEVELAND, Richard J.. Voyages and commercial enterprises of the sons of New England. New York: Leavitt \& Allen, 1855.

COGGESHALL, George. Second series of voyages to various parts of the world, made between the years 1802 and 1841. New York: D. Appleton \& company, 1852.

COLEÇÃO das Leis do Brasil de 1808. Cartas de Lei, Alvarás, Decretos e Cartas Régias de 1808. Rio de Janeiro: Imprensa Nacional, 1891.

COLEÇÃO das Leis do Brasil de 1810. Cartas de Lei, Alvarás, Decretos e Cartas Régias de 1810. Rio de Janeiro: Imprensa Nacional, 1891.

COLEÇÃO das Leis do Brasil de 1811. Decisões de 1811. Rio de Janeiro: Imprensa Nacional, 1890.

COLEÇÃO das Leis do Brasil de 1813. Decisões de 1813. Rio de Janeiro: Imprensa Nacional, 1890.

COLEÇÃO das Leis do Brasil de 1815. Decisões de 1815. Rio de Janeiro, Imprensa Nacional, 1890.

COLEÇÃO das Leis do Brasil de 1817. Cartas de Lei, Alvarás, Decretos e Cartas Régias de 1817. Rio de Janeiro: Imprensa Nacional, 1890.

COLEÇÃO das Leis do Brasil de 1818. Cartas de Lei, Alvarás, Decretos e Cartas Régias de 1818. Rio de Janeiro: Imprensa Nacional, 1889.

COLEÇÃO das Leis do Brasil de 1821. Rio de Janeiro: Imprensa Nacional, 1889.

COLEÇÃO das Leis do Império do Brasil de 1822. Decretos, Cartas e Alvarás de 1822. Rio de Janeiro: Imprensa Nacional, 1887.

COLEÇÃO das Leis do Brasil de 1822. Decisões de 1822. Rio de Janeiro, 
Imprensa Nacional, 1887.

COLEÇÃO das Leis do Império do Brasil de 1823. Decretos, Cartas e Alvarás de 1823. Rio de Janeiro: Imprensa Nacional, 1887.

COLEÇÃO das Leis do Brasil de 1823. Decisões de 1823. Rio de Janeiro, Imprensa Nacional, 1887.

COLEÇÃO das Leis do Império do Brasil de 1824. Constituição Política do Império do Brasil. Rio de Janeiro, Imprensa Nacional, 1886.

COLEÇÃO das Leis do Brasil de 1824. Decretos, Cartas Imperiais e Alvarás de 1824. Rio de Janeiro: Imprensa Nacional, 1886.

COLEÇÃO de Decretos, Cartas Imperiais e Alvarás do Império do Brasil de 1825. Rio de Janeiro: Imprensa Nacional, 1885.

COLEÇÃO das Leis do Império do Brasil de 1826. Rio de Janeiro: Tipografia Nacional, 1880.

COLEÇÃO das Leis do Império do Brasil de 1827. Rio de Janeiro: Tipografia Nacional, 1878.

COLEÇÃO das Leis do Império do Brasil de 1828. Rio de Janeiro: Tipografia Nacional, 1878.

COLEÇÃO das Leis do Império do Brasil de 1829. Rio de Janeiro: Tipografia Nacional, 1877.

COLEÇÃO das Decisões do Império do Brasil de 1829. Rio de Janeiro: Tipografia Nacional, 1877.

COLEÇÃO das Leis do Império do Brasil de 1830. Rio de Janeiro: Tipografia Nacional, 1876.

COLEÇÃO das Leis do Império do Brasil de 1831. Rio de Janeiro: Tipografia Nacional, 1875.

COLEÇÃO das decisões do Império do Brasil de 1831. Rio de Janeiro: Tipografia Nacional, 1876.

COLEÇÃO das Leis do Império do Brasil de 1832. Rio de Janeiro: Tipografia Nacional, 1874.

COLEÇÃO das Leis do Império do Brasil de 1833. Rio de Janeiro: Tipografia Nacional, 1872.

COLEÇÃO das Leis do Império do Brasil de 1834. Rio de Janeiro: Tipografia Nacional, 1866.

COLEÇÃO das Leis do Império do Brasil de 1835. Rio de Janeiro: Tipografia Nacional, 1864.

COLEÇÃO das Leis do Império do Brasil de 1836. Rio de Janeiro: Tipografia Nacional, 1861.

COLEÇÃO das Leis do Império do Brasil de 1837. Rio de Janeiro: Tipografia 
Nacional, 1861.

COLEÇÃO das Leis do Império do Brasil de 1838. Rio de Janeiro: Tipografia Nacional, 1838.

COLEÇÃO das Leis do Império do Brasil de 1840. Rio de Janeiro: Tipografia Nacional, 1863.

COLEÇÃO das Leis do Império do Brasil de 1841. Rio de Janeiro: Tipografia Nacional, 1842.

COLLINS, David. An account of the english colony in New South Wales: with remarks on the dispositions, customs, manners, etc. Of the native inhabitants of that country. To which are added, some particulars of New Zealand. Compiled, by permission, from the Mss. of LieutenantGovernor King. London: T. Cadell Jun. and W. Davies, 1798.

CONSTANT, Benjamin. Principes de politique. Cours de politique constitutionnelle et collection des ouvrages publiés sur le gouvernement représentatif. Paris: INALF, 1961.

CORREIA, Viriato. Brasil dos meus avós. Rio de Janeiro: Companhia Editora Nacional, 1927.

COUTINHO, Gastão Fausto da Câmara. O juramento dos Numes, drama. Para se representar na noite da abertura do Real Teatro de S. João em aplausos ao Augusto nome de Sua Alteza Real o Príncipe Regente Nosso Senhor. Rio de Janeiro: Impressão Régia, 1813.

CUNHA, Luiz Antônio Rosado da. Relação da entrada que fez o excelentíssimo e reverendíssimo senhor D. Fr. Antônio do Desterro Malheiro, Bispo do Rio de Janeiro, em o primeiro dia deste presente ano de 1747 havendo sido seis anos Bispo do Reino de Angola, donde, por nomeação de Sua Majestade e Bula Pontifícia, foi promovido para esta Diocese, composta pelo Doutor Luiz Antônio Rosado da Cunha Juiz de Fora e Provedor dos defuntos e ausentes, Capelas e Resíduos do Rio de Janeiro. Rio de Janeiro: Na segunda Oficina de Antônio Isidoro da Fonseca, 1747.

DAHLHAUS, Carl. Estética musical. Tradução de Artur Mourão. Lisboa: edições 70, 1991.

DARAŸO, Michele. Estratto di alcune cose scritte dal Brasile nell'anno MDCXXI - Collegio e Residenza del Fiume Gennaio. In: VITELLESCHI, Mutio. Lettere annue d'Etiopia, Malabar, Brasil, e Goa. Roma: Francesco Corbelletti, 1627.

DEBRET, Jean Baptiste. Voyage pittoresque et historique au Brésil, ou Séjour d'un artiste français au Brésil, depuis 1816 jusqu'en 1831 inclusivement. Paris: Firmin Didot frères, 1839.

DEMONSTRAÇÃO da receita e despesa do Tesouro Nacional, divida ativa e passiva, orçamentos para o ano futuro. Rio de Janeiro: Na Tipografia Imperial e Nacional, 1827. 
DENIS, Ferdinand Jean. Histoire et description du Brésil. Paris: F. Didot frères, 1839.

DIÁRIO do Príncipe de Joinville. Anuário do Museu Imperial. Notas de Lourenço Luís Lacombe. Rio de Janeiro, v. 11, 1950.

DIDEROT, Denis. Fuvres. Paris: Robert Laffont, 1996.

DINIZ, Jaime, Músicos pernambucanos do passado. Recife: Universidade Federal de Pernambuco, 1969.

DIONISOTTI, Carlo. Notizie biografiche dei vercellesi illustri. Biella: Arnaldo Forni Editore, 1862.

DOCUMENTOS com que se instruiu o seu relatório à Assembléia Geral Legislativa do Império do Brasil o Ministro Secretário de Estado dos Negócios da Fazenda, e Presidente do Tesouro Nacional, Miguel Calmon du Pin e Almeida, na Sessão de 1828. Rio de Janeiro: Na Tipografia Imperial e Nacional, 1828.

DOCUMENTOS com que se instruiu o seu relatório à Assembléia Geral Legislativa do Império do Brasil o Ministro Secretário de Estado dos Negócios da Fazenda, e Presidente do Tesouro Nacional, Miguel Calmon du Pin e Almeida, na Sessão de 1829. Rio de Janeiro: Na Tipografia Imperial e Nacional, 1829.

DOUVILLE, Jean-Baptiste. 30 mois de ma vie avant et après mon voyage au Congo, ou ma justification des infamies débitées contre moi; suivie de détails nouveaux et curieux sur les moeurs et les usages des habitants du Brésil et de Buenos-Ayres, et d'une description de la colonie Patagonia. Paris: l'auteur, 1833.

DROULERS, Frédéric. Répertoire général des monnaies de Louis XIII à Louis XVI. Paris: Copernic, 1987.

DRUMMOND, Antônio de Meneses Vasconcelos de. Anotações de A. M. V. de Drummond à sua biografia publicada em 1836 na Biographie Universelle et Portative des Contemporains. Anais da Biblioteca Nacional. Rio de Janeiro, v. 13, parte 3, 1890.

DUGUAY-TROUIN, René. Mémoires de monsieur Duguay-Trouin, lieutenant général des armées navales de France et commandeur de l'ordre royal \& militaire de Saint Louis. S.I., 1740.

DUMOURIEZ, Charles-François du Périer. État présent du royaume de Portugal, en l'année MDCCLXVI. Lausanne: Chez François Grasset, 1775.

DUPRAT, Régis. A música sacra no Brasil colonial e imperial. Revista do Instituto do Patrimônio Histórico e Artístico Nacional. Rio de Janeiro: IPHAN, 2001.

. Garimpo musical. São Paulo: Novas Metas, 1985.

. Música na Sé de São Paulo colonial. São Paulo: Paulus, 1995. 
ELIAS, Norbert. O processo civilizador. Tradução de Ruy Jungmann. Rio de Janeiro: Jorge Zahar, 1993.

EPANÁFORA festiva, ou relação sumária das festas, com que na cidade do Rio de Janeiro capital do Brasil se celebrou o feliz nascimento do sereníssimo Príncipe da Beira Nosso Senhor. Lisboa: na Oficina de Miguel Rodrigues, 1763.

ESTATUTOS da Sociedade de Música. Rio de Janeiro: Tip. de Paula Brito, 1854.

ESTATUTOS da Sociedade Filarmônica. Rio de Janeiro: Imprensa Americana, 1840.

FAORO, Raymundo. Os donos do poder: formação do patronato político brasileiro. São Paulo: Globo, 2000.

FAZENDA, Vieira. Antiqualhas e memórias do Rio de Janeiro. Revista do Instituto Histórico e Geográfico Brasileiro, t. 86, v. 140, 1919.

Antiqualhas e memórias do Rio de Janeiro. Revista do Instituto Histórico e Geográfico Brasileiro, t. 93, v. 147, 1923.

FERREIRA, Tito Lívio; FERREIRA, Manoel Rodrigues. História da civilização brasileira. São Paulo, Biblos, 1959.

FERRETTI, Jacopo. Matilde Shabran: Dramma Per Musica. Milano: Pirola Giacomo, 1822.

FERREZ, Gilberto. Uma arribada francesa ao tempo de Bobadela (1748). Revista do Instituto Histórico e Geográfico Brasileiro, v. 280, 1988.

FÉTIS, François-Joseph. Biographie universelle des musiciens et bibliographie générale de la musique. Paris: Firmin-Didot, 1866-1868.

FISCHER, Ernst. A necessidade da arte. Tradução de Leandro Konder. Rio de Janeiro: Zahar Editores, 1966.

FLORENTINO, Manolo. Em costas negras. Uma história do tráfico atlântico de escravos entre a África e o Rio de Janeiro: séculos XVIII e XIX. Rio de Janeiro: Arquivo Nacional, 1995.

FOPPA, Giuseppe Maria. L' amico dell'uomo, commedia di sentimento in musica da rappresentarsi nel Teatro in Santa Radegonda la state del 1808. Milano: dai torchi Dova, 1808.

FRAGOSO, João. Afogando em nomes: temas e experiências em história econômica. TOPOI. Revista de História. Rio de Janeiro: PPGHIS/UFRJ, n.5, 2002.

Homens de grossa aventura: acumulação e hierarquia na praça mercantil do Rio de Janeiro, 1790-1830. Rio de Janeiro: Arquivo Nacional, 1992.

FRANCO, Afonso Arinos de Melo. História do Banco do Brasil. Rio de Janeiro, 1979. 
FREYCINET, Louis Claude Desaulces de. Voyage autour du monde, entrepris par ordre du roi exécuté sur les corvettes de S. M. L'Uranie et Le Physicienne. Paris: Chez Pillet aîné, 1826.

GESUALDO, Vicente. Teatros del Buenos Aires Antiguo. Buenos Aires: Ansilta Ediciones, 1990.

GIRON, Luís Antônio. Minoridade crítica. A ópera e o teatro nos folhetins da corte. São Paulo: Edusp, 2004.

GRAHAM, Maria. Escorço biográfico de Dom Pedro I com uma notícia do Brasil e do Rio de Janeiro. Tradução de Américo Jacobina Lacombe. Anais da Biblioteca Nacional. Rio de Janeiro, v. 60, 1938.

. Journal of a voyage to Brazil, and residence there, during part of the years 1821, 1822, 1823. London: Longman, 1824.

GRANDE enciclopédia portuguesa e brasileira. Lisboa; Rio de Janeiro: Editorial Enciclopédia, limitada, [1935-60].

HAMOND, Graham Eden. Os diários do Almirante Graham Eden Hamond. Tradução de Paulo Fontainha Geyer. Rio de Janeiro: Ed. JB, 1984.

HAWKESWORTH, John. An Account of the voyages undertaken by the order of His Present Majesty for making discoveries in the Southern Hemisphere, and successively performed by Commodore Byron, Captain Wallis, Captain Carteret and Captain Cook, in the Dolphin, the Swallow, and the Endeavour. London: Strahan and T. Cadell, 1773.

HEGEL, Georg Wilhelm Friedrich. Estética: a idéia e o ideal. Tradução de Orlando Vitorino. São Paulo: Nova Cultural, 1999.

HENSHAW, Joshua Sidney. Around the world: a narrative of a voyage in the East India Squadron under Commodore George C. Read. New York: Charles S. Francis, 1840.

HISTÓRIA do Brasil desde 1807 até ao presente: originalmente composta em português para servir de continuação à que se publicou vertida do francês. Lisboa: Na Impressão de J. B. Morando; Tip. de Desidério Marques Leão, 1820-1834.

HOBSBAWM, Eric J. A Era das Revoluções (1789 - 1848). Tradução de Maria Tereza Lopes Teixeira e Marcos Penchel. Rio de Janeiro: Paz e Terra, 1977.

HOLANDA, Sérgio Buarque de (org.). História geral da civilização brasileira. São Paulo: Difel, 1985.

. Raízes do Brasil. Rio de Janeiro: José Olympio, 1979.

HORNBLOW, Arthur. A History of the theatre in America. Philadelphia: J.B. Lippincott Company, 1919.

HORNER, Gustavus Richard Brown. Medical topography of Brazil and Uruguay: with incidental remarks. Philadelphia: Lindsay \& Blakiston, 
1845.

INFÂNCIA e Adolescência de D. Pedro II; Documentos interessantes publicados para comemorar o primeiro centenário do nascimento do grande brasileiro, ocorrido em 2 de dezembro de 1825. Rio de Janeiro: Arquivo Nacional, 1925.

INFORMAÇÃO Geral da Capitania de Pernambuco. Sobre se dar posse ao Doutor Antônio Ferreira Castro do Ofício de Procurador da Coroa, pelo mulatismo lhe não servir de impedimento. Anais da Biblioteca Nacional. Rio de Janeiro, v. 28, 1906.

ITIER, Jules. Journal d'un voyage en Chine en 1843, 1844, 1845, 1846. Paris: Chez Dauvin et Fontaine, 1848.

JACQUEMONT, Victor. Correspondance inédite de Victor Jacquemont avec sa famille et ses amis - 1824-1832. Paris: Librairie de H. Fournier, 1835.

Voyage dans l'Inde. Paris: Firmin Didot, 1841.

JOURNAL d'un voyage sur les côtes d'Afrique et aux Indes d'Espagne. Amsterdam: Paul Marret, 1723.

JUNOT, Laure. Mémoires de la Duchesse D'Abrantes. Paris, 1837.

KIDDER, Daniel Parish. Sketches of residence and travels in Brazil: embracing historical and geographical notices of the empire and its several provinces. Philadelphia: Sorin \& Ball; London: Wiley \& Putnam, 1845.

KMEN. Henry A. Music in New Orleans: The Formative Years, 1791-1841. Baton Rouge: Louisiana State University Press, 1966.

KOTZEBUE, Otto von. Neue Reise um die Welt in den Jahren 1823, 24, 25 und 26. Weimar: Wilhelm Hoffmann, 1830.

LA CAILLE, Nicolas Louis de. Journal historique du voyage fait au cap de Bonne-Espérance, par Feu M. I'Abbé de La Caille, de L'Académie des Sciences; précédé d'un discours sur la vie de l'auteur, suivi de remarques \& de réflexions sur les coutumes des Hottentots et des habitants du Cap. Paris: Chez Guillyn, 1763.

LA FLOTTE, M. de. Essais historiques sur l'Inde, précédés d'un journal de voyages et d'une description géographique de la côte de Coromandel. Paris: Chez Herissant le Fils, 1769.

LAGRANGE, Louis Chancel de. Campagne du Brésil faite contre les portugais, 1711. Revista do Instituto Histórico e Geográfico Brasileiro, v. 270, 1967.

LANGE, Francisco Curt. Compositores na Capitania Geral das Minas Gerais, segunda metade do século XVIII. Marília: Estudos Históricos, 1965.

. História da música nas irmandades de Vila Rica. Belo Horizonte: 
Imprensa Oficial, 1981.

- Pesquisas esporádicas de musicologia no Rio de Janeiro: a Irmandade do Santíssimo Sacramento da Igreja da Candelária do Rio de Janeiro. Revista do Instituto de Estudos Brasileiros. São Paulo: IEB/USP, v. 4, 1968.

LANGSDORFF, Victorine Emilie de Sainte-Aulaire, Baronesa de. Diário da Baronesa E. de Langsdorff: relatando sua viagem ao Brasil por ocasião do casamento de S. A. R. o Príncipe de Joinville, 1842-1843. Tradução de Patrícia Chittoni Ramos e Marco Antõnio Toledo Neder. Florianópolis: Editora Mulheres, 1999.

LAPLACE, Cyrille Pierre Theodore. Voyage autour du monde, par les mers de I'Inde et de la Chine, exécuté sur la corvette de l'État La Favorite pendant les années 1830, 1831, 1832. Paris: Imprimerie Royale, 1835.

LAVOLLÉE, Charles Hubert. Voyage en Chine - Teneriffe - Rio Janeiro - Le Cap - Ile Bourbon - Malacca - Singapore - Manille - Macao - Canton - Ports chinois. Paris: Just Rovier \& a Ledoyen, 1852.

LAVRADIO, Luiz de Almeida Portugal, Marquês de. Cartas do Rio de Janeiro. Rio de Janeiro: Arquivo Nacional, 1975.

LEITE, Antonio Bressane. União venturosa. Drama com música para se representar no Real Teatro do Rio de Janeiro no faustíssimo dia dos anos de Sua Alteza Real o Príncipe Regente nosso senhor. Rio de Janeiro: Impressão Régia, 1811.

LEITE, S. I. Serafim. Artes e ofícios dos jesuítas no Brasil. Rio de Janeiro: Livros de Portugal, 1953.

LEITHOLD, Theodor von. Meine Ausflucht nach Brasilien oder reise von Berlin nach Rio de Janeiro und von dort zurück. Berlin: Maurerschen Buchhandlung, 1820.

LIMA, José Dias da Cruz. Reflexões sobre o estado atual das finanças do Brasil: proposta de alguns melhoramentos e medidas que the podem ser aplicadas. Rio de Janeiro: Tip. Americana de I. P. Da Costa, 1843.

LIMA, Manuel de Oliveira. D. João VI no Brasil. Rio de Janeiro: Topbooks, 1996.

LISANTI FILHO, Luís. Negócios coloniais: uma correspondência comercial do século XVIII. Brasília: Ministério da Fazenda, 1973.

LISBOA, M. P. A.. de. Notes sur la race noire et la race mulâtre au Brésil. Nouvelles annales des voyages et des sciences géographiques. Paris: Arthur Bertrand, t. 2, 1847.

LISLE, James George Semple. The life of Major J. G. Semple Lisle; containing a faithful narrative of his alternate vicissitudes of splendor and misfortune. London: W. Stuart, 1799.

LODOISKA, dramma per musica da rappresentarsi nel Regio-Ducal Teatro 
alla Scala di Milano il carnevale dell'anno 1800. Dedicato a sua eccellenza il sig. conte Luigi Cocastelli. Milano: Gio. Batista Bianchi, [1800].

LUCCOCK, John. Notes on Rio de Janeiro, and the Southern Parts of Brazil, taken during a residence of ten years in that country, from 1808 to 1818. London: Samuel Leigh, 1820.

MALERBA, Jurandir. A corte no exílio: civilização e poder no Brasil às vésperas da Independência (1808 a 1821). São Paulo: Companhia das Letras, 2000.

MARCONDES, Marcos Antônio (ed.). Enciclopédia da música brasileira: popular, erudita e folclórica. São Paulo: Art Editora, 1998.

MARINHO, Henrique. O teatro brasileiro. Alguns apontamentos para a sua história. Rio de Janeiro: H. Garnier, 1904.

MARIZ, Vasco. História da música no Brasil. Rio de Janeiro: Nova Fronteira, 2000.

MARROCOS, Luiz Joaquim dos Santos. Cartas de Luiz Joaquim dos Santos Marrocos escritas do Rio de Janeiro à sua família em Lisboa de 1811 a 1821. Anais da Biblioteca Nacional. Rio de Janeiro, v. 56, 1934.

MARTINHO, Lenira Menezes; GORENSTEIN, Riva. Negociantes e caixeiros na sociedade da Independência. Rio de Janeiro: Prefeitura da Cidade do Rio de Janeiro, 1992.

MARTINS, Amélia de Rezende. Um idealista realizador, Barão Geraldo de Resende. Rio de Janeiro: Oficinas Gráficas do Almanak Laemmert, 1939.

MASSIN, Jean (org.). História da música ocidental. Tradução de Ângela Ramalho Viana, Carlos Sussekind e Maria Teresa Resende Costa. Rio de Janeiro: Nova Fronteira, 1997.

MATOS, Cleofe Person de. Catálogo temático das obras do padre José Maurício Nunes Garcia. Rio de Janeiro: Ministério da Educação e Cultura, 1970. . José Maurício Nunes Garcia - biografia. Rio de Janeiro: Biblioteca Nacional, 1997.

MATOS, Ilmar Rohloff de. O tempo saquarema. São Paulo: Hucitec, 2004.

MELO, Francisco Inácio Marcondes Homem de. A constituinte perante a história. Brasília: Senado Federal, 1996. Edição fac-similar.

MEMÓRIAS públicas e econômicas da cidade de São Sebastião do Rio de Janeiro para uso do Vice-Rei Luiz de Vasconcelos por observação curiosa dos anos de 1779 até o de 1789. Revista do Instituto Histórico e Geográfico Brasileiro. Rio de Janeiro, t. 47, parte 1, 1884.

MEROLLA, Gennaro. Correspondência brasileira (1832-1834). São Paulo: 
Instituto Cultural Italo-Brasileiro, 1963.

MONEY of England, reduced into money of Portugal and the money of Portugal reduced into English money, at the exchange of sixty-seven pence halfpenny per mill rea, which is the par of exchange between these kingdoms. Also, the coins, measures, and weights of both kingdoms, compared. Falmouth: M. Allison, 1766.

MONTEIRO, Maurício Mário. A construção do gosto. Música e sociedade no Brasil no tempo de D. João VI (1808-1821). São Paulo, 2001. Tese (Doutorado) - FFLCH/USP.

- João de Deus de Castro Lobo e as práticas musicais nas associações religiosas de Minas Gerais. São Paulo, 1995. Dissertação (Mestrado) - FFLCH/USP.

MOORE, Joseph William. The Revolution of 1831. Notas de J. M. Harvey. São Paulo: Sociedade Brasileira de Cultura Inglesa, 1962.

MOREL, Marco. As transformações dos espaços públicos. Imprensa, atores políticos e sociabilidades na cidade imperial, 1820-1840. São Paulo: Hucitec, 2005.

Papéis incendiários, gritos e gestos: a cena pública e a construção nacional nos anos 1820-1830. TOPOI. Revista de história. Rio de Janeiro: PPGHIS/UFRJ, n. 4, 2002.

MOTT, Frank Luther, A History of American Magazines: 1741-1850. New York: D. Appleton and Company, 1930.

MúSICA no Rio de Janeiro imperial. Rio de Janeiro: Biblioteca Nacional, 1962.

NOVAIS, Fernando. Portugal e Brasil na crise do antigo sistema colonial. São Paulo: Hucitec, 2001.

O BERÇO da arte dramática do Rio de Janeiro. O Teatro de Manuel Luiz. Revista do Instituto Histórico e Geográfico Brasileiro. Rio de Janeiro, v. 255, 1962.

OLIVEIRA, Luiz da Silva Pereira. Privilégios da nobreza e fidalguia em Portugal. Lisboa: na Nova Oficina de João Rodrigues Neves, 1806.

O'NEILL, Thomas. A concise and accurate account of the proceedings of the squadron under the command of Rear Admiral Sir Sydney Smith, K. S. \&c. in effecting the escape of the royal family of Portugal to the Brazils on November 29, 1807; and also the sufferings of the royal fugitives, \&c. during their voyage from Lisbon to Rio Janeiro; with a variety of other interesting and authentic facts. London: J. Barfield, 1810.

ORBIGNY, Alcide Dessalines d'. Voyage dans I'Amérique Méridionale: le Brésil, la République Orientale de I'Uruguay, la République Argentine, la Patagonie, la République du Chili, la République de Bolivia, la République du Pérou, exécuté pendant les années 1826, 1827, 1828, 
1829, 1830, 1831, 1832 et 1833. Paris: Pitois-Levrault, 1835.

OTTONI, Teófilo Benedito. Circular dedicada aos Srs. eleitores de senadores pela província de Minas Gerais no quatriênio atual e especialmente dirigida aos Srs. eleitores de deputados pelo $2^{\circ}$ Distrito Eleitoral da mesma província para a próxima legislatura. Rio de Janeiro: Correio Mercantil de M. Barreto, Filhos, 1860.

PAHLEN, Kurt. História Universal da Música. Tradução de A. Della Nina. São Paulo: Melhoramentos.

PAIXÃO, Múcio da. Do teatro no Brasil. Revista do Instituto Histórico e Geográfico Brasileiro. Rio de Janeiro, tomo especial, parte 5, 1914.

PETRIELLA, Dionisio; SOSA MIATELLO, Sara. Diccionario biográfico italoargentino. Buenos Aires: Asociación Dante Alighieri, 1976.

PIMENTEL, Alberto Augusto de Almeida. A Corte de Dom Pedro IV. Lisboa: Guimarães, 1914.

PIÑEIRO, Théo Lobarinhas. A Construção da Autonomia: o Corpo de Commercio do Rio de Janeiro. In: V CONGRESSO BRASILEIRO DE HISTÓRIA ECONÔMICA E 6a CONFERÊNCIA INTERNACIONAL DE HISTÓRIA DE EMPRESAS, 2003, Caxambu (MG). Anais Eletrônicos do $V$ Congresso Brasileiro de História Econômica e $6^{a}$ Conferência Internacional de História de Empresas. Caxambu: Associação Brasileira de Pesquisadores em História Econômica, 2003.

PINHEIRO, Artidoro Augusto Xavier. Organização das ordens honoríficas do Império do Brasil. São Paulo: Tip. a Vapor de Jorge Seckler, 1884.

PINHEIRO, Francisco Batista Marques. Irmandade do Santíssimo Sacramento da Freguesia de Nossa Senhora da Candelária e suas repartições, coro, caridade e hospital dos lázaros. Rio de Janeiro: Moreira Maximino, 1894.

PITA, Sebastião da Rocha. História da América portuguesa desde o ano de mil e quinhentos do seu descobrimento, até o de mil e setecentos e vinte e quatro. Rio de Janeiro: W. M. Jackson, 1952.

PLESSIR-PARSEAU, Du. Campanha do Rio de Janeiro em 1711 por Du Plessir-Parseau. Tradução de Adalberto Rechsteiner. Revista do Instituto Histórico e Geográfico Brasileiro, v. 176, 1941.

POLIANO, Luiz Marques. Ordens honoríficas do Brasil: história, organização, padrões, legislação. Rio de Janeiro: Imprensa Nacional, 1943.

PORTO ALEGRE, Manuel de Araújo. Apontamentos sobre a vida e a obra do padre José Maurício Nunes Garcia. Revista do Instituto Histórico e Geográfico Brasileiro. Rio de Janeiro, t. 19, 1856.

PRADO JR., Caio. Evolução política do Brasil e outros estudos. São Paulo: Brasiliense, 1969.

PRADO JR., Caio. História econômica do Brasil. São Paulo: Brasiliense, 
1970.

PREUSSEN, Heinrich Wilhelm Adalbert, Prinz von. Aus meinem tagebuche 1842-1843. Berlin: Deckerschen Geh Oberhofbuchdruckerei, 1847.

PROPOSTA e relatório apresentados à Assembléia Geral Legislativa na Sessão Ordinária de 1840, pelo ministro e secretário de estado dos Negócios da Fazenda Manuel Alves Branco. Rio de Janeiro: Na Tipografia Nacional, 1840.

PROPOSTA e relatório apresentados à Assembléia Geral Legislativa na Sessão Ordinária de 1841, pelo Ministro e Secretário de Estado dos Negócios da Fazenda Miguel Calmon du Pin e Almeida. Rio de Janeiro: Tipografia Nacional, 1841.

PRUNETTI, Michelangelo. La selvaggia del Messico, dramma serio per musica. Da rappresentarsi in Bologna nel teatro della Comune, l'autunno del corrente anno 1803, secondo della Rep. Italiana [la musica e del celebre maestro Giuseppe Nicolini]. Bologna: Stampe del Sassi, 1803.

RANGEL, Alberto. A educação do príncipe: esboço histórico e crítico sobre o ensino de D. Pedro II. Rio de Janeiro: Agir Editora, 1945.

RANGEL, Alberto. No rolar do tempo: opiniões e testemunhos respigados no arquivo do Orsay-Paris. Rio de Janeiro: José Olympio, 1937.

RAYNOR, Henry. História social da música: da Idade Média a Beethoven. Tradução de Nathanael C. Caixeiro. Rio de Janeiro: Guanabara, 1986.

RELAÇÃO da Aclamação que se fez na Capitania do Rio de Janeiro do Estado do Brasil, \& nas mais do Sul, ao Senhor Rei Dom João o IV por verdadeiro Rei, \& Senhor do seu Reino de Portugal, com a felicíssima restituição que dele se fez a Sua Majestade que Deus guarde. Lisboa: Jorge Rodrigues, 1641.

RELAÇÃO das festas: que se fizeram no Rio de Janeiro, quando o Príncipe Regente N. S. e toda a sua real família chegaram pela primeira vez àquela capital. Ajuntando-se algumas particularidades igualmente curiosas, e que dizem respeito ao mesmo objeto. Lisboa: na Impressão Regia, 1810.

RELATÓRIO apresentado à Assembléia Geral Legislativa na Sessão Ordinária de 1840, pelo Ministro e Secretário de Estado dos Negócios da Justiça, e interinamente do Império Francisco Ramiro de Assis Coelho. Rio de Janeiro: Na Tipografia Nacional, 1840.

RELATÓRIO apresentado à Assembléia Geral Legislativa na Sessão Ordinária de 1839, pelo Ministro e Secretário de Estado dos Negócios da Justiça. Rio de Janeiro: Na Tipografia Nacional, 1839.

RELATÓRIO apresentado à Assembléia Geral Legislativa na Sessão Ordinária de 1841, pelo Ministro e Secretário de Estado dos Negócios do Império Cândido José de Araújo Viana. Rio de Janeiro: Na 
Tipografia Nacional, 1841.

RELATÓRIO apresentado à Câmara dos Senhores Deputados pelo Ministro e Secretário de Estado dos Negócios da Fazenda Bernardo Pereira de Vasconcelos na Sessão de 1832. Rio de Janeiro: Na Tipografia Nacional, 1832.

RELATÓRIO da Repartição dos Negócios da Fazenda apresentado à Assembléia Geral Legislativa na Sessão Ordinária de 1834; pelo respectivo Ministro e Secretário de Estado Cândido José de Araújo Viana. Rio de Janeiro: Na Tipografia Nacional, 1834.

RELATÓRIO da Repartição dos Negócios da Justiça apresentado à Assembléia Geral Legislativa na Sessão Ordinária de 1833; pelo respectivo Ministro e Secretário de Estado Honório Hermeto Carneiro Leão. Rio de Janeiro: Na Tipografia Nacional, 1833.

RELATÓRIO da Repartição dos Negócios da Justiça apresentado à Assembléia Geral Legislativa na Sessão Ordinária de 1834; pelo respectivo Ministro e Secretário de Estado Aureliano de Sousa e Oliveira Coutinho. Rio de Janeiro: Na Tipografia Nacional, 1834.

RELATÓRIO da Repartição dos Negócios da Justiça apresentado à Assembléia Geral Legislativa na Sessão Ordinária de 1836, pelo respectivo Ministro e Secretário de Estado Antônio Paulino Limpo de Abreu. Rio de Janeiro: Na Tipografia Nacional, 1836.

RELATÓRIO da Repartição dos Negócios da Justiça apresentado à Assembléia Geral Legislativa na Sessão Ordinária de 1838, pelo respectivo Ministro e Secretário de Estado Bernardo Pereira de Vasconcelos. Rio de Janeiro: Na Tipografia Nacional, 1838.

RELATÓRIO da Repartição dos Negócios da Justiça apresentado à Assembléia Geral Legislativa na Sessão Ordinária de 1841, pelo respectivo Ministro e Secretário de Estado Paulino José Soares de Sousa. Rio de Janeiro: Na Tipografia Nacional, 1841.

RELATÓRIO do Ministro e Secretário de Estado dos Negócios da Fazenda José Inácio Borges na Sessão de 1831. Rio de Janeiro: Na Tipografia de Gueffier, 1831.

RELATÓRIO do Ministro, e Secretário de Estado dos Negócios da Fazenda na sessão de 15 de maio de 1830. Rio de Janeiro: Na tipografia imperial e nacional, 1830.

RELATÓRIO, ou exposição do Ministro da Fazenda sobre o estado da administração respectiva em fim do ano de 1825, com o orçamento da renda e despesa que poderá ter lugar no corrente ano de 1826. Rio de Janeiro: Na Tipografia Imperial e Nacional, 1826.

REVISTA do Instituto Histórico e Geográfico Brasileiro. Rio de Janeiro, v. 105, 1902.

RHEINGANTZ, Carlos G. Titulares do império. Rio de Janeiro: Arquivo 
Nacional, 1960.

RIBEIRO, Gladys Sabina. A liberdade em construção: identidade nacional e conflitos antilusitanos no primeiro reinado. Rio de Janeiro: Relume Dumará, 2002.

- Metáforas e ações na longa luta pela liberdade: conflitos entre 'portugueses' e 'homens de cor', Corte do Rio de Janeiro, 1827-1834. Tempo. Rio de Janeiro: Departamento de História da UFF, n. 10, dez. 2000.

RIO BRANCO, José Maria da Silva Paranhos, Barão do. Efemérides brasileiras. Brasília: Senado Federal, 1999.

RIO Janeiro and the adjacent country. Fisher's national magazine and industrial record. New York: Redwood Fisher, 1846.

ROCHA, Justiniano José da. Ação; reação; transação. Rio de Janeiro: Tip. Imp. e Const. de J. Villeneuve, 1855.

RODRIGUES, Guilherme, PEREIRA, Esteves. Portugal - Dicionário Histórico, Corográfico, Heráldico, Biográfico, Bibliográfico, Numismático e Artístico. Lisboa: João Romano Torres, 1911.

RODRIGUES, José Honório. Vida e história. São Paulo: Perspectiva, 1986.

ROMANELLI, Luigi. Coriolano, melodramma serio in due atti del sig. Luigi Romanelli poeta. Da rappresentarsi nel Teatro da S. Agostino nel carnevale dell'anno 1812. Genova: Stamperia della Marina, e della Gazzetta di Genova, [1812].

. Il ritratto, dramma giocoso in musica da rappresentarsi nel Teatro alla Scala di Milano l'autunno del 1799. Milano: per Gio. Batista Banchi, 1799.

- Il trionfo del bel sesso, dramma giocoso in musica da rappresentarsi nel Teatro alla Scala di Milano l'autunno del 1799. Milano: per Gio. Batista Bianchi, 1799.

ROMERO, Silvio. História da literatura brasileira. Rio de Janeiro: José Olympio, 1960.

ROSSELLI, John. Opera Industry in Italy From Cimarosa to Verdi: The Role of the Impresario. Cambridge: Cambridge Univ. Press, 1984.

ROUSSEAU, Jean-Jacques. Collection complète des oeuvres de J.-J. Rousseau. Genève: Du Peyrou, 1782-1789.

RUSCHENBERGER, W. S. W.. Three years in the Pacific: including notices of Brazil, Chile, Bolivia, and Peru. Philadelphia: Carey, Lea \& Blanchard, 1834.

SÁ, Manoel Tavares de Siqueira e. Júbilos da América. Lisboa: Na oficina do Dr. Manuel Álvares Solano, 1754.

SALDONI Y REMENDO, Baltasar. Diccionario biográfico-bibliográfico de 
efemérides de músicos españoles. Madrid: Perez Dubrull, 1881.

SAMPAIO, Antônio Carlos Jucá de. Os homens de negócio do Rio de Janeiro e sua atuação nos quadros do império português. In: FRAGOSO, João, (org); BICALHO, Maria Fernanda, (org); GOUVÊA, Maria de Fátima, (org); O Antigo Regime nos trópicos: a dinâmica imperial portuguesa: (séculos XVI-XVIII). Rio de Janeiro: Civilização Brasileira, 2001.

SANCHES DE BAENA, Augusto Romano Sanches de Baena e Farinha de Almeida, Visconde de. Dicionário aristocrático que contém todos os alvarás de foros de fidalgos da casa real, médicos, reposteiros e porteiros da real câmara, títulos e cartas do conselho; fiel extrato dos livros do registro das mercês existentes no arquivo público do Rio de Janeiro; desde 1808 até setembro de 1822. Lisboa: Tip. do Panorama, 1867.

SANTOS, Corcino Medeiros dos. Relações comerciais do Rio de Janeiro com Lisboa (1763-1808). Rio de Janeiro: Tempo Brasileiro, 1980.

SANTOS, Luiz Gonçalves dos. Memórias para servir à história do reino do Brasil. Belo Horizonte: Itatiaia, 1981.

SARMIENTO, Giulio. Te Deum espressamente composto p. la Cappella di Capo di Monte nell'occasione del felice parto di S. Al. La Regina. Napoli, 1839.

SCARANO, Julita. Devoção e escravidão: a Irmandade de Nossa Senhora do Rosário dos Pretos no Distrito Diamantino no século XVIII. São Paulo: Companhia Editora Nacional, 1978.

SCHERER, Frederic M.. Quarter notes and bank notes: the economics of music composition in the eighteenth and nineteenth centuries. Princeton: Princeton University Press, 2004.

SCHERPEREEL, Joseph. A orquestra e os instrumentistas da Real Câmara de Lisboa, de 1764 a 1834. Tradução de Maria Fernanda Cidrais. Lisboa: Fundação Calouste Gulbenkian, 1985.

SCHLICHTHORST, Carl. Rio de Janeiro wie es ist. Beiträge zur Tages und Sitten Geschichte der Hauptstadt von Brasilien mit vorzüglicher Rücksicht auf die Lage des dortigen deutschen Militairs. Hannover: Hahn, 1829.

SCHUMACHER, Peter Heinrich. Beschreibung meiner Reiser von Hamburg nach Brasilien Juni 1824 nebst Nachrichten über Brasilien bis zum Sommer 1825 über die Auswanderung dahin, der Wahrheit gemäß und zur Warnung niedergeschrieben. Braunschweig: Bei Friedrich Vieweg, 1826.

SCHWARCZ, Lilia Moritz. A fabricação do rei. A construção da imagem pública de Luis XIV. Revista de Antropologia, São Paulo, FFLCH/USP, v. 43, n. $1,2000$. 
As barbas do imperador: D. Pedro II, um monarca nos trópicos. São Paulo: Companhia das Letras, 1998.

SEIDLER, Carl. Brasiliens kriegs-und revolutionsgeschichte seit dem jahre 1825 bis auf unsere zeit. Leipzig: Eduard Kummer, 1837.

. Zehn Jahre in Brasilien während der Regierung Dom Pedro's und nach dessen Entthronung. Leipzig: Gottfr. Basse, 1835.

SIEGMEISTER, Elie. Music and society. New York: Critics Group Press, 1938.

SILBERMANN, Alphons. The sociology of music. Tradução do alemão para o inglês de Corbet Stewart. London: Routledge \& Kegan Paul, 1963.

SILVA, Maria Beatriz Nizza da. Cultura e sociedade no Rio de Janeiro: 18081821. São Paulo, Companhia Editora Nacional, 1977.

SISSON, S. A. (editor). Galeria dos brasileiros ilustres. Brasília: Senado Federal, 1999.

SODRÉ, Alcindo. Um dia de gala no primeiro reinado. Anuário do Museu Imperial. Rio de Janeiro, v. 13, 1952.

SONNERAT, Pierre. Voyage aux Indes Orientales et à la Chine. Paris: Dentu, imprimeur-libraire, 1806.

SOUZA, Carlos Eduardo de Azevedo e. Dimensões da vida musical no Rio de Janeiro: de José Maurício a Gottschalk e além, 1808-1889. Niterói, 2003. Tese (Doutorado) - Universidade Federal Fluminense.

SOUZA, J. Galante de. O teatro no Brasil. Rio de Janeiro: Instituto Nacional do Livro, 1960.

SOUZA, José Antônio Soares de. O Rio de Janeiro nas balanças de comércio de Portugal de 1796 a 1807. Revista do Instituto Histórico e Geográfico Brasileiro. Rio de Janeiro, v. 342, 1984.

SOUZA, Octavio Tarquínio de. História dos fundadores do Império do Brasil. Rio de Janeiro: José Olympio, 1960.

SPIX, Johann Baptist von; MARTIUS, Karl Friedrich Philip von. Reise in Brasilien auf Befehl Sr. Majestät Maximilian Joseph I., Königs von Bayern in den Jahren 1817 bis 1820 gemacht und beschrieben von Joh. Bapt. von Spix; und Carl Friedr. Phil. von Martius. München: M. Lindauer, 1823.

STAUNTON, Sir George. An abridged account of the embassy to the Emperor of China, undertaken by order of the King of Great Britain; including the manners and customs of the inhabitants; and preceded by an account of the causes of the Embassy and voyage to China. Taken principally from the papers of Earl Macartney... London: John Stockdale, 1797.

STENDHAL. Vie de Rossini. Paris: Le Divan, 1929. 
STEVENSON, Robert Murrell. Renaissance and baroque musical sources in the Americas. Washington: General Secretariat, Organization of American States, 1970.

STEWART, Charles Samuel. A visit to the South Seas, in the U.S. ship Vincennes, during the years 1829 and 1830; with notices of Brazil, Peru, Manilla, the Cape of Good Hope, and St. Helena. London: Fisher, son, \& Jackson, 1832.

. Brazil and La Plata: the personal record of a cruise. New York: G.P. Putnam, 1856.

STURZ, Johann Jakob. A review, financial, statistical, and commercial, of the Empire of Brazil and its resources: together with a suggestion of the expediency and mode of admitting brazilian and other foreign sugars into Great Britain for refining and exportation. London: Effingham Wilson, 1837.

SUZANNET, Comte de. Souvenirs de voyages: Les provinces du Cawcase, l'empire au Brésil. Paris: G. A. Dentu, 1846.

TARANTINI, Leopoldo. Antonio Foscarini: tragedia lirica in due atti da rappresentarsi nel Reale Teatro S. Carlo nell'inverno del 1839. Napoli: dalla Tipografia Flautina, 1839.

TARDUCCI, Filippo. Amuratte 2., dramma serio per musica. Da rappresentarsi nel nobil teatro a Torre Argentina il carnevale dell'anno 1813 [la poesia e del sig. Filippo Tarducci; la musica e del maestro sig. Pietro Raimondi]. Roma: Stamperia di Crispino Puccinelli, 1813.

TEATRO cômico português, ou coleção das óperas portuguesas: que se representaram na Casa do Teatro público do Bairro Alto, e Mouraria. Lisboa: S.T. Ferreira, 1787-92.

THE New Grove Dictionary of Music and Musicians. London: Macmillan, 2001.

TILL, Nicholas. Rossini. Tradução de Eduardo Francisco Alves. Rio de Janeiro: Ediouro, 1992.

TONI, Flávia. Música nas irmandades da Vila de São José e o capitão Manoel Dias de Oliveira. São Paulo, 1985. Dissertação (Mestrado) ECA/USP.

TRATADO feito entre Sua Majestade Fidelíssima sobre o reconhecimento do Império do Brasil, aos 29 de agosto de 1825. E ratificado por Sua Majestade o Imperador no dia imediato. Rio de Janeiro: Tipografia Nacional, 1825.

TRINDADE, Jaelson; CASTAGNA, Paulo. Música pré-barroca luso-americana: o grupo de Mogi das Cruzes. Revista Eletrônica de Musicologia. Curitiba: Departamento de Artes da UFPr, v. 1, n. 2, dezembro 1996.

TUCKEY, James Kingston. An account of a voyage to establish a colony at Port Philip in Bass's Strait, on the south coast of New south Wales. 
London: Longman, Hurst, Rees, and Orme, 1805.

TWISS, Richard: Travels through Portugal and Spain: in 1772 and 1773. London: Robinson, Becket and Robson, 1775.

VASCONCELOS, Joaquim de. Os músicos portugueses. Porto: Imprensa portuguesa, 1870.

VASCONCELOS, Rodolfo Smith de Vasconcelos, Barão de. Arquivo nobiliárquico brasileiro. Lausanne: La Concorde, 1918.

VAUX, James Hardy. Memoirs of James Hardy Vaux. Londres: W. Clowes, 1819.

VETRO, Gaspare Nello. Antônio Carlos Gomes. Rio de Janeiro: Cátedra, 1982.

VIANA, Hélio. D. Pedro I e D. Pedro II: acréscimos as suas biografias. São Paulo: Companhia Editora Nacional, 1966.

VIEIRA, Ernesto. Dicionário biográfico de músicos portugueses: história e bibliografia da música em Portugal. Lisboa: Lambertini, 1900.

. Dicionário musical ornado com gravuras e exemplos de música. Lisboa: Tip. Lallemant, 1899.

VITERBO, Francisco Marques de Souza. Subsídios para a história da música em Portugal: a música sagrada nas diversas terras do reino. Lisboa: Tipografia do Comércio, 1911.

WALSH, Robert. Notices of Brazil in 1828 and 1829. London: F. Westley and A. H. Davis, 1830.

ZEMELLA, Mafalda P. O abastecimento da Capitania das Minas Gerais no século XVIII. São Paulo, 1951. Tese (Doutorado) - FFLCH/USP.

ZENO, Apostolo. Sesostri, dramma per musica da rappresentarsi nel Real Teatro di S. Carlo nel di' 12 gennaro 1802 festeggiandosi la nascita di Ferdinando 4. nostro amabilissimo sovrano ed alla S. R. M. dedicato. Napoli: nella Stamperia Flautina, 1802.

\section{BIBLIOGRAFIA DE APOIO}

ANDERSON, Benedict. Nação e consciência nacional. Tradução de Lourenço de Oliveira. São Paulo: Ática, 1989.

ARMITAGE, João. História do Brasil. Belo Horizonte; São Paulo: Itatiaia; Editora da Universidade de São Paulo, 1981.

AZEVEDO, Luiz Heitor Corrêa de. 150 anos de música no Brasil, 1800-1950 . Rio de Janeiro: José Olympio, 1956.

BÖSCHE, Eduardo Theodoro. Quadros alternados; impressões do Brasil de dom Pedro I. Tradução de Vicente de Souza Queirós. São Paulo: 
Tipografia da casa Garraux, 1929.

BUNBURY, Charles James Fox. Viagem de um naturalista inglês ao Rio de Janeiro e Minas Gerais - 1833-1835. Belo Horizonte; São Paulo: Editora Itatiaia; Editora da Universidade de São Paulo, 1981.

CACCIAGLIA, Mário. Pequena história do teatro no Brasil. São Paulo: EDUSP, 1986

CAMPANHOLE, Hilton Lobo. Constituições do Brasil. São Paulo: Atlas, 1998.

CARVALHO, José Murilo de. A construção da ordem: a elite política imperial. Teatro de Sombras: a política imperial. Rio de Janeiro: Civilização Brasileira, 2003.

CERNICCHIARO, Vincenzo. Storia della musica nel Brasile, dai tempi coloniali ai nostri giorni. Milano: Ed. Fratelli Riccioni, 1926.

COARACY, Vivaldo. Memórias da cidade do Rio de Janeiro. Belo Horizonte; São Paulo: Editora Itatiaia; Editora da Universidade de São Paulo, 1988.

COELHO, Jacinto do Prado (org.). O Rio de Janeiro na literatura portuguesa. Lisboa: Comissão Nacional das Comemorações do IV Centenário do Rio de Janeiro, 1965.

CRULS, Gastão. Aparência do Rio de Janeiro: noticia histórica e descritiva da cidade. Rio de Janeiro: J.Olympio, 1965.

DEBRET, Jean Baptiste. Viagem pitoresca e histórica ao Brasil. Belo Horizonte; São Paulo: Itatiaia; Editora da Universidade de São Paulo, 1989.

EDMUNDO, Luiz. O Rio de Janeiro no tempo dos vice-reis - (1763-1808). Rio de Janeiro: Imprensa nacional, 1932.

ELIAS, Norbert. A sociedade de corte: investigação sobre a sociologia da realeza e da aristocracia de corte. Tradução de Pedro Süssekind. Rio de Janeiro: Jorge Zahar, 2001.

FERREIRA, Tito Lívio. História da educação Iuso-brasileira. São Paulo: Saraiva, 1966.

FLEIUSS, Max. História da cidade do Rio de Janeiro. São Paulo: Melhoramentos, 1928.

FRANÇA, Jean Marcel. Outras visões do Rio de Janeiro colonial. Rio de Janeiro: José Olympio, 2000. 1999.

GARDNER, George. Viagem ao interior do Brasil: principalmente nas províncias do Norte e nos distritos do ouro e do diamante durante os anos de 1836-1841. Tradução de Milton Amado. Belo Horizonte; São Paulo: Editora Itatiaia; Editora da Universidade de São Paulo, 1975. 
GINZBURG, Carlo. Sinais: raízes de um paradigma indiciário. In: Mitos, emblemas, ainaia: morfologia e história. Tradução de Federico Carotti. São Paulo: Companhia das Letras, 1989.

GRAHAM, Maria. Diário de uma viagem ao Brasil e de uma estada nesse pais durante parte dos anos de 1821, 1822, 1823. Belo Horizonte: Itatiaia, 1990.

GUIMARÃES, Alberto Carlos de Araújo. A corte no Brasil - Figuras e aspectos. Porto Alegre, Livraria do Globo, 1936.

HAREWOOD, Conde de (org.). Kobbé. O Livro Completo da Ópera. Rio de Janeiro: Jorge Zahar, 1994.

HAUSER, Arnold. História social da literatura e da arte. Tradução de Walter Geenen. São Paulo: Editora Mestre Jou, 1972.

JANCSÓ, István (org.). Independência: história e historiografia. São Paulo: Hucitec, 2005.

A construção dos Estados Nacionais na América Latina. Apontamentos para o estudo do Império como projeto. In: SZMRECSÁNYI, T.; LAPA, J. R. do Amaral. História econômica da Independência e do Império. São Paulo: HUCITEC/FAPESP, 1996.

; PIMENTA, João Paulo Garrido. Peças de um mosaico. In: MOTA, Carlos Guilherme (org). Viagem Incompleta. São Paulo, SENAC/SESC, 2000.

JANOTTI, Maria de Lourdes Mônaco. A Balaiada. São Paulo: Brasiliense, 1987.

KIDDER, Daniel. Reminiscências de viagens e permanência no Brasil. Brasília: Senado Federal, 2001.

KIEFER, Bruno. História da música brasileira dos primórdios ao início do século XX. Porto Alegre: Editora Movimento, 1976.

KOSELLECK, Reinhart. Crítica e crise: uma contribuição à patogênese do mundo burguês. Tradução de Luciana Villas-Boas Castelo-Branco. Rio de Janeiro: EDUERJ, 1999.

LANGE, Francisco Curt. Os compositores na Capitania Geral das Minas Gerais. Marília, 1965.

LANGLOIS, Ch. V., SEIGNOBOS, Ch.. Operações analíticas. In: Introdução aos estudos históricos. Tradução de Laerte de Almeida Morais. São Paulo: Renascença, 1946.

LATIF, Miran Monteiro de Barros. Uma cidade nos trópicos. São Paulo: Martins, 1948.

LEITE, Renato Lopes. Republicanos e libertários. Pensadores no Rio de Janeiro (1822). Rio de Janeiro: Civilização Brasileira, 2000.

LEITHOLD, Johann Gottfried Theodor von. Rio de Janeiro visto por dois 
prussianos. São Paulo: Ed. Nacional, 1966.

LIRA, Heitor, História de D. Pedro II. Belo Horizonte: Itatiaia; São Paulo: EDUSP, 1977

LOBO, Eulália Maria Lahmeyer. História do Rio de Janeiro - Do capital comercial ao capital industrial e financeiro. Rio de Janeiro: IBMEC, 1978.

LUCCOCK, John. Notas sobre o Rio de Janeiro e partes meridionais do Brasil. Tradução de Milton da Silva Rodrigues. Belo Horizonte; São Paulo: Itatiaia; EDUSP, 1975.

MACEDO, Joaquim Manuel de. Memórias da Rua do Ouvidor. São Paulo: Nacional, 1953. 1947.

Passeio pela cidade do Rio de Janeiro. Rio de Janeiro: Valaverde,

MELLO-LEITÃO, Candido de. O Brasil visto pelos Ingleses. São Paulo: Companhia Editora Nacional, 1937.

MELO MORAIS, Alexandre José de. História do Brasil-reino e do Brasilimpério. Belo Horizonte; São Paulo Editora Itatiaia; Editora da Universidade de São Paulo, 1982.

MELO, Guilherme Teodoro Pereira de. Música no Brasil, desde os tempos coloniais ate a primeiro decênio da República. Bahia: Tip. de São Joaquim, 1908.

MENDONÇA, Carlos Süssekind de. Historia do teatro brasileiro - Volume primeiro (1565-1840). Rio de Janeiro: Mendonça, 1926.

MONTEIRO, Tobias. História do Império. O Primeiro Reinado. Rio de Janeiro: F. Briguiet, 1946.

NABUCO, Joaquim. Um estadista do Império. São Paulo, 1936.

NEVES, Lucia Maria Bastos P.. Corcundas e Constitucionais: A Cultura Política da Independência (1820-1822). Rio de Janeiro: Revan, 2003

NOVAIS, Fernando (org.). História da vida privada no Brasil: cotidiano e vida privada na América portuguesa. São Paulo: Companhia das Letras, 1997.

PINHEIRO, Maciel, O Rio de Janeiro através das revistas - Revista do Instituto Histórico e Geográfico Brasileiro. Rio de Janeiro, 1966.

PINHO, Wanderley. Salões e damas do segundo reinado. São Paulo: Livraria Martins, 1959.

PRADO JR., Caio. Formação do Brasil contemporâneo: colônia. São Paulo: Brasiliense, 1981. 
PRADO, Décio de Almeida. História concisa do teatro brasileiro 1570-1908. São Paulo: EDUSP, 1999.

RODRIGUES, José Honório. A Assembléia Constituinte de 1823. Petrópolis: Vozes, 1974.

RUGENDAS, Johann Moritz. Viagem pitoresca através do Brasil. Tradução de Sérgio Milliet. São Paulo: Livraria Martins Editora, Editora da Universidade de São Paulo, 1972.

RÜSEN, Jörn. Critérios de verdade do pensamento histórico. In: Razão histórica: teoria da história: os fundamentos da ciência histórica. Tradução de Estevão de Rezende Martins. Brasília: Editora Universidade de Brasília, 2001.

SALLES OLIVEIRA, Cecília $\mathrm{H}$. de. A astúcia liberal: relações de mercado e projetos políticos no Rio de Janeiro (1820-1824). Bragança Paulista: EDUSF/ICONE, 1999.

SANTOS, Noronha. Memórias do conselheiro Francisco Gomes da Silva (o Chalaça). Rio de Janeiro: Zelio Valverde, 1939.

SCHLICHTHORST, Carl. Rio de Janeiro como é, 1824-1826 (Uma vez e nunca mais). Tradução de Gustavo Barroso e Emmy Dodt. Rio de Janeiro: Ed. Getúlio Costa, 1943.

SEIDLER, Carl. Dez anos no Brasil. Tradução de Bertoldo Klinger. São Paulo, Livraria Martins, 1941.

SILVA, J. M. Pereira da. História do Brasil de 1831 a 1840. Rio de Janeiro: Dias da Silva Júnior, 1878.

SILVA, Lafayette. História do Teatro Brasileiro. Rio de Janeiro: Ministério da Educação e Saúde, 1938.

SPIX, Johann Baptist von; MARTIUS, Friedrich Philipp von. Viagem pelo Brasil: 1817-1820. Tradução de Lucia Furquim Lahmeyer. São Paulo: Melhoramentos, 1976.

STENDHAL. Rome, Naples et Florence. Paris: Le Divan, 1927.

TAUNAY, Affonso de E. Visitantes do Rio Colonial. São Paulo: Companhia Editora Nacional, 1933. . No Brasil de 1840. São Paulo: Imprensa official do Estado, 1935.

- Rio de Janeiro de antanho - Impressões de viajantes estrangeiros. São Paulo: Companhia editora nacional, 1942.

Rio de Janeiro de antanho - Impressões de viajantes estrangeiros. São Paulo: Companhia Editora Nacional, 1942.

TOURINHO, Eduardo. Revelação do Rio de Janeiro. Rio de Janeiro: Civilização Brasileira, 1964.

VIANNA, Helio. Contribuição a historia da imprensa brasileira - (1812-1869). 
Rio de Janeiro, 1945.

WALSH, Robert. Notícias do Brasil. Belo Horizonte; São Paulo: Editora Itatiaia; Editora da Universidade de São Paulo, 1985. 